BUDAPESTI KÖZGAZDASÁGTUDOMÁNYI ÉS ÁLLAMIGAZGATÁSI EGYETEM

\title{
AZ EURÓPAI UNIÓ KELETI BÖVÍTÉSÉNEK ELŐNYEI AZ EURÓPAI UNIÓ SZÁMÁRA
}

PH.D. ÉRTEKEZÉS

Becsey Zsolt

BUDAPEST, 2001 
BECSEY ZSOLT

AZ EURÓPAI UNIÓ KELETI BŐVÍTÉSÉNEK ELŐNYEI AZ EURÓPAI UNIÓ SZÁMÁRA 


\title{
VILÁGGAZDASÁGTAN TANSZÉK
}

\author{
DR. BLAHÓ ANDRÁS
}

TÉMAVEZETÖ

BÍRÁLÓ BIZOTTSÁG NÉVSORA: 


\section{BUDAPESTI KÖZGAZDASÁGTUDOMÁNYI ÉS}

ÁLLAMIGAZGATÁSI EGYETEM

NEMZETKÖZI KAPCSOLATOK PH.D. PROGRAM

AZ EURÓPAI UNIÓ KELETI BŐVÍTÉSÉNEK ELŐNYEI AZ EURÓPAI UNIÓ SZÁMÁRA

PH. D. ÉRTEKEZÉS

BECSEY ZSOLT

BUDAPEST, 2001 


\section{TARTALOMJEGYZÉK}

TÁBLÁZATOK JEGYZÉKE.............................................6

\section{A BŐVÍTÉS GEOPOLITIKAI ÉS TÖRTÉNELMI}

HÁTTERE......................................................... 16

1. Bevezetés........................................................... 16

2. A bővítés helyzetének általános áttekintése, a belépésre váró országok érdekeltsége a csatlakozásban.............................18

2.1. A történelmi változások hatása az európai fejlödésre............... 18

2.2. A csatlakozás előnyei a tagjelölt országok számára................ 23

3. A kapcsolatok történelmi dimenziói a közép- és kelet-európai rendszerváltás elött...............................................29

3.1. Gazdaságtörténelmi vonatkozások............................29

3.2. Kapcsolatok fejlődése a hidegháború időszakában................. 32

3.3. A kétoldalú kapcsolatokban jelentkező problémák..................35

3.4. A kapcsolatok rendezése......................................... 39

4. Történelmi motívumok és fejlődési azonosságok....................44

4.1. Általános történelmi fejlődés................................ 43

4.2. Lengyelország............................................. 44

4.3. Magyarország (Szlovákia)....................................45

4.4. Csehország............................................... 46

4.5. Nyugati keresztény irányultságú területek......................47

4.6. A keleti (bizánci) típusú területek................................49

II. A KÖZVÉLEMÉNY-KUTATÁSOK A BÖVÍTÉSRŐL..............52

1. Az EU-tagállamok közvéleménye............................... 52

2. A tagjelölt országok közvéleménye.................................61

3. Saját kérdőíves felmérés...........................................64

3.1. Az eredmények értékelése................................69

III. A BŐVÍTÉS INTÉZMÉNYI ÉS BIZTONSÁGI

VONATKOZÁSAI.............................................. 72

1. A bővítés hatása az Unió intézményi rendszerére.....................72

1.1. A legfontosabb szervekben történő részvétel a Nizzai szerződés döntései alapján..................................... 72

1.2. Várható kényes kérdések a döntéshozatalban a bővítés után........76 
2. A kibővítés biztonságpolitikai háttere, hatása az Unió közös

kül- és biztonságpolitikájára................................. 82

2.1. A hidegháború végének kedvező hatásai........................ 82

2.2. Konkrét politikai együttmüködés az EU-val......................85

2.3. A tagság jelentette további előnyök az EU számára................ 86

3. Bel- és igazságügyi együttmüködés..............................91

3.1. A határok kiterjesztésének kérdése........................... 92

3.2. A tagság pozitív hatása a jogi együttműködésre.................. 98

3.3. A bünügyi együttmüködés.....................................99

3.4. Menekültpolitika.......................................... 102

3.5. A menekültstátusz kérelmek megoszlása Európában.............. 103

IV. A BŐVÍTÉS ELŐNYEI A HUMÁN TERÜLETEKEN............... 112

1. A lakosság tudati - vallási és tolerancia - szintje................... 112

1.1. A vallási jellegzetességek.......................................112

1.2. Tolerancia és bizalommutatók...............................114

1.3. Az etnikai és nemzeti kisebbségek iránti tolerancia...............117

2. A régió kisebbségi térképe......................................... 119

2.1. Nemzeti kisebbségek......................................120

2.1.1. A hagyományos nemzeti kisebbségek.................... 120

2.1.2. A betelepített nemzeti kisebbségek..................... 122

2.2. A zsidó etnikai kisebbség.................................... 123

2.3. A romák integrálásának sajátosságai.......................... 124

2.3.1. A roma lakosság képzettsége a magyar adatok alapján.............................................. 125

2.3.2. A romák aránya és száma a csatlakozó országokban.........126

3. Demográfiai viszonyok.......................................... 130

3.1. Hosszú távú trendek a világban...............................130

3.2. A munkaképes korúak és az eltartottak arányának alakulása...... 134

3.3. Bevándorlási igények..................................... 139

4. Az egészségügyi állapot jellemzése................................... 140

4.1. Várható élettartam...................................... 141

4.2. Az egészségügyi kiadások hatása az államháztartásra............. 143

4.3. Általános egészségügyi paraméterek összehasonlítása............. 144

5. Szociális helyzet............................................... 145

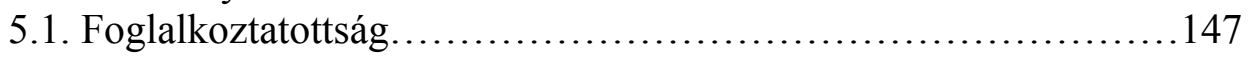

5.2. A szociális ellátás........................................... 149

5.3. Az abszolút és relatív szegénység, a társadalom polarizáltsága a társultaknál................................ 151

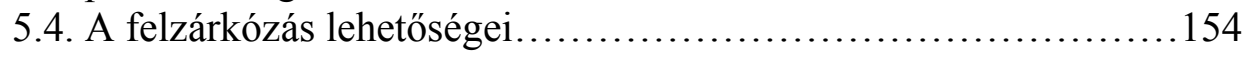

5.5. A szociális dömping vádja.................................... 155

5.6. A férfiak és nők esélyegyenlősége............................ 157 
6. Az oktatási színvonal.......................................... 160

6.1. Az alap-, közép- és felsőfokú oktatásban való részvétel.......... 161

6.1.1. Alap- és középfokú oktatás.............................. 161

6.1.2. Felsőfokú oktatás....................................... 162

6.2. A feladatmegoldási készség................................. 164

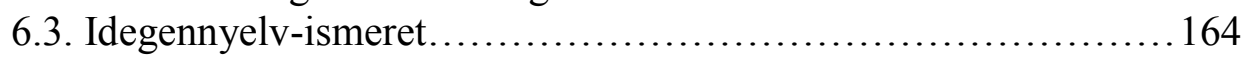

6.4. Anyagi és technikai ráfordítások........................... 165

7. Kutatás és fejlesztés.......................................... 167

7.1. A jelölt országok kutatói életének néhány objektív mércéje........ 168

7.2. Elméleti képzettség..................................... 170

7.3. Az informatikai terület sajátosságai.......................... 172

7.4. A tagjelöltek $\mathrm{K}+\mathrm{F}$ tevékenysége integrálódásának eddigi eredményei....................................... 174

8. A korrupció helyzete és a bürokrácia állapota....................... 176

8.1. Az állami apparátus súlya, szerepe......................... 176

8.2. Korrupciós felmérések.................................... 177

8.3. Az EU-források felhasználási képessége....................... 179

V. A BŐVÍTÉS ELŐNYEI A GAZDASÁGI TERÜLETEKEN........... 182

1. A tagjelölt országok gazdasági fejlettsége........................... 182

1.1. Általános gazdasági fejlettség............................... 182

1.2. Rejtett gazdaság.......................................... 184

1.3. Adósságok................................................. 185

1.4. A gazdaság strukturális reformja............................ 186

1.5. Beruházások.............................................. 187

1.6. A gazdasági termelés hatékonysága............................189

1.7. A gazdasági felzárkózás várható trendjei.........................193

1.8. Az Európai Gazdasági és Monetáris Unióba való belépés..........197

2. A gazdasági és szociális kohézió a kibővülő Európai Unióban..........202

2.1. A kohéziós politika sikerei a jelenlegi EU-ban...................203

2.2. A felzárkózás esélyei makrogazdasági szinten a csatlakozni kívánó országokban.........................................204

2.3. Az egyes régiók fejlettségi szintje............................ 205

2.4. Az új tagállamok relatíve fejlett régiói........................206

2.5. A felvétellel járó költségek.................................. 209 
3. Belső piaci területek, versenypolitika.............................. 213

3.1. Az integráció hatása a versenypolitika terén..................... 213

3.2. A tőkemozgás szabadságából adódó előnyök....................216

3.3. A müködőtőke-befektetések jelentősége az EU-tagállamok számára...................................................218

3.4. A működőtőke-befektetések ágazati irányultsága................ 219

3.5. A tőkebefektetések és a gazdasági kapcsolatok pótlólagos haszna a belső piac kiterjesztésével................. 223

3.6. A pénzügyi szektor versenyképessége......................... 226

3.7. A közbeszerzési piac kiterjedése a tagság révén.................. 226

4. A bővítés közvetlen költségvetési hatásai........................... 228

4.1. A közösségi költségvetés jelenlegi nagyságrendje................228

4.2. Az új tagállamok befizetése a költségvetésbe...................230

4.3. Az új tagok költségvetési támogatása.......................... 233

4.3.1. Strukturális alapok.................................. 233

4.3.2. Részesedés a belső piaci programokból...................2235

4.3.3. Agrártámogatások.................................... 236

4.4. Teljes támogatás..........................................238

5. A bővítés kereskedelempolitikai hatásai...........................242

5.1. A kelet-nyugati kereskedelem súlya és volumene a kilencvenes években......................................243

5.2. A kereskedelem tagság utáni bővüléséből eredő uniós haszon becslése.................................................... 249

5.3. Kereskedelmi mérleg az EU és a Társultak között............... 251

5.4. A kereskedelem szerkezete................................... 252

5.5. Az új tagok vámunióba lépésének hatása a külső partnerekre..... 254

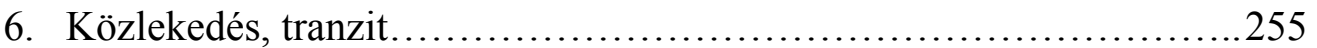

6.1. A vasúti és közúti infrastruktúra............................... 256

6.2. A szállítási piac nagysága és szerkezete......................... 260

6.3. Személyszállítás........................................... 263

6.3.1. Vasúti személyforgalom..............................263

6.3.2. A légi közlekedés....................................... 264

6.3.3. Közúti közlekedés......................................265

6.4. Tényleges piaci lehetőségek a bővülés után az EU számára........ 267

6.5. A tranzittevékenységből származó előnyök.....................270 
7. A tagjelöltek agrárszférájának integrációja..........................273

7.1. Az új tagok mezőgazdasági termelési mértéke és potenciálja..... 274

7.2. Termelési szerkezet összehasonlítása......................... 277

7.3. A kibővített belső piac termelés-fogyasztás egyenlege............ 280

7.3.1. Az EU és a társult országok kereskedelme.................. 280

7.3.2. Az EU és a társult országok termelés-fogyasztás egyenlege............................................. 284

7.4. A mezőgazdasági piaci árak................................ 288

7.5. A birtokszerkezet........................................... 291

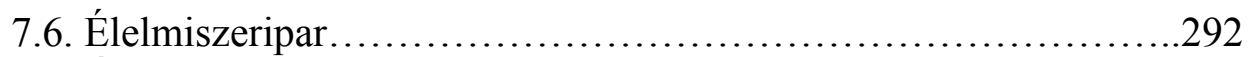

7.7. Állat- és növény-egészségügyi viszonyok................. 292

8. A munkaerőpiacon jelentkező változások.............................294

8.1. A társult országok jelenlegi helyzete............................. 294

8.2. Spanyol és portugál tapasztalat...................................296

8.3. Munkaerő-piaci helyzet az Európai Unióban.......................297

8.4. Gazdasági kilátások..........................................298

8.5. Kulturális hatások, nyelvi, történelmi elem.................... 298

8.6. Jövedelemkülönbségek.......................................299

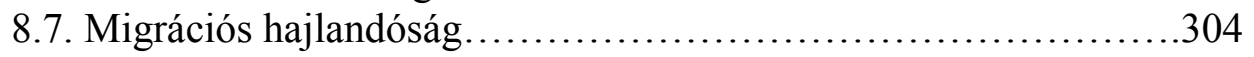

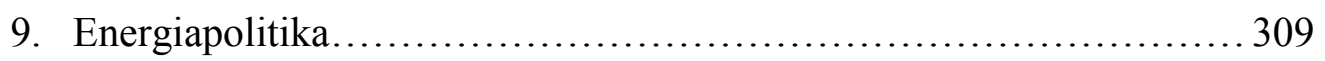

9.1. Az új tagországok energiapiacának nagysága és

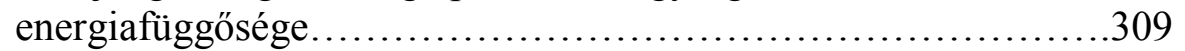

9.2. Energiaszerkezet........................................... 316

9.3. Nukleáris biztonság............................................... 317

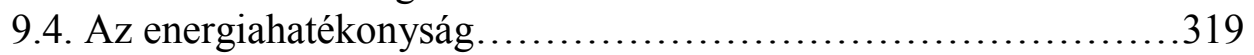

10. Környezetvédelem............................................. 322

10.1. A jelenlegi állapot.......................................... 322

10.2. A környezetvédelmi politika aggregát értékelése................ 324

10.3. A levegő szennyezettségének állapota a tagjelölteknél........... 326

10.4. A vizek szennyezettsége a tagjelölteknél........................327

10.5. Hulladékgazdálkodás........................................ 329

10.6. A felzárkózási költségek nagysága és a környezetvédelmi normák átvételének gazdasági hatása........................330

VI. KÖVETKEZTETÉSEK............................................333

1. A téma aktualitása és jelentősége a közvélemény számára......... 333

2. A bővülés elönyei a történelmi és a humán területeken, valamint hatása az Unió intézményrendszerére.

3. A bővítés kedvező hatásai a közös kül- és biztonságpolitika valamint a bel- és igazságügyi együttmüködés területén............344

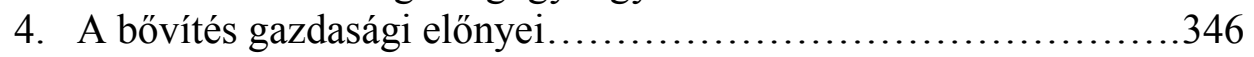

5. Kényes kérdések a csatlakozás menetében........................... 348

VII. IRODALOMJEGYZÉK.....................................353 A SZERZŐ E TÉMÁBAN MEGJELENT PUBLIKÁCIÓI...............363 
I/3.1. sz. A világkereskedelem és a világtermelés változása $\quad 30$

I/3.2. sz. Az EK és az EFTA jelenlegi tagállamaival folytatott 30 kereskedelem aránya a teljes kereskedelmen belül, illetve az európai exportkereskedelemből való részesedés 1928-ban és 1991-ben

I/3.3. sz. Az Európai Unió jelenlegi tagjainak és jelöltjeinek fejlettségi szintje 1938-ban és 1990-ben

I/3.4. sz. A magyar export liberalizációjának mértéke Nyugat-Európában 1968-69-ben

I/3.5. sz. Az EGK és az egyes európai szocialista országok kereskedelmi forgalma 1958-70-ben

I/3.6. sz. Az európai KGST-országok bruttó és nettó eladósodottsága

I/3.7. sz. Az EGK egyes termékeinek export/import szerkezete az európai KGST-országokkal 1985-ben

I/3.8. sz. Az EGK és az egyes európai KGST-országok kereskedelmi egyenlege 1975-85-ben

I/4.1. sz. A tagjelöltek gazdasági, etikai értékelése 1999-ben

II/1. sz. A bővítést fontos feladatnak érző EU-polgárok aránya 1997-ben

II/2. sz. Az EU lakosai elvárásainak prioritása a tagjelöltekkel szemben

II/3. sz. Az egyes EU-tagállamok támogatása a tagjelöltek irányába 2000 tavaszán

II/4. sz. Az egyes tagjelölt országok tagságának támogatottsága az EU-polgárok között

II/5. sz. Egyes közép- és kelet-európai tagjelöltek elfogadása, illetve elutasítottsága Ausztriában, Németországban és Franciaországban 2000 tavaszán

II/6. sz. Ha most lenne az EU népszavazás, akkor hogyan szavazna? (1997 vége illetve 2001) 
II/7. sz. A tagjelölt országok lakosságának véleménye arról, hogy melyik fél (EU vagy saját ország) számára lesz hasznos a bővítés (1997)

III/1.1. sz. Az egyes tag- és tagjelölt államok lakossága és képviseleti arányai a Nizzai csúcsértekezlet döntése alapján

III/2.1. sz. Az EU egyes tagállamainak és tagjelöltjeinek néhány katonai vonatkozású mutatója

III/2.2. sz. A tagjelölt országok által felajánlott katonai és rendőri válságkezelési hozzájárulás

III/3.1. sz. A jelenlegi tagállamok és a tagjelölt országok közötti határszakaszok hossza

III/3.2. sz. A fogva tartottak és a büntetés-végrehajtói helyek 96 száma 1996-ban, Európában

III/3.3. sz. A fogva tartottak 100.000 lakosra jutó száma a volt szocialista országokban

III/3.4. sz. Kábítószerrel kapcsolatos bünözési mutató a tagországokban és a tagjelölteknél (1994)

III/3.5. sz. Menedékjogot kérők száma 1995-ben és 1999-ben

III/3.6. sz. A menekültkérelmekre adott pozitív válasz a 106 tagállamok és a tagjelöltek esetében

III/3.7. sz. A társult országok állampolgárainak menekültkérelmei az európai országokban

III/3.8. sz. Lényegesebb számot elérő menekültek a fontosabb tagjelölt célországokba (1990-1999)

III/3.9. sz. Menekültek Magyarországra érkezésének módja 110

IV/1.1. sz. Az egyes tagjelölt országok hívő lakosságának 113 vallási összetétele

IV/1.2. sz. Vallási jellegzetességek az EU eredeti, későbbi és jelenlegi tagjelöltjei körében

IV/1.3. sz. Tolerancia mások egyéni devianciái iránt

IV/1.4. sz. Bizalomindex másokban 
IV/1.5. sz. Etnikai vagy kisebbségi csoportok jelentős vagy valamilyen veszélyt jelentenek a nemzeti társadalmi fejlődésre

IV/2.1. sz. A magyar nemzeti kisebbség száma és megoszlása az anyaországgal szomszédos országokban (1990 körül)

IV/2.2. sz. A kelet-szlávok aránya a szovjet utódállamokban

IV/2.3. sz. A roma lakosság képzettségi és munkaerő-piaci helyzete 1993-ban Magyarországon

IV/2.4. sz. Becsült roma lakosság és aránya Európában

IV/3.1. sz. Várható lakosságfogyás az EU, illetve a tagjelölt országok körében 2050-ben

IV/3.2. sz. Várható termékenységi ráták az EU tagállamainál

IV/3.3. sz. Termékenységi ráta a tagjelölt országokban

IV/3.4. sz. Az EU-országok és a tagjelöltek legfontosabb korösszetételi adatai 1998-ban

IV/3.5. sz. Születéskor várható élettartam az Unió tagállamaiban 2010-ben és 2050-ben

IV/3.6. sz. A lakosság várható alakulása 2010-ben illetve 2020-ban

IV/3.7. sz. Függőségi ráta becslése néhány OECD-országban 2010-ben és 2020-ban

IV/4.1. sz. A tagországok és tagjelöltek főbb egészségügyi adatai

IV/5.1. sz. A munkaképes korú lakosság foglalkoztatási aránya, összesen és nemek szerint

IV/5.2. sz. A szociális és népjóléti kiadások a GDP százalékában 1995-ben

IV/5.3. sz. A reálbérek növekedése 1997-ben és 1998-ban az előző évhez képest. Átlagos fizetések 1998-ban és prognosztizált nagyságuk 2001-ben

IV/5.4. sz. A napi 1 USD illetve a napi 2 USD alatt élők a teljes lakosság százalékában 
IV/5.5. sz. A társadalmak jövedelmi viszonyainak polarizáltsága a tagállamokban és a tagjelölteknél

IV/5.6. sz. A minimálbér és az átlagbér viszonya az egyes európai uniós és tagjelölt országokban

IV/5.7. sz. A bruttó havi átlagfizetések az egyes tagjelölteknél az EU százalékában

IV/5.8. sz. A munkaadók hozzájárulása a szociális költségekhez és a bruttó fizetés átlagos feldolgozóipari munkásnál maradó része 1998-ban

IV/5.9. sz. A tagjelölt országokban a nők képviseleti aránya a kormányban és a parlamentben (2000-ben)

IV/5.10.sz. A nők keresete az iparban és a szolgáltatásban (1998)

IV/6.1. sz. Középiskolai végzettséggel rendelkezők aránya a 22 éves korosztályban (1997)

IV/6.2. sz. Felsőfokú végzettségüek aránya a kilencvenes évek második felében

IV/6.3. sz. A középiskolai nyelvtanulás föbb mutatói a tagjelölt országokban

IV/6.4. sz. A GNP-ből közoktatásra fordított hányad

IV/7.1. sz. Főbb kutatási mutatószámok a tagállamokban és a tagjelölteknél a 90-es évek közepén

IV/7.2. sz. A tagállamok és a tagjelöltek szellemi teljesítményének szelektív mutatói

IV/7.3. sz. Informatikai mutatószámok a tagjelölteknél és a kohéziós tagállamoknál

IV/7.4. sz. Az EU 5. K+F programjába történő bekapcsolódás föbb mutatói

IV/8.1. sz. Korrupciós Érzékelési Index (CPI)

IV/8.2. sz. Az intézményi minőség terén végzett ICRG teszt néhány tagjelölt országban

IV/8.3. sz. Nemzeti PHARE keretek szerződéskötési és felhasználási mutatói 1990-98 között 
IV/8.4. sz. Lekötött és kifizetett pénzeszközök aránya 1994-98 között

V/1.1. sz. A tagjelöltek gazdasági felzárkózása

V/1.2. sz. Rejtett gazdaság aránya a GDP-ben

V/1.3. sz. A tagjelöltek legfontosabb államadóssági mutatói a 90-es években

V/1.4. sz. Az ipar, a mezőgazdaság és a szolgáltatások aránya a GDP-n belül

V/1.5. sz. Beruházási és tőkebeáramlási mutatók a tagjelölt országokban

V/1.6. sz. A munkaerő termelékenységének mértéke a tagjelölt országokban és Portugáliában, valamint Görögországban 1998-ban

V/1.7. sz. Versenyképességi rangsor

V/1.8. sz. Brit befektetések jellemzői

V/1.9. sz. Az EU Bizottság előrejelzései a társult országok fejlődéséről

V/1.10. sz. A tagjelölt országok részéről szükséges évek száma az EU átlagának 75 százalékára való felzárkózáshoz területeinek főbb gazdasági jellemzői

V/1.12. sz. Főbb mutatók a valutaunióba történő belépéshez (1999)

V/1.13. sz. A tagjelölt országok legfontosabb monetáris mutatói 1999-2000-ben

V/2.1. sz. A tagjelölt országok egy före jutó GDP-je az EU átlagának százalékában

V/2.2. sz. A négy kohéziós ország EU-átlagban mért fejlettségi szintje

V/2.3. sz. Fejlettségi eltérések a NUTS-II régióknál 1996-99-ben

V/2.4. sz. NUTS-II régiók száma 50 százalékos fejlettség felett 208

V/2.5. sz. A társult országok fóbb kohéziós paraméterei 1998-ban 210 
V/2.6. sz. A tagjelölt országok strukturális támogatásának kalkulált összegei a jelenlegi tagállami támogatások alapján

V/3.1. sz. Állami támogatások mutatói néhány tagállamban és tagjelölt országban

V/3.2. sz. A tőkebefektetések főbb mutatói a társult országokban

V/3.3. sz. Az EU tagállamainak befektetési súlya a közép- és kelet-európai térségben (1992-1996)

V/3.4. sz. A müködőtőke szektorális megoszlása a cseh, magyar és lengyel gazdaságban 1996-ban

V/3.5. sz. A német müködőtőke-befektetések munkaerőintenzitása 1996-ban

V/3.6. sz. A Az Európai Unióban eszközölt müködőtőke-befektetések

V/3.7. sz. A brit cégek nettó keresete, tőkebeáramlása és befektetett tőkeszintje 1999-ben néhány közép- és kelet-európai országban

V/3.8. sz. Érzékenységi vizsgálat a reáljövedelmek növekedéséről

V/3.9. sz. A tagjelölt országok, valamint Görögország, Spanyolország, 226 Portugália munkaerő-termelékenysége a pénzügyi és üzleti szolgáltatások területén 1998-ban

V/4.1. sz. A kibővítés költségvetési fejezete a 2002-2006 közötti időszakban

V/4.2. sz. A közösségi költségvetéshez hozzájáruló, illetve haszonélvező tagországok 1998-ban

V/4.3. sz. A tagjelöltek várható hozzájárulása a különböző számítási modellek szerint

V/4.4. sz. A 2006-ra várható GDP és annak 4 százaléka

V/4.5. sz. A tagjelöltek részesedése a belső piaci politikákra szánt támogatásból az 1998-as lakosságszám alapján

V/4.6. sz. Tíz tagjelölt ország teljes támogatási igénye az Európai Bizottság számításai szerint

V/4.7. sz. Tíz tagjelölt közvetlen költségvetési pozíciója teljesen egyenrangú elbánás esetén 
V/4.8. sz. Az egyes tagjelöltek várható befizetései és juttatásai a közösségi költségvetésböl 2005-2006-ban (1997-es becslés)

V/5.1. sz. Főbb kereskedelmi adatok az EU tagállamaiban és a tagjelölteknél 1998-ban I.

V/5.2. sz. Főbb kereskedelmi adatok az EU tagállamaiban és a tagjelölteknél 1998-ban II.

V/5.3. sz. A tíz közép- és kelet-európai ország kereskedelmi szerepe a német tartományok esetében (1997)

V/5.4. sz. Mimosa modellje szerinti növekedési hatás az

EU-tagállamok és a tagjelöltek számára 2012-re

V/5.5. sz. A tagjelöltek kereskedelmi hiánya az EU felé 1994-ben és 1998-ban

V/5.6. sz. A feldolgozott termékek, gépek és közlekedési eszközök és a mezőgazdasági termékek aránya az exportban 1998-ban

V/6.1. sz. Autópályák hossza és sürüsége az Európai Unióban és a jelölt országokban

V/6.2. sz. A vasúthálózat hossza és sürüsége az EU tagállamaiban és a tagjelölteknél

V/6.3. sz. ISPA 2000 közlekedési támogatás

V/6.4. sz. Vasúti, közúti, vízi és csővezetékes áruszállítás megoszlása (1994-1998)

V/6.5. sz. Áruszállítás összesített mutatója a tagjelölteknél és néhány EU-országban

V/6.6. sz. A társult országok és az EU vasúti személyszállítása 263

V/6.7. sz. A személyi légi közlekedés fejlődése a társult országokban

V/6.8. sz. Autóbusszal történő utazás változása a tagjelölt 266 országokban

V/6.9. sz. A személygépkocsik számának alakulása

V/6.10. sz. A tagjelöltek teljes beruházási igénye a közlekedési szektorban

V/6.11. sz. Költségek a nemzetközi közúti áruszállításban 1998-ban 
V/6.12. sz. A FÁK-országok és Törökország kereskedelmi szerepe az Európai Unió szemszögéből

V/6.13. sz. A transz-európai hálózatban kiemelt folyosók és az ehhez csatlakozó kiemelt területek

V/7.1. sz. Főbb mezőgazdasági paraméterek a tagjelölt országokban illetve a három mediterrán kohéziós tagországban I.

V/7.2. sz. Föbb mezőgazdasági paraméterek a tagjelölt országokban illetve a három mediterrán kohéziós tagországban II.

V/7.3. sz. Főbb növénytermesztési konjunktúraszámok (1997/1989) és az EU-hoz mért mennyiségi arányaik (1997)

V/7.4.sz. Főbb állati termékek konjunktúra számai (1997/1989) és az EU-hoz mért arányaik (1997)

V/7.5. sz. A tagjelöltek teljes és EU-val szembeni agrárkereskedelmi egyenlege

V/7.6. sz. Vámmentes kereskedelem aránya 2001. január elsejétöl

V/7.7. sz. A termelés és fogyasztás egyenlege a tíz tagjelöltnél a Bizottság értékei, illetve előzetes becslései alapján a föbb növénytermesztési területeken

V/7.8. sz. Termelés és fogyasztás egyenlege a tíz tagjelöltnél a Bizottság értékei és előzetes becslései alapján a legfontosabb állati eredetü élelmiszereknél I.

V/7.9. sz. Termelés és fogyasztás egyenlege a tíz tagjelöltnél a Bizottság értékei és előzetes becslései alapján a legfontosabb állati eredetű élelmiszereknél II.

V/7.10. sz. Mezőgazdasági termékek árának alakulása az EU-árak 289 százalékában (1994/1997)

V/7.11. sz. PSE százalékos ráta néhány tagjelölt országban

V/7.12. sz. Birtokformák szerinti termőföld megoszlás és ezek átlagos egységnagysága a 90-es évek közepén

V/8.1. sz. A közép-európai tagjelölt országok bérmutatói

V/8.2. sz. Az EU és a közép- és kelet-európai országok határmenti 303 régióinak az ingázás szempontjából lényeges paraméterei (1998) 
V/8.3. sz. Fizetések konvergenciája a magyar-osztrák határon

a jelenlegi felzárkózási ütem (alapszenárió), illetve ezt megduplázó felzárkózás (gyors felzárkózási szenárió) alapján

V/8.4. sz. Migrációs hajlandóság néhány országban 305

V/8.5. sz. A közép-európai tagjelölt országok lakosságának migrációs hajlandósága

306

V/8.6. sz. A közép- és kelet-európai polgárok előkészületei a migrációra (1998)

V/9.1. sz. Főbb energiahatékonysági mutatók a tagállamokban, illetve a társult országokban (1997)

V/9.2. sz. Az EU energiafelhasználási szerkezete energiaforrások szerint

V/9.3. sz. Az EU kőolajimportja eredet szerint (1999)

V/9.4. sz. Az EU földgázimportja eredet szerint (1999) 314

V/9.5. sz. A kőolaj- és földgáztartalék százalékos megoszlása a világon 1997-ben

V/9.6. sz. A teljes energiafelhasználás megoszlása 1998-ban az EU tagállamaiban és a tagjelölteknél

V/9.7. sz. Nukleáris erőművek a tagjelölt országokban

V/9.8. sz. Főbb energiahatékonysági mutatók a tagállamokban, illetve a társult országokban (1997)

V/10.1. sz. Az erdőterület aránya az egyes országok területéből, illetve a védett emlősök, halak, madarak aránya az ismert fajok százalékában

V/10.2. sz. Az $1 \mathrm{~km}^{2}$ szántóföldre jutó nitrogénmütrágya felhasználása (1999)

V/10.3. sz. 2001. évi környezetvédelmi fenntarthatósági index (ESI)

V/10.4. sz. $\quad \mathrm{A} \mathrm{CO}_{2}$, SO és NO kibocsátás mértéke a tagállamokban és a tagjelölteknél

V/10.5. sz. A tagjelöltek és a tagállamok néhány vízgazdálkodási mutatója a kilencvenes években 
V/10.6. sz. Egy före jutó kommunális hulladék egyes EU és tagjelölt országokban (1999)

V/10.7. sz. A teljes befektetési szükséglet a tagjelölteknél a környezetvédelmi területen az EU-elöírások figyelembevételével 


\section{RÉSZ}

\section{A BŐVÍTÉS GEOPOLITIKAI ÉS TÖRTÉNELMI HÁTTERE}

\section{RÉSZ; 1. FEJEZET \\ BEVEZETÉS}

1995. decembere, az Európai Unió madridi csúcsértekezlete óta elkezdődött az EU keleti irányú felvételi folyamata. Ez újabb lökést adott azoknak az elemzéseknek, gyakran politikai megnyilatkozásoknak, amelyek egyes fontos elemeket kiragadva és elemezve azt kívánták bizonyítani, hogy az EU bővülése miért hasznos az EU-nak, illetve a tagjelölteknek. Ezek az elemzések azonban mindig csak egy konkrét aspektust emeltek ki e témában, vagy csak egyes tagjelölt országok szempontjából vizsgálódtak. Eddig nem születtek olyan elemzések, amelyek az érdekeltségeket befolyásoló széles spektrumot elemezve vonják le a következtetéseket. További ürt jelentett az is, hogy általában arról készítettek elemzéseket, hogy a tagjelölt országoknak miért érdemes belépni az Európai Unióba. Ennek motivációi jobban ismertek, viszonylag széles körben kimutatásra kerültek a gazdasági, politikai és föleg költségvetési szempontok. Kisebb figyelmet kapott azonban annak az elemzése, hogy a sok ellentétes és gyakran kombinált hatásból milyen végső mérlege lehet az EU számára a bővítésnek.

Mivel a volt szocialista országok résztagságának elméleti lehetősége lényegében 1993-ban, az EU koppenhágai csúcsértekezletén lekerült a napirendröl, világossá vált, hogy az EU jelenlegi tagállamai számára a bővítés az integráció minden területét át kell hogy ölelje. Ez számukra értelemszerüen nemcsak pozitív, hanem negatív hatásokkal járhat, ami eredőjének összességében és tagországonként is pozitívnak kell lennie, hiszen ennek hiányában az EU nem kezdte volna el a bővítési folyamatot. Mivel a térség országai az Európa Tanács tagjai lettek, demokratikus átalakulásuk után gazdasági-társadalmi fejlődésnek indultak, néhányan (Magyarország, Csehország és Lengyelország) a NATO-ba is beléptek, nyilvánvalóvá vált, hogy az EU érdekeltségét nem morális, hanem tényleges politikai-gazdasági érdekek vezérlik. 
Az EU oldaláról megmutatkozó érdekeltségeket minden aspektus összevetésével elemeztem, ennek során az egyes történelmi, biztonságpolitikai, humán, gazdaságpolitikai, költségvetési szempontokat emeltem ki. A tagállamokra (és nem az EU egészére!) vonatkozó összehasonlító metodikával azt kívántam elérni, hogy a tagjelöltek felvétele kapcsán ne az EU-átlagokra hivatkozó, megítélésem szerint egyoldalú összehasonlítások jelenjenek meg.

Az értekezés fö vonala a tagjelöltek és a tagállamok közvéleményének valamint az uniós szakmai vagy politikai döntéshozók nézetének tükrében annak vizsgálata, hogy az egyes integrációs területeken a bővítésnek milyen hatásai vannak. Ennek analizálására dolgoztam ki egy kérdőívet, hogy szembesítsem a legfontosabb bővítési faktorok tudományos vizsgálatát a tényleges döntési érdekeltséggel.

Az egyes integrációs területek elemzésénél alapvetően a tagjelöltek felzárkózásának létét vagy hiányát jelző mutatószámokra, statisztikai adatokra támaszkodtam, az ebből kiolvasható trendek kimutatására törekedtem.

További módszertani elképzelésem volt, hogy a bővítés közvetett hasznát állítottam szembe a közvetlen költségekkel (vagyis a közösségi költségvetés várható kiadásaival). Az egyes tagállamokra és tagjelölt országokra lebontott elemzés arra is módot adott, hogy lássam a tagjelöltek közötti feltételezett felkészülési különbségeket.

Az egyes bővítési szakterületek (összesen 23 téma köré csoportosítva) elemzése azt is megmutatta, hogy mely területeken érdekelt, és melyeken kevésbé az Unió a bővítésben. Magyarázatot kerestem arra is, hogy miért vált néhány területen nehézkessé a csatlakozási tárgyalások lezárása.

Az értekezés megírása folyamán hangsúlyozottan támaszkodtam az Európai Unió intézményeinek anyagaira, megállapításaira, statisztikáira, mivel megítélésem szerint ez adhat objektív alapot arra, hogy az Unió bővítés iránti valódi érdekeltségét feltárjuk. Emellett elsősorban nemzetközi szakirodalmat igyekeztem feldolgozni. 


\section{RÉSZ; 2. FEJEZET}

\section{A BŐVÍTÉS HELYZETÉNEK ÁLTALÁNOS ÁTTEKINTÉSE, A BELÉPÉSRE VÁRÓ ORSZÁGOK ÉRDEKELTSÉGE A CSATLAKOZÁSBAN}

\section{I/2.1. A történelmi változások hatása az európai fejlődésre}

1989-91-ben kontinensünk keleti felében történelmi változások játszódtak le. Néhány év alatt összeomlott a térségben uralkodó szocializmus, kivonásra kerültek a megszálló szovjet alakulatok, felszámolásra került a NATO-ba való német belépéskor 1955-ben létrehozott Varsói Szerződés politikai és katonai szervezete. Megszünt a KGST, a térség országai világpiaci árakon, konvertibilis valutában kereskedtek egymással. 1991 végén összeomlott maga a Szovjetunió is, maga alá temetve a térség minden országában a szocialista társadalmi rendszert. Függetlenné váltak először az 1940-ben bekebelezett balti államok, majd a többi szovjet tagköztársaság is, így a térségünkkel közvetlenül szomszédságban lévő Belorusszia, Ukrajna, Moldova is. A változások sorát Jugoszlávia - háborús helyzetben megvalósult - szétesése követte 1991-92-ben, melynek fö oka az volt, hogy a szocialista világrendszer általános európai kudarcával párhuzamosan a mesterségesen összetákolt államalakulat népei - történelmi, vallási és kulturális különbségek miatt más kibontakozási modellt képzeltek el, ami a nyugat-orientált szlovén és horvát állam számára csak a függetlenség kivívásával volt megvalósítható. A nagy változások sorát 1992 végén Csehország és Szlovákia békés szétválása fejezte be, mely megteremtette a fejlettebb Csehország számára a gyorsabb fejlődés lehetőségét, míg Szlovákia történelme folyamán először független országként vehette kezébe sorsának irányítását.

A történelmi változások sora azonban itt megállt, hiszen nem került sor a kalinyingrádi (königsbergi) terület státuszának megváltoztatására, maradt Litvánia és Lengyelország közötti enklávéként Oroszország része. Nem jött létre a román politika által hangoztatott két román állam - Románia és Moldova - egyesülése sem, és érintetlen maradt a történelmileg nyugat-orintált Erdély, Vajdaság vagy Nyugat- 
Ukrajna helyzete is, ezek még területi autonómiát sem tudtak kivívni maguknak. 1992 után már csak a Nyugat-Balkánon zajló háborús viszonyok után jöttek létre új státuszok (Dayton következtében Bosznia-Hercegovinában 1995 végén, illetve 1999ben Koszovóban és 2002-ben várhatóan Montenegró-Szerbia kapcsolatában), de ez az EU kibővítésének kérdését csak közvetetten és nem közvetlenül érintette a kilencvenes években.

Az új helyzetben a létrejövő fiatal demokráciák azonnal történelmi gyökereiket keresték, vagyis Európa és az Egyesült Államok felé orientálódtak, amit csak segített az a tény, hogy egymásra támaszkodni - a gazdasági és politikai csődhelyzet miatt csak korlátozottan tudtak. A térségben újra felszínre törtek a tradicionális nyugatorientáltság hullámai, az 1940-es években megszakadt természetes kapcsolatok visszaállításának igénye, végső soron az integráció megvalósítása.

A várt áttörés azonban váratlanul érte a Nyugatot. Sem a NATO, sem az Európai Unió nem volt arra felkészülve, hogy azonnali bővítéssel felkarolja a vákuumba került térséget. Ráadásul a rendszerváltás nyomán megvalósult német egyesülés sem a legkedvezőbb képet mutatta, hiszen a vártnál nehezebbnek bizonyult az új országrész politikai, mentális és gazdasági integrációja. (Még a kilencvenes évek végén is jelentős volt a különbség az új és a régi tartományok között annak ellenére, hogy a német állam évente bruttó 130 (1991) és 189 (1998) milliárd DEM közötti összeggel támogatta az új tartományokat - a Német Statisztikai Hivatal 1999. Évi adatai szerint -, amihez az EU költségvetéséből is jelentős összeg társult. A keletnémet tartományok gazdasági felzárkózása lelassult, gazdasági fejlettségük az egy főre jutó vásárlóerő paritáson mérve az évtized végén is csak az EU 70 százaléka körül mozgott). Az óvatos észak-atlanti és nyugat-európai közösség ezért a felé forduló térség gyors integrálása helyett politika és gazdasági nyitásról döntött az évtized elején, mely irányt és lehetőséget kívánt adni az új demokráciáknak, vagyis el akarták kerülni a visszarendeződést, ami a nyugati világ biztonságát is veszélyeztette volna. Ezért 1990-ben kezdte meg az EU az Európai Megállapodások révén a lehető legliberálisabb piacnyitást megadni a térség országainak. Ezzel párhuzamosan a NATO is megnyitotta politikai konzultációs mechanizmusait 1991ben. Így a két nagy integrációs szervezet időt nyert, hiszen a kilencvenes évek elején lényeges minőségi változásokat kellett magán belül is végrehajtania. A NATO új 
Stratégiai Koncepciót dolgozott ki a hidegháború utáni időszakra, míg az Európai Unió ekkoriban tárgyalta a Maastrichti Szerződés megszületéséhez vezető új európai modellt. Ez utóbbi szerződés megvalósította a hagyományos közösségi kötelékek kiterjesztését, így a közös kül- és biztonságpolitika, bel- és igazságügyi együttmüködés létrehozását, valamint történelmi eredményként a Gazdasági és Pénzügyi Uniót, beleértve a legkésőbb 1999-ben létrehozandó közös európai pénzt. 1989 őszén az EK és az Európa Tanács közötti együttmüködés során - erre utalt az 1989. Novemberi velencei egyeztetés - nyilvánvalóvá vált, hogy a strasbourgi szervezet lesz az európai integráció elöszobája, az új demokráciák európai típusú demokratikus fejlődésének segítője, de egyúttal mércéje is. 1990 őszétől kezdődően megkezdődött a volt szocialista országok csatlakozása az Európa Tanácshoz, amely folyamat az évtized közepére teljesen le is zárult.

1993 után nyilvánvalóvá váltak a fentiekben vázolt fejlődés geopolitikai vonulatai, vagyis láthatóvá vált, hogy a közép-európai térség szilárd és nyugat-orientált demokráciává alakult, súlyos gazdasági nehézségeik ellenére sem omlottak össze és nem kerestek kiutat a keleti - pl. orosz-vezetésü - integrációban, de együttesen nem tudtak egy önálló közép-európai integrációs modellt - a nyugati integráció alternatívájaként - megvalósítani. (Az 1991-ben létrehozott Visegrádi Megállapodás négy olyan ország politika együttmüködési kerete, amelyben a legfejlettebb és egyben EU-val határos országok elsősorban a nyugati orientáció céljából müködnek együtt, és az eredetileg általuk létrehozott CEFTA - Közép-Európai Kereskedelmi Társulás - is csak kiegészítője és nem helyettesítője az európai integrációs igényeknek.)

Mindezek után az Európai Uniónak el kellett gondolkodnia a térséggel kapcsolatos integrációs stratégiáján. Ezért a maastrichti folyamat sikerének láttán már adottak voltak a feltételek ahhoz, hogy szorosabb együttmüködés mellett perspektívát adjanak a közép- és kelet-európai régió országainak. 1993 júniusában ezért a koppenhágai csúcsértekezleten az EU kimondta, hogy megnyitja kapuit azon térségbeli országok előtt, amelyek csatlakozni akarnak, és teljesíteni tudják azokat a politikai és gazdasági feltételeket, amelyeket ekkor megszabott: demokratikus jogállamiság, emberi és kisebbségi jogok tiszteletben tartása, müködő piacgazdaság, versenyképesség a belső piacon, a közösségi vívmányok - beleértve a politika és 
gazdasági uniót - teljes elfogadása. A feltételek közé sorolta azt is, hogy a bővítésre csak akkor kerülhet sor, ha az Unió erre fogadóképes lesz. Az EU a maga részéről ezt a kritériumot az Amszterdami Szerződéssel (1997) és a Nizzai Szerződéssel (2001) intézményi oldalról teljes mértékben megvalósította. Pénzügyi oldalról az 1999 tavaszán megtartott rendkívüli EU-csúcstalálkozón elfogadott kompromisszum - az Unió finanszírozásának biztosítása 2006 végéig, beleértve hat tagjelölt ország (Lengyelország, Szlovénia, Csehország, Magyarország, Ciprus, Észtország) felvételéhez szükséges pénzügyi feltételek megteremtését már 2002-től - szintén biztosította a bővítéshez nélkülözhetetlen hátteret. Ugyanakkor azt is beépítették az előfeltételek közé, hogy csak az Európai Megállapodással rendelkező országokkal lehet szó bővítésről, és azt, hogy mely országnak ajánlják fel az ilyen megállapodásra szóló lehetőséget, azt az EU határozza meg. Ilyen típusú megállapodást csak tíz régióbeli országnak (Lengyelország, Észtország, Csehország, Magyarország, Szlovénia, Szlovákia, Lettország, Litvánia, Románia, Bulgária) ajánlott fel. Az első öt országgal és Ciprussal - az ún. „luxemburgi csoporttal” - 1998 márciusa, míg a második öt országgal és Máltával - az ún. „helsinki csoporttal” - 2000 márciusa óta folytat az Európai Unió tárgyalásokat. Ettől eltérő szerződési formát - Partnerségi és Együttmüködési Megállapodás - kötött a volt FÁK-országokkal (esetükben ígéret sincs a tagságra), valamint 2001-től Stabilitási és Társulási Megállapodás megkötését tervezi a Nyugat-Balkán országaival (Albánia, Jugoszlávia, Macedónia, Horvátország, Bosznia-Hercegovina), amely potenciális tagjelöltként definiálja a szerződő partner országokat. (Ezt a megállapodást 2001 végéig Macedóniával és Horvátországgal már aláírták, de még egyiket sem ratifikálták.) Ezek a külkapcsolatokra vonatkozó szerződési rendszerek kijelölik az Európai Unió jövendő határait, hiszen 10-15 éven belül a volt szocialista térségből 10-15 ország lehet az európai integráció tagja. Természetesen napirendre tüzték még más országok felvételét is, így a két földközi-tengeri szigetország - Málta és Ciprus -, valamint Svájc és Norvégia belépését is, de ez utóbbiak esetében a lakosság integrációs akaratától függ a bővítés sikere.

A térség integrációs képességét jelzi az is, hogy a NATO-ban 1994-től megnyitott tényleges katonai és biztonságpolitikai együttmüködési forma (Partnerség a Békéért) minden közép- és kelet-európai tagjelölt részéről szintén aláírásra került, sőt a tíz tagjelöltből három (Lengyelország, Csehország és Magyarország) 1999 márciusában 
a NATO tagja lett. A többi hét ország célja is ugyanez, hiszen a tagsági elökészületekre létrehozott MAP-programnak (Membership Action Plan) 1999 óta szintén részesei Albániával, Macedóniával együtt. (Az integrációs párhuzamosságot jelzi, hogy mind a NATO-ban, mind az EU-ban 2002-ben lehet arról szó, hogy Horvátország tagjelölti státuszért folyamodjon.)

A bővítés egyik legnagyobb előnye az EU számára - gazdasági, kulturális, politikai nehézségei mellett -, hogy az új tagállamok (az ún. koppenhágai kritériumok alapján) át kell hogy vegyék a közösségi vívmányok teljes körét. Ez nem zárja ki a rövidebb-hosszabb (általában tíz évnél rövidebb) átmenet lehetőségét, de állandó kivételt nem kaphatnak, és nem is kérhetnek, ami az EU integrációs kohézióját erősíti. A koppenhágai kritérium teljesítését könnyíti az is, hogy az új belépő országok katonailag sohasem voltak semlegesek és mindannyian részesei kívánnak lenni a közös valutának illetve a schengeni rendszernek. Ez különösen hasznos akkor, ha tudjuk, hogy az uniós védelempolitika mélyítését behatárolhatja az a tény, hogy a jelenlegi tagállamok között négy katonailag semleges ország (Svédország, Írország, Finnország, Ausztria) található, és Dánia már most sem kíván konkrét müveletek szintjén részt venni a kibontakozó védelempolitikai, katonai válságkezelési tevékenységben. Ezen túlmenően számos állandó kivétel vagy azt tükröző helyzet található meg az integráció fejlődése szempontjából kiemelkedő fontosságú területeken, így a bel- és igazságügyi területen, schengeni együttmüködésben vagy az európai polgárság elismerésében (Nagy-Britannia, Írország, Dánia), illetve az euróövezethez való csatlakozásban (Nagy-Britannia, Dánia, Svédország).

A bővítés megváltoztatja az EU geopolitikai, világpolitikai, valamint világgazdasági helyzetét is. A tíz ország felvétele esetén az EU lakossága az 1999-ben mért 375 millió főről (kerekítve) 480 millió före (28 százalékkal) emelkedik, ami messze meghaladja az Egyesült Államok 271 millió fős lakosságát (Eurostat, [2001]).

1999-ben az EU GDP-je (kerekítve) piaci árakon 7974 milliárd euró volt, ez a 10 országgal való bővüléssel további 342 milliárddal növekszik és eléri a 8316 milliárd eurót, ami 4,3 százalékos növekedésnek felel meg (Eurostat [2001]). Gyakran hangoztatott megjegyzés, hogy a 10 közép- és kelet-európai tagjelölt ország GDP-je 
együttesen nem éri el a holland GDP-t (1999-ben ez mintegy 370 milliárd euró volt). Ez az oka annak, hogy még a bővülés után is az Unió alatta marad a legnagyobb gazdasági erőt képviselő ország, az Amerikai Egyesült Államok gazdasági teljesítményének (8725 milliárd euró 1999-ben). Igaz, a bővítés után megközelíti azt, és mintegy kétszerese lesz a japán GDP-nek (1999-ben 4081 milliárd euró) (Eurostat, [2001]).

Az Unió földterülete 33 százalékkal fog bővülni a 10 tagjelölt csatlakozásával, ami meghaladja a lakosság növekedésénél regisztrált 28 százalékot. Ezek a számok azonban a bővülés általános geopolitikai jelentőségét mutatják, nyilvánvalóan a szektorális mutatószámoknál ettől eltérő eredményeket kapunk (például a mezőgazdaságilag művelt területek aránya a bővítéssel 44 százalékkal nő majd). Mindez azt jelenti, hogy egyes, lélekszámtól függő területeken a bővítés statisztikai súlya jelentősebb (például kutatók vagy fegyveres erők létszáma, a mezőgazdasági termelés potenciálja, a szárazföldi közlekedés adottságai), míg más, föleg anyagi forrásokban mérhető szinteken (ipari vagy szolgáltatási szektor gazdasági teljesítménye, nominális bérek alakulása) a bővítés súlya kisebbnek tűnik.

\section{I/2.2. A csatlakozás előnyei a tagjelölt országok számára}

Dolgozatom elsősorban azt kívánja bemutatni, hogy az Európai Unió számára milyen haszonnal jár a bővítés. Ennek nyereséges voltát szakmai körökben megkérdőjelezik, hiszen a leendő tagállamok részben a több évszázados történelmi lemaradásnak köszönhetően, részben az utóbbi ötven év eredményeképpen nemcsak gazdaságilag, hanem társadalmilag és a humánterületeken is jelentős hátránnyal küszködnek. Ezért nem látható minden EU-ország polgára számára, hogy a történelmi újraegyesítés jelszavai mögött tényleges gazdasági érdekek is amellett szólnak, hogy a bővítést végigvigyék. Ez azt jelenti, hogy alapfeltételezésem szerint a bővítés közvetett gazdasági haszna és biztonsági előnyei meghaladják a bővítés közvetlen költségeit. Az EU számára a nyereséges szaldó már a belépés után megjelenik, és a tagjelöltek csatlakozás utáni felzárkózásával csak növekedni fog.

A csatlakozó országok szemszögéből vizsgálva érdekeltségüket, egyszerübb a képlet, ha azt kutatjuk, hogy milyen faktorok szólnak a belépés mellett. Mivel 
dolgozatomban nemcsak elméleti síkon, hanem konkrét statisztikai adatok segítségével is jellemzem azokat a területeket, amelyekben a tagság a belépés után mindkét fél számára pozitív hozadékot adhat, ezért itt csak felsorolásszerủen emelem ki azokat a legfontosabb tényezőket, amelyek a tagjelöltek részéről a belépés mellett szólnak:

a) Az Európai Unió integráns részeként a történelemben először Nyugat-Európa is felelősséget vállal és védelmet ad a közép-európai térségnek a keletről jövő különböző veszélyekkel szemben. Az egységes schengeni rendszer, a közös bevándorlási vagy várhatóan határőrizeti politika, egységes igazságügyi térség kiépítése, avagy a közös kül- és védelempolitika ezt elkerülhetetlenné teszi. Ez természetesen kötelezettségeket ró a tagjelöltekre is, vagyis a szolidaritáson alapuló egységes menekültpolitika - adott esetben menekültelhelyezés - megvalósulásakor a jelenleginél nagyobb terheket kell vállalniuk.

b) Európa újraegyesítésének folyamata valósul meg, vagyis a természetellenesen szétválasztott kontinensen a közös értékek mentén történhet meg a felzárkózás. Ez a humánterületek illetve a biztonságpolitikai hatások elemzésénél látható, hiszen az azonos, nyugat-európai típusú keresztény gyökerekre és értékekre épülő társadalmak integrációja esetén könnyebb lesz a belépők felzárkózása. (Lásd etika és tolerancia azonosságai, szolidaritás hasonló felfogása, az emberi jogokhoz való viszonyról szóló fejezeteket.)

c) A tagjelölt országok most is nagymértékben függnek az Európai Unió döntéseitől, hiszen kereskedelmi és gazdasági kapcsolataik alapvetően ide kötik őket. A társult országok számára minden esetben az Európai Unió jelenti a legfontosabb kereskedelmi partnert, hiszen az Unió aránya a külkereskedelmükben meghaladja, vagy megközelíti az 50 százalékot, bizonyos esetekben 60-70 százalék közötti, ami több mint néhány EU-tagállam hasonló mutatója (pl. Nagy-Britannia, Svédország) (lásd: V/5. sz. fejezet). Mivel a tagjelöltek exportja az EU-ba rendkívüli fontossággal bír gazdasági fejlődésük szempontjából, lényeges előny lesz az, hogy az Unióba történő kivitelük a tagság után nem ütközik nem kereskedelmi jellegü (pl. müszaki elöírások, különleges eljárási követelmények) akadályokba. 
Ugyancsak nagy a függőség a gazdasági kapcsolatok más területein is, hiszen a jelenlegi müködőtőke vagy portfólió befektetések döntő többsége az EU-ból érkezik a térségbe. Ugyanez érvényes a tranzittevékenységböl származó bevételekre, vagy a turizmus fontosságára, de a kutatási-fejlesztési együttmüködések nyitotta lehetőségekre is. A tagjelölt országok számára előnyös olyan döntéshozatali mechanizmus részesévé válni, melynek következményeihez mindenképpen alkalmazkodniuk kell (ld. árutermékek áramlása), hiszen e nélkül nem lehetne sem az EU áru vagy munkaerőpiacára lépni, sem pedig az ottani tőkét vonzani. A döntéshozatali mechanizmusba való bekapcsolódásnak két nagy előnye lesz:

1. a tagjelölt országok már az előkészítés során tudni fogják - közösségi alkalmazottként dolgozó állampolgárainak vagy a Bizottság tanácsadó vagy jogszabály-elökészítő munkabizottságaiban való részvétele révén, de a tanácsi vagy parlamenti előkészítő vita kapcsán is -, hogy milyen jogszabály készül, azt már az előkészítő fázisban meg lehet ismerni.

2. a döntéshozatalban megfelelő befolyásolási lehetőségük lehet. Egyrészt stratégiai kérdésekben hosszú távon is megmarad a konszenzus elve (alapszerződések módosítása, döntéshozatali formák megváltoztatása, vagy a bővítés kérdése), másrészt tíz országgal történő bővülésnél nehezen alakítható ki legtöbb minősített többségü kérdésben az új tagállamok mindegyikének rovására a kétharmados többség (ld. intézményi kérdések fejezet). További előny, hogy a nagy tagállamok érdekérvényesítéséhez - a konszenzus elv visszaesése miatt - mindig szükség lesz egymással szemben is a kisebb tagállamok támogatására alapvető vitás kérdések eldöntéséhez. Ekkor értékelődik fel a kisebb tagállamok - így az új belépők - szavazata is, amivel hatással lehetnek a számukra úgyis meghatározó döntések kimenetelére. Kétségtelen ugyanakkor, hogy a tagság miatt néhány esetben olyan döntéseket is végre kell hajtani, mely egy felzárkózó ország számára nem mindig könnyen felvállalható, illetve hosszabb átmenettel tudnak csak megoldani. Ilyen például a környezetvédelmi szabályozás néhány kérdése - főleg ami a vállalati magatartást illeti -, a belső piacon abszolút értékben meghatározott küszöbkötelezettségek, amelyek a gyengébb vállalati pozíciók vagy a lakosság alacsonyabb fizetőképessége miatt gondot okozhatnak. 
d) Az új tagállamok az EU átlagánál, sőt Szlovénia és Ciprus kivételével az EUtagországok mindegyikénél alacsonyabb gazdasági teljesítményüek. (Lásd a gazdasági fejlettségről szóló fejezetet). Ezért a felzárkózáshoz fontos számukra a lehető legteljesebb piacnyitás, valamint az a transzfer, amit az EU közös költségvetéséből kapnak. Ez az összeg - melyre az EU 2006-ra nettó 16,8 milliárd eurót számol hat belépő országra (ún. luxemburgi csoport) vonatkozóan, (nézetem szerint a teljes bővülés esetén ez kb. évi 25 milliárd euró lesz; ld. a bővítés költségvetési fejezete) hatalmas lökést adna a térség fejlődéséhez, hiszen az EU által elkülönített ráfordítás a térség 1999-ben mért GDP-jének mintegy 5 százaléka. Ezzel - a felzárkózási ütem tartása mellett - saját forrásból nagyobb pénzösszegeket tudnak fordítani szociális, egészségügyi, oktatási célokra. A regionális és szociális kohézióról írott elemzésem azt is megmutatja, hogy igazán csak a közösségi támogatás segíthet a leginkább leszakadt területek és rétegek felzárkózásához, vagyis a bővítés nélküli makrogazdasági felzárkózás a tagjelölt országokon belül belső polarizációval járna. A közösségi támogatások segítenek olyan beruházások végrehajtásában is (pl. környezetvédelem, schengeni külső határok kialakítása), amelyeket a tagjelölt országoknak egyébként is meg kell valósítaniuk, saját lakosságuk védelme érdekében. A kohézión kívüli másik lényeges jövedelemtranszfer a mezőgazdaságot érinti, ahol a jelenlegi gyenge gazdasági lábakon álló termelők feltőkésítése - főleg a közvetlen kifizetések révén - csak a közösségi források bevonásával lehetséges (ld. agrárfejezet). Jelentős összeg érkezik a közösségi programokba való bekapcsolódásuk révén is, ahol főleg a kutatási területek fognak számottevő közösségi támogatásban részesülni. Nehézséget fog azonban a tagság első éveiben jelenteni az, hogy a közösségi befizetések az államkasszát terhelik, míg a transzferek a régióknál, illetve gazdáknál jelenik meg elsősorban.

e) A felzárkózó országok számára haszon lesz az is, hogy a közös pénzügyi unióba belépve minimális lesz a spekulációs kihívás valutájuk ellen, jelentősen csökkenthetik devizatartalékukat, a magas integráltság miatt mentesülnek az átváltási költségektől, profitál a turizmus is. (A Magyar Nemzeti Bank 2001. decemberében 0,3-0,6 százalékos GDP-növekedést jósolt az euró bevezetésének hatására.) Hátrányos lesz viszont a gazdaságpolitikai önállóság részbeni elvesztése (pl. az árfolyam-mechanizmus révén, de az adópolitika egyre több területén is), ami a 
felzárkózás eszköztárát szükíti. Az uniós tagság és a Monetáris Unióba való kötelező belépés csökkenti a közösségi befektetők kockázatát, ami további pótlólagos befektetéseket hoz. Ezt támasztja alá az előző bővítési körök tapasztalata Görögországban, Spanyolországban és Portugáliában, vagy Írországban, vagyis az ún. kohéziós tagállamokban (Grabbe, [2001]), de kisebb befektetési rizikó okozta pótlólagos befektetési prémiumot elemzett Baldwin is, amelyet dolgozatomban szintén megemlítek.

f) A makrogazdasági felzárkózás, a versenyképesség és a munkaerő termelékenységének további növekedése elősegíti azt is, hogy a tagjelöltek lakosságának munkabére növekedjen. Ez hozzájárul a lakosság egészségügyi, demográfiai, oktatási színvonalának erősödéséhez, és segíti hazájukban maradásukat azokban az országokban, ahol magas a migrációs hajlam (Lengyelország, Románia, Baltikum).

g) Alkalmazkodó képességtől függően profitálhat az új tagállamok agrárszférája a belépésből. Mivel itt a teljes liberalizációt valószínüleg csak a tagság hozza meg, a szintén túltermelő európai és közép-európai országok integrációjából a piaci rostálás alapján lesznek jelentős vesztesek is. Megszünik az a bizonytalanság, hogy az EU állat- vagy növény-egészségügyi okokból vagy más nem kereskedelmi jellegü feltételekre hivatkozva a tagjelöltektől érkező agrárimportra megszorításokat alkalmaz. Megszünik továbbá az EU magas agrárexport-szubvenciója a tagjelölt országokba irányuló mezőgazdasági kivitelére.

h) A közösségi versenyszabályozás átvétele általában segíti a tagjelölt országokat, mivel a tagság jelentette garancia segítheti kiváltani azokat a kedvezményeket, amelyeket a belépés időpontja miatti bizonytalanság következtében kell adniuk hazai vagy külföldi vállalatnak vagy befektetőknek. Ugyanakkor ez kizárja a nem kompatibilis támogatások lehetőségét, ami tradicionális hazai vállalkozások eltűnésével (ld. acél vagy légiforgalmi társaságok, bizonyos agrártermelők) járhat.

i) Az egyik legnagyobb hasznot a térség tranzit jellege miatt a csatlakozó országok közlekedési szektora fogja húzni, de ezt árnyalja, hogy a belépés után sok fuvarozási vállalkozó a versenykihívás miatt csődbe juthat. Másrészt a belső piacon nagyobb 
megterhelést kap a csatlakozó országok szállítási hálózata és környezete, igaz ennek mérséklésére közösségi támogatást kap, ami a közlekedési infrastruktúra fejlesztését segíti.

Mindezek odavezetnek, hogy a csatlakozó országok számára nemcsak a közvetlen költségvetési haszon jelentős, hanem az integrációból eredő közvetett (a gazdasági szereplőknél lecsapódó) profit is. Ez utóbbira példa, hogy kutatóintézetek megvizsgálták a gazdasági - elsősorban kereskedelmi - területeken várható hasznot a két fél számára és arra a következtetésre jutottak, hogy a csatlakozó országok számára jelent nagyobb előnyt a belépés. Baldwin, François és Portes 1997-ben például a belépésnél 15 százalékos kockázati prémiumcsökkenést jósolva a középeurópai országoknak - baltiak nélkül - mintegy 30 milliárd euró hasznot jósoltak a tagságból eredően. Mimosa 1996-ban, a francia szenátus anyagában publikált felmérése a tagjelöltek számára 1 százalék körüli pótlólagos gazdasági növekedést (29,4 milliárd euró) jelölt meg. 2001 novemberében a WIFO szintén 1 százalékos pótlólagos növekedést jósolt a tagjelölt országok - különösen Lengyelország és Magyarország - számára, ami valamivel meghaladja a 30 milliárd eurót. Mindezek meglehetősen egybehangzó elörejelzések arra vonatkozóan, hogy a tagjelölt országok mérhető pótlólagos gazdasági növekedése a tagság révén igen jelentős lesz. Mindehhez járul a közösségi költségvetésből származó közvetlen transzfer is, melyre az uniós pénzügyi irányelv 2006-ra az említett 16,8 milliárd eurót különíti el. Teljes jogú, azonos kezelés szerinti juttatás esetén a felvett országok számától függően további 20-25 milliárd euró közötti összeg kerül át a közösségi költségvetésböl a tagjelöltekhez, így összességében a gazdasági haszon meg fogja haladni 2006 körül az 50 milliárd eurót. 


\section{RÉSZ; 3. FEJEZET \\ A KAPCSOLATOK TÖRTÉNELMI DIMENZÓI \\ A KÖZÉP- ÉS KELET- EURÓPAI RENDSZERVÁLTÁS ELŐTT}

\section{I/3.1. Gazdaságtörténelmi vonatkozások}

Az európai földrész egyesítése - modern kifejezéssel integrációja - már régóta foglalkoztatta az európai nemzeteket. Ennek előfutáraként Nagy Károly Verduni Szerződését szokás emlegetni, de a későbbi középkorban is több szerzőnél, így a rotterdami Erasmusnál is megjelenik az európai egyesülési folyamat gondolata. Később ez az elképzelés - az európai fejlődés, a földrajzi felfedezések, a közlekedés és így a kereskedelem kibontakozásával - egyre élesebben jelent meg a modern gondolkodók körében is, így a századfordulós Monarchiában, majd később Németországban (1914-ben Rathenau), sőt az első világháború után Franciaországban is, pl. 1925-ben Briand elnök pán-európai gondolata révén. A világgazdasági nyitás elsősorban akkor vált jelentőssé, amikor a technikai fejlődés révén lehetővé vált a földrajzi alapon megvalósuló, alapvetően komparatív előnyöket alkalmazó kereskedelem. Már ebben a korban jelentős volt Európa nyugati és keleti fele közötti kapcsolatrendszer, bár ez a müvészeti és politikai kapcsolatokon túlmenően gazdasági téren már jelzett egyfajta alá- és fölérendeltségi viszony megjelenését - a második jobbágyság korának megfelelő szakosodást -, ami a kontinens két felének viszonyrendszerét azóta is meghatározza. Ennek köszönhetően az I. világháborúig komoly gazdasági fejlődés és ennek nyomán kereskedelmi kapcsolatrendszer jelent meg a kontinensen.

Az I. világháború utáni kereskedelem visszaesése (I/3.1. sz. táblázat) érzékeltette hatását a közép- és kelet-európai országok gazdasági fejlödésére, hiszen rendkívül protekcionista tendenciák érvényesültek a 20-30-as években. Ennek ellenére a középés kelet-európai országok megfelelő beágyazottsággal rendelkeztek az európai gazdasági rendszerben, mint azt a I/3.2. sz. táblázat is jelzi. 
I/3.1. sz. táblázat: A világkereskedelem és a világtermelés változásai (százalék)

\begin{tabular}{|c|c|c|}
\hline Évek & Világkereskedelem & Világtermelés \\
\hline $1705-85$ & - & 1,5 \\
\hline $1720-80$ & 1,10 & - \\
\hline $1780-1830$ & 1,37 & 2,6 \\
\hline $1820-40$ & 2,81 & 2,9 \\
\hline $1840-60$ & 4,84 & 3,5 \\
\hline $1860-70$ & 5,53 & 2,9 \\
\hline $1870-1900$ & 3,24 & 2,7 \\
\hline $1900-13$ & 3,75 & 4,2 \\
\hline $1913-29$ & 0,72 & 2,7 \\
\hline $1929-38$ & $-1,15$ & 2,0 \\
\hline $1938-48$ & 0,00 & 4,1 \\
\hline $1948-71$ & 7,27 & 5,6 \\
\hline $1971-74$ & 8,31 & 6,8 \\
\hline $1974-80$ & 4,15 & 3,6 \\
\hline $1980-86$ & 2,94 & 2,7 \\
\hline
\end{tabular}

Forrás: Szentes Tamás: A világgazdaságtan elméleti és módszertani alapjai, Aula, [1995]

I/3.2. sz. táblázat: Az EK és az EFTA jelenlegi tagállamaival folytatott kereskedelem aránya a teljes kereskedelmen belül, illetve az európai exportkereskedelemböl való részesedés 1928-ban és 1991-ben (százalék)

\begin{tabular}{|l|c|c|c|c|}
\hline Ország & $\begin{array}{c}\text { EU - EFTA } \\
\text { országok } \\
\text { részesedése a } \\
\text { kereskedelemben } \\
\text { 1928-ban }\end{array}$ & $\begin{array}{c}\text { EU - EFTA } \\
\text { országok } \\
\text { részesedése a } \\
\text { kereskedelemben } \\
\text { 1991-ben }\end{array}$ & $\begin{array}{c}\text { Részesedés az } \\
\text { európai } \\
\text { exportból } \\
\mathbf{1 9 2 8 - b a n}\end{array}$ & $\begin{array}{c}\text { Részesedés az } \\
\text { európai } \\
\text { exportból } \\
\mathbf{1 9 9 1 - b e n}\end{array}$ \\
\hline Csehszlovákia & 70 & 52 & 4,2 & 0,7 \\
\hline Magyarország & 65 & 55 & 1,0 & 0,7 \\
\hline Lengyelország & 75 & 53 & 1,9 & 1,0 \\
\hline Bulgária & 85 & 48 & 0,3 & 0,2 \\
\hline Románia & 68 & 45 & 1,1 & 0,3 \\
\hline
\end{tabular}

Forrás: R. Baldwin: az EFTA keleti bővítése, London [1992]

Megjegyzés: A szerző a Népszövetség és az IMF adataira támaszkodó mérései alapján Az EK és EFTA 1928-ban nem létezett, a táblázat a később ezeket a szervezeteket alkotó országokra vonatkozik. 
A táblázatból kiolvasható következtetést alátámasztja az is, hogy a WIFO adatai szerint 1924-ben az osztrák import 29,5, 1937-ben 20,7 százaléka áramlott a középkelet-európai térségből, amely még az ezredfordulón regisztrált értéknél is jóval magasabb hányad, hiszen 1989-ben csak 4,4, 1998-ban pedig a 10 százalékot sem haladta meg (WIFO, [1996]). Mindez szerves kapcsolatrendszert jelez 1945-ig Európa két fele között, amit Európa kétpólusúvá szakítása akasztott meg. Igaz, a két világháború közötti korszakban a gazdasági fejlettség eltérése sem volt annyira jelentős, ellentétben a II. világháború utáni időszakkal.

I/3.3. sz. táblázat: Az Európai Unió jelenlegi tagjainak és jelöltjeinek fejlettségi szintje 1938-ban és 1990-ben (1 forre jutó GDP alapján)

$(E U-15=100)$

\begin{tabular}{|l|r|r|r|}
\hline \multicolumn{1}{|c|}{ Ország } & $\mathbf{1 9 3 8}$ & $\mathbf{1 9 5 0}$ & $\mathbf{1 9 9 0}$ \\
\hline Bulgária & 37 & 36 & 36 \\
\hline Csehszlovákia & 67 & 76 & 52 \\
\hline Magyarország & 62 & 54 & 39 \\
\hline Lengyelország & 51 & 53 & 32 \\
\hline Románia & 29 & 26 & 21 \\
\hline Ausztria & 84 & 83 & 104 \\
\hline Belgium & 111 & 117 & 104 \\
\hline Dánia & 130 & 143 & 111 \\
\hline Finnország & 82 & 91 & 110 \\
\hline Franciaország & 104 & 113 & 103 \\
\hline Németország & 120 & $93 *$ & 116 \\
\hline Görögország & 64 & 39 & 62 \\
\hline Írország & 73 & 74 & 69 \\
\hline Olaszország & 64 & 78 & 99 \\
\hline Hollandia & 120 & 124 & 103 \\
\hline Portugália & 40 & 41 & 66 \\
\hline Spanyolország & 47 & 61 & 75 \\
\hline Svédország & 111 & 146 & 109 \\
\hline Egyesült Királyság & 140 & 150 & 101 \\
\hline
\end{tabular}

Forrás: Maddison [1995], Brücker [2000]., Az ENSZ 2000. Évi Gazdasági Felmérése és saját kalkulációk alapján

Megjegyzés: * Nyugat-Németország 
Mint a I/3.3. sz. táblázatból látható, a volt Csehszlovákia és Magyarország a II. világháború előtt elérte vagy meghaladta bármelyik mediterrán tagállam akkori fejlettségi szintjét, sőt Ausztriától vagy Finnországtól való elmaradásuk sem volt jelentős. Ez a felzárkózás történelmi tartalékait jelzi, amit természetesen a mai viszonyok között fenntartással kell kezelni, de egy esetleges természetes potenciálra utaló jelnek mindenképpen lehet tekinteni.

\section{I/3.2. Kapcsolatok fejlődése a hidegháború időszakában}

A háború utáni helyreállításban 1945-47 idején mindkét oldalon eredmények övezték az erőfeszítéseket, hiszen ekkor sikerült elkerülni az éhezést, a termelést is beindították. Ebben szerepe volt annak a négymilliárd dollárnak, amit az UNRRA-n keresztül az Egyesült Államok juttatott a kontinensre. Ezután azonban két olyan esemény következett be, amely a kontinens két felét eltérő pályára állította: egyrészt a két háború protekcionizmusából tanulva nemzetközi kereskedelmi intézményrendszert állítottak fel - az 1947-ben felállított GATT-nak már alapító tagja volt Csehszlovákia is -, másrészt ebben az évben kezdett el beáramlani NyugatEurópába az a Marshall-segély, amelynek áldásait azonban már a szovjetek nem engedték meg az általuk elfoglalt, illetve felügyelt országoknak, pedig Csehszlovákia és Finnország is érdeklődést mutatott. Ezzel kezdetét vette a gazdasági és politikai értelemben vett bezárkózás. Az ideológiai bezárkózással és a COCOM lista megteremtésével a kapcsolatok minimális szintre süllyedtek, hiszen a kereskedelem egyik addigi mozgatórugója - a magas szintü technológia bevitele a közép-európai térségbe - okafogyottá vált. Az ötvenes években Európában a kelet-nyugati kereskedelem volumene minimálisra csökkent, mindkét fél részéről kicsiny szeletet jelentett a külkereskedelmi tevékenységben. Más jellegü gazdasági és politikai kapcsolatok pedig értelemszerüen nem léteztek. Ugyanakkor a szocialista országok ebben az időszakban nem omlottak össze, sőt a konszolidáció bizonyos jelei mutatkoztak. Hasonlóan sikeres kibontakozás jellemezte a kontinens nyugati oldalát is, ahol különösen Németország részéröl gyors gazdasági fejlődés rajzolódott ki.

Új fejleményt jelentett 1957-ben a Római Szerződések aláírása, amely a konszolidáció befejeződése után természetes lépésnek volt tekinthető. Németország egyenjogúsítása megtörtént, az ún. feltartóztatási politika (kommunizmus 
elöretörésének megakadályozása) külső és belső eszközei sikeresek voltak - lásd jóléti társadalom kibontakozása -, emellett a szovjet-amerikai erőegyensúly is enyhülést eredményezett. Ezért az amerikaiak elfogadták az önálló európai fejlődés tényét, (a további konszolidáció gazdasági alapjainak megteremtése céljából ez nekik is tehermentesítést jelentett), így megalakult az EGK. Ezt a szocialista országok nem vették komolyan, Hruscsov megítélése szerint a nemzeti tőke ragadozó jellege miatt eleve kudarcra ítélt kísérlet volt. Ekkor még nem volt a szervezetnek a szocialista országok számára érzékelhető negatív hatása, ezért keleti oldalon inkább csak politikai szlogenekben törekedtek a szervezet marginalizálására. Így nem engedték részvételét a különböző konferenciákon, szerveivel - a tagállamokat reprezentáló Tanács kivételével - nem tartottak fenn kapcsolatokat. Ezt a megközelítést erősítette az a benyomás, hogy az EFTA 1959-ben történt megalakításával a nyugat-európai fejlődés nem tünt nagyon monolitikusnak, vagyis még nem bontakozott ki a brüsszeli európai gravitációs központ.

A kapcsolatokban akkor történt változás, amikor a 60-as évek elején megkezdődött az EGK közös agrárpolitikájának végrehajtása, és már beindultak a közös kereskedelempolitika felépítésének első lépései. Mivel a térség országaiban a mezőgazdasági termékeknek nagy szerepük volt abban, hogy a megfelelő kereskedelmi forgalom fennmaradjon (például Magyarországon az EGK-ba irányuló exporton belül 1965-ben 59 százalék, míg 1969-ben 54 százalék volt a mezőgazdasági termékek aránya), így a kétoldalú kereskedelmi szerződésekkel sikerült a kapcsolatokat megfelelő mederbe terelni. Ezt segítette, hogy ekkor a mezőgazdasági termékek tekintetében nem volt az EGK túltermelő, s a Szovjetunió részéről sem jelentek meg érzékeny termékek nagy tételben. (Bár még nem volt érvényben a közös kereskedelempolitika, az EGK már ekkor is kötött néhány harmadik országgal, így Jugoszláviával átfogó szerződéseket.) A kétoldalú szerződéseket segítő tényező volt még, hogy a szocialista országoknak sikerült a klíring megállapodásokról áttérni a konvertibilis fizetési rendszerre. Mindezeknek megfelelően a nyugat-európai országok - oldva az 50-es évek embargóját érdekeltségüktől függően liberalizálták a szocialista országokból származó behozatalukat (I/3.4. sz. táblázat). 
I/3.4. sz. táblázat: A magyar export liberalizációjának mértéke Nyugat-Európában 1968-69-ben, (százalék)

\begin{tabular}{|c|c|c|c|}
\hline Ország & $\begin{array}{c}\text { Liberalizált } \\
\text { export }\end{array}$ & $\begin{array}{c}\text { KAP szabályozás } \\
\text { alá vont } \\
\text { termékek }\end{array}$ & $\begin{array}{c}\text { Nem liberalizált } \\
\text { export }\end{array}$ \\
\hline EFTA országok & 55 & - & 45 \\
\hline EGK összesen & 31 & 43 & 26 \\
\hline NSZK & 27 & 30 & 43 \\
\hline Franciaország & 29 & 33 & 38 \\
\hline Benelux & 53 & 42 & 5 \\
\hline Olaszország & 14 & 62 & 24 \\
\hline
\end{tabular}

Forrás: Izikné Hedri Gabriella: A Közös Piac és a magyar export. KJK, Budapest [1970]

Megjegyzés: KAP: Közös Agrárpolitika

I/3.5. sz. táblázat: Az EGK és az egyes európai szocialista országok kereskedelmi forgalma 1958-70-ben, (millió ECU)

\begin{tabular}{|l|c|c|c||c|c|c|}
\hline \multirow{3}{*}{ Ország } & \multicolumn{6}{c|}{ Európai Gazdasági Közösség } \\
\cline { 2 - 7 } & $\begin{array}{c}\text { Import } \\
\mathbf{1 9 5 8}\end{array}$ & $\begin{array}{c}\text { Export } \\
\mathbf{1 9 5 8}\end{array}$ & $\begin{array}{c}\text { Egyenleg } \\
\mathbf{1 9 5 8}\end{array}$ & $\begin{array}{c}\text { Import } \\
\mathbf{1 9 7 0}\end{array}$ & $\begin{array}{c}\text { Export } \\
\mathbf{1 9 7 0}\end{array}$ & $\begin{array}{c}\text { Egyenleg } \\
\mathbf{1 9 7 0}\end{array}$ \\
\hline Szovjetunió & 472 & 383 & -89 & 1543 & 1410 & -133 \\
\hline NDK & 61 & 57 & -4 & 225 & 211 & -14 \\
\hline Lengyelország & 219 & 189 & -30 & 667 & 586 & -81 \\
\hline Csehszlovákia & 139 & 133 & -6 & 466 & 551 & 85 \\
\hline Magyarország & 70 & 71 & 1 & 366 & 406 & 40 \\
\hline Románia & 72 & 56 & -16 & 449 & 487 & 38 \\
\hline Bulgária & 33 & 30 & -3 & 185 & 224 & 39 \\
\hline
\end{tabular}

Forrás: Eurostat; Balázs Péter alapján [1996]

A I/3.5. számú táblázatból látható, hogy a kereskedelmi kapcsolatok 1970-re szépen felfutottak, kiegyensúlyozott kereskedelmi mérleg jellemezte, és a szaldó a szocialista országoknak kedvezett inkább. 


\section{I/3.3. A kétoldalú kapcsolatokban jelentkező problémák}

Bár a 60-es években a kétoldalú szerződések révén a kereskedelmi kapcsolatok felfutottak, a 70-es évek elejére néhány probléma már megjelent: a közös kereskedelempolitika bevezetésével párhuzamosan a Közösség kidolgozta az állami kereskedelmü országokra vonatkozó rendelkezését, amelyet 1969-től be is vezetett. Ez a jugoszlávok - kiket mediterrán típusú szerződésrendszerbe ágyazott, és ezért nem büntetett - kivételével a szocialista országok számára rendkívül diszkriminatív jellegü volt. Lényegében az EGK saját maga dönthette el, mikor indít eljárást azon esetekben, amikor szerinte piaczavarás, vagy dömping - azaz nem valós árképzés esete állt fenn.

Bár a szocialista országok közül néhányan beléptek a GATT-ba, (Románia, Lengyelország, Magyarország), ugyanakkor a kereskedelmi mennyiségi korlátozásokat nem oldották fel automatikusan ezen országok számára sem.

További gondot jelentett, hogy mivel az agrártermelés terén az EGK számára már sikerült kiküszöbölni az ellátási alapnehézségeket, több területen (marhahús, halászat) kemény piacvédő intézkedésekkel lépett színre a szervezet.

Az integrációs sikerek - vámunió idő előtti megvalósítása, közös intézményrendszer felállítása, kereskedelempolitika kibontakozása - a hatvanas évek végére megnövelte az EGK ázsióját Európában. Ennek következményeként Nagy-Britannia - az EFTA addigi motorja és kitalálója -, valamint Dánia és Írország belépett az EK-ba, ami eldöntötte azt is, hogy hol lesz az új Európa gravitációs központja. Ezzel egyidejűleg az EGK szabadkereskedelmi szerződést kötött az EFTA-val, sőt megkezdte külső szerződésrendszerének alapos kiépítését. Ennek keretében megerősítette preferenciális szerződési rendszerét a mediterrán országokkal - innen származik még a görög és a török megállapodás is -, valamint a loméi konvenció révén a volt gyarmati közösségekkel. Ezeknél az országoknál az EGK általában 40-50 százalékot képviselt a külkereskedelmi forgalomban, míg a nem preferenciális kereskedelempolitikai rendszerben - ide tartoztak az európai KGST-országok is - a kötődés alacsonyabb szintü volt. (Ebben a viszonyrendszerben a 70-es években az 
EGK 10-20 százalék közötti arányt képviselt a KGST-országok külkereskedelmében.) (Balázs Péter [1996])

Mindez új helyzetet jelentett az EGK és az európai KGST-országok kapcsolatrendszerében. Egyrészt a súlyos szerkezeti válságokkal küszködő KGSTországokban nem lehetett tovább a kétoldalú szerződésekkel operálni, a kereskedelmi kapcsolatok a közös agrár- és kereskedelempolitika kompetenciájába kerültek az immáron kilenctagú és megerősödött EGK minden, a térséggel kapcsolatos problémájával - állami kereskedelem, mennyiségi korlátozások - együtt. Másrészt elötérbe került az, hogy az EGK elvárta azt, hogy a többi lényeges kereskedelmi partneréhez hasonlóan a KGST-országok is elismerjék, mint a nemzetközi jog azon alanyát, amelynek joga van olyan kérdésekben eljárni, amelyre tagállamai erre kizárólagos joggal felruházták. Ezt azonban Moszkva nem fogadta el, illetve megpróbálkozott olyan lépésekkel, amelyek a KGST-t is hasonló pozícióba juttatták volna. A kizárólagos jogosultságnak nem sikerült érvényt szerezni, az EGK végig nem volt hajlandó elfogadni a KGST jogalanyiságát.

A nehézségek mellett azonban az EGK és a KGST részéről is megjelentek olyan szempontok, amelyek a kapcsolatok szorosabbra füzését indítványozták. Egyrészt a sikerek ellenére az EGK számára is sokkoló volt az, hogy a 70-es években az olajválsággal együtt súlyos strukturális válság bontakozott ki a világgazdaságban. Ennek egyik következménye az energiahordozók és egyes nyersanyagok területén megfigyelhető árrobbanás volt. Ez előtérbe állította a közép- és kelet-európai országok nyersanyag és energiakészletének fontosságát, hiszen az EK számára kimondottan döntő volt az energiaellátás diverzifikálásának megoldása, amiben a közel fekvő, és nagy tartalékokkal rendelkező Szovjetunió jelentette a megfelelő bázist. Ízikné 1979-ben publikált könyvében európai szerzőkre hivatkozva már jelezte, hogy a Szovjetunió - az emelkedő saját és KGST-fogyasztás mellett - képes lehet a nyugat-európai igények kielégítésére az olajszállítások területén.

A szocialista országok részéről viszont komoly szerkezeti problémák jelentek meg a válságot követően. Nyilvánvalóan nem sikerült áttenni gazdaságukat intenzív növekedési pályára, vagyis nem sikerült olyan magas feldolgozottságú, eladható termékeket előállítani, ami a világpiacon lehetővé tette volna az új viszonyokhoz 
való alkalmazkodást. Ráadásul nagy részük a válság kapcsán súlyos cserearányromlást szenvedett (Magyarország például két hét alatt kb. 20 százalékosat), amit nem lehetett extenzív módon ellentételezni. Mivel a szocialista országok ennek ellenére szerkezeti módosítások nélkül kívántak új fejlődési pályára lépni, ennek következtében megindult a KGST-országok eladósodottsága a nyugati import megfelelő ellensúlyozásának hiányában (lásd: I/3.6. sz. táblázat). Ez szükségessé tette azt, hogy lényeges, új, fizetőképes piacot keressenek ahhoz, hogy konvertibilis devizában bevételekhez jussanak. Ez a kényszer a közeli EGK-t felértékelte. Ezek tényezők a két felet a közeledésre szorították - bár nem egyforma mértékben -, amit alátámasztott az is, hogy 1973 után enyhülés következett be az európai politikai színtéren (1975-ben egy új egyensúlyi helyzet tükreként aláírták a Helsinki egyezményt).

I/3.6. sz. táblázat: Az európai KGST-országok bruttó és nettó eladósodottsága (milliárd USD)

\begin{tabular}{|l|c|c|r|r|r|c|}
\hline \multirow{2}{*}{\multicolumn{1}{|c|}{ Ország }} & \multicolumn{2}{c|}{1975} & \multicolumn{2}{c|}{1980} & \multicolumn{2}{c|}{1985} \\
\cline { 2 - 7 } & Bruttó & \multicolumn{1}{c|}{ Nettó } & Bruttó & Nettó & Bruttó & Nettó \\
\hline Bulgária & 2,6 & - & 3,5 & 2,7 & 2,4 & 1,0 \\
\hline Lengyelország & 8,1 & - & 25,1 & 25,0 & 29,3 & 27,8 \\
\hline Csehszlovákia & 1,1 & - & 4,9 & 3,6 & 3,5 & 2,5 \\
\hline Románia & 2,9 & - & 9,6 & 9,3 & 7,2 & 6,6 \\
\hline Magyarország & 3,1 & - & 9,5 & 8,1 & 8,6 & 7,1 \\
\hline Szovjetunió & 10,6 & 7,4 & 18,6 & 10,0 & 30,0 & 19,0 \\
\hline NDK & 7,7 & $6,8^{*}$ & 13,3 & 11,1 & 12,2 & $6,8^{* *}$ \\
\hline
\end{tabular}

Forrás: DIW, EP Seeler jelentése, [1983]

Megjegyzés: * 1977, ** 1984

Mint látható, az adósságválság egyre súlyosabb méreteket öltött, és ezt csak akkor lehetett kezelni, ha jelentős devizabevételre tettek volna szert a KGST-országok. (Az adósságtörlesztést a bruttó adóssághoz viszonyították, a nettó adósság különbözete a bruttóhoz képest elsősorban a kintlevőségek után adódott, amelyek sokszor internacionalista alapon, a fejlődő világ szocialista orientáltságú országainak kerültek folyósításra, és behajtásukra kicsiny remény volt.) 
Ennek alapján már a 70-es években megindultak a tárgyalások a két szervezet között, de ezek nem vezettek eredményre a két fél nagyon eltérő megközelítése miatt. A KGST - ezen belül is elsősorban a Szovjetunió - a két szervezet között szerette volna rendezni a KGST-országoknak fájó problémákat, mint diszkriminatív kereskedelmi korlátozások leépítését, vámkedvezmények, mezőgazdasági exportkoncessziók biztosítását. Az EGK pedig továbbra is csak az európai EGKországokkal szeretett volna megállapodást kötni (vagyis elismertetni magát anélkül, hogy ugyanezt megtenné a KGST-vel), mivel így akarta elkerülni azt, hogy a szovjetek beleszólhassanak a kis országokkal kötendő megállapodásokba. Emellett még kisebb problémát okozott a területi klauzula (Nyugat-Berlin kérdése) is, hiszen Moszkva nem fogadta el a Római Szerződések hatályának Berlin nyugati hatalmak által megszállt területére szóló kiterjesztését. Mivel a szovjeteknek ekkor nem volt még feltétlen érdekük az, hogy engedjenek az EGK alapköveteléseinek, a tárgyalások és a közeledés teljes kudarcra voltak ítélve, hiszen a kisebb szocialista országok nem tudtak, de nem is akartak olyan jogi lépéseket tenni, ami a szovjetek súlya nélkül lett volna elképzelhető. (Ez alól kivételt csak az akkor már külön utat képviselő Románia jelentett, amely 1980-ban az ipari termékek preferenciális piacra jutásáról külön megállapodást kötött az EGK-val, de ez is lényegében sikertelen akció volt, mivel a románok által ebben vállalt importnövelést az akkor Romániában bevezetett adósságcsökkentő politika kizárta.) Ezért ebben az időben csak néhány szektorális, ún. önkorlátozó megállapodás született öt európai KGST-ország (Lengyelország, Csehszlovákia, Magyarország, Románia, Bulgária) és az EGK között az ún. érzékeny termékekre (acél, textil, később a juhszektorban), amelyben az egyes közép-európai államok kötelezettséget vállaltak arra, hogy bizonyos mennyiségen felül nem szállítanak az EGK-ba, és elfogadják az EGK szállításokkal kapcsolatos szabályzóit. E súlyosan egyoldalú vállalásnak - mely prolongálta a GATT-tagság ellenére meglévő mennyiségi korlátozásokat - az is következménye lett, hogy de facto módon egyes kis KGST-országok elismerték az EGK létét, hiszen diplomáciai kapcsolatokat nem kötöttek velük, de szerződéses viszonyt létesítettek, még ha ez kis területre is korlátozódott. Magyarország 1978-ban kötötte meg a textil, majd a juhszektorban ezt a megállapodást. A textil-megállapodás történelmi jelentősége abban állt, hogy sikerült megoldani Nyugat-Berlinre vonatkozó 
problémát, amely a későbbiekben az általános szerződéseknek a kiinduló alapjává vált.

\section{I/3.4. A kapcsolatok rendezése}

A 80-as években Európa két felének eltérő fejlödési tendenciája még jobban nyilvánvalóvá vált. Az EGK Görögország (1981), majd Spanyolország és Portugália (1986) felvételével lendületesen bővítette belső piacát, sőt ugyanezt célozta az EFTA-országokkal az Európai Gazdasági Térség megalkotásának folyamata, melynek tárgyalásai 1984-ben kezdődtek el. Emellett már kezdtek napvilágot látni a mai modern Európa csíráit jelentő fejlődési elemek, így az európai pénzügyi rendszer, az ECU, mint elszámolási és hitelpénz, valamint a közös kutatási és fejlesztési programok. (Az amerikai és japán müszaki kihívásra jelent meg válaszként pl. az EURÉKA program.)

Ugyanakkor a KGST országai egyre nagyobb válságba kerültek. A 80-as években egyértelművé vált, hogy az intenzív fejlődési pályára nem tudnak áttérni, a bejövő technológiát nem tudják alkalmazni. Mivel az eladósodottság már nem volt tovább fokozható, a KGST elhatározta saját, 2000-ig szóló tudományos programjának felfuttatását, de ennek megvalósításához már nem volt elegendő ereje. A 80-as években jelentős importmegszigorításokat vezetett be, ugyanakkor belső piaca szükülni, vagy legalábbis stagnálni kezdett.

Fenti folyamatok a kétoldalú kereskedelmi kapcsolatokat is befolyásolták. Ebben meghatározóvá vált a primer termékek cseréje, holott a szerves fejlődést csak megfelelő feldolgozottságú termékek esetén lehet biztosítani. Az energiahordozók KGST exportja ebben a korban megnőtt, míg a hagyományos mezőgazdasági termékeké - az egyre fokozódó közösségi protekcionizmus miatt - csökkent. A nyolcvanas évek folyamán a kelet-európai export és import szerepe az EU számára csökkent: a 70-es évek 3,6 százaléka után 1983-ban 3,0 majd 1988-ban 2,1 százalékra mérséklődött az EGK exportjában a közép- és kelet-európai térség, ami kisebb arány volt, mint 1958-ban ( 2,5 százalék) (Eurostat, External Trade különböző évfolyamai, Balázs Péter [1996] alapján). 
A fenti folyamatok eredőjeként egyre dominánsabbá vált a szovjetek szerepe az EK és a KGST közötti kereskedelemben, (az 1975. évi 40 százalékról 1985-re 60 százalékra). (Balázs Péter, [1996]). A KGST-országok fokozódó agóniája miatt az EGK-ból származó importnak csak 55-60 százalékát tudták exporttal fedezni, vagyis most már az EK irányába is megkezdődött a fokozatos eladósodás. A hagyományos import fenntartása végett az EGK számára azonban fontossá vált a piacnyitás. Ezt erősítette az is, hogy az EGK-n belül a legerősebb tagállam, az NSZK lett abszolút domináns a KGST exportjában, (ide irányult a nyolcvanas években a térség exportjának 40 százaléka), emellett Németország energiaellátásában lényegében a szovjetektől vált függővé.

I/3.7. sz. táblázat: Az EGK egyes termékeinek export/import szerkezete az európai KGST-országokkal 1985-ben (százalék)

\begin{tabular}{|c|c|c|c|c|c|c|c|c|c|c|c|c|c|c|c|c|}
\hline & \multicolumn{2}{|c|}{ Összesen } & \multicolumn{2}{|c|}{$\begin{array}{c}\text { Szovjet- } \\
\text { unió }\end{array}$} & \multicolumn{2}{|c|}{ NDK } & \multicolumn{2}{|c|}{$\begin{array}{c}\text { Lengyel- } \\
\text { ország }\end{array}$} & \multicolumn{2}{|c|}{$\begin{array}{c}\text { Cseh- } \\
\text { szlovákia }\end{array}$} & \multicolumn{2}{|c|}{$\begin{array}{c}\text { Magyar- } \\
\text { ország }\end{array}$} & \multicolumn{2}{|c|}{ Románia } & \multicolumn{2}{|c|}{ Bulgária } \\
\hline & $E$ & $I$ & $E$ & $I$ & $E$ & $I$ & $E$ & $I$ & $E$ & $I$ & $E$ & $I$ & $E$ & $I$ & $E$ & $I$ \\
\hline $\begin{array}{l}\text { Élel- } \\
\text { miszer }\end{array}$ & 11,8 & 4,9 & 14,8 & 0,7 & 16,5 & - & 12,5 & 16,2 & 6,4 & 6,4 & 3,2 & 26,9 & 4,9 & 3,7 & 10,6 & 17,0 \\
\hline $\begin{array}{l}\text { Nyers- } \\
\text { anyag }\end{array}$ & 2,8 & 6,5 & 1,7 & 2,9 & 9,4 & 4,4 & 2,2 & 13,6 & 5,7 & 13,0 & 3,7 & 9,4 & 4,7 & 3,3 & 2,8 & 7,9 \\
\hline Energia & 1,7 & 53,1 & 0,8 & 72,3 & 8,1 & 18,5 & 1,0 & 23,5 & 0,8 & 13,1 & 2,6 & 6,1 & 7,9 & 44,0 & 2,2 & 22,1 \\
\hline $\begin{array}{l}\text { Olajok, } \\
\text { zsíradék }\end{array}$ & 0,6 & 0,2 & 0,6 & 0,1 & - & 0,3 & 1,6 & 0,6 & 0,3 & 0,2 & 0,2 & 0,4 & 0,5 & 0,5 & 0,2 & 0,2 \\
\hline $\begin{array}{l}\text { Vegyipari } \\
\text { termékek }\end{array}$ & 15,8 & 5,5 & 13,3 & 3,5 & 14,8 & 17,2 & 19,7 & 3,9 & 18,7 & 10,7 & 19,7 & 12,0 & 21,1 & 5,3 & 15,8 & 10,2 \\
\hline $\begin{array}{l}\text { Gépek és } \\
\text { közl. } \\
\text { Eszk }\end{array}$ & 27,2 & 4,7 & 24,8 & 1,5 & 19,7 & 18,3 & 29,7 & 8,8 & 34,1 & 11,5 & 30,4 & 10,1 & 19,2 & 5,3 & 37,0 & 6,0 \\
\hline $\begin{array}{l}\text { Egyéb } \\
\text { feldolg. }\end{array}$ & 34,0 & 16,6 & 39,1 & 4,7 & 23,5 & 38,3 & 26,2 & 28,7 & 26,2 & 43,5 & 34,0 & 32,5 & 33,2 & 37,7 & 24,4 & 31,5 \\
\hline
\end{tabular}

Forrás: Eurostat, [1986], Balázs Péter alapján [1996] 
I/3.8. sz. táblázat: Az EGK és az egyes európai KGST-országok kereskedelmi egyenlege 1975-85 (millió ECU)

(EGK felé irányuló import/export)

\begin{tabular}{|c|c|c|c|c|c|c|c|c|c|}
\hline \multirow{2}{*}{ Ország } & \multicolumn{2}{|c|}{1975} & \multirow{2}{*}{ Egyenleg } & \multicolumn{2}{|c|}{1980} & \multirow{2}{*}{ Egyenleg } & \multicolumn{2}{|c|}{1985} & \multirow{2}{*}{ Egyenleg } \\
\hline & Imp & $\operatorname{Exp}$ & & Imp & Exp & & Imp & $\operatorname{Exp}$ & \\
\hline $\begin{array}{l}\text { Szovjet- } \\
\text { unió }\end{array}$ & 3899 & 4989 & 1090 & 11214 & 7583 & -3631 & 20266 & 11858 & -8408 \\
\hline NDK & 494 & 479 & -15 & 911 & 842 & -69 & 1745 & 810 & -935 \\
\hline $\begin{array}{l}\text { Lengyel- } \\
\text { Ország }\end{array}$ & 1624 & 2677 & 1053 & 2723 & 2841 & 118 & 3427 & 2682 & -745 \\
\hline $\begin{array}{l}\text { Cseh- } \\
\text { szlovákia }\end{array}$ & 851 & 1045 & 194 & 1505 & 1368 & -137 & 2222 & 1926 & -296 \\
\hline $\begin{array}{l}\text { Magyar- } \\
\text { ország }\end{array}$ & 702 & 968 & 266 & 1415 & 1592 & 177 & 1996 & 2429 & 433 \\
\hline Románia & 892 & 1070 & 178 & 1767 & 1708 & -59 & 2846 & 1123 & -1723 \\
\hline Bulgária & 204 & 678 & 474 & 478 & 774 & 296 & 550 & 575 & 25 \\
\hline Összesen & 8666 & 11906 & 3240 & 20013 & 16708 & -3305 & 33052 & 21403 & -11649 \\
\hline
\end{tabular}

Forrás: Balázs Péter [1996], Eurostat különbözö évszámai alapján

Az I/3.7-8. sz. táblázatokból látszik, hogy a nyolcvanas évek második felében mindkét fél érdekeltsége megvolt az újabb megegyezéshez: az európai KGSTországoknak szükségük volt a piacnyitásra, mert csak így tudták az importot exportoldalról fedezni, míg az EK oldalon (főleg az NSZK számára) a KGSTországokból érkező nyersanyagok - elsősorban a szovjet olaj - további zavartalan érkezésében voltak érdekeltek.

A tényleges gazdasági célokban szerepet játszottak még a környezetvédelmi és atomenergia kutatási és biztonsági szempontok is (ekkor történt csernobili atomerőmü-katasztrófa), valamint az EGK-nak az a szándéka, hogy nyíló piaci lehetőségekkel segítse a szükséges szerkezeti reformokat. Mivel mindez Gorbacsov nyitási politikájával találkozott - aki a közös Európa-ház koncepcióján túl, a mögötte álló tudományos háttér segítségével már létező realitásként kezelte az EK-t -, megvolt minden lehetőség ahhoz, hogy a várt megegyezés megszülessen. Ez végül is 1988-ban történt meg, és megoldási módozatát tekintve - tükrözve a gazdasági erőviszonyokat - az EGK teljes győzelmét hozta. A KGST és az EGK csak politikai 
nyilatkozatot írt alá az együttmüködésről, ugyanakkor az egyes európai KGSTállamok diplomáciai és szerződéses viszonyra léptek vele, amelyek gazdasági és kereskedelmi együttműködési szerződések voltak. Bár ezek elsősorban kereskedelmi kérdéseket öleltek fel, megnyitották a lehetőséget a kapcsolatok további fejlesztéséhez. A KGST-országok számára előnyt jelentett a piacra jutási kedvezmények sora, beleértve a GATT alapján is diszkriminatívnak minősített mennyiségi korlátozások leépítését.

A szerződéses kapcsolatok a KGST-országok és az EGK között 1988-89-ben léptek életbe, de kibontakozásukat már nem a kétpólusú Európa együttmüködését tükröző szerződések, hanem a közép-európai rendszerváltás határozta meg. Így már 1989-ben sor került az ún. PHARE-segélyek elindítására, a különleges gazdasági kedvezményeket adó GSP (General System of Preference) bevezetésére, sőt 1990-től új típusú szerződések, az Európai Megállapodások tárgyalásának megkezdésére. Mivel idöközben 1989-ben a KGST is áttért a valós piaci értéket jelentő konvertibilis elszámolásra, az európai integráció új fejezete kezdődött el, ahol a rendszerváltó európai KGST-országok szinte rövid idő alatt átstrukturálták kapcsolatrendszerüket. A társadalmi-gazdasági váltással együtt a külpolitikai és külgazdasági rendszerben is az EGK, illetve annak tagállamai és szervezetei váltak elsődleges prioritássá. (Ezt jelzi, hogy a három visegrádi ország - Magyarország, Csehszlovákia és Lengyelország - 1990-es exportjában az EK részaránya már meghaladta a 30 százalékot.) (Balázs Péter [1996]) 1990-91-ben valamennyi volt európai KGSTország (a szovjet utódállamok kivételével) megfogalmazta azt a politikai szándékát, hogy belépjen az EK-ba.

Az 1990 előtti kapcsolatok elemzése során az a következtetés vonható le, hogy tradicionálisan szoros volt a kapcsolat Európa két része között, ami nem szakadt meg a kétpólusú rendszer létrejöttével sem (1947 után), sőt annak végén a kapcsolatok olyan rendezésére is sor került, amely a közép-európai országokat privilegizált helyzetbe hozta volna az EK külkapcsolati rendszerében a kommunizmus esetleges hosszabb agóniája esetén is. Egy másik lényeges konzekvencia az, hogy a térség országainak mind az európai integráltsága, mind európai fejlettsége rendkívül különböző volt a történelem folyamán, de a valamikori fejlettségi szint alapján mindegyik tagjelölt országnak természetes tartalékai vannak az olyan felzárkózáshoz, 
amely révén elérhetik a két világháború közötti, az EU-országok akkori fejlettségi szintjéhez hasonlítható fejlettségi szintjüket és az akkori kapcsolatok mélységét.

\section{RÉSZ; 4. FEJEZET TÖRTÉNELMI MOTÍVUMOK ÉS FEJLŐDÉSI AZONOSSÁGOK}

Amikor a csatlakozni kívánó országok európai örökségéről esik szó, mindig kiemelkedő helyen szerepel az a történelmi, kulturális kötelék, amire hivatkozva szoktuk úgy jellemezni a csatlakozási folyamatot, hogy általa Európa újraegyesítése fog bekövetkezni. Ezt a kérdőíves felmérés eredményei is igazolták (lásd: II. rész). Ehhez kapcsolódva az alábbiakat érdemes megvizsgálni: a keresztény államiság megvalósítása, az európai monarchiákhoz való csatlakozás, a feudális és a modern piacgazdaság kialakulásának lehetőségei, európai szolidaritás és tolerancia konkrét bizonyítékai, valamint az európai kulturális és tudományos életben való részvétel.

\section{I/4.1. Általános történelmi fejlődés}

Legtöbb ország már a korai középkorban keresztény állammá vált és stabil államszerkezetben bontakoztatta ki fejlődését, amely az egyház uralmán, a földbirtokos nemességen alapult, és így eltért az ázsiai népek szokásaitól, akik ellen védekezett és ezáltal védte a nyugati keresztény civilizációt is. A kereszténység felvételétől fogva azonban két irányultság figyelhető meg a térségben: a bizánci befolyás alatti területen az ortodox keresztény vallás vált uralkodóvá, míg KözépEurópa elsősorban a római katolikus vallás felvétele révén a nyugati világ felé orientálta fejlődését, még akkor is, ha ezen országok nagy része szláv eredetű volt. Ez a kettős vonal megmutatkozott a társadalmi felépítésben (az uralkodók és az alattvalók, hübéresek viszonyában), és a modern európai eszmékhez való viszonyulásban is. Az alábbiakban az egyes országok néhány sajátos jellemzőit emelem ki ebben a történelmi összehasonlításban, mely révén érzékelhetővé válik, hogy az EU bővítése miért vezet egy nagyobb és erősebb Európa újraegyesítéséhez. 


\section{I/4.2. Lengyelország}

Bár az ország területén a korai középkorban kialakult államok erős függőségben álltak a Német-Római Birodalomtól, 966-ban már keresztény állam alakult, sőt 1000ben már önálló egyházat is alapíthattak. A modern európai jogállamiság számos jelét sikerült felmutatni a lengyel fejlődésben. Már kezdetektől fogva nagy számú német telepeseket fogadtak be. A kisnemesség (szlachta) a XII. századtól egyre nagyobb befolyásra tett szert. A XIV. századtól kezdve (III. Kázsmér révén) a zsidók szabadságának elismerése megtörtént, mivel ösztönözték letelepedésüket Lengyelországban. (Nyugat-Európában ezután még sok helyen volt zsidóüldözés, elég, ha csak a későbbi 1492-es és 1561-es Spanyolországból való kiűzetésükre gondolunk.) A XIV-XV. században megszületnek az első törvénykönyvek, az alkotmányozás jegyei is megjelennek. Figyelemre méltó, hogy már ekkor megmutatkoznak a parlamentarizmus jegyei (alsóház és felsőház), sőt ezek a szervek a királyválasztásban már fontos szerepet játszanak. A XVI. században Lengyelországban (és Litvániában) elterjedt a lutheránus és kálvinista vallás, sőt e vallások erős oktatási bástyákat építettek ki. A XVI. században az udvari szokásokra erős hatással bírt az olasz reneszánsz. Krakkóban már a korai középkorban egyetemet alapítottak (Kopernikusz itt publikálta leghíresebb müveit).

Lengyelország kivette részét a keresztény civilizáció védelmében, előbb a tatár és mongol támadásokkal nézett szembe, majd a török ellen védekezett (pl. Sobieski megmentette Bécset). Később függetlenségének elvesztése után sem folytatott agresszív magatartást a jelenlegi nyugati hatalmak ellen, legfőbb ellenállási megmozdulásai az orosz cári elnyomás megszüntetése érdekében nyilvánultak meg. Az utóbbi kétszáz év eseményei azonban nemcsak az oroszokkal, hanem a németekkel is feszült helyzetbe hozták Varsót, hiszen a poroszok (németek) és az osztrákok is közremüködtek a lengyel államiság többrendbeli megszüntetésében.

Lengyelország ma viszonylag homogénnek mondható (részben a második világháború alatti és utáni kitelepítéseknek és kegyetlenkedéseknek köszönhetően). A lakosság 98 százaléka lengyel, és 97 százaléka katolikus (L’Europe centrale et Balkanique, [1995]). Mindezeknek megfelelően kulturális befolyása és fejlődése teljes mértékben nyugatorientált. Ebből a szempontból fontos kiemelni, hogy a 
nagyszámú szentek és boldogok mellett a jelenlegi Pápa is lengyel származású. (Ennek hatása különösen az erősen katolikus tagállamokban - Olaszország, Spanyolország, Portugália - érezhető, hiszen Lengyelország tagsága ott erős támogatásra talált, mint azt a II. részben elemeztem.) Nagy létszámú lengyel emigráns él most is Európa különböző városaiban. A katolikus egyház befolyása jelentős (amit az utóbbi évszázadok és évtizedek elnyomásai csak erősítettek), és a mediterrán országokéhoz hasonlítható.

\section{I/4.3. Magyarország (Szlovákia)}

1000-ben országunkban is nyugati típusú keresztény állam alakult, amelyben a középkori európai fejlődés legtöbb attribútuma megtalálható volt. Ilyen az írott államjogi dokumentumok megléte (Aranybulla 1242-ből, vagy a Werbőczy féle Hármaskönyv 1514-ben), a parlamentarizmus megjelenése, és itt is hódított a humanizmus, valamint a reneszánsz (elsősorban Hunyadi Mátyás idejében teljesedett ki). Magyarország egyetemeket és szabad királyi városokat alapított, kereskedelmi és kulturális kapcsolatai erösen kötötték Európához. Kitünt a keleti veszedelmek elleni védekezésével, föleg a tatár és a török elleni harcokban. A lengyelekhez hasonlóan többször szinte reménytelen helyzetben harcolt az ország az oroszok (szovjetek) ellen, ezzel is védve Nyugat-Európát, illetve feltartva az ortodox birodalmi befolyás nyugati terjeszkedését. Tudományos fejlődése terén számos felfedezővel, később Nobel-díjassal segítette elő az egyetemes és európai fejlődést, és hasonló mondható el a kultúra területén is.

Magyarország is erősen homogén állam, hiszen magyar nemzetiségüek alkotják a lakosság 92,3 százalékát, és a kisebbségek közül is csak a cigányok (kb. 5-6 százalék) képviselnek jelentősebb arányt (L’Europe Centrale et Balkanique, [1995]). Ezen kívül németek, dél-szlávok és szlovákok élnek területén. A lakosság vallási, és ezzel kulturális gyökereit vizsgálva megállapítható, hogy a vallásos érzelmű lakosság csaknem kétharmada (65 százalék) katolikus, de ezen kívül csak az európai vallási irányzatok kálvinisták (18 százalék), lutheránusok (8 százalék) dominálnak. Magyarország a középkorban és az újkorban toleráns befogadó állam volt, hiszen a holocaustig a zsidóság nagy számban (aránya elérte a 6-7 százalékot) élt a Kárpátmedencében, és ezt nagy toleranciával, törvényileg is biztosította. (A vallási türelem 
fő bizonyítéka volt, hogy Erdélyben a Tordai Országgyülés ezt már négy évszázaddal ezelőtt biztosította. Az emancipáció a zsidók, valamint bármilyen felekezet számára már több mint száz éve, 1894 óta törvényileg valósággá vált.)

A szlovák törzsek a kilencedik században felvették a kereszténységet, ám modern feudális államot kialakítani nem volt módjuk. Szlovákia mintegy ezer éven keresztül a magyar királyság része volt, ezért a magyar fejlődés előbbiekben jelzett főbb ismérveit rájuk is vonatkoztathatjuk. A lakosság hatvan százaléka katolikus, ezen kívül a protestáns és az ortodox vallás van jelen az országban. Történelmi örökségeként nyugati kulturális és társadalmi irányultság jellemzi, de az önálló államiság eddigi hiánya miatt jelenleg a késői nemzeti ébredés okozta nacionalista érzelmi hullámmal kell megküzdenie. Ez 1993 óta végigkíséri az állam újraalapítását, ami vélhetően még évtizedekig éreztetni fogja hatását, még az Európai Unió tagjaként is. Szlovákia nem tekinthető homogénnek, mivel lakosságának 11 százaléka magyar nemzetiségü (amely azonban erősíti a nyugati orientáltságot), és jelentős a cigány lakosság aránya is.

\section{I/4.4. Csehország}

Visegrádi partnereihez hasonlón több mint ezeréves keresztény államiságra tekint vissza, mivel az első királyságot már a VII. században megalapították, és lényegében 915-re datálható a tényleges cseh állam megalakulása, amely azonban a Pápa, majd a német-római császár fennhatósága alá került. Ez egyrészt vazallusi befolyást jelentett a császár felé (később a cseh király viszont választófejedelem lehetett, gyakran igen erős befolyással és lehetőségekkel), másrészt viszont erőteljes kötődést a nyugati keresztény kultúrához. Ezt jelzi, hogy Prágában már 973-ban püspökséget alapítottak, valamint 1348-ban ugyanitt egyetemet létesítettek (itt tanított Kepler is). Fogékony volt a modern ideológiai áramlatokra, hiszen itt bontakozott ki a husziták harca, és erős volt a hatása a reformációnak, valamint a reneszánsznak is. Orientációt némileg azzal váltott, hogy az 1500-as évek közepén a Habsburg Monarchia részévé vált, amely a török magyarországi győzelme után fontos bástyának tartotta az országot. Ez meghatározta későbbi fejlődését: erőteljes rekatolizálás és németesítés következett be (Magyarországhoz hasonlóan). 
Magyarországtól eltérő volt azonban fejlődésében az, hogy a Habsburg Monarchia alatti alkotmányos önállóságot nem tudta helyreállítani, viszont a közép-európai Habsburg Császárság (későbbi vámunió) keretein belül az iparra szakosodhatott, ami nagyfokú modernizációt eredményezett. Ebből is kifolyólag a modern Csehszlovák Köztársaság a két háború közötti időszakban Európa legfejlettebb államai közé tartozott. Polgári demokratikus berendezkedésének erejét mutatja, hogy 1948-ban csak puccsal sikerült a kommunista hatalomátvételt megvalósítani, vagyis Magyarországhoz hasonlóan itt is hosszabb átmenetre és kifejezetten külső behatásokra volt szükség a szovjet típusú rendszer kialakításához. A zsidók deportálása, majd a szudétanémetek kitelepítését követően homogénnek mondható, mára már 95 százalék a csehek aránya, de itt is jelen van a romakérdés. A vallási kultúrhátterét a katolikus és a protestáns vallások dominanciája egyértelmüen jellemzi.

A három (valójában négy) ország történelmi európai kötődései mellett kiemelhetök még a szoros kereskedelmi kapcsolatok (lásd a Visegrádi Királytalálkozó 1336-ban, a Visegrádi Együttmüködés és a CEFTA megalakítása 1991-ben), a felvilágosodás jelentős szellemi hatása, valamint a kommunista hatalomátvétel erőszakos kényszere mellett az is, hogy ezekben az országokban konkrét kísérletek történtek a szovjetizált rendszerből való kitörésre 1956-ban, 1968-ban illetve 1980-ban. Ez végső soron a szovjet birodalmi politika megrendüléséhez vezetett, hiszen Moszkva katonai megoldása egyrészt nemcsak az általa felügyelt területeken jelentett illúzióvesztést, hanem Nyugat-Európában is hatalmas kiábrándulást okozott a létező marxista rendszerek iránt.

\section{I/4.5. Nyugati keresztény irányultságú területek}

Az önálló állami fejlődésnek és a nyugati értékrendszerhez, valamint társadalmi szerkezethez való kötődésnek - polgárosodás - a fenti három (négy) országon kívül nem volt ilyen meghatározó szerepe, de lényegesebb sajátosságokat esetükben is megfigyelhetünk.

Egyértelmű európai fejlődési trend mutatható ki Szlovéniában. A VII. századtól letelepedett szlovén törzseknél a Karolingok és a bajorok vetették meg a keresztény 
rend alapjait. Velence néhány évszázados befolyását követően a terület 1335 után a Habsburgokhoz tartozott, akik lényegében 1918-ig örökös tartományként kormányozták a szlovénokat. Ez minden esetben (1848-ban is) hüséget jelentett a Habsburg-házhoz, hiszen nem volt sem alkotmányos gyökere, sem önálló állameszménye vagy történelme a kis népnek. Ugyanakkor helyzete megengedte, hogy a Habsburg Birodalom legfejlettebb területeivel tartsa a kapcsolatot, ami gazdasági és társadalmi fejlődése szempontjából kiváltságokat jelentett. Mindezt jól kamatoztathatta a Jugoszláv Királyság idején, ahol számára kedvezőtlen történelmi kötődéseket erőltettek rá (a nyelvi kapcsolatnál sokkal erősebbnek bizonyult az évezredes germán és olasz viszonylat), de relatív gazdagsága és versenyképessége Jugoszlávián belül privilegizált helyzetbe hozta.

Az államiság és alkotmányosság hiánya, az ebből fakadó néhány megoldatlan szomszédsági probléma nehezítheti integrálódását. (Ez is szerepet játszik a gazdasági, társadalmi viszonyokhoz képest meglepően zavaros és instabil pártviszonyok, gyakori kormányválságok létében.) Előnye viszont, hogy a lakosság viszonylag homogén (mind nemzetiségét tekintve a 90 százalék feletti szlovén lakossággal, mind vallási gyökereit nézve a 90 százalékot meghaladó katolikus aránnyal).

Hasonló a három balti állam fejlődésének pályája, hiszen a német lovagrendek hódításával a helyi germanizált szláv népek egyértelmúen nyugati orientáltságú (a kereskedelemben ez szorosan megvalósult) társadalmakká váltak. A korai középkorban az észtek és lettek dán uralom alatt álltak, majd a német lovagrendek után svéd uralomban volt osztályrészük. Ennek köszönhetően meghonosodott a keresztény vallás, sőt közvetítőkön keresztül az evangélikusok száma is az elterjedtebbek közé tartozott. Mindez a protestáns szellem és etika számára nyitott utat. Az oroszok - kihasználva a lengyel birodalom utáni hatalmi ürt - mind a három balti államot uralmuk alá tudták hajtani a XVII-XVIII. század idején.

Litvánia helyzete némileg eltérő volt, mivel a XIII. századtól kezdve római katolikus államként a lengyelekkel sokszor szövetségben (időnként államszövetségben) élt az 1795-ben bekövetkezett orosz hódításig. Ezért az ország fejlődése a lengyelekhez 
kötődött, tolerancia szintjére, az európai értékek védelmére vonatkozó fejlődése párhuzamosságot mutatott nyugati szomszédaival.

A balti államok sajátos módon a két világháború között (1920-tól 1940-ig) létező államok jogutódjai. Ennek kulturális és társadalmi jegyeit mutatják akkor is, ha jelenleg a lakosság összetétele - a szovjet uralom örökeként - nem olyan homogén, mint 1940 előtt volt, hiszen nem csak más nemzetiségü, hanem eltérő kultúrkörbe tartozó lakosság is jelen van.

\section{I/4.6. A keleti (bizánci) típusú területek}

Az eddigiektől lényegesen eltérő a két balkáni állam, Bulgária és Románia, sőt Ciprus történelmi-vallási háttere. Ezekben az országokban az állami és társadalmi élet fő szervező ereje az ortodox vallási és bizánci hatás volt, amihez hozzájárult még az állami függetlenség hosszú ideig fennálló hiánya. Bár a keresztény Bulgária és annak egyháza már a X. században kivívta függetlenségét, (sőt ennek előzményei már a VII. században is fellelhetők), de 1018-tól lényegében bizánci provinciává vált, majd az 1300-as évektől az oszmán birodalom fennhatósága alá került. Ezen nem tudott változtatni az 1800-as évek végéig, bár számára nagy eredmény volt nyelve és kultúrája megtartása. Függetlenségét a Balkánon a vallási és származási alapon befolyást kereső orosz cárnak köszönheti elsősorban. Bár Bulgária szakadatlan törökellenes harcaival és felkeléseivel szintén védte a nyugati kultúrát, lényegében most is az egyik, az iszlám kultúra előtti utolsó szárazföldi európai állam. Társadalmi-gazdasági kapcsolatai - bár pl. az irodalmi felvilágosodás a XVIII. században itt is elindult - nem tudták Európa nyugati részéhez kötni. A kommunista diktatúra idején - Dimitrov kezdeti délszláv konföderációs kísérletének kudarca után - vezetése teljes mértékben Moszkvához kötötte az országot, még a Szovjetunióhoz való önkéntes csatlakozás gondolata is felmerült.

Viharos történelmi öröksége révén Bulgária korántsem tekinthető homogénnek, és a kisebbségeket illetően negligálható helyzetünek. A lakosságnak még mindig csaknem 10 százaléka török eredetű, és hasonlóan magasra tehető a roma származásúak aránya, melynek megfelelően az ortodox és az iszlám vallás az uralkodó, az országban nyugati keresztény befolyás nem létezik. 
Némileg más a helyzet Románia esetében, ahol a két ősi román fejedelemség a XIV. század folyamán jött létre, de megalakulásának első évszázadai a török elleni szakadatlan harccal teltek el. Az 1700-as években némileg sikerült a fejedelemségeknek bizonyos szabadságjogokat kiharcolni (a görög származású fanarióták közül választották ki a kormányzókat), de a három nagyhatalom (orosz, török, osztrák) szorításában létező fejedelemségek csak a XIX. század végén (a Berlini Kongresszus után) váltak igazán függetlenné. A függetlenségi harcokon kívül a jelenlegi Európa történelméhez és kultúrájához csak mérsékelten tudtak hozzájárulni, bár neolatin és nem szláv cirill betűs kultúrájuk van. A Berlini Kongresszus után, mint állam a keleti veszélyek elleni védelmet testesítette meg.

Románia jelenlegi helyzete sajátságos, mivel nem tekinthető homogén államnak. Ennek részben az az oka, hogy - bár a zsidó lakosság nagyrészt a második világháborúban meghalt vagy elmenekült, és a görög-örmény lakosság asszimilációs foka is magas - jelentősebb magyar (a lakosság 7 százaléka) és roma lakossága van. A vallási összetételben az ortodoxok 87 százalékot képviselnek, míg a magyar, valamint német anyanyelvü lakosság a nyugati keresztény vallás részét képezi. (A L'Europe Centrale et Balkanique szerint a nyugati-keresztény vallásúak katolikusok, protestánsok, unitáriusok - teszik ki a romániai lakosság 10 százalékát, ami azt jelzi, hogy a magyar és a német lakosság együttes aránya magasabb a hivatalos adatokban szereplő 7,5 százaléknál.) A jelenlegi Románia részét képező Erdély kulturális és szellemi öröksége (tolerancia és a reneszánsz, valamint a felvilágosodás jelenléte) szintén jelentős, hiszen a török hódoltság alatt Erdély volt a nyugati kereszténység keleti bástyája és gyüjtőhelye.

A fentiekben vázolt állami és kulturális fejlődés, az európai fő szellemi és gazdasági áramlatokhoz való kapcsolódás jelenik meg általában a szerződésekhez, megállapodásokhoz, üzleti, valamint politikai etikához való viszonyulásban. Ez az EU számára a bizalomépítés alapja egy olyan kibővített EU-ban, ahol mind politikai, mind üzleti szinten az integráció komplex jellege miatt kiemelkedő fontossága van az európai értékek tiszteletének. 
I/4.1. sz. táblázat: A tagjelöltek gazdasági, etikai értékelése (1-10-ig terjedö skálán) 1999-ben

\begin{tabular}{|c|c|}
\hline Ország & Pontszám \\
\hline Szlovénia & 8,72 \\
\hline Magyarország & 8,69 \\
\hline Észtország & 8,00 \\
\hline Csehország & 7,30 \\
\hline Lengyelország & 7,30 \\
\hline Lettország & 7,09 \\
\hline Litvánia & 7,09 \\
\hline Szlovákia & 6,75 \\
\hline Bulgária & 5,91 \\
\hline Románia & 5,50 \\
\hline
\end{tabular}

Forrás: CEER, [1999]

A nagyszámú közgazdászok és üzletemberek által adott értékelés szerint jól látható, hogy Szlovénia, Magyarország és némileg Észtország kiemelkedik az üzleti etika terén folytatott vizsgálatban, és Bulgária valamint Románia jelentősen lemaradva található a sor végén. A kulturális örökség szerepét mutatja az is, hogy a balti államok közül a protestáns alapokra épülő észt társadalom értékelése mennyire elválik a másik két balti államtól, és hogy a nemrégen egy országban élt csehek és szlovákok indexe érzékelhetően különbözik egymástól. Az értékelés, ha nem is igazolhatja teljesen Huntingtonnak a civilizációk ütközésére vonatkozó elméletét, jelzi, hogy a történelmi múltnak, államiságnak, a szerződések (alkotmányosság) tiszteletének, a parlamentarizmus és tolerancia létének és a társadalomba való beágyazottságának meghatározó szerepe lehet a kibővített és egyre jobban integrálódó Európai Unióban. 


\section{RÉSZ \\ KÖZVÉLEMÉNY-KUTATÁSOK A BŐVÍTÉSRŐL}

Mielőtt hozzálátnánk az Európai Unió szemszögéből vizsgált előnyök és hátrányok mélyebb elemzéséhez, szükségesnek érzem az EU-tagállamok, a társult és a csatlakozni vágyók közvéleményének hozzáállását bemutatni. Ez fontos azért, mert mindkét fél politikai elitjének magatartását erőteljesen befolyásolja választóinak véleménye. $\mathrm{Az}$ állampolgárok véleményében a trendeket érdemes figyelemmel kísérni, vagyis azt kell megvizsgálni, hogy ugyanarra a kérdésre vonatkozóan hogyan változik a közvélemény reakciója. Megjegyzem, hogy ez esetben a kutatások lehetőséget adnak a differenciált megközelítésre is.

A következtetéseket az Európai Bizottság keblén belül müködő Eurobarometer adataira alapozva fogalmaztam meg, ez az intézet mind a tagállamok, mind a csatlakozni kívánó országok esetében ugyanazon metodika alapján dolgozott, és véleményét mindkét fél ezáltal objektívnek fogadhatja el.

\section{RÉSZ; 1. FEJEZET}

\section{AZ EU-TAGÁLLAMOK KÖZVÉLEMÉNYE}

Nem előzmények nélküli a téma felvetése, hiszen már az előző bővülések kapcsán is végeztek közvélemény-kutatásokat. Igaz akkor más jellegü volt a megközelítés, hiszen nem a hidegháború felszámolásáról és a kommunizmus országairól volt szó, hanem már régebb óta piacgazdaságot építő társadalmakról, akiket ráadásul már ismert és el is fogadott a nyugat-európai közvélemény. Erre legjobb példa annak említése, hogy ezen országokkal való bővítés - főleg Ausztria, Svédország és Finnország 1995-ös belépésekor - elfogadásának határozott aránya magas volt, meghaladta a kétharmadot. A jelenlegi 15 tagállam közvéleményében Svájc és Norvégia esetleges belépésének támogatottsága ma is csaknem 70 százalék (lásd: II/4. sz. táblázat). Ugyanez a magas arány már nem figyelhető meg Ciprus és Málta 
esetében, ahol a politikai bizonytalanság, megosztottság illetve a kevésbé ismertség, valamint a nem egyértelmü európai orientáltság (Máltán az ellenzéki Munkáspárt fenntartását hangoztatja a belépés kapcsán), és a kis méret miatt már nem haladja meg lényegesen a támogatottság a közép-európai országok legkiemelkedőbb tagjainak, Magyarországnak vagy akár Lengyelországnak és Csehországnak a számarányait.

A volt kommunista és tervgazdasági rendszer szerint müködő államok bővítése a német egyesülés által tulajdonképpen már 1990-ben elkezdődött. Mivel a keletnémet terület hirtelenszerü (nem az önálló piacgazdaság kiépítése majd felzárkózása és ez utáni integrálása játszódott le a sajátos történelmi helyzet miatt, hanem politikailag vezérelt azonnali egyesülés) integrálása a vártnál is sokkal több gondot okozott, kihatást gyakorolt a többi átalakuló ország beilleszkedésének megítélésére is.

1992 őszén az EU-tagállamok polgárainak 73 százaléka helyeselte a nyugat-európai egyesülési folyamatot, tudomásul véve a német egyesülési folyamatot is. $\mathrm{Az}$ egyesülésnek sajátos következménye volt a kelet-németek reakciója, akik két év alatt - az egyesülés, illetve az EU-ba történő integrációt követően - az európai (pontosabban nyugat-európai) integráció egyik legpesszimistább alanyai lettek, bár többségük támogatta a folyamatot, akárcsak a többi európai uniós ország lakossága. Így a kelet-németek 64, míg a borúlátó britek 57 százaléka támogatta az európai egyesülési folyamatot. (Special Report of the Eurobarometer Survey, no 38. [1993]) Bár a támogatottság a későbbiekben némileg javult, de a német egyesülés tanulságosnak bizonyult az EU tagállamai számára. Megerősítette azt a véleményt, hogy csak megfelelő piacgazdasági és demokratikus rendszer kiépítése és főleg konszolidációja után érdemes a további keleti bővítést folytatni. 
A többi tagjelölt országgal kapcsolatos vélemények elemzésénél két megjegyzést kell tennem:

1. Csak olyan országok EU-n belüli megítélését elemzem, amelyek az EU-val legkésőbb 2000. márciusában megkezdték a felvételi tárgyalásokat (a tíz közép- és kelet-európai tagjelölt országon kívül Málta és Ciprus). Az elemzés szempontjából tehát nem érdemes hosszasan kitérni Törökország megítélésére, bár a statisztikák szerint meglehetősen alacsony azon közösségi tagállami polgárok aránya (2000-ben a megkérdezettek 30 százaléka, lásd: II/4. sz. táblázat), akik a török tagságot szorgalmazzák.

2. A német egyesítés után az Eurobarometer külön vizsgálta a keletnémet tartományok állampolgárainak hozzáállását, (ugyanúgy 1000 fős minta alapján, mint a tagállamokban), ami a volt szocialista táborban élők szolidaritásának mértékét mutatja a többi közép-európai ország irányába.

Bár hosszú évekre visszamenőleg lehetne elemezni a bővítés kérdését, ez megítélésem szerint nem hozna reális eredményt, mivel az Unió tagállamainak polgárai csak 1995, azaz az előző bővítés befejeződése, illetve a madridi csúcsértekezlet (mely elindította a tényleges bővítési folyamatot) óta szembesülnek a keleti irányú bővítés realitásával.

Folyamatában vizsgálva a kibővítés igenlését, megállapítható, hogy a 90-es évek első felében, majd utána is csak mérsékelt figyelmet kapott az EU-tagállamok közvéleményében a bővítés fontossága. Így 1995-ben a megkérdezettek (65 000 fö) több mint fele a neki feltett kérdésre (a bővítéssel kapcsolatosan mit tegyen az Unió: maradjon a jelenlegi helyzetében, saját belső ügyeit erősítse vagy bővüljön) azzal válaszolt, hogy legfontosabb az Unió belső fejlődése (55 százalék), és csak 13 százalék helyezte első helyre a bővítést. 
II/1. sz. táblázat: A bövitést fontos feladatnak érzö EU-polgárok aránya 1997-ben (a megkérdezettek százalékában)

\begin{tabular}{|c|c|c|}
\hline Ország & $\begin{array}{c}\text { Csatlakozzanak új } \\
\text { tagok } \\
\text { (százalék) }\end{array}$ & $\begin{array}{c}\text { Változás 1995 } \\
\text { tavaszához képest } \\
\text { (százalék) }\end{array}$ \\
\hline Ausztria & 10 & -5 \\
\hline Belgium & 8 & -4 \\
\hline Dánia & 27 & +2 \\
\hline Németország & 11 & -5 \\
\hline Görögország & 10 & -14 \\
\hline Spanyolország & 18 & +2 \\
\hline Franciaország & 8 & -4 \\
\hline Írország & 28 & +2 \\
\hline Olaszország & 11 & -5 \\
\hline Luxemburg & 10 & -2 \\
\hline Portugália & 17 & +1 \\
\hline Svédország & 19 & -3 \\
\hline Finnország & 18 & -3 \\
\hline Egyesült Királyság & 15 & -9 \\
\hline EU 15 & $\mathbf{1 3}$ & $-\mathbf{4}$ \\
\hline
\end{tabular}

Forrás: Eurobarometer 45, [1997]

A II/1. sz. táblázatból látható, hogy a kilencvenes évek közepén, ahogy a bővítés keleti folytatása valódi képpé vált, az európai lelkesedés alábbhagyott. Az európai bővítés kérdését a dánok és az írek tartották különösen fontosnak, de általában az északi országok részéről jelent meg nagy érdeklődés. A másik véglet, a bővítést teljesen jelentéktelennek látók közül kiemelkedik Belgium és Franciaország, ahol csak a megkérdezettek 8 százaléka találta a további bővítést időszerü kérdésnek.

Hasonló képet mutatott az 1999. év végi felmérés is (Eurobarometer, 51.sz. [1999]), amelyben a 12 létező prioritás közül a bővítés kapta a legkisebb támogatottságot. A lakosság 28 százaléka tekintette ezt fontosnak - 59 százalék kifejezetten nemmel válaszolt -, míg a munkanélküliség elleni küzdelmet 90 százalék, a biztonság kérdését 89 százalék, a szegénység elleni harcot 87 százalék nevezte meg, de 80 százalék felett volt azok aránya is, akik a kábítószer-kereskedelem és bűnözés, a környezetvédelem vagy az emberi jogokat jelölték meg első helyen. (A megfelelő fejezetek elemzésénél természetesen kitérek arra, hogy a biztonság erősítését és az új típusú kihívások elleni védekezést a bővítés hogyan erősíti.) 
Ettől némileg kedvezőbb képet mutat az a vizsgálat (Eurobarometer, 51. sz. [1999]), amely az EU csúcsvezetői rétegét (politikusok, gyárosok, köztisztviselők) célozta meg, és arról kérdezte, hogy számukra mi az első számú prioritás. 1999-ben a bővítés kérdése az euró, a munkanélküliség és a gazdasági helyzet után a negyedik helyen állt, és a megkérdezett vezetők, kiemelkedő személyiségek 19 százaléka nevezte meg prioritásként.

A csatlakozási tárgyalások szempontjából nem lényegtelen az sem, hogy mely kérdések felvételi kritériumként való megjelenését tartják az EU-polgárok teljesítendőnek az egyes csatlakozó országoktól:

\section{II/2. sz. táblázat: Az EU lakosai elvárásainak prioritása a tagjelöltekkel szemben a megkérdezettek százalékában}

\begin{tabular}{|l|c|c|}
\hline \multicolumn{1}{|c|}{ Felvételi kritériumok } & Fontos & Nem fontos \\
\hline $\begin{array}{l}\text { Emberi jogok és demokrácia } \\
\text { tiszteletben tartása }\end{array}$ & 95 & 1 \\
\hline $\begin{array}{l}\text { Szervezett bünözés és kábítószer- } \\
\text { ellenes harc }\end{array}$ & 93 & 3 \\
\hline Környezetvédelem & 92 & 4 \\
\hline Tudjon fizetni az EU költségvetésébe & 84 & 7 \\
\hline Döntések elfogadása és megvalósítása & 82 & 8 \\
\hline $\begin{array}{l}\text { Csatlakozása ne legyen drága a } \\
\text { jelenlegi tagoknak }\end{array}$ & 81 & 10 \\
\hline $\begin{array}{l}\text { Gazdasági fejlettsége legyen közel a } \\
\text { tagállamokhoz }\end{array}$ & 75 & 16 \\
\hline $\begin{array}{l}\text { Képes legyen az EU érdekeit sajátja } \\
\text { fölé helyezni }\end{array}$ & 70 & 17 \\
\hline
\end{tabular}

Forrás: Eurobarometer 51., [1999]

A felmérés megmutatja azt - és ezt a további elemzéseknél a dolgozatomban is figyelembe kell vennem -, hogy az EU-polgároknak a bővítéssel kapcsolatos prioritása a szélesebben vett biztonságon alapul, vagyis a demokrácia, belső stabilitás, a bünözés elleni harc, valamint a környezetvédelem (amely utóbbi kettő 
nem ismer országhatárokat) területén jelenik meg. Ennél kisebb erővel nyom latba az, hogy gazdaságilag mennyire képes egy új belépő a követelményeknek eleget tenni. A gazdasági kohézió és föleg az EU érdekei sajátja fölé helyezése már nem olyan kiemelkedő elvárás, amiben szerepet játszik az is, hogy a tagállamok között is jelentős szóródás van ennek megítélésében.

Rendkívül tanulságos a kibővítés, mint prioritás támogatottságának vizsgálata országonkénti bontásban (Eurobarometer, 51.sz. [1999])): eszerint 1999-ben a lakosság több mint fele - Dániában (58 százalék), Görögországban (54 százalék) illetve közel fele - Írországban (49 százalék) és Finnországban (48 százalék) - ezt fontosnak látta. A kibővítés, mint prioritás, a legalacsonyabb a keletnémet tartományokban (17 százalék), valamint a leginkább érintett Németországban (19 százalék), Ausztriában (24 százalék), Finnországban (23 százalék), valamint Franciaországban (19 százalék). Mindez arról tanúskodik, hogy a német-francia tengelynél a keleti bővítés nem élvez elsőbbséget a közvélemény óhajában. Ez jelzi azt, hogy az integráció élharcos országai a mélyülés lehetőségeinek szempontjából nem ítélik meg feltétlen előnyösnek a keleti irányú integrációt.

Ettől némileg eltérő az a megítélés, miszerint ha egyszer mégis sor kerülne a bővítésre, mekkora támogatási hányadot adnának az egyes tagországok a keleti bővítésben érintett 13 országnak 2000 tavaszán (lásd: II/3.sz. táblázat). A skandináv országok leginkább preferált jelöltjei a három balti állam, míg Görögországnak Ciprus, Olaszországnak Málta jelenti a prioritást. A preferenciák történelmi, tradicionális illetve földrajzi kapcsolódásokra utalnak, míg az EU-átlagnál magasabb kibővítési hajlandóságot mutató spanyol lakosságnál Lengyelország favorizálása a katolicizmus mindkét országban megfigyelhető dominanciája, illetve a római katolikus Pápa lengyel nemzetisége játszik szerepet. A történelmi tradíciók jelennek meg abban is, hogy Franciaország leginkább Lengyelország felvételét támogatja, és az is érdekes momentum, hogy a déli tagállamok leginkább a balti országokat utasítják el, míg az északi államok a déli fekvésű tagjelölteket (Románia, Szlovénia, Bulgária) szeretik a legkevésbé. 
II/3. sz. táblázat: Az egyes EU- tagállamok támogatása a tagjelöltek irányába 2000 tavaszán (a megkérdezettek százalékában)

\begin{tabular}{|c|c|c|c|c|c|}
\hline \multirow{2}{*}{ Tagállam } & \multirow{2}{*}{$\begin{array}{c}\text { Támogatás a } \\
13 \text { jelöltnek } \\
\text { (\%) }\end{array}$} & \multicolumn{2}{|c|}{$\begin{array}{c}\text { Leginkább preferált } \\
\text { jelölt }\end{array}$} & \multicolumn{2}{|c|}{$\begin{array}{c}\text { Legkevésbé preferált } \\
\text { jelölt }\end{array}$} \\
\hline & & Ország & $\%$ & Ország & $\%$ \\
\hline Svédország & 61 & Észtország & 74 & Románia & 49 \\
\hline Dánia & 58 & $\begin{array}{l}\text { Észtország } \\
\text { Litvánia } \\
\text { Lettország }\end{array}$ & 70 & $\begin{array}{l}\text { Románia } \\
\text { Bulgária }\end{array}$ & 48 \\
\hline Görögország & 55 & Ciprus & 87 & $\begin{array}{l}\text { Észtország } \\
\text { Litvánia }\end{array}$ & 46 \\
\hline Hollandia & 49 & Málta & 63 & Szlovénia & 42 \\
\hline Spanyolország & 49 & $\begin{array}{l}\text { Lengyelország } \\
\text { Magyarország }\end{array}$ & 52 & $\begin{array}{l}\text { Észtország } \\
\text { Litvánia }\end{array}$ & 46 \\
\hline Finnország & 48 & Észtország & 69 & Románia & 32 \\
\hline Olaszország & 43 & Málta & 60 & Lettország & 35 \\
\hline Írország & 41 & Málta & 53 & Lettország & 35 \\
\hline Portugália & 41 & $\begin{array}{l}\text { Magyarország } \\
\text { Csehország }\end{array}$ & 44 & $\begin{array}{l}\text { Észtország } \\
\text { Lettország } \\
\text { Litvánia }\end{array}$ & 37 \\
\hline Belgium & 38 & Málta & 54 & Románia & 33 \\
\hline Egyesült Királyság & 35 & Málta & 58 & Szlovénia & 27 \\
\hline Luxemburg & 34 & Málta & 49 & Románia & 28 \\
\hline Németország & 34 & Magyarország & 49 & Románia & 23 \\
\hline Ausztria & 30 & Magyarország & 52 & Románia & 13 \\
\hline Franciaország & 26 & Lengyelország & 35 & Lettország & 20 \\
\hline EU-15 & 38 & Málta & 50 & $\begin{array}{l}\text { Románia } \\
\text { Szlovénia }\end{array}$ & 34 \\
\hline
\end{tabular}

Forrás: Eurobarometer 53., [2000]

Megvizsgáltam, hogy az egyes felvételiző országok tagsága milyen támogatottsággal rendelkezik a megkérdezett EU-polgárok összességénél. Míg 1996 elején a 12 állam közül Magyarország élvezte a legnagyobb támogatottságot (51 százalék) Málta előtt (49 százalék), addigra ez 2000 tavaszára Magyarország esetében 46 százalék (-5 százalék) esett vissza, Máltánál 50 százalékra nőtt (lásd II/4. sz. táblázat). A többi tagjelölt ország EU-tagként való elfogadását jelző index 1999. végén 34 és 44 százalék között mozgott (a földközi-tengeri kis országok és a Magyarország melletti másik két NATO-tagállam jelent szignifikánsan jobb elismertséget), ami 1996 elejéhez képest 0 és 5 százalék közötti csökkenést jelez. A dolgozatban külön nem elemzett Törökország támogatottsága 6 százalékos csökkenést mutat, ami határozottan észlelhető csökkenési tendenciát jelez. Érdemesnek tartom megjegyezni, 
hogy mindössze öt jelöltnél (Málta, Magyarország, Lengyelország, Ciprus, Csehország) volt a kedvező állásfoglalás magasabb, mint az elutasító, és meglepő módon rossz eredményt tudhat magáénak Szlovénia, a térség gazdasági fejlettségi értelemben vett éllovasa is.

II/4. sz. táblázat: Az egyes tagjelölt országok tagságának támogatottsága az EU-polgárok között (a megkérdezettek százalékában)

\begin{tabular}{|l|c|c|c|c|}
\hline \multicolumn{1}{|c|}{ Ország } & $\begin{array}{c}\text { 2000 tavasza } \\
\text { támogatottság } \\
(\mathbf{\% )}\end{array}$ & $\begin{array}{c}\mathbf{1 9 9 6} \text { tavasza } \\
\text { támogatottság } \\
\mathbf{( \% )}\end{array}$ & $\begin{array}{c}\text { Különbség } \\
\mathbf{( 1 9 9 6 - 2 0 0 0 )} \\
\mathbf{( \% )}\end{array}$ & $\begin{array}{c}\text { Elutasítók } \\
\mathbf{2 0 0 0} \\
\mathbf{( \% )}\end{array}$ \\
\hline Csehország & 41 & 44 & -3 & 35 \\
\hline Szlovákia & 37 & 38 & -1 & 38 \\
\hline Lengyelország & 44 & 49 & -5 & 34 \\
\hline Magyarország & 46 & 51 & -5 & 31 \\
\hline Románia & 34 & 38 & -4 & 42 \\
\hline Szlovénia & 34 & 34 & 0 & 40 \\
\hline Észtország & 36 & 37 & -1 & 38 \\
\hline Lettország & 36 & 38 & -2 & 38 \\
\hline Litvánia & 35 & 37 & -2 & 38 \\
\hline Bulgária & 36 & 37 & -1 & 39 \\
\hline Ciprus & 44 & 43 & +1 & 32 \\
\hline Málta & 50 & 49 & +1 & 26 \\
\hline Svájc & 69 & 72 & -3 & 14 \\
\hline Norvégia & 70 & 70 & 0 & 13 \\
\hline Törökország & 30 & 36 & -6 & 47 \\
\hline
\end{tabular}

Forrás: Eurobarometer 53. [2000]

Amennyiben az egyes tagállamok és jelentkező országok rokonszenv illetve elutasítottsági mátrixát nézzük (lásd: II/5. sz. táblázat), akkor kiviláglik az a tény, hogy bizonyos tagállamokban jobban ismerik a közép- és kelet-európai térséget és így a differenciált megközelítést részesítik elönyben (Ausztria, volt NDK, Németország), míg mások a térséget egybemosva kezelik, és inkább a bővítés általános óhaja vagy elutasítása dominál (Franciaország, Belgium, Spanyolország, Portugália). Felfedezhetők történelmi-kulturális tradíciók is azokban az esetekben, amikor az adott tagállam állampolgára markáns különbséget tesz, vagy éppen szándékosan nivellál. Ilyen például a volt NDK, Németország vagy Ausztria Magyarországhoz való viszonya, Görögország és Nagy-Britannia Ciprust, a nagy katolikus államok Lengyelországot preferáló magatartása, illetve Franciaország és Belgium nivelláló magatartása. Különösen alátámasztható az a tézis, hogy a keleti 
irányú bővítés megvalósítása a régióhoz közel fekvő tagállamok lakossága szerint jobban kívánatos. Megjegyzem, hogy a volt NDK-ban a határos Cseh Köztársaság felvételét a lakosság 58, Magyarországét 62, Lengyelországét 45 százaléka helyesli, ami meghaladja az országos és a közösségi átlagot is (Eurobarometer, 53. sz. [2000]). Burgenland lakóinak 59 százaléka támogatja Magyarország felvételét (Burgenland brüsszeli irodája, [2001]), szemben az országos 52 vagy az uniós 46 százalékos aránnyal.

II/5. sz. táblázat: Egyes közép-és kelet-európai tagjelöltek elfogadása (+) illetve elutasitottsága (-) Ausztriában (A), Németországban (D) és Franciaországban (F), 2000 tavaszán (a megkérdezettek százalékában)

\begin{tabular}{|l|c|c|c|c|c|c|}
\hline \multicolumn{1}{|c|}{ Ország } & A (+) & A (-) & D (+) & D (-) & F (+) & F (-) \\
\hline Csehország & 34 & 49 & 40 & 41 & 27 & 48 \\
\hline Szlovákia & 27 & 57 & 34 & 45 & 23 & 52 \\
\hline Lengyelország & 23 & 60 & 37 & 46 & 35 & 45 \\
\hline Magyarország & 52 & 35 & 49 & 34 & 32 & 47 \\
\hline Románia & 13 & 69 & 23 & 58 & 24 & 52 \\
\hline Szlovénia & 38 & 45 & 30 & 49 & 21 & 52 \\
\hline Észtország & 28 & 50 & 34 & 43 & 21 & 53 \\
\hline Lettország & 29 & 49 & 34 & 44 & 20 & 53 \\
\hline Litvánia & 27 & 51 & 33 & 44 & 21 & 53 \\
\hline Bulgária & 17 & 65 & 29 & 51 & 25 & 50 \\
\hline
\end{tabular}

Forrás: Eurobarometer 53. [2000]

Magyarország vonatkozásában különösen kiemelendő, hogy Németországban és Ausztriában nagyon magasan meghaladja a tagságot elfogadóknak az elutasítókhoz képest mért arányát (+17 százalék, illetve +15 százalék, bár ez csaknem 10 százalékkal alacsonyabb érték a három évvel korábbi adatokhoz képest), ami a pozitív egyenleget mindkét országban mutató Málta mellett a többiek határozott elutasításának figyelembevételével értékelhető. Feltűnő még, hogy a kiemelkedő jelöltként számon tartott Szlovéniát többen elutasítják, mint támogatják mindkét országban, és 1996-tól eltérően 2000-ben már mindkét országban többen utasítják el Csehországot (Ausztriában jelentősen), mint amennyien tagságát támogatják. (Ebben szerepet játszhatott Klaus előző miniszterelnök arrogáns magatartása csakúgy, mint a cseh gazdasági növekedés visszaesése, vagy a termelini atomerőmü körüli vita.) 
Mivel a bővítés ügyében nem népszavazás, hanem parlamenti jóváhagyás dönt a tagállamokban, érdemes felhívni a figyelmet arra, hogy Ausztriában a magasabb végzettségü férfiak és a városi emberek jóval magasabb arányban támogatják a bővítést, mint az alacsonyabb végzettségü szakipari munkások vagy vidéki lakók, vagyis ez a tény a közvélemény kutatásoknál tapasztaltnál nagyobb parlamenti támogatottságot kell, hogy jelentsen. (Ulram, [1999])

\section{RÉSZ; 2. FEJEZET}

\section{A TAGJELÖLT ORSZÁGOK KÖZVÉLEMÉNYE}

Bár dolgozatom célja az, hogy az EU érdekeltségét mutassam be a bővítésben, ennek meghatározásánál az egyik alapvető faktor éppen az, hogy a jelentkező országokban milyen a belépés támogatottsága. Az EU-államokban ezt a tényt különös figyelemmel kísérik, mivel:

- Norvégia esetében már aláírt csatlakozási szerződés után kétszer (1972-ben és 1994-ben), az EGT-tagság ügyében Svájc egyszer (1992-ben) már népszavazáson elutasította az európai integrációt, sőt Svájc lakossága 2001-ben az EU csatlakozási tárgyalások elkezdését is elhárította.

- Minden felvételiző országban valószínüsíthető népszavazás, méghozzá a ratifikációs időszak várhatóan első felében.

Fenti okok miatt az EU közvéleményét elsősorban az érinti, hogy milyen a bővítés tagjelölteknél észlelhető általános támogatottsága, és nem az, hogy ennek milyen az egyes társadalmi csoportokon belüli megoszlása. (Ez utóbbi inkább a tagjelöltek belső kommunikációs stratégiája miatt érdekes, hiszen a bővítést támogató intézményeknek és szervezeteknek ez alapján kell meggyőző munkájukat végezniük.) 
Az 1995 óta eltelt időszak ez irányban pozitív tendenciát mutatott. Az Eurobarometer térséggel foglalkozó felmérései szerint 1995 és 1997 között a 10 közép- és keleteurópai jelentkező ország népességének 60 százaléka szavazna határozottan a tagság mellett (tehát a véleményt nem nyilvánítók és az elutasítók aránya csak 40 százalék). Megfigyelhető az is, hogy az első tárgyalási körben meghívott országok esetében eröteljes növekedés figyelhető meg, hiszen mind Szlovénia $(+10)$, Észtország $(+6)$, Magyarország (+9) vagy Csehország (+6) esetében nőtt a tagság támogatottsága a kilencvenes évek második felében. Ebben a időszakban már esett a lengyel mutató (7 százalékkal), de ezzel együtt a lengyelek támogatták a legnagyobb arányban (63 százalék) az első hat tárgyaló ország lakossága közül a tagságot. Érdekes módon a luxemburgi csúcsértekezleten (1997. december) a tagsági tárgyalásokra nem meghívott öt országban sem csökkent jelentősen saját országuk EU-tagságának támogatottsága. Ugyanakkor ebben az időszakban nőtt a belépési hajlandóság a negatív országvélemény ellenére Szlovákiában (+16 százalék), és a biztató értékelést kapó Bulgáriában (+6 százalék). (Ekkor a cseheknél, litvánoknál, letteknél és az észteknél volt az EU-t határozottan igenlők aránya 50 százalék alatt, amiben az orosz anyanyelvűek magas aránya, illetve Klaus miniszterelnök euroszkeptikus propagandája is szerepet játszott.)

2001-ben azonban újabb trendmódosulás volt megfigyelhető (ld.: II/6. sz. táblázat), hiszen míg a tagságtól távolálló Bulgária és Románia lakossága még nagyobb lelkesedéssel támogatta a tagságot (a megkezdett tárgyalásoknak és az elmaradottságot ellensúlyozó csodavárás következtében), addig csökkent a lengyel támogatottság, és továbbra is alacsony a lett-észt mutató. Magas maradt a támogatás Magyarországon, Szlovákiában és Szlovéniában is. A nagy differenciák ellenére az jósolható, hogy minden tagjelölt országban meglesz a tagságot támogatók többsége a referendumokon. 
II/6. sz. táblázat: Ha most lenne az EU népszavazás, akkor hogyan szavazna? (1997 vége illetve 2001) (százalékos eloszlásban)

\begin{tabular}{|l|c|c|c|c|}
\hline \multirow{2}{*}{\multicolumn{1}{c|}{ Ország }} & \multicolumn{2}{c|}{ Mellette } & \multicolumn{2}{c|}{ Ellene } \\
\cline { 2 - 5 } & $\mathbf{1 9 9 7}$ & $\mathbf{2 0 0 1}$ & $\mathbf{1 9 9 7}$ & $\mathbf{2 0 0 1}$ \\
\hline Románia & 71 & 85 & 11 & 3 \\
\hline Lengyelország & 63 & 54 & 17 & 26 \\
\hline Szlovákia & 62 & 66 & 16 & 11 \\
\hline Szlovénia & 57 & 56 & 11 & 22 \\
\hline Bulgária & 57 & 80 & 17 & 4 \\
\hline Csehország & 49 & 54 & 19 & 18 \\
\hline Litvánia & 40 & 50 & 26 & 20 \\
\hline Lettország & 40 & 46 & 32 & 32 \\
\hline Észtország & 35 & 38 & 37 & 27 \\
\hline Magyarország & 56 & 70 & 20 & 10 \\
\hline
\end{tabular}

Forrás: Közép és Kelet-Európai Eurobarometer [1997], [2001]

$\mathrm{Az}$ Eurobarometer felméréseit támasztja alá az is, hogy az osztrák GFK Kutatóintézet kimutatásai szerint 1999-ben a visegrádi négy ország esetében eltérő tendenciák játszódtak le 1995-höz képest. Magyarországon nőtt az EU lakossági támogatottsága, míg Lengyelországban és Csehországban szignifikánsan csökkent, sőt Szlovákiában is enyhe csökkenést figyeltek meg, amit alátámasztanak a nemzeti közvélemény-kutatási eredmények is. Mindebben közrejátszott az, hogy Lengyelországban és Csehországban a társulási időszak alatt egyre több probléma merült fel, illetve tárgyalásaik lelassulása már nemcsak a csatlakozási optimizmust csökkentette, hanem a csatlakozási kedvet is (a gördülékenyebb társulási viszonyt folytató Magyarországgal ellentétben).

A tagjelölt országok lakosságának döntő hányada arra számít, hogy a csatlakozás kiegyensúlyozott hasznot hoz, míg a valamelyik fél nagyobb hasznát feltételező polgárok - Észtország kivételével - inkább saját hazájuk, mint az EU számára remélnek nagyobb előnyt (lásd: II/7. sz. táblázat). (Az I/2. fejezetben elemzett feltételek és kutatások alapján ez utóbbi feltételezés reálisnak mondható.) 
II/7. sz. táblázat: A tagjelölt országok lakosságának véleménye arról, hogy melyik fél (EU vagy saját ország) számára lesz hasznos a bövités

(1997-ben a megkérdezettek százalékában)

\begin{tabular}{|l|c|c|c|}
\hline \multicolumn{1}{|c|}{ Ország } & Kiegyensúlyozot & EU & Saját ország \\
\hline Lettország & 40 & 19 & 19 \\
\hline Szlovénia & 36 & na & na \\
\hline Csehország & 35 & na & na \\
\hline Lengyelország & 40 & 22 & 22 \\
\hline Magyarország & 40 & 15 & 24 \\
\hline Észtország & 31 & 32 & 22 \\
\hline Románia & 53 & na & na \\
\hline Szlovákia & 43 & na & 25 \\
\hline Bulgária & 38 & na & 30 \\
\hline Litvánia & na & na & 39 \\
\hline
\end{tabular}

Forrás: KKEU, Eurobarometer 8. [1997]

A tagjelöltek szemszögéből vizsgálva a bővítést, annak támogatottsága magas (jóval meghaladja az EU-tagállamok szintjét), bár a csatlakozási tárgyalások húzódásával némileg csökkenő szintet mutat. Kivétel ebben Magyarország, ahol a vezető tagjelöltek közül változatlanul magas a tagság igenlése. A tagjelöltek általában a mindkét fél számára hasznos („,win-win”) hozadékot látják a belépéskor, de az EUtárgyalások elhúzódása (Baltikum, Lengyelország, Csehország) jelentős illúzióveszteséget hozhat. Meglepő a tagság alacsony támogatottsága a balti államokban, ahol - a dánokhoz és svédekhez hasonlóan - a kis országok nemzeti érdekeinek védelme fontos szempont.

\section{RÉSZ; 3. FEJEZET}

\section{SAJÁT KÉRDŐÍVES FELMÉRÉS}

Annak céljából, hogy a disszertációban meghivatkozott közvélemény-kutatásokat és szakmai elemzéseket az uniós szervekben hivatalban lévő döntés-előkészítők és döntéshozók csoportjának véleményével össze tudjam vetni, kérdőívet szerkesztettem, aminek segítségével - személyes ismeretségre alapozva megkerestem az Európai Parlamentben, az Európai Bizottság Kibővítési 
Főigazgatóságán valamint az Európai Unió Tanácsa Főtitkárságán a bővítésért felelős vezető tisztviselőket és politikusokat. A megkeresettek 70 százaléka (14 fö) adott választ. A felmérést úgy készítettem el, hogy a válaszadók személyazonossága - tekintettel magas funkcióikra - nem állapítható meg. Ez adta annak garanciáját, hogy a kérdőívben feltett kérdésekre az interjúalanyok valóban őszinte választ adjanak. A kérdőívben arra kerestem feleletet, hogy mely faktorok (történelmihumán; biztonsági-környezetvédelmi; gazdasági-költségvetési) az igazán döntőek abban, hogy az EU-államok felvegyék a közép- és kelet-európai országokat tagjaik sorába. Vizsgáltam továbbá azt is, hogy milyen befolyással van a döntéshozókra a bővítésnek az EU külső környezetére gyakorolt hatása (az előző bővítések tapasztalatai, a bővítésnek az új tagállamok egymás közötti viszonyai, valamint az EU-nak a más jelentős világgazdasági pólusokkal fennálló kapcsolatai).

Az alábbiakban ismertetem a kiküldött kérdőívet és a kapott válaszok eredményét. Az interjúalanyoktól minden feltett kérdésre 1-től 5-ig kértem választ (általában 1 a kevésbé lényeges vagy elutasító válasz, míg 5 a lényeges vagy teljes mértékben igenlő álláspont jele volt). A válaszok alapján számított számtani átlagot a kérdések mellett zárójelben közlöm. 
Scale 1 to 5 ( 1 is negative or insignificant, 3 is neutral, and 5 is positive or significant response to the questions) (1-töl 5-ig terjedö skála: 1 elutasitó vagy lényegtelen, 3 semleges, 5 pozitív vagy lényeges a kérdés megválaszolása szempontjából)

Private questionnaire on the impact of the eastern enlargement of the EU (Személyes kérdöiv az EU keleti bövitési hatásairól)

1. What type of impact you consider the most important factor in the decision on enlargement (Milyen hatást gondol a legfontosabb tényezönek a bövitéshez szükséges döntéshez):

- historical (történelmi) (4,08)

- political (politikai) $(4,64)$

- economic (gazdasági) (3,76)

- security (biztonsági) $(3,86)$

- environmental (környezetvédelmi) (2,92)

- $\quad$ social (szociális) (2,31)

2. What are the most advantageous factors for the present EU of the enlargement to the East? (Melyek a legelönyösebb tényezök a jelenlegi EU keleti bövitését illetôen?)

- political and cultural reunification of Europe (Európa politikai és kulturális újraegyesitése) (4,29)

- military security (katonai biztonság) (2,92)

- internal security (border control, fight against crime, migration and asylum policy etc. Belsö biztonság (határellenörzés, bünözés elleni harc, bevándorlás és menekültpolitika stb.) (4,31)

- enlargement of the internal market (a belsö piac bövitése) $(3,71)$

- extension of the euro zone (az euró-övezet szélesitése) (2,62)

- strengthening of the competitiveness of the European economy internally and externally (az európai gazdaság belső és külső versenyképességének erösitése) $(3,00)$

- better transit possibilities (jobb tranzit lehetöségek) (2,33)

- increasing purchase power of the newly emerging countries (a felemelkedö országok vásárlóerejének növekedése) (3,07)

- better control and consequently improvement of environmental and competition policies and conditions in the adjacent countries (a közeli országok környezetvédelmi és versenypolitikájának valamint feltételeinek jobb ellenörzése és ennek megfelelöen fejlesztési lehetösége) $\quad(3,33)$ 
3. What are the most disadvantageous impacts for the present EU of the Eastern enlargement? (Melyek a jelenlegi EU keleti irányú bövitésének leginkább hátrányos hatásai?)

- social dumping or disequality (szociális dömping és egyenlötlenség) $(2,38)$

- internal security (belső biztonság) (2,67)

- external security (külsö biztonság) (2,25)

- raising unemployment in the present EU as consequence of free movement of cheap labour force (az olcsó munkaerö szabad áramlása következtében növekvö munkanélküliség) $(2,69)$

- agriculture-overproduction and lower prices (mezögazdasági túltermelés és alacsonyabb árak) (3,21)

- losing competitiveness of the present EU companies in the internal market (a jelenlegi EU-vállalatok belső piaci versenyképességének csökkenése) $(1,83)$

- inclusion of minority problems in the EU (national minorities, Romas) (kisebbségi problémák - nemzeti kisebbség, romák - EU-ba vitele) (2,62)

- cultural and traditional divergence of the old and new countries (heritage of communism, corruption) (az új és a régi tagállamok kulturális és hagyományos különbségei - kommunizmus öröksége, korrupció) (2,58)

- economic differences within the EU will be too large for the first decades (az EU-n belüli gazdasági különbségek az elsö évtizedekben túl nagyok lesznek) $(3,15)$

- negative impact on the EU budget (negatív hatás az EU költségvetésére) $(3,54)$

- negative impact on the function of EU institutions (negativ hatás az EU intézményeinek müködésére) $(3,33)$

4. What influence do the previous enlargements exert on the EU public and political opinion for this enlargement? (Milyen hatása van az elözö bövitéseknek a mostani bövitéssel kapcsolatos, az EU-ban megnyilvánuló közvéleményre és a politikai megitélésre?)

- Greece (Görögország) (3,00)

- Spain, Portugal (Spanyolország, Portugália) (3,00)

- East Germany (Kelet-Németország) $(3,17)$

5. Do you think that the possibility of enlargement will be carried out in the form of...? (Gondolja, hogy a bövités az alábbi formákban valósulhat meg...?)

- individual countries (egyedi országokkal) $(2,18)$

- group of countries (egy országcsoporttal) $(4,36)$

- with large group of candidates (nagyszámú jelölt országgal) 
6. Do you think, the candidates are able to converge macroeconomically? (Gondolja, hogy a tagjelöltek képesek makrogazdasági értelemben felzárkózni?)

- as countries to the EU average (mint ország az EU átlaghoz) (3,93)

- regionally within the candidate countries (regionálisan, az egyes tagjelölt országokon belül) $(3,30)$

7. Do you think that the candidates can converge socially, culturally educationally to the EU? (Gondolja, hogy a tagjelöltek szociálisan, kulturálisan és az oktatás terén fel tudnak zárkózni az EU-hoz?) (4,00)

8. Do you expect positive implications for the reactions on enlargement by the EU main partners? (Pozitív következményeket vár az alábbi föbb EU partnerekkel a bövités utáni kapcsolatokban?)

- US (Egyesült Államok) (4,07)

- Russia (Oroszország) (2,85)

- Japan (Japán) (3,08)

- China (Kina) (2,54)

9. Do you think the enlargement will improve or deteriorate the regional cooperation among the new democracies (5 improve, 3 neutral, 1 deteriorate)? (Gondolja, hogy a bövités javitja vagy rontja az új demokráciák közötti regionális együttmüködést? (5 javitja, 3 semleges, 1 rontja) (4,07)

10. Where are the borders of Europe in 12-15 years (socially, economically, institutionally)? (Melyek lesznek 12-15 év múlva Európa határai (szociálisan, gazdaságilag, intézményileg?)

- the enlargement with 6-7 countries (bövités 6-7 országgal) (4,00)

- the enlargement with 12 Europe Agreement countries and Norway and Switzerland (a 12 Európai Megállapodást kötött országgal valamint Norvégiával és Svájccal megvalósuló bövülés) $(3,81)$

- the enlargement with all the candidates and some CIS and Western Balkan countries (minden tagjelölt ország és néhány FÁK valamint NyugatBalkáni országgal történö bövülés) $\quad(2,36)$ 


\section{II/3.1. Az eredmények értékelése}

A bővítést leginkább meghatározó tényezőnek a politikai elem $(4,64)$ tekinthető. Kiemelkedőnek mondható a megkeresett személyek szerint a biztonsági elem is (3,86, de a belső biztonságra szúkítve már 4,31) annak ellenére, hogy a felmérés még a 2001. szeptember 11-i terrorcselekmények előtt készült. Fontos, de nem kiemelkedő a gazdasági tényező $(3,76)$, ugyanakkor alacsony a környezetvédelmi $(2,92)$ és a szociális elem $(2,31)$ szerepe a döntéshozatal szempontjából. (Ez utóbbiak ellentétesek az EU-tagállamok lakosságánál vizsgált véleményekkel - 1d. II/2. sz. táblázat - főleg a környezetvédelmet illetően.)

Az egyes faktorok fontosságát tükrözi az is, hogy mi a válaszadók szerint a legelőnyösebb tényező a bővítéskor. Itt a politikai és kulturális újraegyesítést $(4,29)$, valamint a belbiztonság területén kibontakozó együttmüködést emelték ki a válaszadók (már az amerikai merényletek előtt is ez utóbbi volt a legnagyobb érték, 4,31 átlag!). Ezek a szempontok megegyeznek az állampolgárok véleményével is. (Lásd. II/2. sz. táblázat). A belső piac bővülését emelték még ki lényegében a válaszadók (3,71), akárcsak a környezetvédelmi és versenypolitika jobb ellenőrizhetőségét $(3,33)$. Nem játszik ugyanakkor kiemelkedő szerepet az Unió katonai megerősödése $(2,92)$, a közvetlen gazdasági haszon (növekvő kereslet - 3,07 -, megfelelő tranzit - 2,33). Feltünően alacsony az eurózóna bővítéséből eredő előnyök értékelése $(2,62)$. A bővítést segítő faktorok közül semlegesnek ítélték az európai gazdaság versenyképességének javulását (3,00). Mindebböl az a következtetés vonható le, hogy a politikai döntéshozók és előkészítők számára sem a gazdasági tényezők jelentik a bővítés legfontosabb elemeit.

Ha megnézzük azt, hogy a közvélemény-kutatások szerint (lásd II/2. sz. táblázat) mely tényezők a legfontosabbak a jelenlegi európai polgárok számára, akkor számukra is a politikai motívumok (emberi jogok és demokrácia tiszteletben tartása a megkérdezettek 95 százalékának fontos), illetve a biztonsági tényezők (93 százalék számára lényeges) dominánsak. A közvéleményben - a politikai döntéshozóktól és előkészítőktől eltérően - azonban kiemelkedően fontos szerepe van a környezetvédelem kérdésének. 
A kérdőíves felmérésben vizsgált kedvezőtlen tényezők közül a legnagyobb jelentőséget a megkérdezettek az EU költségvetésre gyakorolt hatásának tulajdonítottak $(3,54)$. Ez önmagában - a gazdasági haszon nélkül - vizsgálva valóban érthető, hiszen az új tagok szinte kivétel nélkül nettó haszonélvezők lesznek. Az átlagosnál nagyobb a félelem a bővítésnek az uniós intézmények müködésére $(3,33)$ kifejtett következményétől (ez érdekes módon nem jelenik meg élesen az ismertetett közvélemény-kutatásokban). Említésre méltó még az agrárintegrációval kapcsolatos aggály $(3,21)$, és a gazdasági elmaradottság okozta kohéziós probléma is $(3,15)$. Ez a két kiemelkedően fontos témakör középpontba helyezi a tagjelöltek közötti differenciált megközelítést, amit a következö fejezetekben ki fogok mutatni.

Kérdôíves felmérésem alapján azonban optimizmus csillan ki a válaszadók részéről az új tagállamok felzárkózási képességét illetően. Ebben is föleg a kulturális, szociális felzárkózás esélyei jók $(4,00)$, de bizakodó a megitélésük a gazdasági utolérést illetően is $(3,93)$. Ez utóbbinál kisebb optimizmust jelzett arra a kérdésemre kapott válasz, hogy a tagjelölt országokon belül regionálisan hogyan sikerül megoldani az elmaradt térségek felzárkóztatását $(3,30)$. Ezt az óvatosságot tükrözi, hogy a leginkább felzárkózó tagjelölt országokon belül lesz a legnehezebben megvalósítható a gazdasági-szociális konvergencia.

A bővítésnek az EU külső világgal meglévő kapcsolatait illetően a döntéshozók szerint javulni fognak a transzatlanti kapcsolatok $(4,07)$, (ez még inkább érvényes 2001. szeptember 11-e után), de lényegében semleges véleményt fogalmaztak meg Oroszország vonatkozásában $(2,85)$, nyilvánvalóan az orosz piacvesztéstől való félelem, valamint az EU és a NATO bővítés - mely utóbbit Moszkva elutasít párhuzamos jellege miatt.

Ugyancsak a külkapcsolatok terén mondták ki azt a véleményt, hogy a bővítés a tagjelölt országok, illetve közvetlen szomszédaik között javulást fog eredményezni $(4,07)$. Ez ellentmond azoknak a véleményeknek, amelyek szerint regionális konfliktusok kerülnének a bővítéssel az EU-n belülre, illetve áttételesen azt is cáfolja, hogy a bővítés elindítása rontja a kapcsolatokat a térség országai között. 
Tanulságos továbbá az is, hogy a döntéshozók majdnem akkora valószínüséget adnak egy közel 30 tagú Uniónak 2010 után $(3,81)$, mint egy 20-22 tagú szervezetnek $(4,00) .30$ tagnál szélesebb (nyugat-balkáni és FÁK-országokat is felölelő) bővítést azonban még 12-15 éves távlatban sem tartanak valószínünek $(2,36)$. Ez a következő 2-3 évtizedre meghatározza Európa határait, vagyis nem valószínüsíthető a jelenlegi bővítési körnél lényegesen nagyobb országcsoportot felölelő EU-szélesítés. 


\section{RÉSZ}

\section{A BŐVÍTÉS INTÉZMÉNYI ÉS BIZTONSÁGI VONATKOZÁSAI}

\section{RÉSZ; 1. FEJEZET}

\section{A BŐVÍTÉS HATÁSA AZ UNIÓ INTÉZMÉNYI RENDSZERÉRE}

Könyvtárnyi szakirodalom foglalkozott már azzal, hogy miként alakul az Unió legfőbb szerveinek müködőképessége a bővítés hatására. Ezért a jelenlegi fejezetben, azokra az elemekre hívom fel a figyelmet, amelyek a tagság szempontjából tartalmilag lényegesek lehetnek.

\section{III/1.1. A legfontosabb szervekben történő részvétel a Nizzai szerződés döntései alapján}

A 2001. február 26-án aláírt szerződéshez a 2000. decemberében kitárgyalt végső kompromisszum kapcsán egy nyilatkozatot csatoltak, amely meghatározta az Unió tárgyalási pozícióját a legfontosabb intézményi kérdésekben, a kiemelt döntéshozói vagy azt befolyásoló intézményekben való részvételt illetően. A pozíció nem tért ki az Európai Bíróság, az Európai Számvevőszék és a közös pénzzel kapcsolatos szervekre, hiszen ezekben eddig is minden esetben a tagállamok alanyi jogon képviselték magukat. Ezt az elvet a bővítés után sem kérdőjelezték meg, vagyis a jelenlegi tagjelöltek számára országuk képviselete biztosított lesz. Mivel az Európai Bíróság müködése már a jelenlegi 15 tagállam esetén is müködőképességének határán van, a bővítések után tevékenységének jelentős átszervezésére lesz szükség. Erre már 1999-2000 folyamán készültek javaslatok, de a bővítések megkezdése után ez előtérbe fog kerülni. A tagállamok alanyi jogon való részvételi lehetősége nem kérdőjeleződhet meg.

Az Unió müködésének és Alapszerződéseinek egyszerüsítése érdekében lépett fel az Európai Bizottság elnökének kérésére írott tanulmányában Richard von Weizsäcker, Jean-Luc Dehaene és David Simon 1999. októberében, de az Alapszerződések 
egyszerüsítése mellett szállt síkra a Nizzában lezárult Kormányközi Értekezlet is, amikor mandátumot adott a 2004-ben összeülő következő kormányközi értekezletnek.

További érdekesség, hogy a Nizzai szerződés csak 12 új tagállam felvétele esetére dolgozott ki javaslatokat az egyes, kiemelt fontosságú intézményekben történő tagállami részvételre, vagyis Törökországgal pillanatnyilag még nem számoltak, hiszen felvétele alapvetően új helyzetet teremtene az egész Unió fejlödése szempontjából. (Elég, ha arra gondolunk, hogy Törökország már most is az EU második legnépesebb tagállama lenne, és jelenlegi demográfiai trendje alapján, 15-20 éven belül a legnépesebb tagállammá válna annak minden intézményi - és föleg az EU belső piacának és politikájának müködésére vonatkozó - gyakorlati következményével együtt.) Valószínüleg a jelenlegi bővitési körök befejeződése után ezért reálissá válik Európa határainak meghatározása, illetve a kiterjesztés földrajzi lehetőségeinek definiálása. (Mivel ez nem érinti jelenlegi dolgozatomat, így részleteiben nem kívánok vele foglalkozni.)

A Nizzai döntés alapján igazi tétje a három döntéshozói szerv, a Tanács, a Bizottság és a Parlament összetételének van. A Régiók Bizottságainak és a Gazdasági Szociális Tanácsnak pillanatnyilag csak kötelező konzultációs szerepe van, ami lényeges döntésbefolyásoló tényezö, de a tényleges döntéshozatalban nincs meghatározó szerepe. Ezt mutatja az is, hogy ezekben a szervekben való részvételröl nem alakult ki vita, vagyis hogy a tagjelölteknek megadják-e a hozzájuk hasonló tagállamokra jellemző képviseleti számot. 
III/1.1. sz. táblázat: Az egyes tag- és tagjelölt államok lakossága, és képviseleti arányai a Nizzai csúcsértekezlet döntése alapján

\begin{tabular}{|c|c|c|c|c|c|c|}
\hline Ország & $\begin{array}{l}\text { Lakosság } \\
\text { (millió fó) }\end{array}$ & $\begin{array}{c}\text { Lakosság } \\
(\%)\end{array}$ & $\begin{array}{l}\text { EP helyek } \\
\text { (fó) }\end{array}$ & $\begin{array}{c}\text { EP helyek } \\
(\%)\end{array}$ & $\begin{array}{c}\text { Tanács } \\
\text { szavazati } \\
\text { szám }\end{array}$ & $\begin{array}{c}\text { Tanács } \\
\text { szavazati } \\
\text { súly (\%) }\end{array}$ \\
\hline Belgium & 10,213 & 2,12 & 22 & 3,0 & 12 & 3,5 \\
\hline Dánia & 5,313 & 1,10 & 13 & 1,8 & 7 & 2,0 \\
\hline Németország & 82,038 & 17,04 & 99 & 13,5 & 29 & 8,4 \\
\hline Görögország & 10,533 & 2,18 & 22 & 3,0 & 12 & 3,4 \\
\hline Spanyolország & 39,394 & 8,19 & 50 & 6,8 & 27 & 7,8 \\
\hline Franciaország & 58,966 & 12,25 & 72 & 9,8 & 29 & 8,4 \\
\hline Írország & 3,744 & 0,78 & 12 & 1,6 & 7 & 2,0 \\
\hline Olaszország & 57,612 & 11,97 & 72 & 9,8 & 29 & 8,4 \\
\hline Luxemburg & 0,429 & 0,09 & 6 & 0,8 & 4 & 1,2 \\
\hline Hollandia & 15,760 & 3,28 & 25 & 3,4 & 13 & 3,8 \\
\hline Ausztria & 8,082 & 1,68 & 17 & 2,3 & 10 & 2,9 \\
\hline Portugália & 9,980 & 2,07 & 22 & 3,0 & 12 & 3,4 \\
\hline Finnország & 5,160 & 1,07 & 13 & 1,8 & 7 & 2,0 \\
\hline Svédország & 8,854 & 1,84 & 18 & 2,5 & 10 & 2,9 \\
\hline Egyes. Királyság & 59,247 & 12,31 & 72 & 9,8 & 29 & 8,4 \\
\hline Bulgária & 8,230 & 1,71 & 17 & 2,3 & 10 & 2,9 \\
\hline Ciprus & 0,752 & 0,16 & 6 & 0,8 & 4 & 1,2 \\
\hline Észtország & 1,446 & 0,30 & 6 & 0,8 & 4 & 1,2 \\
\hline Magyarország & 10,092 & 2,10 & 20 & 2,7 & 12 & 3,4 \\
\hline Lettország & 2,439 & 0,51 & 8 & 1,1 & 4 & 1,2 \\
\hline Litvánia & 3,701 & 0,77 & 12 & 1,6 & 7 & 2,0 \\
\hline Málta & 0,377 & 0,08 & 5 & 0,7 & 3 & 0,8 \\
\hline Lengyelország & 38,667 & 8,04 & 50 & 6,8 & 27 & 7,8 \\
\hline Csehország & 10,290 & 2,14 & 20 & 2,7 & 12 & 3,4 \\
\hline Románia & 22,489 & 4,67 & 33 & 4,5 & 14 & 4,0 \\
\hline Szlovákia & 5,393 & 1,12 & 13 & 1,8 & 7 & 2,0 \\
\hline Szlovénia & 1,978 & 0,41 & 7 & 1,0 & 4 & 1,2 \\
\hline Összesen & 481,179 & 100,00 & 732 & 100,0 & 345 & 100,0 \\
\hline EU-15 & 375,325 & 78,00 & 535 & 73,1 & 237 & 68,7 \\
\hline
\end{tabular}

Forrás: Eurostat, Európai Bizottság COM (2000) 34. [2000], Nizzai szerződés melléklete $\mathrm{OJ} / \mathrm{C} / 2001 / 80$ [2001],

Megjegyzés: A lakosságszámot az 1999-es Eurostat adat alapján számolták, kivéve Máltát (1998) illetve Törökországot (nemzeti adat) és becsülve Németország és az Egyesült Királyság lakosságát. Az EP és Tanácsi helyek súlya egy tizedesre kerekítve.

Mint látható a III/1.1. sz. táblázatból, a képviseleti rend az egyes tagállamok lakosságának növekedésével párhuzamosan erösen degresszív lesz, amely a kisebb tagállamoknak kedvez. (A népképviseleti arányosság elve Hollandia és Románia között vált át a kisebb ország számára kedvező trendbe, vagyis a Hollandiánál kisebb lélekszámú országok egyre kedvezőbb, Romániánál nagyobbak pedig egyre kedvezőtlenebb képviseleti arányt kapnak.) Mivel az új tagállamok közül csak Lengyelország számít nagy tagállamnak, ezért a többi országnál méretétől függően - 
azzal csökkenve - lesz elönyösebb országuk képviselete. Degresszív növekedés elvétől való eltérés csak a cseh és magyar parlamenti helyek esetében látható, hiszen itt fordul elő az, hogy kisebb lakosságszámhoz nagyobb számú EP képviselőt párosítanak, ami példátlan az EU történetében. (Portugália úgy kapna két képviselöi hellyel többet Magyarországhoz és Csehországhoz képest, hogy formálisan 1999-es lakosságszáma még kisebb a két új tagállaménál.) Ezért ennek a helyzetnek a módosítása várható. A megoldás módja még nem ismert, valószínüleg a csatlakozási tárgyalások intézményi kérdéssel foglalkozó fejezetében kerül erre sor.

A bővítésnek a minősített döntéshozatalra vonatkozó várható hatását nehéz megjósolni. Ez alapvetően attól függ, hogy hány országot vesznek fel a most érvényes döntéshozatali rendszerben. Nem tagadható, hogy mint minden politikai kompromisszum, ez is addig él, amíg újabb kormányközi konferencián nem döntenek másként. Bár Nizza azt határozta meg, hogy 27 tagállamig a jelenlegi kompromisszum - melyben benne van az is, hogy 2005. január 1-től minden tagállamnak egy állampolgára lesz a Bizottságban (most Németország, az Egyesült Királyság, Franciaország, Olaszország és Spanyolország két bizottsági taggal rendelkezik) - megmaradhat, de az Unió a következő, 2004-ben tartandó kormányközi értekezleten ezt felülvizsgálhatja. Függetlenül attól, hogy hány új tagállammal történik meg az EU bővítése, az bizonyos, hogy a Tanácsban a szavazati számok (lásd: III/1.1. sz. táblázat) legalább 71,7 százaléka szükséges ahhoz, hogy minősített többségü döntést hozzanak. (A mostani tagállamok esetében 2005. január 1-től ez lesz a minimum limit a minősített többségü döntések meghozatalához, és a teljes - tizenkettő állammal történő - bővítés után a szükséges 258 minimum szavazat eléri a 74,6 százalékot. Addig viszont részleges - tizenkettő államnál kevesebbet felölelő - bővítés esetén Nizza alapján a minősített döntés határa nem haladhatja meg a szavazati számok összességének 73,4 százalékát.) Mindez azt jelenti, hogy a teljes mértékben kibővült EU-ban lehetne csak az a helyzet a Tanácsban, hogy a régi tagállamok nem tudják megszavazni minősített többséggel az újak ellenében akaratukat, kisebb körű bővítés esetén (pl. Románia és Bulgária kívülmaradásáig) ezt meg tudnák elméletileg tenni. A minősített többséget igénylő döntéshez az EU lakosságának legalább 62 százalékát képviselő országok igen szavazata szükséges, - ez akkor is megvan a jelenlegi tagállamok lakosságszáma alapján, ha mind a 12 új tagállam belép - és legalább a tagállamok fele, ha a 
Bizottság tesz javaslatot, egyébként pedig a tagállamok kétharmada (ami 23 tagállamig a jelenlegi 15 tagállam révén biztosítható, utána ehhez már az új tagállamok szavazata is szükséges lesz. Nizzai Szerződés [2000]). Az Unió fejlődéséből kiindulva ez a helyzet (a régi tagállamok leszavazzák az új tagállamokat) valószínüleg nem áll fenn, hiszen az új tagállamok az ,egy állam-egy bizottsági tag” elvvel lehetőséget kapnak egy ilyen, a jaltai vonalakon alapuló hátrányos döntés veszélyének kiküszöbölésére. (A minősített többségü kérdések általában a belső piachoz kapcsolódnak, amikor is a Bizottság tesz javaslatot. Ebben a testületben pedig az elnök egyhangúságra törekszik, és a testület kollegiális jellegének, nemzetek feletti helyzetének végét jelentené, ha erőszakkal leszavaznák egy javaslat kapcsán az új tagállamok képviselőit.)

Az Európai Parlamentben legtöbb kérdésben egyszerü többséggel folyik a döntéshozatal (itt bármikor leszavazhatók az új tagállamok képviselöi), de a bizottsági elnök megválasztását illetően kétharmados döntés szükséges (gyakorlatilag a teljes bővülésig ez biztosítható a jelenlegi tagországok révén). Az Európai Parlamentben egyébként a frakciók nem nemzeti, hanem politikai alapon szerveződnek, ami segít feloldani a régi-új tagállamok közötti esetleges ellentéteket. Természetesen további garanciát jelent, hogy az EU szerveinek apparátusában az új tagok állampolgárai is szerepet kapnak, hiszen ezek új szemlélete révén - kötelező nemzetek feletti viselkedési elvárásuk figyelembevételével - mindenféleképpen reális képet segíthetnek kialakítani már a javaslatok időpontjában is. Ezt erősítik a Bizottság ún. tanácsadói vagy jogalkotást előkészítő munkacsoportjai is, amelyekbe nemzeti szakértők bevonására is lehetőséget adnak.

\section{III/1.2. Várható kényes kérdések a döntéshozatalban a bővítés után}

Az előzőekben vizsgált szavazási (képviseleti) helyzet régi-új tagokra bontott elméleti elemzésénél fontos vizsgálati elem az, hogy milyen kérdésekben alakulhatnak ki olyan helyzetek, amikor az új tagállamok érdekei ellentétben állnak a régiekkel. Megítélésem szerint ilyen helyzet valójában nem állhat elő túl sok területen, hiszen az uniós joganyag átvétele, a célok megvalósítása ugyanúgy érdeke az új tagállamoknak, mint a régieknek. Nézetem szerint az alábbi témákban várható az új tagállamok részéről sajátos érdekérvényesítés: 
1. Harmadik országokkal való viszony, illetve kereskedelempolitikai, vízumpolitikai vagy beutazási-menekültügyi, határellenőrzési gyakorlat az új tagállamokkal szomszédos területen. (Ebben közrejátszhat a sajátos regionális történelmi helyzet, a határok és nemzetiségek viszonya, ahogy azt a vonatkozó fejezetekben kifejtettem.) Ezek a kérdések Nizza ratifikációja után minősített többségbe kerülnek.

2. További új tagok felvétele (ez az Alapszerződések módosítását igényli, amely mindig is a tagállamok konszenzusán fog alapulni). Ennek oka az, hogy további új tagállamok a mostani tagjelöltekkel határosak, ami a közöttük meglévő történelmi, nemzetiségi viszonyok szerint fogja segíteni vagy gátolni a további bővítést.

3. A tagfelvételi tárgyalásokon számukra hosszabb távon diszkriminatívnak érzett kérdések reformja. Ilyen a jelenlegi helyzet szerint két területen alakulhat ki. Amennyiben az agrárpolitika területén a termelők számára járó közvetlen kifizetések biztosítását nem tudják elérni az új tagállamok, a csatlakozás után nehezen tudják korrigálni ezt a jelenlegi tagállamokkal szemben. A másik ilyen terület a strukturális politikánál a pénzügyi transzferek egyenlő elvek szerinti biztosítása. (Ez utóbbinál a konszenzusos döntés elvét csak 2006 után oldják fel.) Mindez oda vezethet, hogy a hátrányosan megkülönböztetett új tagállamok a következő kormányközi konferenciákon vétójogot fognak gyakorolni, ha a fentiekben jelzett két diszkriminációs elbánás fennáll.

4. Sajátos gazdasági helyzetből eredő érdekeltségek. Ezen a területen - a tagfelvételi tárgyalások tapasztalatai alapján - nem a különböző jogszabályok elvi, hanem abszolút számokban meghatározott szerepe lesz döntő, vagyis az, hogy az alacsonyabb jövedelmi viszonyok között lévő új tagjelölteknek nehezen lesz elfogadható olyan új intézkedés megszavazása, mely konkrét pénzösszegben kifejezhető korlátokat szab meg, vagy kötelezettségeket ír elő számukra. (Ilyen nehézség például az az abszolút összeghatár, amit az EU szabott meg a befektetővédelmi alapnál - minimum 20.000 eurós alsó határ -, vagy ami felmerült a cigaretta jövedéki adójánál, mely nemcsak a legnépszerübb hazai cigaretta 
termelői árának minimum 57 százalékát, de ezer szálanként a 64 euró alsó határt is el kell hogy érje.) A lehetséges gazdasági felzárkózással és így a lakosság jövedelmének növekedésével párhuzamosan (ld. a makrogazdasági fejezetet) csökken az abszolút értékhatárokból eredő sajátos konfliktusok szerepe, de a tagság első időszakában feszítő gondként jelenhetnek meg az új tagállamok egy része számára.

Ebben a gazdasági felzárkózásban sajátos terhet jelent majd az infrastruktúra vagy a környezetvédelem területe, melyek szintén beruházás-igényes szektorok a közösségi szabályozás végrehajtása esetén. Ez azonban csak a gazdaságilag jobban elmaradott új országoknál okozhat problémát, hiszen ha a gazdaságilag fejlettebb tagjelöltek szövetségre tudnak lépni a hozzájuk hasonlítható jelenlegi kohéziós tagállamokkal (Görögország, Portugália, Spanyolország), akkor nem lehet e csoport ellenében minősített többségű döntést hozni.

5. Olyan lehetséges döntéshozatali területek, ahol az új tagállamok sajátos érdekei megjelenhetnek. Nagyon sok nemzeti érdek konszenzust igénylö területeken jelenik meg, amit a jelenlegi tagállamok most is nehezen tudnak áttenni minősített többséget igénylő döntések körébe. Ilyen konszenzusos elven alapul az EU bővítése, az alapszerződések módosítása, az adózás, a társadalombiztosítás, 2006-ig a regionális politika, bevándorlás-politika, kultúra, egészségügy, a külés biztonságpolitika nagy része és a védelempolitika teljes mértékben. Konszenzusos döntésnek minősíthetjük az EK pénzügyi irányelveinek (többéves, évenkénti lebontásban a főbb költségvetési sarokszámok meghatározása) elfogadását is. Ezeken a területeken nincs jelentősége annak, hogy milyen a reprezentációs arány, hiszen bármely tagállam vétójoga fennáll.

A belső piacot érintő, minősített többséggel eldöntendő területeken közép és hosszú távon nem számíthatunk olyan fellépésre, ami az új tagállamok külön csoportokban való szavazását és érdekeltségét a többiekkel szemben előrevetítené. Például a külföldi tőke vonzása és a kohézió közösségi segítésének folytatása nem regionális sajátosság, hiszen ebben a három mediterrán kohéziós ország is különböző fokon, de érdekelt. Az agrárkérdésekben is olyan érdekkoalíciók kötése várható az Unión belül, amelyek a különböző tagállamok adottságain és nem a regionális megközelítésen 
alapulnak. (Pl. a szántóföldi kultúra vagy az állattenyésztés területén a tagjelöltek és a tagállamok közötti hasonlóság vagy különbség minden bizonnyal vegyes csoportosulásokat hoz majd létre.) Az agrárkérdésekben a vita inkább a nagy és kis államok között bontakozhat ki, hiszen a nagy államok, mint jeleztem, relatíve alulreprezentáltak a döntéshozatalban. Ezt a konfrontációt egyelöre mérsékli, hogy a döntéseknek - kérés esetén - a lakosság 62 százalékát és a tagállamok felét kell maguk mögött tudniuk. Ez azt jelenti, hogy a nagy tagállamok nélkül nem lehet igazán jelentős közösségi vagy uniós döntést hozni. (Ez föleg a nettó befizető Németország és Nagy-Britannia álláspontja.) Regionális sajátosságként a bővítés után az új tagállamokkal határos külső régiókkal (Balkán, FÁK térsége) kialakítandó szorosabb kapcsolatok kapnak nagyobb hangsúlyt, míg a távolabbi - elsősorban a gyarmati múlt miatt az EU-hoz kapcsolódó - régiók (például lásd ACP-országok köre) szerepe mérséklődik az Unió külkapcsolataiban a bővítést követően.

Természetesen nem kizárható, hogy az új Európában a nagy kiterjedés, a sokszínüség miatt szűkebb regionális politikai és gazdasági-politikai csoportosulások jelenjenek meg. (Ilyen lehet a visegrádi formáció, a BENELUX-kezdeményezés újjáélesztése, a balti tengeri vagy északi együttmüködés, de e regionális érdekszövetségek megalakulásának már nem szigorúan a régi-új tagok mentén kell megtörténnie, mint azt az előzőekben is kifejtettem.) Az, hogy a kibővült EU-ban lesznek-e több országot úgy felölelő regionális csoportok, melyek koordinált fellépést, netán a közösségi politikák végrehajtását valósítanák meg, most nehezen megjósolható.

Sajátos intézményi következménye lesz a bővülésnek a hivatalos nyelvek számának gyarapodása. Ez hatalmas anyagi áldozatot jelent a közös költségvetésnek, hiszen valószínüleg Málta és Ciprus kivételével az új tagok mindannyian saját nyelvet szeretnének az Unióban hivatalos közösségi nyelvként meghonosítani (10 új nyelv jelenhet meg a jelenlegi 11 mellett). Technikai értelemben - az üléstermek mérete, tolmácskabinokkal való ellátottsága miatt - nehezen kivitelezhető, hogy az üléseken valamennyi hivatalos nyelv használata zökkenőmentesen megvalósuljon. Minden valószínüség szerint felerősödnek azok a nézetek, melyek szerint a hivatalos dokumentumok lefordítása és utólagos kihirdetése mellett a tényleges üléseken formailag is rögzítsék a munkanyelveket (az angol, francia és német nyelvek jöhetnek szóba), ami inkább a nagyobb méretű tagállamok között fog feszültségeket 
okozni, hiszen a munkanyelvek rendszerét nem lehet mind a hat nagy nyelvre (így a fenti három mellett az olasz, spanyol és lengyelre) kiterjeszteni, hiszen ez megkérdőjelezné a munkanyelvek kiemelésének értelmét. Valószínüleg 27 országig kivitelezhető az a megoldás, amely a választott politikai képviselők (EP, miniszteri szintű tanácsülés) ülésein valamennyi nyelv tolmácsolását megoldják, míg a többi fórumon ezt nem biztosítják. (A térség lakosságának idegen nyelvi preferenciáiról az oktatási fejezetben adtam számot.) Az mindenesetre nem valószínüsíthető, hogy az új tagállamok saját nyelvük hivatalossá tétele mellett azok munkanyelvvé való fejlesztését vagy elismertetését követelnék, ami egyszerüsíti az egyébként várható vitát.

További technikai jellegü következmény lesz a közösségi intézmények alkalmazotti létszámának növekedése, mely időnként - pl. az épületek, üléstermek és irodák száma és mérete - új, minőségi fejlesztéseket tesz szükségessé, ami azonban már nem intézményi, hanem költségvetési kérdésnek tekinthetö. (Lásd V/4. fejezetnek a kibővítés adminisztratív költségeiről szóló része.)

A bővítés után több mint húsz, egyre jobban heterogén összetételü tagállam miatt az Amszterdami Szerződés által életre hívott ún. megerősített együttmüködés kerül előtérbe, amelyet nyolc tagállam indíthat el. Ez az integráció mélyítésében élszerepet játszó országok mozgásterét fogja bővíteni és nem a felzárkózási kérdésekkel viaskodó új tagállamokat helyezi előtérbe. Mindenesetre nem zárható ki, hogy közülük néhányan - pl. Szlovénia - a megerősített együttmüködésben már a tagság első szakaszában partnerként lépjenek fel. Az új tagállamok önálló, megerősített együttmüködést jelentő fellépése azonban nem valószínűsíthető. Nem téveszthető össze a megerősített együttmüködéssel bizonyos tagállamok uniós vagy közösségi intézményeken kívüli fellépése, (ilyen volt a terrorista-ellenes akciókhoz kötődő 2001. október-novemberi genti és londoni mini csúcsértekezlet), ami független államok konzultációja a közösségi rendszeren kívüli területeken (például védelem) történő együttműködésről, vagy a közösségi (uniós) döntések előkészítésének céljából.

Összegezve megállapítható, hogy a bővítés köre (mennyi és melyik ország), és a csatlakozási szerződések tartalma (vagyis, hogy az új tagok megkapják-e átmenettel 
vagy a nélkül az őket megillető részvételi, anyagi jellegü jogokat) határozza meg a bővítés utáni határokat. Amennyiben e kérdésekben megfelelő és igazságos döntések születnek, nem várható olyan regionális csoportosulás, amely az új és régi tagállamok között hasadást feltételez. Ez érvényes mind a föbb közösségi politikákkal kapcsolatos döntéshozatalra, mind a regionális szövetségekre (Ausztria a közép-európai, Finnország az északi dimenzióban mindenképpen részt vesz megítélésem szerint) mind a megerősített együttmüködésre. Mivel azonban az egyre nagyobb létszámmal és így bonyolultabban müködö Unió döntés- és működőképességét, valamint állampolgárai számára az átláthatóságot biztosítani kell, az Unió müködése az egyhangú döntéshozatal további visszaszorulását fogja eredményezni. Az is megjósolható, hogy az Uniós intézmények (Tanács, Bíróság, Bizottság) strukturáltabb formában - a tagok egy részét felölelő kollégiumok, munkacsoportok révén - fogják elérni a gyorsabb döntés-előkészítést, időnként döntést is pl. belső eljárási ügyekben. Nem elsősorban az Unió bővítésének, hanem az integráció mélyülésének hatása lehet az a fejlődés, amely az Alapszerződések egyszerüsítésének (például egypilléres, egységes szerkezet kialakítása a Maastrichtban létrehozott hárompilléres, részben közösségi, részben kormányközi struktúra helyett), alkotmányos kérdéseknek az Alapszerződésből való kiemelésének, a nemzeti parlamentek beemelése a döntéshozatalba illetve a szubszidiaritás elvének erösítése irányába hat. Ez mindenképpen a nem-kormányközi együttmüködési intézmények (főleg az Európai Parlament és az Európai Bizottság) megerősödéséhez fog vezetni a döntéshozatalban. 


\section{RÉSZ；2. FEJEZET \\ A KIBŐVÍTÉS BIZTONSÁGPOLITIKAI HÁTTERE, HATÁSA AZ UNIÓ KÖZÖS KÜL- ÉS BIZTONSÁGPOLITIKÁJÁRA}

\section{III/2.1. A hidegháború végének kedvező hatásai}

1990-ben a rendszerváltás a közép-európai országok számára új biztonsági helyzetet teremtett. Egyrészt ezek az országok - az akkori meggyengült szovjet birodalommal kooperálva - némi bizonytalanság után úgy döntöttek, hogy vissza kívánják nyerni katonai szuverenitásukat (vagyis kérik a szovjet csapatok kivonását. Magyarországon és a volt Csehszlovákiában a csapatkivonás már 1991-ben megtörtént, míg a volt NDK, és az ahhoz utánpótlási vonalat jelentő Lengyelországban ez később következett be. (Jugoszláviában és Romániában nem állomásoztak szovjet csapatok.) Másrészt ezek az országok biztonságpolitikai doktrínájukban is kifejezésre juttatták a rendszerváltás értékváltást jelentő paradigmáját, vagyis nem kívánták értékalapon fenyegetni a korábban ellenséges nyugati országokat az esetleges támadás veszélyével. Az értékváltást és a nyugati orientációt jelzi az is, hogy megszüntették a Varsói Szerződés mind katonai, mind politikai együttműködési szervezetét 1991-ben. Ezzel párhuzamosan a volt szovjet és jugoszláv birodalomból kivált, jelenleg tagjelölt három balti állam és Szlovénia azonnal nyugat-orientált politikába kezdtek.

1990-től kezdve a tagjelöltek az évtized közepéig felvételt nyertek az európai együttműködési és demokratikus értékrendszer egyik alapszervezetébe, az Európa Tanácsba, ezzel együtt elismerték az Európai Emberi Jogi Egyezmény, valamint az Európai Emberi Jogi Bíróság joghatóságát. Mindezek következtében az évtized elején rögtön nyilvánvalóvá vált a kelet-nyugati konfrontáció lehetőségének kizárhatósága, sőt az is valószínü volt, hogy a volt FÁK területéről - főleg Oroszországból - nyugatra csapó esetleges konfliktusban az új demokráciák a nyugati oldal mellé állnának. Ezt erősítette, hogy a Varsói Szerződés feloszlatása után, még 1991-ben felállított Észak-Atlanti Együttmüködési Tanácsba mindannyian beléptek, és ott a NATO-val szoros együttmüködést folytattak. Mindez hozzájárult 
ahhoz, hogy a hidegháborús évekhez képest az európai NATO-tagállamok csökkenteni tudták védelmi kiadásaikat és katonáik számát.

A III/2.1. sz. táblázatból jól látható, hogy miközben a GDP 1990 után is nőtt az EUtag szövetségesek esetében, a védelmi kiadások területén szinte minden tagállam jelentősen visszafogta a kiadásokra szánt összegeket a GDP-hez mérten (Belgiumban és Németországban a csökkenés meghaladta a 7 százalékot), és igazán csak a kilencvenes évek végén kezdődött meg a védelmi kiadások növekedése alapvetően eltérő okokból. Mindez a GDP 1-1,5 százalékának megtakarításához vezetett a kilencvenes években a hidegháborús évekhez képest, ami jelentős következménye annak, hogy a közép-európai régióban szövetséges, illetve azonos értékrendszerü országok jelentek meg. (Éppen a török és görög mutatók jelzik, hogy a hidegháborútól eltérő egyéb okok miatt megmaradt, sőt még nőtt is a katonai kiadások szerepe a nemzeti költségvetésben.)

Hasonlóan meglepő adatokat látunk akkor, ha nemcsak a kiadásokat, hanem a katonaságnál foglalkoztatott munkaerőt vizsgáljuk (ld. III/2.1. sz. táblázat). Ebből azt a következtetést szürhetjük le, hogy abszolút értékben is (Görögország és Törökország kivételével, ám ez esetben többek között az egymással szembeni és nem a volt kelet-nyugati veszélyérzet dominál) csökkent a katonák létszáma, néhány esetben radikálisan felére vagy azon is túl. A munkaerőpiacon pedig kivétel nélkül 2 százalék alá vagy annak közelébe csökkent a katonai és védelmi alkalmazottak aránya, ami már a mezőgazdaságban foglalkoztatott népesség arányánál is kisebb lett. 
III/2.1. sz. táblázat: Az EU egyes tagállamainak és tagjelöltjeinek néhány katonai vonatkozású mutatója

\begin{tabular}{|c|c|c|c|c|c|c|c|}
\hline \multirow[t]{2}{*}{ Ország } & \multicolumn{3}{|c|}{$\begin{array}{c}\text { Védelmi költségek a GDP } \\
\text { százalékában }\end{array}$} & \multicolumn{2}{|c|}{$\begin{array}{l}\text { Katonák száma } \\
\text { (ezer fó) }\end{array}$} & \multicolumn{2}{|c|}{$\begin{array}{c}\text { Katonai és polgári } \\
\text { alkalmazottak száma } \\
\text { a munkaerő } \\
\text { százalékában } \\
\end{array}$} \\
\hline & 1992 & 1997 & 1999 & 1990 & 1999 & 1990 & 1998 \\
\hline Ausztria & 1,0 & 0,9 & 0,8 & na & na & na & na \\
\hline Belgium & 1,8 & 1,5 & 1,5 & 106 & 43 & 2,7 & 1,1 \\
\hline Dánia & 2,0 & 1,7 & 1,6 & 31 & 25 & 1,4 & 1,2 \\
\hline Finnország & na & na & 1,4 & na & na & na & na \\
\hline Németország & 2,1 & 1,6 & 1,5 & 545 & 334 & 2,6 & 1,2 \\
\hline Görögország & 4,4 & 4,6 & 4,9 & 201 & 205 & 5,7 & 5,3 \\
\hline Franciaország & 3,4 & 3,0 & 2,8 & 550 & 421 & 2,7 & 2,1 \\
\hline Írország & na & na & 0,9 & na & na & na & na \\
\hline Olaszország & 2,1 & 2,0 & 2,0 & 493 & 391 & 2,4 & 2,0 \\
\hline Hollandia & 2,5 & 1,9 & 1,8 & 104 & 55 & 2,1 & 1,1 \\
\hline Portugália & 2,7 & 2,4 & 2,2 & 87 & 72 & 2,2 & 1,8 \\
\hline Spanyolország & 1,6 & 1,5 & 1,4 & 263 & 155 & 2,0 & 1,4 \\
\hline Svédország & na & na & 2,3 & na & na & na & na \\
\hline Egyesült Kir. & 3,8 & 2,7 & 2,6 & 308 & 218 & 1,7 & 1,2 \\
\hline Csehország & 2,7 & 1,9 & 2,2 & $n a$ & 53 & $n a$ & $n a$ \\
\hline Magyarország & 2,1 & 1,9 & 1,6 & $n a$ & 61 & $n a$ & $n a$ \\
\hline Lengyelország & 2,3 & 2,3 & 2,2 & $n a$ & 187 & $n a$ & $n a$ \\
\hline
\end{tabular}

Forrás: Világbank World Development Indicators [2000], NATO tükör [1999], [2000]

A rendszerváltás után, a kilencvenes évek közepén új együttmüködési lehetőségek jelentek meg, ami javította az EU-országok biztonságpolitikai helyzetét. Ezek közül kiemelhető a NATO által indított Partnerség a Békéért (PfP) program, amely kétoldalú együttmüködési formát jelentett az Észak-atlanti Szövetség és a térség egyes országai között. Ezt 1994 után valamennyi tagjelölt ország aláírta és ezáltal az együttmüködést konkrét katonai területen meg is kezdte.

Szintén ezzel egy időben kezdtek el életbe lépni az EU és a tagjelöltek között az Európai Megállapodások (mint azt már említettem a történelmi bevezetőben), és ezáltal - a koppenhágai csúcsértekezlet állásfoglalása alapján - megnyílt az út a közép- és kelet-európai országok EU tagsága felé. 1994-től az ún. Kirschbergi Nyilatkozattal a Nyugat-Európai Unió lehetővé tette az ún. társult partneri viszony megteremtését, ami új mederbe terelte a kormányközi és parlamenti együttmüködési lehetőségeket. Mindez folyamatosan elörevetítette azt, hogy a Nyugat Európai Unió 
keretein belül is megbeszéljék az új tagjelöltekkel az európai biztonságpolitikát érintő kérdéseket, sőt közös lépések kidolgozásának egyeztetése is megindulhatott.

\section{III/2.2. Konkrét politikai együttmüködés az EU-val}

A NATO és a NYEU kooperációval párhuzamosan megkezdődött az EU-val a közvetlen politikai együttmüködés megvalósítása. 1993 végén Hurd és Andreatta (akkori olasz és brit külügyminiszterek) kezdeményezése alapján döntött az EU Tanács úgy, hogy 1994 végétől megkezdi az EU a társult országokkal azt a politikai együttmüködési rendszert, ami gyakorlatilag a tagságig tart. Ez két szempontból fontos. Egyrészt a társult országok már ekkor csatlakozhattak azokhoz a külpolitikai eszközökhöz - közös akciók, nyilatkozatok, demarche-ok -, amelyeket a tagállamok is alkalmaznak a Mastrichti Szerződés életbe lépése (1993. november 1.) óta. (Ezt a lehetőséget időközben kiterjesztették a közös pozíciókra is, mint az Unió közös külés biztonságpolitikájának fontos eszközére.) Ezek között már voltak olyan területekre vonatkozó akciók vagy nyilatkozatok is (pl. délszláv hadifogolycserék sürgetése, belorusz helyzet megítélése), amely nemcsak a világban jelenlévő közvetett, hanem közvetlen európai érdekeket is érintették. Ennek a folyamatnak egyenes eredménye volt az, hogy a 2001 szeptemberében bekövetkezett amerikai terrortámadások nyomán a társult országok csatlakoztak valamennyi EU szolidaritási nyilatkozathoz, valamint a 2001. szeptember 21-én megrendezett rendkívüli EU-csúcsértekezlet következtetéseihez és akciótervéhez, ami azonnal megerősítette az EU világban elfoglalt pozícióját.

Másrészt segített abban is, hogy az általános értékrendszerek terén a harmonizációt megvalósítsa és ebben is erősítse az európai pozíciókat a világban. Ebben játszik fontos szerepet az is, hogy a közös kül- és biztonságpolitika területén már 14 EUmunkacsoport valósít meg folyamatos együttmüködést a tagjelölt országokkal. Ezen túlmenően a legfontosabb eredmény az EU számára az, hogy a nemzetközi szervezetekben a tagjelölt országok már most egyeztetnek a tagállamokkal abban, hogy milyen álláspontot foglaljanak el, és így információkkal, véleményekkel a tagjelöltek is segíthetik az EU-t, nemcsak fordítva. Az Európa Tanácsban a 25 ország - kiegészülve Ciprussal, Máltával és szükség esetén Törökországgal - már most is teljes mértékben domináns álláspontot jelent, de hasonlóan fontos politikai-földrajzi 
tömörülést alkothat az EBESZ-ben is. A tömörülésnek komoly súlya van megfelelő közös fellépés esetén az ENSZ-ben is. Már most is fontos hozzájárulás az EU külpolitikájának sikeréhez, hogy a délszláv térségben folytatott külpolitikai akciók terén (szankciók, Stabilitási Egyezmény) a térségben lévő társult országok tényleges együttmüködése az európai siker záloga. A tagjelöltségi dátum nagyban hozzájárult ahhoz, hogy az EU-nak oly fontos szankciókat (beleértve az önálló, nem ENSZ döntésen alapulókat), a térség országai teljesítették (pl. a délszláv válságok idején), ami segített az EU számára döntéseinek hatékonyabbá tételében.

Már a tagság lehetősége is sokat segített abban, hogy a tagságra pályázó országok egymás között, a jelenlegi tagállamokkal, illetve a közvetlen szomszédságot jelentő, de tagsággal csak a távolabbi jövőben számoló országokkal (Balkán, FÁK nyugati része) politikai egyezmények jöjjenek létre. (Ezeket a közvélemény elsősorban csak a határok erőszakos és egyoldalú megváltoztatása és a kisebbségekre vonatkozó passzusok miatt ismeri, de ezek az államközi kapcsolatok szélesebb körét is felölelik.)

\section{III/2.3. A tagság jelentette további előnyök az EU számára}

A fentiek alapján nyilvánvaló, hogy a politikai együttmüködés már jelenleg is fontos politikai hasznot hozott az EU számára, de léteznek olyan pótlólagos előnyök, amelyek csak a tagsághoz kötődnek:

- Megváltozik majd az EU geopolitikai helyzete, hiszen olyan területek kerülnek közvetlen szomszédságába (a volt szovjet és délszláv régió, valamint az iszlám területek is), amelyek még hosszú ideig nem lesznek az EU tagjai, illetve sohasem lesznek azok, de ezen országokkal fenntartott kapcsolatok európai normák szerinti stabilizálásához nélkülözhetetlen lesz az új tagállamok szomszédos kapcsolatainak kihasználása, illetve az Unió új határán a helyzet ellenőrzése. Ennek nemcsak katonai vagy belbiztonsági, hanem kereskedelempolitikai vonatkozásai is lesznek, vagyis az EK szerződéseinek kiterjesztésével az új tagokra, a szomszédos országokkal való kapcsolatok is szorosabbá válnak és európai szinten jobban kontrollálhatók lesznek. (Elég, ha csak arra utalunk, hogy a bővítés után Oroszország külkereskedelméből az EU 
több mint 50 - egyes becslések szerint 65 - százalékkal fog részesedni, és megnő aránya az EU energiaellátásában is. Lásd az energiapolitikáról szóló fejezetet.) Ez jelenti például a FÁK-országokkal kötött partnerségi és társulási megállapodások, valamint a nyugat-balkáni országokkal aláírt stabilizációs és társulási megállapodások új belépők által történő átvételét. A bővítés kötelezi az új tagokat arra, hogy a mediterrán térséggel barcelonai folyamatként ismert együttmüködést átvegyék, amelyekben a politikai együttmüködés mellett kereskedelmi liberalizációs lépések is megvalósitásra kerülnek majd. (A nyugatbalkáni és a mediterrán országokkal átmeneti időszak után az EU részéről a szabadkereskedelmi kapcsolat is megvalósulhat). Ez a lépés egyébként segít abban is, hogy az új tagok és közvetlen szomszédaik között fontos stabilizációs szerepet betöltő kapcsolatok az EU külső politikai kapcsolatrendszere részévé váljanak, ezáltal is erősítve a térségben létrehozott kétoldalú alapszerződéses rendszerek erejét.

- Az EU-val a nemzetközi szervezetekben történő együttmüködésre a tagjelölt országok politikai kötelezettséget vállaltak (az egyeztetés minden esetben megtörténik 1994 óta), de ez nem jelenti azt, hogy a tagjelöltek minden esetben követik is az EU-álláspontokat. Tartalmi probléma eddig nem jelentkezett a stratégiai érdekazonosság miatt, és politikai okokból ez az együttmüködés jelentheti az egyéni álláspont kinyilvánításának lehetőségét (pl. személyi jelölésnél). Ezen túlmenően a tagállami egyeztetés szélesebb kört ölel fel és teszi erősebbé a fellépést olyan nemzetközi szervezetekben (pl. OECD és WTO), ahol az EU nem foglal el azonos pozíciót még a fejlettebb atlanti kultúrkörbe tartozó partnereivel (USA, Kanada, Japán) sem, alapvetően eltérő helyzete vagy taktikai érdekei miatt. Az Amszterdami Szerződés alapján a politikai együttmüködési kötelezettség a nemzetközi szintéren kilép az eddigi jogi kereteket nélkülöző státuszból, hiszen a közös külpolitikai eszközök már a közösségi joganyag részét képezik.

- Konkrétan sokat jelent a tagság minden olyan külpolitikai akció esetében, amelyeknél a konkrét politikai döntést - annak a közösségi kompetenciát illető jellege miatt - közösségi jogszabályban, rendeletben vagy bizottsági, tanácsi döntésként kell megfogalmazni. Ez esetben, a jogi értelemben vett kötelezettség 
- a Bíróság joghatálya - csak a tagállamokra érvényes. Különösen lényeges ez akkor, ha az EU szankciói nem az ENSZ döntésén alapulnak - tehát nem minden ENSZ-tagállamra kötelezőek - hanem autonóm jellegüek. Ekkor a tagjelöltek, bár valószínűleg osztják a rendelkezések okait és értékközösséget vállalnak az EU-val, de különböző okok miatt ezt nem kívánják mindig alkalmazni. (Ilyen példa volt az EU pénzügyi szankciói a jugoszláv vállalatok ellen; ettől eltérő volt jogi értelemben az Ausztria elleni diplomáciai embargó, amely azonban a politikai kötelezettségek végrehajtását sem tette kötelezővé a tagjelölt országok számára.)

- Külpolitikai szempontból is lényeges az EU számára a térség országainak a teljes harmadik pilléres (bel- és igazságügyi) együttmüködéshez történő csatlakozása, hiszen mind a jogsegélyre vonatkozó együttmüködések terén (pl. terrorizmus kapcsán a kiadatás), mind a vízumrendszer és a szigorított határőrizet, vagy az Europol-tagság jelenthet segítséget a külpolitikai kooperáció hatékony végrehajtásához. (Erre legjobb példa a Milosevics rezsim vezetőinek beutazására hozott tilalmak voltak, hiszen ezt csak vízumkötelezettség révén lehet hatékonyan ellenőrizni, ez azonban még a magyar-jugoszláv viszonylatban a tagságig nem áll fenn.)

- További segítséget adhat a tagállamoknak a tagjelöltek kiterjedt diplomáciai hálózata is, hiszen a régmúlt, egyébként sok szempontból negatív örökségének szerencsés részeként befolyással, helyismerettel és kapcsolatokkal rendelkeznek olyan területeken (Európa keleti része, Ázsia vagy Afrika), ahol az EU tagállamai (gyarmati múlt vagy ideológiai közelmúltbeli konfrontációk miatt) nehezebben tudnak kapcsolatokat kiépíteni.

- Jelentősége van annak is, hogy milyen erőket tud felajánlani az új tagállamok összessége az EU válságkezelési képességéhez, mely 2001 decembere után a laekeni csúcsértekezlet nyilatkozata révén operatívvá vált. Ebben eligazítást adhatnak a katonai és a nem katonai válságkezelési rendszerhez történő felajánlások (ld. III/2.2. sz. táblázat). Kiemelhető, hogy a tagjelöltek vélhetően több ezer főre tehető, megfelelő specializációt mutató hozzájárulásra készek, különösen Lengyelország felajánlása tekinthető katonai szempontból 
számottevőnek. Ez a jövőbeni helyzetre vonatkozó felajánlás akkor értékelhető igazán, ha figyelembe vesszük, hogy a különböző ENSZ, EBESZ vagy NATO válságkezelési feladatokhoz (így Európában a koszovói, és boszniaihorvátországi) jelentős - nemcsak katonai, hanem rendőri - felajánlást tettek már eddig is a társult országok.

III/2.2. sz. táblázat: A tagjelölt országok által felajánlott katonai és rendöri válságkezelési hozzájárulás

\begin{tabular}{|c|c|c|c|}
\hline \multirow{2}{*}{ Ország } & \multirow{2}{*}{$\begin{array}{l}\text { Katonai felajánlás } \\
\text { 2000. november }\end{array}$} & \multicolumn{2}{|c|}{$\begin{array}{c}\text { Rendőri erők felajánlása } \\
\text { 2001. november }\end{array}$} \\
\hline & & Általános & $\begin{array}{l}30 \text { napon belül } \\
\text { mozgósítható }\end{array}$ \\
\hline Csehország & $\begin{array}{l}\text { Gépesített lövész zászlóalj } \\
\text { Vegyvédelmi század } \\
\text { Egészségügyi század } \\
\text { Szállító helikopterraj }\end{array}$ & 100 & 25 \\
\hline Bulgária & - & 200 & 50 \\
\hline Románia & $\begin{array}{l}\text { Gépesített zászlóalj } \\
\text { Müszaki vagy katonai rendész } \\
\text { század } \\
1 \text { hegyivadász század }\end{array}$ & 75 & 20 \\
\hline Lengyelország & $\begin{array}{l}1 \text { dandár } \\
\text { felderítő század }\end{array}$ & 115 & 15 \\
\hline Litvánia & $\begin{array}{l}\text { Lengyel-litván zászlóalj litván } \\
\text { része } \\
\text { Gépesített lövész zászlóalj }\end{array}$ & 20 & - \\
\hline Lettország & Gyorsreagálású század & 35 & - \\
\hline Észtország & $\begin{array}{l}\text { Balti zászlóalj észt része } \\
\text { Katonai rendőri csoport }\end{array}$ & $\begin{array}{l}\text { Még nem } \\
\text { döntött }\end{array}$ & - \\
\hline Magyarország & $\begin{array}{l}\text { Gépesített lövész zászlóalj } \\
\text { Légvédelmi szakasz }\end{array}$ & 107 & 50 \\
\hline Szlovénia & $\begin{array}{l}\text { Gépesített század } \\
\text { Katonai rendész szakasz }\end{array}$ & 80 & 20 \\
\hline Szlovákia & $\begin{array}{lll}\text { Gépesített } & \text { század légi } \\
\text { támogatással } & & \\
\end{array}$ & 50 & - \\
\hline
\end{tabular}

Forrás: Társult országok EU melletti missziói.

Megjegyzés: A felsorolás a katonai felajánlásnál csak a szakasznagyságokat elérő felajánlásokat tartalmazza.

- Bár az EU alapszerződésében eddig nem szerepelt a kollektív védelem - ez valószínüleg a NATO-ra, valamint egyetlen lényegi feladatként, a tényleges eszközöket nélkülöző NYEU-ra marad -, de hosszú távon nem elképzelhetetlen, hogy külön jegyzőkönyvként ez is bekerül az európai alapszerződések joganyagába, önálló csatlakozási lehetőségként. Ekkor két fontos szempont fogja segíteni a jelenlegi tagállamok csatlakozását: 
1. A csatlakozni kívánó országok egyike sem volt 1990 előtt semleges, ilyen jellegü tradíció sem a politikai vezetésben, sem a lakosságban nincs. Mindannyian vagy NATO-tagok (1999. márciusa óta Lengyelország, Csehország és Magyarország), vagy kifejezték azon szándékukat, hogy a NATO tagjai szeretnének lenni (bár a tagsághoz formálisan a NATO meghívása szükséges). Ennek megfelelően a PfP-ben és az 1999-ben a tagsági felkészülésre elindított MAP-programban (Membership Action Program) a másik hét tagjelölt régióbeli ország is részt vesz. Ez azt jelzi, hogy egy esetleges kollektív védelmi elképzelésben - akár teoretikusan a NYEU-ban, akár potenciálisan az EU-ban, de EU-támogatással a NATO-ban is - a válságkezelésben sem fog a bővítés alkotmányos vagy politikai okokból visszahúzó erőt jelenteni.

2. A konkrét katonai képességek terén is erősödni fog az EU az új tagok felvételével. Bár igazán azonos nevezőjü elszámolás alapján csak a NATO metódusai szerint a három tagról (Lengyelország, Csehország, Magyarország) van pontos adatunk, de ennek alapján látható a katonai potenciál mértéke. Lengyelország 1999-ben 187 ezer fős haderővel rendelkezett, (a hasonló nagyságrendű Spanyolország 155 ezer fővel), míg Csehország 53 ezer, Magyarország 61 ezer fővel rendelkezett (összehasonlításképpen Belgium 43 ezer, Portugália 73 ezer fös haderőt tart fenn, lásd III/2.1. sz. táblázat). Mindhárom ország azonban kötelezettséget vállalt arra, hogy a haderőreformot (vagyis fegyveres erőit) az új típusú kihívásokhoz, illetve a NATO szövetségesi elvárásokhoz igazítja, ezért haderő létszáma csökkeni fog, ellenben a katonai kiadások növekednek majd. (Egyébként a haderöreform szükségessége a hidegháború elmúltával nemcsak az új szövetségeseknek jelent komoly feladatot, hanem olyan régi EU-NATO tagállamok is a reform elött állnak, mint Németország, Franciaország). A III/2.1. sz. táblázatban láthatjuk, hogy a GDP-hez viszonyított védelmi kiadások a NATO-tag EU-tagállamok és a szintén az Észak-atlanti Szövetséghez tartozó, EU-tagságért még csak folyamodó országokban nem mutatnak kirívó eltérést. (Csehország és Lengyelország a GDP 2 százaléka fölött költ erre a célra, míg Magyarország 1,6 százalékot). 
Ugyanakkor mindhárom szövetséges vállalta, hogy a védelmi kiadások arányát a NATO-tagság első éveiben növelni fogja, és reformok megvalósítására használja fel. Ugyanezt vállalta a MAP keretébe bevont többi potenciális EU és NATO-ország is, vagyis a modern időknek megfelelő az EU számára is hasznosítható haderő ezekben az országokban is rendelkezésre fog állni az elkövetkező 10-15 évben. Természetesen az egy före jutó USD-ben mért védelmi ráfordítás nagy lemaradást mutat, de ez azzal is magyarázható, hogy folyó áron (nem reálértékben) mért nemzeti jövedelmük is csak töredéke az EU-tagokénak. Az ebben számolt lemaradás az eltérő - az új tagjelölteknél nagyobb - gazdasági növekedést jelző előrejelzések (lásd makrogazdasági fejezet) alapján csökkenő tendenciát fog mutatni.

- A magasabb gazdasági növekedési ütem és a haderőreform szükségessége miatt az elkövetkezendő években a tagjelölt országok jelentős piacot fognak jelenteni a magas technikai színvonalat jelentő katonai eszközök (elsősorban a légierő, légvédelem, szállítás és kommunikáció) terén, hiszen az elavult, szovjet típusú és nagyrészt ottani eredetű eszközöket modern eszközökre kívánják majd lecserélni. (Magyarország és Csehország 2001. őszén jelentette be döntését a svéd-brit Gripen vadászgépek vásárlásáról ill. bérléséről.) Nem lehet jelentéktelen a csatlakozó országok haditechnikai együttmüködés terén hasznosítható szellemi felkészültsége sem, ami különösen a terület esetleges potenciális közösségi kompetenciába vonása kapcsán lehet hasznos az EU számára.

\section{RÉSZ; 3. FEJEZET}

\section{BEL- ÉS IGAZSÁGÜGYI EGYÜTTMÜKÖDÉS}

Mint a közvélemény-kutatásokkal foglalkozó fejezet vizsgálatánál láthattuk, az egyik legfontosabb elvárás a közvélemény részéről a belső és külső biztonság erősítése, amiben a bel-és igazságügyi együttmüködés területén megvalósítandó integráció kiemelt helyet foglal el. Új helyzetet teremtett e téren is a 2001. szeptember 11-én történt USA elleni terrorista merénylet, mely nemcsak mélységében, de 
horizontálisan is (minél több állam bevonása a terrorista és más típusú bünözés elleni fellépésbe) az együttmüködés erősítésére sarkallta az EU-t. Ezért ennek a területnek néhány kiemelt aspektusát külön meg kell vizsgálnunk.

\section{III/3.1. A határok kiterjesztésének kérdése}

Az új tagok felvételével az Unió keleti határai kitolódnak keleti irányba. Az is nyilvánvaló, hogy a tagság előtt vagy már a tagságig létrejövő új közösségi politikák miatt ez jelentős kockázatot, de előnyöket is ad a jelenlegi tagállamok számára:

- A keleti bővítés után (az új tagok schengeni rendszerbe való lépésével) lényegében megszűnnek a jelenlegi keleti tagállamok számára saját külső szárazföldi határaik védelmére fordított költségek. Különösen nagy haszonnal jár ez a közvetlenül érintett Németország (Lengyelországgal és Csehországgal határos), emellett Ausztria (jelenleg Csehországgal, Szlovákiával, Magyarországgal és Szlovéniával határos), valamint kisebb részben Olaszország (Szlovéniával vannak szárazföldi határai) és Görögország (Bulgáriával határos) számára. Mint a III/3.1. sz. táblázatból látszik a jelenlegi keleti szárazföldi külső határszakaszok 78 százalékának védelme Németországra és Ausztriára esik.

III/3.1. sz. táblázat: A jelenlegi tagállamok és a tagjelölt országok közötti határszakaszok hossza

\begin{tabular}{|l|l|c|c|}
\hline \multirow{2}{*}{ EU-tagállam } & \multirow{2}{*}{ Tagjelölt ország } & \multicolumn{2}{|c|}{$\begin{array}{c}\text { Határ hossza } \\
\text { (km) }\end{array}$} \\
\cline { 3 - 4 } & & Országonként & Összesen \\
\hline \multirow{2}{*}{ Németország } & Lengyelország & 442 & \multirow{2}{*}{1252} \\
\cline { 2 - 3 } & Csehország & 810 & \\
\hline \multirow{4}{*}{ Ausztria } & Csehország & 466 & \multirow{2}{*}{1258} \\
\cline { 2 - 3 } & Szlovákia & 106 & \\
\cline { 2 - 3 } & Magyarország & 356 & 232 \\
\cline { 2 - 3 } & Szlovénia & 330 & $\mathbf{3 2 3 5}$ \\
\hline Olaszország & Szlovénia & 232 & 293 \\
\hline Görögország & Bulgária & $\mathbf{3 2 3 5}$ & \multicolumn{2}{|c|}{} \\
\hline Összesen & & \multicolumn{2}{|c|}{} \\
\hline
\end{tabular}

Forrás: Brücker et al [2001] 
E négy jelenlegi frontország számára a bővülés után nem lesz szárazföldi külső határellenőrzési rendszerre szükség, hiszen sem a kereskedelempolitikában, sem a schengeni rendszer kiterjesztése után a bel-és igazságügyi együttmüködésben nem lesz szükség és lehetőség arra, hogy valamely tagállam belső határellenőrzése megmaradjon. Ezt garantálja az a kitétel, amely szerint a schengeni külső határellenőrzési rendszerhez való csatlakozás nem lehet kivétel vagy átmenet kérdése, hiszen az Amszterdami Szerződéshez csatolt 8. Jegyzőkönyv az alkalmazást kifejezetten kötelezővé tette az új tagállamok számára. Ez a tény főleg Ausztriának jelent relatíve nagy lehetőséget, hiszen Luxemburg után a második olyan országgá válik, amelynek olyan szárazföldi határai vannak, amelyek mind EU-tagállamokkal lesznek határosak a bővítés után, tehát a határellenőrzést gyakorlatilag a repülőterekre kell korlátoznia, ami a bővítés előtti helyzethez képest szükebb feladatot jelent. Az új tagállamok közül ilyen helyzetbe csak Csehország fog kerülni, hiszen a régi csehszlovák-ukrán határt - a szétválás eredményeként - a szlovák államnak kell majd biztosítania. Ez a cseh felvételt egyszerüsítő helyzet, mivel nekik csak a repülőtéri ellenőrzést kell hosszú távon megfelelően biztosítaniuk, míg a többi új tagállam külső szárazföldi határai több ezer kilométert jelentenek, nem is beszélve arról, hogy Magyarország és Szlovákia kivételével - az új tagállamoknak tengeri határaikat is biztosítaniuk kell. A külső szárazföldi határok megszünése Ausztriában és Németországban több ezer fős munkaerő más területre történő átcsoportosítását teszi lehetővé, míg a jelenlegi tagállamok külső schengeni határain befektetett „schengen-konform” technikának az új tagállamok részére történő eladására, illetve leépítésére nyújt lehetőséget.

A jelenlegi EU határvonalat jelentő tagállamok (főleg Ausztria, Németország) számára a belső határ leépítése kockázattal is jár, hiszen jobban kiszolgáltatottá válik az elötte lévő szürőállamnak. Ugyanakkor a közösségi szabályozás lehetőséget ad a régi schengeni tagoknak arra, hogy az uniós taggá válás után, a régi schengeni tagállamok döntése (és bizalma) alapján válhassanak csak az új belépők a schengeni rendszer részévé. A közösségi teherviselés jegyében nem kizárt (erre utalt Schröder kancellár 2001-ben, és erről bizottsági elemzés is készült ugyanebben az évben), hogy közös határellenőrzés váltja fel a jelenlegi rendszert. Ez a költségek tagállamok közötti szétterítése mellett nagyobb 
biztonságot ad a jelenlegi tagállamoknak ahhoz, hogy maguk is ellenőrizni tudják a közösségi határokon az illegális tevékenység szürését.

- Sajátos helyzetet teremt a bővítés kapcsán a határok kiterjesztésekor Kalinyingrád (Königsberg), hiszen a lengyel és a várható litván bővüléssel Oroszországnak egy integráns, de földrajzilag sajátos része - melyet csak tranzit egyezmények révén, Litvánián keresztül, illetve tenger felöl lehet megközelíteni - beékelődik a jövőbeli EU területére. Mivel a két új tagállam számára a schengeni rendszer, és a közös kereskedelempolitika bevezetése nem lehet alku tárgya, ennek a területnek a megközelítése Oroszország felől nehezebbé válik, és mindenféleképpen az EU-orosz viszonyt is érinti. (Nem véletlen, hogy a Bizottság 2001 elején erről már tett javaslatot a Tanácsnak, melyben a helyzet feloldását kéri, és persze az oroszok is szeretnének erről külön egyezményt kötni.) A terület fontosságát jelzi, hogy jelenleg a szervezett bünözés egyik központjává vált, és nagy a veszélye annak, hogy a kalinyingrádi terület gazdasági lebénulása esetén - ha nem sikerül az EU és az oroszok számára is megfelelő kiutat mutatni - a bünözés és a gazdasági depresszió erősödhet. Megfelelő megoldással viszont kaput lehetne nyitni Oroszország felé a gazdasági együttműködés terén is.

- A schengeni rendszer, vagyis a közös elvek és gyakorlat szerinti külső határellenőrzés megvalósítása, keletre történő kiterjesztése tehát védi a jelenlegi tagállamok érdekeit. Olyan határvédelmi fejlesztések megvalósítását írja elő a külső országok számára, amely a zöld határ hatékony, szigorított védelmét teszi kötelezettséggé. Ez az illegális határátlépések minimálisra csökkenését hozza magával, ami nagyrészt a jelenlegi tagállamokat védi, mivel e belépéseknek a célpontja mindig az Unió fejlettebb régiója. Másrészt egységesíti a legális határbelépésre vonatkozó feltételeket (úti okmányok, pénzügyi feltételek). Ezen felül pedig a belépőket az egységes schengeni információs rendszerbe (SIS) kapcsolja. (A SIS révén kizárható a nemkívánatos harmadik országbeli személyek belépése a Közösség területére.) Ehhez kapcsolódóan külön kérdésként jelenik meg az Unió egységes vízumpolitikai gyakorlata és főleg listája. Ennek megfelelően a három hónapnál nem hosszabb időre belépőkkel szemben az új tagállamok nem folytathatnak korlátlanul nemzeti gyakorlatot. Ez 
a régi tagállamoknak fontos előnyöket hoz, hiszen a tagság arra kényszeríti a tagjelölteket, hogy legkésőbb a tagság pillanatában - ebben átmenet nem lesz mindazon országok állampolgáraira bevezessék a vízumkényszert, amelyek a 2001 tavaszán elfogadott közös vízumlistán szerepelnek. Ennek elsősorban az illegális bevándorlási és bünözést kibocsátó országok szempontjából van jelentősége, hiszen a tagjelöltek a volt szocialista országokkal és a harmadik világ EU számára is fókuszban lévő országaival - Kubától Afganisztánig gyakran vízummentességi viszonyban álltak vagy állnak. Gyakorlati szempontból nagy jelentősége van az orosz, ukrán, belorusz, valamint jugoszláv, macedón és albán állampolgárok elleni vízumkötelezettség kikényszerítésének.

- Maga a tagság kiterjesztése közvetlen hatást abban fejthet ki - és ez a régi tagállamok állampolgárainak elsőszámú félelme -, hogy maguk az új tagok milyen bünözési veszélyt jelentenek. Mivel az új tagállamok büntetőjogi harmonizációja előrehaladott - ezt garantálja az új tagállamok belépése az Európa Tanácsba, illetve az Európai Megállapodás szerint sok jogharmonizációs lépés megtétele - a bűnözésre vonatkozó statisztikák jellemzően mutatják azt, hogy az új tagállamok milyen valós veszélyt jelentenek a régi tagállamok számára. (A belépés után, mint előzőleg jeleztem, a belső határok a schengeni tagság következtében eltörlésre kerülnek, nemcsak a munkavállalók, hanem a személyek - így a bünözők - is szabadon áramolhatnak.) 
III/3.2. sz. táblázat: A fogva tartottak és a büntetés-végrehajtói helyek száma 1996-ban, Európában

\begin{tabular}{|c|c|c|c|}
\hline Ország & $\begin{array}{c}\text { Fogva tartottak } \\
\text { száma } \\
\text { 100.000 lakosra }\end{array}$ & $\begin{array}{l}\text { Fogva tartottak } \\
\text { száma } \\
100 \text { büntetés- } \\
\text { végrehajtói helyre }\end{array}$ & $\begin{array}{c}\text { Büntetés- } \\
\text { végrehajtói helyek } \\
\text { 100.000 lakosra } \\
\text { (1995. szept. 1.) }\end{array}$ \\
\hline Lettország & 405,0 & 104,1 & 390 \\
\hline Litvánia & 323,0 & 89,4 & 366 \\
\hline Csehország & 202,0 & 111,5 & - \\
\hline Románia & 194,0 & 144,3 & 128 \\
\hline Lengyelország & 148,5 & 87,9 & 169 \\
\hline Szlovákia & 144,0 & 83,8 & - \\
\hline Portugália & 140,0 & 175,5 & 91 \\
\hline Magyarország & 129,0 & 114,7 & 108 \\
\hline Bulgária & 126,4 & 83,9 & 156 \\
\hline Anglia & 106,8 & 104,4 & 98 \\
\hline Luxemburg & 104,4 & 91,1 & - \\
\hline Skócia & 101,0 & 102,7 & 107 \\
\hline Franciaország & 89,9 & 109,9 & 84 \\
\hline Olaszország & 85,0 & 118,3 & 60 \\
\hline Ausztria & 84,0 & 85,8 & 105 \\
\hline Németország & 82,6 & 95,0 & - \\
\hline Belgium & 75,6 & 111,6 & 50 \\
\hline Hollandia & 75,2 & 96,9 & 76 \\
\hline Svédország & 65,0 & 93,7 & 58 \\
\hline Írország & 62,3 & 96,9 & 63 \\
\hline Málta & 62,0 & 73,1 & 67 \\
\hline Dánia & 61,0 & 86,9 & 74 \\
\hline Finnország & 57,8 & 75,8 & 75 \\
\hline Görögország & 51,0 & 122,4 & 41 \\
\hline Ciprus & 35,1 & 97.9 & 33 \\
\hline Szlovénia & 31,0 & 55,2 & 55 \\
\hline
\end{tabular}

Forrás: Kertész Imre: A bün útján, Belügyi Szemle, 99/9. [1999]

Megjegyzés: az ENSZ 2000. évi Emberi és Szociális jelentésében a fentieknél a tagjelöltekre vonatkozóan kedvezőbb összehasonlító statisztikát találtam, de a magyar szakmai minisztérium a fenti számokkal dolgozik, így magam is ezt idéztem.

A jelzett statisztikák (III/3.2. sz. táblázat) alapján kimutatható, hogy a csatlakozó országokban a statisztikák magasabb bünözési intenzitást jeleznek, mint a tagállamok legtöbbjében. Különösen elrettentő a helyzet a balti államok esetében, ahol ráadásul a hosszú távú trendek (ld. III/3.3. sz. táblázat) is csak az észteknél mutattak javuló tendenciát. Sajnos a balti mutatószámok sokkal közelebb állnak az orosz-ukrán modellhez, mint az európai viszonyokhoz. Meglepően magas még a cseh mutató is. 
III/3.3. sz. táblázat: A fogva tartottak 100.000 lakosra jutó száma a volt szocialista országokban (fö)

\begin{tabular}{|l|c|c|c|}
\hline \multicolumn{1}{|c|}{ Ország } & $\mathbf{1 9 8 0}$ & $\mathbf{1 9 8 9}$ & $\mathbf{1 9 9 7}$ \\
\hline Lettország & 490 & 430 & 407 \\
\hline Észtország & 405 & 295 & 300 \\
\hline Litvánia & 325 & 245 & 356 \\
\hline Románia & 145 & 125 & 197 \\
\hline Csehország & 255 & 215 & 209 \\
\hline Lengyelország & 280 & 105 & 148 \\
\hline Magyarország & 165 & 155 & 136 \\
\hline Szlovákia & 240 & 225 & 138 \\
\hline Bulgária & 155 & 140 & 142 \\
\hline
\end{tabular}

Forrás: Kertész Imre: A bün európai útjain, Belügyi Szemle [1999] 99/9. (Walmsley, Rax.Prison Systems in Central and Eastern Europe, Heuni, Helsinki alapján)

Megjegyzés: Szlovéniáról nincs adat

A volt szocialista országokat (lásd: III/3.3. sz. táblázat) illetően biztató az, hogy a fogva tartottakra vonatkozó trendek csökkenő tendenciát mutatnak, ami bizonyos stabilitást jelez, még ha a jelenlegi helyzet az európai átlagnál magasabb rátákat is mutat. Ezen a téren tehát a bővítés nem fogja javítani az EU helyzetét, de a tagjelöltek között differenciált megközelítést kell, hogy alkalmazzuk, mivel Bulgária, Magyarország, Szlovákia és Lengyelország jóval közelebb áll e téren az EUtagállamokhoz, mint a többi tagjelölt ország.

A börtönzsúfoltsági mutató általában európai trendeket jelez, akárcsak a börtönhelyek relatív sürüsége. A börtönviszonyok - így a higiéniai kérdések, a modernizáció, és az egy fogva tartottra jutó négyzetméter - még jelentős lemaradást jeleznek, amint azt az Európa Tanács időnkénti jelentései is leszögezik. A bünözési intenzitáson túl a jelenlegi tagállamok közvéleményét a felderítési mutatók is érdekelhetik, mivel ez jelzi a rendőrségi munka hatékonyságát. A magyar Belügyminisztériumtól kapott adatok szerint 1999-ben Magyarországon például 85 százalékos volt az emberöléseknél ez a mutató, ami jobb volt a tagállamok közül Írország (80 százalék), Portugália (62,1 százalék), Finnország (75,7 százalék), Görögország (71,7 százalék), Franciaország (81,4 százalék), Olaszország (66,7 százalék) mutatóinál. 


\section{III/3.2. A tagság pozitív hatása a jogi együttmúködésre}

A tagság ezen a területen nagy lehetőségeket nyit meg a tagállamok számára. A tagjelöltek a tagsággal együtt el kell, hogy fogadják nemcsak a közösség alapszerződéseiből származó kötelezettségeket, hanem a másodlagos jogalkotás mellett az Európai Bíróság létező ítéleteinek és értelmezéseinek hatályát is, sőt ezt az első pillanattól kezdve alkalmazniuk kell. Ez növeli a befektetők biztonságát és a négy szabadságjog alapvető érvényesülését bármelyik új tagállam területén.

Emellett a Római Szerződés 220. Cikkével összhangban a tagjelöltek számára kiemelt feladatként fogalmazódik meg a választott bírósági határozatok kölcsönös elismerésének és végrehajtásának biztosítása. Az Amszterdami Szerződés révén a közösségi jog részévé vált több olyan együttmüködési konvenció, mely a közösségen belül az ítéletek szabad forgalmához, a szakirodalomban gyakran az ötödik szabadságjogként elnevezett lehetőséghez kacsolódik. Ilyen kiemelkedő fontosságú egyezmény a bírósági joghatóságról és bírósági határozatok végrehajtásáról szóló egyezmény (az ún. Brüsszeli Egyezmény), ennek kiegészítése az 1988-ban kötött luganoi egyezmény, amely az ítéletek végrehajtására vonatkozóan jelent elörelépést. Mindez széles lehetőségeket teremt arra, hogy közösségi szinten is végrehajtsák a különböző ítéleteket (szükítve ebben azt a lehetőséget, hogy Európán belül az új tagállamok területén eltérö értelmezések kibúvót adjanak, pl. adóbüntettek ügyében.) Bár az egyezmények általában zárt - csak tagállamokra vonatkozó - egyezmények, de néhány tagjelölt, így Magyarország esetében már a tagságot megelőzően megtörtént a meghívás a csatlakozásra, ami jelentős előrehaladás elismeréséről tesz tanúbizonyságot.

A nyugat-európai közvéleményre ennél is nagyobb hatással van azonban az a lehetőség, hogy a büntetöügyekben és az együttmüködés terén átveszik az új tagállamok a közösségi vívmányokat. Ebből kiemelhetők a kiadatási egyezmények (amelyet 2001. szeptember 11. nyomán több területen felváltanak az európai egységes letartóztatási paranccsal 2004-től kezdődően), ennek egyszerüsítéséhez kapcsolódó szabályok, a büntetőeljárásokhoz és végrehajtáshoz kapcsolódó kötelezettségek, a nemzetközi bünügyi jogsegély terén megnyilvánuló lehetőségek. 
Ezek kiegészültek néhány politikailag fontos követelménnyel - ilyen például a Spanyolországnak oly fontos terrorizmus elleni küzdelem terén megnyilvánuló együttmüködés -, ahol a szabályozást és a jogi együttmüködést szintén egységesíteni kell valamennyi tagjelölt részéről. Mindezek a lépések lehetővé teszik, hogy a kibővült EU-ban hatékonyabban lépjenek fel a büntetőügyekben, kizárva az ezzel kapcsolatos kibúvók lehetőségét. A 2001. szeptember 11-én elkövetett new yorki és washingtoni terrorcselekmények után az EU szeptember 21-én intézkedési tervet, majd a 2001. november 17-i Tanácsülésén 79 pontos útitervet (road map) fogadott el, amelyek alapján felgyorsult az összefogás a büntetőjogi együttmüködés területén, így a terrorizmus közös definíciójának meghatározása, az egységes letartóztatási parancs kidolgozása, a pénzmosás valamint a bünözők mozgására vonatkozó adatáramlás, a repülési biztonság megteremtése érdekében. Ehhez a küzdelemhez már 2001. szeptember 22-én csatlakoztak a tagjelölt országok, vagyis ezekben a kérdésekben már a bővítés előtt egységes európai jogi és együttműködési övezet alakult ki.

\section{III/3.3. A bünügyi együttműködés}

Bár minden tagjelölt ország tagja az Interpolnak, európai szinten a közös bünüldözési térség megvalósítása szükségessé vált, hiszen a személyek szabad áramlása a bűnözés szabad áramlásával is együtt járt.

Büntetőjogi és konkrét bünüldözési területeken az együttmüködés még kormányközi jellegü, vagyis nagyrészt nem közösségi kompetencia, de itt is olyan szoros együttmüködési formát határoztak meg, amely már hatékonyan segít felvenni a küzdelmet a bünözés ellen.

Egyrészt meghatározták azokat a területeket, amelyeken az együttműködés prioritásnak tekinthető (ilyen a szervezett bünözés, a terrorizmus, az emberkereskedelem, a kábítószer-kereskedelem, a csalás és pénzmosás valamint a korrupció elleni küzdelem). Ezt az együttmúködést az új tagokra kiterjesztve jelentősen nő a jelenlegi tagállamok biztonsága, és mérsékelhető a határok lebontásából származó valós vagy vélt veszélyek sorozata is. 
Másrészt sokat jelent az, hogy a kiadatási rendre, illetve annak egyszerüsítésére létrejött egyezményeket átveszik az érintett országok, valamint a büntetőeljárás terén azokat a bünügyi jogsegély-egyezményeket alkalmazzák, amelyek vagy az Európai Unió tagállamai, vagy az Európa Tanács tagállamai közötti eljárásokat szabályozzák. Mindez - kiegészülve a jelenlegi tagállamok számára oly nagy fontosságú terrorizmus elleni küzdelemről szóló egyezményekkel - nagy jelentőségü, hiszen a bővüléssel egy egységes kiadatási, bünügyi eljárási térség jön létre. (A rendszerváltás előtt a terrorizmus és az ezzel is összefüggő szervezett bünözésnek titkos területét jelentette a volt szocialista tábor, ezért a tagjelöltek e téren történő bevonása a tagállamok számára történelmi jelentőségü.) Ezt a folyamatot erősíti, hogy a 2001. decemberében a Tanács által elfogadott közösségi letartóztatási parancs rendszerét is automatikusan kiterjesztik minden új belépő országra.

A kétoldalú együttmüködés - melynek során az új tagállamoknál is bevezethető az összekötő rendőrtisztek, valamint a koordinációval foglalkozó központi szervek rendszere is - mellett a kormányközi együttmüködés központi formája lesz az alapszerződések által bevezetett Europol intézménye, melynek révén a prioritásként meghatározott bünüldözési területeken multilaterális formában kezdhető meg az együttmüködés. Ennek előfeltételeként az új tagok megfelelő adatvédelmi és központi koordinációs egységet kell, hogy létrehozzanak, ami olyan hatékony bünüldözést tesz lehetővé (beleértve a határon átnyúló bünüldözést abban az esetben, ha a tettes másik tagállamba menekül), amellyel az egész Unió területén párhuzamosan lehet a bűnözőket felkutatni. Ebben a kérdésben már a tagság előtt megfelelő elörehaladást értek el a tagjelöltek közül Magyarország, Lengyelország, Szlovénia és Észtország, ami lehetővé tette számukra, hogy az Europolon keresztül a tagállamokkal már 2001-ben (Csehország 2002-ben) szerződéses együttmüködést valósítsanak meg. Mindez jelentős anyagi áldozatokat kívánt és fog kívánni a tagjelölt országoktól, amit azonban elsősorban nekik kell meghozniuk, hiszen ebben a közösségi költségvetés nem segít, és a PHARE, mint elöcsatlakozási alap is csak technikai segítségnyújtáshoz ad lehetőséget. Az USA elleni terrortámadás ezen a téren is katalizátorhatást váltott ki, hiszen az Europol tevékenységének kiépítése felgyorsult, sőt az ügyészségi együttmüködés (Eurojust) területén is előrelépés várható. 
Mint a közvéleményekkel foglalkozó II. részben is kiderült, az EU-tagállamok polgárai a bővítésnél kiemelt fontosságot tulajdonítanak a szervezett bünözés és a kábítószer-ellenes harcnak (93 százalékuk ezt fontosnak ítélte).

III/3.4. sz. táblázat: Kábítószerrel kapcsolatos bünözési mutató a tagországokban és a tagjelölteknél (100 000 lakosra jutó esetek száma) (1994)

\begin{tabular}{|c|c|}
\hline Ország & $\begin{array}{c}\text { Kábítószeres } \\
\text { büncselekmények száma }\end{array}$ \\
\hline Belgium & 148,0 \\
\hline Svédország & 350,5 \\
\hline Hollandia & 39,4 \\
\hline Franciaország & 93,1 \\
\hline Finnország & 116,5 \\
\hline Dánia & 270,9 \\
\hline Ausztria & 148,4 \\
\hline Luxemburg & 196,6 \\
\hline Olaszország & 67,3 \\
\hline Írország & 128,6 \\
\hline Spanyolország & 65,5 \\
\hline Görögország & 24,2 \\
\hline Portugália & 60,2 \\
\hline Ciprus & 18,6 \\
\hline Málta & 66,8 \\
\hline Szlovénia & 20,7 \\
\hline Lengyelország & 10,4 \\
\hline Magyarország & 2,5 \\
\hline Szlovákia & 1,6 \\
\hline Észtország & 2,2 \\
\hline Litvánia & 9,1 \\
\hline Románia & 1,2 \\
\hline Lettország & 10,9 \\
\hline
\end{tabular}

Forrás: ENSZ Gazdasági és Szociális Jelentés, [2000]

Megjegyzés: Hollandiára, Dániára, Luxemburgra, Ausztriára, Portugáliára vonatkozóan a kalkuláció az 1990es adatok alapján történt.

Bár a III/3.4. sz. táblázatból levonható következtetésnél figyelembe kell venni a büntethetőség (pl. Hollandia esetében) és bünüldözési képességek eltérő jellegét, azt azonban látni lehet, hogy a tagjelölteknél a kábítószeres bünözés - bár növekszik számuk - lényegesen alacsonyabb, mint a tagállamokban. Ez részben összefügg a helyi fizetőképes kereslet alacsony voltával és a valuta konvertibilitásának kérdésével is, de tranzit országként a tagjelölt államok már most is fontos (negatív, megfelelő védelemnél viszont pozitív) szerepet töltenek be. Mivel a kábítószerek révén szerzett jövedelmek a terrorizmus és a szervezett bünözés fontos finanszírozási 
forrásai, e témában való kiterjedtebb (a tagjelölteket is felölelö) együttmüködés kulcskérdés az EU és az Europol számára. Nem véletlen, hogy az EU szakosított ügynökségei közül a Környezetvédelmi Ügynökség után (2001) a kábítószerrel foglalkozó ügynökségekbe (ECCMDA) vonják be a tagjelölt országokat még a belépés elött, 2002-ben.

\section{III/3.4. Menekültpolitika}

A jelenlegi fejezetben tárgyalt témakörök közül a menekültpolitika a menekültek egyre nagyobb száma miatt az utóbbi időben a középpontba került. Ezt jelzi az is, hogy az 1999-ben életbe lépett Amszterdami Szerződés lényeges menekültjogi anyagot emelt be az alapszerződések rendszerébe. Ezt öt év alatt - vagyis a várható bővülésig - részleteiben kell kidolgozni az Amszterdami Szerződés szerint. A munkálatok felgyorsítását segítette elő a finn elnökség alatt szinte kifejezetten erre a célra összehívott tamperei csúcsértekezlet 1999 októberében. Ennek kapcsán valószínüleg a joganyag részeként beépül annak a szabályozása, hogy mely tagállam, milyen feltételekkel felel a benyújtott menedékjogi kérelmek elbírálásáért. Alapvetően annak az országnak lesz felelőssége, amelyiknek a területére az EU-ba először érkezett a kérelmező, ami a jelenlegi tagállamok számára feltétlen előnyként határozható meg, hiszen a szabályozás nem a célirány - ami a jelenlegi tagállamok fejlett részét öleli fel - szerint határozza meg a menedékjog kérése teljesítésének helyét. Emellett közösségi szabályozás tárgya lesz az elbírálásra vonatkozó eljárási rendszer - beleértve az időhorizontokat is -, valamint a menedékkéröknek adott minimális védelem, minimális ellátás és a családegyesítéssel járó minimális szociális rendszabályok. Mindezek ahhoz járulnak hozzá, hogy a menedékkérők eloszlása egyenletes legyen, ne csak néhány kiemelt tagállam - pl. Németország - viselje az ezzel kapcsolatos terheket, hanem a többi ország is, beleértve az újonnan belépőket. (Az még eldöntetlen kérdés, hogy lesz-e közös menedékalap, amiből a kötelező minimumellátás megvalósítását segítenék elsősorban a kevésbé tehetős tagállamok esetében.) Mindezek a menekültkérdéssel foglalkozó intézményrendszer azonos nevezőre helyezését vonják maguk után, ahol az elhelyezés, a bírói rendszer, az elbírálással foglalkozó intézmények és tisztviselők kiképzése közös szabályok szerint történik. Ez komoly lépés lesz a jelenlegi tagállamok számára, mivel az új tagállamoknak meg kell tudni felelni az új kihívásoknak a belépők számára az lehet 
megnyugtató, hogy tagságuk révén részesei lehetnek e politika továbbfejlesztésének, ami kapcsán saját érdekeiket - demográfiai, munkaerőigénnyel összefüggő, és főleg anyagi jellegü - jobban tudják érvényesíteni.

További előnyt jelent a jelenlegi tagállamok számára az is, hogy a menekültpolitikát segítendő, az új tagállamoknak a régiekkel minden esetben kiadatási egyezményt kell kötniük - ez egyébként a tagjelöltek nagy részével kétoldalú alapon már megtörtént aminek eredményeképpen az a szabály lép majd életbe, hogy ahhoz a tagállamhoz irányítják az illegálisan érkezőt, és menekültstátusra nem jogosult személyeket, ahol azok először az Unió területére léptek. Mindez oda vezet, hogy a mostani tagállamokhoz hasonlóan az új tagállamoknál is kényszerként lép fel az, hogy a külső, határos tranzit, vagy a főbb kibocsátó országokkal szintén ilyen toloncegyezményeket kössenek. (Ezért volt kiemelkedően fontos pl. Magyarország számára Jugoszláviával ilyen egyezmény létrehozása, hiszen ennek híján az innen eredő, vagy legalábbis ezt nyilatkozó illegális bevándorlók visszaadása nehézkessé vált, ami nemcsak a tagjelölt ország, hanem később az egész Unió problémájává válhat.) Az illegális bevándorlók léte az USA elleni támadás után kulcskérdéssé vált egyrészt biztonsági okokból (sok a muzulmán, instabil térségből - Afganisztán, Irak - bevándorlók száma), másrészt ez a szervezett bünözés legnagyobb profitot hozó ága, mely többek között a terrorizmus finanszírozására is szolgál.

\section{III/3.5. A menekültstátusz kérelmek megoszlása Európában}

A kérelmek számát vizsgálva kiderül, hogy a kilencvenes években megszaporodott a menedékjogot kérők száma egész Európában. Míg 1995-ben 285.860 kérelmet regisztráltak a vizsgálatba bevont 25 ország esetében (az EU-ban 263.660 darabot), addig ez a szám fokozatosan növekedve 1999-re elérte a 452.260 kérvényt (ld. III/3.5. sz. táblázat). Ebből a mintegy 180.000 fős növekményből az Európai Unió tagállamaira jutott valamivel több, mint 100.000 fö, míg a hét (baltiak kivételével) társult és tagjelölt országban ez a szám 3720-ról 28.200-ra nőtt. Mindez azt jelenti, hogy a menekültstátuszt kérők számát vizsgálva a hét jelentkező ország 1995-ben csak 1,3 százalékot képviselt Európában (EU, EGT és EFTA országokat, valamint a hét közép-és kelet-európai tagjelöltet figyelembe véve), míg 1999-re ez már 6 százalék fölé futott fel szemben az EU 92,2 illetve 81,2 százalékos arányával, amely 
fokozatos csökkenést mutat. Ez a trend nem éri ugyan el az EU jelenlegi és a tagjelölt országok lakosságának népesség szerinti arányait, mivel a menekültügyi statisztikákban kimutatott kérelmek tagjelölt-EU aránya 1:12, míg a népesség szerinti aránya 1:4, de a statisztikákból kiolvasható, hogy az új tagállamok is egyre gyakoribb célpontok lettek. (1999-ben egész Európában Jugoszláviából érkezett a menekültkérők 28 százaléka. Főleg a koszovói menekültek száma emelkedett, Nyugat-Európában a kérelmek 33, Közép- és Kelet-Európában 25 százalékát tették ki (Béla Hovy [2001]). Békeidőben ezek az arányok alacsonyabbak, és nem mutatnak állandó trendet.) III/3.5. sz. táblázat: Menedékjogot kérök száma
1995-ben és 1999-ben

\begin{tabular}{|l|r|r|r|r|}
\hline \multicolumn{1}{|c|}{ Célország } & $\begin{array}{c}\mathbf{1 9 9 5} \\
\text { (fö) }\end{array}$ & $\begin{array}{c}\mathbf{1 9 9 5} \\
\mathbf{( \% )}\end{array}$ & $\begin{array}{c}\mathbf{1 9 9 9} \\
\text { (fö) }\end{array}$ & $\begin{array}{c}\mathbf{1 9 9 9} \\
\mathbf{( \% )}\end{array}$ \\
\hline Bulgária & 520 & 0,18 & 1330 & 0,29 \\
\hline Csehország & 1410 & 0,49 & 8550 & 1,80 \\
\hline Magyarország & 590 & 0,20 & 11500 & 2,54 \\
\hline Lengyelország & 840 & 0,29 & 2960 & 0,65 \\
\hline Románia & - & - & 1670 & 0,36 \\
\hline Szlovákia & 360 & 0,12 & 1320 & 0,29 \\
\hline Szlovénia & - & - & 870 & 0,19 \\
\hline $\begin{array}{l}\text { Közép- és kelet- } \\
\text { európai jelölttek }\end{array}$ & $\mathbf{3 7 2 0}$ & $\mathbf{1 , 3 0}$ & $\mathbf{2 8 2 0 0}$ & $\mathbf{6 , 2 3}$ \\
\hline Dánia & 5100 & 1,78 & 6470 & 1,43 \\
\hline Finnország & 850 & 0,29 & 3110 & 0,68 \\
\hline Írország & 420 & 0,14 & 7720 & 1,70 \\
\hline Svédország & 9050 & 3,16 & 11230 & 2,48 \\
\hline Egyesült Királyság & 43970 & 15,38 & 71150 & 15,70 \\
\hline Görögország & 1310 & 0,45 & 1530 & 0,33 \\
\hline Olaszország & 1730 & 0,60 & 33360 & 5,18 \\
\hline Portugália & 450 & 0,15 & 270 & 0,05 \\
\hline Spanyolország & 5680 & 1,98 & 8410 & 1,85 \\
\hline Ausztria & 5920 & 2,07 & 20130 & 4,45 \\
\hline Belgium & 11420 & 3,99 & 35780 & 7,91 \\
\hline Franciaország & 20170 & 7,05 & 30830 & 6,81 \\
\hline Németország & 127940 & 44,75 & 95110 & 21,02 \\
\hline Luxemburg & 390 & 0,13 & 2910 & 0,64 \\
\hline Hollandia & 29260 & 10,23 & 39300 & 8,68 \\
\hline EU & 263660 & 92,23 & 367310 & 81,21 \\
\hline $\begin{array}{l}\text { EURÓPA } \\
\text { (EU, tagjelöltek, } \\
\text { EGT-EFTA) }\end{array}$ & $\mathbf{2 8 5 8 6 0}$ & $\mathbf{1 0 0 , 0 0}$ & $\mathbf{4 5 2} \mathbf{2 6 0}$ & $\mathbf{1 0 0 , 0 0}$ \\
\hline & & & & \\
\hline
\end{tabular}

Forrás: Béla Hovy: Statistically Correct Asylum Data: Prospects and Limitations (Eurostat és UNHCR adatai alapján) [2001] 
A III/3.5. számú táblázatból kiderül, hogy a földrajzilag közeli válságok miatt megnőtt a menekültkérelmek szempontjából Magyarország és Csehország súlya (ami nyilvánvalóan összefügg azzal is, hogy ezen országokban a kérelmezők számára a többi tagjelölthöz képest kedvezőbb viszonyok ígérkeznek), és ez a trend a térséghez közelálló egyéb válságok megismétlődése esetén tovább erősödhet. (Ezt támasztja alá az is, hogy Csehország a nagyszámú - 2001 első félévében több mint 1600 romániai menekültkérő miatt vízumkényszert vezetett be Románia irányába, miközben az EU 2002. január elsejétől Romániával szemben ennek eltörléséről döntött.) $\mathrm{Az}$ is látható, hogy a kibővített EU-t figyelembe véve rendkívül egyenlőtlenül oszlik el a menedékjogot kérők száma, hiszen szembetűnő Németország, valamint méreteihez képest Hollandia, Belgium és Ausztria leterheltsége.

Ugyanakkor eltérő az a ráta, amelynek alapján a tagjelölt országok és a tagállamok a menekültek kérelmére pozitív választ adtak (ld. III/3.6. sz. táblázat). Az ENSZ Menekültügyi Konvenciója alapján 1999-ben csak 900 esetben adták meg a menekültkérelmet a csatlakozó országok, és közel háromszor ennyi (2540) esetben tették ugyanezt a Konvención kívüli - humanitárius vagy de facto stb. jelzővel illethető - okokból. A tagállamok esetében a pozitív válaszok száma eltérő, hiszen az EU összességében ugyanebben az évben 23.610 esetben adta meg a menedékjogot a Konvenció alapján, és 30.960 esetben tette ugyanezt egyéb (elsősorban humanitárius) okokra hivatkozva. Mindez azt jelenti, hogy az új tagállamokban egyre kisebb lesz az ENSZ Konvenció alapján kiadott menekültkérelmek aránya (1999-ben Csehországban, Magyarországon és Lengyelországban 5 százalék alatt volt), míg ez az EU-ban szintén csökkenő tendenciát mutat, de ennek aránya azért még 10 százalék fölött maradt. Együttvéve a menekültkérelmek pozitív elbírálása tárgyában a csatlakozni kívánó országok viszonylatában nem lehet kirívóan eltérő gyakorlatról beszélni, mindössze Bulgária magas, és Csehország, Lengyelország alacsony hányadosa érdemel figyelmet. 
III/3.6. sz. táblázat: A menekültkérelmekre adott pozitív válasz a tagállamok és a tagjelöltek esetében

(százalék)

\begin{tabular}{|l|c|c|}
\hline \multicolumn{1}{|c|}{ Ország } & $\mathbf{1 9 9 5}$ & $\mathbf{1 9 9 9}$ \\
\hline Bulgária & 87,5 & 75,7 \\
\hline Csehország & 75,0 & 4,1 \\
\hline Magyarország & 32,1 & 37,1 \\
\hline Lengyelország & 34,4 & 2,2 \\
\hline Románia & $14,8 *$ & 27,3 \\
\hline Szlovákia & 53,8 & 14,3 \\
\hline Szlovénia & $n . a$ & 5,6 \\
\hline Dánia & 85,0 & 51,8 \\
\hline Finnország & 47,1 & 58,3 \\
\hline Írország & 42,9 & 13,1 \\
\hline Svédország & 39,8 & 34,5 \\
\hline Egyesült Királyság & 24,4 & 72,5 \\
\hline Görögország & 16,0 & 26,3 \\
\hline Olaszország & 16,9 & 72,6 \\
\hline Portugália & 8,9 & 25,0 \\
\hline Spanyolország & 10,2 & 11,7 \\
\hline Ausztria & 13,0 & $12,5 *$ \\
\hline Belgium & 25,5 & 32,4 \\
\hline Franciaország & 15,6 & $17,5 *$ \\
\hline Németország & 18,7 & 13,3 \\
\hline Luxemburg & $25,0 * *$ & 36,4 \\
\hline Hollandia & 65,6 & $\mathbf{2 4 , 9}$ \\
\hline EU & $\mathbf{2 9 , 5}$ & \\
\hline & & \\
\hline
\end{tabular}

Forrás: Bela Hovy: Statistically Correct Asylum Data: Prospects and Limitations (Eurostat és UNHCR adatai alapján) [2001]

Megjegyzés: * 1998, **1996

Az adatokból az is látható, hogy elsősorban az északi tagállamok - skandinávok és britek - mutatnak nagyvonalúbb magatartást az elbírálás területén, míg a délebbre fekvő területeken szigorúbb hozzáállást tanúsítanak, és ez utóbbihoz állnak közelebb a tagjelölt országok is.

A várható hatásoknál természetesen azt is elemezni kell, hogy milyen irányból érkeznek a menekültkérök. Ebben az a meglepő, hogy a tagjelöltek között szereplő Románia 1997-ben Franciaországban, Spanyolországban és Belgiumban az elsők között szerepelt, mint menedékkérőket kibocsátó ország. (Az Európán belüli menekült statisztikákban Románia az előkelő második helyen áll a jugoszlávok után.) A 18 legfontosabb európai befogadó országban, a kilencvenes években 397.410 fö 
román állampolgár kért menedékjogot (ld. III/3.7. sz. táblázat), igaz az évtized végére ez a szám 10 százalékára csökkent az évtized elején mért adatoknak. Jelentős kibocsátó ország Európában a szintén tagjelölt Bulgária is, amelyet az évtized folyamán 111.390 állampolgára hagyott el. A rendszerváltás után szintén jegyzett, bár az ország méreteihez képest elhanyagolható, alig több mint 43.000 fö hagyta el menekültként Lengyelországot.

III/3.7. sz. táblázat: A társult országok állampolgárainak menekültkérelmei az európai országokban (db)

\begin{tabular}{|l|c|c|c|c|}
\hline \multicolumn{1}{|c|}{ Ország } & $\mathbf{1 9 8 0 - 8 9}$ & $\mathbf{1 9 9 0 - 1 9 9 9}$ & $\mathbf{1 9 9 0}$ & $\mathbf{1 9 9 9}$ \\
\hline Románia & 52790 & 397410 & - & 6710 \\
\hline Bulgária & 10510 & 111390 & 13020 & 1720 \\
\hline Lengyelország & 213780 & 43600 & 16650 & 2310 \\
\hline Csehország & 49290 & n.a & n.a & 460 \\
\hline Szlovákia & - & - & n.a & 2700 \\
\hline Magyarország & 38250 & n.a & n.a & - \\
\hline
\end{tabular}

Forrás: UNHCR, statisztikai áttekintés, [1999].

A 100-nál nagyobb számú esetek jegyzésénél kiderül, hogy a három említett társult országon (Románia, Bulgária, Lengyelország) kívül a többi tagjelölt ország menekültkérelmeinek száma a rendszerváltás után fokozatosan minimálissá vált. Az évtized végére lecsökkent az előbbi három országból a kivándorlások száma. (Igaz, az EU által 2001-ben a bolgárok, és a 2002-ben a románok irányába megszüntetett vízumkényszer utáni időszakra érdemes lesz a statisztikákat újra vizsgálni.) Csehország és Szlovákia 1999-es adataiból a célországok vizsgálata - skandináv, illetve Benelux-államok - alapján az állapítható meg, hogy a menekültkérelmek száma elsősorban a romák új keletủ exodusával magyarázható, mintsem az országra jellemző tartós problémával. (Ugyanerre utal az európai kivándorlóként nem jegyzett Magyarország esetében az, hogy az országból Kanadába 900 fö - vélhetően roma etnikumú - kért menedékjogot.) Differenciált képet mutat azonban az, hogy míg az évtized végén a Csehországból, Szlovákiából és Lengyelországból menedéket kérők közül 85-100 százalék között volt a romák aránya, addig Romániában csak 30-60 százalék között, ennél valamivel magasabb lehetett Bulgáriában. (ICPMB, Bécs [2001]) Ez azt jelzi, hogy a legfejlettebb tagjelölteknél nem a többségi nemzethez tartozók jelentik a migrációs problémát, hanem kifejezetten a romák társadalmi 
beágyazottságának hiánya. Romániában és Bulgáriában ettől eltérő a kép, itt a többségi - vagy legalább is nem roma származású - lakosság körében is nagy a migrációs hajlam.

A kibővített EU-n kívüli - tehát nem tagjelölt - országokból érkező személyek eredetét illetően több hasonlóság, és több különbség is megállapítható. Az egyik következtetés, hogy igazán jelentős befogadó képessége és vonzereje csak Lengyelországnak, Magyarországnak és Csehországnak van. Másrészt ezekben az országokban kicsi más tagjelöltek (románok, törökök, bulgárok, és általában Európa) menekültjeinek száma. Viszonylag mérsékelt a volt FÁK-országok lakosainak térségbe irányuló menekvése, és még az orosz, ukrán kérelmek száma is alacsony ezekben az országokban annak ellenére, hogy földrajzilag közel fekszenek egymáshoz, gyakran szomszédosak. Ez arra enged következtetni, hogy ezekből a térségekből (Balkán, FÁK) sokkal nagyobb arányban mennek menekültek NyugatEurópába, mint más volt szocialista országba.

Hasonlóságok a régi és az új tagok között elsősorban a volt Jugoszlávia kapcsán mutathatók ki, főleg az 1999-s koszovói események miatt. Mivel 2000-ben már Koszovóban voltak a KFOR erők, ezért abban az évben minimális mértékre zuhant vissza a tagjelölt országokba kivándorló jugoszlávok száma. Boszniából inkább csak Nyugat-Európába érkeztek menekültek, ami az elmúlt évtized gyakorlata volt, hiszen a 162.310 fős ottani menekült áradatból a három társult országban nem érte el az 500 főt a kérelmezők száma. 2001-ben a balkáni helyzet alapján időlegesen megnőtt a Macedóniából érkezők száma is.

Az Európán kívülről a tagjelöltekhez érkezők közül kiemelkedik Irakból (kurdok), Sri Lankából, valamint Afganisztánból érkező személyek száma, de az európai trendekhez hasonlóan magas a bangladesi menekültek aránya is (ld. III/3.8. sz. táblázat). 
III/3.8. sz. táblázat: Lényegesebb számot elérö menekültek a fontosabb tagjelölt célországokba (1990-1999)

\begin{tabular}{|l|r|r|r|r|r|}
\hline \multicolumn{1}{|c|}{ Célország } & Bulgária & Csehország & $\begin{array}{c}\text { Magyar- } \\
\text { ország }\end{array}$ & $\begin{array}{c}\text { Lengyel- } \\
\text { ország }\end{array}$ & $\begin{array}{c}\text { Európa } \\
\text { orsszesen }\end{array}$ \\
\hline Jugoszlávia & 470 & 1680 & 8220 & 870 & 865960 \\
\hline Románia & - & 2200 & 170 & 340 & 397410 \\
\hline Irak & 560 & 1290 & 1490 & 850 & 191040 \\
\hline Sri Lanka & 20 & 1480 & 310 & 2290 & 150200 \\
\hline Afganisztán & 680 & 4670 & 3920 & 2090 & 136910 \\
\hline Pakisztán & 50 & 360 & 450 & 790 & 86320 \\
\hline India & 10 & 1270 & 180 & 620 & 81790 \\
\hline Oroszország & 10 & 940 & 50 & 1920 & 71820 \\
\hline Örményország & 160 & 1360 & 260 & 2810 & 45810 \\
\hline Banglades & 90 & 310 & 1650 & 610 & 32800 \\
\hline Összesen & 3620 & 26280 & 28520 & 18350 & 4278930 \\
\hline
\end{tabular}

Forrás: UNHCR, Statistical Review, [1999]

Megjegyzés: Európa: EU, Norvégia, Svájc. Az EU-államok közül az összesített adatokban Luxemburg és Îrország nem szerepel, de ez az adatokból levonható következtetéseket nem befolyásolja.

Látható, hogy elsősorban azok a fontos menekült-kibocsátó országok szerepelnek a társultaknál elökelö helyen, amelyekből a menekültek az illegális szárazföldi csempészútvonalon próbálnak meg az Európai Unióba bejutni, de sok esetben ez nem sikerül nekik.

Ezért lényeges megnézni, hogy milyen az illegálisan érkező menekültek aránya a tagjelölt országokba, hiszen ez mind a haszonszerző szervezett bünözői körök tevékenységének az eredménye, ami ellen a tagállamoknak a leendő tagokkal való összefogása kiemelkedő fontosságú feladat.

E területről statisztikával csak a magyar kormánytól rendelkezem, amiből látni lehet a legfejlettebb tagjelöltekre vonatkozó trendeket. Eszerint míg a kilencvenes évek közepén csak néhány százalékra volt tehető az illegálisan érkező menekültek száma, az évtized végére - a szervezett bünözés erre való áthangolódása következtében - ez lett a domináns bevándorlási módszer. 
III/3.9. sz. táblázat: Menekültek Magyarországra érkezésének módja (százalék)

\begin{tabular}{|c|c|c|}
\hline Év & $\begin{array}{c}\text { Legálisan érkezők } \\
\text { aránya }\end{array}$ & $\begin{array}{c}\text { Illegálisan } \\
\text { érkezők aránya }\end{array}$ \\
\hline 1988 & 52,5 & 47,5 \\
\hline 1989 & 20,6 & 79,4 \\
\hline 1990 & 81,3 & 18,7 \\
\hline 1991 & 88,4 & 11,6 \\
\hline 1992 & 88,3 & 11,7 \\
\hline 1993 & 98,3 & 1,70 \\
\hline 1994 & 96,4 & 3,60 \\
\hline 1995 & 94,1 & 5,90 \\
\hline 1996 & 96,0 & 4,00 \\
\hline 1997 & 29,1 & 70,9 \\
\hline 1998 & 29,2 & 70,8 \\
\hline 1999 & 57,3 & 42,7 \\
\hline 2000 & 18,9 & 81,1 \\
\hline
\end{tabular}

Forrás: BM Bevándorlási és Állampolgársági Hivatal [2001]

Mindez nemcsak a külső határellenőrzések szigorú megvalósítására - pl. hőérzékelő eszközök, zöldhatár infravédelme stb. - hívja fel a figyelmet, hanem a szervezett bünözők miatt a bünügyi együttmüködést - pl. az Europolon keresztül - is szükségessé teszik. A kibocsátó országokkal kapcsolatos külpolitika (a kivándorlások prevenciója) mellett a tranzitországok - pl. Bulgária, Törökország, Jugoszlávia, Moldova - védekezésének megerősítését is követeli ezen a területen. Mivel az illegális kereskedelem célországai vélhetően továbbra is a jelenlegi EU-tagállamok lesznek, a bővítés és az ebben szereplő lehetőségek az EU számára egyértelmüen kimagasló fontosságúak.

Összességében megállapítható, hogy a bővítés e fontos szektorában a büntetőjogi, polgári jogi és bünüldözési terület jelent fokozott együttmüködési formát a tagállamok számára; emellett a határok kiterjesztése kelet felé lényeges adminisztratív megtakarításokkal is jár a jelenlegi tagállamok számára. Ugyanakkor nem teszi egyszerübbé a bevándorlás-politika érvényesítését, ha nem megfelelő a határvédelem. Az ehhez történő hozzájárulás az EU-tagállamoknak messzemenő érdeke, hiszen ez ad számukra lehetőséget, hogy tervezni tudják bevándorlási 
politikájukat, és ne kelljen küzdeniük az illegális bevándorlók nem várt hatásától. Az illegális bevándorlás - mely a szervezett bünözés egyik fontos jövedelemforrása a kábítószer-bevételek mellett - szárazföldi tranzitvonalai kivétel nélkül a tagjelölt országokon haladnak át. 


\section{RÉSZ}

\section{A BŐVÍTÉS ELŐNYEI A HUMÁN TERÜLETEKEN}

\section{RÉSZ; 1. FEJEZET \\ A LAKOSSÁG TUDATI - VALLÁSI ÉS TOLERANCIA - SZINTJE}

A történelmi tények áttekintése után és a humán faktorok vizsgálata során elöször kitérek arra, hogy a lakosság szellemi-vallási jellemzői milyen hasonlatosságot jeleznek az európai társadalmakkal. Ennek érzékeltetésére a lakosság vallási összetételét, a valláshoz való hozzáállását, illetve toleranciaküszöbét jelző mutatót találtam alkalmasnak. Nyilvánvaló ugyanakkor, hogy a XXI. század elején a vallás már nem tölt be olyan központi szerepet, mint az elöző évszázadokban, de a társadalom európai beágyazottságára és gyökereire jól rá tud mutatni, és az új tagállamok európai beilleszkedését is segítheti.

\section{IV/1.1. Vallási jellegzetességek}

Az adatok elemzése során kiderül (IV/1.1. sz. táblázat), hogy az EU tagállamaihoz hasonlóan a tagjelölt országokban is a történelmileg domináns keresztény egyházak befolyása jellemző. Lengyelországban, Csehországban, Magyarországon, Litvániában, Szlovéniában és Szlovákiában a katolikus egyház az uralkodó, de a két másik balti államban is kiemelkedő a nyugati keresztény kultúra szerepe, elsősorban a skandinávok által elterjesztett evangélikus tanok révén. Romániában és Bulgáriában az európai történelmi fejlődés következtében az ortodox vallási irányzat az uralkodó, ám Bulgáriában a török kisebbség révén a muzulmán, míg Romániában, elsősorban az erdélyi magyar közösség révén a katolikus és protestáns vallás befolyása is jelentős. A balti államoknál a különböző történelmi hullámokban megvalósított orosz hódoltság következtében szintén jelentős az ortodox vallásúak aránya. 
IV/1.1. sz. táblázat: Az egyes tagjelölt országok hívö lakosságának vallási összetétele (százalék)

\begin{tabular}{|l|c|c|c|c|}
\hline \multicolumn{1}{|c|}{ Ország } & Katolikus & Protestáns & Ortodox & Muzulmán \\
\hline Bulgária & - & - & 88,5 & 9 \\
\hline Magyarország & 65 & 26,0 & 0,4 & - \\
\hline Lengyelország & 97 & 0,5 & 1,5 & - \\
\hline Románia & 5 & 4,0 & 87,0 & - \\
\hline Szlovákia & 60 & - & - & - \\
\hline Szlovénia & 90 & - & - & - \\
\hline Csehország & 90 & 7,0 & 2,0 & - \\
\hline Litvánia & 66 & 12,0 & 11,0 & - \\
\hline Észtország & 6 & 70,0 & 23,0 & - \\
\hline Lettország & 40 & 41,0 & 7,0 & - \\
\hline
\end{tabular}

Forrás: L’Europe Central et Balkanique, Brüsszel, [1995], Útitárs 5/2000, [2000]

Az EU tagországai, és a három, a tagság szempontjából meghatározó katolikus ország lakosainak vallási szokásait vizsgáló felmérésből kitünik, hogy a magyar, lengyel és szlovén emberek számára a vallás legalább olyan szerepet tölt be, mint a szekularizálódó Nyugaton (IV/1.2. sz. táblázat). Ebben nagy szerepet játszott az is, hogy a több mint negyven éves marxista diktatúra - mely alig ölelt át egy emberöltőt - nem tudta megtörni a vallási tradíciókat. Másrészt a marxizmus, mint ateista ideológia bukása után sokan a tradicionális értékeket keresték, és nem fordultak azonnal a modern korra jellemző világi értékek felé. Ez a folyamat jelentős segítséget adhat a kibővült Európának a globális kihívásokkal szembeni regionális válaszok megadásához. Érdekes, hogy az európai átlagnál mélyebb vallási gyökereket mutató brit-ír és osztrák mutatókhoz képest az eredeti alapítók, valamint az új tagállamok mérsékeltebb képet mutatnak. A vallási hitben és a személyes érintettségben vagy gyakorlatban a tagjelöltek minimálisan vannak lemaradva az eredeti alapítóktól, ugyanakkor a tényleges vallási tolerancia, a vallás védelme vagy az utókor felé való terjesztése kapcsán magas a támogatottság aránya (lásd: IV/1.2. sz. táblázat utolsó előtti sora.) Ez jól jelzi, hogy az a korosztály, mely élete jelentős részét az államilag uralkodó ateizmus jegyében élte le, a következő generációk felé már az európai viszonyokra jellemző aurát kívánja örökül hagyni. 
IV/1.2. sz. táblázat: Vallási jellegzetességek az EU eredeti,

késöbbi és jelenlegi tagjelöltjei körében

(a zárójelben lévö meghatározásra igent mondók százaléka)

\begin{tabular}{|l|c|c|c|}
\hline \multicolumn{1}{|c|}{ Kérdések } & $\begin{array}{c}\text { Eredeti } \\
\text { tagállamok }\end{array}$ & $\begin{array}{c}\text { Késöbbi } \\
\text { tagállamok }\end{array}$ & Tagjelöltek \\
\hline $\begin{array}{l}\text { Azok, akik nem hisznek Istenben, } \\
\text { alkalmatlanok a közszolgálatra (erösen } \\
\text { egyetértők) }\end{array}$ & 8,8 & 17,7 & 8,9 \\
\hline $\begin{array}{l}\text { Jobb lenne, ha a hívők vállalnának } \\
\text { közszolgálatot (egyetért, erösen egyetért) }\end{array}$ & 16,8 & 22,9 & 16,7 \\
\hline $\begin{array}{l}\text { A megkérdezett hisz Istenben } \\
\text { (Isten valóban létezik) }\end{array}$ & 32,2 & 41,6 & 28,4 \\
\hline $\begin{array}{l}\text { A megkérdezett hisz az ördögben (akik } \\
\text { szerint ez létezik) }\end{array}$ & 28,2 & 31,0 & 18,6 \\
\hline $\begin{array}{l}\text { A megkérdezett hisz a mennyországban (igen } \\
\text { bizonyosan vagy valószínúleg) }\end{array}$ & 45,8 & 68,5 & 36,4 \\
\hline $\begin{array}{l}\text { A megkérdezett hisz a Pokolban (\% igen, } \\
\text { bizonyosan vagy valószínüleg) }\end{array}$ & 28,6 & 44,4 & 24,5 \\
\hline $\begin{array}{l}\text { A megkérdezett hisz a vallási jellegü } \\
\text { csodákban (igen, bizonyosan vagy } \\
\text { valószínüleg) }\end{array}$ & 49,8 & 63,8 & 43,7 \\
\hline $\begin{array}{l}\text { Az élet fontos, mert Isten létezik (erősen } \\
\text { vagy általában egyetért) }\end{array}$ & 25,2 & 36,8 & 24,2 \\
\hline $\begin{array}{l}\text { Milyen gyakran imádkozik a megkérdezett } \\
\text { (sohasem) }\end{array}$ & 29,5 & 19,1 & 38,3 \\
\hline Milyen gyakran jár templomba (sohasem) & 58,5 & 50,3 & 66,1 \\
\hline $\begin{array}{l}\text { Legyen-e napi imádság az iskolában (igen, } \\
\text { bizonyosan vagy valószínüleg) }\end{array}$ & 35,8 & 74,4 & 30.0 \\
\hline $\begin{array}{l}\text { A vallást támadó könyvek és filmek betiltásra } \\
\text { kell, hogy kerüljenek (igen, bizonyosan vagy } \\
\text { valószínüleg) }\end{array}$ & 38,2 & 44,3 & 41,9 \\
\hline $\begin{array}{l}\text { A megkérdezett gyakran vesz-e igénybe } \\
\text { vallási szolgáltatásokat (soha) }\end{array}$ & 32,6 & 20,4 & 35,0 \\
\hline
\end{tabular}

Forrás: G. Amato - J. Batt: The Long Term Implications of EU Enlargement: The Nature of the New Border

Megjegyzés: Eredeti tagok: NSZK, Hollandia, Olaszország

Későbbi tagok: Egyesült Királyság, Észak-Írország, Írország, Ausztria

Tagjelöltek: Magyarország, Szlovénia, Lengyelország

\section{IV/1.2. Tolerancia és bizalommutatók}

A négy jelentős devianciához (homoszexualitás, prostitúció, abortusz vagy a válás) kapcsolódó toleranciaszint - egy felmérés tanúsága szerint - a társadalmi-gazdasági fejlettséggel egyenes arányban mutatható ki. 
IV/1.3. sz. táblázat: Tolerancia mások egyéni devianciái iránt (a megkérdezettek százalékában)

\begin{tabular}{|l|c|c|c|}
\hline \multicolumn{1}{|c|}{ Ország } & Toleráns & $\begin{array}{c}\text { Vegyes } \\
\text { megközelítésü }\end{array}$ & Dogmatikus \\
\hline Nyugatnémet tartományok & 45,3 & 37,1 & 17,6 \\
\hline Svédország & 39,7 & 49,3 & 11,0 \\
\hline Keletnémet tartományok & 34,9 & 38,1 & 27,0 \\
\hline Spanyolország & 23,4 & 43,5 & 33,1 \\
\hline Szlovénia & 20,1 & 38,8 & 41,1 \\
\hline Finnország & 19,9 & 44,0 & 36,1 \\
\hline Bulgária & 14,5 & 41,7 & 43,9 \\
\hline USA & 8,9 & 35,6 & 55,6 \\
\hline Lettország & 8,3 & 50,2 & 41,5 \\
\hline Észtország & 4,8 & 46,1 & 49,1 \\
\hline Lengyelország & 4,5 & 30,3 & 65,2 \\
\hline Litvánia & 3,0 & 27,4 & 69,6 \\
\hline
\end{tabular}

Forrás: G. Amato és J. Batt: The Long Term Implications of EU Enlargement: The Nature of the New Border, Firenze, [1999]. (A szerzők részére készített felmérés alapján)

A IV/1.3. sz. táblázat alapján egyértelmüen látszik, hogy részint a társadalmi fejlödés történelmileg kevésbé toleráns jellege miatt, részint az utóbbi fél évszázad kommunisztikus értékrendjének hatása miatt - mely a devianciák büntetésére és a társadalom ettől való megtisztítására épült - a volt szocialista országok, bár eltérő jelleggel, de nem mutatnak olyan rugalmasságot, mint az elmúlt negyven évben a kérdés megvitatásán átesett nyugat-európai társadalmak. (Érdemes megjegyezni, hogy a Franco-érában intoleráns felfogást tükröző Spanyolországban még most is a társadalom harmada tekinthető dogmatikusnak.) Ezért kijelenthető, hogy a társadalmi tolerancia tekintetében az új tagállamok beilleszkedése nem lesz könnyü. Az utóbbi időszakban az európai törvénykezésben is megjelentek olyan elemek (pl. a homoszexuális kapcsolatok jogi elismerése, egyes tagállamokban a legális kábítószer-használat vagy az eutanázia elfogadtatása), amelyek kapcsán még további lépések várhatók az EU-ban, ami nehezen befogadható az új tagállamok számára a lakosság konzervativizmusa miatt. (Az Amszterdami Szerződésben már megjelent a diszkrimináció-mentesség fogalma, amit már direktívákban is kibontottak.) A jelenlegi európai tudati viszonyok alapján azonban nehezen határozható meg az, 
hogy az új tagok merevebb felfogása mely esetben lesz az európai fejlődés gátja, vagy esetleg moderátora.

Ugyancsak fontos a jövendőbeli Európa szempontjából az, hogy az új tagállamok milyen bizalmi jelleggel lépnek be az Európai Unióba (ld. IV/1.4. sz. táblázat). A felmérések itt is azt mutatják, hogy az új tagországok - a részbeni történelmi tapasztalatok, a közelmúlt hatalmas csalódásai és a közerkölcsök meglazulása miatt általában bizalmatlanabbak, mint a hagyományos fejlődésen átesett nyugat-európai lakosság. (Ezt jól tükrözi a nyugat-német és a kelet-német tartományok közötti jelentős különbség.) Ennek különösen abban van nagy jelentősége, amikor a tagság után a közösségi jogkörök fokozatos kiépítése kapcsán le kell mondani bizonyos tagállami jogokról - ilyen például a tagállamonként garantált bizottsági tag intézménye -, de ugyanez előfordulhat az Európai Bíróság döntéseinél vagy a Tanács minősített többségi határozatainál, ahol az Európai Unió és az azt alkotó más államok iránti bizalom fontos tényező lesz. Megjegyzem, hogy a rendszerváltás utáni nyugateurópai magatartás - beleértve a csatlakozási tárgyalásokat is - nem minden esetben segítette a bizalom növekedését térségünkben, aminek feloldására hosszabb időre lesz szükség a tagság után. (Mint a tagság intézményi kérdéseivel foglalkozó fejezetben, valamint az egyes közösségi politikák taglalása esetén utalok rá, általában a közösségi kompetencia kiterjesztése nem okozhat nehézséget az új tagok számára. A jelenlegi helyzetben az esetleges negatív hatások veszélye - főleg anyagi vonatkozású területeken a másodosztályú tagságtól való félelem - megtarthatja az új tagok részbeni óvatosságát addig, míg helyzetük az Unión belül nem konszolidálódik.) 
IV/1.4. sz. táblázat: Bizalomindex másokban

(a megkérdezettek százalékában)

\begin{tabular}{|l|c|c|}
\hline \multicolumn{1}{|c|}{ Ország } & $\begin{array}{c}\text { Legtöbb ember } \\
\text { megbízható }\end{array}$ & $\begin{array}{c}\text { Valaki sohasem } \\
\text { lehet elég óvatos }\end{array}$ \\
\hline Svédország & 56,6 & 43,4 \\
\hline Finnország & 47,9 & 52,1 \\
\hline $\begin{array}{l}\text { Nyugatnémet } \\
\text { tartományok }\end{array}$ & 39,9 & 60,1 \\
\hline Spanyolország & 28,8 & 71,2 \\
\hline $\begin{array}{l}\text { Keletnémet } \\
\text { tartományok }\end{array}$ & 24,3 & 75,7 \\
\hline Lengyelország & 24,3 & 75,7 \\
\hline Lettország & 23,9 & 76,1 \\
\hline Bulgária & 23,7 & 76,3 \\
\hline Litvánia & 21,3 & 78,7 \\
\hline Észtország & 21,1 & 78,9 \\
\hline Szlovénia & 15,3 & 84,7 \\
\hline
\end{tabular}

Forrás: G. Amato - J Batt: The Long Term Implications of EU Enlargement: The Nature of the New Border, Firenze [1999]

\section{IV/1.3. Az etnikai és nemzeti kisebbségek iránti tolerancia}

A valláshoz való viszony, a tolerancia és bizalomszint mellett a negyedik vizsgált tényező a nemzeti kisebbségek szerepe a régió országaiban. Közép-Európában ez a kérdés mindig is jelen volt, ám eltérő jelleget öltött a nyugat-európaitól. Míg NyugatEurópában a nemzeti öntudat a polgárosodással párhuzamosan, a már többé-kevésbé létező nemzetállami keretek között jött létre (ezt nevezi a szakirodalom bizonyos része polgári típusú nemzetfejlődésnek), addig régiónkban a nagy multietnikus birodalmak (Orosz Birodalom, Ottomán Birodalom és főleg a Habsburg Monarchia) méhében fejlődött ki, és a nemzeti ébredés, nemzeti függetlenség és a polgári fejlődés párhuzamos megjelenését eredményezte. Ezért Közép- és Kelet-Európában sokkal erőszakosabb színben jelent meg az etnikai jellegü nemzetiségi kérdés, amit tetőzött az is, hogy nyugati hatalmi döntések (gyakorlatilag ide sorolható a berlini konferenciától kezdve a két világháborút lezáró békerendszereken keresztül a délszláv állam szétesését szentesítő nagyhatalmi magatartás a kilencvenes évek elején) határozták meg az etnikai és uralmi viszonyok összehangolását, ami gyakran nélkülözte a racionalitást és a tisztán etnikai elvet. A birodalmi fejlődés részeként 
lehet aposztrofálni azt is, hogy a kisebbségekben - talán a régi múlt tapasztalatai miatt - államokat felbontó veszélyes tényezőt láttak, ellentétben a nyugat-európai viszonylattal, ahol ezt a fejlődési lépcsőt - mesterséges birodalmak fel- és leépítése nem kellett bejárni.

Ugyanakkor a nemzeti kisebbségek léte pozitív értékeket is jelent. A rendszerváltás óta a nemzeti kisebbségek több országban politikailag megszervezték magukat, pártokat és politikai mozgalmakat hoztak létre, és bekerültek a parlamentbe is (ilyen a török kisebbség Bulgáriában vagy a magyar kisebbség Romániában és Szlovákiában). Eltérően az EU-országokban tapasztalható erőszakos fellépésektől (Észak-Írország, Baszkföld vagy Korzika), a közép-európai kisebbségek tagjai a politikai csatornákat tekintik elsődleges érdekérvényesítési formának, és nem fogékonyak a terrorizmusra vagy a fegyveres önrendelkezési harcra. A tagjelölt országokban a nemzeti kisebbségek létét az adott ország fejlődése szempontjából némileg csökkenő mértékben tekintik a nemzeti társadalmi fejlödést veszélyeztető fő problémának, ami a többségi nemzet részéről némi bizalom megnyilvánulását jelzi (lásd: IV/1.5. sz. táblázat). E tekintetben Szlovénia, Magyarország és Lengyelország kisebbségi csoportokkal szembeni türelme eltér a többi ország intoleránsabb szintjétöl.

IV/1.5. sz. táblázat: Etnikai vagy kisebbségi csoportok jelentös vagy valamilyen veszélyt jelentenek a nemzeti társadalmi fejlödésre (százalék, igen válaszok)

\begin{tabular}{|l|c|c|c|}
\hline \multicolumn{1}{|c|}{ Ország } & $\mathbf{1 9 9 3}$ & $\mathbf{1 9 9 8}$ & Változás \\
\hline Szlovákia & 53 & 43 & -10 \\
\hline Románia & 60 & 32 & -28 \\
\hline Bulgária & 46 & 29 & -17 \\
\hline Csehország & 44 & 25 & -19 \\
\hline Magyarország & 26 & 19 & -7 \\
\hline Lengyelország & 35 & 17 & -18 \\
\hline Szlovénia & 13 & 10 & -3 \\
\hline
\end{tabular}

Forrás. R. Rose és C. Haerpfer: Trends in Democracies and Markets: New Democracies Barometer 1991-98, Glasgow, [1998], p.41 in: G. Amato - J Batt: The Long Term Implications of EU Enlargement: The Nature of the New Border, Firenze [1999] 
A nemzeti kisebbségeknek az etnikai kisebbségektől eltérő sajátossága, hogy jól elkülöníthetőek azok a földrajzi területek, amelyeken többségben élnek. Ezek vizsgálata mind az egy főre jutó GDP, mind a munkanélküliségi rátát illetően azt mutatja, hogy e kisebbségek megfelelő integráltságot értek el, egyik mutató sincs a nemzeti átlag alatt. (Ez a megállapítás nem igaz az oroszok lakta balti térségre, ahol a munkanélküliség is magasabb.) A nemzeti kisebbségek megfelelő társadalmigazdasági fejlettsége segítheti annak felismerését is, hogy e kisebbségek helyhez kötése (vagyis elvándorlásuk megakadályozása) nemcsak a többségi lakosság nemzeti érdeke, hanem európai érdek is, mivel az ún. összekötő kapocs mellett húzóerőként kapcsolódnak az európai fejlődési trendekhez. (Ilyen pozitív példa az olaszok által alkotott szlovén területek, vagy a magyarok által többségben lakott dunaszerdahelyi járás Szlovákiában, vagy Hargita és Kovászna megye Romániában. Boeri és társai, [2000]) A nemzeti kisebbségek jogainak teljesítésével, oktatási és autonómia igényeik megfelelő kezelésével ezt az európai és nemzeti érdeket segíteni lehet.

\section{RÉSZ; 2. FEJEZET A RÉGIÓ KISEBBSÉGI TÉRKÉPE}

Az Európai Unió figyelemmel kíséri azt, hogy a nemzetiségi összetétel szerint nem homogén országok milyen politikát tudnak teremteni ahhoz, hogy felvételük kapcsán a kisebbségek megfelelő kezelése stabilizáló (és ne destabilizáló) hatású legyen az adott országban és közvetve az EU-ban. Az EK már 1993-ban, a koppenhágai csúcsértekezleten az új tagok felvétele kapcsán kijelentette, hogy az új belépőknek tiszteletben kell tartaniuk az emberi, valamint a kisebbségi jogokat. Maga az Unió is komoly lépéseket tett az Amszterdami Szerződésben, illetve az Alapvető Jogok Chartájában az ezzel kapcsolatos kérdések rendezéséért, és ezt a célt szolgálja a különböző diszkrimináció-ellenes intézkedéscsomag bevezetése is (lásd pl. az Amszterdami Szerződés 13. pontját vagy a 43/2000 direktívát). Amennyiben a közép- és kelet-európai régióban meglévő helyzetet vizsgáljuk, két területet kell kiemelnünk: 
- az egyik a háborúk utáni békerendezések következtében kialakult határokon belüli kisebbségi problémák,

- a másik a régió (és Európa) sajátos etnikai problémájaként megjelenő romakérdés kezelése.

\section{IV/2.1. Nemzeti kisebbségek}

IV/2.1.1. A hagyományos nemzeti kisebbségek

A „hagyományos” kisebbségi csoportok közül kitünik a térségben található magyar nemzeti kisebbségi csoport, melynek nagyobb fele (79,4 százaléka) olyan ország polgára, mely közép vagy hosszabb távon, de belátható időn belül az Európai Unió tagja lesz (Szlovénia, Szlovákia, Románia), míg kisebb részüket (19,3 százalék) befogadó országok (Ukrajna, Horvátország, Jugoszlávia) pillanatnyilag nem tekinthetők tagjelöltnek (bár hosszabb távon ez nem kizárt). A mostani tíz országra vonatkozó bővítési elképzelés után a magyar kisebbségek bekerülnek az Unió határain belülre, ezért nem fogják az Unió külkapcsolati rendszerét terhelni.

IV/2.1. sz. táblázat: A magyar nemzeti kisebbség száma és megoszlása az anyaországgal szomszédos országokban (1990 körül)

\begin{tabular}{|l|c|c|}
\hline \multicolumn{1}{|c|}{ Ország } & $\begin{array}{c}\text { Létszám } \\
\text { (ezer fö) }\end{array}$ & $\begin{array}{c}\text { Megoszlás } \\
\text { (százalék) }\end{array}$ \\
\hline Szlovákia & 608 & 21,4 \\
\hline Ukrajna & 180 & 6,3 \\
\hline Románia & 1640 & 57,7 \\
\hline Jugoszlávia & 350 & 12,3 \\
\hline Horvátország & 20 & 0,7 \\
\hline Szlovénia & 9 & 0,3 \\
\hline Ausztria & 33 & 1,2 \\
\hline Összesen & 2840 & 100,0 \\
\hline
\end{tabular}

Forrás: Kocsis Károly - Kocsis-Hodosi Eszter: Ethnic geography of the Hungarian minorities in the Carpathian Basin [1998] (nemzeti népszámlálási adatok alapján) 
A magyar kisebbségekről az alábbiak emelhetők ki:

- Területileg jól behatárolhatóan (Kárpát-medence) élnek Európában, és így helyi identitásuk, kötődésük nagyon erős. Több (országokon belüli) régióban a lakosság abszolút többségét alkotják (pl. Székelyföld, Csallóköz). Problémáik abban nyilvánulnak meg, hogy néhány országban nem kapják meg a helyzetüknek és a müködő európai gyakorlatnak megfelelő kisebbségi jogokat, mely megmaradásukat, és így saját, valamint környezetük gyarapodását szolgálná. (Ezt mutatja többek között az, hogy Romániában és Szlovákiában közülük egyetemet végzettek aránya jóval alacsonyabb a többségi uralkodó nemzetbélieknél és jelentősen elmarad az anyaországtól is.) A magyar kormánytól származó információk szerint Szlovákiában a magyarok között a felsőfokú végzettségüek aránya 3,6 százalék, szemben a szlovákiai 7,5 százalékos országos átlaggal. Romániában az 1992-es népszámlálás hivatalos adatai szerint a magyaroknál a felsőfokú végzettségüek aránya 3,6 százalék, míg a romániai összlakosság vonatkozásában 5,1 százalék. (Külügyminisztérium, [2001])

- Mind a magyar kisebbségek, mind az anyaország törekszik a problémák politikai úton való megoldására, a kisebbségek részt vesznek a parlamenti és a kormányzati (Románia, Szlovákia, Jugoszlávia) munkában, vagyis nem áll fenn a politikai nézeteltérések fegyveres (terrorizmus) úton való megoldásának szándéka, mint azt számtalan EU-országbeli példa (Spanyolország, Egyesült Királyság, Franciaország) mutatja.

- Részt vesz az otthont adó ország politikai életében, abban minden esetben az EU által preferált politikai irányzatokat vagy személyeket támogatja (pl. Schuster, Constantinescu, Kostunica megválasztásánál), vagyis az illető országok társadalmán belül a jelenlegi európai értékrendet hordozó erőknek minősülnek.

- Arányuk a jelentkező országokban igen jelentős (11 százalék Szlovákiában, 7,4 százalék Romániában a 90-es évek eleji népszámlálási adatok szerint, Kocsis Kocsis-Hódosi, [1998]).

Ez utóbbi jellemző kivételével a fenti megállapítások igazak a térségben élő német kisebbségre, valamint a Litvániában őshonos lengyelekre is, akik főleg Vilniusban és 
környékén jelentenek fontos politikai erőt. A Baltikumban már hagyományosan is létezett őshonos orosz lakosság (lásd IV/.2.2. sz. táblázat).

A magyarokhoz hasonlóan több mint 3,5 millió román nyelvü él a jelenlegi Románia határain kívül. Ebből a leglényegesebb, a több mint 3 millió lakosú Moldova, amely Romániával hasonlatos nyelvi-kulturális csoportnak mondható, de pillanatnyilag nem kíván Romániával egyesülni, és maga is kisebbségi problémáktól (oroszok, gagauzok) terhes.

A hagyományos kisebbségek közül még fontos arányú a bulgáriai török kisebbség, mely a lakosságnak több mint 10 százalékát teszi ki. A bolgár rendszerváltás óta ez a közösség is a parlamenti képviselet révén kívánja érdekeit érvényesíteni.

Az bizonyos, hogy a magyar nemzetiségek kivételével a hagyományos (több évszázada ugyanazon a földrajzi területen élő) nemzetiségek befolyásolni fogják az Unió külkapcsolati rendszerét, hiszen az ebben érintett szomszédos anyaállamok nem számítanak még hosszú távon sem tagjelöltnek.

IV/2.1.2. A betelepített nemzeti kisebbségek

A 90-es évek elején nagy problémának látszott a balti államok függetlenségének elnyerése után ott maradt orosz kisebbség integrálása. Szintén „új”, a XX. században betelepített kisebbségnek minősül a térségben a szlovéniai szerb és horvát, valamint csehországi szlovák, illetve a szlovákiai cseh csoport is, de arányuk viszonylag kicsi, 1-5 százalék közötti.

A baltikumi kelet-szláv közösség (mely kulturálisan nem az Unió népeihez kötődik) aránya meglehetősen magas, ráadásul státusza is csak lassan rendeződik. Eltérően más volt szovjet utódállamoktól (pl. Kazahsztán), a balti államok nem állapítottak meg két-nemzetiségü állammodellt, hanem történelmi alapon nemzetállamnak deklarálták magukat. (A két háború között létezett a három balti állam, beolvadásukat a szovjet államba erőszak útján megvalósult volta miatt a baltiak nem tekintik legitimnek). Ezért az állampolgárság és nemzet-állam visszaállítása szerepelt a napirenden a 90 -es évek elején. A problémát az okozta, hogy időközben a szovjet 
hatalom által jelentős orosz betelepítés történt 1940 után, ami megváltoztatta az eredeti etnikai összetételt. (Litvánia ez alól alapvetően mentesült.) Így a függetlenség visszanyerése után az állampolgárság helyreállítása feszültséget okozott (az eredeti állampolgárok leszármazottjai kapták meg azonnali hatállyal ezt a jogot), elsősorban Lettországban és Észtországban. Itt arányaiban is magas volt a betelepültek száma, és az állampolgárság megszerzésének egyéb (nyelvi, helybenlakási, állambiztonsági) szempontjai miatt a lakosság 30 százaléka még nem volt helyi állampolgár a 90-es évek közepén. Bár a helyzet azóta sokat javult (egyre több személy nyeri el az állampolgárságot és kisebbségi helyzetük is fejlődik), azonban a viszony a két balti államban még sokáig feszült marad. Mindenesetre az EU szempontjából nem megnyugtató a helyzet, hogy önmagukat nemzetállamnak deklaráló országok esetében a lakosság jelentékeny, 30-40 százaléka kelet-szláv anyanyelvü, és ezen országokban jelentős azon nyugalmazott orosz katonatisztek, vagy néhai állambiztonsági alkalmazottak aránya, akik az EU leendő tagállamában élnek majd. A helyzet rendezését az új generációk felnövése segíti, akik már teljesíteni tudják az állampolgársághoz szükséges feltételeket. Az azonban tény, hogy Lettországban és Észtországban az orosz kisebbség helyzetének rendezése a csatlakozás után az EU-n kívüli harmadik országokkal (elsősorban Oroszországgal) fennálló kapcsolatokat terheli meg.

IV/2.2. sz. táblázat: A kelet-szlávok aránya a szovjet utódállamokban (százalék)

\begin{tabular}{|c|c|c|}
\hline \multirow{2}{*}{ Ország } & \multicolumn{2}{|c|}{ Kelet-szlávok aránya } \\
\cline { 2 - 3 } & Háború elött & $\mathbf{1 9 8 9}$ \\
\hline Litvánia (1923) & 2,6 & 12,3 \\
\hline Lettország (1935) & 8,3 & 35,2 \\
\hline Észtország (1934) & 12,1 & 42,0 \\
\hline
\end{tabular}

Forrás: Georg Brunner: Nationality Problems and Minority Conflicts in Eastern Europe, Bertelsmann Foundation Publishers [1996]

\section{IV/2.2. A zsidó etnikai kisebbség}

A II. világháború következtében a zsidó származásúak aránya a tagjelölt országokban a korábbi jelentős hányadról (7-10 százalék) lényegtelen mértéküre (1 százalék körüli vagy az alattira) zsugorodott. Integráltságuk azonban minden esetben 
megfelelő, iskolai végzettségük és munkanélküliségi rátájuk, szellemi-gazdasági befolyásuk a többségi társadalomnál általában jobb vagy annak megfelelő. Létük a régi beidegződöttségek alapján inkább ad feszültségre okot, mint integráltságuk hiánya. Ebben a vonatkozásban a régió teljesen hasonlatos az EU jelenlegi tagállamaiban megnyilvánuló állapotokhoz.

\section{IV/2.3. A romák integrálásának sajátosságai}

E különleges etnikumnak a bővités után megnyilvánuló helyzete, annak rendezése egész Európát érinteni fogja. A bővités szempontjából két aspektus érdemel említést:

- a romák aránya az új tagállamokban meglehetösen magas,

- kisebb kötődésük, nemzettudatuk, valamint hagyományosan vándorló életmódjuk miatt nagyobb migrációs forrásnak számítanak, mint a többségi lakosság.

A társult országokban a rendszerváltás legnagyobb vesztesének a roma lakosság számított. Alacsony szakképzettségük, iskolázottságuk, a munkaerőpiacon betöltött helyzetük miatt a munkanélküliség terén a leginkább kiszolgáltatott helyzetbe kerültek. Mivel statisztikailag és sok államban alkotmányosan is nehéz felmérni, hogy ki a roma nemzetiségü (diszkrimináció-mentesség miatt legtöbb országban nem tartható nyilván), csak becslések lehetnek iskolázottsági helyzetükről, munkanélküliségi arányukról, a fizikai és szellemi munkakörökben betöltött szerepükről. Iskolázottságukat tekintve a középfokú és föleg a felsőfokú végzettséget tekintve van lemaradás, ez utóbbi például Magyarországon nem haladja meg a roma lakosság 1 százalékát (lásd: IV/2.3. sz. táblázat), és a közülük a munkában állókon belül a fizikai foglalkozásúak tették ki e népcsoport 98,2 százalékát 1993-ban (Igazságügyi Minisztérium, [2000]). Ez azért is sajnálatos, mert olyan, a kisebbségek számára általában megfelelő mutatókkal rendelkező országokban, (mint pl. Magyarország a 90-es évek elején), ez a felmérés komoly lemaradást jelzett.

Ugyanakkor elmondható, hogy az EU-ba igyekvő országok észlelték az ebből eredő problémákat, és ilyen módon konkrét programokat indítottak el a halmozottan hátrányos helyzet, a diszkrimináció nem tudatos formáinak csökkentésére. Az Európai Bizottság PHARE programokat indított a romák integrációjának 
elősegítésére. (Az EU PHARE programjai keretében átlagosan évi 100 ezer eurót fordítottak a roma programokra, ám ezt 1998-tól a nemzeti PHARE keretein belül megemelték: 1999-ben Magyarországon 5 millió eurót, Romániában 2 milliót, Szlovákiában 1,8 millió eurót szánnak e programra, míg Csehországban és Bulgáriában 500-500 ezer eurót fordítanak közvetlenül erre a célra. (Európai Bizottság, [1999])

IV/2.3.1. A roma lakosság képzettsége a magyar adatok alapján

Magyarországon 1971-ben és 1993-ban mérték fel a képzettségi szintet a roma lakosság körében. (Ezt követően az adatvédelmi törvény alapján erre már nem volt mód.) Ennek alapján egy javuló, de a többségi társadalomtól még mindig elmaradó képet kaptunk. Míg 1971-ben a romák 39 százaléka volt analfabéta, addig 1993-ban 9 százalékra csökkent arányuk, és míg 1971-ben Magyarországon a romák 26 százaléka fejezte be az általános iskolát, addig 1993-ban 77 százalékuk.

\section{IV/2.3. sz. táblázat: A roma lakosság képzettségi és munkaerö-piaci helyzete 1993-ban Magyarországon (százalék)}

\begin{tabular}{|l|c|c|}
\hline & $\begin{array}{c}\text { Teljes } \\
\text { lakosság }\end{array}$ & Romák \\
\hline Középiskolai képzésben részesült & 91,4 & 33,6 \\
\hline $\begin{array}{l}\text { Középfokú képzést } \\
\text { bizonyítvánnyal befejezte (1996) }\end{array}$ & 34,7 & 13,0 \\
\hline Diplomát szerzett (1996) & 12,1 & 0,5 \\
\hline Foglalkoztatott & 54,8 & 28,7 \\
\hline Munkanélküli & 9,0 & 28,8 \\
\hline Inaktív & 36,2 & 42,5 \\
\hline
\end{tabular}

Forrás: Igazságügyi Minisztérium, Nemzeti és Etnikai Hivatal, [2000]: Measures taken by state to promote the social integration of Roma living in Hungary

A IV/2.3. sz. táblázatból látszik, hogy a roma lakosság integráltságának két lényegi eleme a tanulás és foglalkoztatás megoldása, mivel a két tényező nagy korrelációt mutat. A szociális piacgazdaságban sem létezik kötelező és teljes foglalkoztatottság, de a rendszerváltás idején megfigyelt nagy olló a teljes lakosság és a romák foglalkoztatását illetően a munkanélküliség általános csökkentésével együtt zárulni fog. Reményre adhat okot, hogy a 70-es évek elején a magyar társadalomban 
általánosan 87, míg a romák körében 85 százalék volt az aktív foglalkoztatási ráta, vagyis akkor lényeges különbség e mutatóban nem jelentkezett.

IV/2.3.2. A romák aránya és száma a csatlakozó országokban

E tekintetben a legkülönfélébb becslések látnak napvilágot. Ennek egyik oka az, hogy bár a romák külső jegyeikben viszonylag jól felismerhetők, a statisztikai felmérések ezt nem tudják tükrözni, hiszen csak olyan személyek sorolhatók e nemzetiségek közé, akik ennek vallják magukat. Mivel a romák nagy része nem beszéli az eredeti cigány nyelvet, így nyelvi alapon sem lehet valódi arányukat felmérni. Gyenge a politikai pártszerveződésük, illetve, ha ilyenre volt példa, pl. Romániában, akkor sem támogatták őket a roma választók olyan számban, mint ami a valós arányukat mutatná, eltérően pl. a szlovákiai vagy romániai magyaroktól, vagy a bulgáriai törököktől. Mivel a cigányok értelmiségének nagy része az integrálódást követően nem vállalja identitását, ezért munkanélküliségi, szakképzettségi mutatóik is valószínűleg jobbak a IV/2.3. sz. táblázatban jelzetteknél.

A létszámról becsült adatok inkább a ténylegesen halmozottan hátrányos helyzetűekről szólnak. (A számarányok megállapításának nehézségét jelzi, hogy a magyar Országos Cigány Önkormányzat elnöke szerint 15 millió roma él Európában, ebből 800 ezer Magyarországon, míg a tudományos felmérések szerinti értékek 10 millió fő körüli számot mutatnak.) A roma lakosság számarányát erőteljesen befolyásolja, hogy a romák többségénél az átlagos gyerekszám jóval magasabb, mint az európai hagyományos nemzeti vagy népcsoportoké, így számuk és arányuk folyamatosan nő. (A becslések egy része 8-10 százalékos növekedést mutat a 90-es évek folyamán.) 
IV/2.4. sz. táblázat: Becsült roma lakosság és aránya Európában (1998)

\begin{tabular}{|c|c|c|c|c|c|c|}
\hline Ország & $\begin{array}{c}\text { Minimum } \\
\text { szám } \\
\text { (ezer fó) }\end{array}$ & $\begin{array}{l}\text { Maximum } \\
\text { szám } \\
\text { (ezer fó) }\end{array}$ & $\begin{array}{c}\text { Össz- } \\
\text { lakosság } \\
\text { (ezer fö) }\end{array}$ & $\begin{array}{c}\text { Minimum } \\
\text { arány } \\
(\%)\end{array}$ & $\begin{array}{c}\text { Maximum } \\
\text { arány } \\
(\%)\end{array}$ & $\begin{array}{l}\text { Munka- } \\
\text { nélküliségi } \\
\text { ráta } \\
\text { (országos) } \\
(\%) \\
\end{array}$ \\
\hline Bulgária & 700,0 & 800,0 & 8.283 & 8,45 & 9,66 & 16,0 \\
\hline Ciprus & 0,5 & 1,0 & 658 & 0,08 & 0,15 & 3,3 \\
\hline Csehország & 250,0 & 300,0 & 10.299 & 2,43 & 2,91 & 6,5 \\
\hline Észtország & 1,0 & 1,5 & 1.454 & 0,07 & 0,10 & 9,6 \\
\hline Magyarország & 550,0 & 600,0 & 10.135 & 5,43 & 5,92 & 7,8 \\
\hline Lettország & 2,0 & 3,5 & 2.458 & 0,08 & 0,14 & 13,8 \\
\hline Litvánia & 3,0 & 4,0 & 3.704 & 0,08 & 0,11 & 13,3 \\
\hline Lengyelország & 50,0 & 60,0 & 38.660 & 0,13 & 0,16 & 10,6 \\
\hline Románia & $1.800,0$ & 2500,0 & 22.526 & 7,99 & 11,10 & 6,3 \\
\hline Szlovákia & 480,0 & 520,0 & 5.387 & 8,91 & 9,65 & 12,5 \\
\hline Szlovénia & 8,0 & 10,0 & 1.985 & 0,40 & 0,50 & 7,9 \\
\hline Málta & n.a. & n.a. & 376 & - & - & 5,1 \\
\hline Nem EU tagok & $3.844,5$ & 4800,0 & 105.925 & 3,63 & 4,53 & \\
\hline Ausztria & 20,0 & 25,0 & 8.075 & 0,25 & 0,31 & 4,7 \\
\hline Belgium & 10,0 & 15,0 & 10.192 & 0,10 & 0,15 & 9,5 \\
\hline Dánia & 1,5 & 2,0 & 5.295 & 0,03 & 0,04 & 5,1 \\
\hline Finnország & 7,0 & 9,0 & 5.147 & 0,14 & 0,17 & 11,4 \\
\hline Franciaország & 280,0 & 340,0 & 58.727 & 0,48 & 0,58 & 11,7 \\
\hline Görögország & 160,0 & 200,0 & 10.511 & 1,52 & 1,90 & 10,7 \\
\hline Németország & 110,0 & 130,0 & 82.057 & 0,13 & 0,16 & 9,4 \\
\hline Írország & 22,0 & 28,0 & 3.694 & 0,60 & 0,76 & 7,8 \\
\hline Olaszország & 90,0 & 110,0 & 57.563 & 0,16 & 0,19 & 12,2 \\
\hline Luxemburg & 0,1 & 0,2 & 424 & 0,02 & 0,04 & 2,8 \\
\hline Portugália & 40,0 & 50,0 & 9.957 & 0,40 & 0,50 & 5,1 \\
\hline Spanyolország & 650,0 & 800,0 & 39.348 & 1,65 & 2,03 & 18,7 \\
\hline Svédország & 15,0 & 20,0 & 8.848 & 0,17 & 0,23 & 8,3 \\
\hline Egyesült Kir. & 90,0 & 120,0 & 59.090 & 0,15 & 0,20 & 6,3 \\
\hline Hollandia & 35,0 & 40,0 & 15.654 & 0,22 & 0,26 & 4,0 \\
\hline EU & 1530,6 & 1889,2 & 374.582 & 0,41 & $\mathbf{0 , 5 0}$ & 10,0 \\
\hline Összesen & 5375,1 & 6689,2 & 480.507 & 1,12 & 1,39 & - \\
\hline
\end{tabular}

Forrás: RSC, G. Amato - J. Batt: The Nature of the New Border Firenze, [1999], saját számítás

Megjegyzés: * kerekítve

A fentiekből adódóan egyszerű a következtetés, miszerint az új tagállamok - változó mértékben - növelik nemcsak a roma lakosság lélekszámát, de relatív arányát is az EU-ban. (A minimum arány szerint 0,41 százalékról 1,12 százalékra, míg a maximum arány szerint 0,5 százalékról 1,39 százalékra.) Az adatokból egyértelműen 
látszik, hogy a romák száma a társult országokban a szakértői becslések szerint két és félszerese a jelenlegi tagállamokban lévőknek.

Országonként vizsgálva nagy eltéréseket tapasztalunk, míg Romániában, Bulgáriában és Szlovákiában a romák a lakosság közel 10 százalékát teszik ki, és Magyarországon is 5-6 százalékot képviselnek, (emellett Csehországban jelentős még arányuk), addig a többi társult országban számuk - az összlakossághoz mérten nem jelentős. (Az EU-tagállamok közül Spanyolországban és Görögországban magas az arányuk, de kisebb, mint a markánsan kiemelkedő öt jelölt országban.) A romák viszonylag magas száma egyes tagjelölteknél azt eredményezi, hogy a felzárkózó, európai viszonylatban nem gazdag országok esetében jóval nehezebb megoldani a lakosság közel 10 százalékát kitevő roma polgárok társadalmi integrációját. Mivel a romák történelmi hagyományaik miatt rendkívül mobilak, fennáll annak a veszélye, hogy a nagy megélhetési különbség okán az egységes belső piacon kontrollálatlanul indul meg vándorlásuk. Intő jel, hogy a romániai, bulgáriai és szlovákiai menedékjogot kérők száma a kilencvenes években magas volt, akik között jelentős roma népesség feltételezhető annak ellenére, hogy ezt tisztán statisztikailag nem lehet kimutatni. (A menedékjogi statisztikákra a bel-és igazságügyi fejezetben tértem ki.) Az EU Odüsszeusz programja által finanszírozott kutatás szerint (2001. február) jelentős a jelenlegi tagállamokban azon romák száma, akik nem a tagállamban születtek, hanem külföldön, nagyrészt Dél- illetve Közép-és Kelet-Európában (Svédországban pl. a romák 80 százaléka). Történelmileg a romák elsősorban Görögés Törökországból, és a volt Jugoszlávia területéről érkeztek, a vasfüggöny lehullása előtt mobilitásra a jelenlegi tagjelöltek irányából nem volt lehetőségük. Az utóbbi évtizedben a tagjelöltek jelentős erőfeszítéseket tettek a romák megkötésére, ezért mobilitásuk nem azonos pl. a franciaországi vándorcigányok helyzetével.

Bár az összefüggés laza, de érdemes megfigyelni, hogy a munkanélküliségi ráta azokban az EU, illetve társult országokban (pl. Spanyolország, Bulgária vagy Szlovákia) magas, ahol a romák aránya az átlagosnál magasabb (lásd IV/2.4. sz. táblázat). Az Európai Bizottság 1999-ben a roma PHARE támogatásokról készített összefoglalójában 50-90 százalék közötti arányban tippelte a munkaképes korú lakosságon belüli munkanélküliségi rátát a tagjelölt országok roma lakosságánál. 
Mindez azt jelzi, hogy a nemzeti kisebbségektől eltérően a roma kisebbségnél törvényszerủ a nemzeti átlagnál magasabb munkanélküliség.

Ami a roma lakosság régi tagállamok felé való migrációs hajlamát illeti - a személyes adatok védelme miatt - mérvadó tudományos felmérések nem születtek. Bár a migrációval foglalkozó fejezetben (V/8. fejezet) részletesen elemzem általában a kiváltó okokat, itt csak azt idézném, amit a tagállamok adatszolgáltatásai révén az ICMPD (International Centre for Migration Policy Development, Bécs [2001]) megállapított. Eszerint a tagállamok kormányainak becslései szerint a Csehországból, Szlovákiából és Lengyelországból érkező bevándorlók 85-90 százaléka roma származású, ugyanakkor a Romániából érkezőknek csak 30-60 százaléka roma, vagyis ez utóbbinál feltételezhető, hogy a többségi nemzetnek is jelentős a vándorlási hajlama. A Bulgáriából kivándorlók közül sok roma török nyelven beszél, és török származásúnak vallja magát. Létszámát tekintve elsősorban a romániai romák németországi vándorlása lehet makrogazdasági szempontból jelentős (a németek becslései szerint 1990-95 között körülbelül 60 ezer romániai roma kért menedékjogot). Ugyanakkor például Magyarországról vagy Szlovéniából nem volt lényeges számú menedékkérő roma lakosság Európában.

A régió nemzetiségi térképéről összegezve megállapítható, hogy az örökölt kisebbségi viszonyok - a határmódosításokkal szétszabdalt nemzetiségek, különböző ajkú bevándoroltak és betelepítettek, illetve romák - új helyzetet teremtenek az EUban. A nemzeti kisebbségek részéröl még nagyobb lesz a nyomás helyzetük megfelelő formában való kezelésére, uniós alapszerződésekbe (pl. Alapvető Jogok Kartája révén) való foglalására. Ez több jelenlegi tagállam érdekeit sérti, de a probléma súlyos volta miatt a kibővített EU-ban a megoldások keresése elodázhatatlan lesz, ami viszont összeurópai szinten stabilizáló hatású lehet. Ugyancsak figyelmet érdemel az eddigieknél arányában és létszámában nagyobb roma lakosság megjelenése, amely az eddigi két millió roma mellé újabb öt milliót hozhat az EU-ba a teljes bővítés esetén. Ezért a diszkrimináció kizárására törekvő jogalkotás bővítése, a halmozottan hátrányos helyzetủek kiemelt kezelése a közösségi és strukturális programokban (Szociális Alap, Acces, Equel programok) megkerülhetetlen lesz. 


\section{RÉSZ; 3. FEJEZET \\ DEMOGRÁFIAI VISZONYOK}

A demográfiai viszonyok vizsgálatának az a jelentősége a jelenlegi és a kibővített EU-ban, hogy ezáltal képet kapunk az EU nemzetközileg betöltött szerepéről, súlyáról, a társadalom korösszetétele révén a várható szociális, egészségügyi helyzetről és az eltartotti arányokról.

Ebben a fejezetben a demográfiai trendeket és az eltartotti arány fenntartásának lehetséges módozatait vizsgálom meg, és az előzőekben jelzett más területekre való hatását a dolgozat többi fejezeteiben elemzem.

\section{IV/3.1. Hosszú távú trendek a világban}

Az EU Bizottság a jövendő fejlődéssel foglalkozó részlegének felmérései szerint, (melyet az ENSZ becsléseire alapozott), a világ népessége a jelenlegi 6 milliárdról 2010-re mintegy 6,9 milliárdra fog nőni. Mindez oda vezethet, hogy globális méretekben nézve - az ún. Harmadik Világ demográfiai robbanásai és Európa megtorpanása miatt - az EU jelenlegi tagállamainak lakossága a mostani 6,3 százalékról a világ népességének 5,6 százalékára fog csökkenni. Mindezek következtében a világ legnépesebb 20 államában az EU-tagok közül 2020-ra már csak Németország (szerény 19. helyen) fog szerepelni. (Scenarios Europe 2010. Európai Bizottság [1999]) Ez a folyamat nemcsak az Európai Unió világgazdaságban elfoglalt helyét illetően jelenthet visszaszorulást, hanem biztonságpolitikai értelemben is átrendezi az erőviszonyokat. Míg Európában a 20 év alatti lakosság jelenleg is csak a népesség 25 százalékát alkotja, addig az ún. szegény országokban ez az arány eléri a 40 százalékot. A mediterrán tagállamokban az elkövetkező években a lakosság stagnálása, majd rohamos csökkenése várható, addig a velük szemben fekvő és fő bevándorlási potenciált jelentő országok (Marokkó, Algéria, Tunézia, Líbia, Egyiptom) lakossága az elkövetkezendő 10 évben 32 millióval nő majd, és számában már meghaladja a Mediterrán terület északi részén fekvő tagállamokét. Önmagában Törökország lakosságának növekedése évtizedenként 10 milliós nagyságrendüre becsülhető. 
Az ENSZ népesedéssel foglalkozó egysége 2000-ben megvizsgálta a világ fejlettebb részének népesedési adatait, majd a kilencvenes évek közepének adatai alapján extrapolálta a lényeges pólusok 2050-re várható népesedési trendjeit a jelenlegi lakosságszám alapján, illetve a migrációs hatásokkal korrigálva. Ennek kapcsán különböző faktorokat érdemes egyidejüleg figyelembe venni: a lakosság növekedését illetve csökkenését általában, ezen belül a munkaképes korú (15 és 64 év közötti) személyek számát és arányát, valamint ezek arányát az efölötti idősebb nemzedékhez (az ún. potenciális támogatottsági arányt, PSR-t). Ennek vizsgálata folyamán egyértelmüvé válik, hogy a jelenlegi Európai Unió (de a tágabb Európa is) súlyos elöregedéssel néz szembe, akárcsak Japán vagy Korea. Ugyanakkor az egyik legnagyobb gazdasági versenytárs, az Egyesült Államok, a jelenlegi bevándorlási és természetes szaporodási trendjei alapján jóval egészségesebb képet fog mutatni. A következőkben bemutatásra kerülő számok elemzésénél azt a dinamikus tényezőt is figyelembe kell venni, hogy a várható gazdasági fellendüléssel párhuzamosan a csatlakozásra váró közép- és kelet-európai országokban, illetve az ennél is rosszabb mutatókkal rendelkező orosz-ukrán régióban a halálozási ráták csökkennek majd, illetve a várható életkor nőni fog, ami felzárkózást jelenthet a fejlett világ hasonló üteméhez képest. Ennek mértéke megjósolhatatlan, modellezhetetlen, de várható torzító hatását mindenféleképpen figyelembe kell venni.

Mint a IV/3.1. sz. táblázat mutatja, Írország, a stagnáló Franciaország, valamint Luxemburg kivételével minden EU-tagállamban fogyni fog a népesség 2050-re a 2000-hez képest. Különösen súlyos lakosságcsökkenés várható (20 százalék feletti zuhanás) Spanyolországban, Olaszországban és Görögországban, de a bővítés munkaerő-piaci hatásaitól félő Ausztriában valamint Németországban is meghaladja a csökkenés a 10 százalékot 2000-hez képest. A vizsgálat szerint a csatlakozásra váró országok a mediterrán tagállamokhoz hasonló tendenciák elé néznek, lakosságuk erőteljesen csökkenni fog. Ezen belül is hangsúlyozni kell, hogy csak Lengyelországban és Szlovákiában várható az EU átlagánál alacsonyabb (10 százalékos) csökkenés, míg Bulgáriában 31, Észtországban 34, Magyarországon, Szlovéniában és Csehországban is 20 százalék fölötti népességfogyást prognosztizáltak. 
IV/3.1. sz. táblázat: Várható lakosságfogyás az EU, illetve a tagjelölt országok körében 2050-ben

\begin{tabular}{|c|c|c|c|c|c|c|}
\hline Ország & $\begin{array}{c}\text { Lakosság } \\
\text { 2000-ben } \\
\text { (ezer fö) }\end{array}$ & $\begin{array}{c}\text { Lakosság } \\
\text { 2050-ben } \\
\text { (ezer fó) }\end{array}$ & $\begin{array}{l}\text { Változás } \\
\text { (ezer fó) }\end{array}$ & $\begin{array}{c}\text { Változás } \\
(\%)\end{array}$ & $\begin{array}{c}65 \text { év }+ \\
2000 \\
(\%)\end{array}$ & $\begin{array}{c}65 \text { év + } \\
2050 \\
(\%)\end{array}$ \\
\hline Ausztria & 8211 & 7094 & -1117 & -14 & 15 & 30 \\
\hline Belgium & 10161 & 8918 & -1243 & -12 & 17 & 28 \\
\hline Bulgária & 8225 & 5673 & -2552 & -31 & 16 & 30 \\
\hline Csehország & 10244 & 7829 & -2415 & -24 & 14 & 33 \\
\hline Dánia & 5293 & 4793 & -500 & -9 & 15 & 24 \\
\hline Észtország & 1396 & 927 & -469 & -34 & 14 & 29 \\
\hline Finnország & 5176 & 4898 & -278 & -5 & 15 & 26 \\
\hline Franciaország & 58020 & 59883 & 1863 & 3 & - & - \\
\hline Németország & 82220 & 73303 & -8917 & -11 & 16 & 28 \\
\hline Görögország & 10645 & 8233 & -2412 & -23 & 18 & 34 \\
\hline Magyarország & 10036 & 7488 & -2548 & -25 & 15 & 28 \\
\hline Olaszország & 57298 & 41197 & -16101 & -28 & 18 & 35 \\
\hline Lettország & 2357 & 1628 & -729 & -31 & 14 & 27 \\
\hline Litvánia & 3670 & 2967 & -703 & -19 & 13 & 27 \\
\hline Luxemburg & 431 & 430 & $\begin{array}{ll}- & 1\end{array}$ & 0 & 14 & 27 \\
\hline Lengyelország & 38765 & 36256 & -2509 & -6 & 12 & 26 \\
\hline Portugália & 9875 & 8137 & -1738 & -18 & 16 & 31 \\
\hline Románia & 22327 & 16419 & -5908 & -26 & 13 & 31 \\
\hline Szlovákia & 5387 & 4836 & -551 & -10 & 11 & 27 \\
\hline Szlovénia & 1986 & 1487 & -499 & -25 & 14 & 32 \\
\hline Spanyolország & 39630 & 30226 & -9404 & -24 & 17 & 37 \\
\hline Svédország & 8910 & 8661 & -249 & -3 & 17 & 27 \\
\hline Egyesült Királyság & 58830 & 56667 & -2163 & -4 & 16 & 25 \\
\hline Írország & 3609 & 4710 & 1101 & 31 & - & - \\
\hline
\end{tabular}

Forrás: ENSZ Népesedési Részleg, [2000]

A kibontakozó pesszimista kép magyarázatát az EU-országokban elsősorban az alacsony termékenységi rátában kell keresni. A szakirodalom szerint ahhoz, hogy egy társadalom képes legyen számszerüleg újratermelni magát, minden szülöképes korú nőre 2,1 gyermek születése szükséges (Európai Bizottság, [1999]), addig az EU egészében ez az adat csak 1,58 gyermek, néhány országban - Németország, Olaszország, Spanyolország - ez alatti (lásd: IV/3.2. sz. táblázat). Mindeközben az EU-ban a várható élettartam fokozatosan növekszik, 1995-ben elérte a 76,5 évet. 
IV/3.2. sz. táblázat: Várható termékenységi ráták az EU tagállamainál (egy szülöképes korú nőre jutó gyermekek száma)

\begin{tabular}{|l|r|r|r|c|}
\hline \multicolumn{1}{|c|}{ Ország } & $\mathbf{2 0 0 0}$ & $\mathbf{2 0 0 5}$ & $\mathbf{2 0 1 0}$ & $\mathbf{2 0 5 0}$ \\
\hline Belgium & 1,54 & 1,61 & 1,68 & 1,80 \\
\hline Dánia & 1,77 & 1,76 & 1,76 & 1,80 \\
\hline Németország & 1,40 & 1,45 & 1,47 & 1,50 \\
\hline Görögország & 1,34 & 1,42 & 1,45 & 1,60 \\
\hline Spanyolország & 1,19 & 1,28 & 1,34 & 1,50 \\
\hline Franciaország & 1,73 & 1,78 & 1,79 & 1,80 \\
\hline Írország & 1,89 & 1,85 & 1,83 & 1,80 \\
\hline Olaszország & 1,22 & 1,31 & 1,36 & 1,50 \\
\hline Luxemburg & 1,72 & 1,74 & 1,75 & 1,80 \\
\hline Hollandia & 1,71 & 1,76 & 1,79 & 1,80 \\
\hline Ausztria & 1,31 & 1,38 & 1,41 & 1,50 \\
\hline Portugália & 1,53 & 1,60 & 1,64 & 1,70 \\
\hline Finnország & 1,73 & 1,71 & 1,69 & 1,70 \\
\hline Svédország & 1,50 & 1,56 & 1,61 & 1,80 \\
\hline Egyesült Királyság & 1,72 & 1,73 & 1,75 & 1,80 \\
\hline
\end{tabular}

Forrás: EU Bizottság, ECFIN Főigazgatóság, [2000]

Mint látható, a termékenységi ráta fokozatosan stabilizálódik, az EU-Bizottság elörejelzései szerinti 1,5 és 1,8 közötti gyerekszámra. Ez a becslés nem túl kedvező, mivel a természetes reprodukciót nem tudja biztosítani, de a jelenlegi termékenységi ráta némi javulásával számol.

A társult országokban a rendszerváltás és az ezzel járó súlyos életszínvonalcsökkenés, a szociális és a foglalkoztatási biztonság csökkenése, valamint a nyugati fogyasztói hatások eredményeképpen a gyermekvállalási kedv lényeges csökkenése figyelhető meg (lásd: IV/3.3. sz. táblázat). Ezek az adatok nem egy természetes állapotot tükröznek, hanem történelmi mélypontnak tekinthetök. (1998-ban 1,1 és 1,4 közötti volt a termékenységi mutató a tagjelölteknél, ami jelentősen elmarad az EUtagállamok 1,15-1,93 mutatóitól. Eurostat, [2001]). Minden előrejelzés szerint ezért az életszínvonal és a társadalmi viszonyok konszolidálása esetén 2000 után a termékenységi ráta némi javulása várható. Igaz, a nyugati demonstrációs hatások, a fogyasztói társadalom kibontakozása és a nők foglalkoztatásának növekedése révén a szülési kedv olyan mértékü visszaállása, amely akár a társadalmi reprodukcióhoz vezetne (2,1 gyermek), nem valószínüsíthető (ld. IV/3.3. sz. táblázat). Ebben a 
vonatkozásban egészen biztosan kijelenthetö, hogy a tagjelöltek a tagállamok számára nem fognak kedvező impulzusokat adni a XXI. század elején.

IV/3.3. sz. táblázat: Termékenységi ráta a tagjelölt országokban (egy szülöképes korú nöre jutó gyermekszám)

\begin{tabular}{|l|c|c|c|}
\hline \multicolumn{1}{|c|}{ Ország } & $\mathbf{1 9 9 3}$ & $\mathbf{1 9 9 8}$ & Változás \\
\hline Bulgária & 1,5 & 1,1 & $-0,4$ \\
\hline Csehország & 1,7 & 1,2 & $-0,5$ \\
\hline Észtország & 1,5 & 1,2 & $-0,3$ \\
\hline Magyarország & 1,7 & 1,3 & $-0,4$ \\
\hline Lettország & 1,5 & 1,1 & $-0,4$ \\
\hline Litvánia & 1,7 & - & - \\
\hline Lengyelország & 1,9 & 1,4 & $-0,5$ \\
\hline Románia & 1,5 & 1,3 & $-0,2$ \\
\hline Szlovákia & 1,9 & 1,4 & $-0,5$ \\
\hline Szlovénia & 1,3 & 1,2 & $-0,1$ \\
\hline
\end{tabular}

Forrás: Eurostat évkönyvei [2000-2001]

\section{IV/3.2. A munkaképes korúak és az eltartottak arányának alakulása}

Mint a IV/3.1. és IV/3.4. sz. táblázatokból látható, a 65 éves és efölötti - tehát már nyugdíjasként - eltartottak aránya gyakorlatilag a jelenlegi mutatók kétszeresére nő az EU-ban országonként változó mértékben. Az Európai Bizottság becslései szerint 2010-re 29,8 százalékra, majd 2050-re 53,4 százalékra módosul a 65 éves és efölötti korú lakosság aránya. A spanyol és olasz időskorúak aránya (ahol ezt 2050-re 65,7 illetve 66,8 százalékra becsülik) kirívóan magas értéket mutat, a legjobb helyzet Dániában (41,9 százalék) és Luxemburgban (41,8 százalék) van. Figyelembe véve az alacsony termékenységi rátákat, nyilvánvaló, hogy ennek a billenésnek az egyik fó oka - a migrációs trendek mellett - a népesség várható életkorának jelentős növekedése. Az ún. öregségi hányados (75 év felettiek aránya a munkaképes korú lakossághoz) a 2000-ben számított 3,1 százalékról 2020-ra 4,6, 2050-re 10 százalékra fog növekedni az Európai Unióban (Európai Bizottság, [2000]). 
IV/3.4. sz. táblázat: Az EU-országok és a tagjelöltek legfontosabb korösszetételi adatai 1998-ban (százalék)

\begin{tabular}{|c|c|c|c|}
\hline Ország & $\begin{array}{c}\text { 15-64 évesek } \\
\text { (a teljes lakosság } \\
\text { százaléka) }\end{array}$ & $\begin{array}{c}65 \text { éves és felette } \\
\text { (a teljes lakosság } \\
\text { százaléka) }\end{array}$ & $\begin{array}{c}65 \text { év felettiek } \\
\text { aránya a 15-64 } \\
\text { éveshez képest }\end{array}$ \\
\hline Belgium & 66 & 17 & 25,8 \\
\hline Dánia & 67 & 15 & 22,4 \\
\hline Németország & 68 & 16 & 23,5 \\
\hline Görögország & 68 & 17 & 25,0 \\
\hline Spanyolország & 69 & 17 & 24,6 \\
\hline Franciaország & 65 & 16 & 24,6 \\
\hline Írország & 67 & 12 & 17,9 \\
\hline Olaszország & 68 & 17 & 25,0 \\
\hline Luxemburg & 67 & 14 & 20,9 \\
\hline Hollandia & 67 & 13 & 19,4 \\
\hline Ausztria & 68 & 16 & 23,5 \\
\hline Portugália & 68 & 15 & 22,1 \\
\hline Finnország & 67 & 14 & 20,9 \\
\hline Svédország & 64 & 18 & 28,1 \\
\hline Egyesült Királyság & 64 & 16 & 25,0 \\
\hline Bulgária & 68 & 16 & 23,5 \\
\hline Csehország & 69 & 14 & 20,3 \\
\hline Észtország & 67 & 14 & 20,9 \\
\hline Magyarország & 68 & 14 & 20,6 \\
\hline Lettország & 66 & 14 & 21,2 \\
\hline Litvánia & 66 & 13 & 19,7 \\
\hline Lengyelország & 67 & 12 & 17,9 \\
\hline Románia & 68 & 13 & 19,1 \\
\hline Szlovákia & 68 & 11 & 16,2 \\
\hline Szlovénia & 70 & 13 & 18,6 \\
\hline
\end{tabular}

Forrás: Eurostat, [2000]

A IV/3.4. sz. táblázatból látható, hogy a tagjelöltek lakosságának korösszetételi adatai kedvezőbbek, ami azonban a rövidebb életkorból, és nem a magasabb termékenységből adódik. Különösen kedvező a 65 év felettiek aránya a munkaképes korúakhoz képest a lengyeleknél $(17,9)$ és a szlovákoknál $(16,1)$, de 20 százalék alatti Szlovéniában is. Ehhez képest a tagállamok közül 20 százalék alatti mutatót csak Írországban és Hollandiában találhatunk. Az EU-ban ez az arány tovább fog nőni, mivel a születéskor várható élettartam az Unió tagállamaiban szintén nőni fog (lásd: IV/3.5. sz. táblázat). 
IV/3.5. sz. táblázat: Születéskor várható élettartam az Unió tagállamaiban, 2010-ben és 2050-ben (életév)

\begin{tabular}{|l|c|c|c|c|}
\hline \multicolumn{1}{|c|}{ Ország } & $\begin{array}{c}\text { Férfi } \\
\mathbf{( 2 0 1 0 )}\end{array}$ & $\begin{array}{c}\text { Nö } \\
\mathbf{( 2 0 1 0 )}\end{array}$ & $\begin{array}{c}\text { Férfi } \\
\mathbf{( 2 0 5 0 )}\end{array}$ & $\begin{array}{c}\text { Nó } \\
\mathbf{( 2 0 5 0 )}\end{array}$ \\
\hline Belgium & 77,6 & 83.3 & 80,5 & 85,5 \\
\hline Dánia & 76,5 & 80,2 & 79,0 & 83,0 \\
\hline Németország & 76,6 & 82,3 & 80,0 & 85,0 \\
\hline Görögország & 77,7 & 82,4 & 81,0 & 85,0 \\
\hline Spanyolország & 75,9 & 83,3 & 79,0 & 85,0 \\
\hline Franciaország & 76,8 & 84,2 & 80,0 & 87,0 \\
\hline Írország & 75,8 & 81,0 & 79,0 & 84,0 \\
\hline Olaszország & 77,4 & 83,4 & 81,0 & 86,0 \\
\hline Luxemburg & 77,1 & 82,5 & 80,0 & 85,0 \\
\hline Hollandia & 77,0 & 82,0 & 80,0 & 85,0 \\
\hline Ausztria & 76,1 & 82,1 & 81,0 & 86,0 \\
\hline Portugália & 73,8 & 80,7 & 78,0 & 84,0 \\
\hline Finnország & 75,7 & 82,5 & 80,0 & 85,0 \\
\hline Svédország & 78,2 & 82,8 & 82,0 & 86,0 \\
\hline Egyesült Királyság & 77,0 & 81,7 & 80,0 & 85,0 \\
\hline
\end{tabular}

Forrás: Európai Bizottság, ECFIN Főigazgatóság, [2000]

A bizottsági becslések szerint a várható életkor folyamatosan nőni fog, azonban a felmérések szerint 2030 körül le fog lassulni. (Természetesen nehezen jósolható meg, hogy az orvostechnika és technológia hogyan fejlődik a következő évtizedekben). A Bizottság szerint a lakosság száma 2020 után kezd majd el látványosan csökkeni az EU-ban, addig az öregedéssel járó lakossági létszám szinten tartása jósolható, egyre nagyobb eltartott-eltartói hányaddal. 
IV/3.6. sz. táblázat: A lakosság várható alakulása 2010-ben, illetve 2020-ban

\begin{tabular}{|c|c|c|c|c|c|c|c|}
\hline \multirow{2}{*}{ Ország } & \multirow{2}{*}{\begin{tabular}{|c|}
$\begin{array}{c}1998 \\
\text { tény } \\
\text { (millió fö) }\end{array}$ \\
Eurostat
\end{tabular}} & \multicolumn{2}{|c|}{$\begin{array}{c}2010 \\
\text { várt } \\
\text { (millió fó) }\end{array}$} & \multicolumn{2}{|c|}{$\begin{array}{c}1998 \\
\text { tény } \\
\text { (ezrelék) }\end{array}$} & \multicolumn{2}{|c|}{$\begin{array}{c}2020 \\
\text { várt } \\
\text { (millió fó) }\end{array}$} \\
\hline & & Eurostat & ENSZ & $\begin{array}{l}\text { Természetes } \\
\text { szaporodás }\end{array}$ & Migráció & Eurostat & ENSZ \\
\hline Belgium & 10,2 & 10,4 & 10,1 & 1,0 & 1,1 & 10,5 & 10,0 \\
\hline Dánia & 5,3 & 5,5 & 5,3 & 1,4 & 2,1 & 5,6 & 5,2 \\
\hline Németország & 82,1 & 83,4 & 82,0 & $-0,9$ & 0,6 & 83,3 & 80,9 \\
\hline Görögország & 10,5 & 10,8 & 10,6 & 0,0 & 2,1 & 10,8 & 10,1 \\
\hline Spanyolország & 39,3 & 39,9 & 39,0 & 0,1 & 1,1 & 39,5 & 37,6 \\
\hline Franciaország & 58,7 & 61,4 & 60,6 & 3,4 & 0,7 & 62,8 & 61,5 \\
\hline Írország & 3,7 & 4,1 & 4,0 & 6,0 & 7,7 & 4,4 & 4,3 \\
\hline Olaszország & 57,6 & 57,3 & 55,7 & $-0,9$ & 1,8 & 56,0 & 52,9 \\
\hline Luxemburg & 0,4 & 0,5 & 0,5 & 3,5 & 9,4 & 0,5 & 0,5 \\
\hline Hollandia & 15,6 & 16,7 & 16,0 & 3,9 & 2,8 & 17,3 & 15,9 \\
\hline Ausztria & 8,1 & 8,1 & 8,3 & 0,4 & 0,6 & 8,2 & 8,3 \\
\hline Portugália & 10,0 & 10,3 & 9,8 & 0,7 & 1,5 & 10,5 & 9,5 \\
\hline Finnország & 5,1 & 5,3 & 5,2 & 1,5 & 0,9 & 5,3 & 5,3 \\
\hline Svédország & 8,8 & 9,0 & 9,0 & $-0,5$ & 1,2 & 9,1 & 9,1 \\
\hline Egyesült Királys. & 59,1 & 60,9 & 59,3 & 1,5 & 1,1 & 62,2 & 59,8 \\
\hline Bulgária & 8,2 & - & - & $-6,4$ & 0,0 & - & - \\
\hline Csehország & 10,3 & - & - & $-1,8$ & 0,9 & - & - \\
\hline Észtország & 1,5 & - & - & $-5,0$ & $-0,7$ & - & - \\
\hline Magyarország & 10,1 & - & - & $-4,3$ & 0,0 & - & - \\
\hline Lettország & 2,5 & - & - & $-6,4$ & $-1,3$ & - & - \\
\hline Litvánia & 3,7 & - & - & $-1,0$ & 0,2 & - & - \\
\hline Lengyelország & 38,7 & - & - & 0,5 & $-0,3$ & - & - \\
\hline Románia & 22,5 & - & - & $-1,4$ & $-0,3$ & - & - \\
\hline Szlovénia & 2,0 & - & - & $-0,6$ & $-2,7$ & - & - \\
\hline Szlovákia & 5,4 & - & - & 0,8 & 0,2 & - & - \\
\hline
\end{tabular}

Forrás: Eurostat, [2000], és ENSZ népesedési becslések [1999]

A IV/3.6. sz. táblázatból látható, hogy a különböző elemzések (Eurostat, ENSZ) is alátámasztják az Európai Bizottság megállapítását, miszerint 2020-ig nem fog csökkenni a tagállamok lakossága. A táblázat azt is megmutatja, hogy 2010-ig legtöbb tagállam még számszerủen növelni tudja lakosságát, ám ettől fogva 2020-ig a lélekszám stabilizálódni fog. Látható az is, hogy 1998-ban a lakosságszám fenntartásában jelentős hányadot biztosított a migráció (lásd: IV/3.3. alpont).

Ugyanakkor az Eurostat felmérései már nem ilyen optimisták tagjelöltek vonatkozásában: a jelenlegi trendek (termékenység, halálozás) alapján 2015-ben csak Lengyelország és Szlovákia lakossága fogja meghaladni az 1995-ben mért lakosságszámot, míg a Cseh Köztársaságban, Litvániában, Romániában, 
Szlovéniában és Bulgáriában 90-100 százaléka, Észtországban, Magyarországon, Lettországban az 1995-ös lakosságszám 85-90 százaléka körül fog alakulni. (Európai Bizottság, Demographic Report [1997]) A különbség a tagállamok javára elsősorban a bevándorlásoknak köszönhető, e nélkül a természetes szaporodási ráta már több tagállamban (Németország, Olaszország, Svédország) most is negatív (lásd: IV/3.6.sz. táblázat). A tagjelölt országokból inkább a kivándorlás, mint a betelepedés jellemző, ez a helyzet idővel nyilvánvalóan meg fog fordulni.

Összehasonlításképpen kimondható, hogy a tagállamokban a termékenységi ráta magasabb, de az életkor is jóval hosszabb, mint a tagjelölteknél és ez együttvéve öregedő társadalommal is együtt jár. Nem véletlen, hogy ezért magasabb a nyugdíjkorhatár a jelenlegi tagállamoknál - ld. a szociális fejezetet - fokozva ezzel a munkaerő-piaci feszültségeket. Mindez fordítottan azt jelenti, hogy az új tagállamok negatív demográfiai trendjei ellenére ma még egy fiatalabb társadalom képét mutatják, vagyis az időskori eltartottság - föleg ha a tagjelöltek is emelik a nyugdíjkorhatárt a 65 év irányába - még egy ideig nem fog komoly megterhelést jelenteni az aktív dolgozói korosztálynak. Az ENSZ-előrejelzés szerint is (IV/3.1. sz. táblázat) csak Csehországban, Szlovéniában és Romániában haladná meg 2050-ben a 65 éven felüliek aránya a 30 százalékot. A nagy lakosságszámmal rendelkező Lengyelországban ez az arány 26 százalékra jósolt - EU-viszonylatban is megfelelő ráta -, de Magyarországon is 30 százalék alatti.

A tagállamok és a tagjelöltek demográfiai helyzetének vizsgálata a munkaképes korúak számának és arányának felmérése miatt lényeges. Az integráció feszültségét az okozza, hogy 2010-ig a jelenlegi európai munkaerőpiacon néhány tagállam kivételével nem jelentkezik olyan munkaerő-hiány, ami a tagjelöltek munkaerejének szabad bevonását feltétlen indokolná. Ugyanakkor 2010 után Európában a munkaképes korú lakosság száma és aránya fokozottabban csökkeni fog. Ezzel magyarázható, hogy a tagállamok egy része szeretné a bővülésnek munkaerő szabad mozgásával kapcsolatos átmeneti időszakát 2010-ig kitolni. A jelenlegi demográfiai helyzet azért nem hasonlítható össze pontosan, mert az EU-tagság után - föleg a közös migrációs és menekültpolitika esetén - az új tagállamok is kapnak és szükségeltetnek bevándorlókat ahhoz, hogy a belső társadalmi viszonyokat normál mederben fenntartsák. 


\section{IV/3.3. Bevándorlási igények}

Mint az előzőekből is kiderül, a jelenlegi tagállamokban erőteljesen megbomlik az eltartottak-munkaképes korúak aránya. Az ENSZ modellezte azt, hogy mekkora bevándorlásra van szükség ahhoz, hogy a jelenlegi PSR-ráta (15-64 éves korosztály aránya az ennél idősebbekhez) megmaradjon. Ez az EU-ban 2000 és 2050 között mintegy 701 millió személy bevándorlását feltételezné, vagyis évente átlagosan 12,7 milliót! Ha nem ez a cél, hanem a munkaképes korú lakosság szinten tartása az 1995ben mért 249 millióhoz képest, akkor méréseik szerint az Európai Uniónak 79,6 millió bevándorlót kell fogadnia, ami évente 1,4 millió főt jelent. Ez fokozatosan futna fel, eleinte kevesebb személy kellene ehhez, de 2050-ben már 2,8 millió fó évente. (Az EU-ban 1996-ban összesen 1,89 millió személy bevándorlását regisztrálták, s bár nincs pontos adat a kivándorlásról, de a nettó egyenleg a becslések szerint 600 ezer fő körül alakul évente. A Bizottság 2000-re prognosztizált egyenlege 661 ezer fö, amelyből 300 ezer föt tenne ki maga Németország.)

Az OECD is végzett számításokat arról, hogy mekkora bevándorlásra lenne szükség a tagállamainak ahhoz, hogy a függőségi ráta (PSR) szinten maradjon.

IV/3.7. sz. táblázat: Függőségi ráta becslése néhány OECD-országban 2010-ben és 2020-ban

\begin{tabular}{|l|c|c|c|c|}
\hline \multicolumn{1}{|c|}{ Ország } & $\begin{array}{c}\text { PSR } \\
\mathbf{2 0 1 0} \\
\mathbf{( \% )}\end{array}$ & $\begin{array}{c}\text { PSR } \\
\mathbf{2 0 2 0} \\
\mathbf{( \% )}\end{array}$ & $\begin{array}{c}\text { Szükséges munkaerö } \\
\text { a 2010-es ráta } \\
\text { fenntartásához } \\
\text { (ezer fö) }\end{array}$ & $\begin{array}{c}\text { Migrációs } \\
\text { egyenleg } \\
\mathbf{1 9 8 5 - 1 9 9 5} \\
\text { (ezer fö) }\end{array}$ \\
\hline Ausztria & 22.9 & 27,8 & 121 & 310 \\
\hline Finnország & 24,2 & 34,2 & 134 & 60 \\
\hline Franciaország & 25,6 & 33,0 & 1095 & 630 \\
\hline Hollandia & 22,4 & 31,0 & 404 & 340 \\
\hline Írország & 18,4 & 24,8 & 84 & -190 \\
\hline Nagy-Britannia & 25,0 & 30,1 & 764 & 720 \\
\hline Németország & 27,7 & 30,0 & 470 & 4560 \\
\hline Olaszország & 30,4 & 36,4 & 676 & 850 \\
\hline Spanyolország & 26,2 & 30,6 & 428 & -80 \\
\hline Csehország & 18,8 & 26,4 & 265 & -20 \\
\hline Lengyelország & 16,6 & 22,9 & 1009 & -280 \\
\hline Magyarország & 21,7 & 26,8 & 142 & -130 \\
\hline
\end{tabular}

Forrás: OECD, Trends International Migration, [1999] 
Mint látható, a mai kedvező korstruktúrát (ld. IV/3.1. és IV/3.4. sz. táblázatok) a jelenlegi természetes szaporodási trendek mellett csak úgy tudja megtartani az újonnan érkező országok mindegyike (IV/3.7. sz. táblázat), ha nagy számú bevándorlót enged be országába. (A lengyelek esetében ez elvileg évi 1 millió fő lenne, de Csehország esetében is évi 265 ezer, Magyarországon 142 ezer fő, amely utóbbi az osztrák vagy a finn szükségletekhez mérhető nagyságrend.) Mindez rámutat arra, hogy a tagjelöltek jelenlegi migrációs politikájának olyan átalakítására van szükség, amely biztosítja a pozitív migrációs szaldót. Ezt azonban segíti a várhatóan gyors gazdasági növekedés (V/1. fejezet) és ennek nyomán a reálbérek felzárkózása (V/8. fejezet). Ennek hatására vélhetően gyorsan emelkedik a lakosság életszínvonala, és ezért piaci eszközökkel visszaszorítható az EU jelenlegi tagállamaiba történő kivándorlás. Ezért a kibővülő Európának külső bevándorlási forrásokra is szüksége lesz, ami lehet a volt FÁK szláv térsége, vagy a Mediterrán medence, Törökország. Utóbbi azonban fokozatosan megváltoztatná Európa kulturális vonalát. Az új tagállamok közül Magyarország és Románia rendelkezik határain kívül olyan nagy létszámú nemzeti kisebbséggel, amely a szükséges munkaerő-forrásokhoz természetes tartalékot ad. Az mindenesetre egyértelmüen megállapítható, hogy már középtávon is a tagjelöltek inkább befogadó, mint kibocsátó országok lesznek.

\section{RÉSZ; 4. FEJEZET AZ EGÉSZSÉGÜGYI ÁLLAPOT JELLEMZÉSE}

A demográfiai helyzethez hasonló, de nemcsak ezzel összefüggő kérdés az, hogy az új közép-és kelet-európai országok milyen egészségi állapotban lévő lakossággal kívánnak csatlakozni, és milyen lesz ennek jövöbeli trendje.

A csatlakozni kívánó országok egészségügyi politikája a rendszerváltás óta jelentős változáson ment keresztül, reformjuk része az államháztartási megújulásnak. Legtöbb országban megjelent a magánbiztosítási forma az egészségügyi (és nem csak a nyugdíj) szférában, bár az alacsony jövedelmű társadalmi rétegek miatt az 
állam szerepvállalása még sokáig domináns marad. Mivel az államháztartások egyensúlya nagyban függ az egészségügyi helyzettől is, az EU számára tétje van annak, hogy milyen egészségi állapotú és perspektívájú országokat vesz fel soraiba. (Az EU-Bizottság és a társult országok közös makrogazdasági értékeléseiben - 2001 óta PEP (pre-accession economic program) keretében - együttesen elemzik ezt a területet is.)

E rövid fejezet keretében nem az egészségügyi rendszereket kívánom összehasonlítani, hanem néhány olyan tényezőt szeretnék kiemelni, ami jelzi az EU jelenlegi tagállamai és tagjelöltjei lakosságának (mely a munkaerő révén az egyik legfontosabb termelési tényező) egészségügyi állapota közötti különbséget, illetve azonosságot. Nem véletlen, hogy bár az egészségügy területén kevés a közösségi szabályozás, de a közösség tagállamai és kormányzatai, valamint szakmai szervezetei közötti együttmüködést segítő ún. közösségi programok révén fontos szerepet kapott a közegészségügyi programokban való részvétel kiterjesztése (1998 óta) a társult országok felé. Az alábbiakban három oldalról vizsgálom meg a tagállamok és középeurópai csatlakozni kívánó országok helyzetét:

- a várható élettartam és a várhatóan egészségesen - nem állandó ellátásra szoruló - megélt élettartam;

- milyen az egyes tagállamokban és a jelentkezőknél az egészségügyre relatíve fordított anyagi erőforrások aránya;

- az egészségügyi helyzet és az ellátás különböző paraméterei összegzésével súlyozott összevont egészségügyi mutató;

\section{IV/4.1. Várható élettartam}

Erre vonatkozóan a IV/4.1. sz. táblázatban foglaltam össze a legfontosabb adatokat a tagállamok, a tagjelöltek és a szélesebb összehasonlítás kedvéért az USA vonatkozásában. 
IV/4.1. sz. táblázat: A tagországok és tagjelöltek föbb egészségügyi adatai

\begin{tabular}{|c|c|c|c|c|c|c|c|}
\hline \multirow[t]{2}{*}{ Ország } & \multirow{2}{*}{\multicolumn{2}{|c|}{$\begin{array}{l}\text { Várható életkor } \\
\text { születéskor } \\
\text { (férfiak) } \\
\text { (években) }\end{array}$}} & \multirow{2}{*}{$\begin{array}{c}\text { DALE } \\
\text { (férfiak) } \\
\text { (években) } \\
\text { (1997) }\end{array}$} & \multirow{2}{*}{\begin{tabular}{|c} 
Egészség- \\
ügyi kiadás \\
(GDP \\
\%-ában) \\
(1997)
\end{tabular}} & $\begin{array}{l}\text { Állami } \\
\text { kiadás } \\
\text { aránya }\end{array}$ & $\begin{array}{c}\text { Magán- } \\
\text { kiadás } \\
\text { aránya } \\
\end{array}$ & \multirow{2}{*}{$\begin{array}{l}\text { WHO } \\
\text { index } \\
\text { (1997) }\end{array}$} \\
\hline & & & & & \multicolumn{2}{|c|}{$\begin{array}{l}\text { A teljes egészségügyi } \\
\text { kiadásból } 1997(\%)\end{array}$} & \\
\hline Franciaország & 74,5 & 1,2 & 69,3 & 9,8 & 76,9 & 23,1 & 0.994 \\
\hline Olaszország & 74,9 & 0,5 & 70,0 & 9,3 & 57,1 & 42,9 & 0.991 \\
\hline Spanyolország & 74,4 ('96) & 0,5 & 69,8 & 8,0 & 70,6 & 29,4 & 0.972 \\
\hline Ausztria & 74,3 & 1,3 & 68,8 & 9,0 & 67,3 & 32,7 & 0.959 \\
\hline Portugália & 71,6 & 1,0 & 65,9 & 6,2 & 57,5 & 42,5 & 0.945 \\
\hline Görögország & 75,6 & 0,6 & 70,5 & 8,0 & 65,8 & 34,2 & 0.933 \\
\hline Luxemburg & 74,1 & 1,9 & 68,0 & 6,6 & 91,4 & 8,6 & 0.928 \\
\hline Hollandia & 75,2 & 1,2 & 69,6 & 8,8 & 70,7 & 29,3 & 0.928 \\
\hline Egyesült Kir. & 74,7 & 1,2 & 69,7 & 5,8 & 96,9 & 3,1 & 0.925 \\
\hline Írország & 73,4 & 0,8 & 67,5 & 6,2 & 83,8 & 16,2 & 0.924 \\
\hline Belgium & 74,1 & 1,1 & 68,7 & 8,0 & 83,2 & 16,8 & 0.915 \\
\hline Svédország & 76,7 & 1,2 & 71,2 & 9,2 & 78,0 & 22,0 & 0.908 \\
\hline Németország & 74,0 & 1,3 & 67,4 & 10,5 & 77,5 & 22,5 & 0.902 \\
\hline Finnország & 73,4 & 0,8 & 67,2 & 7,6 & 73,7 & 26.3 & 0.881 \\
\hline Dánia & 73,6 & 1,0 & 67,2 & 8,0 & 84,3 & 15,7 & 0.862 \\
\hline Szlovénia & 71,0 & 0,4 & 64,9 & 9,4 & 80,8 & 19,2 & 0.838 \\
\hline Csehország & 70,5 & 1,3 & 65,2 & 7,6 & 92,3 & 7,7 & 0.805 \\
\hline Lengyelország & 68,5 & 1,1 & 62,3 & 6,2 & 71,6 & 28,4 & 0.793 \\
\hline Szlovákia & 68,9 & 0,5 & 63,5 & 8,6 & 81,8 & 18,2 & 0.754 \\
\hline Magyarország & 66,4 & 1,9 & 60,4 & 5,3 & 84,9 & 15,1 & 0.743 \\
\hline Litvánia & 65,9 & 2,6 & 60,6 & 6,4 & 75,7 & 24,3 & 0.722 \\
\hline Észtország & 64,7 & 2,2 & 58,1 & 6,4 & 78,9 & 21,2 & 0.714 \\
\hline Románia & 65,2 & $-0,7$ & 58,8 & 3,8 & 60,3 & 39,7 & 0.645 \\
\hline Bulgária & 67,2 & n.a. & 61,2 & 4,8 & 81,9 & 18,1 & 0.639 \\
\hline Lettország & 64,2 & 2,6 & 57,1 & 6,1 & 61,0 & 39,0 & 0.630 \\
\hline USA & - & - & 67,5 & 13,7 & 44,1 & 55,9 & 0.838 \\
\hline
\end{tabular}

Forrás: WTO World Health Report, [2000], Eurostat [2000]

Megjegyzés: DALE évek: a várhatóan egészségesen - állandó ellátásra nem szorulva - leélt életkor.

A várhatóan egészségesen leélhető élettartamot (Disability Adjusted Life Expectancy) tekintve megállapítható (lásd: IV/4.1. sz. táblázat), hogy - a rajnai modell sikere eredményeként - mind a 15 tagállam a világ első 30 országában található. A leggyengébb mutatókkal rendelkező Portugáliában a férfiaknál 65,9 év a leélhető egészséges élettartam. Az aspiránsok közül a lehető legjobb mutatóval Csehország $(65,2)$, Szlovénia $(64,9)$ büszkélkedhet, míg a többieknél a DALEmutató a férfiaknál 57,1 (Lettország) és 63,5 (Szlovákia) év közé esik. Utóbbi körbe tartozik mindhárom balti állam és a csatlakozás más paramétereinél jobb szintet elért Magyarország is. Ebből adódik az a prognózis, hogy a lakosság nagyon jelentős 
része még a várhatóan emelkedő nyugdíjkorhatár elérése elött munkaképtelenné válik, vagy munkája mellett sokat betegeskedik. Hátrányos a csatlakozni kívánók számára az, hogy míg a tagállamok esetében a férfiak csak 3-5 évvel hamarabb esnek ki az egészséges kategóriából, mint a nők (ilyen Svédország, Hollandia Görögország), addig a csatlakozni kívánóknál akár 7-10 évvel korábban is megtörténhet mindez (Baltiak, Magyarország, Lengyelország). (WHO Statistics, [2000]). A nyugdíjkorhatár elérése előtti kiesés a munkából a munkaerőpiacot súlyosan érinti, hiszen a tagjelölt országokban a férfiak foglalkoztatási hányada hagyományosan jóval magasabb, mint a nőké (lásd szociális fejezet). Ezzel is magyarázható, hogy az aktív foglalkoztatási ráta a tagjelölt országoknál igen alacsony.

Ugyanakkor pozitív elmozdulásnak értékelhető az, hogy 1993-hoz képest a férfiak várható élethossza 1997-ben a társult országokban általában a tagállamokat meghaladóan több mint egy évvel nött. Több mint két évvel nőtt ebben az időszakban a három balti állam férfi lakosságának születéskor várható életkora, de Magyarországon is e rövid periódus alatt 1,9 évvel javult a mutató. (Az EUtagállamoknál csak Luxemburgban haladta meg a javulás az 1,3 évet.) Romániában a vizsgált időszakban 0,7 évvel csökkent a férfiak születéskor várható élettartama és viszonylag szerény volt a javulás Szlovákiában $(0,5)$ és Szlovéniában $(0,4)$ is.

\section{IV/4.2. Az egészségügyi kiadások hatása az államháztartásra}

A WHO adatai alapján elemezhető, hogy az egyes EU-tagállamok és a jelentkezők GDP-jük hány százalékát fordítják egészségügyi kiadásokra, ezen belül mekkora az állami hozzájárulás aránya, illetve ezt kiegészítendő, a magánszféra bekapcsolódása az egészségügyi finanszírozásba.

A IV/4.1. sz. táblázatban látható, hogy az európai szociális modell ebben a vonatkozásban nagyon erős: Németország, Franciaország, Olaszország vagy Ausztria a GDP 9 százaléka fölött költ az egészségügyre, míg a rajnai modelltől eltérő brit-ír minta csak 6 százalék körüli összeget fordít erre a célra. A társultak közül kiemelkedik a csehek $(7,6)$, szlovénok $(9,4)$ és szlovákok $(8,6)$ európai mércével mérhető ráfordítása. Ugyancsak elgondolkodtató, hogy a rendkívül alacsony GDP- 
vel rendelkező románok $(3,8)$, bolgárok $(4,8)$ nemcsak nominálisan, de arányaiban is alacsony összeget fordítanak erre a területre. Sajnálatos Magyarország $(5,3)$ elmaradása is e téren. (Mint látni fogjuk, a privát hozzájárulás - legalábbis kimutathatóan - nem tudja ellensúlyozni az állami finanszírozás hiányát.)

Az állami szféra alapvetően domináns az egészségügy finanszírozásában mind a tagok, mind a tagjelöltek vonatkozásában, általában meghaladja a 70 százalékot. Erősebb magánfinanszírozási arány csak az olaszoknál $(42,9)$, portugáloknál $(42,5)$ és a görögöknél $(34,2)$, illetve letteknél $(39,0)$ figyelhető meg, nyilvánvalóan eltérő okokból és filozófiából. Valószínüsíthető, hogy a tagjelölteknél a jövőben a javuló gazdasági helyzettel egyidejüleg a magánfinanszírozás aránya nőni fog.

\section{IV/4.3. Az általános egészségügyi paraméterek összehasonlítása}

WHO-szakértők által készített felmérések a világ országait egy egységes mutató alapján egészségügyi helyzetüket illetően sorrendbe állították. Ez természetesen súlyozása miatt vitatható, hiszen egy ilyen aggregát rendszernél nagyon relatív az, hogy mi fog egy valós összképhez hozzásegíteni: a WHO itt 25-25 százalékos súllyal számolta be az egészségügyi állapotot, az egészségügyi állapot lakosságon belüli eloszlását, a finanszírozás mértéket, valamint 12,5 százalékos súllyal vette figyelembe azt, hogy mennyire képes a rendszer a kihívásokkal valóban szembenézni, valamint ugyanekkora súllyal számította be azt is, hogy mennyire méltányos, „fair” a társadalmon belül a pénzügyi hozzájárulás rendszere az egészségügyhöz. E vitatható, de mindenféleképpen orientációs jellegü táblázat és rangsor alapján elmondható (IV/4.1. táblázat utolsó oszlopa), hogy az EU 15 tagállama rendkívül jó helyen áll, hiszen a világ országai közötti sorrendben mindannyian az első 35 országba esnek (sőt Finnország és Dánia kivételével a többiek az első 25-be tartoznak), ami az európai egészségügyi színvonal magas mércéjét mutatja. (Az USA 37., Japán a 10. helyen áll.) A társult országok közül Szlovénia, Csehország, Lengyelország és Szlovákia esik a 34-60. hely közé a világranglistán, míg Magyarország csak a 66., Litvánia és Észtország a 70. hely fölött van. Lettország, Románia és Bulgária nagyon megalázó helyen áll, gyakorlatilag a szegényebb fejlődő országokkal (Moldova, Örményország, Irak) egy csoportban. 
A társultak e világrangsorban elfoglalt helye alapján feltételezhető, hogy általában elmaradott egészségügyi állapotban lévő új tagokat, így társadalmilag bizonytalanabb tagjelölteket fogad be az EU, hiszen ilyen helyzetben vagy többet kell költeniük a GDP-ből egészségügyre, vagy a lakosság egészségügyi helyzetének polarizálódásával nézhetnek szembe. Nem véletlen, hogy az EU részéről a felvételi tárgyalásokat megelőző és követő vizsgálatok előtérbe helyezik az egészségügy finanszírozásának reformját, hiszen az államháztartási vonatkozáson kívül negatív következményekkel jár, ha a munkaképes korú lakosság, - melyet gyakran EU-ból származó tőke foglalkoztat - egészségi állapota elégtelen. Az egészségügyi helyzet általános javulása ugyanakkor lehetővé teszi a munkaerőre rakódó, jelenleg magas egészségügyi járulékok csökkentését is.

A lakosság egészségügyi állapotára vonatkozóan tehát megállapítható, hogy Európa (az Európai Unió, de ide sorolhatóak az EGT-EFTA országok, Norvégia, Svájc, Izland is) igen modern és fejlett egészségügyi adottságokkal és rendszerrel rendelkeznek, míg a csatlakozó országoknál ezt csak a gazdasági felzárkózással párhuzamosan lehet megvalósítani. Ezt támasztja alá, hogy a tagjelöltek közül a legmagasabb egy főre jutó GDP-vel rendelkező Szlovénia és Csehország egészségügyi állapota a legjobb. A tagjelöltek erősen polarizálódó egészségügyi helyzete és gazdasági felzárkózása között szoros korreláció (ez alól Magyarország kivétel) mutatható ki. Az egészségügyi helyzet rendezetlensége (az állami finanszírozási hányad túlsúlya miatt) a bővítés után negatív hatást gyakorolhat az EU Gazdasági és Pénzügyi Uniójának stabilitására is azért, mert a hirtelen felmerülő konszolidációs igények destabilizálhatják az államháztartás egészét.

\section{RÉSZ; 5. FEJEZET}

\section{SZOCIÁLIS HELYZET}

Mivel Európa fejlődésének egyik kulcseleme a II. világháború után a szociális piacgazdaság kibontakozása (a társadalmi rétegek leszakadásának megakadályozása, esélyegyenlőség megvalósítása) volt, ezért az új országok integrálásánál nem 
elhanyagolható, hogy milyen a szociálpolitikájuk. (Bár mint az általam elkészített kérdőíves felmérés mutatta, ez a döntéshozók számára nem a legfontosabb prioritás.) Az e téren elért közösségi vívmányok megvalósítását számon kérik a tagjelölt országokon, ami nemcsak az európai szociális modell kiterjesztését, hanem a belső piacon a versenyegyenlőséget is segíti a belépés után. E témakör érinti a munkavállalók munkafeltételeinek alakulását, a munkahelyi biztonságot és egészségvédelmet, a nők és férfiak esélyegyenlőségét, a foglalkoztatáshoz való jogot, a munkajog bizonyos területeinek szabályozását, a szociális védelmet és a szociális kirekesztés kizárását, valamint a szociális partnerek közötti párbeszéd kötelező megvalósítását. (Ez utóbbi területen meg kell jegyezni, hogy a közösségi vívmányok eddig inkább csak a párbeszéd tényét és demokratikus formáját, de nem a jogköreit határozták meg.) Az EU szempontjából lényeges, hogy a tagjelölteknek alkalmazniuk kell a munkaadó fizetésképtelenségére, a tömeges (csoportos) elbocsátásokra, a tulajdonosváltásra vonatkozó szigorú európai irányelveket, amelyek a versenytorzulás és a felesleges migráció kizárásának további lehetőségét, és a szociális Európa kiépítését vonják maguk után.

Emellett fontos - bár anyagilag egyik fél számára sem könnyen prognosztizálható következmény az, hogy az új és a régi tagállamok között megvalósuljon a szociális rendszerek koordinációja. Ez nemcsak a társadalombiztosítás működési rendszerének egységesítését teszi lehetővé (ennek a juttatási rendszernek a meghatározása és főleg mértéke tagállami hatáskör), hanem meghatározza a jogosultságok lehetséges, azonos elven alapuló körét akkor is, ha a munkavállaló és családtagjai nem saját szülőhazájukban, hanem másik tagállamban végeznek munkát, vagy tanulnak. Ez egy fontos koordinációs mechanizmus, melynek révén attól függetlenül lehet különböző típusú jogosultságokat szerezni, hogy melyik tagállamban végez az uniós polgár munkát. Sok EU-tagállam állampolgára végez járulékra jogot adó tevékenységet a tagjelölt országokban (főleg a működőtőke befektetések menedzsmentje), ezért a régi tagállamok polgárai számára a közösségi rendszer kiterjesztése a bővítéssel járó előny lesz, bár kétségtelen, hogy összességében az új tagállamok kivándorlói szám szerint egy ideig meg fogják haladni a jelenlegi EU-ból érkező munkavállalók számát (lásd: V/8. fejezet). 
A szociális jogok területén nemcsak az EU közösségi jogának elöírásait tekinthetjük a tagság szempontjából fontos mérföldkőnek, hanem az Európa Tanács Szociális Kartáját is, amely az EU-ban érvényes kötelezettségek nagy részét a ratifikáló államok számára alkalmazandóvá teszi. (2001 tavaszáig a tagállamok mindegyike ratifikálta a Szociális Kartát, ám a tagjelöltek közül csak Csehország, Magyarország, Lengyelország és Szlovákia hagyta jóvá a megállapodást, a többiek még nem vállalták a benne lefektetett kötelezettségek teljesítését.)

\section{IV/5.1. Foglalkoztatottság}

A közép- kelet-európai rendszerváltás után hirtelen megnövekedett munkanélküliség az évtized közepétöl fokozatosan csökkenni kezdett (lásd: V/1. fejezet). Ezzel az ezredfordulóra több tagjelölt - így Magyarország - már az Uniónál kedvezőbb munkanélküliségi rátákat tudott elérni, sőt a kedvező tendencia az előrejelzések szerint tovább fog folytatódni. A közösségi szociálpolitikát azonban igazából a munkahelyteremtés kérdése, vagyis a foglalkoztatási ráta tényleges alakulása érdekli, ez adja meg ugyanis a munkaképes korosztály valós társadalmi szerepét, azaz, hogy mennyire képesek a társadalom számára abban eltartóként szerepelni. Ebben lehet választ kapni arra is, hogy mennyire érvényesül a két nem közötti egyenlő esélyek elve.

A tagállamoknál 1993-98 között általában nőtt a foglalkoztatási arány, hét országban 1998-ban meghaladta a 70 százalékot (mint a IV/5.1. sz. táblázat is mutatja). A foglalkoztatási szint terén a kilencvenes évek elején a tagjelölteknél megindult egy csökkenési tendencia, ami 1998 körül megállt, sőt a 2001-ben kiadott bizottsági Kohéziós Jelentés szerint már növekvő tendenciát mutatott. A tagjelölt országok kilencvenes években megfigyelhető foglalkoztatási rátáját meghatározta az is, hogy melyik országban milyen eredménnyel sikerült megoldani a privatizációt, veszteséges üzemek bezárását, csődtörvényt stb. A társult országok általános foglalkoztatási szintje 1998-ban elmaradt a tagállamokétól (lásd: IV/5.1.sz. táblázat). A 2. Kohéziós Jelentés 1999-re vonatkozóan minden tagjelölt ország esetében már magasabb foglalkoztatási rátát jelzett, mint az Eurostat 1998-ra, az eltérés pozitív irányban 1,5-2 százalékos volt, vagyis a tagjelöltek - Bulgária, Magyarország és 
Lengyelország kivételével - meghaladták a 60 százalékos foglalkoztatási küszöböt. Európai Bizottság, [2001]).

IV/5.1. sz. táblázat: A munkaképes korú lakosság foglalkoztatási aránya, összesen és nemek szerint (százalék)

\begin{tabular}{|l|c|c|c|c|}
\hline \multicolumn{1}{|c|}{ Ország } & $\begin{array}{c}\text { Teljes } \\
\text { lakosság } \\
\mathbf{1 9 9 3}\end{array}$ & $\begin{array}{c}\text { Teljes } \\
\text { lakosság } \\
\mathbf{1 9 9 8}\end{array}$ & $\begin{array}{c}\text { Férfiak } \\
\mathbf{1 9 9 8}\end{array}$ & $\begin{array}{c}\text { Nők } \\
\mathbf{1 9 9 8}\end{array}$ \\
\hline Belgium & 60,9 & 63,2 & 72,5 & 53,8 \\
\hline Dánia & 81,2 & 79,3 & 83,5 & 75,1 \\
\hline Németország & 70,5 & 70,7 & 79,2 & 62,1 \\
\hline Görögország & 58,7 & 62,5 & 77,1 & 48,5 \\
\hline Spanyolország & 58,9 & 61,3 & 75,5 & 47,5 \\
\hline Franciaország & 67,2 & 68,2 & 75,1 & 61,6 \\
\hline Írország & 60,9 & n.a. & n.a & n.a \\
\hline Olaszország & 57,8 & 58,1 & 72,2 & 44,2 \\
\hline Luxemburg & 62,4 & 61,9 & 76,0 & 47,6 \\
\hline Hollandia & 67,8 & 72,6 & 82,4 & 62,5 \\
\hline Ausztria & n.a. & 71,3 & 80,2 & 62,5 \\
\hline Portugália & 68,1 & 70,2 & 79,0 & 61,9 \\
\hline Finnország & n.a. & 73,1 & 76,1 & 70,0 \\
\hline Svédország & n.a. & 75,5 & 78,7 & 72,2 \\
\hline Egyesült Királyság & 75,2 & 74,9 & 82,8 & 66,9 \\
\hline Bulgária & 55,4 & 50,4 & 55,6 & 45,6 \\
\hline Csehország & 63,3 & 61,0 & 70,8 & 52,0 \\
\hline Észtország & 70,2 & 60,5 & 69,4 & 53,0 \\
\hline Magyarország & 59,2 & 51,7 & 60,0 & 44,1 \\
\hline Lettország & $n . a$ & 58,8 & 68,8 & 50,7 \\
\hline Litvánia & 65,3 & 61,7 & 69,6 & 54,9 \\
\hline Lengyelország & 60,9 & 57,4 & 65,4 & 50,0 \\
\hline Románia & $n . a$. & 63,6 & 71,4 & 56,3 \\
\hline Szlovákia & 62,1 & 59,9 & 68,9 & 51,5 \\
\hline Szlovénia & 57,7 & 59,4 & 66,3 & 52,9 \\
\hline & & & & \\
\hline & & & & \\
\hline
\end{tabular}

Forrás: Eurostat, [2000] az ILO LFS egységes statisztikai rendszere alapján

A tagjelöltek foglalkoztatási szerkezetét vizsgálva elmondható, hogy a szolgáltató szektor nyújt nagy felvevőpiacot, míg országon belül régiónként (1999-ben 70 és 52 százalék között) kevésbé kiegyenlített eloszlást mutat a tagállamokkal való összehasonlításban. A nők foglalkoztatási helyzete messze nem romlott 1993-98 között olyan mértékben, mint a férfiaknál, a nemek közötti foglalkoztatási különbség 1998-ban a tagjelölteknél kedvezőbb (20 százalék alatti), mint a tagok egy részénél (Görögországban, Spanyolországban, Olaszországban és Luxemburgban közel 30 százalékos a foglalkoztatási különbség). Mindez akkor különösen nagy eredmény, ha figyelembe vesszük, hogy a tagjelölteknél 1999-ben csak a nők 8 százaléka dolgozott 
részmunkaidőben, míg az EU-ban ez 18 százalékos arányt mutatott (2. Kohéziós Jelentés). Mint a gazdasági fejlettséggel foglalkozó részben (V/l. fejezet) elemzem, a Bizottság véleménye szerint a foglalkoztatottság nőni fog a térség országaiban (Románia és talán Csehország kivételével), és néhány országban a következő években elérheti, vagy meghaladhatja az évi egy százalékos növekedést (Észtország, Szlovákia, Magyarország Bulgária). Mindenesetre a 2000 áprilisában Lisszabonban megtartott csúcsértekezlet célkitüzései - 2010-re általánosan 70 százalékos, a nők esetében 60 százalék foglalkoztatási ráta elérése - a legtöbb tagjelölt vonatkozásában még jelentős erőfeszítéseket igényel.

\section{IV/5.2. A szociális ellátás}

A volt szocialista rendszer örökségeként az egyes tagjelölt országok egy igen fejlett szociális rendszert tudtak felmutatni, amit nagyrészt máig fenntartottak. Ennek megfelelően közkiadásaikon belül előkelő helyet foglal el a szociális biztonságra és népjóléti kiadásokra fordított összegek nagysága. 1995-ben Lengyelország, Magyarország, Csehország, Szlovákia, Szlovénia átlagosan a GDP 21,7 százalékát költötték a közkiadásokból szociális és népjóléti célokra, míg az EU-országok 1990ben 19 százalékot (Boeri, [2000]. Ezen belül is sajátos képet mutat Nagy-Britannia és Portugália (lásd: IV/5.2. sz. táblázat) alacsony állami hozzájárulása a szociális kiadásokhoz (a GDP 13,7 illetve 10,5 százaléka), ahol az állam mellett az egyéni öngondoskodás szerepe került előtérbe. Ugyanakkor komoly szociális hálót épített ki Hollandia, Szlovénia, Franciaország és Németország is. A fejlettebb csatlakozni kívánók közül Magyarországnak, Csehországnak és Szlovéniának magasabb, az EUátlag körüli a szociális kiadások aránya a GDP-ből, míg a balti és balkáni tagjelölteknél alacsonyabb. 
IV/5.2. sz. táblázat: A szociális és népjóléti kiadások a GDP százalékában, 1995-ben

\begin{tabular}{|l|c|c|}
\hline \multicolumn{1}{|c|}{ Ország } & $\begin{array}{c}\text { Közkiadásokból } \\
\text { (GDP százalékában) }\end{array}$ & $\begin{array}{c}\text { Összesen (köz- és } \\
\text { magánkiadás } \\
\text { (GDP százalékában) }\end{array}$ \\
\hline Belgium & 24,8 & 29,5 \\
\hline Dánia & 20,5 & 34,3 \\
\hline Franciaország & 23,5 & 30,6 \\
\hline Németország & 19,3 & 29,5 \\
\hline Írország & 16,4 & 19,9 \\
\hline Olaszország & 18,9 & 24,5 \\
\hline Hollandia & 29,1 & 31,7 \\
\hline Egyesült Királyság & 13,7 & 27,7 \\
\hline Portugália & 10,5 & 20,7 \\
\hline Spanyolország & 16,1 & 22,6 \\
\hline Görögország & 16,1 & 22,7 \\
\hline Lengyelország & 21,0 & 29,5 \\
\hline Magyarország & 18,8 & 32,3 \\
\hline Csehország & 19,4 & 25,5 \\
\hline Szlovákia & 20,5 & 26,0 \\
\hline Szlovénia & 28,6 & 28,6 \\
\hline Észtország & $n \cdot a$. & 26,0 \\
\hline Bulgária & $n \cdot a$. & 14,1 \\
\hline Lettország & $n \cdot a$. & 26,5 \\
\hline Litvánia & $n . a$. & 19,3 \\
\hline Románia & $n \cdot a$. & 16,5 \\
\hline Szlovákia & $n \cdot a$. & 26,0 \\
\hline & & \\
\hline & & \\
\hline
\end{tabular}

Forrás: EPI, Fiscal Policy in Transition, CEPR [1997], Eurostat [1998], Boeri [2000]

Megjegyzés: A teljes kiadás a tagjelöltekre nem 1995, hanem 1991-95 évek átlagára vonatkozik.

A szociális kiadásokon belül szembetünő, hogy a fejlettebb tagjelölt országok az ún. nem foglalkoztatási jellegü kiadásokra (munkanélküliségi segély, szociális segély, korai nyugdíj, rokkantság és táppénz) a GDP 3,6-5 százalékát fordítják, míg a kevésbé fejlett tagjelölteknél ez a mutató csak 0,5-1,9 százalék közötti. A fejlettebb tagjelöltek GDP-jük 10-16 százalékát fordították öregkori nyugdíjra, míg a balkáni és a balti államoknál erre a GDP 10 százaléka alatti összeget szántak. (Boeri, [2000]). Főleg a nem foglalkoztatási jellegü kiadások alacsony volta lehet veszélyes más területek (belső társadalmi biztonság, kivándorlás veszélye, közbiztonság stb.) szempontjából. Ez a helyzet különösen akkor fenyegető, ha megnézzük a munkanélküliségi mutatót a tagjelölteknél (ld. V/1.9. sz. táblázat), amelyből jól látható, hogy több, szociális téren relatíve keveset áldozó országban ez 10 százalék fölött van. (Szlovákia, Bulgária, Észtország esetében különösen veszélyes tendenciák bontakoznak ki.) 


\section{IV/5.3. Az abszolút és relatív szegénység, a társadalom polarizáltsága a társultaknál}

Az 1999-ben beindult jelentős gazdasági növekedés a térségben kiemelkedő reálbérnövekedést tesz lehetővé a közeljövőben több ország esetében. A Bizottság elemzése szerint az elkövetkező néhány évben az ún. magánfogyasztás (private consumption) jelentősen nőni fog a tagjelölt országokban, ahol 2000 és 2001-re 3,9, de még 2002re is 3,7 százalékos növekedést jósolnak.

A Deutsche Bank Research adatai szerint (lásd: IV/5.3. sz. táblázat) 1997-ben Romániában és Bulgáriában, 1998-ban pedig Csehországban csökkent a reálbér, minden más tagjelölt országban jelentős reálbér-növekedés volt megfigyelhető, bár több országban csak az új évezredben sikerül elérni a szocializmus utolsó évében megfigyelt reálkereseteket.

IV/5.3. sz. táblázat: A reálbérek növekedése 1997-ben és 1998-ban az elözö évhez képest

Átlagos fizetések 1998-ban és prognosztizált nagyságuk 2001-ben

\begin{tabular}{|l|c|c|c|c|}
\hline \multicolumn{1}{|c|}{ Ország } & $\begin{array}{c}\text { Reálbér } \\
\text { növekedés } \\
\mathbf{1 9 9 7} \\
\text { (elöző év=100) } \\
\text { (százalék) }\end{array}$ & $\begin{array}{c}\text { Reálbér } \\
\text { növekedés } \\
\mathbf{1 9 9 8} \\
\text { (elözó év=100) } \\
\text { (százalék) }\end{array}$ & $\begin{array}{c}\text { Bruttó átlagbér } \\
\mathbf{1 9 9 8} \\
\text { (euró) }\end{array}$ & $\begin{array}{c}\text { Prognosztizált } \\
\text { átlagbér } \\
\mathbf{2 0 0 1} \\
\text { (euró) }\end{array}$ \\
\hline Bulgária & 83,2 & 120,2 & 106 & 143 \\
\hline Csehország & 101,8 & 98,7 & 322 & 414 \\
\hline Észtország & 108,0 & 107,0 & 262 & 340 \\
\hline Magyarország & 104,9 & 103,6 & 282 & 357 \\
\hline Lettország & 112,2 & 106,1 & 201 & 290 \\
\hline Litvánia & 113,9 & 114,7 & 222 & 300 \\
\hline Lengyelország & 106,1 & 103,8 & 335 & 522 \\
\hline Románia & 77,8 & 106,6 & 136 & 135 \\
\hline Szlovákia & 106,6 & 102,7 & 253 & 299 \\
\hline Szlovénia & 103,0 & 101,6 & 850 & 925 \\
\hline
\end{tabular}

Forrás: Eurostat, Deutsche Bank Research, [2000]

A reálbérek átlagának erősödése mellett meg kell vizsgálni azt is, hogy milyen társadalmi rétegek lesznek ennek haszonélvezői, vagyis milyen a társadalom jövedelmek szerinti tagoltsága. 
Az abszolút szegénységre az ENSZ Millenniumi csúcsértekezletén meghatározták a napi 1 USD limitet, vagyis aki ez alatt él, az a világ bármilyen tájékán szegénynek minősül. A WDI mérései szerint a lakosság 2 százaléka alatti arány nem tekinthető szignifikánsnak, ezért az EU-tagállamokban az abszolút szegénységi küszöb statisztikailag nem mérhető, csak a társultaknál mutatható ki. A IV/5.4. sz. táblázatban a világbanki adatok alapján a napi 1 és 2 USD alatt élők arányát emeltem ki.

IV/5.4. sz. táblázat: A napi 1 USD illetve a napi 2 USD alatt élök a teljes lakosság százalékában

\begin{tabular}{|l|c|c|c|}
\hline \multicolumn{1}{|c|}{ Ország } & Felvétel éve & $\begin{array}{c}\text { 1 USD/nap } \\
\text { (százalék) }\end{array}$ & $\begin{array}{c}\text { 2 USD/nap } \\
\text { (százalék) }\end{array}$ \\
\hline Bulgária & 1995 & $<2$ & 7.8 \\
\hline Csehország & 1993 & $<2$ & $<2$ \\
\hline Észtország & 1995 & 4.9 & 17.7 \\
\hline Magyarország & 1993 & $<2$ & 4.0 \\
\hline Lettország & 1998 & $<2$ & 8.3 \\
\hline Litvánia & 1996 & $<2$ & 7.8 \\
\hline Lengyelország & 1993 & 5.4 & 10.5 \\
\hline Románia & 1994 & 2.8 & 27.5 \\
\hline Szlovákia & 1992 & $<2$ & $<2$ \\
\hline Szlovénia & 1993 & $<2$ & $<2$ \\
\hline
\end{tabular}

Forrás: World Development Indicator, [2000]

Megjegyzés: < kisebb, mint

A táblázat tanúsága szerint a világ abszolút szegénységi küszöbe szerinti napi 1 USD-t nem kapja meg Romániában, Lengyelországban és Észtországban a lakosság több mint 2 százaléka; a napi 2 USD alatti megélhetés pedig csak Csehország, Szlovákia és Szlovénia esetében esik a lakosság 2 százaléka alá a kilencvenes évek szerinti felmérésekben. Különösen drámai arányt ért el a szegények száma Lengyelországban, Romániában és Észtországban.

Az abszolút szegénység melletti másik fontos mutató a relatív szegénység vizsgálatához nem állt rendelkezésemre a tagjelölt országokról olyan adatsor, amelyet az Eurostat a tagállamokra vonatkozóan használ, vagyis azok arányának meghatározása a társadalmon belül, akik a nemzeti átlagjövedelmek 60 százaléka alatt élnek. Így a társadalmon belüli divergenciát két mutatón mérem le a IV/5.5. sz. 
táblázatban: egyrészt, hogy a társadalom legszegényebb és leggazdagabb dekádja hogyan részesül a fogyasztásból, másrészt a társadalom polarizáltságát jelző Giniindexböl.

IV/5.5. sz. táblázat: A társadalmak jövedelmi viszonyainak polarizáltsága a tagállamokban és a tagjelölteknél

\begin{tabular}{|l|c|c|c|c|c|c|}
\hline \multicolumn{1}{|c|}{ Ország } & Felvétel éve & Gini index & $\begin{array}{c}\text { Alsó } \\
\mathbf{1 0 \%}\end{array}$ & $\begin{array}{c}\text { Alsó } \\
\mathbf{2 0} \%\end{array}$ & $\begin{array}{c}\text { Felső } \\
\mathbf{1 0} \%\end{array}$ & $\begin{array}{c}\text { Felső } \\
\mathbf{2 0 \%}\end{array}$ \\
\hline Ausztria & 1987 & 23,1 & 4,4 & 10,4 & 19,3 & 33,3 \\
\hline Belgium & 1992 & 25,0 & 3,7 & 9,5 & 20,2 & 34,5 \\
\hline Bulgária & 1995 & 28,3 & 3,4 & 8,5 & 22,5 & 37,0 \\
\hline Csehország & 1996 & 25,4 & 4,3 & 10,3 & 22,4 & 35,9 \\
\hline Dánia & 1992 & 24,7 & 3,6 & 9,6 & 20,5 & 34,5 \\
\hline Észtország & 1995 & 35,4 & 2,2 & 6,2 & 26,2 & 41,8 \\
\hline Finnország & 1991 & 25,6 & 4,2 & 10,0 & 21,6 & 35,8 \\
\hline Franciaország & 1995 & 32,7 & 2,8 & 7,2 & 25,1 & 40,2 \\
\hline Németország & 1994 & 30,0 & 3,3 & 8,2 & 23,7 & 38,5 \\
\hline Görögország & 1993 & 32,7 & 3,0 & 7,5 & 25,3 & 40,3 \\
\hline Magyarország & 1996 & 30,8 & 3,9 & 8,8 & 24,8 & 39,9 \\
\hline Írország & 1987 & 35,9 & 2,5 & 6,7 & 27,4 & 42,9 \\
\hline Olaszország & 1995 & 27,3 & 3,5 & 8,7 & 21,8 & 36,3 \\
\hline Lettország & 1998 & 32,4 & 2,9 & 7,6 & 25,9 & 40,3 \\
\hline Litvánia & 1996 & 32,4 & 3,1 & 7,8 & 25,6 & 40,3 \\
\hline Hollandia & 1994 & 32,6 & 2,8 & 7,3 & 25,1 & 40,1 \\
\hline Lengyelország & 1996 & 32,9 & 3,0 & 7,7 & 26,3 & 40,9 \\
\hline Portugália & $1994-95$ & 35,6 & 3,1 & 7,3 & 28,4 & 43,4 \\
\hline Románia & 1994 & 28,2 & 3,7 & 8,9 & 22,7 & 37,3 \\
\hline Szlovákia & 1992 & 19,5 & 5,1 & 11,9 & 18,2 & 31,4 \\
\hline Szlovénia & 1995 & 26,8 & 3,2 & 8,4 & 20,7 & 35,4 \\
\hline Spanyolország & 1990 & 32,5 & 2,8 & 7,5 & 25,2 & 40,3 \\
\hline Egyesült Kir. & 1991 & 36,1 & 2,6 & 6,6 & 27,3 & 43,0 \\
\hline Svédország & 1992 & 25,0 & 3,7 & 9,6 & 20,1 & 34,5 \\
\hline
\end{tabular}

Forrás: WDI, [2000]

Megjegyzés: Alsó és felső százalékok: a társadalom jövedelméből vagy fogyasztásából való részesedés a társadalom legszegényebb és leggazdagabb 10 ill. 20 százalékánál. Gini-indexnél az alacsonyabb érték jelzi a társadalom szociális, jövedelmi viszonyainak kiegyensúlyozottabb helyzetét.

A szociálpolitikára egyébként is jelentős összeget költő élenjáró országok, különösen Csehország, Szlovákia, Szlovénia, viszonylag jó elosztási arányokkal élték meg a kilencvenes évek elejét, míg mások - lengyelek, baltiak és a balkániak - már jobban polarizálódó társadalmat jeleznek, amire példa a déli, javarészt elmaradottabb EUtagállamokban de pl. az Egyesült Királyságban is megtalálható. Csehországban például a Gini-index 25,4 százalékos és a társadalom alsó 20 százaléka fogyasztja el a GDP 10,3 százalékát, ami a társadalmi-szociális viszonyokat illetően a 
szélsőségektől mentes társadalmat mutat. Ez mérvadó lehet a társadalom jövedelmi polarizáltságára akkor is, ha a felmérések időpontjai meglehetősen eltérőek voltak.

IV/5.6. sz. táblázat: A minimálbér és az átlagbér viszonya az egyes európai uniós és tagjelölt országokban

\begin{tabular}{|l|c|c|}
\hline \multicolumn{1}{|c|}{ Ország } & $\begin{array}{c}\text { Minimálbér } \\
\text { (euró) }\end{array}$ & $\begin{array}{c}\text { Minimálbér } \\
\text { az átlagbér } \\
\text { százalékában }\end{array}$ \\
\hline Belgium & 1074 & 53 \\
\hline Görögország & 458 & 47 \\
\hline Spanyolország & 486 & 42 \\
\hline Franciaország & 1036 & 61 \\
\hline Luxemburg & 1162 & 48 \\
\hline Hollandia & 1064 & 54 \\
\hline Portugália & 357 & 59 \\
\hline Egyesült Királyság & 920 & 41 \\
\hline Bulgária & 38 & 32 \\
\hline Csehország & 126 & 35 \\
\hline Szlovákia & 100 & 42 \\
\hline Lengyelország & 176 & 37 \\
\hline Magyarország & 152 & 48 \\
\hline Románia & 47 & 42 \\
\hline Szlovénia & 358 & 40 \\
\hline
\end{tabular}

Forrás: Eurostat, [2000] illetve Német-Magyar Ipari és Kereskedelmi Kamara, [2001]

Megjegyzés: Az EU-államok adatai az 1998-as, míg a Társultaké a 2000-2001-es állapotot tükrözik.

A minimálbér és az átlagbér viszonyában a tagjelölteknél alacsonyabb értékeket látunk, mint a tagállamok legtöbbjénél, de kedvező a magyar, szlovák, román és szlovén mutató. Ez azonban még messze esik az EU-ban fontos szociális célként emlegetett 60 százalékhoz képest. Ugyanakkor a tagállamok között Spanyolországban, Görögországban, de például az Egyesült Királyságban is 50 százalék alatti ez az arány, vagyis nemcsak az új tagállamoknál kell még közelíteni a legképzetlenebb rétegek javadalmazását az átlagbérhez.

\section{IV/5.4. A felzárkózás lehetőségei}

A kibővített belső piac szociális helyzetét illetően is nyilvánvaló, hogy a jelenlegi portugál bérek 60-70 százalékát kitevő átlagfizetések nélkül az új belépők szociális problémákkal nézhetnek szembe, hiszen nem függetleníthetik magukat az ott 
megjelenő fogyasztói árak nagy részétől. (Az OECD 2000-ben nyilvánosságra hozott adatai szerint Portugáliában 1999-ben 1021 USD volt az átlagos havi fizetés.)

A nominális átlagbérek tekintetében jelentős a tagjelöltek lemaradása, de - a várható valutafelértékelődés, valamint a jelentős reálbér-növekedés miatt - vélhetően ez a szakadék az EU és a tagjelöltek között zárulni fog. Ennek a belső piacon belüli migrációs veszély csökkentése szempontjából is nagy jelentősége van (lásd: V/8. fejezet).

IV/5.7. sz. táblázat: A bruttó havi átlagfizetések az egyes tagjelölteknél az EU százalékában

\begin{tabular}{|l|c|c|c|c|c|c|}
\hline \multirow{2}{*}{ Ország } & \multicolumn{2}{|c|}{1999} & \multicolumn{2}{c|}{2000} & \multicolumn{2}{c|}{ 2001 (becslés) } \\
\cline { 2 - 7 } & euró & $\mathbf{\%}$ & euró & \% & euró & $\mathbf{\%}$ \\
\hline Bulgária & 105 & 6 & 117 & 6 & 143 & 8 \\
\hline Csehország & 343 & 19 & 379 & 21 & 414 & 22 \\
\hline Észtország & 284 & 16 & 312 & 17 & 340 & 18 \\
\hline Magyarország & 304 & 17 & 337 & 19 & 357 & 19 \\
\hline Lettország & 258 & 15 & 281 & 15 & 290 & 16 \\
\hline Litvánia & 252 & 14 & 293 & 16 & 300 & 16 \\
\hline Lengyelország & 405 & 23 & 524 & 29 & 522 & 28 \\
\hline Románia & 118 & 7 & 142 & 8 & 135 & 7 \\
\hline Szlovákia & 242 & 14 & 282 & 16 & 299 & 16 \\
\hline Szlovénia & 886 & 50 & 1028 & 57 & 925 & 50 \\
\hline EU & $\mathbf{1 7 5 9}$ & $\mathbf{1 0 0}$ & $\mathbf{1 8 1 4}$ & $\mathbf{1 0 0}$ & $\mathbf{1 8 5 2}$ & $\mathbf{1 0 0}$ \\
\hline
\end{tabular}

Forrás: Deutsche Bank Research, EU Enlargement Report, [2000] szeptember

A IV/5.7. sz. táblázat szerint már két év alatt is jelentős felzárkózás várható a bruttó bérek nominális értékében, hiszen a románok kivételével a többi csatlakozni kívánó ország legalább évi 1 százalékkal kerülhet közelebb az EU átlagához, sőt a nagy félelemmel kezelt Lengyelországban - mely a legnagyobb migrációs potenciállal rendelkezik - a bérek mintegy 5 százalékkal zárkóznak fel. (A megélhetési költségek természetesen eltérnek az egyes tagjelölt országokban.) A reálértékben történő felzárkózást támasztja alá az is, hogy az OECD felmérések szerint 1996-ban PPS-ben mérve a portugál nem szellemi (blue collar) foglalkoztatású dolgozók átlagfizetése 10.573 USD, Görögországban 12.739 USD, míg Csehországban 10.142, Lengyelországban 7902, Magyarországon 6716 USD-nek felelt meg, vagyis reálértékben a lemaradás már most sem jelentős. (OECD, [1997]). 


\section{IV/5.5. A szociális dömping vádja}

Gyakran éri az a vád a feltörekvő államokat, hogy szociális dömpinget folytatnak, vagyis nem költenek a szociális védelemre akkora hányadot, mint a tagállamok. A fejezet elején már leszögeztem, a GDP-hez mérten ezek az országok jelentős összegeket költenek szociálpolitikára, átlagosan 20 százalékot meghaladó mértékben.

Az EU részéről néhányan elsősorban azt nehezményezik, hogy nem a munkabérhez kapcsolódóan fizetik meg a belépő országok a szociális költségeket és így jogosulatlan versenyelőnyt élveznek. Az OECD e kérdésben felmérést végzett és kimutatta, hogy a bérre rakodó járulékok az OECD-országok közül a három EUtagjelölteknél is magas volt. Reálisan akkor tudjuk a helyzetet áttekinteni, ha emellett megnézzük azt is, hogy a munkaadók mekkora hányadot vállalnak a szociális kiadásokból (IV/5.8.sz. táblázat).

A versenyképesség semlegessége szempontjából megállapítható, hogy az európai szinthez képest a társult országokban is magas a szociális költségekhez történő munkaadói hozzájárulás aránya, pl. Magyarország, Csehország, Szlovákia és Szlovénia esetében meghaladja a 30 százalékot, a románoknál pedig a 40 százalékot. Egyedül a lengyeleknél állapítható meg a közép-európai tagjelöltek közül alacsonyabb munkáltatói hozzájárulás, de ez sem kirívó az ír, luxemburgi, vagy dán, brit arányhoz képest. Így ez nem jelent a tagjelöltek munkáltatóinak aránytalan versenyelőnyöket.

Az OECD-felmérés alapján látható, hogy a három EU-tagjelöltnél a munkások által kézhez kapott bérek aránya a bruttó bérhez képest 71,1 és 84,2 százalék között van (az EU átlaga 70,1 százalék), vagyis a munkavállalóktól relatíve nagy hányadot elvonnak, ugyanakkor számos tagállamban (pl. Portugália, Görögország) a bruttó fizetés több mint 80 százaléka marad a dolgozóknál, vagyis a munkabér teljes relatív adó és járulékterhe a három tagjelölthöz viszonyítva még alacsonyabb. 
IV/5.8. sz. táblázat: A munkaadók hozzájárulása a szociális költségekhez és a bruttó fizetés átlagos feldolgozóipari munkásnál maradó része 1998-ban

\begin{tabular}{|l|c|c|}
\hline \multicolumn{1}{|c|}{ Ország } & \multicolumn{1}{c|}{$\begin{array}{c}\text { Munkaadói } \\
\text { hozzájárulás } \\
\text { (százalék) }\end{array}$} & $\begin{array}{c}\text { A bruttó fizetés } \\
\text { dolgozónál maradó } \\
\text { része (százalék) }\end{array}$ \\
\hline EU & 39,2 & 70,1 \\
\hline Belgium & 44,5 & 58,2 \\
\hline Dánia & 9,6 & 56,6 \\
\hline Németország & 39,1 & 57,9 \\
\hline Görögország & 38,0 & 81,7 \\
\hline Spanyolország & 52,0 & 79,8 \\
\hline Franciaország & 49,9 & 72,7 \\
\hline Írország & 21,9 & 75,1 \\
\hline Olaszország & 49,3 & 70,9 \\
\hline Luxemburg & 25,8 & 75,4 \\
\hline Hollandia & 23,2 & 65,6 \\
\hline Ausztria & 37,4 & 71,4 \\
\hline Portugália & 26,0 & 81,9 \\
\hline Finnország & 34,9 & 64,6 \\
\hline Svédország & 40,0 & 65,6 \\
\hline Egyesült Kírályság & 24,7 & 74,8 \\
\hline Csehország & 35,0 & 77,2 \\
\hline Szlovákia & 38,0 & - \\
\hline Lengyelország & 20,4 & 84,2 \\
\hline Bulgária & 28,7 & - \\
\hline Magyarország & 33,0 & 71,1 \\
\hline Románia & 48,0 & - \\
\hline Szlovénia & 31,8 & \\
\hline & & - \\
\hline
\end{tabular}

Forrás: Eurostat, [2000], Német-Magyar Ipari és Kereskedelmi Kamara, [2001], OECD in figures, [2000]

Megjegyzés: A munkaadói hozzájárulás mértékénél Az EUtagországok adatai 1996-ra, míg a csatlakozni kívánó országok adatai 2000-re vonatkoznak.

\section{IV/5.6. A férfiak és nők esélyegyenlősége}

A két nem közötti egyenjogúságot a makrogazdaság szintjén a politikai és társadalmi életben való egyenrangú részvételük, valamint a gazdasági területeken megnyilvánuló lehetőségeik jellemzik leginkább.

Ami a politikai döntéshozatalban való részvételt illeti, a tagjelölt országok mind a kormányzati szerepvállalásban, mind a parlamenti képviselet területén lemaradtak az európai átlagtól. A legbiztatóbb képet a skandináv példához legközelebb álló balti országoknál találtam. 
IV/5.9. sz. táblázat: A tagjelölt országokban a nök képviseleti aránya a kormányban és a parlamentben (2000-ben)

\begin{tabular}{|c|c|c|}
\hline Ország & $\begin{array}{c}\text { Nők a } \\
\text { kormányban (\%) }\end{array}$ & $\begin{array}{c}\text { Nők a } \\
\text { parlamentben (\%) }\end{array}$ \\
\hline Bulgária & 18,8 & 10,8 \\
\hline Csehország & 0,0 & 13,1 \\
\hline Észtország & 13,3 & 17,8 \\
\hline Magyarország & 6,1 & 8,4 \\
\hline Lettország & 30,0 & 17,0 \\
\hline Litvánia & 0,0 & 11,0 \\
\hline Lengyelország & 5,3 & 13,4 \\
\hline Románia & 18,5 & 11,9 \\
\hline Szlovákia & 10,0 & 13,3 \\
\hline Szlovénia & 18,7 & 12,2 \\
\hline EU-átlag & 24,7 & 20,6 \\
\hline Málta & 7,7 & 9,2 \\
\hline Ciprus & 0,0 & 7,7 \\
\hline
\end{tabular}

Forrás: Éves jelentés a férfiak és nők egyenjogúságáról az Európai Unióban 2000-ben, Európai Bizottság, [2001]

Amennyiben megvizsgáljuk a nőknek a felsőoktatási hallgatók között 1997-98-ban betöltött arányát, akkor kiderül, hogy a tagjelölteknél ez az arány messze jobb, mint az EU-ban (Eurostat, [2000] alapján). Míg a tagállamok közül Németországban, Hollandiában és Ausztriában a nők aránya 50 százalék alatt van az összes felsőfokú hallgatóhoz képest, addig ez az arány a tagjelölt országokban ebben az időszakban csak Csehországban volt hasonló. Ugyanakkor egyetlen tagállamban sem volt az 1996-97-es tanévben a 60 százalék közelében a női hallgatók aránya, míg ugyanebben az évben a tagjelölteknél Bulgáriában és Litvániában elérte a 60 százalékot, Lettországban az 59, Észtországban és Lengyelországban az 57 százalékot. Ez a tény a nők társadalmi esélyegyenlősége megteremtésének irányába mutat a csatlakozó országokban.

A politikai és a társadalmi esélyegyenlőség mellett a keresetek összehasonlítása révén megvizsgáltam a nők gazdasági emancipációjának helyzetét. 
IV/5.10. sz. táblázat: A nök keresete az iparban és a szolgáltatásban a férfiak keresetének százalékában, 1998

\begin{tabular}{|lc|}
\hline Belgium & 69,2 \\
\hline Dánia & 81,6 \\
\hline Németország & 76,8 \\
\hline Görögország & 72,9 \\
\hline Spanyolország & 76,9 \\
\hline Franciaország & 79,8 \\
\hline Írország & 67,2 \\
\hline Olaszország & 79,0 \\
\hline Luxemburg & 64,7 \\
\hline Hollandia & 74,2 \\
\hline Ausztria & 67,5 \\
\hline Portugália & 72,7 \\
\hline Finnország & 78,7 \\
\hline Svédország & 82,4 \\
\hline Egyesült Királyság & 61,2 \\
\hline Csehország (1996) & 75,8 \\
\hline Észtország & 74,2 \\
\hline Magyarország & 81,4 \\
\hline Lettország (1996) & 78,4 \\
\hline Litvánia & 74,2 \\
\hline Lengyelország & 83,2 \\
\hline Románia & 77,5 \\
\hline Szlovákia & 77,5 \\
\hline Szlovénia & 88,9 \\
\hline
\end{tabular}

Forrás: Eurostat, [2001]

A férfiak és a nők keresetének összehasonlításakor megállapítható, hogy míg a tagjelöltek mindegyikénél a nők keresete legalább 74 százaléka a férfiakénak, addig a 15 tagállamból csak nyolcban érik el a gyengébb nem fizetései ezt az értéket. A gazdasági természetü összehasonlító adatok (foglalkoztatási ráta - lásd: IV/5.1. táblázat -, illetve a keresetek) terén nem lehet megkülönböztető vonalat húzni a jelenlegi és jövőbeli tagállamok között. A foglalkoztatási rátát illetően inkább a tradicionális választóvonalak érvényesülnek (északi és déli mediterrán vonal). Mivel a felsőoktatásban való női részvétel aránya a tagjelölteknél az európai trendnél is kedvezőbb, a jövőben a nők bérének felzárkózását lehet prognosztizálni. Ennek a politikai érdekképviseletben történő lecsapódása már középtávon is megjósolható, vagyis az EU a bővüléssel a nemek esélyegyenlőségét tekintve kifejezetten erősödni fog. 


\section{IV.RÉSZ; 6. FEJEZET}

\section{AZ OKTATÁSI SZÍNVONAL}

Az EU belső piacának egységesítése miatt a képesítések kölcsönös elismerése közösségi szinten is szükségessé vált. A bővítés révén nemcsak a diplomák és szakképesítések elfogadása valósul meg, hanem néhány területen, ahol a szakképesítések megszerzésének illetve a hozzá kapcsolódó gyakorlati minimumnak a feltételeit is egységesítették (például egészségügyi vagy jogászi pályán), az EU profitálni fog, hiszen így egy nagyobb belső piacon tudja a garantált képzettségi színvonalat megkövetelni az új tagállamoktól. Másrészt a különböző szakmai képzettségüek versenye a kibővült piacon hatékonyság-növekedést is eredményezhet. Ettől eltekintve az oktatási kérdések alapvetően nemzeti hatáskörben maradnak, vagyis a nemzeti oktatási rendszerek súlypontjai egyénileg kerülnek kiválasztásra.

Az Unió foglalkoztatáspolitikai céljainak elérése, valamint a tudásalapú, versenyképes európai gazdaság megvalósítása középpontba helyezte az oktatási rendszer továbbfejlesztését. Ezt szolgálja az a folyamat is, mely 2000. áprilisában a lisszaboni csúcsértekezleten vette kezdetét, és meghirdette a teljes foglalkoztatás elérését, valamint a versenyképesség javítását, melynek középpontjába a képzést, így a teljes életen át történő tanulást, az üzlet és az oktatási rendszer kapcsolatát állította. Ez adta az ötletet arra, hogy az Európai Bizottság vezetésével egy olyan munkacsoportot hozzanak létre, amelyben a tagállamok és a csatlakozási tárgyalást folytató országok nemzeti szakemberei segítségével felmérjék az egyes országok tanulói egymáshoz viszonyított, és abszolút értékben is mérhető felkészültségét.

Statisztikailag mérhető mutatók is segíthetnek a képzettség színvonalának feltérképezésében, így a különböző oktatási szinteken résztvevők számának, vagy a technikai felszereltséggel rendelkezők arányának vizsgálata, valamint az oktatási rendszer fejlesztésére fordított relatív anyagi források emelhetők ki. 


\section{IV/6.1. Az alap-, közép- és felsőfokú oktatásban való részvétel}

IV/6.1.1. Alap- és középfokú oktatás

Az EU-ban és a tagjelölteknél az állampolgárok alap- és középfokú oktatási rendszerekben való részvétele magas. Európa mindkét felén nagyon alacsony az alapfokú oktatásból kiesők száma, sőt - a közelmúlt erőteljes iskolakötelezettségei miatt - az újonnan csatlakozni kívánó országok nagyobb sikert könyvelhetnek el, mint több jelenlegi tagállam (Portugália, Egyesült Királyság vagy Spanyolország). Az EU-tagállamokban az növeli sikeresen a középfokú képzettséggel rendelkezők arányát, hogy a munkanélkülieket átképzések révén bevonják a középfokú oktatásba. A csatlakozni kívánó országok esetében a középiskolát végzettek aránya szintén magas (gyakorlatilag nyolcvan százalék feletti).

A Bizottság által megbízott munkacsoport felmérése alapján látható (lásd: IV/6.1. sz. táblázat), hogy a társult országokban azon 22 éves személyek aránya, akik befejezték középiskolai tanulmányaikat - ez tekinthető a nappali tagozatos képzésnek hasonló korú társaik összességéhez képest elérte a 70 százalékot. Különösen magas ez a cseheknél, szlovákoknál (90 százalék feletti), a szlovénoknál és a lengyeleknél pedig 80 százalék feletti. Ugyanezen metszet szerint az EU-n belül csak a finneknél és a svédeknél mutatható ki 90 százalékhoz közelítő arány, sőt a briteknél, portugáloknál vagy a spanyoloknál, luxemburgiaknál 70 százalék alatt maradt ez a mutató. 
IV/6.1. sz. táblázat: Középiskolai végzettséggel rendelkezök aránya a 22 éves korosztályban (1997)

\begin{tabular}{|c|l|}
\hline $\begin{array}{c}\text { Középiskolai végzettségúek } \\
\text { (százalék) }\end{array}$ & \multicolumn{1}{c|}{ Ország } \\
\hline $90-100$ & Csehország, Szlovákia \\
\hline $80-90$ & $\begin{array}{l}\text { Belgium, Ausztria, Finnország, Svédország, } \\
\text { Lengyelország, Románia, Szlovénia }\end{array}$ \\
\hline $70-80$ & $\begin{array}{l}\text { EU-átlag, Dánia, Németország, } \\
\text { Görögország, Franciaország, Írország, } \\
\text { Hollandia, Észtország, Magyarország, }\end{array}$ \\
\hline $60-70$ & $\begin{array}{l}\text { Spanyolország, Olaszország, } \\
\text { Egyesült Királyság, }\end{array}$ \\
\hline $50-60$ & Luxemburg, Portugália \\
\hline
\end{tabular}

Forrás: EU Bizottság, Oktatási és Kulturális Főigazgatóság, [2000]

Megjegyzés: Bulgária, Lettország és Litvánia esetében nem volt megbízható adat, Luxemburg adatai pedig a sajátos szociológiai - pl. rengeteg portugál betelepedő viszonyok miatt a többi tagállammal nehezen összehasonlítható.

IV/6.1.2. Felsőfokú oktatás

Az utóbbi két évtized fejlődését világosan jelzi, hogy a felsőfokú képzésben részt vevők száma Európa mindkét felében látványosan nőtt. A Világbank [1999] kimutatása szerint 1980-ban 34, 1996-ban 58 százalék szerezte meg a kontinensen a felsőfokú szakképesítést. Az Európai Unió tagállamaiban 1980 óta radikálisan (20-30 százalékkal) nőtt a felsőfokú végzettségüek száma, és több tagállamban (Franciaország, Belgium, Hollandia, Spanyolország, Egyesült Királyság) elérte az adott korosztály több mint felét (lásd: IV/6.2. sz. táblázat). Ugyanezen metszet szerint vizsgálva a csatlakozni kívánó országokat, 4-17 százalékos növekedést állapíthatunk meg és csak Litvánia esetében regisztrálható némi csökkenés. Az e területen leginkább előrehaladott országokban (Szlovénia vagy a Baltiak, Bulgária) a felsőfokú végzettségüek aránya jóval meghaladja a 30 százalékot, és messze meghaladja a közepesen gazdag országok 15 százalékos mutatóját. Ezek az arányok a tagjelöltek versenyképességét hosszabb távon befolyásoló és kedvező irányba ható tényezőnek tekinthetők. Bár a jelölt országoknak nem sikerült az elmúlt 20 évben az EU-hoz képest felzárkózni a felsőfokú végzettségüek arányát illetően, de a gazdasági 
növekedéssel egyidejűleg egyre több diák számára biztosítottá válik a továbbtanulás lehetősége a felsőfokú intézményekben.

IV/.6.2. sz. táblázat: Felsőfokú végzettségüek aránya (az ennek az iskolázottsági formának megfelelö korosztályban) a kilencvenes évek második felében

\begin{tabular}{|c|c|}
\hline Ország & $\begin{array}{c}\text { Felsőfokú képzésben } \\
\text { részesülttek aránya (\%) }\end{array}$ \\
\hline Ausztria & 48 \\
\hline Belgium & 57 \\
\hline Dánia & 46 \\
\hline Finnország & 71 \\
\hline Franciaország & 52 \\
\hline Németország & 45 \\
\hline Görögország & 43 \\
\hline Írország & 40 \\
\hline Olaszország & 43 \\
\hline Hollandia & 50 \\
\hline Portugália & 38 \\
\hline Spanyolország & 51 \\
\hline Svédország & 49 \\
\hline Egyesült Királyság & 50 \\
\hline Bulgária & 41 \\
\hline Csehország & 23 \\
\hline Észtország & 42 \\
\hline Magyarország & 25 \\
\hline Lettország & 33 \\
\hline Litvánia & 31 \\
\hline Lengyelország & 24 \\
\hline Románia & 23 \\
\hline Szlovákia & 22 \\
\hline Szlovénia & 36 \\
\hline EU átlag & 49 \\
\hline
\end{tabular}

Forrás: Világbank, [1999]

A Bizottság felmérése (amely 24 éves korig, vagy e fölött az egyetemi végzettség megszerzését vizsgálta) kimutatta, hogy az EU-tagállamok egy részében későbbi korban is nagy számban végeznek egyetemet az emberek, a diplomaszerzés életkora kitolódik (például Görögországban vagy Németországban), míg a közép-európai országokban ez eddig nem volt jellemző. Egzisztenciális okokból 24-25 éves korban a fiatalok már igyekeztek munkába állni, így valószínüleg ez is közrejátszik abban, hogy a várható tanulmányi idő a tagjelölt országokban 1-2 évvel kevesebb, mint az EU-tagállamokban. (A tagjelölteknél a tanulással eltöltött idő 12-13 év, míg a tagállamoknál 13-17 év között mozog.) (EU Bizottság, [2000]) 


\section{IV/6.2. A feladatmegoldási készég}

A csatlakozni kívánó országok igyekeznek az oktatás minőségi követelményei terén is versenyben maradni a tagországokkal szemben. Nem kevésbé fontos mutató az oktatás hatásfoka, azaz annak vizsgálata, hogy milyen feladatmegoldó képességgel rendelkezik a diáksereg.

Az Európai Bizottság által feldolgozott kutatási eredmények a következőket mutatják:

- A matematikai képességek (vagyis a kombinatorika, logika) terén a csatlakozni kívánó országok 13-14 éves diákjai megállják a helyüket az összehasonlítások terén, sőt Csehország, Szlovákia és Szlovénia, Bulgária vagy Magyarország még az EU-átlagot is jóval meghaladó eredményeket produkált.

- Az olvasás (megértés, feldolgozás, reprodukálás) területén szlovén és magyar diákok szintén az EU-átlagot meghaladó eredményt értek el, Ciprus ennél gyengébbet.

- A természettudományok területén történt felmérés a társultak részéröl már az EU-átlag alatti eredményeket hozott, ám nagy szórással. Míg Ciprus, Lettország, valamint Litvánia, de még Románia is jelentékenyen az EU-átlag alatt teljesített, addig Magyarországon, Csehországban, Szlovéniában, Bulgáriában, Szlovákiában az eredmények a legjobb EU-tagállamok (Hollandia, Ausztria, Anglia) szintjét érték el.

\section{IV/6.3. Idegennyelv-ismeret}

Fontos modernizációs tényezőnek tekinthető a nyelvtanulási hajlam, illetve képesség, amit nehéz azonos nyelvvizsga-rendszer szerint objektív mércével mérni, ezért csak az iskolai nyelvtanítás alapján tudunk ennek szerepére következtetni. 
IV/6.3. sz. táblázat: A középiskolai nyelvtanulás föbb mutatói a tagjelölt országokban (diákok százalékában)

(1996-97)

\begin{tabular}{|l|c|c|c|c|c|}
\hline \multicolumn{1}{|c|}{ Ország } & $\begin{array}{c}\text { Idegen nyelvek } \\
\text { átlagos száma }\end{array}$ & Angol & Német & Francia & Orosz \\
\hline Bulgária & 1,3 & 59 & 20 & 18 & 29 \\
\hline Csehország & 1,1 & 58 & 53 & 3 & 0 \\
\hline Észtország & 2,1 & 82 & 35 & 2 & 59 \\
\hline Magyarország & 1,2 & 49 & 50 & 4 & 3 \\
\hline Lettország & 1,5 & 75 & 32 & 2 & 36 \\
\hline Litvánia & 1,7 & 68 & 33 & 8 & 57 \\
\hline Lengyelország & 1,7 & 75 & 54 & 15 & 23 \\
\hline Románia & 1,5 & 51 & 9 & 74 & 14 \\
\hline Szlovákia & 1,4 & 63 & 61 & 4 & 8 \\
\hline Szlovénia & 1,2 & 82 & 35 & 1 & 0 \\
\hline
\end{tabular}

Forrás: Eurostat, [1998]

Mint látható, a tagjelöltek is elindultak az orosz nyelv dominanciája után - ettöl a kommunizmus éveiben Szlovénia és talán Románia volt mentes - az európai nyelvek felé, bár az idegen nyelvek átlagos számát tekintve két európai nyelv általános oktatása még nem tudott beépülni a középiskolák tanrendjébe. Az angol nyelv fokozatos térnyerése szembetűnő, valamint az is, hogy a románok kivételével praktikus okokból a német a második legfontosabb nyelv és nem a francia. Ez az új belépő országok nyelvi orientációja mellett a kulturális és társadalmi kötődést, valamint a gazdasági (turisztikai) kapcsolatokat is jelzi.

\section{IV/6.4. Anyagi és technikai ráfordítások}

Érdemes megvizsgálni, hogy az illető országok nemzeti jövedelmük mekkora hányadát fordítják oktatásra, hiszen ez az arány reálisabban mutatja meg a ráfordításokat, mint a gazdasági fejlődéstől függő abszolút számok. 
IV/6.4. sz. táblázat: A GNP-böl közoktatásra fordított hányad

\begin{tabular}{|l|c|c|}
\hline \multicolumn{1}{|c|}{ Ország } & $\begin{array}{c}\mathbf{1 9 8 0} \\
\text { (százalék) }\end{array}$ & $\begin{array}{c}\mathbf{1 9 9 7} \\
\text { (százalék) }\end{array}$ \\
\hline Ausztria & 5,5 & 5,4 \\
\hline Belgium & 6,0 & 3,1 \\
\hline Bulgária & 4,5 & 3,2 \\
\hline Csehország & - & 5,1 \\
\hline Dánia & 6,7 & 8,1 \\
\hline Észtország & - & 7,2 \\
\hline Finnország & 5,3 & 7,5 \\
\hline Franciaország & 5,0 & 6,0 \\
\hline Németország & - & 4,8 \\
\hline Görögország & 2,0 & 3,1 \\
\hline Magyarország & 4,7 & 4,6 \\
\hline Írország & 6,3 & 6,0 \\
\hline Olaszország & - & 4,9 \\
\hline Lettország & 3,3 & 6,3 \\
\hline Litvánia & - & 5,4 \\
\hline Hollandia & 7,7 & 5,1 \\
\hline Lengyelország & - & 7,5 \\
\hline Portugália & 3,8 & 5,8 \\
\hline Románia & 3,3 & 3,6 \\
\hline Szlovákia & - & 5,0 \\
\hline Szlovénia & - & 5,7 \\
\hline Spanyolország & 2,3 & 5,0 \\
\hline Svédország & 9,0 & 5,3 \\
\hline Egyesült Királyság & 5,6 & 4,1 \\
\hline Luxemburg & 5,7 & \\
\hline
\end{tabular}

Forrás: Világbank, WDI [2000/2001], UNESCO Statisztikai Évkönyv, [1998]

Jól látható, hogy a tagjelölt országok ebben a viszonylatban is kiállják a próbát, hiszen gyakorlatilag mindegyikük meghaladja a görögök $(3,1)$ közoktatásra fordított forrásait, bár a skandináv $(7,5-8,3)$ modelltől nyilvánvalóan elmaradnak. Különösen az észtek $(7,2)$, a lengyelek $(7,5)$, lettek $(6,3)$ ráfordításai magasak. (Tanulságos az is, hogy az utóbbi tíz évben gazdasági csodát elért Írország is magas GNP-hányadot fordított a közoktatásra.) Alacsony szint mindössze a románoknál $(3,6)$ és a bolgároknál $(3,2)$ tapasztalható. A tagjelölt országokban változatlan ráfordítás figyelembe véve a gyors gazdasági növekedés biztosította lehetőségeket - garanciát ad arra, hogy a felzárkózás a lakosság képzettsége terén is biztosított legyen.

A képzettség színvonalához technikai oldalon kapcsolódó mutató, hogy hány tanulóra jut egy számítógép a tagállamokban, illetve a jelölteknél. Ez természetesen fenntartásokkal fogadható információ, hiszen nem tudhatjuk, hogy ezek a gépek 
milyen teljesítményűek, milyen korúak, mennyire modernek (Internet kapcsolat) stb., de magát a használati készséget jól jelzik. Az Európai Bizottság 1995-ös és 1998-as felmérése jól mutatja, hogy 1998-ra a tagállamokban - ahonnan pontos adatszolgáltatás érkezett - már jóval 20 alá esett az egy gépre eső diákok száma, míg a tagjelölteknél is jelentősen csökkent ez a szám: míg például Bulgária, Ciprus és Románia esetében több száz diákra jutott egy számítógép, addig Magyarországon és Szlovéniában már 30 alá esett, és az adatokat szolgáltató csehek esetében is megközelítette a harmincat. Az EU-tagállamok legtöbbje már beépítette iskolai rendszerébe az informatikai ismereteket (ez alól csak Portugália és Olaszország volt kivétel), illetve több országban ezt már más tantárgyak eszközéül is használják a tanrendben (Norvégia vagy Izland mellett a tagok közül Svédország, Írország, de a tagjelöltek közül Lettország és Észtország is).

\section{RÉSZ; 7. FEJEZET \\ KUTATÁS ÉS FEJLESZTÉS}

A régió hagyományosan magas müszaki kultúrával rendelkezik. Ezt támasztja alá a kiemelkedő fejlesztések sora - Skoda cég vagy az Egyesült Izzó -, melyek megfelelő versenyképességgel rendelkeztek. Emellett az elméleti kutatásokban is kimagasló sikereket tudtak elérni a régióban nevelődött kutatók, elég ha csak Madame Curie, Szilárd Leó vagy Neumann János nevét említjük. Igaz ők a világhírnevet már nem a régióban érték el, hanem az európai vagy amerikai kutatási centrumokban, de a hazai iskolarendszer nevelte ki és indította útra őket. A XX. században 12 magyar származású Nobel-díjas tudóst tartanak számon, melyböl 10 fő a természettudományok terén alkotott kimagaslót. (Külügyminisztérium, [2001])

A kutatási témakör vizsgálatának azért is van nagy szerepe, mert Európa számára a kutatási programok integráltsága alapvető fontosságú a többi nagy pólusokkal amerikai földrész, illetve a dél-kelet ázsiai terület és Japán - szemben vívott harcban. Nem véletlen, hogy már 1998-ig is lényeges programok - 4. Kutatási és Fejlesztési Keretprogram, Euréka, Cost stb. - indultak be, amelyekhez fejlett partnerek - pl. Izrael, Norvégia, Svájc - is csatlakoztak, de a jelölt országok részéről is komoly 
érdeklődés mutatkozott meg. A minél szélesebb európai kutatási térség kialakítása nemcsak az ipari szférában, vagy a szolgáltatásoknál - pl. közlekedés, Airbus, Galileo müholdprogram - jelent fontos elemet az európai kontinensnek, hanem a hadiipari és logisztikai fejlesztések számára is, melynek fontosságát a kibontakozó védelmi dimenzió, a Nyugat-Európai Védelmi Csoport - WEAG - adja meg, amely a fejlesztések, beszerzések koordinálását lesz hivatott müködtetni.

\section{IV/7.1. A jelölt országok kutatói életének néhány objektív mércéje}

Bár a jelölt országok jelentős szellemi kapacitással rendelkeznek, de ezeket úgy kell felhasználni, hogy a modern kor kihívásainak és az európai elvárásoknak is megfeleljenek. Az EU Bizottság 1997-ben megfogalmazott hatástanulmánya szerint a jelölt országokra az RTD tevékenység (kutatási és fejlesztési) háttérbe szorulása, a kutatói túlkínálat, valamint az alkalmazott kutatási tevékenység hiányos volta, a kutatás és termelés nem megfelelő kapcsolata jelenti a fő problémát egy egységes európai kutatási térségbe való bekapcsolódáshoz.

A tagjelölt országok kutatási tevékenységre fordított forrásai abszolút összegben jelentősen elmaradnak az EU-hoz képest, mivel 1998-ban az EU hasonló ráfordításainak csak 1,9 százalékát költötték erre a célra, ami messze elmarad nemcsak az EU-hoz mért lakosságszámtól (28 százalék), hanem a tagjelöltek folyó áron mért GDP-jének EU-hoz mért arányától $(4,4)$ is. (Eurostat, [2000]). Országokra lebontva látható, hogy Csehország és Szlovénia relatív $\mathrm{K}+\mathrm{F}$ ráfordítása egy százalék feletti (lásd IV/7.1. sz. táblázat), ami magasabb, mint a tagállamok közül Görögország $(0,5)$, Portugália $(0,6)$, Spanyolország $(0,9)$ vagy Olaszország $(1,0)$ mutatója, de alacsonyabb, mint az EU-átlag $(1,9)$. A relatív ráfordítás nagyon alacsony Románia $(0,5)$ és Lettország $(0,5)$ esetében. 
IV/7.1. sz. táblázat: Föbb kutatási mutatószámok a tagállamokban és a tagjelölteknél a 90-es évek közepén

\begin{tabular}{|l|c|c|c|c|c|}
\hline \multicolumn{1}{|c|}{ Ország } & $\begin{array}{c}\text { K+ F } \\
\text { (GNP } \\
\text { százalé- } \\
\text { kában) } \\
\mathbf{( 1 9 9 8 )}\end{array}$ & $\begin{array}{c}\text { Az üzleti } \\
\text { szektor } \\
\text { hozzájárulása } \\
\text { (százalék) }\end{array}$ & $\begin{array}{c}\text { Oktatás } \\
\text { (GNP } \\
\text { százalé- } \\
\text { kában) }\end{array}$ & $\begin{array}{c}\text { Tudósok és } \\
\text { mérnökök } \\
\text { száma } \\
\text { egy millióón } \\
\text { före }\end{array}$ & $\begin{array}{c}\text { Tudósok és } \\
\text { kutatók } \\
\text { aránya } \\
\text { a lakosság } \\
\text { százalékában }\end{array}$ \\
\hline Ausztria & 1,8 & 55,4 & 5,4 & 1.631 & 0,5 \\
\hline Belgium & 1,8 & 73,6 & 3,1 & 1.814 & 1,2 \\
\hline Dánia & 1,9 & 63,9 & 8,1 & 2.647 & 1,0 \\
\hline Finnország & 2,9 & 70,0 & 7,5 & 2.812 & 0,7 \\
\hline Franciaország & 2,2 & 59,8 & 6,0 & 2.584 & 1,1 \\
\hline Németország & 2,4 & 64,4 & 4,8 & 2.843 & 0,5 \\
\hline Görögország & 0,5 & 53,1 & 3,1 & 774 & 0,4 \\
\hline Írország & 1,4 & 77,8 & 6,0 & 1.871 & 0,3 \\
\hline Olaszország & 1,0 & 48,9 & 4,9 & 1.325 & 0,6 \\
\hline Portugália & 0,6 & 31,7 & 5,8 & 1.185 & 0,1 \\
\hline Svédország & 3,8 & 73,2 & 8,3 & 3.714 & 0,9 \\
\hline Spanyolország & 0,9 & 61,3 & 5,0 & 1.210 & 0,3 \\
\hline Egyesült Kir. & 1,8 & 68,9 & 5,3 & 2.417 & 0,4 \\
\hline Hollandia & 2,0 & 61,0 & 5,1 & 2.656 & 0,5 \\
\hline Bulgária & 0,6 & 18,7 & 3,2 & 1.742 & 0,4 \\
\hline Csehország & 1,3 & 64,6 & 5,1 & 1.159 & 0,6 \\
\hline Észtország & 0,6 & 19,6 & 7,2 & 2.018 & 0,2 \\
\hline Magyarország & 0,7 & 38,4 & 4,6 & 1.033 & 0,5 \\
\hline Litvánia & 0,6 & 1,8 & 5,4 & 2.021 & 0,3 \\
\hline Lengyelország & 0,7 & 41,5 & 7,5 & 1.299 & 0,4 \\
\hline Románia & 0,5 & 76,7 & 3,6 & 1.382 & 0,4 \\
\hline Lettország & 0,5 & 21,0 & 6,3 & 1.189 & 0,3 \\
\hline Szlovénia & 1,4 & 53,0 & 5,7 & 2.544 & 0,4 \\
\hline Szlovákia & 0,9 & 65,8 & 5,0 & 1.821 & 0,4 \\
\hline EU-átlag & $\mathbf{1 , 9}$ & $\mathbf{6 3 , 7}$ & - & - & - \\
\hline & & & & & \\
\hline
\end{tabular}

Forrás: Second European Report on Science and Technology-indicators [1997], Európai Bizottság Kutatási Főigazgatósága, [2000], WDI [2000], Eurostat, [2000]

Megjegyzés: Az üzleti szféra $\mathrm{K}+\mathrm{F}$-hez való hozzájárulásának hányada a tagállamoknál minden kormányzati forráson kívüli hozzájárulást magába foglal.

A kutatás-fejlesztésre fordított források visszaesésének köszönhetően a 90-es évek első felében csökkent a kutatásban és fejlesztésben részt vevők száma a tagjelölt országokban, különösen a kutatási eredmények alkalmazásához szükséges technikusok, alkalmazó kutatók száma alacsony. Az egyik modernkori kihívás az elméleti kutatás és a gazdasági alkalmazás közötti szakadék áthidalása. Ez összefügg azzal is, hogy a privatizáció során magánkézbe került vállalatok nemzetközi munkamegosztásba való bekapcsolódása nem járt a kutatási bázisok áttelepülésével, vagyis a közép- és kelet-európai országok vállalatai beszállítói funkciót töltöttek be, 
ami nem igényli a magas szintủ vállalati kutatói munkát és gátja a magas müszakitermelői kultúra kialakulásának. A kilencvenes évek közepén (lásd: IV/7.1. sz. táblázat) a fenti tendencia miatt a magasan képzett müszaki kutatók és alkalmazó személyek aránya a tagjelöltek lakosságán belül általában alacsonyabb hányadot képviselt, mint a tagállamok nagy részében. Európai összehasonlításban is jó volt a mutatója Csehországnak és Magyarországnak, melyek nemcsak a mediterrán tagállamokhoz képest, hanem az Egyesült Királyság, Ausztria és Németország szintjéhez is mérhető. A Eurostat adatai szerint 1994-98 között a Cseh Köztársaságban (21,2 százalékos), Lengyelországban (8,8 százalékos) és Magyarországon (3,8 százalékos) nőtt a $\mathrm{K}+\mathrm{F}$ területén alkalmazottak száma - az EU-ban ebben az időszakban 3,7 százalékkal nőtt -, míg a többi társult országban ez idő alatt is csökkenés volt észlelhető (Bulgáriában, Lettországban vagy Romániában meghaladta a tíz százalékot). (Eurostat, [2000])

Mint a IV/6.3. sz. táblázat elemzésénél (a GNP-ből közoktatásra fordított hányad) említettem, a tagjelölt országok közoktatásra fordított forrásai általában megfelelnek az európai átlagnak és a prognosztizált gyors gazdasági növekedés (lásd: V/1. fejezet) révén ez a hányad remélhetően csak javulni fog, ami a kutatásra fordítható forrásokat is növelni fogja.

A $\mathrm{K}+\mathrm{F}$ tevékenységre fordítandó források növelése szempontjából lényeges, hogy az üzleti szektor milyen hányadban veszi ki részét az erre fordítandó költségekből. Csehországban, Szlovákiában és Romániában az üzleti szektor hozzájárulása meghaladja az EU-átlagot (lásd: IV/7.1. sz. táblázat), de a portugál mutatónál jobb a magyar és a szlovén szint, sőt ez utóbbi az olasz és a spanyol üzleti szektor hozzájárulás mértékét is eléri.

\section{IV/7.2. Elméleti képzettség}

A tagjelölteknek a világ tudományos életében betöltött szerepére az elméleti kutatások erejét mérendő két fontos mutatót választottam ki, az idézettségi mutatót (a nemzetközi szakirodalomban az adott ország szerzőinek mások által történő meghivatkozásának száma), illetve a bejegyzett szabadalmak számát és relatív arányát. 
IV/7.2. sz. táblázat: A tagállamok és a tagjelöltek szellemi teljesitményének szelektív mutatói

\begin{tabular}{|c|c|c|c|c|c|c|}
\hline \multirow{2}{*}{ Ország } & \multirow{2}{*}{$\begin{array}{c}\text { Lakosság } \\
1998 \\
\text { (millió fó) }\end{array}$} & \multirow{2}{*}{$\begin{array}{c}\text { Idézetek } \\
\text { száma } \\
\text { (1993) }\end{array}$} & \multirow{2}{*}{$\begin{array}{c}\text { Idézetek } \\
1 \text { millió } \\
\text { före } \\
\text { százalék }\end{array}$} & \multicolumn{2}{|c|}{$\begin{array}{c}\text { Szabadalmi kérelmek } \\
\text { száma (1997) }\end{array}$} & \multirow{2}{*}{$\begin{array}{l}\text { Szabadalmak } \\
\text { I millió fóre }\end{array}$} \\
\hline & & & & Összesen & $\begin{array}{c}\text { Ebből } \\
\text { rezidens }\end{array}$ & \\
\hline Belgium & 10,19 & 27.171 & 2.666 & 86.645 & 1.687 & 8.503 \\
\hline Dánia & 5,29 & 25.289 & 4.781 & 109.061 & 2.658 & 20.616 \\
\hline Németország & 82,05 & 179.847 & 2.192 & 175.595 & 62.052 & 2.140 \\
\hline Görögország & 10,51 & 5.143 & 489 & 82.443 & 53 & 7.844 \\
\hline Spanyolország & 39,34 & 37.539 & 954 & 113.767 & 2.856 & 2.892 \\
\hline Franciaország & 58,72 & 134.101 & 2.284 & 112.631 & 18.669 & 1.918 \\
\hline Írország & 3,69 & 3.930 & 1.065 & 83.430 & 946 & 22.610 \\
\hline Olaszország & 57,56 & 70.677 & 1.228 & 91.410 & 2.574 & 1.588 \\
\hline Luxemburg & 0,42 & 65 & 155 & na & - & - \\
\hline Hollandia & 15,65 & 64.391 & 4.114 & 90.629 & 5.227 & 5.791 \\
\hline Ausztria & 8,17 & 16.400 & 2.007 & 111.224 & 2.681 & 13.614 \\
\hline Portugália & 9,95 & 2.868 & 288 & 106.687 & 92 & 10.722 \\
\hline Finnország & 5,14 & 19.035 & 3.703 & 109.437 & 4.061 & 21.291 \\
\hline Svédország & 8,84 & 47.313 & 5.352 & 115.000 & 7.893 & 13.009 \\
\hline Egyes. Kir. & 59,09 & 224.990 & 3.808 & 148.209 & 26.591 & 2.508 \\
\hline Csehország & 10,28 & 5.591 & 544 & 30.577 & 601 & 2.974 \\
\hline Szlovákia & 5,39 & 2.102 & 390 & 28.207 & 234 & 5.233 \\
\hline Magyarország & 10,09 & 6.938 & 688 & 30.105 & 774 & 2.984 \\
\hline Lengyelország. & 38,66 & 11.893 & 308 & 32.538 & 2.401 & 842 \\
\hline Bulgária & 8,23 & 1.992 & 242 & 28.000 & 400 & 3.402 \\
\hline Románia & 22,48 & 1.140 & 51 & 29.055 & 1.709 & 1.292 \\
\hline Litvánia & 3,70 & $n a$ & - & 26.798 & 125 & 7.242 \\
\hline Észtország & 1,45 & $n a$ & - & 26.644 & 18 & 18.375 \\
\hline Lettország & 2,43 & $n a$ & - & 27.023 & 163 & 11.121 \\
\hline Szlovénia & 1,97 & $n a$ & - & 27.447 & 285 & 13.932 \\
\hline
\end{tabular}

Forrás: EU Bizottság, [1997], World Development Index, [2000], saját számítások

A nemzetközileg is elismert tudományos eredmények terén igen jelentős a társult országok ereje, hiszen a cseh és a magyar relatív idézettségi mutatók már a kilencvenes évek első felében meghaladják nemcsak a kicsinyke (és így szerény kutatói élettel rendelkező) Luxemburgot, de Portugáliát és Görögországot (lásd: IV/7.2. sz. táblázat), és a magyar szerzők idézettsége már ekkor hasonlítható volt a spanyolokéhoz. Amennyiben a szabadalmi kérelmek számát vesszük figyelembe, a lemaradás még nyilvánvaló. Ha a rezidens szabadalmi kérelmek számát vizsgáljuk, akkor a magyarok, a csehek, a lengyelek és románok nemcsak a portugál és a görög mértéket verik magasan, hanem pl. a spanyolokéhoz is mérhetők. Ha lakosságszámhoz viszonyítjuk a szabadalmi kérelmek számát, akkor a közép-európai tagjelöltek mutatói alacsonyak a baltiakat kivéve. 
$\mathrm{Az}$ ún. függőségi mutatót tekintve (hazai és külföldi eredetű szabadalmak bejegyzésének aránya az adott országban) Lengyelország, Csehország és Magyarország jobb eredményeket ért el, mint pl. Dánia, Belgium vagy Írország. Magyarország például ebben megelőzi az osztrákokat is. Hasonló helyzetet lehetne kimutatni a világ publikációs statisztikájában az új tagjelöltek és a már tagok között. Így például 1995-ben a cseh (2609) vagy a magyar (2582) nemzetközi publikációk száma meghaladta vagy elérte a hasonló lélekszámú portugál (1359), vagy görög (2650) publikációk számát, de elmaradt a belga (7129) vagy az osztrák (4585) mutatótól. Ez tovább erősíti azt, hogy a társult országok tudományos élete az EU kohéziós országokéval összemérhető, ugyanakkor a társultak között Magyarország, Csehország és néhány esetben Lengyelország kiemelkedik a többi tagjelölt közül (EU Bizottság, Second European Report on S\&T Indicators, [1997]). Tekintve, hogy a legtöbb országban a fenti elemzésben szereplő valamennyi mutató erősítése a célok között szerepel, ez serkentőleg hat a felzárkózás ütemére.

\section{IV/7.3. Az informatikai terület sajátosságai}

Az informatika világméretü térhódítása a közép- és kelet-európai tagjelölt országokat sem kerüli el, elengedhetetlen, hogy aktív részesei legyenek a kilencvenes évek közepén meghirdetett európai információs társadalom akció tervének. A 2000-ben Lisszabonban elindított folyamat, mely a belső piac kiteljesedése mellett a tudásalapú társadalom kiépítését célozza, kiemelt hangsúlyt helyez az európai közös informatikai térség megfelelő kiépítésére is. Az ebből a célból elindított közösségi programok (eContent, eGovernement, IDA) már 2001-től megnyíltak a tagjelölt országok számára. Az európai informatikai rendszerbe történő integrálódás legfontosabb feltétele az, hogy a tagjelölteknél megoldódjon az elérhetőség aktív és passzív válfaja, lehessen szolgáltatni, illetve kapcsolatba kerülni.

A tagság legfontosabb eredménye az lesz, hogy az EU szabályozók szerint a társult országokban megvalósul az informatikai (telekommunikációs) piac teljes szabadsága. Ez az EU belső piacán már megoldottnak tekinthető, sőt ezen a téren a térségbeli államok jelentős előrehaladást értek el, mivel az évtized folyamán nagy lemaradást faragtak le hátrányukból. Ám az eltérő jövedelmi és költségviszonyok 
miatt az aspiráns országokban a telekommunikációs szolgáltatások kiépítésének és használatának költsége még a liberalizációs verseny hamarosan beálló volta ellenére is lényegesen magasabb, mint az európai uniós országokban, ami korlátot szab annak, hogy utolérésről beszéljünk. Egyidejüleg az is tény, hogy a telekommunikációs kapcsolatok elterjedése több jelölt esetében jónak mondható egyre nagyobb teret kap az új softwerek kifejlesztése az írekhez hasonlóan -, ami a szellemi felkészültség oldaláról jelzi a megfelelő felzárkózási igényt a jelöltek részéröl.

IV/7.3. sz. táblázat: Informatikai mutatószámok a tagjelölteknél és a kohéziós tagállamoknál

\begin{tabular}{|l|c|c|c|c|c|}
\hline Ország & $\begin{array}{c}\text { Vezetékes } \\
\text { telefonvonalak } \\
\text { száma /ezer fón } \\
\text { (1999) }\end{array}$ & $\begin{array}{c}\text { Telefon- } \\
\text { vonalak } \\
\text { száma } \\
\mathbf{( 1 9 9 9 / 1 9 9 4 )}\end{array}$ & $\begin{array}{c}\text { Mobil- } \\
\text { telefonszám// } \\
\text { ezer fó, } \\
\mathbf{( 1 9 9 9 )}\end{array}$ & $\begin{array}{c}\text { Internet } \\
\text { host } \\
\text { /ezer fó } \\
(\mathbf{1 9 9 9 )}\end{array}$ & $\begin{array}{c}\text { Internet } \\
\text { használók } \\
\text { /száz fó } \\
\text { (1999) }\end{array}$ \\
\hline Bulgária & 344 & 1,30 & 43 & 2 & 2,9 \\
\hline Csehország & 370 & 2,34 & 189 & 12 & 6,8 \\
\hline Észtország & 353 & 1,59 & 268 & 21 & 13,8 \\
\hline Magyarország & 407 & 4,13 & 161 & 12 & 6,0 \\
\hline Lettország & 314 & 1,18 & 90 & 4 & 4,3 \\
\hline Litvánia & 300 & 1,49 & 112 & 8 & 2,8 \\
\hline Lengyelország & 260 & 3,06 & 102 & 4 & 5,4 \\
\hline Románia & 166 & 1,58 & 62 & 2 & 2,7 \\
\hline Szlovákia & 307 & 2,33 & 170 & 5 & 11,1 \\
\hline Szlovénia & 381 & 1,80 & 310 & 12 & 12,6 \\
\hline Spanyolország & 418 & $1,09^{*}$ & 312 & 12 & 7,0 \\
\hline Görögország & 533 & $1,09^{*}$ & 314 & 7 & 7,0 \\
\hline Portugália & 424 & $1,18^{*}$ & 468 & 8 & 7,0 \\
\hline EU & 536 & $1,10^{*}$ & 391 & 23 & 14,9 \\
\hline
\end{tabular}

Forrás: Eurostat, [2001], saját számítás

Megjegyzés: * 1999/1995

A IV/7.3. sz. táblázatból megállapítható, hogy a társult országok felzárkózása az informatikai mutatók tekintetében meglehetősen nagy ütemben zajlik. Az eltérő jövedelmi viszonyok miatt (magasabb relatív költségek) még nem érték utol a tagállamok átlagának teljesítményét, de a görög, portugál számadatokhoz viszonyítva nagy a felzárkózás. Az a következtetés is megengedhető, hogy olyan infrastrukturális fejlesztés, mely esetében nem kell évtizedes lemaradást pótolni (ilyen a mobiltelefon használata, illetve az internet-hozzáférés), a csatlakozni kívánó országok zöme azonnal adaptív volt a fejlődésre, vagyis nem kellett megvárniuk a szerves fejlődés 
lépcsőit. Ez jól illusztrálja a modernizációs igény megjelenését, illetve a mediterrán országokhoz hasonló, vagy azokat megelőző modern informatikai integrálódási képességeket.

Az új telekommunikációs technikák, mint az Internet alkalmazása terén a tagjelöltek egy része - Észtország, Szlovákia, de Magyarország, Csehország és Lengyelország is - jelentős fejlődést mutat fel. Az Interneten történő szolgáltatói megjelenésben mely nem annyira függ a gépek relatív (jövedelmek szerinti) árától - kimagasló szintet nyújtanak, megelőzve több európai uniós tagot is (pl. Észtország és Szlovénia nemcsak a három mediterrán tagállamot, hanem Olaszországot is felülmúlja.) Ezzel szemben több társult országban (Románia, Bulgária, Lettország, Litvánia) a felzárkózás még várat magára, ami a modern szolgáltatási formákra való fogékonyság vagy gazdasági képesség változó szintjét jelzi. A mobiltelefon használatában közelítik vagy lépést tartanak az európai átlaggal.

A modern telekommunikációs formák EU-piacának bővülése a csatlakozás után nem GDP-arányos (mintegy 4-5 százalékos) lesz, hanem közelebb esik a lakosság számában bekövetkező növekedéshez (mintegy 28 százalék), ami a belső piacon a jelenlegi EU telekommunikációs vállalatok számára szignifikáns további piacot nyit.

\section{IV/7.4. A tagjelöltek K + F tevékenysége integrálódásának eddigi eredményei}

A csatlakozni kívánó országok 1999-ben megkapták a lehetőséget arra, hogy pályázatokat nyújtsanak be az $5 . \mathrm{K}+\mathrm{F}$ keretprogram égisze alatt meghirdetett együttmüködési programba. Az alábbiakban ismertetem az EU Bizottsága 2000. március 31-ig bezárólag elkészített kimutatását a tagjelöltek e programba történő bekapcsolódásának eredményeiről. 
IV/7.4. sz. táblázat: Az EU 5. K+F programjába történö bekapcsolódás fóbb mutatói

\begin{tabular}{|l|r|r|r|r|r|r|}
\hline \multirow{2}{*}{ Ország } & \multicolumn{2}{|c|}{ Pályázat } & \multicolumn{2}{|c|}{ Szerződés } & \multirow{2}{*}{$\begin{array}{c}\text { Sikerarány } \\
\text { (százalék) }\end{array}$} & $\begin{array}{c}\text { Pályázat } \\
\text { millió före) }\end{array}$ \\
\cline { 2 - 5 } & \multicolumn{1}{|c|}{ Db } & \multicolumn{1}{c|}{$\mathbf{\%}$} & \multicolumn{1}{c|}{ Db } & \% & & \\
\hline Bulgária & 377 & 0,42 & 11 & 0,10 & 2,92 & 45,8 \\
\hline Csehország & 865 & 0,95 & 85 & 0,74 & 9,83 & 84,0 \\
\hline Észtország & 201 & 0,22 & 14 & 0,13 & 6,97 & 139,1 \\
\hline Magyarország & 959 & 1,05 & 73 & 0,64 & 7,61 & 95,0 \\
\hline Lettország & 170 & 0,19 & 6 & 0,06 & 3,53 & 69,7 \\
\hline Litvánia & 136 & 0,15 & 8 & 0,07 & 5,88 & 36,7 \\
\hline Lengyelország & 1173 & 1,29 & 93 & 0,81 & 7,93 & 30,3 \\
\hline Románia & 403 & 0,45 & 15 & 0,13 & 3,72 & 17,9 \\
\hline Szlovákia & 329 & 0,36 & 26 & 0,23 & 7,90 & 61,0 \\
\hline Szlovénia & 434 & 0,48 & 46 & 0,40 & 10,60 & 219,4 \\
\hline Málta & 19 & 0,02 & 2 & 0,02 & 10,53 & 50,5 \\
\hline Ciprus & 150 & 0,17 & 13 & 0,12 & 8,67 & 226,3 \\
\hline Összesen: & $\mathbf{5 2 1 6}$ & $\mathbf{5 , 7 2}$ & $\mathbf{3 9 2}$ & $\mathbf{3 , 4 1}$ & $\mathbf{7 , 5 2}$ & $\mathbf{5 0 , 2}$ \\
\hline EU-15, ebböl & 76267 & 83,58 & 10347 & 89,87 & 13,57 & 203,6 \\
\hline \multicolumn{1}{|c|}{ Portugália } & 1870 & 2,05 & 195 & 1,70 & 10,43 & 187,8 \\
\hline Görögorsz. & 3502 & 3,84 & 391 & 3,40 & 11,17 & 333,1 \\
\hline \multicolumn{1}{|c|}{ Spanyolo. } & 6440 & 7,06 & 734 & 6,38 & 11,40 & 163,6 \\
\hline Teljes & $\mathbf{9 1 2 6 0}$ & $\mathbf{1 0 0 , 0 0}$ & $\mathbf{1 1 5 1 4}$ & $\mathbf{1 0 0 , 0 0}$ & $\mathbf{1 2 , 6 2}$ & - \\
\hline
\end{tabular}

Forrás: EU Bizottság, Kutatási Főigazgatósága, [2000]

Megjegyzés: Sikerarány: szerződések a beadott pályázatok százalékában

Táblázat utolsó sora: Tagjelöltek + EU-15 + Egyéb harmadik országok

A társult országok pályázati aktivitása az új lehetőségek ismeretének és technikájának jártassága hiányában kisebb, mint az EU-átlag, ahol 1 millió lakosra 204 pályázat jut, míg a társultaknál csak 50 pályázat (lásd: IV/7.4. sz. táblázat). Ugyanakkor a csatlakozni kívánó országok közül Szlovénia (219) és Ciprus (226) az EU-átlagot meghaladva megelőz jó néhány tagállamot. Ugyancsak a pályázati rutin hiányával magyarázható, hogy a társult országok a benyújtott pályázataik arányánál (5,72 százalék) kisebb arányban részesültek a győztes pályázatokból (3,41 százalék). Az uniós sikerarányhoz (13,57 százalék) képest a társult országok csak a beadott pályázatok 7,52 százalékánál tudtak szerződést kötni. Figyelemre méltó, hogy Szlovénia nemcsak a pályázati aktivitásban, hanem szerződésekben is testet öltő eredményeket ért el (10 százalék körüli sikerarány). Magyarország és Lengyelország magas pályázati aktivitását $(1,05$ és 1,29$)$ már nem követte a Szlovénokhoz hasonló szerződéskötés $(7,61$ és 7,93). 
A tagjelölt országok európai integrációját segíti elő az is, hogy számukra a kutatási együttmüködés erősítése céljából ún. kitünőségi központokat (Centre of Excellence) hoztak létre (általában egyetemeken vagy kutató intézetekben), amelyeknek nagy szerepük lehet abban, hogy bekapcsolják a tagjelölt országok tudományos életét az európai vérkeringésbe. (Ugyanilyen kitünőségi központok révén fogják a jelenlegi tagállamokban is kialakítani a $6 . \mathrm{K}+\mathrm{F}$ programmal megvalósítandó európai kutatási térség bázisait.) A szigorú pályázati feltételek alapján választották ki a győzteseket, melyek alapján Lengyelországban 9, Magyarországon 6 központot jelöltek ki az EU programokhoz tudományos, kutatási bázisként. A többi tíz tagjelölt országban (Ciprust és Máltát beleértve) további 19 intézet kapta meg ezt az elismerést.

A megvalósuló integráció összességében tagjelöltektől függő mértékben bővíteni fogja az EU tudományos kapacitásait és a modern informatikai eszközök piacán további lehetőségeket fog jelenteni az erre a piacra egyébként már korábban betört befektetőknek.

\section{RÉSZ; 8. FEJEZET A KORRUPCIÓ HELYZETE ÉS A BÜROKRÁCIA ÁLLAPOTA}

\section{IV/8.1. Az állami apparátus súlya, szerepe}

A felvételi kritériumok között szerepel nemcsak az alkalmas jogállami keretek kiépítése, hanem az ország megfelelő adminisztratív kapacitása az EU-tagság jelentette kihívások helyes kezelésére (ún. madridi kritérium, amelyet az 1995. decemberi EU-csúcsértekezlet határozott meg). Ennek keretében megfelelő mennyiségü és minőségü tisztviselőket felvonultató állami szakapparátus felállítása válik szükségessé.

Az állami apparátus létszámát illetően Boeri [2000] megállapította, hogy a 10 középés kelet-európai országban a központi és önkormányzati apparátusokban és a hadseregben alkalmazottak száma a foglalkoztatottakhoz viszonyítva az 1990-es 2,5 százalékról 4 százalékra nőtt 1996 végére. Felmérései szerint számszerűleg ez 20 százalékos növekedést jelent, miközben az üzleti életben körülbelül ugyanilyen 
mértékben csökkent a foglalkoztatottak száma. Mindez nagy létszámú, bár rosszabbul fizetett állami apparátust hozott létre. Az új tagjelölteknek kettős kihívással kell szembenézniük: miközben az EU oldalán a közösségi joganyag alkalmazása miatt a minél nagyobb létszámú apparátust kérik számon a súlyozott helyeken (Magyarországon pl. az OECD plusz tízezer alkalmazottat kér a megfelelő piacgazdasági teljesítményhez), eközben azok a vádak érik a tagjelölt országokat, hogy a szocializmus közismerten túlméretezett apparátusát még tovább növelik, forrásokat vonva el az egészséges gazdasági növekedéstől és a strukturális reformoktól. Ez a kritika annyiban valós, hogy az államilag foglalkoztatottak jelentős strukturális átcsoportosítására van szükség, hiszen bizonyos helyzetekben csökkentésükre (pl. a hadseregben), vagy növelésükre (pl. a független felügyeleti szerveknél, akkreditációs és szabványügyi részlegeken) van szükség. A kibővített belső piac akadálytalan müködésének egyik legfontosabb feltétele az igazságszolgáltatás mennyiségi és minőségi megerősítése, amit a felkészülés során külön prioritásként vizsgál az Európai Bizottság.

\section{IV/8.2. Korrupciós felmérések}

Bár Boeri szerint egy 1998-ban végrehajtott felmérés alapján a térségben csak a lakosság 12 százaléka gondolja úgy, hogy a kormányzati apparátus korrupciótól mentes, célszerű ennek mértékét a leginkább elismert tudományos intézet (Transparency International, TI) felmérése alapján áttekinteni. A TI 1998-ban és 1999-ben felmérte a világ 85 illetve 90 országának korrupciós helyzetét, az illető országgal üzleti vagy egyéb kapcsolatot fenntartók értékelései alapján. E szerint az EU-országok igen jó eredményt értek el (főleg az északi államok), és legtöbbjük az átlagosnál jobb értékelést kapott (lásd IV/8.1. sz. táblázat). Ugyanakkor a társult országok közül a legjobb megítéléssel büszkélkedő Szlovénia is csak 6 pontot kapott a 10 pontos skálán. Igaz, ezzel 1999-ben Észtországgal együtt megelőzte Belgiumot $(5,3)$, valamint a leszakadó Görögországot (4,9 pont), illetve Olaszországot $(4,7$ pont). E két tagjelöltön kívül még Magyarország indexe mondható elfogadhatónak $(5,3)$, míg a csehek $(4,6)$ és a szlovákok $(3,7)$ mutatója a humán fejlettségi mutatóikhoz képest alacsonyabb, a többi társult ország (4 alatti mutatóval) már a harmadik világ meglehetősen kétes tisztaságát tükrözi. 
Megjegyezném, hogy ezek a mutatók nem a különböző bünözési statisztikákon, hanem szubjektív (elöítéletektől sem mentes) értékeléseken alapulnak. Ugyanakkor az is látszik, hogy a csatlakozni kívánók - a törvénykezésben megvalósított lépések, valamint a reálértékben növekvő gazdaság, és így a szintén növekvő közszolgálati fizetések révén - egy év alatt is javítottak helyzetükön.

IV/8.1. sz. táblázat: Korrupciós Érzékelési Index (CPI) (Skála 1-10)

\begin{tabular}{|c|c|c|}
\hline Ország & 1999 & 1998 \\
\hline Dánia & 10.0 & 10.0 \\
\hline Finnország & 9.8 & 9.6 \\
\hline Svédország & 9.4 & 9.5 \\
\hline Hollandia & 9.0 & 9.0 \\
\hline Luxembourg & 8.8 & 8.7 \\
\hline Egyesült Királyság & 8.6 & 8.7 \\
\hline Németország & 8.0 & 7.9 \\
\hline Írország & 7.7 & 8.2 \\
\hline Ausztria & 7.6 & 7.5 \\
\hline Portugália & 6.7 & 6.5 \\
\hline Franciaország & 6.6 & 6.7 \\
\hline Spanyolország & 6.6 & 6.1 \\
\hline Szlovénia & 6.0 & - \\
\hline Észtország & 5.7 & 5.7 \\
\hline Belgium & 5.3 & 5.4 \\
\hline Magyarország & 5.2 & 5.0 \\
\hline Görögország & 4.9 & 4.9 \\
\hline Olaszország & 4.7 & 4.6 \\
\hline Csehország & 4.6 & 4.8 \\
\hline Lengyelország & 4.2 & 4.6 \\
\hline Litvánia & 3.8 & - \\
\hline Szlovákia & 3.7 & 3.9 \\
\hline Törökország & 3.6 & 3.4 \\
\hline Lettország & 2.7 & 3.4 \\
\hline Bulgária & 3.3 & 2.9 \\
\hline Románia & 3.3 & 3.0 \\
\hline
\end{tabular}

Forrás: Transparency International, [2000]

A korrupciós mutató mellett figyelmet érdemel az intézményrendszerek müködésének hatékonysága. Az egyik erre vonatkozó összetett mutató az ún. ICRGteszt (International Country Risk Guide), amely alapján az EBRD 1997-es Transition Report-ban jellemezte a tagságra pályázó országokat. 
IV/8.2. sz. táblázat: Az intézményi minőség terén végzett ICRG teszt néhány tagjelölt országban

$\begin{array}{ll}\text { Bulgária } & 37 \\ \text { Csehország } & 42 \\ \text { Magyarország } & 46 \\ \text { Lengyelország } & 44 \\ \text { Románia } & 34 \\ \text { Szlovákia } & 39 \\ \text { Nyugat-Európa és Japán } & 44\end{array}$

Forrás: EBRD [1997] in: Boeri [2000]

\begin{abstract}
Megjegyzés: A tagjelölteknél a felmérés 1995-ben készült, míg Nyugat-Európa és Japán esetében 1984-ben.

Az ICRG-teszt maximum 49 pontot mutathat, és öt indexet takar széleskörü felmérések alapján: a tulajdonbiztonságot, a jogállamiságot, a kormányok szerződések iránti tiszteletét, a korrupciót a kormányban és a adminisztráció minőségét.
\end{abstract}

A kimutatás szerint a magyar, és a lengyel adminisztráció és intézményi rendszer magas értékelést kapott. Ennek értékét növeli, hogy ezt amerikai módszerekkel maga az EBRD dolgozta ki. A kapott eredmények alapján a kilencvenes évek közepén Magyarország jobb intézményi rendszert tudott felmutatni, mint Nyugat-Európa és Japán tíz évvel korábban. Míg a lengyel és a cseh adminisztráció is megfelelő értéket kapott, addig a román, bolgár és a szlovák adminisztráció ennél jóval gyengébb eredményt mutatott fel.

\title{
IV/8.3. Az EU-források felhasználási képessége
}

A tagjelöltek intézményi rendszerének megítélésénél az EU szempontjából központi kérdés, hogy a közösségi forrásokat a tagjelöltek milyen arányban képesek felhasználni (az ún. közösségi nyelvezetben ezt hívják abszorpciós kapacitásnak). Ezt a tagjelöltek esetében egyelőre a PHARE, míg a tagállamoknál a Strukturális Alapok felhasználásán lehet jól felmérni és összehasonlítani. 
IV/8.3. sz. táblázat: Nemzeti PHARE keretek szerzödéskötési és felhasználási mutatói 1990-98 között, (millió euró)

\begin{tabular}{|l|c|c|}
\hline \multicolumn{1}{|c|}{ Ország } & $\begin{array}{c}\text { Szerződéssel } \\
\text { lekötött rész } \\
(\%)\end{array}$ & $\begin{array}{c}\text { Tényleges } \\
\text { kifizetésre } \\
\text { került összeg } \\
(\%)\end{array}$ \\
\hline Bulgária & 69 & 64 \\
\hline Csehország (93-tól) & 63 & 50 \\
\hline Észtország & 72 & 59 \\
\hline Magyarország & 68 & 66 \\
\hline Lettország & 72 & 56 \\
\hline Litvánia & 73 & 54 \\
\hline Lengyelország & 80 & 72 \\
\hline Románia & 69 & 62 \\
\hline Szlovákia (93-tól) & 59 & 53 \\
\hline Szlovénia & 73 & 59 \\
\hline
\end{tabular}

Forrás: EU Bizottság, [2000], saját számítás

Megjegyzés: Felhasználásra az EU által elkülönített összeg =100

Mint látható a IV/8.3. sz. táblázatból, a PHARE nemzeti alapok változó százalékban kerültek végső felhasználásra, a legjobb abszorpciós kapacitást a lengyel és a magyar apparátus mutatta, mivel az EK költségvetése által elkülönített pénzösszegek kétharmada a PHARE szabályok szerint és az adott időkeretben került felhasználásra. Ebben a vonatkozásban azonban az adminisztrációknak még fejlődést kell mutatniuk, hogy elérjék a jóval nagyobb összegre vonatkozó Strukturális Alapoknál elvárható 70-75 százalékos arányt. (A PHARE 90-es években kb. 1-1,5 milliárd euró nagyságrendü volt, míg a bővítés után az EU költségvetésből a tagjelölteknek Románia és Bulgária nélkül - a teljes támogatás megítélése esetén évi mintegy 23,7 milliárd eurót kell felhasználniuk. Lásd: V/4. fejezet) Amennyiben az EU által elkülönített strukturális pénzeszközöket a tagjelölt országok a tagság után megfelelően fel tudják használni, az új tagok belépése az EU számára is kedvező hatással jár, hiszen a leghatékonyabb módon segíti elő a tagjelöltek gazdasági és társadalmi felzárkózását.

A tagállamoknál vizsgálva a pénzügyi felszívó képességet az 1994-1998 közötti időszakra vonatkozóan megállapítható, hogy uniós szinten a rendelkezésre álló 
strukturális források 80 százalékát kötötték le, és 61 százalék került kifizetésre. (Európai Bizottság, [1998])

Az egyes tagállamok esetében összehasonlításképpen megvizsgáltam az 1 . Célterületen (ez adja ki a strukturális források mintegy kétharmadát) elkülönített, lekötött és kifizetett pénzeszközök arányát 1994-1998 között.

IV/8.4. sz. táblázat: Lekötött és kifizetett pénzeszközök aránya 1994-1998 között

\begin{tabular}{|l|c|c|}
\hline \multicolumn{1}{|c|}{ Ország } & $\begin{array}{c}\text { Szerzödéssel } \\
\text { lekötött rész }\end{array}$ & $\begin{array}{c}\text { Kifizetésre került } \\
\text { rész }\end{array}$ \\
\hline Belgium & 75 & 49 \\
\hline Németország & 84 & 68 \\
\hline Görögország & 82 & 61 \\
\hline Spanyolország & 81 & 66 \\
\hline Franciaország & 63 & 46 \\
\hline Írország & 89 & 74 \\
\hline Olaszország & 73 & 52 \\
\hline Hollandia & 75 & 66 \\
\hline Ausztria & 72 & 52 \\
\hline Portugália & 96 & 72 \\
\hline Egyesült Királyság & 75 & 60 \\
\hline
\end{tabular}

Forrás: A strukturális alapokról kiadott éves jelentés, [1998] Európai Bizottság

Megjegyzés: Mivel a pénzügyi irányelvek 1999-ig tartottak, ezért a tagállamoknál a tényleges kifizetésekre kerülö rész a táblázatban szereplőnél némileg kedvezőbb szintet is mutathat.

Az adatokból világosan kitünik, hogy a közösségi források felszívásának képessége a tagállamoknál még nagyobb, mint az egyébként gazdaságilag jóval kisebb volumenü PHARE alapok esetében a tagjelölteknél. Mindazonáltal az is észrevehető, hogy a hatékonyság az Unióban is változó, néhány régióban (pl. az osztrák Burgenland vagy a tengerentúli francia területek) a kifizetésre került rész még alacsony. Ugyanakkor a kohézió szempontjából összehasonlítható országok (Spanyolország, Portugália, Görögország, volt NDK) a jelenlegi tagállamok számára is példaként szolgálhatnak. 


\section{RÉSZ}

\section{A BŐVÍTÉS ELŐNYEI A GAZDASÁGI TERÜLETEKEN}

\section{RÉSZ; 1. FEJEZET \\ A TAGJELÖLT ORSZÁGOK GAZDASÁGI FEJLETTSÉGE}

A jelenlegi tagállamok közvéleményének és politikusai egy részének megítélése szerint a közép-kelet-európai országok felvétele gazdasági fejletlenségük miatt súlyos károkat okozna a közösségi belső piac müködésében, épp ezért felzárkózásuk komoly anyagi segítséget kívánna meg a tagállamoktól. A gazdasági különbség jelenleg még olyan nagy mértéket mutat, hogy vélemények szerint nem lehet a két fél számára megrázkódtatás nélkül az egyesülést megvalósítani. Az aggodalmak egy része az előkészítés nélküli német egyesítés tanulságaiból származik, hiszen a vártnál nehezebben valósult meg a kelet-német felzárkózás, annak ellenére, hogy a német kormány - és jóval kisebb hányadban az EU költségvetése - jelentős pénzösszegeket fektetett a felzárkóztatásba (1991 és 1998 között Nyugat-Németország nettó 1032 milliárd DEM-et folyósított a keleti tartományokba; Német Statisztikai Hivatal, [1999]). Ezért vizsgálom meg azokat a tényezőket, amelyek az új tagjelölt országok felvétele esetén a német példától eltérőek lehetnek, és amelyek azt igazolják, hogy összeomlástól, vagy a kelet-németekre jellemző nehézségektől nem kell tartani az egyébként nagyon szélsőséges teljesítményt mutató új tagországokban.

\section{V/1.1. Általános gazdasági fejlettség}

A rendszerváltást követően valamennyi országban a megkezdett átalakítás eredményeképpen eltérő mértékü, de jelentős gazdasági visszaesés következett be, amelynek következtében a kilencvenes évek közepére az EU fejlettségéhez mérten mélypontot értek el, felzárkózásuk csak ezután kezdődhetett meg. A sikeres átalakítást végző országok 1999-ban már elérték vagy megközelítették azt a nemzeti jövedelmet, amit 1989-ben, vagyis a szocializmus utolsó évében felmutattak. (Lásd: V/1.1. sz. táblázat.) Hozzá kell ehhez tenni, hogy Lengyelország volt a szóban forgó országok közül az egyetlen, amely lényegében 1980-ban gazdaságilag összeomlott, 
így számára nem 1989 jelentette a történelmi csúcsértéket, ezért a többi vizsgált országnál hamarabb haladta meg gazdasági teljesítménye a rendszerváltás előtti utolsó év eredményeit.

V/1.1. sz. táblázat: A tagjelöltek gazdasági felzárkózása

\begin{tabular}{|l|c|c|c|}
\hline \multicolumn{1}{|c|}{ Ország } & $\begin{array}{c}\text { GDP } \\
\mathbf{1 9 9 9 / 1 9 8 9} \\
(\mathbf{\%})\end{array}$ & $\begin{array}{c}\mathbf{1 9 9 3} \\
\mathbf{E U = 1 0 0} \\
\text { (PPS) }\end{array}$ & $\begin{array}{c}\mathbf{2 0 0 0} \\
\mathbf{E U = 1 0 0} \\
\text { (PPS) }\end{array}$ \\
\hline Bulgária & 71 & 28 & 24 \\
\hline Csehország & 95 & $60 *$ & 60 \\
\hline Észtország & 78 & 32 & 38 \\
\hline Magyarország & 99 & 45 & 52 \\
\hline Lettország & 60 & 25 & 29 \\
\hline Litvánia & 64 & $28 * *$ & 29 \\
\hline Lengyelország & 121 & 33 & 39 \\
\hline Románia & 76 & 30 & 27 \\
\hline Szlovákia & 102 & 40 & 48 \\
\hline Szlovénia & 105 & 62 & 72 \\
\hline
\end{tabular}

Forrás: EGB, [2000], Eurostat [2000-2001]

Megjegyzés: PPS: vásárlóerő-paritás; * 1994;**1995

Az összehasonlító táblázatból látszik, hogy a felzárkózás terén egészen különböző teljesítményt nyújtottak a régió országai. Míg Csehország, Magyarország, Lengyelország, Szlovákia valamint Szlovénia az ezredfordulóra megközelítették vagy utolérték a rendszerváltáskor mért GDP-t - közben természetesen hatalmas szerkezeti átalakításokat hajtottak végre -, addig a többi ország még messze állt ettől. (Az EBRD becslései alapján tudható, hogy a térségben lévő nagyhatalmak Oroszország és Ukrajna - szintén elmaradtak 1989-es termelésükhöz képest.) Ugyanez mondható el az EU átlagos fejlettségi szintjéhez való felzárkózásról is, hiszen csak Szlovénia, Magyarország, Szlovákia és Észtország közelített jelentős mértékben (1993 és 2000 között), a többi ország vagy szinten maradt, vagy leszakadt az Európai Unióhoz képest.

Ugyanakkor, ha figyelembe vesszük, hogy belépésük évében Portugália és Írország, valamint Görögország az EU fejlettségi szintjének mintegy 55-62 százalékát mutatták, és felzárkóztatásuk az első két ország esetében sikeres volt, akkor megállapítható, hogy ezt a szintet az egyébként is dinamikusan fejlődő országok közül a tagságkor Szlovénia, Csehország, Magyarország és esetleg Szlovákia is el 
fogja érni, a többiek azonban ettől messze állnak. Meglepő ebben a vonatkozásban Lengyelország fejletlensége az EU-átlaghoz képest, de az egyébként jó minőségi paraméterekkel rendelkező Észtország is hasonlóan rossz helyzetben van. (Megjegyzem, hogy Szlovénia jelenlegi fejlettségi szintje már meghaladja Görögországét, és lényegében Portugáliához hasonlítható.)

\section{V/1.2. Rejtett gazdaság}

A tényleges gazdasági teljesítmények elemzésénél figyelembe kell venni azt is, hogy az egyes országok gazdasági eredményeiben nem csak a látható, hanem a rejtett gazdaság produkciója is megjelenik. Ezt természetesen nehéz számszerűsíteni hiszen pontosan attól maradt rejtett, hogy közvetlenül nem mérhető -, de becsülni lehet, amelyekre különböző módszereket (modellezési módszerek, készpénzkeresleti módszerek, a háztartási energiafogyasztás alapján) használ a szakirodalom. Itt e témakör részletes elemzése helyett példaként Laczkó Máriának a háztartási energia fogyasztások alapján a rejtett gazdaságról kimutatott adatait érintem. Eszerint 1990ben az uniós tagállamok rejtett gazdaságának aránya 11,0 százalék (Svédország) és 22,9 százalék (Spanyolország) között mozgott. Ugyanez az arány a csatlakozó országok esetében - ex post számítás alapján - általában magasabb volt.

V/1.2. sz. táblázat: Rejtett gazdaság aránya a GDP-ben

\begin{tabular}{|l|c|c|c|}
\hline \multicolumn{1}{|c|}{ Ország } & $\mathbf{1 9 9 2}$ & $\mathbf{1 9 9 8}$ & Változás \\
\hline Bulgária & 32,3 & 34,5 & $+2,2$ \\
\hline Csehország & 29,5 & 19,9 & $-9,6$ \\
\hline Magyarország & 31,8 & 20,8 & $-11,0$ \\
\hline Lengyelország & 31,5 & 13,4 & $-18,1$ \\
\hline Románia & 40,6 & 30,0 & $-10,6$ \\
\hline Szlovákia & 29,6 & 17,0 & $-12,6$ \\
\hline Szlovénia & 33,4 & 18,4 & $-15,0$ \\
\hline Észtország & 41,6 & 28,7 & $-12,9$ \\
\hline Lettország & 45,1 & 40,8 & $-4,3$ \\
\hline Litvánia & 40,4 & 32,5 & $-7,9$ \\
\hline
\end{tabular}

Forrás: Laczkó Mária, [2000], az EBRD és más külföldi szerzők becslései alapján

$\mathrm{Az} \mathrm{V} / 1.2$. sz. táblázatból - minden bizonytalansága ellenére - egyértelmüen leszürhető, hogy a gazdasági reformok előrehaladása - elsősorban a privatizáció, 
állami strukturális és adóreformok - hajtóerőt képez a gazdaság kifehéredéséhez, ebben a korreláció viszonylag nagy biztonsággal kimutatható. A térségbeli országokban a rejtett gazdaság aránya még mindig nagyobbra becsülhető 1998-ban, mint az EU-országokban 1990-ben (11 és 22,9 százalék között). Az is igaz, hogy néhány, a reformokon már átesett tagjelölt ország a felzárkózó kohéziós tagállamok (Portugália, Írország, Spanyolország) 90-es évek elején mért rejtett gazdaságának nagyságánál (20 százalék fölött) alacsonyabb értéket mutatott. Az is szembetünő, hogy a tagjelöltek csoportján belül a fejlettebb és fejletlenebb országok közötti különbség hatalmas, a 30 százalék fölötti arányt mutató rejtett gazdasággal (Baltikum, Bulgária, Románia) nem lehet belépni Európába. Amennyiben azonban az elmaradottabb jelentkezők a rejtett gazdaság kifehérítésében előrelépést tudnak felmutatni, akkor kimutatható GDP-jük magasabb lesz (ami nagyobb adót és járulékfizetést von maga után), bár ettől ők még sokáig elmaradott országok lesznek.

\section{V/1.3. Adósságok}

A csatlakozó országok bruttó és nettó adóssága csökkent a kilencvenes évek folyamán, ami a gazdasági növekedésre kedvezően hatott. (Megjegyzem, hogy a kilencvenes évek elején Románia tulajdonképpen adósságok nélkül indult el, míg Lengyelország a Párizsi Klubban radikálisan tudta csökkenteni adósságát.)

V/1.3. sz. táblázat: A tagjelöltek legfontosabb államadóssági mutatói a 90-es években

\begin{tabular}{|l|c|c|c|c|}
\hline \multicolumn{1}{|c|}{ Ország } & $\begin{array}{c}\text { Bruttó } \\
\text { adósság/GDP } \\
\mathbf{( 1 9 9 0 )} \mathbf{( \% )}\end{array}$ & $\begin{array}{c}\text { Bruttó } \\
\text { adósság/GDP } \\
\mathbf{( 1 9 9 7 )}(\mathbf{\% )}\end{array}$ & $\begin{array}{c}\text { Nettó adósság } \\
\mathbf{( 1 9 9 0 )} \\
\text { (md USD) }\end{array}$ & $\begin{array}{c}\text { Nettó adósság } \\
\mathbf{( 1 9 9 7 )} \\
\text { (md USD) }\end{array}$ \\
\hline Bulgária & 55 & 96 & 10,9 & 7,5 \\
\hline Csehország & 14 & 42 & 4,0 & 11,9 \\
\hline Észtország & - & 7 & - & $-0,4$ \\
\hline Magyarország & 60 & 53 & 20,2 & 15,3 \\
\hline Lettország & - & 7 & - & $-0,3$ \\
\hline Litvánia & - & 15 & - & 0,4 \\
\hline Lengyelország & 82 & 28 & 44,0 & 18,2 \\
\hline Románia & 3 & 27 & 0,6 & 5,7 \\
\hline Szlovákia & 13 & 51 & 1,9 & 6,7 \\
\hline Szlovénia & 11 & 23 & 1,9 & 0,9 \\
\hline
\end{tabular}

Forrás: ENSZ EGB, [2000] 
Az államadósság terén különböző adottságokkal indultak a rendszerváltó országok, hiszen a Baltikumnak kedvezett, hogy a volt szovjet adósságot Oroszország vállalta át, míg Szlovéniát a kilencvenes években érintette, hogy rendezetlen volt az exjugoszláv adósság helyzete. Ennek ellenére megállapítható, hogy Bulgária kivételével a külső adósság mértéke megfelelően kordában tartható volt, sőt több dinamikusan fejlődő ország - Magyarország, Lengyelország - ki tudta nőni ezt a hatalmas adósságot. Ezért az eladósodottsági tényező önmagában nem jelenti a fejlődés akadályát most már a régióban.

A továbbiakban röviden kitérek azon növekedési tényezőkre, amelyek segítik a csatlakozni kívánó országok felzárkózását.

\section{V/1.4. A gazdaság strukturális reformja}

A felvételre jelentkező országokban lényeges átrendeződés ment végbe a három nagy szektor (ipar, mezőgazdaság, szolgáltatás) GDP-hez való hozzájárulása terén. A rendelkezésre álló adatok szerint a kilencvenes években a jelentkezők mindegyikében csökkent a mezőgazdasági termelés részesedése a GDP előállításában, sőt ugyanez a tendencia figyelhető meg az ipari termelés GDP-n belüli arányaiban is. Magyarországon és Lengyelországban - amelyek a legtöbb müködő tőkét vonzották - megfigyelhető, hogy az ipar GDP-n belüli aránya ugyan csökkent, de teljesítménye elérte, illetve meghaladta a rendszerváltás előtti értéket. Majdnem elérte a rendszerváltás előtti arányt, és enyhe növekedés figyelhető meg Csehországban és Szlovéniában.

A strukturális átalakítás tehát trendjeiben tükrözi az európai folyamatokat, vagyis a mezőgazdaság és az ipar visszaszorult a szolgáltatások javára. Ugyanakkor látható, hogy az ír csoda egyik alapja az ipar látványos - tudásalapú iparágakra épülő felfutása, hiszen növelte részesedését az egyébként is gyorsan növekvő ír GDP-ből. Ez az ipari hatékonyságnövekedés 1997-98-ban megindult Szlovéniában, Magyarországon és Csehországban, de a közeljövőben várható Lengyelországnál is. Érdemes megjegyezni, hogy 1990 óta a román és a bolgár ipari termelés aránya csökkent, sőt Románia a mezőgazdaság terén növelte GDP-n belüli arányát. 
V/1.4. sz. táblázat: Az ipar, a mezőgazdaság és a szolgáltatások aránya a GDP-n belül (százalék)

\begin{tabular}{|l|r|c|c|c|c|c|}
\hline \multirow{2}{*}{ Ország } & \multicolumn{2}{|c|}{ Agrárium } & \multicolumn{2}{c|}{ Ipar } & \multicolumn{2}{c|}{ Szolgáltatások } \\
\cline { 2 - 7 } & $\mathbf{1 9 8 9}$ & $\mathbf{1 9 9 8}$ & $\mathbf{1 9 8 9}$ & $\mathbf{1 9 9 8}$ & $\mathbf{1 9 8 9}$ & $\mathbf{1 9 9 8}$ \\
\hline Csehország & 8,2 & 4,6 & 47,5 & 43,3 & 44,3 & 52,1 \\
\hline Észtország & - & 4,0 & - & 39,0 & - & 57,0 \\
\hline Magyarország & 15,6 & 5,5 & 42,6 & 32,8 & 41,8 & 61,7 \\
\hline Lengyelország & 12,9 & 4,8 & 52,4 & 36,1 & 34,7 & 59,1 \\
\hline Szlovénia & 4,8 & 3,9 & 47,3 & 37,7 & 47,9 & 58,4 \\
\hline Bulgária & 18,3 & 21,1 & 49,9 & 28,7 & 31,8 & 50,2 \\
\hline Lettország & - & 5,0 & - & 26,0 & - & 69,0 \\
\hline Litvánia & - & 10,0 & - & 29,0 & - & 61,0 \\
\hline Románia & 15,7 & 16,1 & 56,4 & 36,3 & 27,9 & 47,6 \\
\hline Szlovákia & 9,3 & 4,6 & 58,5 & 36,3 & 32,2 & 59,1 \\
\hline Portugália & 6,3 & 4,1 & 32,5 & 29,5 & 61,2 & 66,4 \\
\hline Spanyolország & 5,0 & 3,3 & 30,0 & 25,9 & 65,0 & 70,8 \\
\hline Írország & 9,1 & 4,5 & 34,3 & 38,2 & 56,6 & 57,3 \\
\hline Görögország & 16,3 & 8,1 & 23,9 & 20,4 & 59,8 & 71,5 \\
\hline EU (1997) & $\mathbf{3 , 2}$ & $\mathbf{2 , 1}$ & - & $\mathbf{2 5 , 8}$ & - & $\mathbf{7 2 , 1}$ \\
\hline
\end{tabular}

Forrás: WIIW, WB, [2000], Eurostat, [2000], saját számítások

\section{V/1.5. Beruházások}

A beruházási és a tőke-beáramlási mutatók fontos jelzők annak megítélésében, hogy milyen gazdasági növekedési potenciállal rendelkeznek az illető országok, illetve milyen felzárkózási lehetőséget tudnak mutatni még a tagság előtt. A gyors felzárkózáshoz egyrészt az EU-t meghaladó beruházási rátára, másrészt a folyó fizetési mérleg (modernizációs igény következtében megnövekedő importszükséglet miatti) deficitjének semlegesítésére kell törekednie a csatlakozó országoknak. Ennek a mobil portfolió befektetések mellett a müködő tőke befektetés lehet az egyik forrása. 
V/1.5. sz. táblázat: Beruházási és tökebeáramlási mutatók a tagjelölt országokban

\begin{tabular}{|c|c|c|c|c|c|c|c|}
\hline \multirow{2}{*}{ Ország } & \multirow{2}{*}{$\begin{array}{c}\text { Megtaka- } \\
\text { rítási ráta } \\
(\%) \\
(1999)\end{array}$} & \multirow{2}{*}{$\begin{array}{c}\text { Befekte- } \\
\text { tési ráta } \\
(\%) \\
(1999)\end{array}$} & \multirow{2}{*}{$\begin{array}{c}\text { FDI } \\
\text { millió } \\
\text { USD } \\
(1989- \\
1998)\end{array}$} & \multirow{2}{*}{$\begin{array}{c}\text { FDI/fö } \\
\text { USD } \\
\text { (1997) }\end{array}$} & \multirow{2}{*}{$\begin{array}{l}\text { Fizetési } \\
\text { mérleg } \\
\text { hiánya } \\
\text { GDP } \\
\text { \%-ában } \\
\text { (1999) }\end{array}$} & \multicolumn{2}{|c|}{$\begin{array}{c}\text { FDI/GDP } \\
(\%)\end{array}$} \\
\hline & & & & & & 1997 & 1999 \\
\hline Bulgária & 12,6 & 18,0 & 1222 & 147 & $-5,3$ & 4,8 & 6,3 \\
\hline Csehország & 26,9 & 28,5 & 8473 & 823 & $-2,0$ & 2,4 & 9,6 \\
\hline Észtország & 21,3 & 31,0 & 1010 & 695 & $-5,8$ & 2,7 & 5,9 \\
\hline Magyarország & 26,6 & 31,5 & 16903 & 1667 & $-4,3$ & 4,6 & 4,1 \\
\hline Lettország & 20,8 & 28,9 & 1358 & 543 & $-10,6$ & 6,3 & 5,9 \\
\hline Litvánia & 11,8 & 23,0 & 1271 & 344 & $-11,2$ & 2,3 & 4,6 \\
\hline Lengyelország & 20,1 & 27,6 & 12442 & 321 & $-7,5$ & 2,2 & 4,7 \\
\hline Románia & 16,1 & 19,9 & 3370 & 149 & $-3,8$ & 3,5 & 3,1 \\
\hline Szlovákia & 28,0 & 33,0 & 1223 & 227 & $-5,9$ & 0,3 & 1,7 \\
\hline Szlovénia & 24,9 & 25,2 & 63 & 9 & $-2,9$ & 1,8 & 0,4 \\
\hline$E \boldsymbol{E}$ & 20,9 & 20,2 & - & - & 0,2 & - & 4,3 \\
\hline
\end{tabular}

Forrás: WB, WIFO, EBRD, EU Bizottság, Eurostat, [2001]

Megjegyzés: FDI: Müködő tőke befektetés

Az összegyüjtött adatokból kiolvasható, hogy a csatlakozni kívánó országokban továbbra is magas a megtakarítási ráta, bár néhány országban - Bulgária, Románia, Litvánia - komoly gondok jelentkeznek. A beruházási ráta azonban továbbra is magas, meghaladja az EU mutatóit - a románok és bulgárok kivételével - minden tagjelöltnél. Ez elsősorban annak köszönhető, hogy az EU-hoz hasonló megtakarítási ráta mellé a GDP-hez mérten jelentős külföldi müködő-tőke (FDI) beáramlása figyelhető meg, mely garanciát ad arra, hogy a beruházási ráta több tagjelöltnél 2833 százalékos legyen. Másrészt az is látszik (lásd V/1.5. sz. táblázat 6-7. oszlopa), hogy a fizetési mérleg hiányát nagyrészt fedezi a befolyó működő tőke, így a fizetési mérleg hiánya miatt nem kell a fejlődést megszorító intézkedéseket tenni. Aggodalomra okot csak a baltiak magas fizetési mérleg hiánya - nagyfokú függősége a müködő tőke beáramlástól - adhat. Szlovákiát és Szlovéniát még erőteljesen elkerüli a külföldi tőke, ami különösen Szlovákia esetében lehet probléma, mert fizetési mérleg hiányát nem tudja müködő tőke bevonásával kompenzálni, ami az ország eladósodásához vezethet. Szlovénia esetében ismert, hogy a külföldi beruházásokkal kapcsolatban nagyon óvatos, elsősorban erős exportteljesítményében bízva kívánja megoldani tőkefelhalmozási feladatait. 
Ugyanakkor az tény, hogy az élenjárónak minősülő országok az FDI bevonása révén nagyon magas függőségbe kerülnek a külföldi befektetőktől. Ezt jelzi, hogy míg Magyarországon a GDP 40, Csehországban több mint 30 százalékát adta az FDI kumulált összege, addig ez a mutató Portugália, Spanyolország vagy Görögország esetében alatta marad a 20 százaléknak, és Írországban közelítette meg 1997-ben a 23 százalékot. A fentiek miatt, pl. Magyarországon az FDI jelenti a tőkeképződés csaknem felét, Csehországban 28-29 százalékát, míg a kohéziós EU-államoknál (Írország kivételével) 10 százalék alatt marad. Mindez jelzi a belső tőke jelentős hiányát a fejlődő gazdaságokban. (Landesmann [2000] a különböző társult országokból származó számításai alapján azt írta, hogy a feldolgozóiparban a FDI teszi ki 1996-97-ben Magyarországon a befektetés 82, Lengyelországban 43, a Cseh Köztársaságban 33 százalékát, a többi országban ez az arány alacsonyabb.)

\section{V/1.6. A gazdasági termelés hatékonysága}

A rendszerváltás óta a termelékenység nőtt (lásd V/1.6. sz. táblázat), hiszen több országban ugyanazon létszámú munkaerő az utóbbi néhány évben látványosan növelte termelését. Ennek többirányú okai vannak, amelyeket a dolgozat több fejezetében elemzek (oktatás, kulturális örökség, amely a fegyelmet, történelmi kapcsolatok, amely a kooperációs hajlamot erősíti; erős kereskedelmi és gazdasági kötődés az EU-hoz). Az egyik legfontosabb tényező a lehetséges felzárkózáshoz és a nyugat bővítési érdekeltségének megteremtéséhez a termelési hatékonyság növelése. Nem véletlen, hogy a müködő tőke befektetések területén ez került előtérbe, hiszen megfelelő versenyképesség elérése - főleg a munkaintenzív területeken - a kiterjedt belső piacon belül a lehető legtermelékenyebb helyszínek kiválasztását követeli meg.

A VIIW felmérése szerint a feldolgozóiparban 1991-97 között a térségben lévő társult országokban nőtt a termelékenység, sőt Ausztriához képest lényeges felzárkózást is mutattak. A lengyelek, csehek, szlovénok és szlovákok az időszak végére az osztrák termelékenység 30-40 százalékáról 50 százalékára jöttek fel, míg a magyarok 65 százalékra. Románia és Bulgária felzárkózása és trendje ettől elmaradt, nyugati szomszédunk termelékenységének csak 30-35 százalékát tudták felmutatni 1997-ben. 
$\mathrm{Az}$ Eurostat felmérte a tagjelölt országok termelékenységét az egy fő foglalkoztatottra eső termelést nominális összegben és PPS-ben (vásárlóeröparitáson) kalkulálva (ld. V/1. sz. táblázat). Ennek alapján megállapítható, hogy a reálértékben számolt lemaradás kisebb, mint az egy főre jutó GDP alapján. Az is tény, hogy Portugália reálértékben számolt munkaerő termelékenységét három tagjelölt (Szlovénia, Magyarország, Csehország) meghaladja, sőt Szlovénia ezen mutatója Görögországét is utolérte. A föbb ágazatok szerinti bontás alapján különösen szembetűnő a pénzügyi és üzleti szolgáltatások terén való felzárkózás (Szlovákia és Magyarország elérte vagy megközelítette az EU-átlagot). Az átlagos nemzeti termelékenységnél jobb a magyar, cseh és szlovén mezőgazdasági termelékenységi mutató is az EU-átlaghoz viszonyítva. Ugyanakkor a nemzetgazdasági átlagnál gyengébbek a feldolgozóipari és a közszolgáltatásoknál kimutatható egy alkalmazottra eső termelési adatok.

V/1.6. sz. táblázat: A munkaerö termelékenységének mértéke a tagjelölt országokban és Portugáliában, valamint Görögországban 1998-ban (PPS, EU=100)

\begin{tabular}{|l|c|c|c|}
\hline \multicolumn{1}{|c|}{ Ország } & $\begin{array}{c}\text { Egy } \\
\text { foglalkoztatottra } \\
\text { jutó termelés } \\
\text { euróban }\end{array}$ & \multicolumn{2}{c|}{$\begin{array}{c}\text { Egy foglalkoztatottra } \\
\text { jutó termelés } \\
\text { (EU=100) }\end{array}$} \\
\cline { 3 - 4 } & nominális & PPS \\
\hline Bulgária & 3426 & 7 & 25 \\
\hline Csehország & 10176 & 21 & 58 \\
\hline Észtország & 7271 & 15 & 37 \\
\hline Magyarország & 11340 & 24 & 58 \\
\hline Lettország & 5213 & 11 & 27 \\
\hline Litvánia & 5789 & 12 & 30 \\
\hline Lengyelország & 9201 & 19 & 38 \\
\hline Románia & 4185 & 9 & 32 \\
\hline Szlovákia & 8374 & 18 & 53 \\
\hline Szlovénia & n.a. & n.a. & 71 \\
\hline Görögország & 27662 & 58 & 72 \\
\hline Portugália & 20918 & 44 & 55 \\
\hline
\end{tabular}

Forrás: Eurostat, Európai Bizottság 2. Kohéziós Jelentése, [2001]

A magasabb gazdasági növekedéssel rendelkező tagjelölteknél a termelékenység további javulása megfelelő felzárkózást fog eredményezni, de az EU átlagát elérni, meghaladni - Szlovénia kivételével - belátható időn belül ezek az országok nem 
fogják. Mivel azonban bizonyos tagállami termelékenységet (Portugália) néhány tagjelölt ország (Csehország, Magyarország, Szlovénia) már meghalad, a legfejlettebbek belépése nem okozhat megoldhatatlan alkalmazkodási kényszert a belső piacon. A többi tagjelölt munkaerő termelékenysége (Szlovákia kivételével) mélyen alatta marad reálértékben számolva az EU-átlagnak, de még a legalacsonyabb mutatóval rendelkező Portugáliát sem éri el.

A különböző nemzetközi kutatóintézetek versenyképességi sorrendet állítottak fel a csatlakozni kívánó országok és a tagállamok között. A lausanne-i IMD Kutatóintézet nyolc faktor alapján vizsgált versenyképességi rangsora az alábbi eredményeket mutatta 47, a világon megvizsgált ország esetében:

V/1.7. sz. táblázat: Versenyképességi rangsor

\begin{tabular}{|c|c|c|c|}
\hline \multicolumn{2}{|c|}{ Helyezés } & Ország & $\begin{array}{c}\text { Versenyképesség } \\
\text { (USA-100) }\end{array}$ \\
\hline $\mathbf{2 0 0 0}$ & $\mathbf{1 9 9 6}$ & Finnország & 80,87 \\
\hline 3 & 15 & Hollandia & 79,74 \\
\hline 4 & 7 & Luxemburg & 76,64 \\
\hline 6 & 8 & Írország & 74,34 \\
\hline 7 & 22 & Németország & 73,74 \\
\hline 8 & 10 & Svédország & 73,36 \\
\hline 9 & 14 & Dánia & 72,97 \\
\hline 12 & 5 & Egyesült Királyság & 70,02 \\
\hline 15 & 19 & Ausztria & 68,43 \\
\hline 18 & 16 & Franciaország & 66,29 \\
\hline 19 & 20 & Belgium & 65,56 \\
\hline 20 & 17 & Spanyolország & 61,17 \\
\hline 24 & 29 & Magyarország & $\mathbf{5 6 , 4 2}$ \\
\hline $\mathbf{2 7}$ & $\mathbf{3 9}$ & Portugália & 54,24 \\
\hline 29 & 36 & Olaszország & 51,83 \\
\hline 30 & 28 & Görögország & 49,34 \\
\hline 32 & 40 & Szlovénia & $\mathbf{4 6 , 4 7}$ \\
\hline $\mathbf{3 5}$ & - & Csehország & $\mathbf{4 4 , 2 8}$ \\
\hline $\mathbf{3 7}$ & $\mathbf{3 4}$ & Lengyelország & $\mathbf{4 3 , 0 2}$ \\
\hline $\mathbf{4 0}$ & $\mathbf{4 3}$ & &
\end{tabular}

Forrás: IMD Lausanne, [2000]

Természetesen több faktor más súlyozása alapján is lehet versenyképességet számolni, de az valószínüsíthető, hogy a sorrendben nem mutatkozik nagy eltérés. A társult országok némelyikének versenyképessége már most is megállja helyét az EU belső piacán. Első helyen ki kell emelni Magyarországot, amely a ranglistán (V/1.7. 
sz. táblázat) három tagállamot is maga mögé utasít (Portugália, Olaszország és Görögország), de jelentős felzárkózás mutatható ki Szlovénia, Csehország, Lengyelország versenyképességében is. Ezt a sorrendet támasztja alá az egyes országok kereskedelmi mérlegének helyzete is, amit a V/5. fejezetben vizsgálok. A tagjelöltek felzárkózása a belső piaci versenyt élezi, de ugyanakkor javítja az EU versenyképességét is a világban. A feldolgozóipar és a szolgáltatások termelékenységének növekedése jó lehetőséget nyújt az európai tőkebefektetőknek. Ennek alátámasztására a Bank of England 2000. december 13-án megjelentetett külföldi befektetésekről szóló elemzését említem, amely szerint a brit befektetések közül 1999-ben a legjobb profitrátát Közép-Kelet-Európában lehetett elérni.

\section{V/1.8. sz. táblázat: Brit befektetések jellemzői}

\begin{tabular}{|l|c|c|c|}
\hline \multicolumn{1}{|c|}{ Tájegység } & $\begin{array}{c}\text { Befektetések } \\
\text { összege 1999-ig } \\
\text { (md Font) }\end{array}$ & $\begin{array}{c}\text { Nyereség } \\
\text { 1999-ben } \\
\text { (md Font) }\end{array}$ & $\begin{array}{c}\text { Profitráta } \\
\text { (\%) }\end{array}$ \\
\hline Európa & 169,0 & 14,1 & 8,3 \\
\hline Amerika & 207,2 & 13,0 & 6,3 \\
\hline Ázsia & 25,3 & 2,7 & 10,7 \\
\hline $\begin{array}{l}\text { Ausztrália és } \\
\text { Óceánia }\end{array}$ & 11,9 & 1,5 & 12,6 \\
\hline Afrika & 9,9 & 1,1 & 11,1 \\
\hline $\begin{array}{l}\text { Közép- és } \\
\text { Kelet-Európa }\end{array}$ & 1,5 & 0,3 & 20,0 \\
\hline Összesen & 424,8 & 32,7 & 7,7 \\
\hline
\end{tabular}

Forrás: Bank of England, [2000], saját számítás

\section{Megjegyzés:}

Európa: EU, EFTA, FÁK

Amerika: Észak és Dél-Amerika

Közép- és Kelet-Európa: Albánia, Bulgária, Horvátország, Csehország, Észtország, Magyarország, Lettország, Litvánia, Lengyelország, Románia, Szerbia és Montenegró, Szlovákia, Bosznia-Hercegovina, Macedónia és Szlovénia

1999-re vonatkozóan jól láthatóan térségünk volt a relatív nyereség terén a listavezető. Feltételezhető, hogy a bővítés után a befektetési lehetőségek a profitrátát minden bizonnyal növelni fogják, hiszen a befektetések elött jelenleg álló technikai akadályok meg fognak szünni. 


\section{V/1.7. A gazdasági felzárkózás várható trendjei}

Az EU-átlagot meghaladó gazdasági növekedési ütem miatt a társult országok gazdasági felzárkózása folytatódni fog. Ennek azonban komoly feltétele az, hogy a nyitott országok (ld. V/5. fejezet) számára fontos relációkban (EU és Oroszország) a gazdasági növekedés illetve a nyersanyagárak - főleg az energiahordozóké kedvező tendenciát mutassanak.

Bár számtalan kutatóintézet készített elemzéseket, extrapolációkat a várható fejlődési trendekről, jelenleg csak az EU Bizottsága által készült olyan elemzést emelném ki, mely a társult országokkal közös értékelések alapján készítette el elemzését a 20002002-es időszakra (ld. V/1.9. sz. táblázat). Eszerint a közép-kelet-európai társult országok mindegyike növelni fogja GDP növekedési ütemét, összesítve 2000-ben 4,2 százalékkal, a következő két évben legalább 4,3 illetve 4,4 százalékkal szemben az Európai Unió 3,4 és 3,1 illetve 3,0 százalékával. Emellett évente legalább öt százalékkal fog nőni a tőkeképződés, amely a hosszú távú növekedés fenntartásának alapfeltétele. (Ez a 2000-ben várható 5,4 százalékos növekedési ütem mellett 2001ben és 2002-ben 6 százalék fölötti értéket mutat.) Ha a közép-kelet-európai országokat egyenként vizsgáljuk, akkor megállapíthatjuk, hogy míg Észtország, Magyarország, Lengyelország - az egyébként is jobb teljesítményt nyújtó országok GDP fejlődése meghaladja az 5 százalékot, addig a többiek felfutása lassabban halad. Kilóg a sorból Románia, de Litvánia is az alacsonyabb bázis miatt nehezebben indul meg a fejlődésben. A növekedés kibontakozása egyrészt nemcsak az EU átlagához való közelítést segíti - Románia és talán Litvánia kivételével -, hanem a mérvadó kohéziós országokhoz, valamint a bővítésben messze a legjobban érintett Ausztriához történő felzárkózást is elindítja, mivel a térség húzó országai ezek növekedési ütemét is meghaladják.

További kedvező fordulat, hogy a termelékenység növekedésének egyik negatív hatása, a foglalkoztatottság csökkenése minden térségbeli államban kedvező irányba indult, ami a kivándorlásokkal kapcsolatosan megnyilvánuló aggályokat bizonyos fokig kezelni fogja (lásd V/1.9. sz. táblázat). A foglalkoztatás növekedése egyedül Románia esetében nem mondható el, inkább a kisebb ütemű csökkenés a jellemző. Az előrejelzések szerint 2002-re néhány országban (Bulgária, Észtország, 
Magyarország, Szlovákia) egy százalékkal fog nőni a foglalkoztatás rátája és ennek következményeként az adó és járulékfizetők száma. Ez is hozzájárul többek között ahhoz, hogy a térség minden országában 2002-ben 2000-hez képest is csökkenni fog a munkanélküliségi ráta (Románia kivételével). A munkanélküliségi rátát a térségben tehát nemcsak a negatív demográfiai viszonyok, hanem az új munkahelyteremtések is csökkentik. Ennek ellenére jelentős méretei és migrációs hajlama miatt rettegett Lengyelország munkanélküliségi rátája 2002-ben még 15 százalék fölötti lesz, hasonlóan a szlovák és bolgár magas arányhoz, ami a roma kivándorlástól való félelem miatt is veszélyes lehet. Ezek a trendek azért figyelemre méltóak, mert a magas gazdasági növekedéshez és az EU-átlaghoz való felzárkózáshoz jelentős munkaerő tartalékra is szükség van. Tekintettel arra, hogy a tagjelölt országokban az EU-tagállamokhoz képest most még alacsony a foglalkoztatási ráta (lásd: IV/5.1. sz. táblázat), ami még az alacsonyabb munkanélküliségi rátával rendelkező tagjelölteknél is további munkaerő tartalékokat tesz mozgósíthatóvá.

V/1.9. sz. táblázat: Az EU Bizottság előrejelzései a társult országokfejlődéséröl (százalék)

\begin{tabular}{|l|c|c|c|c|c|c|r|r|r|r|r|r|}
\hline \multirow{3}{*}{ Ország } & \multicolumn{3}{|c|}{ GDP változás } & \multicolumn{3}{c|}{$\begin{array}{c}\text { Foglalkoztatás } \\
\text { növekedése }\end{array}$} & \multicolumn{3}{c|}{ Munkanélküliség } & \multicolumn{3}{c|}{$\begin{array}{c}\text { Tókeképződés } \\
\text { növekedése }\end{array}$} \\
\cline { 2 - 17 } & $\mathbf{2 0 0 0}$ & $\mathbf{2 0 0 1}$ & $\mathbf{2 0 0 2}$ & $\mathbf{2 0 0 0}$ & $\mathbf{2 0 0 1}$ & $\mathbf{2 0 0 2}$ & $\mathbf{2 0 0 0}$ & $\mathbf{2 0 0 1}$ & $\mathbf{2 0 0 2}$ & $\mathbf{2 0 0 0}$ & $\mathbf{2 0 0 1}$ & $\mathbf{2 0 0 2}$ \\
\hline Bulgária & 5,4 & 4,9 & 4,5 & $-3,0$ & 0,5 & 1,0 & 18,0 & 17,6 & 16,8 & 9,6 & 12,5 & 15,0 \\
\hline Csehország & 2,5 & 3,0 & 3,7 & $-3,0$ & $-0,1$ & 0,0 & 9,1 & 8,9 & 8,8 & 3,5 & 4,2 & 5,0 \\
\hline Észtország & 6,2 & 6,3 & 6,4 & $-1,2$ & 1,0 & 1,7 & 13,3 & 12,6 & 11,2 & 6,0 & 11,0 & 14,0 \\
\hline Magyarorsz. & 5,4 & 5,5 & 5,2 & 0,6 & 0,9 & 1,0 & 6,5 & 6,2 & 5,3 & 9,0 & 11,0 & 11,0 \\
\hline Lettország & 3,6 & 4,5 & 4,9 & 0,1 & 0,1 & 0,1 & 8,4 & 7,9 & 6,9 & 3,5 & 4,5 & 4,7 \\
\hline Litvánia & 2,3 & 3,2 & 3,9 & 0,2 & 0,5 & 0,8 & 8,2 & 7,8 & 7,3 & 1,0 & 4,0 & 6,0 \\
\hline Lengyelorsz. & 5,1 & 5,0 & 4,8 & $-2,0$ & 0,7 & 0,8 & 16,4 & 16,1 & 15,7 & 6,8 & 6,4 & 6,1 \\
\hline Románia & 1,4 & 1,9 & 2,4 & $-0,8$ & $-0,8$ & $-0,3$ & 7,2 & 7,7 & 7,8 & $-1,0$ & 3,0 & 4,0 \\
\hline Szlovákia & 2,0 & 3,1 & 4,1 & $-1,5$ & 0,8 & 1,2 & 19,2 & 18,8 & 18,4 & $-1,3$ & 3,9 & 6,9 \\
\hline Szlovénia & 4,3 & 4,2 & 4,3 & 0,0 & 0,5 & 0,5 & 7,1 & 6,6 & 6,2 & 7,7 & 7,5 & 6,0 \\
\hline Ausztria & 3,5 & 2,9 & 2,8 & 0,9 & 0,7 & 0,6 & 3,3 & 3,0 & 2,7 & - & - & - \\
\hline Spanyolorsz. & 4,1 & 3,5 & 3,3 & 3,1 & 2,4 & 2,3 & 14,2 & 12,9 & 12,0 & - & - & - \\
\hline Portugália & 3,0 & 2,7 & 2,7 & 1,5 & 0,8 & 0,8 & 4,0 & 4,2 & 4,3 & - & - & - \\
\hline Görögország & 4,1 & 4,5 & 4,8 & 1,2 & 1,5 & 1,6 & 11,2 & 10,6 & 10,1 & - & - & - \\
\hline EU & $\mathbf{3 , 4}$ & $\mathbf{3 , 1}$ & $\mathbf{3 , 0}$ & $\mathbf{1 , 6}$ & $\mathbf{1 , 3}$ & $\mathbf{1 , 2}$ & $\mathbf{8 , 4}$ & $\mathbf{7 , 8}$ & $\mathbf{7 , 3}$ & - & - & - \\
\hline
\end{tabular}

Forrás: EU Bizottság, Pénzügyi Főigazgatóság, [2000]

A makrogazdasági felzárkózás egyik lehetséges modelljét számolta ki az Európai Bizottság 2001. októberében, amikor az utóbbi években regisztrált növekedési 
ütemek segítségével azt kalkulálta, hogy a tagjelölteknek hány évre van szükségük ahhoz, hogy az egy főre jutó PPS-ben (vásárlóerő-paritáson) elérjék az EU-átlag 75 százalékát, vagyis azt a szintet, amikor már az EU-terminológia sem minősíti elmaradottnak az adott országot.

V/1.10. sz. táblázat: A tagjelölt országok részéröl szükséges évek száma az EU átlagának 75 százalékára való felzárkózáshoz (EU=100)

\begin{tabular}{|c|c|c|}
\hline \multirow{2}{*}{ Ország } & \multicolumn{2}{|c|}{ Évek száma } \\
\cline { 2 - 3 } & $\begin{array}{c}\text { EU-15 } \\
\mathbf{7 5} \text { százaléka }\end{array}$ & $\begin{array}{c}\text { EU-27 } \\
\text { 75 százaléka }\end{array}$ \\
\hline Bulgária & 31 & 31 \\
\hline Csehország & 15 & 6 \\
\hline Észtország & 19 & 16 \\
\hline Magyarország & 11 & 7 \\
\hline Lettország & 27 & 25 \\
\hline Litvánia & 31 & 30 \\
\hline Lengyelország & 33 & 33 \\
\hline Románia & 34 & 33 \\
\hline Szlovákia & 20 & 16 \\
\hline Szlovénia & 1 & - \\
\hline
\end{tabular}

Forrás: EU Bizottság, [2001]

Megjegyzés: A bizottsági becslés a tagjelöltek Tagság Előtti Gazdasági Programjai és ezek várható gazdasági növekedési becslései extrapolálásával készültek.

EU-27: Tagállamok és valamennyi tagsági tárgyalást folytató ország.

Külön kell szólni a határmenti területek felzárkózásáról, hiszen a belső piac bővítése itt mutatkozik meg a legélesebb feszítő erővel. Kedvező, hogy az új tagállamok nyugati, a jelenlegi tagállamokkal határos területei a legfejlettebbek, (kivétel Bulgária), itt a munkanélküliségi ráták is rendkívül jónak mondhatók (lásd: V/1.11. sz. táblázat). 
V/1.11. sz. táblázat: Az EU-tagállamok és tagjelölt országok határmenti területeinek fóbb gazdasági jellemzöi

\begin{tabular}{|c|c|c|c|}
\hline Régió & $\begin{array}{c}\text { GDP/fö } \\
(E U=100) \\
(1998)\end{array}$ & $\begin{array}{c}\text { GDP- } \\
\text { növekedés } \\
\text { (1995-98) } \\
\text { éves átlag (\%) }\end{array}$ & $\begin{array}{c}\text { Munka- } \\
\text { nélküliségi ráta } \\
\text { (százalék) } \\
\text { (1998) } \\
\end{array}$ \\
\hline Mecklenburg (D) & 70,7 & 9,2 & 17,5 \\
\hline Brandenburg (D) & 70,6 & 8,9 & 16,0 \\
\hline Berlin (D) & 102,2 & 1,8 & 13,7 \\
\hline Drezda (D) & 74,1 & 6,0 & - \\
\hline Zachodnopomorske (PL) & 35,2 & 5,9 & 14,9 \\
\hline Lubuske (PL) & 32,9 & 5,9 & 15,3 \\
\hline Dolnoslaske (PL) & 36,0 & 5,9 & 13,8 \\
\hline Chemnitz (D) & 63,2 & 4,6 & - \\
\hline Oberfranken (D) & 104,2 & 0,8 & 6,5 \\
\hline Oberfalz (D) & 94,1 & 0,6 & 5,4 \\
\hline Alsóbajorország (D) & 98,3 & 1,8 & 4,8 \\
\hline Severovychod (CS) & 52,7 & 0,1 & 7,3 \\
\hline Severozapad (CS) & 52,9 & $-2,1$ & 12,6 \\
\hline Jihozapad (CS) & 57,4 & 0,0 & 6,4 \\
\hline Felső Ausztria (A) & 104,9 & 1,8 & 2,7 \\
\hline Alsó Ausztira (A) & 91,4 & 1,8 & 3,1 \\
\hline Jichovychod (A) & 53,4 & $-0,2$ & 6,4 \\
\hline Pozsony (SK) & 99,4 & 6,2 & 5,9 \\
\hline Burgenland (A) & 68,8 & 1,9 & 3,3 \\
\hline Nyugat-Dunántúl (H) & 54,1 & 6,1 & 4,4 \\
\hline Karintia (A) & 91,6 & 1,9 & 4,7 \\
\hline Stájerország (A) & 90,1 & 2,2 & 4,1 \\
\hline Friuli-Venezia Giulia (I) & 113,5 & 0,6 & 5,6 \\
\hline Veneto (I) & 118,9 & 2,1 & 4,9 \\
\hline Szlovénia (SI) & 68,8 & 4,0 & 7,3 \\
\hline
\end{tabular}

Forrás: Európai Bizottság, Eurostat, Kohéziós jelentés, [2001]

A számadatok alapján látható, hogy különböző mértékben indult meg a határmenti területek felzárkózása. Ebben élen jár a pozsonyi terület, bár egy fővárosi körzet önmagában való elemzése némileg torzíthat, hiszen jelentős, vidéken folytatott gazdasági tevékenységet is a fövárosi központokban vesznek számításba. Csehország és a vele határos kelet-német területek fejlettségi szintje között nincs lényeges különbség, ami a történelmi közelmúlt miatt érthető. Nyugat-Magyarország felzárkózása is jelentős ritmusban folyik, a jelenlegi helyzet tartóssá válása esetén néhány éven belül utolérheti Burgenlandot. Szlovénia a vele szomszédos osztrák tartományok viszonylatában nagyobb különbséget kell, hogy behozzon, de a fejlödési trendek (1995-98 között évi átlag 4 százalékos gazdasági növekedés) felzárkózást jeleznek. 
Tíz-tizenöt éves előretekintéssel az sem zárható ki, hogy a jelenlegi tagállamok egyes határmenti tartományaiból az új tagállamok nyugati határvidékére fog munkaerő ingázni. Külön is igaz ez olyan esetekben, ahol az új tagállamok nyugati határmenti régióiban alacsony a munkanélküliségi ráta, sőt bizonyos munkáknál munkaerőhiány lép fel (pl. Szlovénia, Nyugat-Magyarország, Pozsony, Nyugat-Csehország).

\section{V/1.8. Az Európai Gazdasági és Monetáris Unióba való belépés}

A gazdasági hasznok közül átütő erejü lesz az a hatás, amit a közös gazdaságpolitikai rendszerbe, azon belül a közös valutaövezetbe történő belépés idéz elö. (Ezt a kérdőíves felmérésem nem igazolta vissza, igaz ezt nem az üzleti szférában végeztem.) Nem véletlen, hogy a bővítésről elvileg döntést hozó 1993. júniusi koppenhágai csúcsértekezlet külön kiemelte azt, hogy a Gazdasági és Monetáris Unióhoz, ezen belül is a közös valutához való csatlakozás nem lehet kivétel (opt-out) tárgya. Ez azért is jelentős kihívás, mivel a maastrichti szerződést létrehozó országok közül Dánia és Nagy-Britannia - bár teljesítik a tagságra vonatkozó feltételeket kivételt kaptak a Monetáris Unióba való belépést illetően (2000-ben az euró övezetből való kimaradást egy újabb dán népszavazás meg is erősítette), míg Svédországnál ezt a jogot szerződésileg nem adták meg, így a hiányzó politikai és lakossági szándék miatt lényegében mondvacsinált indokok (a központi bank függetlensége körüli kérdések) miatt az eurózónába való belépés nem valósult meg. A tagjelölt országok a felvételi tárgyalásokon a vonatkozó fejezeteknél lényegében már elfogadták a Gazdasági és Pénzügyi Unióban való teljes részvélt, sőt a legtöbb esetben e kérdésről a tárgyalások már be is fejeződtek, ami jelzi, hogy a tagjelöltek részéről mind a szándék, mind a képesség megvan arra, hogy a közös valuta övezet tagjaivá váljanak.

Számokban kifejezve ez azt jelenti, hogy 2001 elejétől a 12 tagállamot felölelő euró övezet lélekszáma 301 millió főről további 103 millió fővel nőhet, ami több mint egyharmados gyarapodás. Ezzel nem csak az euróban használt belső piaci tranzakciók mennyisége nőhet, hanem a világ legnagyobb gazdasági erejét felvonultató valutává válhat az euró. Megerősödésével a nemzetközi piacon a tartalékvaluta szerepét jelenleg alapvetően betöltő amerikai dollár méltó vetélytársává válhat, sőt azt meg is előzheti. Mivel Európa nyitott gazdaság, a térség 
legjelentősebb külső partnereivel fennálló kapcsolatokban is várható az euró elterjedése (ilyenek lehetnek a FÁK Államok, beleértve az oroszokat is), de a legjelentősebb külső partnerek közül az ázsiai olajországok kedvező hozzáállása, a mediterrán térség esetében az európai kapcsolatok dominanciája eredményezheti a szerződéses kapcsolatokban az euró elterjedését. Mivel az euró övezethez olyan országok fognak csatlakozni, melyeknek gazdasági növekedési üteme magasabb, mint az övezethez jelenleg tartozó országoké, ezért ez az euró felértékelődését, megerösödését is eredményezni fogja (EU Bizottság, Enlargement argumentaire [2001]).

Mindemellett előnyt jelent az EU számára az is, hogy az előbbiekben látott fontos kereskedelmi és befektetési partnerként megjelenő kelet-közép-európai tagjelöltekkel folytatott gazdasági kapcsolatokban nem lesznek tranzakciós költségek, így a jelenleg is meglévő külkereskedelmi aktívum, valamint a kiaknázható befektetési lehetőségek, és az ezzel járó profitráta is nőni fog, sőt az övezeten kívüli partnerekkel szemben jobb versenyhelyzetbe kerülnek az euró övezet jelenlegi és jövendő tagjai. (A tagjelöltek közül az euró övezetbe irányul a Cseh Köztársaság, Magyarország, Lengyelország, Románia, Szlovákia és Szlovénia exportjának több mint 50 százaléka.)

További előnye lehet a bővítésnek, hogy az euró övezethez való csatlakozás - sőt már elötte két évvel a stabil árfolyamrendszerbe (ERM II) való belépés - a tagjelöltek önálló árfolyam-politikájának feladását jelenti a tagság pillanatában. (Jelenleg több tagjelölt ország - lásd: V/1.17. sz. táblázat - nemcsak az euróhoz köti árfolyamrezsimjét, illetve az ERM II-höz képest nagyon merev valutatanácsrendszert vezetett be.) Ez segíti azt, hogy a jelenleg alulértékelt nemzeti valuták (lásd: V/1.13. sz. táblázat) kiküszöbölésre kerüljenek, és ezzel az eszközzel a társult országok ne tudjanak gazdasági versenyelőnyöket elérni a költségek mesterségesen alacsony szinten tartásával. (Ezért fontos, hogy a gazdasági reformok - privatizáció, árliberalizálás, veszteséges szektorok felszámolása - olyan helyzetet teremtsenek a belépők számára, hogy a gazdaságpolitikai korlátozások és az önálló árfolyampolitika megszünése után is helyt tudjanak állni.) Ezért már 1996 óta az ún. közös gazdaságpolitikai értékelések (joint assessment) révén próbálja mindkét fél a gazdaságpolitika közeledését segíteni. 2001-től ezt már a tagállamokra jellemző 
makrogazdasági konzultációs rendszer váltotta fel (PEP), amelynek során részletesen elemzik a Gazdasági és Pénzügyi Unióhoz vezető úton elért és elérendő haladást is.

V/1.12 sz. táblázat: Főbb mutatók a valutaunióba történö belépéshez (1999)

\begin{tabular}{|l|c|c|c|c|c|}
\hline \multicolumn{1}{|c|}{ Ország } & $\begin{array}{c}\text { Infláció } \\
\mathbf{( \% )}\end{array}$ & $\begin{array}{c}\text { Kamatláb } \\
\mathbf{1 0} \text { éves } \\
\text { lejáratra } \\
\mathbf{( \% )}\end{array}$ & $\begin{array}{c}\text { Paritástól való } \\
\text { eltérés } \\
\mathbf{( 1 9 9 8 - 9 9 )}\end{array}$ & $\begin{array}{c}\text { Éves } \\
\text { államháztar- } \\
\text { tási hiány } \\
\text { (GDP } \\
\text { százalékában) }\end{array}$ & $\begin{array}{c}\text { Összevont } \\
\text { kormány- } \\
\text { adósság } \\
\text { (éves GDP } \\
\text { százalékában) }\end{array}$ \\
\hline Bulgária & 0,3 & 5,0 & 3,0 & $-1,0$ & 93,5 \\
\hline Csehország & 2,1 & 7,1 & 6,8 & $-4,2$ & 29,0 \\
\hline Észtország & 3,3 & 6,9 & 0,0 & $-4,7$ & 11,0 \\
\hline Magyarország & 10,0 & 8,4 & 8,0 & $-3,9$ & 72,7 \\
\hline Lettország & 2,4 & 11,1 & 14,4 & $-3,8$ & 10,6 \\
\hline Litvánia & 0,8 & 10,0 & 18,5 & $-8,6$ & 28,6 \\
\hline Lengyelország & 7,3 & 12,3 & 11,9 & $-3,7$ & 43,0 \\
\hline Románia & 44,8 & 45,0 & 47,5 & $-4,0$ & 32,3 \\
\hline Szlovákia & 10,6 & 7,7 & 15,5 & $-4,1$ & 26,5 \\
\hline Szlovénia & 6,1 & - & 7,5 & $-0,7$ & 24,3 \\
\hline Referencia & $\mathbf{2 , 0}$ & $\mathbf{7 , 5}$ & $\mathbf{1 5 , 0}$ & $\mathbf{- 3 , 0}$ & $\mathbf{6 0 , 0}$ \\
\hline
\end{tabular}

Forrás: Deutsche Bank Research, [2000]

$\mathrm{Az} \mathrm{V} / 1.12$. sz. táblázat alapján látható, hogy a tagjelölt országok a mutatók nagy részénél jelentős előrelépést tettek a maastrichti kritériumok teljesítése irányába. A DB adatai szerint csak Magyarország és Bulgária haladja meg a kumulált adósságküszöböt, de ezek is nagy léptékben csökkentik adósságukat. Az euró bevezetéséről szóló döntés (1998. május) idején Belgium, Olaszország és a 2000-ben csatlakozó Görögországban ez a hányad meghaladta a 100 százalékot, és csökkentése csak igen lassan valósul meg. Az éves államháztartási hiányra, illetve az összevont kormányzati adósságokra vonatkozó adatok mérése igen nagy eltérésekkel valósul meg, a nemzeti számlák terén még nem sikerült tagjelölteknek egységes módszert bevezetni. (Pl. a magyar adósság az EU Bizottsággal együtt írt közös értékeléseknél már 1999-ben alatta volt a 60 százalékos küszöbnek.) Megjegyzem, hogy a három balti állam nem örökölt volt szovjet adósságokat, vagy az ismert román és csehszlovák felfogás miatt a múlt rendszerben nem volt jelentős belső és külső adósság. (Csak az orosz válság által 1999-ben sújtott balti államoknál emelkedett meg hirtelen a hiány, de a közös értékelések szerint ez a hiány hamarosan kezelhető 
mértékü lesz.) 1997-ben az infláció az EU átlagában 2,4 százalék volt (Eurostat, [2000]), és több eurótagnál - Németország, Franciaország, Spanyolország, Ausztria, Portugália - nehézségeket okozott a pénzromlás referencia-érték alá szorítása.

A hosszú távú kamatlábak esetében nehéz tisztán látni, mivel a 10 éves lejáratú értékpapírok bevezetése csak néhány országban történt meg a közelmúltban Magyarországon, Csehországban és Lengyelországban -, a többi tagjelöltnél csak rövidtávú - 1 vagy maximum 5 éves kötvények - jelentek meg a piacon. A tagjelöltek nagy része - talán Magyarország és Csehország kivételével, ahol a szint már nagyon közelíti az európai 7,5 százalékos referenciaértékeket - még jóval felette van a valuta unióba való belépéshez meghatározott referencia-szintnek (lásd: V/1.12. sz. táblázat 3. oszlopa).

A leglátványosabb eredményt a csatlakozni vágyó országok az infláció terén érték el (lásd V/1.12. sz. táblázat). A kilencvenes évek elejének magas inflációja után a szükséges árliberalizációk következtében ez a ráta - Románia kivételével egyszámjegyüre zsugorodott. Bár az árfolyamok most még jelentősen, 34-79 százalékkal alulértékeltek, de a valuták kezdődő felértékelődése miatt megindult a felzárkózás. Ebben nagy szerepet játszott az is, hogy komolyan sikerült csökkenteni a hatósági árak körét, és megfelelő árfolyamrezsimet kialakítani. Ez utóbbiban az élen azok járnak, akik valutájukat az euróhoz kötötték. A románok és a lengyelek módszere (valutájuk szabadon lebegtetése) nem járt hatásos eredménnyel, mivel a dollár komoly piaci hatása révén fennállt annak a veszélye, hogy valutájuk hirtelen árfolyamváltozáson mehet keresztül az euróhoz képest.

Az euróövezetbe való belépéshez szükséges stabilitás megteremtésének feltétele, hogy a magánszektor aránya magas legyen, valamint minél kisebb területre korlátozódjon a központilag meghatározott (és nem a verseny eredményeképpen kialakuló) árak aránya. A magánszektor az ezredforduló tájékán európai szinten is magas értékkel járult hozzá a GDP-hez Csehországban és Magyarországon, de magas, 70 százalék feletti volt Szlovákiában és a Baltikumban is. A magánosítás aránya nem volt megfelelő Romániában; Szlovéniában pedig a volt jugoszláv sajátos tulajdonviszonyoknak megfelelően regisztrálható a magánszektor alacsony aránya. A központi árak aránya minden tagjelöltnél (Észtország kivételével) alacsony, 20 
százalék alatti, ami a belépés miatt (például energia- vagy közlekedési piac felszabadítása) tovább csökken majd.

V/1.13. sz. táblázat: A tagjelölt országok legfontosabb monetáris mutatói 1999-2000-ben

\begin{tabular}{|c|c|c|c|c|c|}
\hline Ország & $\begin{array}{c}\text { Reálfelér- } \\
\text { tékelödés } \\
\mathbf{2 0 0 0 / 1 9 9 9} \\
\mathbf{( \% )}\end{array}$ & $\begin{array}{c}\text { A valuta } \\
\text { alulérté- } \\
\text { keltsége } \\
\mathbf{( \% )}\end{array}$ & $\begin{array}{c}\text { Központi árak } \\
\text { aránya a } \\
\text { fogyasztói } \\
\text { árindex szerinti } \\
\text { kosárban (\%) }\end{array}$ & $\begin{array}{c}\text { Árfolyam- } \\
\text { rezsim }\end{array}$ & $\begin{array}{c}\text { A magán- } \\
\text { szektor } \\
\text { aránya a } \\
\text { GDP-ben } \\
\text { (\%) }\end{array}$ \\
\hline Bulgária & 6,2 & $-54,1$ & 17,2 & $\begin{array}{c}\text { Valutatanács, } \\
\text { euró (1997) }\end{array}$ & 70 \\
\hline Csehország & $-0,7$ & $-57,4$ & 13,3 & $\begin{array}{c}\text { Irányított } \\
\text { lebegtetés (1997) }\end{array}$ & 80 \\
\hline Észtország & $-1,4$ & $-54,1$ & 75,0 & $\begin{array}{c}\text { Irányított } \\
\text { lebegtetés, euró } \\
\text { (1992) }\end{array}$ & 75 \\
\hline $\begin{array}{c}\text { Magyar- } \\
\text { ország }\end{array}$ & 2,1 & $-53,6$ & 15,9 ('97) & $\begin{array}{c}\text { Irányított } \\
\text { lebegtetés, euró } \\
\text { (2001) }\end{array}$ & 80 \\
\hline Lettország & 11,0 & $-53,0$ & 20,4 ('98) & $\begin{array}{c}\text { SDR-hez kötött } \\
\text { (1995) }\end{array}$ & 65 \\
\hline Litvánia & 14,3 & $-48,7$ & - & $\begin{array}{c}\text { Valutatanács } \\
\text { USD (1994) }\end{array}$ & 70 \\
\hline $\begin{array}{c}\text { Lengyel- } \\
\text { ország }\end{array}$ & 2,5 & $-48,2$ & 9,0 & $\begin{array}{c}\text { Lebegtetetés } \\
\text { Irányított } \\
\text { lebegtetés }\end{array}$ & 65 \\
\hline Románia & 12,9 & $-70,9$ & 7,0 ('97) & $\begin{array}{c}\text { Irányított } \\
\text { lebegtetés, euró }\end{array}$ & 75 \\
\hline Szlovákia & 14,5 & $-60,3$ & 15,2 & $\begin{array}{c}\text { Irányított } \\
\text { lebegtetés }\end{array}$ & 55 \\
\hline Szlovénia & 7,7 & $-34,4$ & 14,3 & & 50 \\
\hline
\end{tabular}

Forrás: Deutsche Bank Research, [2000], EU Bizottság, [2001]

Összegezve az állapítható meg, hogy a felkészültebb tagjelöltek olyan gazdasági reformokat hajtottak végre, ami lehetővé teszi a megalapozott gazdasági növekedést úgy, hogy az EU számára is fontos eurózóna-kiterjesztés a bővülés után néhány éven belül megvalósulhatóvá váljon. 


\section{RÉSZ; 2. FEJEZET \\ A GAZDASÁGI ÉS SZOCIÁLIS KOHÉZIÓ A KIBŐVÜLŐ EURÓPAI UNIÓBAN}

Az egyik alapvető kifogás a közép- és kelet-európai tagjelöltek felvételével szemben, hogy társadalmi és gazdasági fejlettségi szintjük olyan messze elmarad a jelenlegi tagállamok átlagos szintjétől, ami az EU belső piacának egységes jellegét - beleértve a közös pénz bevezetését is - veszélyezteti. Érdemes megvizsgálni, hogy ez a vélemény - melyet nem tükröztek a kérdöíves felmérésre adott válaszok sem mennyire igazolható.

A jelenlegi tagállamokat érintő kérdés - az általános gazdasági fejlettségen túlmenően - az, hogy a csatlakozni kívánó országok képesek lesznek-e már a tagság előtt, és utána a spanyol, ír, portugál mintához hasonlóan olyan felzárkózási ütemet mutatni, ami belátható időn belül (20-25 év) reálissá teszi azt, hogy az illető országok, vagy régióik nagy része kikerüljön abból a fejlettségi kategóriából, amelyre jelenleg a strukturális támogatások nagy hányada fordítható. Negatív példaként a görög modell szerepel, ahol lényegi felzárkózásról az EU-tagság 20 éve alatt sem beszélhetünk, a jelentős közösségi pénzügyi transzfer inkább a leszakadás megakadályozását segítette elő.

Konkrétan arra is választ keresnek az európai elemzők, hogy a csatlakozó országok felzárkózása mellett az ország régióin belül vajon a konvergencia vagy a divergencia jegyei jelennek-e meg, vagyis ilyen értelemben a feltörekvő országok felzárkózása vagy éppen elszegényesedése figyelhetö-e meg. (E vonatkozásban a kérdőíves felmérésem optimista véleményt tükrözött.)

További kérdés az EU számára, hogy a szükséges felzárkóztatás milyen pénzösszegeket emészt fel, valamint az új országok képesek lesznek-e az erre fordítandó összegeket úgy felhasználni, hogy az elősegítse felzárkózásukat. 


\section{V/2.1. A kohéziós politika sikerei a jelenlegi EU-ban}

Az Európai Unió különleges figyelmet szentelt és szentel ma is annak, hogy területén a kiegyenlítődés területileg és szociálisan is megtörténjék. (Erre vonatkozóan a legjobb adatokat az 1996-ban kiadott Első Kohéziós Jelentés és az ezt követő 2001ben kiadott Második Kohéziós Jelentés szolgáltatott.) Erre legjobb példa az, hogy GDP-jének 0,45-0,46 százalékát költi a közösségi költségvetésböl erre a célra (ehhez járul még a nemzeti költségvetésekből ide szánt összegek), ami az EU 1989-1999 között kalkulált átlagos évi GDP-jének 6,5 százaléka volt. (A Marshall-segély négy éven át évente az USA GDP-jének 1 százalékát tette ki.) A felzárkóztató politika egyre jobban szükségszerüvé vált, hiszen az új tagok felvétele után 1986-ban a görög és portugál GDP-átlaga több mint 40 százalékkal alatta maradt a legjobban prosperáló tagállamokénak, míg 1973 előtt a német (legmagasabb) és az olasz (legalacsonyabb) egy főre jutó GDP között csak 25 százalékos különbség volt. A befektetett energia és pénzeszköz azonban nem volt hiábavaló, hiszen a négy legfejletlenebb (átlagos fejlettségét tekintve a közösségi GDP 90 százaléka alatti egy főre jutó nemzeti jövedelmet produkáló) ország - Spanyolország, Portugália, Görögország, Írország - nemzeti jövedelme az EU átlagához mérten az 1983. évi 66 százalékról 1993-ra 74 százalékra emelkedett és ez később tovább javult. (Első Kohéziós Jelentés, Európai Bizottság, [1996].) 1998-ban Írország az EU-átlag 108 százalékát, Görögország 68 százalékát, Portugália 72 százalékát, Spanyolország 81 százalékát tudta felmutatni.

Természetesen jobb, ha az eredményeket nemcsak az országok egészének teljesítményében vizsgáljuk, hanem aszerint, hogy az országokon belül az egyes régiók külön-külön milyen fejlődést tudtak elérni. Biztató, hogy 1983-1993 között a legfejletlenebb 10 európai NUTS-II (nemzeti szint alatti, ideálisan kb. 1,6 millió lakosú) régió az EU-átlag 53 százalékáról 55 százalékára tudott felfejlődni, és a 10 legfejlettebb és legfejletlenebb régió közötti mutató ez idő alatt 3,5-szeres különbségről 3,3-szoros különbségre csökkent. 


\section{V/2.2. A felzárkózás esélyei makrogazdasági szinten a csatlakozni kívánó országokban}

Mint már említettem (lásd: V/1. fejezet) az EU-hoz csatlakozni kívánó országok gazdasági növekedési üteme nagyrészt meghaladja az EU átlagos növekedési ütemét. Ezt azonban teljesen értelmetlen dolog összesítve vizsgálni, hiszen a jelentkezők gazdasági fejlettsége olyan lényeges differenciákat mutat egymáshoz viszonyítva, hogy azokat külön-külön érdemes megvizsgálni a felzárkózási esélyek tükrében:

V/2.1. sz. táblázat: A tagjelölt országok egy före jutó GDP-je az EU átlagának százalékában (EU = 100, PPS)

\begin{tabular}{|l|c|c|c|c|c|c|}
\hline \multicolumn{1}{|c|}{ Ország } & $\mathbf{1 9 9 5}$ & $\mathbf{1 9 9 6}$ & $\mathbf{1 9 9 7}$ & $\mathbf{1 9 9 8}$ & $\mathbf{1 9 9 9}$ & $\mathbf{2 0 0 0}$ \\
\hline Bulgária & 28 & 25 & 23 & 23 & 22 & 24 \\
\hline Csehország & 63 & 65 & 63 & 60 & 59 & 60 \\
\hline Románia & 32 & 34 & 35 & 36 & 27 & 27 \\
\hline Magyarország & 47 & 47 & 48 & 48 & 51 & 52 \\
\hline Lengyelország & 32 & 34 & 35 & 36 & 37 & 39 \\
\hline Észtország & 32 & 33 & 36 & 36 & 36 & 38 \\
\hline Lettország & 24 & 25 & 27 & 27 & 27 & 29 \\
\hline Litvánia & 27 & 29 & 30 & 31 & 29 & 29 \\
\hline Szlovákia & 41 & 44 & 45 & 46 & 49 & 48 \\
\hline Szlovénia & 64 & 66 & 67 & 68 & 71 & 72 \\
\hline EU & 100 & 100 & 100 & 100 & 100 & 100 \\
\hline
\end{tabular}

Forrás: Eurostat, [2001], EU Bizottság, [2001]

Mivel időközben változtak a mérési módszerek, az eredmények nem minden esetben jelzik az évente megvalósított kohéziós felzárkózást, de az 1998-2000-es már minden esetben iránymutatóak. Megállapítható, hogy Bulgária, Románia és Csehország nem tudott az elmúlt évtized végén lényeges felzárkózást elérni, a többi tagjelölt viszont az EU-átlaghoz mérve képes volt elindulni a felzárkózás útján.

Összehasonlításképpen érdemes megfigyelni azt is, hogy milyen mutatókat tapasztalhatunk a jelenlegi négy ún. kohéziós ország esetében akkor, ha csatlakozásuk idején vizsgáljuk meg az EU átlagában mért fejlettségüket és ezt összehasonlítjuk az 1998-ban mutatott eredményekkel. 
V/2.2. sz. táblázat: A négy kohéziós ország EU-átlagban mért fejlettségi szintje (EU =100, PPS)

\begin{tabular}{|l|c|c|c|c|c|c|}
\hline $\begin{array}{c}\text { Ország } \\
\text { (belépés éve) }\end{array}$ & $\mathbf{1 9 7 0}$ & $\mathbf{1 9 8 0}$ & $\mathbf{1 9 8 3}$ & $\mathbf{1 9 8 5}$ & $\mathbf{1 9 9 8}$ & $\begin{array}{c}\mathbf{1 9 9 8} / \\
\text { belépés } \\
\text { éve }\end{array}$ \\
\hline $\begin{array}{l}\text { Írország } \\
(1973)\end{array}$ & 60 & 64 & 64 & 65 & 108 & 183 \\
\hline $\begin{array}{l}\text { Görögország } \\
(1981)\end{array}$ & 63 & 70 & 62 & 64 & 68 & 99 \\
\hline $\begin{array}{l}\text { Spanyolország } \\
(1986)\end{array}$ & 71 & 70 & 71 & 70 & 81 & 116 \\
\hline $\begin{array}{l}\text { Portugália } \\
(1986)\end{array}$ & 50 & 55 & 55 & 53 & 72 & 133 \\
\hline
\end{tabular}

Forrás: Eurostat, Európa Bizottság, Világbank, [1999]

Az V/2.1. és az V/2.2-es táblázat összehasonlításából kiderül, hogy csatlakozáskor (2-3 éven belül) Szlovénia fejlettsége várhatóan meghaladja mind a négy ún. kohéziós tagállam belépéskori fejlettségi szintjét, de ugyanez elmondható Csehországról is, aki Spanyolország akkori szintjét vélhetően nem éri el, de megközelíti. A többi jelentkező közül Magyarország és Szlovákia lehet esélyes arra, hogy beéri Portugália vagy Írország csatlakozáskori szintjét. (Az V/1.10-es táblázatban látható, hogy az utóbbi évek felzárkózási üteme alapján az Európai Bizottság szerint az egyes tagjelölt országok hány év múlva érik el a jelenlegi EU átlagos fejlettségi szintjének 75 százalékát.)

\section{V/2.3. Az egyes régiók fejlettségi szintje}

Az EU kiemelten kezeli a csatlakozó országok régióinak fejlettségi szintjét, hiszen ez adja meg a választ arra, hogy mennyire szélsőséges vagy kiegyensúlyozott fejlődést mutatnak a nemzeti szint alatti (ún. NUTS-II) régiók. Célszerü az átlagolás helyett a tagállamoknál és a tagjelölteknél e változások irányait vizsgálni, és így következtetéseket levonni.

A regionális politika alakulásában további fontos elem az, hogy a csatlakozó országok hogyan tudják kialakítani regionális beosztásukat, meglehet azokat a felvételi tárgyalások előrehaladtával a tárgyaló feleknek 2002 folyamán 
véglegesíteniük kell. A kérdésben tisztázandóak az NUTS-II körzetek belső határai (kisebb országok esetében az is kérdés, hogy ez lehetséges-e a teljes országterület megvalósításával), illetve a fővárosok, mint önálló régiók, elfogadhatóak-e.

A közösségi költségvetés szempontjából az a lényeges, hogy mely NUTS-II körzetek fognak a közösségi átlag 75 százalékát meghaladó szintü régiók közé tartozni, hiszen az EU strukturális politikájában a támogatások döntő ( $\mathrm{kb}$. kétharmad) részét az ez alatti fejlettségi szintủ régiók támogatására fordítja, és a strukturális politika reformja ellenére ez az arány marad a jövőben is várhatóan érvényes.

Több jelenlegi tagállam és ezek számos régiója az által eshet ki a leginkább támogatott területek köréből, hogy a bővítés révén relatív fejlettsége emelkedik, ezért e régiók most jelentős lobbytevékenységet fejtenek ki azért, hogy továbbra is kedvezményezett régiónak minősüljenek és ennek megfelelő anyagi támogatást kapjanak. A továbbiakban a jelenlegi EU-átlaghoz mért mutatók alapján dolgozom, mivel jelen pillanatban az még tisztázatlan, hogy a bővülés után milyen elvek szerint állapítják meg az elmaradottság kritériumait.

\section{V/2.4. Az új tagállamok relatíve fejlett régiói}

Az 1999-es évre vonatkozó adatok szerint az 53 közép- és kelet-európai NUTS II régióból háromról állapítható meg bizonyosan, hogy bármilyen szük körü bővítés esetén kiesnek a legfejlettebb régiók köréből, vagyis elérik a mostani közösségi átlag 75 százalékát. Ezek Prága (124 százalék), Pozsony (95 százalék), illetve a középmagyarországi régió (75 százalék). Mindezek alapján a 104,68 milliós lakosságból (1998) kb. 4,6 millió lakosról mondható most el nagy bizonyossággal, hogy nem fog elmaradott térséghez tartozni (lásd V/2.5. sz. táblázat). Amennyiben Szlovénia egy NUTS-II körzetet alkot, akkor a 2000-es évre számolt 72 százalékos fejlettségi szintjével, valamint felzárkózási ütemével reálisan számolhatunk arra, hogy a belépéskor vagy az azt követő két-három éven belül kiesik a legelmaradottabb régiók ún. 1-es számú céltámogatásából. Érdemes megfigyelni, hogy a bővítés után a többi közép-kelet-európai régió közül egy sem haladná meg a bővítés után számolt közösségi GDP 75 százalékát. 
A térség régióinak fejlödési különbségét tekintve megállapítható, hogy a jelenlegi Unión belül az egy före jutó GDP-ben mért különbség a legfejlettebb és legfejletlenebb régiók között (1:5 arány) hasonló arányú a 10 jelentkező régiói között is. A bővítés után azonban a legfejlettebb (Belső London) és legfejletlenebb (Északkelet Románia) NUTS-II régió közötti különbség 1:13 lesz. Érdemes megvizsgálni az egyes tagállamok és tagjelölt országokon belül a legfejlettebb és legfejletlenebb NUTS II régióknál az egy főre jutó GDP-ben mért különbséget. Innen látszik az, hogy országonként mekkora eltérést lehet regisztrálni.

V/2.3. sz. táblázat: Fejlettségi eltérések a NUTS-II régióknál 1996-99-ban (EU 15=100, PPS)

\begin{tabular}{|l|c|c|c|c|c|c|c|c|}
\hline \multirow{1}{*}{ Ország } & \multicolumn{2}{c|}{$\begin{array}{c}\text { EU átlagában } \\
\text { (országos } \\
\text { vonatkozás) }\end{array}$} & \multicolumn{2}{c|}{$\begin{array}{c}\text { Legfejlettebb } \\
\text { régió }\end{array}$} & \multicolumn{2}{c|}{$\begin{array}{c}\text { Legfejletlenebb } \\
\text { régió }\end{array}$} & \multicolumn{2}{c|}{ Különbség } \\
\cline { 2 - 10 } & $\mathbf{1 9 9 6}$ & $\mathbf{1 9 9 9}$ & $\mathbf{1 9 9 6}$ & $\mathbf{1 9 9 9}$ & $\mathbf{1 9 9 6}$ & $\mathbf{1 9 9 9}$ & $\mathbf{1 9 9 6}$ & $\mathbf{1 9 9 9}$ \\
\hline Belgium & 112 & 107 & 173 & 217 & 81 & 69 & 92 & 148 \\
\hline Dánia & 119 & 119 & - & - & - & - & - & - \\
\hline Németország & 108 & 106 & 192 & 183 & 61 & 63 & 131 & 120 \\
\hline Görögország & 68 & 68 & 77 & 83 & 44 & 51 & 33 & 32 \\
\hline Spanyolország & 79 & 82 & 101 & 112 & 55 & 52 & 46 & 60 \\
\hline Franciaország & 104 & 100 & 160 & 154 & 40 & 51 & 120 & 103 \\
\hline Írország & 97 & 112 & - & 122 & - & 83 & - & 39 \\
\hline Olaszország & 103 & 103 & 132 & 136 & 59 & 63 & 73 & 73 \\
\hline Luxemburg & 169 & 186 & - & - & - & - & - & - \\
\hline Hollandia & 107 & 114 & 134 & 146 & 75 & 80 & 59 & 66 \\
\hline Ausztria & 112 & 111 & 167 & 150 & 71 & 71 & 96 & 79 \\
\hline Portugália & 70 & 74 & 89 & 100 & 50 & 53 & 39 & 47 \\
\hline Finnország & 97 & 101 & 130 & 140 & 74 & 74 & 56 & 66 \\
\hline Svédország & 101 & 101 & 123 & 133 & 92 & 89 & 31 & 44 \\
\hline Egyesült Kir. & 100 & 101 & 224 & 242 & 71 & 71 & 153 & 171 \\
\hline Bulgária & 28 & 27 & 34 & 37 & 24 & 23 & 10 & 14 \\
\hline Csehország & 65 & 59 & 120 & 124 & 49 & 47 & 71 & 77 \\
\hline Magyarország & 47 & 50 & 70 & 75 & 33 & 32 & 37 & 43 \\
\hline Észtország & 34 & 37 & - & - & - & - & - & - \\
\hline Lettország & 29 & 29 & - & - & - & - & - & - \\
\hline Litvánia & 29 & 33 & - & - & - & - & - & - \\
\hline Lengyelország & 35 & 39 & $65 *$ & 58 & $23 *$ & 27 & 42 & 31 \\
\hline Románia & 32 & 23 & 44 & 34 & 26 & 18 & 18 & 16 \\
\hline Szlovákia & 45 & 48 & 97 & 95 & 36 & 39 & 61 & 56 \\
\hline Szlovénia & 67 & 68 & - & - & - & - & - & - \\
\hline & & & & & & & & \\
\hline
\end{tabular}

Forrás: 2. Kohéziós Jelentés első felülvizsgálata, [2002], Európai Bizottság más belső anyagai

Megjegyzés: *(Vajdaságokra számolva) 
V/2.4. sz. táblázat: NUTS-II régiók száma 50 százalékos fejlettség felett

\begin{tabular}{|c|c|c|c|}
\hline \multirow{2}{*}{ Ország } & \multirow{2}{*}{ Összrégió } & \multicolumn{2}{|c|}{$\mathbf{5 0} \%$ felett } \\
\cline { 3 - 4 } & & $\mathbf{1 9 9 6}$ & $\mathbf{1 9 9 9}$ \\
\hline Bulgária & 9 & - & - \\
\hline Csehország & 8 & 7 & 5 \\
\hline Észtország & 1 & - & - \\
\hline Magyarország & 7 & 2 & 2 \\
\hline Lettország & 1 & - & - \\
\hline Litvánia & 1 & - & - \\
\hline Lengyelország & 16 & 1 & 1 \\
\hline Románia & 8 & - & - \\
\hline Szlovákia & 4 & 1 & 1 \\
\hline Szlovénia & 1 & 1 & 1 \\
\hline Összesen & $\mathbf{5 6}$ & $\mathbf{1 2}$ & $\mathbf{1 0}$ \\
\hline
\end{tabular}

Forrás: EU Bizottság, [2002]

Az alábbi megállapításokat tehetjük:

- A területi kiegyenlítődést illetően mind a tagállamoknál, mind a társultaknál nagy szórás figyelhető meg. Ahol a fővárosoknak vagy kiemelt városoknak külön körzete van (Prága, Hamburg, Madrid, Pozsony, Budapest), ott torzítottan nagyobb értéket kapunk a legfejletlenebb és legfejlettebb régiók összehasonlításában.

- Az Unióban minden vizsgált tartomány eléri az 50 százalékos fejlettségi fokot. Ugyanakkor a három kohéziós tagországban is szép számmal megtalálhatók olyan területek, amelyek 60 százalék alatt vannak, így teljes Dél-Spanyolország, Közép-Görögország, Portugália tengeren túli része.

- Szlovénia és Csehország összesen kilenc régiójából 6 meghaladja az 50 százalékos küszöböt (beleértve a Szlovénián belül külön régiót nem alkotó Muraközt is), ami megfelelő fejlettségi szintet jelent. Szlovénia a 60 százalékos küszöböt is átlépte. Az 50 és 60 százalékot meghaladó fejlettségi szintnek a csatlakozás után a regionális alapon nyújtott állami támogatás szempontjából is lesz jelentősége (ld. versenypolitikával foglalkozó fejezet).

- A nagysága miatt alapvető fontosságú Lengyelországban nemcsak a régiók, hanem a vajdaságok vizsgálata alapján is csak a varsói körzet haladja meg az 50 
százalékos fejlettséget (sőt a többi régió meglehetősen messze van ettől). A három balti államban, illetve a két balkáni államban még a fővárosok körzete sem éri el a közösségi átlag felét, ez alól csak 1996 óta Tallinn kivétel.

- A rendelkezésre álló közép- és kelet-európai adatok alapján látható, hogy a felzárkózó országok fővárosai nagymértékben kerülnek közelebb az európai átlaghoz vagy meghaladják azt (Prága, Pozsony, Budapest, Varsó, Ljubljana), míg a többi régió kohéziós teljesítménye stagnáló (néhol csökkenő) illetve enyhén javuló (0-3 százalék). A tagjelöltekhez hasonló nyíló olló jellemzi a kohéziós tagállamokat is, hiszen Spanyolországban három év alatt 46-ról 60 százalékra nőtt a legfejlettebb és legfejletlenebb régió közötti különbség, Portugáliában 39-ről 47 százalékra, de Írországban is eltérő felzárkózási ütemet láthatunk az ország újonnan létrehozott két régiója között. (Az írek fejletlenebb területe 1991-97 között 14 százalékponttal zárkózott fel, míg a fövárost is magában foglaló fejlettebb régióban ugyanezen időszak alatt 33 százalékkal.) Mindez azt jelzi, hogy a müködőtőke beáramlások koncentrált hatásaként a felzárkózás - akár az EU átlagánál elmaradottabb tagállamról, akár tagjelöltről van szó - egy nyíló ollóval valósul meg, ami nem jelenti feltétlen a legrosszabb helyzetben lévő régiók leszakadását, ám igazi felzárkózásuk csak a tagság után, a nemzeti területfejlesztési politikát kiegészítő közösségi eszközök révén valósítható meg. Mint láttuk, ez az EU-ban sem egyszerü (a 10 legfejletlenebb régió 2 százalékos relatív felzárkózása 10 év alatt), vagyis ebben nem hoznak az új tagok a jelenlegihez képest rosszabb helyzetet.

\section{V/2.5. A felvétellel járó költségek}

Mint az előzőekben említettem, a kiegyensúlyozott közösségi fejlődés egyik motorja a strukturális politika, ami középpontba fog kerülni a közép- és kelet-európai országokkal történő bővülésnél. A Berlinben, 1999 tavaszán elfogadott uniós költségvetési irányelvek azt rögzítik, hogy a 15 tagállam esetében a strukturális eszközökre fordított 2000. évi 32.678 milliárd euró 2006-ra 30.343 milliárd euróra csökken, ami a strukturális politika költségeinek mintegy kétharmadát kitevő, az 1-es célkitűzés alá eső területek támogatásának fokozatos leépítésével valósítható meg elsősorban. 
Tekintettel az új tagok nagy támogatási igényére, illetve a közösségi költségvetés véges kapacitására, az Unió strukturális politikáinak reformja során azt a korlátozó intézkedést hozta, hogy e politika alatt (kohéziós, illetve strukturális alapok) adott éves támogatás az egyes tagállamok esetében nem haladhatja meg az éves GDP 4 százalékát. Ez alapvetően azzal a következménnyel jár, hogy a jelenlegi 15 tagállam mindegyike ezután is megkaphatja az eddigi pénzügyi irányelvek során élvezett támogatásait. Másrészt azt az elvet hozták be (az abszorpciós képességre hivatkozva), hogy minél fejlettebb egy csatlakozó ország, annál több pénz felvételére lehet lehetősége, legalábbis e kritérium alapján. Ezt igazolja az is, hogy ha megnézzük a társult országok GDP adatait, illetve annak 4 százalékát.

\section{V/2.5. sz. táblázat: A társult országok föbb kohéziós paraméterei} 1998-ban

\begin{tabular}{|l|c|c|c|c|c|}
\hline \multicolumn{1}{|c|}{ Ország } & $\begin{array}{c}\text { GDP } \\
\text { (ezer millió } \\
\text { euró) }\end{array}$ & $\begin{array}{c}\text { Lakosság } \\
\text { (millió fö) }\end{array}$ & $\begin{array}{c}\text { GDP 4 \%-a } \\
\text { (támogatási } \\
\text { korlát) } \\
\text { (millió euró) }\end{array}$ & $\begin{array}{c}\text { 1 fóre jutó } \\
\text { támogatási } \\
\text { korlát } \\
\text { (euró) }\end{array}$ & $\begin{array}{c}\text { 1. célki- } \\
\text { túzésre } \\
\text { jogosult } \\
\text { lakosság } \\
\text { (millió fó) }\end{array}$ \\
\hline Bulgária & 11,0 & 8,23 & 440 & 53,46 & 8,23 \\
\hline Csehország & 50,1 & 10,29 & 2004 & 194,75 & 9,09 \\
\hline Észtország & 4,6 & 1,44 & 184 & 127,78 & 1,44 \\
\hline Magyarország & 41,9 & 10,09 & 1676 & 166,11 & 7,23 \\
\hline Lettország & 5,7 & 2,43 & 228 & 93,83 & 2,43 \\
\hline Litvánia & 9,6 & 3,70 & 384 & 103,78 & 3,70 \\
\hline Lengyelország & 140,2 & 38,66 & 5608 & 145,06 & 38,66 \\
\hline Románia & 36,9 & 22,48 & 1476 & 65,66 & 22,48 \\
\hline Szlovákia & 18,1 & 5,39 & 724 & 134,32 & 4,77 \\
\hline Szlovénia & 17,4 & 1,97 & 696 & 353,30 & 1,97 \\
\hline Összesen: & $\mathbf{3 3 5 , 5}$ & $\mathbf{1 0 4 , 6 8}$ & $\mathbf{1 3 4 2 0}$ & $\mathbf{1 2 8 , 2 0}$ & $\mathbf{1 0 0 , 0 0}$ \\
\hline
\end{tabular}

Forrás: Eurostat, [2000], saját számítás

A 2000-2006-os költségvetési irányelv alapján tudjuk, hogy kb. 63 millió före (Spanyolország, Írország, Portugália, Görögország) jut évi kb. 2,7 milliárd euró Kohéziós Alap (ez kb. 42,9 euró/fö), valamint az 1. célkitűzésre átlagosan 220 euró/fö. Feltételezve, hogy ezt a kohéziós támogatást az új belépők is megkapnák, (hiszen egyikük fejlettsége sem éri el az EU-átlag 90 százalékát), valamint azt, hogy az 1. célkitüzés alá eső területek szintén megkapják a 220 euró/fős támogatási 
keretet, ha nem ütközik az ország GDP-jének 4 százalékát jelentő korlátba, az alábbiakat állapíthatjuk meg:

- Az 1. célkitüzésből kiesik Prága (1,2 millió fö), Közép-Magyarország (2,8 millió fó) és Pozsony (0,6 millió fö).

- A különböző korlátok miatt most a 2. és 3. célkitüzés alá eső támogatástól pillanatnyilag - nagyságrendjének kisebb volta miatt - eltekintek.

A térség 104,7 millió lakosából kiindulva, valamint az 1. célkitüzésnél szóba jöhető lakosságszám alapján az egyes támogatások az alábbiak szerint alakulhatnak:
V/2.6. sz. táblázat: A tagjelölt országok strukturális támogatásának kalkulált összegei a jelenlegi tagállami támogatások alapján (1998-as adatok)

\begin{tabular}{|l|c|r|r|r|r|c|}
\hline \multicolumn{1}{|c|}{ Ország } & $\begin{array}{c}\text { Kohéziós } \\
\text { alap } \\
\text { (m euró) }\end{array}$ & $\begin{array}{c}\text { l. cél- } \\
\text { kitüzés } \\
\text { (m euró) }\end{array}$ & $\begin{array}{c}\text { Valós } \\
\text { határ } \\
\text { (m euró) }\end{array}$ & $\begin{array}{c}\text { Jogosultság } \\
\text { korlát } \\
\text { nélkül } \\
\text { (m euró) }\end{array}$ & $\begin{array}{c}\text { Valós } \\
\text { támogatás } \\
\text { (m euró) }\end{array}$ & $\begin{array}{c}\text { Valós } \\
\text { támogatás } \\
\mathbf{( \% )}\end{array}$ \\
\hline Bulgária & 353,1 & $1.810,6$ & 440 & $2.163,7$ & 440 & 20,3 \\
\hline Csehország & 441,44 & $1.999,8$ & 2.004 & $2.441,2$ & 2.004 & 82,1 \\
\hline Észtország & 61,8 & 316,8 & 184 & 378,6 & 184 & 48,6 \\
\hline Magyarország & 432,9 & $1.590,6$ & 1.676 & $2.023,5$ & 1.676 & 82,8 \\
\hline Lettország & 104,2 & 534,6 & 228 & 638,8 & 228 & 35,7 \\
\hline Litvánia & 158,7 & 814,0 & 384 & 972,7 & 384 & 39,5 \\
\hline Lengyelország & 1658,5 & $8.505,2$ & 5.608 & $10.163,7$ & 5.608 & 55,2 \\
\hline Románia & 964,4 & $4.945,6$ & 1.476 & $5.910,0$ & 1.476 & 25,0 \\
\hline Szlovákia & 231,2 & $1.049,4$ & 724 & $1.280,6$ & 724 & 56,5 \\
\hline Szlovénia & 84,5 & 433,4 & 696 & 517,9 & 518 & 100,0 \\
\hline Összesen: & $\mathbf{4 4 9 0 , 7}$ & $\mathbf{2 1 . 9 9 9 , 9}$ & $\mathbf{1 3 . 4 2 0}$ & $\mathbf{2 6 . 4 9 0 , 7}$ & $\mathbf{1 3 . 2 4 2}$ & - \\
\hline
\end{tabular}

Forrás: Eurostat, saját számítás

Megjegyzések:

Kohéziós alap: Lakosság x 42,9 euró

1. célkitüzés: Jogosult lakosság x 220 euró

Valós határ: GDP 4 százaléka

Jogosultság korlát nélkül: Kohéziós alap +1 . célkitüzés

Valós támogatás százaléka: Valós támogatás/Jogosultság korlát nélkül

Mint az V/2.6. sz. táblázatból látható, 1998-ban csak Szlovénia tudta volna - a bevezetett korlátozással - felvenni a kohéziós alapból és legelmaradottabb térségek számára juttatandó támogatási alapból a teljes összeget (sőt a strukturális alapok 2. és 
3. célkitüzéseiből is lehetősége nyílna 178 millió eurós összeg felvételére). A többi tagjelölt ország a négy százalékos korlát miatt a tagállamokkal egyenlő elbánás szerinti támogatásokat nem tudta volna teljes mértékben felvenni 1998-ban. Az V/2.6-os táblázat legutolsó oszlopából látható, hogy a viszonylag magasabb egy fơre jutó GDP-vel rendelkező tagjelöltek (Csehország, Magyarország) már 1998-ban is közel jártak ahhoz az értékhez (több mint 80 százalék), amelyet egyenlő elbánás szerint felvehettek volna. A kisebb GDP-vel rendelkező tagjelölteknél a négy százalékos korlát csak az egyenlő elbánás szerint kalkulált összegek töredékét (Bulgária esetében alig több mint 20 százalékát, Romániánál mintegy 25 százalékát, de Lengyelországban is csak 55 százalékát) engedte volna folyósítani. Tekintettel azonban arra, hogy a társult országok GDP-je az elkövetkezendő években várhatóan lendületesen nőni fog és arra, hogy 2006 végéig - az elkülönített bővítési pénzek meghatározott jellege miatt - átmeneti szabályozásra van szükség, joggal feltételezhető, hogy Szlovénia után Csehország és Magyarország (esetleg Szlovákia) is eléri azt a GDP-szintet, ami a jelenlegi átlagos uniós támogatás alapján a kohéziós alapból és az 1. célkitűzésből megilletné. A többieknek a 4 százalékos korlátozás miatt még nagyon hosszú ideig erre nem lesz esélyük. Az 1998-as évre vonatkozó számításaim alapján maximum 13,4 milliárd euró folyósítása válna lehetővé. Az 1999-ben Berlinben elfogadott közösségi pénzügyi irányelvek 2002-ben 3,9, 2006ban 12,6 milliárd euró támogatásával számoltak. Gyakorlatilag ez azt jelenti, hogy 2006-ban még 12 új tagállammal is folyósítható lenne a négy százalékos küszöbbel kalkulált pénzösszegek nagy része, ennél kevesebb új tagnál pedig már 2006-ban is biztosítható az egyenlő elbánás elve.

Mindezek alapján feltételezhető, hogy 2007-től, a következő uniós pénzügyi irányelvek kezdetétől az újonnan felvettek számára finanszírozhatóak a strukturális költségek. Ugyanakkor a tagjelöltek gazdasági növekedése miatt a strukturális támogatásokra bevezetett négy százalékos felső korlát összege az 1998-ra számított 13,4 milliárd euróról néhány éven belül 16-17 milliárd euróra nő. Csökkenti viszont a közösségi költségvetés ebből eredő leterheltségét az, hogy a jelenlegi tagállamok régiói közül többen kikerülnek a legelmaradottabb térségeknek járó pénzügyi kategóriából. 


\section{RÉSZ; 3. FEJEZET \\ BELSŐ PIACI TERÜLETEK, VERSENYPOLITIKA}

\section{V/3.1. Az integráció hatása a versenypolitika terén}

A versenypolitika kiemelését az EU oldaláról az indokolja, hogy a bővítés után megnövekedő belső piac zavartalanul, torzulásoktól mentes müködése biztosítható legyen.

A vállalati magatartásokra vonatkozó közösségi versenyjogi előírások alkalmazását nagyrészt már a tagság előtt (az Európai Megállapodások révén) kikényszerítették a tagjelölt országoktól, így számukra a szabályok betartása már nem jelent új elemet a belépéskor.

Az ún. állami támogatási szabályokat illetően azonban csak a tagság után várható tisztább kép. Az már a tagság előtt is kiviláglik, hogy a közösségi forrásokból összegszerüen a legtöbb tagjelölt nem számíthat akkora támogatásra, mint a tagállamok (lásd $V / 2$. fejezet), ezért néhány specifikus területen az állami támogatásoknak kiemelkedő szerepük lesz. Az is nyilvánvaló, hogy a múltból egy erős állami szubvencióra épülő rendszert (nemcsak az ipar, de a szolgáltatások terén is) örököltek a tagjelöltek, és ennek átalakítása, lebontása nem minden országban valósult még meg (lásd V/1. fejezet).

A versenypolitika terén ezért az egyik nagy minőségi előnye a bővítésnek az lesz, hogy átláthatóvá teszi a nemzeti támogatáspolitikákat, vagyis nemcsak a kormányzati, de a regionális és önkormányzati szinten nyújtott támogatásokat is nyomon követhetővé teszi az ezért felelős brüsszeli Bizottság számára. Csak az átláthatóság révén tudják Brüsszelben garantálni azt, hogy a támogatásokat az EU versenyjogi szabályozásának megfelelően folyósítsák. Ennek az lehet az előnye, hogy a jelenlegi nagy beruházási kedvet ösztönző adókedvezményeket a közösségi szabályozásnak megfelelően korlátozzák. (Magyarországon például a beruházások teljes összege leírható adókedvezményként, míg az EU-ban maximum 50 százalék.) 
Ezáltal lehetséges annak is érvényt szerezni, hogy csak a gazdaságilag fejletlen régiókban, illetve csak meghatározott tevékenységre adjanak az új tagállamok nemzeti szintü támogatást. Így tudják megoldani az autóipar, hajó- és acélgyártás Közösségben érzékeny területek - folyamatos támogatásának kizárását. Szintén csak a tagság révén tudják azt ellenőrizni, hogy az Unió által is kedvezményezett kis- és középvállalkozások fejlesztése, a foglalkoztatás növelése, környezetvédelmi, kutatási és képzési célok a támogatások révén valóban érvényesültek-e. Mivel az Unió az áruforgalom terén már most is szabadkereskedelmi viszonyban van a tagjelöltekkel, (ennek aránya több tagállam külkereskedelmében nem elhanyagolható, lásd V/5. fejezet) számára is előnyös, ha a másik fél versenyjogi viselkedése minél hamarabb ellenőrizhetővé válik. Versenyjogi szempontból lényeges, hogy a tagjelöltek NUTSII régiói (800 ezer és 3 millió fő közötti lakosú terület) milyen fejlettséget érnek el (lásd V/2. fejezet), hiszen a fejlettebb területeknél a támogatások intenzitása alacsonyabb lehet (az egy före jutó GDP-t tekintve a közösségi átlag 60 százalékát elérő területeken pl. már csak 40 százalék lehet). Ennek alapján a fejlettebb jelöltek közül Szlovéniában és Csehországban (de hamarosan ide sorolható lesz Magyarország tekintélyes része is), a támogatási intenzitás nem fogja meghaladni a 40 százalékot, ami segíti a jelenlegi tagállamok vállalatainak versenyhelyzetét.

Az Unió célja a támogatások mérséklésének megvalósítása, vagyis tiszta versenyviszonyok teremtése. Mint azt a Bizottság második Kohéziós Jelentése is leszögezte, 1994-1996-hoz képest 1996-1998-ban az állami támogatások összege a Közösségben jelentősen csökkent a mezőgazdaságon (mely külön közös politikát képez) kívüli területeken, 104,215 milliárd euróról 93,127 milliárd euróra. A tagállamok közül szélsőségesek az egy lakosra jutó támogatási mértékek, hiszen míg Németországban 327 euró volt, addig a másik végletet jelentő Finnországban csak 97 euró, vagyis kevesebb, mint harmada. Jelentős eredmény az Unió számára, hogy az igazán nagy támogatást nyújtó országok (Németország, Olaszország, Luxemburg) az előző időszakhoz képest szignifikáns módon csökkentették az egy főre jutó támogatásukat, ami azt eredményezte, hogy az 1994-96 közötti időszak 1:4 körüli szélső értéke (a legnagyobb egy főre jutó támogatást adó tagállam szubvenciójának értéke a legkisebb egy főre jutó támogatást adó tagország szubvenciójához képest) 1:3 körülire csökkent. Jellemző az Unión belüli helyzetre, hogy a kohéziós országok 
abszolút támogatási mutatói a kisebb GDP és jövedelmi viszonyok miatt alacsonyak, lényegében stagnálnak (120-148 euró/fö).

Az új tagállamokban az egy före jutó támogatás a jelenlegi tagállamokénál minden bizonnyal alacsonyabb összeget fog elérni. 1998-ban Magyarországon például egy före 82,6 euró támogatás jutott, Litvániában ez 26,9 euró volt, míg Lettországban 18,5 euró.

Természetesen a társult országok alacsonyabb GDP mutatói miatt relatíve magas az új tagállamok állami segélypolitikáját jelző mutató, de a fejlettebb tagjelölt államoknál ez sem fogja meghaladni a GDP 2 százalékát. Mario Monti, az EU Bizottság versenyjogi ügyekért felelős tagja, a tagjelöltek esetében ezt az arányt 0,54,5 százalék közöttinek becsülte 2000-ben. Az is valószínüsíthető, hogy a tagság után a gazdasági növekedés további folytatódása révén ez az arány csökkenni fog. A csökkenési tendencia egyértelmü, hiszen Boeri 2000-ben (az EPI és a CEPR kutatóintézetek adataira hivatkozva) azt állapította meg, hogy 1995-ben pl. Magyarországon a teljes támogatás a GDP 3,5 százaléka, Csehországban 3,4, Szlovákiában 4,8, Szlovéniában 3,7 és Lengyelországban 1,8 százaléka volt.

Az V/3.1. sz. táblázatból látható, hogy a tagjelölt országokban az ipari szabadkereskedelem szempontjából fontos feldolgozóipari területre magasabb arányban jut támogatás, de ennek abszolút összege (egy foglalkoztatottra) így is jelentősen alatta marad az EU-átlagnak, és a tagállamok többségének. Mindezek alapján kijelenthető, hogy az állami támogatások összege már most sem jelent kirívó arányt, sőt abszolút értékben szerénynek is mondható. Különösen feltűnő ez az 1989ig szintén szocialista rendszert építő keletnémet tartományokkal összehasonlítva. Ez arra enged következtetni, hogy nem fog látványosan zuhanni a legtöbb tagjelöltnél a támogatás összege, viszont átláthatóvá válik és a közösségi jogszabályokkal összhangba kerül. 
V/3.1. sz. táblázat: Állami támogatások mutatói néhány tagállamban és tagjelölt országban

\begin{tabular}{|l|c|c|c|c|}
\hline \multicolumn{1}{|c|}{ Ország } & $\begin{array}{c}\text { GDP } \\
\text { százalékában }\end{array}$ & $\begin{array}{c}\text { Egy főre jutó } \\
\text { támogatás } \\
\text { (euró) }\end{array}$ & $\begin{array}{c}\text { Feldolgozóipar } \\
\text { támogatása a } \\
\text { teljes támoga- } \\
\text { tásból (\%) }\end{array}$ & $\begin{array}{c}\text { A feldolgozó- } \\
\text { iparban az egy } \\
\text { dolgozóra esó } \\
\text { támogatás (euró) }\end{array}$ \\
\hline Németország & 1,45 & 327 & 40 & 1434 \\
\hline volt NDK & - & - & - & 6021 \\
\hline Olaszország & 1,57 & 276 & 51 & 1955 \\
\hline Spanyolország & 0,98 & 120 & 31 & 691 \\
\hline Portugália & 1,63 & 148 & 11 & 188 \\
\hline Finnország & 0,47 & 97 & 19 & 959 \\
\hline Görögország & 1,24 & 125 & 43 & 997 \\
\hline Magyarország & 2,00 & 83 & 63 & 573 \\
\hline Litvánia & 1,03 & 27 & 57 & - \\
\hline Lettország & 1,8 & 19 & 43 & - \\
\hline Bulgária & 3,34 & - & 66 & 1113 \\
\hline EU & 1,12 & 214 & 35 & \\
\hline
\end{tabular}

Forrás: EU Bizottság Versenyjogi Főigazgatóság, PM Budapest, [2001]

Megjegyzés: az EU-országok esetében az adatok 1996-98 átlagát tükrözik; míg Magyarország, Litvánia esetében 1998-ra, Lettország esetében 1999-re, Bulgária esetében 2000-re vonatkoznak.

\section{V/3.2. A tőkemozgás szabadságából adódó előnyök}

Mint közismert, a szocializmus igájából kitört tagjelölt országok számára igen nagy gondot jelent a tőkehiány. Ezért minden ország igyekezett kedvező feltételeket teremteni a tőkebeáramláshoz, hogy fedezni tudják a piacgazdaság átállásából eredő fizetési mérleg nehézségeket. Az igazán jelentős tőkebeáramlás 1991-ben, az Európai Megállapodások aláírása után indult meg, és az évtized közepére vált jelentőssé. A tőkemozgások jellegzetességéből az alábbiak emelhetők ki:

- A tőkebeáramlás alapvető formája a müködőtőke. Míg a portfólió befektetések 1993-1999 között az IMF adatai szerint 37,7 milliárd USD-t tettek ki, addig a nettó müködőtőke beáramlás meghaladta a 60 milliárd USD-t (lásd: V/3.2. sz. táblázat). Az ezredforduló idején nem változott a két mutató divergens jellege. A portfólió befektetések terén a fejletlenebb pénzpiaci viszonyok miatt óvatosak voltak a befektetők, és a globalizálódó világban az elaprózott közép-európai 
tőzsdék nem jelentettek akkora vonzerőt az egyre jobban koncentrálódó, mobil pénztömegek tulajdonosai számára.

- A befektetett tőke a megfelelő profitlehetőségeket és az üzleti körülményeket keresve a legfejlettebb tagjelöltekre koncentrálódott, lényegében Lengyelország, Csehország és Magyarország szívta fel a befektetések több mint 80 százalékát.

- A jelenlegi tagállamok által a térségben befektetett tőke mennyisége és gazdasági potenciálja számukra elenyésző volt, mindössze GDP-jük 0,15 százalékát tette ki, ugyanakkor a tagjelöltek GDP-jének 5-7 százalékát is elérte évente.

- Az EU országaiból származó befektetések minden társult ország esetében meghaladták a teljes befektetések több mint felét (Csehországban 82, Lengyelországban, Észtországban 77, de Magyarországon, Szlovéniában és Szlovákiában is 70 százalék feletti, lásd V/3.2 sz. táblázat). Az Európai Unió országaiban 1997-ben az EU-ból érkező befektetések aránya 61,5 százalék volt, tehát elmaradt a tagjelöltek nagy részének hasonló mutatójától (Eurostat, [2001]). Megállapítható, hogy hasonlóan az EU és a tagjelöltek közötti kereskedelmi függéshez, a tőkebefektetések vonatkozásában már a tagság előtt is domináns az európai eredetű tőke a tagjelölt országokban, vagyis e téren integráltsági fokuk nagyon magas. 
V/3.2. sz. táblázat: A tökebefektetések föbb mutatói a társult országokban

\begin{tabular}{|l|c|c|c|r|r|r|}
\hline \multicolumn{1}{|c|}{ Ország } & $\begin{array}{c}\text { Nettó FDI } \\
\mathbf{1 9 9 3 - 1 9 9 9} \\
\text { (millió } \\
\text { USD) }\end{array}$ & $\begin{array}{c}\text { FDI } \\
\text { megosz- } \\
\text { lása } \\
\text { (százalék) }\end{array}$ & $\begin{array}{c}\text { EU } \\
\text { országok } \\
\text { aránya a } \\
\text { befekte- } \\
\text { tésekböl }\end{array}$ & $\begin{array}{c}\text { FDI } \\
\text { készlet } \\
\mathbf{1 9 9 7} \\
\text { (GDP } \\
\text { százalé- } \\
\text { kában) }\end{array}$ & $\begin{array}{c}\text { Portfólió } \\
\text { befektetés } \\
\mathbf{1 9 9 3 - 1 9 9 9} \\
\text { (millió } \\
\text { USD) }\end{array}$ & $\begin{array}{c}\text { Portfólió } \\
\text { befektetés } \\
\text { megoszlása } \\
\text { (százalék) }\end{array}$ \\
\hline Bulgária & 1187 & 1,97 & 63 & 4,5 & 254 & 0,67 \\
\hline Csehország & 7777 & 12,90 & 82 & 13,6 & 11552 & 30,64 \\
\hline Észtország & 1402 & 2,33 & 77 & 20,4 & 584 & 1,55 \\
\hline Magyarország & 14973 & 24,84 & 72 & 33,2 & 10366 & 27,49 \\
\hline Litvánia & 2039 & 3,38 & 53 & 13,5 & 696 & 1,85 \\
\hline Lettország & 2018 & 3,35 & 57 & 8,3 & -446 & $-1,18$ \\
\hline Lengyelország & 23966 & 39,76 & 77 & 9,7 & 10999 & 29,17 \\
\hline Románia & 3657 & 6,07 & 60 & 4,1 & 1916 & 5,08 \\
\hline Szlovákia & 1860 & 3,09 & 71 & 5,8 & 721 & 1,91 \\
\hline Szlovénia & 1394 & 2,31 & 75 & 10,8 & 1063 & 2,82 \\
\hline
\end{tabular}

Forrás: IMF, Eurostat, saját számítások, Boeri, [2000]

Megjegyzés: FDI: működőtőke befektetés

\section{V/3.3. A müködőtőke-befektetések jelentősége az EU-tagállamok számára}

Az EU-tagállamok teljes európai működő tőke kivitelének 8,6 százalékát kötötte le a tagjelölteket felölelő térség 1992-1996 között. Ez az arány magas Ausztria esetében (39 százalék), de Olaszországnál (17 százalék) vagy Németországnál (13 százalék) sem alacsony. Ezen országoknak, de különösen Ausztriának kedvez e téren a bővítés, mivel így nőni fog befektetésük biztonsága és haszna.

Németország adja a közép-kelet-európai térségben befektetett tőke csaknem felét, de jelentős befektető volt még Hollandia, Franciaország valamint Ausztria is. Ezek az országok adták a 90-es évek közepén a befektetések 83 százalékát. Az Európán belüli befektetési aktivitás is hasonló képet mutat azzal a különbséggel, hogy Ausztria helyett Nagy-Britannia is jelentős befektető a kontinensen belül. A közép-keleteurópai országokba befektetett tőke az európai befektetéseken belül 8,6 százalékot képez, ami meglehetősen alacsonynak tünik, de összehasonlítva az EU és a tagjelöltek GDP-jét (kb. 4 százalék), ez a százalék kedvezőnek értékelhető. 


\section{V/3.3. sz. táblázat: Az EU tagállamainak befektetési súlya} a közép-és kelet-európai térségben

(1992-1996)

\begin{tabular}{|l|c|c|c|}
\hline \multicolumn{1}{|c|}{ Ország } & $\begin{array}{c}\text { FDI * } \\
\text { (százalék) }\end{array}$ & $\begin{array}{c}\text { Európába } \\
\text { fektetett } \\
\text { tőkk*** }\end{array}$ & $\begin{array}{c}\text { FDI / Európába } \\
\text { fektetett } \\
\text { arány*** }\end{array}$ \\
\hline Ausztria & 11,30 & 2,52 & 38,70 \\
\hline Belgium/Luxemburg & 3,70 & 7,09 & 4,50 \\
\hline Dánia & 2,90 & 2,10 & 12,00 \\
\hline Finnország & 1,30 & 3,97 & 2,90 \\
\hline Franciaország & 12,50 & 20,39 & 5,30 \\
\hline Németország & 46,40 & 30,94 & 12,90 \\
\hline Görögország & 0,00 & 0,00 & 0,00 \\
\hline Olaszország & 3,70 & 1,88 & 16,80 \\
\hline Hollandia & 12,80 & 16,40 & 6,70 \\
\hline Portugália & 0,00 & 0,37 & 0,70 \\
\hline Spanyolország & 0,30 & 2,52 & 1,10 \\
\hline Svédország & 2,90 & 2,10 & 12,00 \\
\hline Egyesült Királyság & 2,90 & 9,70 & 2,60 \\
\hline Európai Unió & $\mathbf{1 0 0 , 0 0}$ & $\mathbf{1 0 0 , 0 0}$ & $\mathbf{8 , 6 0}$ \\
\hline
\end{tabular}

Forrás: Eurostat, Boeri (2000)

Megjegyzés: *FDI a 10 közép-kelet-európai országban egy tizedesre kerekítve

**Európába fektetett tőke tagállamok közötti megoszlása

***A közép-kelet-európai országokba fektetett FDI tőke aránya az Európába fektetett tőkéhez képest

\section{V/3.4. A müködőtőke-befektetések ágazati irányultsága}

A szakértői elemzések (OECD) szerint a térségben eszközölt befektetéseknek csak mintegy 40 százaléka irányul azokba a szektorokba, ahol kereskedésre alkalmas termékeket (feldolgozóipar és nyersanyagszektor) állítanak elő és kb. 45 százalék irányul nem kereskedelmi termékeket előállító ágazatokba (lásd: V/3.4. sz. táblázat). A három OECD-tag társult országban (melyek az FDI több mint 80 százalékát felszívják) a feldolgozóiparon belül a motorgép-gyártás és élelmiszeripar dominál. A 90-es évek közepén nem az árutermelésbe való bekapcsolódás, hanem a piacszerzés motiválta a külföldi befektetőket. 
V/3.4. sz. táblázat: A müködötőke szektorális megoszlása a cseh, magyar és lengyel gazdaságban 1996-ban

\begin{tabular}{|c|c|c|}
\hline Szektor & $\begin{array}{c}\text { Megoszlás } \\
\text { (százalék) }\end{array}$ & $\begin{array}{c}\text { Növekedési ütem } \\
\mathbf{1 9 9 2 - 1 9 9 6} \\
\text { (százalék) }\end{array}$ \\
\hline Nyersanyag & 1,4 & 46 \\
\hline Feldolgozóipar & 38,1 & 28 \\
\hline Építőipar & 4,0 & 16 \\
\hline $\begin{array}{c}\text { Közmúvek } \\
\text { és kommunikáció }\end{array}$ & 16,0 & n.a. \\
\hline Szolgáltatások & 24,3 & 489 \\
\hline Egyéb & 16,2 & - \\
\hline Összes & 100,0 & 47 \\
\hline
\end{tabular}

Forrás: OECD [1998], Boeri és társai, [2000]

Annak a vizsgálatára, hogy a befektetések milyen töke vagy munkaintenzív területeket vettek célba, a beruházások csaknem felét adó német tökeinvesztíció lehet mérvadó. Az elmúlt évtized derekán a német beruházásoknál a munkaerő-intenzív területek mellett egyre fontosabb szerepet tölt be a gépjármüvek és az elektronikai termékek piaca (ld. V/3.5. sz. táblázat). Ezeken a területeken a müködőtőkebefektetések munkaerő-intenzitása hasonló értéket mutat, mint más befektetési célországokban.

\section{V/3.5. sz. táblázat: A német müködötöke-befektetések} munkaerö-intenzitása 1996-ban

\begin{tabular}{|l|c|c|}
\hline & $\begin{array}{c}\text { 1 millió DM-re eső } \\
\text { alkalmazottak }\end{array}$ & $\begin{array}{c}\text { 1 millió DM-re eső } \\
\text { alkalmazottak a } \\
\text { KKE-országokban }\end{array}$ \\
\hline Feldolgozóipar általában & 11,4 & 24,4 \\
\hline $\begin{array}{l}\text { Ebböl példaszerúen: } \\
-\quad \text { textiltermékek }\end{array}$ & 19,5 & 41,3 \\
\hline$-\quad$ gépjármüvek & 13,9 & 11,2 \\
\hline$-\quad$ elektronikai termékek & 18,8 & 19,4 \\
\hline
\end{tabular}

Forrás: Német Nemzeti Bank, Boeri és társai, [2000]

Látható, hogy a német befektetéseknél a gépjárművek gyártásánál a munkaerőintenzitás kisebb, mint a német külföldi befektetéseknél általában, sőt az elektronikai termékek előállításánál is kedvező értéket észlelhetünk. Ezzel azt bizonyíthatjuk, hogy még az ún. kereskedelemre alkalmas termékeket gyártó szektorban sem az olcsó munkaerő dominál a térségben való német befektetésnél, hanem a jó 
forráslehetőségek és a munkaerő hatékonysága válnak ösztönző erővé. Ezért megállapítható, hogy a közép-európai müködőtőke-befektetések nem gyakorolnak negatív hatást az anyavállalatokra, sem annak munkaerőpiacára, sem a fizetésekre. Sőt az ún. „home office effects” alapján az anyavállalatoknál is haszon keletkezik, ami ott újabb beruházásokat, munkahelyeket indukál. Sajátos munkamegosztás alakul ki az európai uniós anyavállalat és a közép-európai cég között, mivel a relatíve olcsóbb, de képzett munkaerőre épülő termelési szektorokat telepítik ki a térségbe. Ez azonban a társult országok számára is hasznot hoz, hiszen jelentős hozzáadott értéket realizálnak és modern technológiát valamint munkakultúrát adaptálhatnak. Mindössze az EU-országok térségbeli befektetéseinek ötöde épült a skálahozadék elvét kereső alacsony és nagyrészt képzetlen munkaerőre. (Boeri, [2000])

A közép-kelet-európai térségben növekvő beruházás (az EU részéről évente nem haladja meg a 10 milliárd USD-t) mértéke nem jelentős az EU-n belüli vagy odaérkező befektetésekhez képest, vagyis nincs lényeges, a belső piacot érintő elszívó hatása.

\section{V/3.6. sz. táblázat: Az Európai Unióban eszközölt müködötöke-befektetések (milliárd euró)}

\begin{tabular}{|l|c|c|c|}
\hline & $\mathbf{1 9 8 9}$ & $\mathbf{1 9 9 4}$ & $\mathbf{1 9 9 9}$ \\
\hline EU-n kívülröl & 27,943 & 21,814 & 83,435 \\
\hline EU-n belüli & 33,234 & 36,101 & 222,980 \\
\hline
\end{tabular}

Forrás: Eurostat, [2001]

Jól látható, hogy az EU-országokban eszközölt közvetlen tökebefektetés a kilencvenes években robbanásszerüen nőtt és 1999-ben meghaladta a 300 milliárd eurót, ilyen összegnél az évi 8-10 milliárdos az EU által eszközölt közép-európai befektetések az EU-ba történt teljes befektetéseknek mindössze néhány százalékát jelentik. (A 90-es években Spanyolországban és Írországban is növekedett a külföldi befektetés, Portugáliában pedig a kétségtelenül észlelhető működőtőke-befektetés visszaesését nem lehet tendenciaként vagy elszívó hatásként értékelni. Még a portugál Műszaki Egyetem 1998-ban készült tanulmánya is elismeri, hogy a portugál 
befektetési környezet megváltoztatása jelenti a legfontosabb feladatot és nem a közép-európai országok hibáztathatók az ottani befektetések visszaeséséért.)

További előnye a müködőtőke-áramlásnak, hogy egy iparágon belüli munkamegosztás optimalizálása mellett a társult országok bérére is növekvő hatással van. Magyarországon a külföldi beruházások által alkalmazottak bére 20-30 százalékkal van fölötte a hasonló szektorban foglalkoztatottak átlagának. (Boeri, [2000]) Ez a bérek gyorsabb kiegyenlítődése mellett a migrációs nyomás csökkenését is eredményezheti az egységes belső piacon.

A térségbeli müködőtőke-befektetések magas megtérülési rátát mutatnak. A Bank of England felmérései szerint a Közép- és Kelet-Európába befektetett brit tőkén a haszon (earning) 1999-ben a beruházott összeg 19 százaléka volt, míg ez az arány Nyugat-Európában 8,3, Amerikában 6,2 százalék volt (lásd: V/1.8. sz. táblázat).

V/3.7. sz. táblázat: A brit cégek nettó keresete, tökebeáramlása és befektetett tökeszintje 1999-ben néhány közép- és kelet-európai országban (millió font)

\begin{tabular}{|l|c|c|c|c|}
\hline \multicolumn{1}{|c|}{ Ország } & $\begin{array}{c}\text { Nettó } \\
\text { nyereség }\end{array}$ & $\begin{array}{c}\text { Nettó } \\
\text { beáramlás }\end{array}$ & Nettó szint & $\begin{array}{c}\text { Nettó } \\
\text { nyereség/ } \\
\text { Nettó szint }\end{array}$ \\
\hline Bulgária & 41 & 91 & 137 & 29,9 \\
\hline Csehország & 57 & 60 & 497 & 11,5 \\
\hline Magyarország & 67 & -649 & -413 & - \\
\hline Lengyelország & 24 & 272 & 710 & 3,4 \\
\hline Románia & 34 & 130 & 186 & 18,3 \\
\hline Összes KKE & $\mathbf{2 9 4}$ & $\mathbf{2 1 9}$ & $\mathbf{1 5 2 1}$ & $\mathbf{1 9 , 3}$ \\
\hline
\end{tabular}

Forrás: Egyesült Királyság Statisztikai Hivatala, külföldi befektetési kérdőív, [2000]

Megjegyzés: Magyarországon a nagyarányú tőkekivonás ebben az évben kalkulálhatatlanná tette az eredményt, de a nettó nyereség Magyarországon a legjelentősebb, és a brit Statisztikai Hivatal illetékesei szerint a nyereség/teljes összeg arány itt a legjobb, bár adatszerúen nem hozzáférhető. 


\section{V/3.5. A tőkebefektetések és a gazdasági kapcsolatok pótlólagos haszna a belső piac kiterjesztésével}

Gravitációs modellekhez (lásd V/5. fejezet) hasonlóan készültek kutatói elemzések arról is, hogy milyen hasznot hoz a tagállamok számára a tőke kockázati prémiumának csökkenése a bővítés után. Ezt a szakirodalomban is leginkább idézett módon 1997-ben Baldwin, François és Portes vizsgálta.

Az nyilvánvaló, hogy a tőkebefektetések számára az EU-tagság egyértelmủen nagyobb garanciát és így kisebb kockázatot jelent. Baldwin és társai szerint makrogazdasági szinten az új belépők esetében az inflációs ráta és a kamatráták garantált leszorítására, valamint a közös pénzbe való kötelező belépés révén az árfolyamok ingadozásának kiküszöbölésére bizonyossággal számolhatunk. Mikroszinten a rendkívül kemény közösségi versenypolitika, állami segélypolitikai szabályozás, a konvertibilitási gondok kizárása és az adópolitika garantálhatósága (főleg a közvetett adózás területén), valamint a befektetésekre vonatkozó magasabb garanciahatár is serkentőleg hat. Történelmi tapasztalatok alapján az EU átlagfejlettsége alatt belépők részéről többéves befektetési boom is garantálható, ami mind a megtérülési mutatók növekedését eredményezi. Ezért a portugál példából kiindulva, mintegy 15 százalékos kockázati prémium csökkenést feltételezve az 1992. évi ECU-ben számolva jelentős anyagi haszonszerzést (EU-tagállamoknak 11,2, míg Közép- és Kelet-Európa 7 országának - baltiak nélkül - 30 milliárd ECU-t) lehet jósolni, amit a kereskedelem révén tudnak realizálni.

V/3.8. sz. táblázat: Érzékenységi vizsgálat a reáljövedelmek növekedéséröl (1992. évi milliárd ECU-ben)

\begin{tabular}{|c|c|c|}
\hline Kockázati prémium & $\begin{array}{c}\text { Közép- és Kelet- } \\
\text { Európa }\end{array}$ & $\begin{array}{c}\text { Európai Unió 15 } \\
\text { tagországa }\end{array}$ \\
\hline $0 \%$ csökkenés & 2,5 & 9,8 \\
\hline $5 \%$ csökkenés & 6,2 & 10,0 \\
\hline $10 \%$ csökkenés & 14,5 & 10,3 \\
\hline $15 \%$ csökkenés & 30,1 & 11,2 \\
\hline
\end{tabular}

Forrás: Economic Policy 1997/24 [1997], p. 149 
A kockázati prémium csökkenése a tagállamok számára garantált nyereséget hoz, míg a tét a társultak számára az, hogy a kockázat csökkenése révén exponenciálisan nőjön nyereségük (lásd: V/3.8. sz. táblázat). Baldwin a várható hatások tükrében (mely tagállam mely szektora nőhet jelentősen a bővítés után) kimutatta, hogy a tagállamok közül Németország, Franciaország és Nagy-Britannia profitálna a legtöbbet (a 11,2 milliárd ECU-ből 7,6 milliárdot), de Portugália kivételével valamennyi állam nyereségre számíthat. (Svédország esetében a GDP 0,29 százalékát teszi ki a nyereség, a többiek relatíve ennél kevesebbet, de az arány 11 ország esetében meghaladja a GDP 0,1 százalékát.)

Bár a modell számtalan elvi absztrakciója torzítva jelenik meg, de érdekes, hogy a nyereséget a gravitációs modell alapján nemcsak a kereskedelmi kapcsolatok felfutása nyújtotta lehetőségek (ld. V/5. sz. fejezet), hanem a gazdasági kapcsolatok kisebb kockázata révén is mérte és bebizonyította; kimutatta, hogy ezen mindkét fél nyer, sőt az uniós oldalon Portugália minimális vesztesége mellett minden tagállam nyertese ennek a faktornak. Ha csak a bővítés közvetlen költségével hasonlítjuk össze ezt az egy mutatót, akkor is látható, hogy ez önmagában fedezné a közvetlen költségvetési kiadások csaknem felét (2006-ban számításaim szerint kb.25 milliárd euró, lásd V/4. fejezet).

A nyereségnek a tagállamokra történő lebontása kapcsán az Európai Bizottság Gazdasági és Pénzügyi Főigazgatósága megbízásából 1999-2001 között kutatók felmérték a bővítésnek Ausztria, Németország, Dánia és Olaszországra gyakorolt makrogazdasági hatását. A kimutatások szerint Ausztriában a GDP 1,08 százalékkal nőne (a jóléti hatás ennek fele, kb. 0,51 százalékos, míg az államháztartási bevételek emelkedése 1,496 százalék lenne). Ez azonban elsősorban a luxemburgi országok bővítéséből keletkezne, az ún. helsinki országok bővítése lényegében semleges hatással lenne Ausztriára (Keuschnigg, Kohler [1999]). Németországban a GDP növekedése 0,447 százalék lenne, míg a jóléti hatásból kimutatható növekedés a GDP 0,375 százaléka lenne és ott az államháztartás bevételei 0,52 százalékkal növekednének elsősorban a luxemburgi öt ország felvétele hatására (Keuschnigg, Kohler [1999]). Dániában a kutatói becslések szerint 2005-ben még enyhén veszteséges lenne a bővítés, mivel a GDP 0,2 százalékos növekedésével szemben ennek finanszírozása a dán állam számára a GDP 0,3 százalékát vonná el. 2010-ben 
azonban a GDP 0,6 százalékos növekedése állna szemben a pótlólagos finanszírozási igényként megjelenő, a GDP 0,2 százalékát kitevő finanszírozási igénnyel, vagyis abban az évben a tiszta nyereség már a GDP 0,4 százaléka lenne. (Kristensen Jensen, [2001].

A szabad tőkepiac más lehetőséget is nyújt az EU számára a bővítés után. Csak így válik számára lehetővé a tagjelölt országok mezőgazdasági és ingatlanpiacához a nemzeti elbánás szerinti hozzáférés. (Azonos minőségü földet feltételezve jelenleg az EU-országokban a föld ára többszöröse a társultakénak; ez különösen a határmenti relációkban vonzó, vagyis e kérdés fő nyertesei az osztrák és a német parasztgazdák, illetve turisztikai és hosszú távú pénzspekulánsok lesznek.)

Az EU gazdasági szereplői a bővítés után bármelyik tagállamból végezhetnek pénzügyi müveleteket, nem kell kötelezően letelepedniük az új tagállamokban. Szintén hasznos lesz számukra az is, hogy a pénzintézetek esetében az új tagállamok el kell, hogy fogadják az olyan magas alaptőkére vonatkozó követelmények betartását, ami a helyi konkurencia megroppanását vagy visszaszorulását eredményezi.

\section{V/3.6. A pénzügyi szektor versenyképessége}

A bővítés pozitívan hat a belső piacon belüli versenyre és ezáltal a versenyképesség növekedésére a pénzügyi és üzleti szolgáltatások területén is. Hatékonyságát tekintve a tagjelöltek ezen a területen tudtak a legjobban felzárkózni az EU átlagához köszönhetően elsősorban a szektor privatizációjának. Itt is nagy a különbség a tagjelöltek között, de Szlovákia, Szlovénia vagy Magyarország esetében már az EU átlagához közeli eredményt lehet regisztrálni (lásd: V/3.9. sz. táblázat). Amennyiben a tagjelöltek gazdasága továbbra is az EU átlagát meghaladó módon növekszik, akkor a pénzügyi szolgáltatások terén még kedvezőbb hatékonysági adatokat lehet majd kimutatni, ami az egy alkalmazottra jutó eredményeket tekintve nemcsak reál, hanem abszolút értékben is jelentős felzárkózást tesz lehetővé például a portugál teljesítményhez képest. Ez rentábilissá teszi azokat a befektetéseket, amelyeket az EU-országok pénzintézetei a tagjelölteknél tettek vagy tenni fognak. 
V/3.9. sz. táblázat: A tagjelölt országok, valamint Görögország, Spanyolország, Portugália munkaerö-termelékenysége a pénzügyi és üzleti szolgáltatások területén 1998-ban

\begin{tabular}{|c|c|c|}
\hline Ország & $\begin{array}{c}\text { Folyóáron egy } \\
\text { alkalmazottra } \\
\text { jutó teljesítmény } \\
\text { (euró) }\end{array}$ & $\begin{array}{c}\text { Reálértéken az } \\
\text { EU } \\
\text { százalékában }\end{array}$ \\
\hline Bulgária & - & 69 \\
\hline Csehország & - & 54 \\
\hline Észtország & 16.620 & 44 \\
\hline Magyarország & 32.554 & 99 \\
\hline Lettország & 9.811 & 27 \\
\hline Litvánia & 15.380 & 47 \\
\hline Lengyelország & 17.652 & 43 \\
\hline Románia & 9.023 & 77 \\
\hline Szlovákia & 28.179 & 107 \\
\hline Szlovénia & - & 82 \\
\hline Görögország & 88.782 & - \\
\hline Portugália & 47.250 & - \\
\hline Spanyolország & 76.999 & - \\
\hline
\end{tabular}

Forrás: Eurostat, 2. Kohéziós Jelentés, [2001]

\section{V/3.7. A közbeszerzési piac kiterjedése a tagság révén}

A belső piac kapcsán kiemelem még azt az előnyt, amely a közbeszerzési piac kiteljesedéséből, a vonatkozó EU jogszabályok új tagállamokra való kiterjesztéséből adódik. Bár a tagság előtt az Európai Megállapodások révén már rákényszerítette az EU a tagjelölteket arra, hogy a közbeszerzés területén felszámolják a közösségi pályázókkal szembeni hátrányos megkülönböztetésüket, vagyis az EU-tagállamok is megkapják a nemzeti elbánást a régió országain belül. (Magyarország esetében a nemzeti elbánás biztosítása az Európai Megállapodás alapján 2004. február elsején lenne esedékes, ha addig hazánk nem lép be az EU-ba.) Ez még nem jelenti azt, hogy a tagság előtt a közösségi szabályozások érvényesülnek a tagjelölteknél is. A belépés után azonban a teljes közbeszerzési eljárás - beleértve a kiírásokat, értékhatárokat, valamint a jogi kikényszeríthetőséget is - a belső piaci szabályok szerint alakul, ami a közösségi vállalatok számára ugyanazt a jogi szabályozási lehetőségeket feltételezi a régióban, amit az EU-n belül most élveznek. Ennek nemcsak teljesen világos és átlátható rendszer lesz a következménye a jelenlegi közösség szereplői számára, hanem az is, hogy a közbeszerzésekre szakosodott vagy ebben nagy szerepet játszó 
vállalatok a skálahozadék elve alapján tudják termelésüket tervezni és megvalósítani.

A jelenlegi helyzetben nehéz megmondani, hogy körülbelül mekkora közbeszerzési piac áll rendelkezésre a tagság után a tagjelölt országokban. Az is a képhez tartozik, hogy több európai befektető privatizáció vagy cégalapítás révén most is jelen van a társult országokban, sőt vállalataik hazai cégeknek minősülnek már most is, ami számukra helyismeretükböl adódóan piaci előnyöket jelent.

A közösségi piacon 1994-es szinten 15 tagállam 720 milliárd euró nagyságrendü közbeszerzési piacot müködtetett - ez az évtized végére már 900 milliárdra gyarapodott, ami a teljes GNP 11,5 százalékát jelentette (Várhelyi Olivér, [2001]). Ebből kiindulva, az új tagállamoknál is legalább a GDP 12-13 százalékával számolhatunk a közbeszerzési szektorban. (Ennek értéke most meghaladja az évi 3536 milliárd eurót.) Tudjuk, hogy a közösségi belső közbeszerzési piac nyitottsága a nyolcvanas évek közepén mért 2 százalékról a kilencvenes évek közepére 10 százalékra nőtt (vagyis az ügyletek ekkora hányadát nyeri meg más tagállambeli pályázó), és ez az arány könnyen jósolható módon nőni fog. Ez alapján garantálhatóan 3,5-4 milliárd euróra tehető a jelenlegi adatok alapján az az összeg, amit évente biztosan megnyernek a tenderek révén a jelenlegi tagállamok pályázói.

\section{RÉSZ; 4. FEJEZET A BŐVÍTÉS KÖZVETLEN KÖLTSÉGVETÉSI HATÁSAI}

\section{V/4.1. A közösségi költségvetés jelenlegi nagyságrendje}

Az szinte minden elemző számára nyilvánvaló, hogy az Európai Unió bővítése során olyan új tagállamok fognak belépni az EU-ba, amelyek az EU átlagánál jóval fejletlenebbek, jelentős a mezőgazdasággal foglalkozó népességük és területük aránya, jók az agrártermelés adottságai. Ezért minden kutató számára kézenfekvő, hogy a bővítés miatt a közösségi költségvetést növelni kell. Ezért a kibővítési 
tárgyalások kapcsán már a kilencvenes évek elejétől ádáz politikai és szakmai viták dúltak arról, hogy a bővítés anyagi finanszírozását hogyan oldja meg az Európai Unió. Az már az 1992. decemberi EU-csúcstalálkozón világossá vált (ekkor fogadták el az 1993-1999. évi periódusra vonatkozó pénzügyi irányelveket), hogy az EU közös költségvetése növelésének gátja lesz az, hogy a kiadások nem haladhatják meg a közösségi GNP 1,27 százalékát. (Szintén a közösségi jogszabályokból és a politikai egyezségekből adódik, hogy az EU költségvetése - eltérően a nemzetállami büdzséktől - nem adósodhat el.) Lényegében ezt hagyták jóvá a jelenlegi időszakra (2000-2006) vonatkozó irányelvekben is, mindezt évi 2,5 százalékos közösségi fejlődést, valamint a tagjelöltek részéről 4 százalékos bővülését feltételezve, vagyis a bővítés miatt nem hajlandók a közös költségvetés plafonját (GNP 1,27 százaléka) emelni.

Abban minden elemző egyetért, hogy a bővítés nem lesz zéróösszegü játszma, hiszen a bővítéssel gazdasági értelemben minden régi és új tagállam nyer. A jelenlegi tagállamok közül a bővítés valódi nyertesei elsősorban azok a tagállamok lesznek, amelyek a bővítésnél szóba jöhető országokkal kiterjedt gazdasági (kereskedelmi és befektetési), valamint a szolgáltatásokra és a személyek szabad áramlására vonatkozóan szoros kapcsolatokat tartanak fenn (lásd: V/3., V/5. fejezetek). Nem elhanyagolható az a következmény, amit ezek az országok a bővítés biztonságpolitikai, a bel- és igazságügyi együttmüködés, a környezetvédelem vagy a tranzit lehetőségek révén profitálnak.

A közösségi költségvetés 2006-ra kb. 10.000 milliárd euró GNP-vel készült, s még a Berlinben (1999 március) jóváhagyott költségvetés is ugyanerre az évre 0,174 százalék körüli (17,455 milliárd euró) költségvetési ráfordítást tervezett a bővítéssel kapcsolatos kiadásokra. Emellett azt is érdemes figyelembe venni, hogy 2006-ra az Unió a GNP 0,2 százalékát - vagyis további mintegy 20 milliárd eurót - tervezett tartalékként, amelyet elöre nem látható kiadásként a vártnál nagyobb létszámú bővítésre tud szánni. (Az uniós politikusok a berlini csúcsértekezlet után bejelentették, hogy a kompromisszumot 2006-ig csak az ún. luxemburgi csoport hat tagjára - Lengyelország, Magyarország, Csehország, Szlovénia, Ciprus, Észtország és a mezőgazdasági közvetlen támogatások nélkül tervezték.) 
V/4.1. sz. táblázat: A kibövités költségvetési fejezete a 2002-2006 közötti idöszakban

\begin{tabular}{|c|c|c|c|c|c|}
\hline $\begin{array}{l}\text { A közös költségvetés } \\
\text { fö́csoportjai }\end{array}$ & 2002 & 2003 & 2004 & 2005 & 2006 \\
\hline Bővítés (milliárd euró) & 6.709 & 9.393 & 12.076 & 14.770 & $\mathbf{1 7 . 4 5 5}$ \\
\hline Mezőgazdaság (milliárd euró) & 1.665 & 2.112 & 2.549 & 3.048 & 3.537 \\
\hline Strukturális politika (md euró) & 3.902 & 6.066 & 8.240 & 10.404 & 12.568 \\
\hline Belső politikák (milliárd euró) & 758 & 789 & 820 & 851 & 883 \\
\hline $\begin{array}{l}\text { Adminisztrációs költségek } \\
\text { (milliárd euró) }\end{array}$ & 384 & 426 & 467 & 467 & 467 \\
\hline $\begin{array}{l}\text { Teljes közösségi } \\
\text { költségvetésre elkötelezettség } \\
\text { (milliárd euró) }\end{array}$ & 104.406 & 106.330 & 107.473 & 109.532 & 111.734 \\
\hline $\begin{array}{l}\text { Teljes kifizetési } \\
\text { előirányzat (milliárd euró) }\end{array}$ & 102.281 & 105.560 & 104.828 & 105.658 & 107.989 \\
\hline $\begin{array}{l}\text { Kifizetési kötelezettség a } \\
\text { GNP százalékában }\end{array}$ & 1,13 & 1,13 & 1,10 & 1,08 & 1,07 \\
\hline $\begin{array}{l}\text { Elöre nem látott költségek a } \\
\text { GNP százalékában }\end{array}$ & 0,14 & 0,14 & 0,17 & 0,19 & 0,20 \\
\hline $\begin{array}{l}\text { Költségvetési plafon a GNP } \\
\text { százalékában }\end{array}$ & 1,27 & 1,27 & 1,27 & 1,27 & 1,27 \\
\hline
\end{tabular}

Forrás: EU Berlini Csúcsértekezlet Elnökségi következtetései, 1999. március 26.

Érdemes megfigyelni azt is, hogy mely tagállamok alkotják a legjelentősebb befizetők csoportját az Unióban. Ekkor kiderül, hogy az egyébként a bővítés legnagyobb haszonélvezőjének tekintett Németország adja a nettó befizetéseknek mintegy 56 százalékát, és a bővítésben szintén érdekelt Ausztria, Hollandia valamint a bővítést minden politikai kurzuson támogató Egyesült Királyság adja még a költségvetési hozzájárulások tekintélyes hányadát.

Az V/4.2. sz. táblázat megmutatja, hogy a négy, ún. kohéziós ország kapja a legnagyobb támogatást, az ország GDP-jében mérve a legnagyobb haszonélvező Görögország, ám ez sem haladja meg a 4 százalékot. Ebből is látható, hogy tagállamok strukturális támogatására meghatározott 4 százalékos küszöböt egyik tagállam sem lépi át, mindössze Görögország közelíti meg $(3,96)$. 
V/4.2. sz. táblázat: A közösségi költségvetéshez hozzájáruló, illetve haszonélvezö tagországok 1998-ban

\begin{tabular}{|c|c|c|c|c|}
\hline \multirow[b]{2}{*}{ Ország } & \multirow{2}{*}{$\begin{array}{c}\text { Egy före jutó } \\
\text { befizetés (+) vagy } \\
\text { támogatás (-) a } \\
\text { közösségi } \\
\text { költségvetéshez } \\
\text { (euró/fó) }\end{array}$} & \multirow{2}{*}{$\begin{array}{c}\text { Lakosság } \\
\text { száma } \\
\text { (millió fó) }\end{array}$} & \multicolumn{2}{|c|}{ Országegyenleg } \\
\hline & & & md euró & $\begin{array}{c}\text { GDP } \\
\text { százaléká- } \\
\text { ban }\end{array}$ \\
\hline Hollandia & 149 & 15,6 & 2,3 & 0,66 \\
\hline Németország & 135 & 82,0 & 11,1 & 0,57 \\
\hline Svédország & 128 & 8,8 & 1,0 & 0,47 \\
\hline Luxemburg & 124 & 0,4 & 0,5 & 3,05 \\
\hline Belgium & 112 & 10,2 & 1,1 & 0,49 \\
\hline Ausztria & 91 & 8,1 & 0,7 & 0,37 \\
\hline Nagy-Britannia & 32 & 59,1 & 1,9 & 0,15 \\
\hline Franciaország & 17 & 58,7 & 1,0 & 0,07 \\
\hline Olaszország & 3 & 57,6 & 0,2 & 0,02 \\
\hline Dánia & -7 & 5,3 & $-0,1$ & 0,06 \\
\hline Finnország & -9 & 5,1 & $-0,5$ & 0,43 \\
\hline Spanyolország & -150 & 39,3 & $-5,9$ & 1,13 \\
\hline Portugália & -274 & 9,9 & $-2,7$ & 2,76 \\
\hline Görögország & -415 & 10,5 & $-4,3$ & 3,96 \\
\hline Írország & -478 & 3,7 & $-1,8$ & 2,37 \\
\hline
\end{tabular}

Forrás: svájci kormány számításai [1999], Eurostat (kerekített értékek)

\section{V/4.2. Az új tagállamok befizetése a költségvetésbe}

Az új tagállamok a Berlinben elhatározott költségvetési irányelvek és reformok alapján fogják befizetéseiket eszközölni várhatón az alábbiak szerint:

- cukor és izoglukóz illetékek

- vámbevétel (ebből a beszedés díjaként 25 százalék visszatartható)

- ÁFA elem (a beszedett pénz 0,75 százaléka)

- brit visszatérítési elem (rebate)

- GNP elem (ezt meghatározott arány szerint kell befizetni, ez 1998-ban 0,4895 százalék volt) 
Tekintettel arra, hogy az egyes tagjelölt országok szabadkereskedelmi politikája (és így vámbevétele), valamint adópolitikája teljesen eltérő - akárcsak a GNP-je - ezért nehéz valós becslést adni a jövendőbeli befizetéseikről.

Némi támpontot csak az általunk ismert adatok alapján tudunk felvázolni. A hozzájárulás mértékét illetően érdemes megjegyezni, hogy míg az EU jelenlegi tagállamai esetében a befizetések egyre nagyobb hányadát teszik a GNP-arányos befizetések (50 százalék fölötti érték is megjelent az EU szintjén), addig az új csatlakozó országok alacsony GNP-je miatt ez nem esik ilyen súllyal latba. A magyar befizetésre vonatkozóan elvégzett előzetes számítások mintegy 600 millió euró fölötti összeget kalkuláltak, amiből az 1998-as adatok és az akkori szabályzók alapján három tétel - a vámbefizetés, az ÁFA-befizetés és a GNP-arányos teljesítés közel ugyanannyi, mintegy 200-220 millió euró befizetést feltételezett volna, ettől azonban a fokozódó liberalizáció, a várható ÁFA-kulcs csökkentések miatt lefelé is eltérhet a saját részként beszedett pénz összege.

Reálisnak tünik az a számítás, amit Berlinben 1999 tavaszán elfogadtak, ahol kalkuláltak a hat új tag felvételével és az ezzel járó befizetésekkel is. Eszerint a luxemburgi csoport (Lengyelország, Csehország, Észtország, Szlovénia, Magyarország, Ciprus) befizetéseit 2002-re 2,31 milliárd euróra, 2006-ra 2,57 milliárd euróra becsülték. Ezzel összecseng az a számítás, amelyet a londoni székhelyü CEPR készített a várható hozzájárulások mértékéről 1992-ben. Ebben a térség országai - a kisebb méretü országok nélkül - hozzájárulását az 1989-es GDP elérése esetén 2,434 milliárd euróra, míg annak megkétszereződése esetén 4,5 milliárd euróra jósolta. Mivel az V/.1. fejezetben látott adatok alapján a középeurópai tagjelöltek GDP-je az ezredfordulón érte el illetve haladta meg az 1989 évit ez változó, Lengyelország hamarabb, míg a többiek később -, ez megfelelő kiindulópont lehet a kalkulációkhoz.

Ezért az alábbi táblázatban az 1998-as GDP alapján végeztem számítást arra vonatkozóan, hogy mekkora hányad esne tisztán GDP-arányosan az egyes tagjelölt országokra (a 2006. évi 2,57 milliárd euró felosztásával, illetve a második körös tagjelöltekre való extrapolálásával). 
V/4.3. sz. táblázat: A tagjelöltek várható hozzájárulásai a különbözö számítási modellek szerint (millió euró)

\begin{tabular}{|l|c|c|c|c|}
\hline \multicolumn{1}{|c|}{ Ország } & $\begin{array}{c}\text { Befizetés az } \\
\text { 1989-es GDP } \\
\text { szerint } \\
\text { (CEPR 1992) }\end{array}$ & $\begin{array}{c}\text { Befizetés az } \\
\text { 1989-es GDP } \\
\text { kétszerese } \\
\text { szerint } \\
\text { (CEPR 1992) }\end{array}$ & $\begin{array}{c}\text { Befizetés 2006- } \\
\text { ban az Agenda } \\
\text { 2000 Bizottsági } \\
\text { javaslatának } \\
\text { becslése } \\
\text { szerint } \\
\text { (1997) }\end{array}$ & $\begin{array}{c}\text { Befizetés 2006- } \\
\text { ban a jelenlegi } \\
\text { költségvetési } \\
\text { javaslat } \\
\text { szerint* }\end{array}$ \\
\hline Lengyelország & 817 & 1534 & - & 1372 \\
\hline Magyarország & 341 & 641 & 648 & 411 \\
\hline Csehország & 617 & 1161 & 756 & 490 \\
\hline Szlovákia & - & - & 324 & 177 \\
\hline Bulgária & 263 & 493 & 216 & 108 \\
\hline Románia & 396 & 743 & 324 & 361 \\
\hline Észtország & - & - & 108 & 43 \\
\hline Lettország & - & - & 108 & 56 \\
\hline Litvánia & - & - & 108 & 94 \\
\hline Szlovénia & - & - & 324 & 169 \\
\hline Málta & - & - & - & 30 \\
\hline Ciprus & - & - & - & 79 \\
\hline Összesen & $\mathbf{2 4 3 4}$ & $\mathbf{4 5 7 2}$ & $\mathbf{2 9 1 6}$ & $\mathbf{3 3 9 0}$ \\
\hline
\end{tabular}

Forrás: Kengyel Ákos: Az Európai Unió regionális politikája, EU berlini csúcsértekezletének közleménye, Külügyminisztériumi és saját számítás

Megjegyzés: * A hat luxemburgi ország által elöirányzott 2,57 milliárd euró befizetésének GDParányos felosztásával, illetve a helsinki csoportra GDP-arányos extrapolálásával

Az V/4.3. sz. táblázat alapján megállapítható, hogy az új rendszernek megfelelően valamivel kevesebbet fognak a tagjelöltek befizetni, mint azt 1999 előtt (Agenda 2000) számolták, a Bizottság javaslatát kalkulálva teoretikusan 3,4 milliárd euró lenne 2006-ban, ha mindannyian tagok lennének, ami valamivel több mint 3 százaléka lenne a 21 tagúra számolt Unió költségvetésének.

A kérdés természetesen azért is teoretikus, mivel nem tudható elöre, hogy a felvételi tárgyalásokon - az előző bővítés tapasztalatai alapján - milyen hosszúságú és tartalmú átmeneti időszakok kerülnek megállapításra az új tagok befizetéseit illetően. 


\section{V/4.3. Az új tagok költségvetési támogatása}

Az Unió költségvetésének négy területen jelent kiadást az új tagok felvétele, de ebből a belépők csak három területen (mezőgazdasági támogatás, strukturális müveletek, belső piaci programok) jutnak támogatáshoz, mivel az ún. adminisztratív költségek (mely a közösségi hivatalnokok létszámának emelkedését, új épületek szükséges biztosítását, illetve a bővítésből eredő rendezvényi költségeket takarja) nem kerülnek az újonnan belépőkhöz. A három forrásból a döntő hányadot az agrárköltségvetés és a strukturális politika jelenti, a belső piaci műveletek részesedése az új tagállamok támogatásából marginális, 5 százalék alatt marad.

\section{V/4.3.1. Strukturális alapok}

Mint a gazdasági kohézióról írott fejezetben (V/2.) ismertetett adatok mutatják, a jelenleg érvényes szabályok szerint az 1999. március 26-án (a Berlini Csúcsértekezlet napján) rendelkezésre álló GDP-adatok alapján lehet számolni a különböző támogatási jogosultságot. (A jelenlegi tagjelölt államoknál minden valószínüség szerint 1997-99 közötti átlagos GDP alapján határozzák meg a jogosultságot, magam az 1998-as adatokkal kalkuláltam.) Ebböl az elmaradott térségek említhetők meg első helyen, hiszen ők adják a strukturális alapokból kifizethető támogatások 70 százalékát. Emellett az ezekből kimaradó régiók számíthatnak a másik két támogatási célkitüzés (strukturális átalakulással és nehézségekkel viaskodó terület, illetve az oktatási-képzési programok) igénybevételére, de ezek már csak akkor vehetők számításba (akárcsak az ún. közösségi programokból való részesedés), ha az illető ország strukturális támogatásai (elmaradott térségek támogatása illetve kohéziós alap) nem érik el a GDP 4 százalékát. Mint láttuk az V/2. fejezetben, Szlovénia, Csehország, Magyarország és Szlovákia esetében lehetséges a 2-es és 3-as célkitüzés valamilyen igénybevétele, de a náluk fejletlenebb - kisebb egy főre jutó GDP-vel rendelkező - országokban már nem lehet ezzel forrásként kalkulálni.

Feltételezem, hogy a bővítést követően is a jelenlegi 15 országot felölelő egy före jutó közösségi GDP 75 százaléka lesz az elmaradott területek támogatásának 
jogosultsági határa, ami a jelenleg jogosult közösségi régiók bővítés miatti kiesését elkerüli. Mivel a strukturális politikát illetően 2006-ig konszenzusos döntés van érvényben az EU-ban (ezt Nizzában is megerősítették), célszerű ezt a feltételezést fenntartani, hiszen a szabályozók megváltoztatásához is egyhangúságra van szükség. A jelenlegi tagállamoknál 46 régió egy före jutó GDP-je esett a közösségi átlag 75 százaléka alá 1999-ben. 25 tagú EU-ban a jelenlegi tagállami régiók közül már csak 29, a román és bolgár felvétel esetén a 27 tagú EU-n belül a jelenlegi tagállamok régiói közül már csak 19 esne a 75 százalékos küszöb alá. Elsősorban a legnagyobb nettó befizető Németország legszegényebbnek mondható kelet-német tartományai veszítenének ezzel, hiszen 6 illetve 7 tartomány veszítené el a legelmaradottabb területekre vonatkozó státuszát a bővítés után, de Olaszország, Görögország és Spanyolország 4-4 régiója esne ki a teljes bővítés után a legnagyobb kedvezménnyel támogatott régiók közül. (Európai Bizottság, [2002]) Amennyiben az EU következő pénzügyi irányelveinek vitájában (vélhetően 2005-2006-ban) az a döntés születik, hogy a kibővített EU átlagos egy főre jutó GDP-je alapján határozzák meg az Unióban a 75 százalékos küszöböt, az előbbiekben jelzett tagállamok jóval érzékenyebbek lesznek a bővítés differenciált megvalósítására, hiszen alapvetően Lengyelország és Románia felvétele fogja azt eredményezni, hogy nem érik el a 75 százalékos küszöböt.

Mivel a strukturális politika területén is lesz az új tagok számára egy bevezetési (phase in) szakasz, ezért célszerü a jelenlegi pénzügyi irányelvek utolsó évét (2006) alapul venni, hiszen az új tagok akkor kapják a legmagasabb támogatást. Számításaim szerint a 2006-os éves GDP-re az 1998. évi értéknél 24 százalékkal nagyobb gazdasági produkciót számolhatunk a tagjelölteknél (évente bizonyosan 3 százalék), ami megítélésem szerint reálisabban tükrözi a várható növekedést. (Az Európai Unió évi átlagos 4 százalékos növekedéssel számolt.) (A tagjelöltek GDPjének növekedésének kiszámításánál a várható valuta-felértékelődéseket figyelmen kívül hagytam.) 
V/4.4. sz. táblázat: A 2006-ra várható GDP és annak 4 százaléka (milliárd euró)

\begin{tabular}{|l|c|c|c|}
\hline \multicolumn{1}{|c|}{ Ország } & GDP 1998-ban & GDP 2006-ban & $\begin{array}{c}\text { GDP négy } \\
\text { százaléka } \\
\text { 2006-ban }\end{array}$ \\
\hline Lengyelország & 140,2 & 173,8 & 6,95 \\
\hline Ciprus & 8,1 & 10,0 & 0,40 \\
\hline Csehország & 50,1 & 62,1 & 2,48 \\
\hline Észtország & 4,6 & 5,7 & 0,23 \\
\hline Magyarország & 41,9 & 52,0 & 2,08 \\
\hline Szlovénia & 17,4 & 21,6 & 0,86 \\
\hline Szlovákia & 18,1 & 22,4 & 0,90 \\
\hline Bulgária & 11,0 & 13,6 & 0,54 \\
\hline Lettország & 5,7 & 7,1 & 0,28 \\
\hline Litvánia & 9,6 & 11,9 & 0,48 \\
\hline Románia & 36,9 & 45,8 & 1,83 \\
\hline Málta & 3,1 & 3,8 & 0,15 \\
\hline Összesen & $\mathbf{3 4 6 , 7}$ & $\mathbf{4 2 9 , 9}$ & $\mathbf{1 7 , 2 0}$ \\
\hline
\end{tabular}

Forrás: Eurostat, [2000], saját számítás

A gazdasági kohéziós fejezetben (V/2) végzett részletes számítások alapján 2006-ra megállapítható, hogy egyenlő elbánás alapján lényegében Magyarország és Szlovákia éri el a 4 százalékos plafonértéket úgy, hogy megkapja az elmaradott térségekre, és a kohéziós alapokra járó teljes támogatást. Csehország és Szlovénia ezen felül még részesülhet a 2. és 3. célkitüzések, valamint a közösségi kezdeményezések révén uniós támogatásból. Mivel 2006-ra kalkulálva a 12 tagjelölt ország teljes jogosultsága 17,2 milliárd euró lenne, több mint 4,74 milliárd euróval haladja meg az Agenda 2000-ben jóváhagyott értéket (12,56). Az 1998-as GDP alapján kalkulálva a jogosultság (13,87 milliárd euró) azonban már csak 1,31 milliárd euróval haladná meg a rendelkezésre álló összeget (lásd: V/2. fejezet).

V/4.3.2. Részesedés a belső piaci programokból

Ennél a forrásnál az egyenlő elbánás szerint az egy före jutó támogatással érdemes számolni, bár igaz, hogy itt is van szerepe az abszorpciós kapacitásnak, pl. a kutatási, vagy a transzeurópai projecteknek. 
Az EU 1998-as népességszámmal számolva 18,295 euró/fő́t fordít belső piaci politikákra. Egyenlő elbánást kalkulálva jelenleg a 12 új tagállamra az alábbi számokat kapjuk 2006-ra:

V/4.5. sz. táblázat: A tagjelöltek részesedése a belső piaci politikákra szánt támogatásból az 1998-as lakosságszám alapján

\begin{tabular}{|l|c|c|}
\hline \multicolumn{1}{|c|}{ Ország } & $\begin{array}{c}\text { Lakosság } \\
\mathbf{1 9 9 8} \\
\text { (millió fó) }\end{array}$ & $\begin{array}{c}\text { Támogatás } \\
\text { (millió euró) }\end{array}$ \\
\hline Bulgária & 8,25 & 150,93 \\
\hline Ciprus & 0,66 & 12,07 \\
\hline Csehország & 10,29 & 188,26 \\
\hline Észtország & 1,45 & 26,53 \\
\hline Magyarország & 10,11 & 184,96 \\
\hline Lettország & 2,44 & 44,64 \\
\hline Litvánia & 3,70 & 67,69 \\
\hline Málta & 0,38 & 6,95 \\
\hline Lengyelország & 38,66 & 707,28 \\
\hline Románia & 22,50 & 411,64 \\
\hline Szlovákia & 5,39 & 98,61 \\
\hline Szlovénia & 1,98 & 36,22 \\
\hline Összesen & $\mathbf{1 0 5 , 8 1}$ & $\mathbf{1 9 3 5 , 7 9}$ \\
\hline
\end{tabular}

Forrás: saját számítás, Eurostat, [2000], Berlini csúcsértekezlet, [1999]

A Berlini Csúcsértekezleten elfogadott kompromisszum szerint a hat országra számított bővítésre 883 millió eurót szánnak. Az egyenlő elbánás szerinti elosztásnál a hat ország 1155 millió eurót kapna, vagyis 30,84 százalékkal többet, mint amit a költségvetés elöirányzott.

\section{V/4.3.3. Agrártámogatások}

A teljes felvételi tárgyalási folyamat legnagyobb próbatétele az agrártámogatások rendszere, ugyanis a berlini kompromisszumban deklaráltan nem számoltak a tagjelöltek közvetlen kifizetésével arra a formális indokra hivatkozva, hogy az alacsonyabb piaci árak miatt nincs kompenzációs igényre lehetőségük az új tagállamok gazdáinak. Szlovénia és néhány ország egyes agrártermékei esetében már most vitatható ez a megközelítés, hiszen a termelői árak több esetben meghaladják a 
közösségi árakat. A tagjelöltek nem fogadják el a közvetlen kifizetésből való kizárást azért sem, mert a tagállamok termelői esetében az 1992-es közösségi reform után kialakult kompenzáció már régen átalakult közvetlen termelői támogatássá, vagyis tíz év múltán elszakadt eredeti céljától (a reform során elszenvedett jövedelem-kiesés kompenzálása), és egyszerü termelői szubvencióvá vált. Ennek megtagadása a tagjelöltektől az egységes belső agrárpiacot torzítja, ami a Közösség versenypolitikát jellemző érzékenységét figyelembe véve elfogadhatatlan. Mivel a tagországok termelőinek közvetlen támogatása a jelenlegi közösségi költségvetés agrárkiadásainak kétharmadát éri el, az új tagállamok számára a támogatás megadása az egész csatlakozási folyamat egyik kulcskérdése.

2001 folyamán nyilvánosságra került a hat luxemburgi ország agrártámogatásokra vonatkozó csatlakozási pozíciója. Eszerint a hat ország közvetlen kifizetésre valamivel több mint 5 milliárd eurót kért a tagság kezdetétől fogva. Ehhez kértek még agrárpiaci rendtartás címén mintegy 1,6 milliárd euró támogatást (többek között ide tartozik az exportszubvenció, intervenciós felvásárlás stb. költsége is). Szintén több mint egy milliárd euró igényt fogalmaztak meg a hat ország a közösségi agrárpolitika egyre fontosabbá váló pillére, az ún. vidékfejlesztés (például fiatal farmerek támogatása, erdészeti fejlesztés, agrárkörnyezet-védelem, korai nyugdíjazás) támogatására is. Költségvetési becslésemnél azonban nem ezt, hanem az Európai Bizottság 2002. január 30-án nyilvánosságra hozott, a tagjelölt államok agrárintegrációjának megvalósítására kidolgozott munkaanyagból a Magyar Külügyminisztériumban készített elemzést használtam. (A kifizetés tényleges összegét befolyásolja az is, hogy mekkora kvótákban fognak megállapodni a tárgyalások végén a felek.)

Az V/4.6. sz. táblázatban szereplő adatok mérsékeltebb költségvetési terhet jelentenek, mint a Bizottság 1997-ben nyilvánosságra hozott Agenda 2000 dokumentuma, mely 12 új tagállamra 2005-ben kb. 11 milliárd euróra taksálta a bővítés évi agrárköltségét a FEOGA garancia-alapból. Ebből jóslatok szerint 7 milliárd euró lenne a közvetlen kifizetés, a többit a piaci támogatások, illetve kapcsolódó intézkedések tennének ki. 
V/4.6. sz. táblázat: Tíz tagjelölt ország teljes támogatási igénye az Európai Bizottság számításai szerint (millió euró)

\begin{tabular}{|l|c|c|c|c|c|}
\hline \multicolumn{1}{|c|}{ Ország } & $\begin{array}{c}\text { Közvetlen } \\
\text { támogatás }\end{array}$ & $\begin{array}{c}\text { Agrárpiaci } \\
\text { rendtartás } \\
\text { (átlag) }\end{array}$ & $\begin{array}{c}\text { Vidék- } \\
\text { fejlesztési } \\
\text { támogatás } \\
\text { (átlag) }\end{array}$ & $\begin{array}{c}\text { Összes } \\
\text { közösségi } \\
\text { agrár- } \\
\text { támogatás }\end{array}$ & Megoszlás \\
\hline Magyarország & 1103 & 235 & 300 & 1638 & 18,13 \\
\hline Lengyelország & 2407 & 500 & 1300 & 4207 & 46,56 \\
\hline Csehország & 723 & 155 & 200 & 1078 & 11,93 \\
\hline Szlovénia & 76 & 40 & 140 & 256 & 2,83 \\
\hline Észtország & 67 & 30 & 175 & 272 & 3,01 \\
\hline Szlovákia & 329 & 125 & 200 & 654 & 7,24 \\
\hline Lettország & 98 & 50 & 115 & 263 & 2,91 \\
\hline Litvánia & 281 & 125 & 175 & 581 & 6,43 \\
\hline Ciprus & 4 & 30 & 30 & 64 & 0,71 \\
\hline Málta & 1 & 13 & 8 & 22 & 0,24 \\
\hline Összesen & $\mathbf{5 0 8 9}$ & $\mathbf{1 3 0 3}$ & $\mathbf{2 6 4 3}$ & $\mathbf{9 0 3 5}$ & $\mathbf{1 0 0 , 0 0}$ \\
\hline
\end{tabular}

Forrás: Európai Bizottság munkaanyaga, [2002], Külügyminisztérium, [2002]

Megjegyzés: Mivel Románia és Bulgária EU-tagsága az EU Bizottság szerint 2006-ig nem reális, ezért agrárpiaci integrációjuk költségét nem készítették el.

\section{V/4.4. Teljes támogatás}

Az előző pontokban kifejtettek alapján a strukturális támogatásokra, a belső piaci programok támogatására, az agrárpiaci integrációra megvonható a tíz tagjelölt felvételének közvetlen közösségi költségvetési mérlege. (2002 elejére nyilvánvalóvá vált, hogy Románia és Bulgária tagfelvétele 2006 utánra nyúlik, ezért nincs értelme a rájuk vonatkozó költségvetési hatást elemezni, hiszen az Unió pénzügyi irányelveit is csak 2006-ig készítették el.) 
V/4.7. sz. táblázat: Tíz tagjelölt közvetlen költségvetési pozíciója teljesen egyenrangú elbánás esetén

(milliárd euró)

\begin{tabular}{|l|c|c|c|c|c|c|}
\hline \multicolumn{1}{|c|}{ Ország } & $\begin{array}{c}\text { Befizetés } \\
\text { (2006) }\end{array}$ & $\begin{array}{c}\text { Strukturális } \\
\text { támogatás } \\
\text { (2006) (GDP 4 } \\
\text { százaléka) }\end{array}$ & $\begin{array}{c}\text { Agrár- } \\
\text { támogatás }\end{array}$ & $\begin{array}{c}\text { Belső piaci } \\
\text { támogatás }\end{array}$ & Egyenleg & $\begin{array}{c}\text { Egy före } \\
\text { jutó } \\
\text { támogatás } \\
\text { (euró) }\end{array}$ \\
\hline Magyarország & 0,411 & 2,080 & 1,638 & 0,185 & 3,492 & 345 \\
\hline Lengyelország & 1,372 & 6,952 & 4,207 & 0,707 & 10,494 & 271 \\
\hline Csehország & 0,490 & 2,484 & 1,078 & 0,188 & 3,260 & 317 \\
\hline Szlovénia & 0,169 & 0,864 & 0,256 & 0,036 & 0,987 & 498 \\
\hline Észtország & 0,043 & 0,228 & 0,272 & 0,027 & 0,482 & 332 \\
\hline Szlovákia & 0,177 & 0,896 & 0,654 & 0,099 & 1,472 & 273 \\
\hline Lettország & 0,056 & 0,284 & 0,263 & 0,045 & 0,536 & 219 \\
\hline Litvánia & 0,094 & 0,476 & 0,581 & 0,068 & 1,031 & 278 \\
\hline Ciprus & 0,079 & 0,400 & 0,064 & 0,012 & 0,397 & 599 \\
\hline Málta & 0,030 & 0,152 & 0,022 & 0,007 & 0,151 & 391 \\
\hline Összesen & $\mathbf{2 , 9 2 1}$ & $\mathbf{1 4 , 8 1 6}$ & $\mathbf{9 , 0 3 5}$ & $\mathbf{1 , 3 7 4}$ & $\mathbf{2 2 , 3 0 4}$ & $\mathbf{2 9 7}$ \\
\hline
\end{tabular}

Forrás: Berlini csúcsértekezlet elnökségi következtetései (1999. március 26.), saját számítás

Megjegyzés: Az egy főre jutó támogatást az 1998-as lakosságszám alapján számítva

Mint látható, a tíz tagságra rövid időn belül esélyes országgal teljesen azonos átmenet és alacsonyabb támogatási összegek nélküli - támogatás esetén a bővítés 22,304 milliárd eurót emésztene fel 2006-ban a közösségi költségvetésböl. Ez valamivel meghaladná a tíz új tagnak kifizetendő, Berlinben meghatározott összeget. (2006-ra kifizetésre 16,988 milliárd eurót határoztak meg az állam- és kormányfők.) A hiányzó 5,316 milliárd euró fedezhető a költségvetés 2006-ra szóló több mint 20 milliárdos tartalékából. A jogosultság és a berlini keret-irányelvek különbsége nagyrészt az agrárköltségvetésen belüli közvetlen támogatások (5,089 milliárd euró) miatt adódik. Megjegyezném, hogy a költségvetésért felelős bizottsági tag, Michaele Schreyer 2001. február 16-án elhangzott beszédében 2006-ra 16 és 25 milliárd euró közötti összegre becsülte a tíz (tehát Románia és Bulgária nélküli) közép-európai és mediterrán ország felvételének éves költségvetési összegét, ami teljes mértékben összhangban van számításaimmal, hiszen az általam kalkulált 22,304 milliárd eurós kifizetés, valamint a 467 millió eurós adminisztratív költség összesen 22,771 milliárd euróval terhelné 2006-ban a közösségi költségvetést. Ennél a számításnál azt az elvet is figyelembe vettem, hogy az ún. előcsatlakozási alapok (PHARE, ISPA, SAPARD) 2006-ra elkülönített 3,24 milliárd eurós összege az akkor még be nem lépett tagjelöltek számára felhasználhatóvá válik. Ettől eltérő későbbi döntés esetén a közösségi költségvetés terhei csökkennek. (Schreyer számolt a közvetlen 
mezőgazdasági támogatások bizonyos biztosításával, ezért jutott reálisabb eredményre, mint a jelenlegi pénzügyi irányelvek.) Szintén csökkentő tényező lehet, ha a tagjelöltek GDP-jének mintegy 1,1 százalékát (ez lenne a teljesen arányos hozzájárulás, mivel a közös költségvetés is körülbelül így viszonyul a közösségi GDP-hez) szedi be a közös költségvetés, hiszen ekkor az új tagok befizetése eléri az 5,7 milliárd eurót tíz ország esetében 2006-ban. (Ez esetben a bővítés nettó költsége nem haladja meg a 20 milliárd eurót tíz ország csatlakozása esetén 2006-ban.)

Az is látható, hogy az egy före jutó támogatás a tíz ország (297 euró) esetében némileg meghaladja a portugál (274 euró) mutatót 1998-ban, de elmarad a görög (415 euró) és az ír (478 euró) értéktől (lásd: V/4.2. sz. táblázat). Az egyéni sajátosságoknak megfelelően (agráradottságok vagy az egy főre jutó GDP szintje) az egyes tagjelöltek egy főre jutó támogatása nagy eltérést mutat, hiszen Lengyelország, Szlovákia, Litvánia és Lettország részesülne az átlag alatt, még például Ciprus, Szlovénia, Észtország jóval az átlag felett, a szlovénok és a ciprusiak esetében még az ír vagy a görög értékeket is meghaladva.

Természetesen az EU költségeinek oldaláról is történnek olyan fejlemények, amelyek lehetővé teszik, hogy az 1,27 százalék/GNP küszöbbel könnyebben lehessen megvalósítani a bővítést. Egyrészt az Unió legnagyobb költségvetési tételét kitevő agrárkiadásoknál a bővítéstől függetlenül is csökkeni fog a kiadások abszolút és relatív mértéke a jelenlegi tagállamok esetében is, mivel részben a GATT legutóbbi fordulójában vállalt kötelezettség miatt, részben a belső válságok okozta reformok miatt vissza kell fogni a közösségi agrártámogatások összegét. Ezt mi sem jelzi jobban, mint hogy a nagyjából változatlan vidékfejlesztésen (4,5 milliárd euró körüli) kívüli többi agrárkiadások - közvetlen kifizetés és a rendtartás - költsége a 2002-es csúcsról (41,169 milliárd euró) 2006-ra 38,797 milliárd euróra csökken a 15 országra készített pénzügyi irányelvben. Mindez azt is jelentheti, hogy ha a közösségi agrárpolitikára a GNP ugyanakkora hányadát költené az EU a bővülés után, mint előtte, akkor 2006-ban (a 2001. évi 44,53 milliárd euró évi 2,5 százalékos - a gazdasági növekedést tükröző - emelése után) 50,10 milliárd euró, valamint a mezőgazdasági bővítésre már elkülönített 3,537 milliárd euró, összesen 53,637 milliárd euró állna a teljes agrárpolitikai támogatásra rendelkezésre, amiből már az egyenlő elbánás szerinti bővítés is lehetővé válna. (Ez esetben mód nyílna a 9 
milliárd euró kifizetésére a tíz új tagállam számára anélkül, hogy a jelenlegi tagállamok számára kifizetésre előirányzott 43,344 milliárd eurót csökkentenék.)

A másik forrásnövelő tényezőt az teszi lehetővé, hogy az EU-tagállamokban a jelenlegi kohéziós politika hatásaként leszakadt területek zárkóztak fel, (ez országszinten érvényes Írországra), ami azt eredményezte, hogy egyes térségek a bővítéstől függetlenül kikerüljenek bizonyos jogosultságból. (Ennek pénzügyi jelentősége az 1. célkitűzésből kikerülő NUTS II régióknál és a Kohéziós Alapot vélhetően elhagyó Írországnál van.) Mindezek következtében a strukturális politikára meghatározott összegek a jelenlegi tagállamok számára a 2000. évi 32,6788 milliárd euróról 2006-ra 30,343 milliárd euróra csökken (lásd: Berlini Csúcsértekezlet, [1999]). Ez már az 1999-re Edinburghban (1992. december) meghatározott plafon (a közösségi GNP 0,46 százaléka fordítható strukturális politikára) alapján azt jelenti, hogy a jelenlegi tagállamok esetében a strukturális kiadások a GNP 0,3 százalékára csökkennek, és 2006-ban az új tagállamokra szánt összegekkel (12,568 milliárd euró) együtt sem haladja meg 2006-ban a GNP 0,45 százalékát. Mindez azt tükrözi, hogy a kohéziós folyamatok arányaiban (a közösségi GNP-hez viszonyítva) azt a pénzügyi terhet jelentik a tíz tagállammal számolt bővülés után 2006-ban, mint 15 tagállamra számolva a kilencvenes évek végén.

Tájékoztatásul megadom az Agenda 2000-ben a Bizottság által a 10 országra tett becslést. Ebből látszik, hogy 1997-ben az EU Bizottság az általam kiszámítottnál valamennyivel nagyobb befizetést kalkulált a tagjelöltekre, és a közös költségvetésből visszajuttatandó támogatást is valamivel alacsonyabbra becsülte, így az akkori számítások szerint maximum 19 milliárd euróba került volna az EU költségvetésének a tíz országgal megvalósítandó bővítés. 
V/4.8. sz. táblázat: Az egyes tagjelöltek várható befizetései és juttatásai a közösségi költségvetésböl 2005-2006-ban (1997-es becslés)

\begin{tabular}{|l|c|c|c|c|c|}
\hline \multirow{2}{*}{\multicolumn{1}{c|}{ Ország }} & \multirow{2}{*}{$\begin{array}{c}\text { Befizetés } \\
\text { (becslés átlaga) }\end{array}$} & \multicolumn{2}{c|}{ Juttatás } & \multicolumn{2}{c|}{ Egyenleg } \\
\cline { 3 - 6 } & 0,216 & Min. & Max. & Min. & Max. \\
\hline Bulgária & 0,756 & 2,6 & 1,2 & 0,784 & 0,984 \\
\hline Csehország & 0,108 & 0,3 & 0,4 & 1,844 & 2,444 \\
\hline Észtország & 0,648 & 2,5 & 3,1 & 1,852 & 0,292 \\
\hline Magyarország & 0,108 & 0,4 & 0,5 & 0,292 & 0,452 \\
\hline Lettország & 0,108 & 0,7 & 0,9 & 0,592 & 0,792 \\
\hline Litvánia & 1,944 & 7,5 & 9,5 & 5,556 & 7,556 \\
\hline Lengyelország & 0,324 & 2,1 & 2,5 & 1,776 & 2,176 \\
\hline Románia & 0,324 & 1,0 & 1,3 & 0,676 & 0,976 \\
\hline Szlovákia & 0,324 & 1,0 & 1,3 & 0,676 & 0,976 \\
\hline Szlovénia & $\mathbf{4 , 8 6 0}$ & $\mathbf{1 9 , 1}$ & $\mathbf{2 4 , 0}$ & $\mathbf{1 4 , 2 4}$ & $\mathbf{1 9 , 0 4}$ \\
\hline Összesen & & & & &
\end{tabular}

Forrás: Agenda 2000. országjelentések, Európai Bizottság, [1997]

2002 januárjában az EU Bizottság által elkészített javaslat 2006-ra 16 milliárd eurót javasolt a tagállamoknak a tíz új tagjelölt felvételének finanszírozására, ami inkább tükrözi az Agenda 2000 alapján 1997-ben készített becslést, mint a tagjelöltek számára az egyenlő elbánás szerint kiszámított összeget (22,3 milliárd eurót).

Összefoglalásként megállapítható, hogy a bővítés költsége semmilyen körülmények között nem fogja 2006-ban meghaladni a közösségi GNP 0,25 százalékát (25 milliárd euró bővítési költséggel és 10.000 milliárd euró közösségi GNP-vel számolva), ami a tagállamok számára alatta marad a kalkulált közvetett gazdasági és biztonsági haszonnak.

\section{RÉSZ; 5. FEJEZET}

\section{A BŐVÍTÉS KERESKEDELEMPOLITIKAI HATÁSAI}

Mint Nyugat-Európa és a közép-kelet európai térség kapcsolatairól írott történelmi bevezető részben ( $I / 3$. fejezet) bemutattam, a térség rendszerváltása előtt lényegében csak áruforgalmi kapcsolatok voltak jellemzőek azokon a területeken, amelyek a belső piac müködése szempontjából kiemelkedő fontossággal bírtak. A térség kereskedelmi súlya 1945 előtt jelentősebb volt Európa életében, mint jelenleg, ami az 
új tagállamokban meglévő természetes felzárkózási képességet jelzi. Azt is láttuk, hogy a kereskedelem mértéke a kelet-nyugati viszonylatban a II. világháború után az EU elődei számára elhanyagolható volumenű volt, és a rendszerváltás előtt a KGSTtagállamok számára sem a Nyugat-Európával való kereskedés jelentette a fó relációt, bár a fokozódó strukturális zavaraik egyre jobban előtérbe állították ezt a kapcsolatrendszert. Ugyanakkor a kétpólusú rendszer az ún. négy szabadságjog (áruk, szolgáltatás, tőke és személyek szabad áramlása) közül az árukereskedelmen kívüli másik három területen teljes mértékben jelképessé tette a kapcsolatokat, a rendszerváltás elött szó sem lehetett számottevő volumenben ezek áramlásáról a két tábor között, a technológiai együttmüködések is inkább az áruk mozgásához kapcsolódtak.

Az Európai Unió bővítése kereskedelem-politikai hatásának felméréséhez meg kell vizsgálnunk, hogy a tagság előtt milyen liberalizáció ment végbe, ennek milyen hatása és jelentősége volt a két fél számára, és milyen kereskedelmi munkamegosztás, valamint szerkezet bontakozott ki. Azt is megvizsgáltam, hogy hogyan hat a közép- és kelet-európai országok tagsága harmadik országok kereskedelmi pozícióira.

\section{V/5.1. A kelet-nyugati kereskedelem súlya és volumene a kilencvenes években}

A kilencvenes évek elején megkötött Európai Megállapodásoknak köszönhetően jelentősen csökkent a kétoldalú kereskedelemben a vámjellegü akadályok mértéke. 1997-re minden tagjelölt számára szabaddá vált a vámmentes ipari export lehetősége az EU-val (ezzel együtt megszüntek a kvóták és más vámjellegű akadályok is az ipari termékekre, amit legkésőbb 2002-re a tagjelöltek is leépítettek). A mezőgazdasági kereskedelem terén, mint látjuk majd, szintén jelentős liberalizálás jött létre, de a tagsághoz képest még jelentős az aszimmetria, mivel a tagjelöltek exportjában a vámmentes áruk több, mint 70 százalékos arányt érnek el, addig ez az EU számára ennél alacsonyabb, 50-60 százalék közötti, vagyis a tagfelvétel ebböl a szempontból az EU számára jelent nagyobb piacnyitást. (Lásd részletesen az agrárintegrációval foglalkozó fejezetet.) Mindeközben mind az ipari, mind a mezőgazdasági területen megjelentek olyan egyezmények (az ún. PECA-egyezmény - kölcsönös termékmegfelelőségi jegyzőkönyvek - aláírása Csehországgal és Magyarországgal, 
illetve az agrárliberalizáció kapcsán az exportszubvenció bizonyos termékeknél való kizárása), amely már nemcsak a szabadkereskedelmi, hanem a belső piaci viszonyokat is a tagság előttre hozta. Ezért a kereskedelmi területen a tagság várható hatását és jelentőségét már most is megítélhetjük, a pillanatnyi helyzet ennek extrapolálását könnyen lehetővé teszi.

V/5.1. sz. táblázat: Főbb kereskedelmi adatok az EU tagállamaiban és a tagjelölteknél 1998-ban I.

\begin{tabular}{|c|c|c|c|c|c|}
\hline \multirow{2}{*}{ Ország } & \multirow{2}{*}{$\begin{array}{c}\text { Export } \\
1998 \\
\text { (md euró) }\end{array}$} & \multicolumn{2}{|c|}{$\begin{array}{c}\text { EU aránya } \\
1998 \text { (százalék) }\end{array}$} & \multirow{2}{*}{$\begin{array}{c}\text { Egy fóre jutó } \\
\text { export } \\
1998 \text { (euró) }\end{array}$} & \multirow{2}{*}{$\begin{array}{c}\text { Export } \\
\text { változása } \\
\text { 1998/1993 }\end{array}$} \\
\hline & & Export & Import & & \\
\hline Ausztria & 55,2 & 63 & 69 & 6836 & 1,61 \\
\hline Belgium & 159,5 & 75 & 71 & 15650 & 1,46 \\
\hline Dánia & 43,7 & 66 & 71 & 8253 & 1,49 \\
\hline Finnország & 39,0 & 56 & 54 & 7587 & 1,94 \\
\hline Franciaország & 286,0 & 63 & 62 & 4870 & 1,51 \\
\hline Németország & 482,5 & 56 & 54 & 5880 & 1,49 \\
\hline Görögország & 9,5 & 55 & 67 & 904 & 1,32 \\
\hline Írország & 58,9 & 68 & 54 & 15945 & 2,37 \\
\hline Olaszország & 215,6 & 56 & 62 & 3745 & 1,49 \\
\hline Luxemburg & - & 83 & 89 & - & - \\
\hline Hollandia & 186,6 & 73 & 54 & 11920 & 1,56 \\
\hline Portugália & 21,6 & 82 & 77 & 2169 & 1,64 \\
\hline Spanyolország & 93,3 & 70 & 68 & 2372 & 1,69 \\
\hline Svédország & 75,5 & 55 & 64 & 8533 & 1,77 \\
\hline Egyes. Királyság & 243,9 & 53 & 48 & 4128 & 1,57 \\
\hline Bulgária & 3,8 & 50 & 45 & 467 & 1,21 \\
\hline Csehország & 23,5 & 64 & 64 & 2284 & 1,90 \\
\hline Észtország & 2,9 & 67 & 68 & 2006 & 4,21 \\
\hline Magyarország & 20,5 & 73 & 64 & 2031 & 2,70 \\
\hline Lettország & 1,6 & 57 & 55 & 658 & 1,89 \\
\hline Litvánia & 3,3 & 38 & 47 & 892 & 1,93 \\
\hline Lengyelország & 25,2 & 68 & 66 & 652 & 2,08 \\
\hline Románia & 7,4 & 65 & 58 & 329 & 1,75 \\
\hline Szlovákia & 9,5 & 56 & 50 & 1761 & 2,05 \\
\hline Szlovénia & 8,0 & 66 & 69 & 4044 & 1,55 \\
\hline
\end{tabular}

Forrás: IMF, [2000], Eurostat, [2000], EU Bizottság, [2001], saját számítás

Megjegyzés: Exportadatok az Eurostat, az EU-ba irányuló export-import aránya a tagállamoknál az IMF, a tagjelölteknél az Európai Bizottság Gazdasági és Pénzügyi Főigazgatósága [2001] alapján 
V/5.2. sz. táblázat: Föbb kereskedelmi adatok az EU tagállamaiban és a tagjelölteknél 1998-ban II.

\begin{tabular}{|l|c|c|c|c|}
\hline \multirow{1}{*}{ Ország } & \multicolumn{2}{c|}{$\begin{array}{c}\text { KEK 10 aránya a } \\
\text { külkereskedelemben } \\
\mathbf{1 9 9 8} \text { (százalék) }\end{array}$} & \multicolumn{2}{c|}{$\begin{array}{c}\text { KEK 10 ill. EU } \\
\text { kereskedelmének aránya a } \\
\text { GDP-hez képest (százalék) }\end{array}$} \\
\cline { 2 - 5 } & Export & Import & Export & Import \\
\hline Ausztria & 14 & 9 & 3,96 & 2,96 \\
\hline Belgium & 2 & 2 & 1,64 & 1,08 \\
\hline Dánia & 4 & 3 & 1,14 & 0,91 \\
\hline Finnország & 8 & 4 & 2,59 & 1,01 \\
\hline Franciaország & 3 & 2 & 0,56 & 0,39 \\
\hline Németország & 8 & 8 & 2,04 & 1,72 \\
\hline Görögország & 8 & 3 & 0,57 & 0,86 \\
\hline Írország & 1 & 1 & 0,77 & 0,55 \\
\hline Olaszország & 5 & 4 & 1,08 & 0,74 \\
\hline Luxemburg & 2 & 2 & 1,02 & 0,40 \\
\hline Hollandia & 3 & 2 & 1,21 & 0,96 \\
\hline Portugália & 1 & 1 & 0,20 & 0,24 \\
\hline Spanyolország & 2 & 1 & 0,40 & 0,28 \\
\hline Svédország & 4 & 4 & 1,44 & 1,06 \\
\hline Egyesült Királyság & 2 & 2 & 0,39 & 0,35 \\
\hline Bulgária & 18 & 13 & 17,4 & 18,2 \\
\hline Csehország & 6 & 6 & 29,5 & 32,4 \\
\hline Észtország & 21 & 13 & 34,7 & 55,7 \\
\hline Magyarország & 15 & 6 & 35,7 & 35,0 \\
\hline Lettország & 10 & 7 & 16,0 & 27,5 \\
\hline Litvánia & 5 & 9 & 13,1 & 25,4 \\
\hline Lengyelország & 9 & 7 & 12,2 & 19,7 \\
\hline Románia & 33 & 29 & 12,9 & 16,6 \\
\hline Szlovákia & 7 & 7 & 29,4 & 32,2 \\
\hline Szlovénia & 15 & 19 & 30,3 & 35,9 \\
\hline Európai Unióy & 5 & 4 & 1,18 & 0,92 \\
\hline & & & & \\
\hline
\end{tabular}

Forrás: IMF, [1999], in Boeri, [2000], saját számítás

Megjegyzés: KEK 10 ország a tagsági tárgyalásokat folytató közép- és kelet-európai országok.

Érdemes megjegyezni, hogy az Eurostat felmérései szerint a közép- és kelet-európai országokba (mely magába foglalja a nyugat-balkáni országokat, de nem öleli fel a Baltikumot) irányuló EU export öt és félszeresére nőtt az 1988-1998-as időszakban, míg az importja majdnem négyszeresére duzzadt ebben az időszakban. Ezzel a két régió számára az egymással folytatott kereskedelem mutatta a legnagyobb fejlődést. 1998-ban az EU exportpiacán csak az Amerikai Egyesült Államok haladta meg a fenti térség részarányát és például a közép- és kelet-európai országokba irányuló EUexport 1997 óta meghaladja a Mediterrán Medencébe irányuló kivitel értékét is (Eurostat, [2000]). Ki kell emelni, hogy a tagjelölt országok kereskedelmi 
tevékenysége még jóval kisebb összegü, mint az EU-országoké, de a versenyképességet jelző exportot néhány ország feltünően nagyobb arányban növelte, mint az EU-tagállamok nagy része. Ilyen például Észtország, Magyarország, Lengyelország és Csehország vagy Szlovákia, ahol a kivitel legalább megkétszereződött 1993 és 1998 között, ilyen teljesítményt az EU-tagállamok között csak Írországnál láttunk (ld. V/5.1. sz. táblázat). Ugyanakkor a tagjelöltek egy före jutó exportteljesítménye még elmarad a tagállamok nagy részétől, de Szlovénia (4044), Magyarország (2031), Észtország (2006) és Csehország (2284) már most is megközelíti, illetve meghaladja a három mediterrán kohéziós ország, Görögország (904), Portugália (2169), és Spanyolország (2372) mutatóját.

A tagjelöltek legfontosabb külkereskedelmi partnerévé az EU vált, minden esetben meghaladva az 50 százalékos értéket. Mivel a tagjelöltek többsége a volt Szovjetunióból szerzi be nyersanyagszükségleteit, (lásd energiafejezet), de oda már nehezebben tud exportálni, ezért számukra az exportban nagyobb súlyt jelent az EU, mint az importban. Feltűnő, hogy alig tíz évvel a rendszerváltozás és a KGST összeomlása után milyen magas az EU külkereskedelmi szerepe a régióban annak ellenére, hogy a térség országai egymás irányában is megnyitották a piacaikat (lásd CEFTA-tagság). Mindez azt jelzi, hogy a fejlett technológia importja az EU-ból származik elsősorban, másrészt a jelenlegi tagországok rendelkeznek fizetőképes kereslettel.

Az EU számára Közép- és Kelet-Európa külkereskedelmi jelentősége jelenleg még viszonylag csekély. A térségbe irányuló exportja a teljes kivitelének 5, míg az onnan származó importja a teljes behozatalának 4 százalékát képviselte. (Összehasonlításként: az USA az EU exportjában összességében 8, importjában 9 százalékot jelent, van olyan tagállam - Nagy-Britannia és Írország - ahol ez jóval meghaladja a 10 százalékot.)

Hasonló eredményre jutunk, ha az EU GDP-jéhez mérten vizsgáljuk meg a kölcsönös kereskedelem súlyát: az EU jövedelmének 1,18 százalékát adja a tagjelöltek felé irányuló export, és kevesebb mint egy százalékát az onnan származó import, míg a tagjelölteknél 12,2 és 55,7 százalék szélső értékek között mozog a GDP-hez mért EU-ba irányuló vagy onnan érkező áruforgalom értéke (ld. V/5.2. sz. 
táblázat). Ezért kijelenthetjük, hogy az EU számára nem jár jelentős hatással a bővítés külkereskedelmi rendszerében, ennek következtében a Közösség belső piacára hatása nem számottevő. Éppen ezért a kereskedelem kibontakozása, és a szabad áruáramlás önmagában nem fog jelentős befolyást gyakorolni a tagállamok bérviszonyaira, a munkanélküliségi mutatókra. Ezt támasztja alá az is, hogy a bővítés után jelentős rugalmatlanság marad fenn Európa két fele között a munkaerő illetve a tőkeintenzív iparágak földrajzi eloszlása miatt (mint látni fogjuk a munkaerő mobilitása az új tagállamoknál is korlátozott), ezért a tőke és a munkaerő árának kiegyenlítődése (lásd: Heckschler-Ohlin-Samuelson tétel) a szabad kereskedelem révén is csak korlátozott lesz Európa két fele között (Brücker és társai [2001]).

A földrajzi tényezőnek tekintélyes szerepe van a kereskedelmi folyamatokban. Ezt mutatja az is, hogy az előbbi megállapítás - miszerint a kétoldalú kereskedelem EU-n belülre kerülésének nincs lényeges hatása az EU fejlődésére - már nem igaz akkor, ha a tagjelöltekkel szomszédos országokat vizsgáljuk meg. Ekkor kiderül, hogy a bővítési régióval határos országok - sőt azon belül is a határmenti tartományok - számára fontos kereskedelmi partnerek a velük szomszédos tagjelöltek. Így látható, hogy a közvetlen határos tagországok (Ausztria, Németország, Görögország) exportján belül a tagjelöltek több mint nyolc százalékot képviselnek. Az osztrák exporton belül részesedésük elérte a 14 százalékot, de a németeknél, a finneknél vagy a görögöknél is a 8 százalékot, sőt a GDP-hez mérten is jelentős az osztrákok, a finnek és a németek térségbe irányuló exportja. Különösen fontos a térségbe irányuló export GDP-hez mért aránya Ausztria számára, ahol ez csaknem 4 százalékot ért el 1998-ban, és magas, több mint 2,9 százalék volt a finneknél, és 2,04 százalék a németeknél. A többi tagállamnál ez a mutató messze 2 százalék alatt marad, vagyis számukra pillanatnyilag nincs makrogazdasági jelentősége a tagjelöltekkel folytatott kereskedelemnek (ld. V/5.2. sz. táblázat).

A földrajzi tényező fontos kereskedelempolitikai szerepét támasztja alá az is, hogy a tagjelöltekkel határos tagállamokon belül az országos átlagnál jóval magasabb a határmenti régiók részesedése a közép- és kelet-európai országokkal megvalósított kereskedelemből (V/5.3. sz. táblázat). Mivel a tagság előtt már elkezdődött a határok szigorú jellegének leépítése, a gazdasági, szociális racionalitások alapján a határokon átnyúló kapcsolatok lesznek fontosak. Ugyanez figyelhető meg a további keleti 
terjeszkedéseknél; így a magyar-román viszonylatban, vagy a lengyel, ukrán, litván vonatkozásban a befektetések, gazdasági kapcsolatok élénkítésében nagy szerepük lesz a határmenti területek együttmüködésének.

V/5.3. sz. táblázat: A tíz közép- és kelet-európai ország kereskedelmi szerepe a német tartományok esetében (1997)

\begin{tabular}{|c|c|}
\hline Tartomány & $\begin{array}{c}\text { KEK-10 aránya a } \\
\text { kereskedelemben } \\
\text { (százalék) }\end{array}$ \\
\hline Szászország & 20,2 \\
\hline Mecklenburg - Nyugat Pomeránia & 16,6 \\
\hline Felsö-Szászország & 14,7 \\
\hline Brandenburg & 14,2 \\
\hline Türingia & 11,0 \\
\hline Berlin & 9,4 \\
\hline Bajorország & 8,9 \\
\hline Alsó-szászország & 8,4 \\
\hline Rajnavidék & 6,7 \\
\hline Észak-Rajna-Vesztfália & 6,5 \\
\hline Baden-Würtemberg & 6,5 \\
\hline Hessen & 5,5 \\
\hline Schleswig-Holstein & 5,2 \\
\hline Saar-vidék & 4,6 \\
\hline Hamburg & 3,5 \\
\hline Bréma & 3,2 \\
\hline
\end{tabular}

Forrás: Brücker, [2000], német szövetségi statisztikák alapján

Az előzőekben kifejtetteket alátámasztja, hogy Bajorország - Brücker adatai szerint - külkereskedelmében Csehország önmaga több mint 3, Magyarország pedig több mint 2 százalékot képvisel, míg Lengyelország csak 0,45 százalékot. Brandenburg külkereskedelméből pedig Lengyelország önmaga 8,8 százalékkal részesedik, míg Csehországnál ez 2,2 százalék, Magyarországnál már csak szük 1,5 százalék. A táblázatból az is jól megfigyelhető, hogy míg a tíz közép- és kelet-európai tagjelölt aránya a német exporton és importon belül nyolc százalék (lásd: V/5.2. sz. táblázat), addig a kelet-német tartományok illetve Bajorország a térséggel fennálló kereskedelme ezt az értéket felülmúlja. 


\section{V/5.2. A kereskedelem tagság utáni bővüléséből eredő uniós haszon becslése}

A kereskedelem bővülésének a gazdasági növekedésre gyakorolt hatásáról eltérő becslések vannak, Weiss 1996-ban úgy tippelte, hogy az exportnak Németországban kb. 60 ezer munkahelyet teremtő hatása volt már 1993-ban (Boeri, [2000]), ami az össznémet vonatkozásban nem igazán befolyásolta a gazdasági növekedést, ugyanakkor a WIFO különböző becslései már a kilencvenes évek közepén 1,5 százalékra teszik azt a pótlólagos növekedést (2,9 százalék a beruházások, 0,9 százalék a foglalkoztatás - 30 ezer személy -), amit Ausztria számára önmagában a négy visegrádi ország felvétele jelent.

A különböző gravitációs modellek (melyek azzal számolnak, hogy mind az EU, mind az EU-nál gyorsabban fejlődő tagjelöltek gazdasági növekedése folytatódni fog), különböző súlyokkal veszik figyelembe a kereskedelemre ható tényezőket (EUtagság, földrajzi távolság, tradíció, képzettség kultúra stb.). Ezek a modellek azt mutatják ki, hogy a jelenlegi helyzethez képest jelentős tartalékok vannak az EU és a tagjelöltek közötti kereskedelmi kapcsolatok fejlődésében. Schumacher 1999-ben készült háttértanulmánya (lásd Brücker és társai háttértanulmánya [2000]) olyan reális modellt állított fel, amely az elkövetkezendő tíz évben az EU 2 százalékos növekedésével és a tagjelöltek évi 2 százalékos konvergenciájával számol. Az így kialakított modell szerint az EU exportpotenciálja a közép- és kelet-európai országok felé 2000-2010 közötti időszakban 73 százalékkal nő majd, míg importja 79 százalékkal növekedhet. Becslései szerint a kereskedelmi többlet ez idő alatt 59 százalékkal nőhet az EU számára. Ezek a becslések ugyanazt a trendet mutatják, mint ami a mediterrán tagországok csatlakozás utáni felzárkózása idején történt. Schumacher háttértanulmánya alapján valószínüsíthető, hogy a közép-kelet-európai térségtől messze eső államok - Portugália, Spanyolország, Franciaország, NagyBritannia - tudják majd legjobban felfuttatni a régióval fennálló kereskedelmi kapcsolataikat, de az is tény, hogy a domináns partnerek továbbra is Németország, Ausztria és Olaszország maradnak. A közép-európai országoknál a legnagyobb kihasználatlan potenciált Schumacher 1999-ben Csehországra, Szlovákiára és Lengyelországra - abszolút mértékben ez utóbbi a többi tagjelöltet messze felülmúlóan - jósolja 2010-re. A gravitációs elképzelések alapján az is bizonyossággal megállapítható, hogy az EU-országok külkereskedelmének általános 
fejlődését felülmúlja a térséggel folytatott kereskedelem növekedésének üteme, így annak súlya, és a GDP növekedésére gyakorolt hatása is nöni fog, vagyis 8-10 év múlva ez már nemcsak Ausztria és Finnország gazdaságára jelent érzékelhető hatást, hanem a földrajzilag távolabb eső régiókra is.

A különböző kutatói becslések alapján számított közösségi nyereségek közül csak Mimosa elemzését emelném ki, akinek az integráció kereskedelmi hatásai kapcsán elvégzett elemzéseit több hivatalos helyen (francia Szenátus 1996, portugál kormány megbízásából a lisszaboni tudományegyetem, 1998) is átvették, megidézték. Eszerint a bővítés előtt a társulási megállapodások végrehajtásának hatása 2002-ben az EU számára alig érzékelhető a hozzáadott érték növekedése (nulla és 0,1 százalék közötti, de pl. Olaszországnál 0,3 százalékos), míg az érintett társult országoknak ez évi 1 százalék körüli gazdasági növekedést hoz.

Mimosa becslései szerint a tagság után azonban a kereskedelem előtt álló akadályok lebontása valamint a strukturális alapok okozta pótlólagos importigény miatt (ld. spanyol, portugál példa) az EU 2012-ben évi 0,4 százalékos pótlólagos GDPnövekedéssel számolhat és a munkanélküliség is 0,2 százalékkal csökken ennek hatására. Érdekes, hogy a relatíve legnagyobb nyertesek között Olaszországot és Franciaországot említette.

V/5.4. sz. táblázat: Mimosa modellje szerinti növekedési hatás az EU-tagállamok és a tagjelöltek számára 2012-re

\begin{tabular}{|l|c|c|}
\hline \multicolumn{1}{|c|}{ Ország } & $\begin{array}{c}\text { GDP-növekedés } \\
\text { (százalék) }\end{array}$ & $\begin{array}{c}\text { Munkanélküliség } \\
\text { csökkenése } \\
\text { (százalék) }\end{array}$ \\
\hline Németország & 0,4 & 0,2 \\
\hline Franciaország & 0,5 & 0,2 \\
\hline Olaszország & 0,9 & 0,6 \\
\hline Egyesült Királyság & 0,1 & 0,0 \\
\hline EU-15 & 0,4 & 0,2 \\
\hline Tagjelöltek & 29,4 & n.a. \\
\hline
\end{tabular}

Forrás: Mimosa Modell, OFCE: in Rapport d'information, Sénat (Francia Szenátus) [1996] 


\section{V/5.3. Kereskedelmi mérleg az EU és a Társultak között}

Mint az előzőekben már jeleztem, a modernizáción áteső tagjelölt országok igen jelentős importigénnyel lépnek fel, aminek pénzügyi fedezetét nem tudják minden esetben megfelelő exportkapacitással ellensúlyozni. A kilencvenes években az EU és a térség országai között jelentősen növekedett a kétoldalú kereskedelem aktívuma. Míg az EU teljes külső partnerekkel folytatott kereskedelmében 1993-ban mindössze 3,4 milliárd euró aktívumot ért el, addig a közép- és kelet-európai térséggel - a tagjelölteken kívül beleértve a volt Jugoszláviát is - 8,5 milliárd euró aktívuma volt, ugyanez 1998-ban 21 és 26,7 milliárd euró volt, vagyis a mediterrán medencével együtt térségünk jelenti a legnagyobb aktívumot hozó kereskedelmi partnert. A tagjelöltek teljes kereskedelmi mérlegének hiányát tekintve - melyek Lengyelország kivételével nem haladják meg a 2-3 milliárd eurót - a legnagyobb tétel 1998-ban (53,1 százalék) az EU-relációban keletkezett negatív szaldó volt (a 10 országnál összesen 17,3336 milliárd euró, lásd V/5.5. sz. táblázat). Ebböl a negatívumból a modernizációs importigény, a versenykihívások, valamint az export magas importigénye miatt a jövőben nehezen tudnak lefaragni.

V/5.5 sz. táblázat: A tagjelöltek kereskedelmi hiánya az EU felé 1994-ben és 1998-ban (millió euró)

\begin{tabular}{|c|c|c|}
\hline Ország & $\mathbf{1 9 9 4}$ & $\mathbf{1 9 9 8}$ \\
\hline Bulgária & +38 & -81 \\
\hline Csehország & -789 & -1449 \\
\hline Észtország & -125 & -972 \\
\hline Magyarország & -966 & +261 \\
\hline Lettország & -29 & -656 \\
\hline Litvánia & -82 & -1181 \\
\hline Lengyelország & -1339 & -10462 \\
\hline Románia & -239 & -1317 \\
\hline Szlovákia & +142 & -507 \\
\hline Szlovénia & -107 & -972 \\
\hline Összesen & -3496 & -17336 \\
\hline
\end{tabular}

Forrás: Eurostat, [2000]

Megjegyzés: 1994-ben csak a 12 EU-tagállammal számolva 
Mint a V/5.5. sz. táblázatból is látható, a közép-kelet-európai tagjelöltekkel folytatott kereskedelem önmagában is nagy kereskedelmi hasznot hoz a jelenlegi EU-tagok számára. Érdemes azonban azt is megfigyelni, hogy a kereskedelem minden tagjelöltnél észlelhető felfutása mellett a mérleg kedvező irányba fordult Magyarország számára, de Csehország is viszonylag kiegyensúlyozott trendet tudott fenntartani. Az EU-aktívum több mint felét 1998-ban Lengyelország révén érték el a Tizenötök. (Az eredmények értékelésénél figyelembe kell venni azt, hogy a különleges gazdasági övezetekben termelt árucikkek beszámításánál metodikai viták vannak, (pl. Magyarország esetében), ugyanígy a hiány kisebb lehet akkor, ha Lengyelország és Németország közötti határmenti kiskereskedelmet számoljuk, mivel sok keleti tartományban élő német statisztikailag nem érzékelhető módon exportál árucikkeket Lengyelországból Németországba!) A fenti adatok azt támasztják alá, hogy az árutermelés területén Magyarország versenyképessége az EU-piacokon nagyon jó, de exportjának volumenéhez képest viszonylag kedvező Csehország, Szlovákia kereskedelmi mérlege is.

\section{V/5.4. A kereskedelem szerkezete}

A társult országok rendszerváltás utáni gazdasági irányváltásának egyik legfontosabb bizonyítéka az, hogy a tagjelöltek export szerkezete az EU export szerkezetéhez hasonlóvá vált. Míg a váltás előtt (IV/1. fejezet) az alapvetően érzékeny agrár és acél, valamint alacsony feldolgozottságú termékek domináltak, addig a kilencvenes években a magas feldolgozottságú gépek és termékek adják az export domináns hányadát, az agrárkereskedelem aránya pedig visszazuhant. Ugyanez mondható el a hajdanán nagy félelemmel megközelített acél és vastermékek piacán is, ahol a középeurópai országok nagy része jelentős kapacitáscsökkentést hajtott végre, és az alacsony forgalom mellett is csak Lengyelország és Szlovákia jelentős nettó exportőr e területen. 
V/5.6. sz. táblázat: A feldolgozott termékek (1), gépek és közlekedési eszközök (2), és a mezögazdasági termékek (3) aránya az exportban, 1998-ban (százalék)

\begin{tabular}{|c|c|r|r|}
\hline Ország & $\mathbf{1}$ & $\mathbf{2}$ & $\mathbf{3}$ \\
\hline Bulgária & 28,0 & 12,0 & 14,1 \\
\hline Csehország & 26,5 & 41,3 & 4,3 \\
\hline Észtország & 19,1 & 24,5 & 15,2 \\
\hline Magyarország & 12,4 & 50,2 & 10,5 \\
\hline Lettország & 25,3 & 9,0 & 9,7 \\
\hline Litvánia & 14,6 & 18,8 & 13,1 \\
\hline Lengyelország & 25,2 & 28,4 & 10,4 \\
\hline Románia & 25,4 & 14,6 & 3,7 \\
\hline Szlovákia & 30,0 & 37,4 & 3,7 \\
\hline Szlovénia & 25,8 & 36,7 & 3,7 \\
\hline EU & 27,6 & 47,0 & 6,0 \\
\hline Görögország & 44,2 & 10,5 & 24,2 \\
\hline Portugália & 49,0 & 32,8 & 6,5 \\
\hline Spanyolország & 27,9 & 42,8 & 13,7 \\
\hline
\end{tabular}

Forrás: Eurostat, [2000] saját számítás

A V/5.6. sz. táblázaton teljes mértékben lemérhető a szerkezetváltás végrehajtásának mikéntje, a beáramló müködő tőke hatása. Az igazán nagy hozzáadott értéket jelentő gépipari termékek exportjában csak Magyarország (50,2 százalék) és Csehország (41,3 százalék), valamint kisebb mértékben Szlovénia $(36,7)$ és Szlovákia $(37,4)$ jelent az EU-hoz $(47,0)$ hasonlítható szerkezetet. A feldolgozott termékeknél az összes tagjelöltet tekintve jobb az arány, az EU-tól nincs akkora elmaradás. Az előbbiekben említett négy ország exportszerkezetének fejlődését nemcsak az EU egészéhez lehet hasonlítani, hanem a mediterrán tagországok struktúrájánál is modernebbek, amelyek magas feldolgozottságú ipari termékek előállításába való bevonása még a közép-európai térség tükrében is alacsony. Ebben a versenyképességet és modernizációt is jelző mutatóban a mediterrán országokhoz hasonlóan a románok és a bolgárok mellett a baltiak bekapcsolódása is gyengének mondható. Figyelemre méltó, hogy alacsony szintet képviselnek a mezőgazdasági termékek az exporton belül a tagjelölt országok nagy részében is. (Csehországban, Szlovákiában és Szlovéniában messze az EU-arány alatti.) 
Schumacher 1999-ben készített és már idézett jelentése szerint a kihasználatlan exportkapacitások (amennyiben a tagság megvalósul és a tagjelöltek makrogazdasági konvergenciája folytatódik) kihasználásában az EU számára nem a termékkereskedelem felfuttatása jelenti majd a kitörési lehetőséget, hanem az iparágakon belüli munkamegosztás intenzívebbé tétele. Az bizonyos, hogy az új tagoknak nagyon nagy előnyük lesz az ún. forrásigényes termelési ágazatokban, és a munkaerő-intenzív területeken, bár a konvergencia elörehaladtával ez utóbbi nem fog erősödni, sőt meggyengül a munkamegosztáson belül. Az EU számára komoly elönyök jelentkeznek a kutatásintenzív, a szérianagyságra épülő, és a szakosodott beszállítókat foglalkoztató területeken, ami mind a foglalkoztatás, mind a gazdasági növekedés terén egyértelmű hasznot fog jelenteni a jelenlegi tagok számára.

\section{V/5.5. Az új tagok vámunióba lépésének hatása a külső partnerekre}

Az új tagok felvétele általában kedvezően hat a harmadik országok kereskedelmi lehetőségeire, ami erősíti az EU külső kapcsolatrendszerét is. A vámunióba való belépés kereskedelemteremtő vagy térítő hatása a külső partnerek szempontjából elsősorban attól függ, hogy hogyan tudnak alkalmazkodni az új helyzethez. Az új tagok energiaellátásuk jelentős részét, valamint bizonyos nyersanyagokat a volt Szovjetunió országaiból (elsősorban Oroszországból) szerzik be, ez a tagsággal nem fog változni, sőt a jelenlegi Unió egyirányú energiafüggőségét főleg az olaj területén (OPEC és az arab országok túlzó szerepe, ld. energiafejezet) csökkenteni fogja.

Az ipari termékek területén a harmadik országoknak új lehetőséget fog nyitni a bővülés után az, hogy a jelenlegi ipari vámokra vonatkozó MFN-tarifa (legnagyobb kedvezmény) a tagjelölteknél magasabb, mint az EU 3,6 százalékos (1998) tarifája (az Unió ezt 2004-ben pl. az acéltermékek esetében meg is szünteti), ami a tagság után a közösségi tarifák átvételével értelemszerüen csökkenni fog. Ugyanakkor a mezőgazdaság területén a magas közös vámtarifák, szubvenciók kiterjesztése az új tagokra nehezítik a harmadik országok számára a jelenlegi tagjelöltek piacára való bejutást. Ezen a területen azonban nincs jelentős érdeksérelem a harmadik országok részéről, mivel a 27 országon kívüli körböl a tagjelöltek felé nincs jelentősebb agrárexport-érdekeltség (a WTO-szabályok azt is lehetővé teszik, hogy a bővítés miatti veszteségek miatt kompenzációs igénnyel lépjenek fel az érintett harmadik 
országok az EU felé). Mivel a szolgáltatások terén a tagjelöltek a WTO-előírásokon túlmenően átveszik a közösségi belső piac szabályozását is, ez általában javítja a harmadik országok vállalkozásainak helyzetét, ettől eltérö hatásnál szintén lehetőség van kompenzációs igény benyújtására. Ezen túlmenően a harmadik országbeli partnerek számára - akárcsak magának az EU-nak - jogi értelemben biztonságot fog nyújtani az, hogy az új tagállamok végérvényesen működő piacgazdaságként kell, hogy funkcionáljanak (állami szubvenciók és dömpingek leépítése, belső piaci szabályok érvényesítése).

\section{RÉSZ; 6. FEJEZET KÖZLEKEDÉS, TRANZIT}

A bővülésnek több okból kifolyólag jelentős hatása lesz az Unió közlekedési helyzetére és politikájára. Ezek az alábbiak:

- Önmagában a közlekedés, mint infrastrukturális iparág jelentős piacot hoz az Európai Unió számára.

- Az újonnan belépő országok nem szárazföldi végállomások a kontinensen, ezért egyszerübbé válik a többi fontos európai kereskedelmi és gazdasági partner (Balkán, Törökország, FÁK-államok) elérése. (Az Európai Bizottság 2001-ben kiadott közlekedési Fehér Könyve kiemeli, hogy az eddigi 4000 km kontinentális belső fesztávolság további 3000 km-rel nő Lisszabon és Constanza között mérve.)

- Az Unió kelet-nyugati közlekedési és szállítási tevékenységében képes lesz diverzifikálni a belső szállítási útvonalakat, különös tekintettel Ausztria és Svájc leterheltségére.

- Megfelelö hátteret tud nyújtani a tagság az Unió számára nélkülözhetetlen munkaerő és turisztikai áramláshoz mind az új tagok, mind a létfontosságú Szerbia, Törökország felé.

- Segíthet az Unió számára is fontos közlekedési-szállítási ágak (vasút, vízi közlekedés) fellendítéséhez. 
- Az Európai Bizottság által kiemelt egyik legfontosabb következmény az, hogy a bővülés után több mint 25 ország tud közösen fellépni a nemzetközi fórumokon, ahol az eddig is szétaprózódottan megjelenő EU-tagállamok érdekérvényesítő képessége eddig meglehetősen gyenge volt. Ez különösen a nemzetközi légi közlekedési vagy a tengerészeti konferenciákon lehet jelentős politikai súlytöbblet.

- A tagság által nyílik meg kölcsönösen és teljes mértékben a másik fél számára a közlekedési szolgáltatások (szállítás) piaca.

\section{V/6.1. A vasúti és közúti infrastruktúra}

A közép- és kelet-európai országok közlekedési és szállítási infrastruktúrája részben a történelmi lemaradás, részben a szocializmus időszakában történt elhanyagoltság miatt - jelentős fejlesztésre szorul, és az illető országok várható arányú gazdasági növekedése révén és miatt ez fokozottabban elötérbe kerül. Különösen fontos kiemelni, hogy ezekben a felújítási-fejlesztési munkálatokban az Unió építési vállalatai számára a közbeszerzéshez a teljes hozzáférést (lásd V/3.7. alfejezet) és a valódi (a Bizottság és a Bíróság előtti kikényszerítéssel) nemzeti elbánást csak a tagság jelentheti (ld. M3-as kivitelezés esete Magyarországon). Jelenleg ezekben a munkálatokban a közösségi juttatások - 2000-ig a PHARE, utána az ISPA - (és az ezekhez kapcsolódó feltételek) csak egy részt képviselnek, nagy részük nyilvánvalóan nemzeti forrásból (vagy hitelekből) kerül megvalósításra, ahol a tagságon kívül nem érvényesülnek a közösségi jog elöírásai. (A Bizottság 2001. szeptemberi Fehér Könyve 91 milliárd euróra becsüli a 2015-ig szükséges közlekedési beruházásokat a térség országaiban, ami GDP-jük 1,5 százalékát fogja jelenteni. Az Unió jelenleg évi 520 millió eurót biztosít az ISPA rendszeren keresztül közvetlen módon közlekedési beruházásra, ebből látható, hogy a beruházások évi 6 milliárd euró összege a tagság előtt alapvetően a tagjelölt országokat fogják terhelni; lásd később V/6.4. alfejezet.)

Az infrastrukturális igény felméréséhez megvizsgáltam a legfontosabb jellemzőket, valamint ezek fejlesztési ütemét. 
V/6.1. sz. táblázat: Autópályák hossza és sürüsége az Európai Unióban és a jelölt országokban

\begin{tabular}{|c|c|c|c|c|}
\hline \multirow{2}{*}{ Ország } & \multicolumn{2}{|c|}{$\begin{array}{c}\text { Autópályák hossza } \\
(\mathrm{km})\end{array}$} & \multirow{2}{*}{$\begin{array}{c}\text { Terület } \\
1998 \\
(\text { ezer km²) }\end{array}$} & \multirow{2}{*}{$\begin{array}{c}\text { Sürüség } \\
1998 \\
\left(\mathrm{~km} / 1000 \mathbf{k m}^{2}\right)\end{array}$} \\
\hline & 1994 & 1998 & & \\
\hline Bulgária & 277 & 319 & 111 & 2,87 \\
\hline Csehország & 392 & 498 & 79 & 6,30 \\
\hline Észtország & 64 & 74 & 45 & 1,64 \\
\hline Magyarország & 293 & 448 & 93 & 4,82 \\
\hline Lettország & - & - & 65 & - \\
\hline Litvánia & 394 & 417 & 65 & 6,42 \\
\hline Lengyelország & 245 & 268 & 313 & 0,86 \\
\hline Románia & 113 & 113 & 238 & 0,47 \\
\hline Szlovákia & 198 & 198 & 49 & 4,04 \\
\hline Szlovénia & 277 & 330 & 20 & 16,50 \\
\hline Belgium & 1665 & 1682 & 31 & 54,25 \\
\hline Dánia & 786 & 861 & 43 & 20,02 \\
\hline Németország & 11143 & 11427 & 357 & 32,00 \\
\hline Görögország & 380 & 500 & 132 & 3,78 \\
\hline Spanyolország & 6485 & 8257 & 505 & 16,35 \\
\hline Franciaország & 7956 & 9303 & 544 & 17,10 \\
\hline Írország & 56 & 94 & 69 & 1,36 \\
\hline Olaszország & 6401 & 6453 & 301 & 21,43 \\
\hline Luxemburg & 121 & 115 & 3 & 38,33 \\
\hline Hollandia & 2167 & 2360 & 41 & 57,56 \\
\hline Ausztria & 1589 & 1613 & 84 & 19,20 \\
\hline Portugália & 587 & 1252 & 92 & 13,60 \\
\hline Finnország & 388 & 467 & 338 & 1,38 \\
\hline Svédország & 1141 & 1428 & 411 & 3,47 \\
\hline Egyesült Királyság & 3286 & 3421 & 242 & 14,13 \\
\hline
\end{tabular}

Forrás: Eurostat, [2000], saját számítás

Ha figyelembe vesszük a népsűrűségi adatokat, Svédország, Finnország és Írország relatíve gyenge eredményére ez adhat magyarázatot, ugyanakkor látható, hogy a térség lemaradása - az általános gazdasági szintet is meghaladóan - jelentős, hiszen mindössze csak Szlovénia (16,5) tud az EU-államok egy részéhez - pl. Egyesült Királyság (14,13), Spanyolország (16,35), Ausztria (19,2), Dánia (20) - hasonló autópálya-sűrüséget felmutatni. Csehország, Litvánia, Magyarország és Szlovákia mutatói meghaladják a görög értéket, de elmaradnak a portugáltól. A tagjelöltek közötti éles szakadékot jelzi, hogy Lettországban nincs autópálya, Lengyelországban, Romániában, Bulgáriában, de még Észtországban is rendkívül alacsony az autópályasűsűség. A tagjelölt országok jórészében elkezdték az autópálya fejlesztéseket Magyarországon és Csehországban több mint 100 km épült 1994-98 között -, ami a 
gazdasági növekedés felgyorsulásához elengedhetetlen. Ez a tagság után a várható strukturális és kohéziós támogatások nyújtásával az Unió részéről is támogatást kap.

A vasút vonatkozásában már kedvezőbb a helyzet, hiszen az örökölt infrastruktúra az 1945. előtti időkből jónak mondható, csak nyilvánvalóan korszerüsítésre szorul.

V/6.2. sz. táblázat: A vasúthálózat hossza és sürüsége az EU tagállamaiban és a tagjelölteknél

\begin{tabular}{|c|c|c|c|}
\hline Ország & $\begin{array}{l}1994 \\
(\mathrm{~km})\end{array}$ & $\begin{array}{l}1998 \\
(\mathrm{~km})\end{array}$ & $\begin{array}{c}(1998) \\
1 \mathrm{~km} / 1000 \\
\mathrm{~km}^{2}\end{array}$ \\
\hline Bulgária & 4291 & 4292 & 38,66 \\
\hline Csehország & 9413 & 9430 & 119,36 \\
\hline Észtország & 1024 & 1018 & 22,62 \\
\hline Magyarország & 7715 & 7642 & 82,17 \\
\hline Lettország & 2413 & 2413 & 37,12 \\
\hline Litvánia & 2002 & 1917 & 29,49 \\
\hline Lengyelország & 24313 & 23210 & 74,15 \\
\hline Románia & 11374 & 11010 & 46,26 \\
\hline Szlovákia & 3661 & 3665 & 74,79 \\
\hline Szlovénia & 1194 & 1194 & 59,70 \\
\hline Belgium & 3396 & 3410 & 110,00 \\
\hline Dánia & 2349 & 2232 & 51,91 \\
\hline Németország & 41401 & 38126 & 106,80 \\
\hline Görögország & 2474 & 2503 & 18,96 \\
\hline Spanyolország & 12646 & 12303 & 24,36 \\
\hline Franciaország & 32275 & 31727 & 58,32 \\
\hline Írország & 1944 & 1909 & 27,67 \\
\hline Olaszország & 16002 & 16041 & 53,29 \\
\hline Luxemburg & 275 & 274 & 91,33 \\
\hline Hollandia & 2757 & 2808 & 68,49 \\
\hline Ausztria & 5636 & 5643 & 67,18 \\
\hline Portugália & 3070 & 2794 & 30,37 \\
\hline Finnország & 5880 & 5867 & 17,36 \\
\hline Svédország & 9661 & 11156 & 27,14 \\
\hline Egyesült Királyság & 16998 & 16847 & 69,62 \\
\hline EU összesen: & 156764 & 153640 & 48,15 \\
\hline
\end{tabular}

Forrás : Eurostat [2001], saját számítások

Megállapítható, hogy az EU vasúti pályasürüség terén igen jól ellátott területet kap a bővítés révén (pl. Csehország Európa legsürübb vonalhálózatával rendelkezik, de jók a lengyel, magyar és szlovák mutatók is), ami különösen akkor fontos, amikor a szállítás lebonyolításában a vasút (és a vízi út) kiemelkedő szerepet kap az új EUkoncepcióban, sőt ennek fejlesztését (modernizálását) támogatja mind a tagállamok, mind a jelentkező országok esetében a brüsszeli székhelyü szervezet. Különösen 
kedvező ez akkor, ha az európai vasúti közlekedés teljes liberalizálása megvalósul, (ennek első lépése volt a pályavasút és a versenyvasút szétválasztása), hiszen ekkor ezt az infrastruktúrát nem hazai vállalatok is hasznosítani tudják. Az is igaz, hogy ezek a vasútvonalak nagyrészt elavultak és így terhelhetőségük, áru és személytovábbítási képességük (pl. a $120 \mathrm{~km} / \mathrm{h}$ sebességet meghaladó vagy elérő szakaszok) limitáltak, ami lényeges fejlesztési igényeket vet fel. (pl. Magyarországon a személyszállító vonatok átlagos sebessége az 1990. évi 46,3 km/h sebességről 1999-re 45,8 km/h sebességre csökkent, igaz a tehervonatoknál 23,5 km/h-ról 28,6 $\mathrm{km} / \mathrm{h}-\mathrm{ra}$ nött, amiben közrejátszott az is, hogy a kisebb szállítási igény miatt szabadabb volt a pályakapacitás. Közlekedési és Vízügyi Minisztérium, [2000]). Nem véletlen, hogy 2000-ben az ISPA keretében a közlekedésre fordított támogatásoknál az EU kiemelten kezelte a vasúti modernizáció kérdését.

V/6.3. sz. táblázat: ISPA 2000 közlekedési támogatás (százalék)

\begin{tabular}{|l|r|r|c|}
\hline \multicolumn{1}{|c|}{ Ország } & Vasút & Közút & $\begin{array}{c}\text { Egyéb } \\
\text { (légi } \\
\text { közlekedés) }\end{array}$ \\
\hline Bulgária & - & 46 & 54 \\
\hline Csehország & 67 & 33 & - \\
\hline Észtország & - & 100 & - \\
\hline Magyarország & 100 & - & - \\
\hline Lettország & - & 100 & - \\
\hline Litvánia & 73 & 27 & - \\
\hline Lengyelország & 49 & 51 & - \\
\hline Románia & 61 & 39 & - \\
\hline Szlovákia & 100 & - & - \\
\hline Szlovénia & 100 & - & - \\
\hline
\end{tabular}

Forrás: EU Bizottság, [2001]

Természetesen fontos szerepe lesz a vízi útvonalak EU belső útvonalakká válásának is, elsősorban a nagyobb folyók (Odera, Elba, Duna, Tisza, Vltava) kapnak jelentőséget. 


\section{V/6.2. A szállítási piac nagysága és szerkezete}

A nemzetközi trendek alapján a szolgáltatások GDP-n belüli részesedése nő - a fejlett országokban már elérte a kétharmados arányt -, mely irányt a tagjelölt országok is hamar követtek (lásd: V/1. fejezet). Ehhez képest azonban a közlekedésiszállítási szolgáltatások aránya világszinten csökken: a világkereskedelemben az 1970. évi 35,1 százalékról 1994-re 23,1 százalékra (Ehrlich Éva: ISM tanulmány, [1999]). Általános tendencia, hogy a szolgáltatások, illetve a szállításra kevésbé érzékeny ágazatok (pl. informatika), a magas feldolgozottsági fok elötérbe kerülése miatt a közlekedési ágazat fejlődése kevésbé követi (a visszaeső megrendelések miatt) a GDP növekedését.

Tartós tendenciának mondható, hogy a vasúti és vízi szállítás aránya visszaesik a közúti és a légi szállítások térhódítása miatt, ami a személyi közlekedésben is egyre jelentősebb részt vállal.

V/6.4. sz. táblázat: Vasúti, közúti, vízi és csővezetékes áruszállitás megoszlása (1994-1998)

\begin{tabular}{|l|c|c|c|c|r|r|r|r|}
\hline \multirow{3}{*}{ Ország } & \multicolumn{2}{|c|}{ Vasúti } & \multicolumn{2}{c|}{ Közúti } & \multicolumn{2}{c|}{ Vízi } & \multicolumn{2}{c|}{ Csővezetékes } \\
\cline { 2 - 9 } & \multicolumn{2}{|c|}{ százalék* } & \multicolumn{2}{c|}{ százalék* } & \multicolumn{2}{c|}{ százalék* } & \multicolumn{2}{c|}{ százalék* } \\
\cline { 2 - 10 } & $\mathbf{1 9 9 4}$ & $\mathbf{1 9 9 8}$ & $\mathbf{1 9 9 4}$ & $\mathbf{1 9 9 8}$ & $\mathbf{1 9 9 4}$ & $\mathbf{1 9 9 8}$ & $\mathbf{1 9 9 4}$ & $\mathbf{1 9 9 8}$ \\
\hline Bulgária & 15,9 & 17,5 & 68,7 & 66,1 & 15,3 & 16,2 & 0,7 & 0,7 \\
\hline Csehország & 45,8 & 33,7 & 47,3 & 60,8 & 2,3 & 1,4 & 4,3 & 3,7 \\
\hline Észtország & 33,6 & 40,2 & 13,1 & 25,0 & 53,2 & 34,6 & - & - \\
\hline Magyarország & 50,6 & 30,0 & 17,3 & 46,4 & 5,0 & 5,7 & 27,0 & 17,7 \\
\hline Lettország & 34,7 & 42,4 & 5,1 & 10,9 & 43,5 & 25,1 & 16,6 & 21,4 \\
\hline Litvánia & 27,4 & 27,3 & 16,1 & 14,0 & 50,0 & 49,7 & 6,3 & 8,7 \\
\hline Lengyelország & 36,5 & 30,3 & 25,6 & 34,5 & 30,0 & 25,9 & 8,0 & 9,1 \\
\hline Románia & 53,9 & 29,0 & 39,9 & 23,2 & 0,0 & 47,7 & 6,1 & 3,3 \\
\hline Szlovákia & 68,0 & 65,1 & 27,2 & 26,3 & 4,7 & 8,4 & 0,0 & 0,0 \\
\hline Szlovénia & 25,4 & 21,9 & 20,0 & 14,4 & 54,5 & 63,9 & 0,0 & 0,0 \\
\hline Ausztria & 35,8 & 35,6 & 40,0 & 39,0 & 4,9 & 5,5 & 19,0 & 19,8 \\
\hline Portugália & 11,2 & 13,7 & 88,8 & 86,3 & - & - & - & - \\
\hline Európai Unió & $\mathbf{1 4 , 5}$ & $\mathbf{1 4 , 1}$ & $\mathbf{7 2 , 5}$ & $\mathbf{7 3 , 7}$ & $\mathbf{7 , 4}$ & $\mathbf{7 , 1}$ & $\mathbf{5 , 6}$ & $\mathbf{5 , 1}$ \\
\hline
\end{tabular}

Forrás: Eurostat, [2000], saját számítás

Megjegyzés: Az EU-tagállamok esetében a vízi szállítás adatai nem állnak pontosan rendelkezésre.

* Részesedés tonnakilométerben a hazai szállítási teljesítményből (légi szállítás nélkül) 
V/6.5. sz. táblázat: Áruszállitás összesitett mutatója a tagjelölteknél és néhány EU-országban

\begin{tabular}{|l|c|c|c|c|}
\hline \multirow{3}{*}{ Ország } & \multicolumn{2}{c|}{$\begin{array}{c}\text { Összes áruszállítás } \\
\text { (légi szállítás kivételével) } \\
\text { (millió tonna/km) }\end{array}$} & \multicolumn{2}{c|}{$\begin{array}{c}\text { Változás } \\
\mathbf{1 9 9 8 / 1 9 9 4} \\
\text { (százalék) }\end{array}$} \\
\cline { 2 - 5 } & $\mathbf{1 9 9 4}$ & $\mathbf{1 9 9 8}$ & Szállítás & GDP \\
\hline Bulgária & 47.428 & 34.029 & 72 & 134 \\
\hline Csehország & 49.750 & 55.562 & 112 & 143 \\
\hline Észtország & 10.742 & 15.108 & 141 & 247 \\
\hline Magyarország & 15.227 & 27.102 & 178 & 120 \\
\hline Lettország & 27.429 & 30.628 & 112 & 174 \\
\hline Litvánia & 29.092 & 30.197 & 104 & 267 \\
\hline Lengyelország & 177.114 & 201.005 & 113 & 170 \\
\hline Románia & 45.826 & 67.929 & 148 & 146 \\
\hline Szlovákia & 17.992 & 18.031 & 100 & 164 \\
\hline Szlovénia & 9.635 & 13.208 & 137 & 145 \\
\hline Ausztria & 36.674 & 39.795 & 109 & $105^{*}$ \\
\hline Portugália & 14.635 & 16.448 & 112 & $120^{*}$ \\
\hline Európai Unió & $\mathbf{1 . 5 0 6 . 0 5 9}$ & $\mathbf{1 . 7 0 2 . 7 2 8}$ & $\mathbf{1 1 4}$ & $\mathbf{1 2 0}$ \\
\hline
\end{tabular}

Forrás: Eurostat, [2000], saját számítás

Megjegyzés: * 1998/95

A rendelkezésre álló adatokból megállapítható, hogy

- a világtendenciához hasonlóan a társult országokban és az EU-ban is a GDPnél általában mérsékeltebben nő a szállítások aránya (ez igaz annak ellenére, hogy a 90-es évek elején a tagjelölteknél a szállításban komoly visszaesés volt). Mindössze Magyarországon volt jóval alacsonyabb az euróban mért GDP-növekedés, mint a millió tonnakilométerben számított szállítás bövülése. (Mivel a két adat nem értékben került összehasonlításra, ezért az árfolyamhatások némi torzítást adhatnak.)

- a társult országokban visszaesik a vasúti szállítás szerepe (aránya növekedik, vagy stagnál a balti országoknál), ugyanakkor a közúti szállítás részesedése jelentősen nő Csehországban, Magyarországon. Éles a vasút aránycsökkenése Magyarországon (50-ről 30 százalékra), Romániában (53,9-ről 29 százalékra), valamint Csehországban (45,8-röl 33,7 százalékra). Mérsékelt csökkenés látható Lengyelországban, Szlovéniában, Szlovákiában. A balti államokban a 
vasút reneszánszát éli, teljesítménye és aránya is nő. Az időnként magas vonalsürüség strukturális gondot is jelent a tagjelölt országokban, hiszen az itt kibontakozó tendenciák (a vasúttársaságok reformjának szükségessége, valamint a belépéskor várható liberalizálás hatása) alapján jóval rövidebb és hatékonyabb (korszerübb) vasútra lenne szükségük. Ugyanakkor a közúti közlekedésben az európai fejlődési tendencia alapján komoly fejlesztés várható a közeli jövőben az alapinfrastruktúra európai színvonalának megközelítéséhez (lásd V/6.1. sz. táblázat).

Nem véletlen, hogy az ISPA támogatásnál is a vasúti és közúti közlekedési forma került elötérbe. Az európai közlekedési politika, valamint a környezetvédelmi szempontok alapján a fejlettebb társultaknál a vasúti támogatás messze felülmúlja a közútit (Csehország, Magyarország, Szlovénia, Szlovákia, de ugyanez érvényes még Litvániára is). Az elmaradott közúti vagy légügyi infrastruktúrájú országoknál a jelenlegi tranzitgondok miatt prioritást élvez a közúti fejlesztés támogatása (Lengyelország, Észtország, Lettország), és hasonló ISPA-támogatást könyvelhet el a balkáni tranzit miatt fontos Bulgária és Románia is.

A szárazföldi szállításban mérvadó vasút-közút arány az EU-ban 1998-ban - mint korábban - az 1:5 arányt mutatta, a társultaknál ez jóval kedvezőbb volt, hiszen Szlovákia, Szlovénia, Észtország, Lettország és Litvánia vasúti teljesítménye meghaladta a közútit. Ugyanakkor Lengyelországban pontosan ebben az időszakban lépte túl a közúti szállítás a vasútit, és Csehországban vagy Magyarországon került ez az arány az 1:2 közelébe, ami jelzi az EU-val szoros gazdasági kapcsolatok hatását. (Az EU-ban 1:2-nél kedvezőbb arányt csak Ausztria mondhat magáénak, a mediterrán országokra és Írországra az 1:8 vagy 1:10 arány a jellemző, de több fejlett tagállam - pl. Hollandia, Olaszország - vasút-közút aránya is nagyon magas ollót mutat.) Az Európai Bizottság 2001 szeptemberében kiadott Fehér Könyve ezt a tényt kiemeli, hiszen míg az EU-ban csak 8 százalékot reprezentál a teljes körü teherszállítási piacon a vasút, addig a tagjelölteknél 40 százalékot. (Környezetvédelmi szempontból is kiemelkedően hasznos ez a mérték, hiszen az európai felmérések szerint jóval több ember szenved a légi közlekedés vagy a közúti közlekedés zajártalmaitól, mint a vasútitól). Az Európai Bizottság számításai szerint a tagjelöltek teherszállításaiban a jelenlegi trendek alapján a vasút aránya 2010-re 30 
százalékra zuhanna vissza. Közösségi fellépést tartanak fontosnak annak érdekében, hogy ez csak 35 százalékra essen vissza a következő évtizedfordulóra.

\section{V/6.3. Személyszállítás}

Az 1994-től történő vizsgálat folyamán - tekintettel a tagjelöltek legtöbbjében bekövetkezett gazdasági növekedésre - megállapíthatóak azok a tendenciák, amelyek alapján az EU-ba való belépés személyszállításban várható hatása elemezhető. Ebben a föszerepet a vasút és a légi közlekedés, illetve a személygépjármüvek növekvő aránya adja, és ebböl az is jól nyomon követhető, hogy a tagjelölt országokban melyek a személyszállítás főbb módozatai.

V/6.3.1. Vasúti személyforgalom

V/6.6. sz. táblázat: A társult országok és az EU vasúti személyszállitása (millió fö)

\begin{tabular}{|l|r|r|r|r|c|}
\hline \multicolumn{1}{|c|}{ Ország } & $\mathbf{1 9 9 4}$ & $\begin{array}{c}\text { EU=100 } \\
\mathbf{( \% )}\end{array}$ & $\mathbf{1 9 9 8}$ & $\begin{array}{c}\text { EU=100 } \\
\mathbf{( \% )}\end{array}$ & $\mathbf{1 9 9 8 / 1 9 9 4}$ \\
\hline Bulgária & 5059 & 1,9 & 4740 & 1,6 & 0,94 \\
\hline Csehország & 8481 & 3,2 & 7018 & 2,4 & 0,83 \\
\hline Észtország & 537 & 0,2 & 236 & 0,1 & 0,44 \\
\hline Magyarország & 8508 & 3,2 & 8884 & 3,1 & 1,04 \\
\hline Lettország & 1794 & 0,7 & 1059 & 0,4 & 0,59 \\
\hline Litvánia & 1574 & 0,6 & 715 & 0,2 & 0,45 \\
\hline Lengyelország & 27610 & 10,3 & 25664 & 8,9 & 0,93 \\
\hline Románia & 18313 & 6,8 & 13422 & 4,6 & 0,73 \\
\hline Szlovákia & 4548 & 1,7 & 3092 & 1,1 & 0,68 \\
\hline Szlovénia & 590 & 0,2 & 645 & 0,2 & 1,09 \\
\hline Portugália & 5110 & 1,9 & 4563 & 1,6 & 0,89 \\
\hline Európai Unió & $\mathbf{2 6 8 9 3 1}$ & $\mathbf{1 0 0 , 0}$ & $\mathbf{2 8 9 7 8 1}$ & $\mathbf{1 0 0 , 0}$ & $\mathbf{1 , 0 8}$ \\
\hline
\end{tabular}

Forrás: Eurostat, [2000, 2001], saját számítás

A vasúti személyszállítás terén a legtöbb tagjelölt országban komoly visszaesés következett be az évtized második felében. A nehezebb életszínvonal miatt általában visszaesett a személyutazás, valamint átstrukturálódás történt a személygépkocsik és a légi közlekedés irányába. 1998-ban ennek ellenére a vasúton szállított utasok száma az EU utas számának 22,6 százalékát tette ki, (ez alig marad el a lakosság mintegy 27 százalékos arányától), ami jelentős piacbővülést ígér. Az EU enyhe fejlődő tendenciát mutat, mely a tagállamok között eltérő előjelü eredményekből 
tevődik össze, például a portugál személyszállítás 11 százalékkal csökkent (Eurostat [2001]). Az EU fejlődését csak Szlovénia és Magyarország követte, a többi tagjelölt államban a vasúti személyszállítás visszaesése jelentős (pl. a balti államokban majdnem a felére zuhant vissza, ami a vasút modernizációját még jobban nehezíti, hiszen ezzel a bevételek is jelentősen csökkennek).

Az EU számára súlyos gond saját vasúttársaságai helyzete, hiszen jelenleg számottevő állami támogatással müködnek, mely így is nehezen tartja a versenyt a többi közlekedési ágazattal szemben (Ehrlich, [1999]). Az EU-n belül a hamarosan kibontakozó verseny új helyzetet teremt, ez azonban elkerülhetetlen ennek a közlekedési ágazatnak a belső piacon történő megerősítéséhez. Ugyanilyen kihívással néz szembe a szintén támogatott és fejlődésre nehezen képes keleti vasút is, ugyanakkor piacszerzési lehetőséget is nyújt a bővítés után a tagállamok vasúti társaságainak, ha a vasúti liberalizációt a személyszállításra is kiterjesztik.

\section{V/6.3.2. A légi közlekedés}

A rendszerváltással a légi közlekedési piac nagyfokú növekedését figyelhetjük meg a társult országoknál, mely dinamizmus minden bizonnyal messze túlmutat az EUországok növekedési rátáján.

V/6.7. sz. táblázat: A személyi légi közlekedés fejlödése a társult országokban (millió utaskilométer)

\begin{tabular}{|c|c|c|c|}
\hline Ország & 1994 & 1998 & $1998 / 1994$ \\
\hline Bulgária & 1,542 & 1,269 & 0,82 \\
\hline Csehország & 2,903 & 4,865 & 1,68 \\
\hline Észtország & 0,176 & 0,324 & 1,84 \\
\hline Magyarország & 1,605 & 2,188 & 1,36 \\
\hline Lettország & 0,192 & 0,262 & 1,36 \\
\hline Litvánia & n.a. & 0,528 & - \\
\hline Lengyelország & 2,825 & 4,901 & 1,73 \\
\hline Románia & n.a. & 2,026 & - \\
\hline Szlovákia & 0,067 & 0,141 & 2,10 \\
\hline Szlovénia & 0,504 & 0,807 & 1,60 \\
\hline Összesen: & n.a. & 17,311 & - \\
\hline Európai Unió & n.a. & 517,000 & - \\
\hline
\end{tabular}

Forrás: Eurostat, [2000], saját számítás 
A tagjelölteknél az utasszám különösen jelentősen, több mint duplájára nőtt Szlovákiában, 83 százalékkal Észtországban, de több mint 30 százalékkal emelkedett Magyarországon, Lettországban és főleg Csehországban. Az utasszám azonban így is csak az EU forgalmának 3,4 százalékát tette ki 1998-ban (lakosságszám arányához képest ez még mindig csak kb. a nyolcada), de ez az arány a trendek alapján hamarosan nőhet. A csatlakozni kívánó országok légitársaságai azonban nagyrészt elavult gépparkkal müködnek, nehezen bontakozik ki strukturális átalakításuk. Jelenleg is ezek átszervezése, illetve stratégiai szövetségesek keresése, magánosításuk folyik, ami kedvez az EU-országoknak, hiszen ennek keretében egy feltörekvő piacra már a bővülés előtt bejuthatnak. Az igazi előnyt azonban a belépéskor várható liberalizáció (az új tagállamok piacának - egyrészt az útvonalak, másrészt a légi kikötők kiszolgáló egységeinek - megnyitása) jelenti, bár nem elhanyagolható a müszaki normák átvételéből eredő versenyelőny sem, hiszen ezzel a FÁK és más elmaradott térségből jövő zajos gépek kötelező kitiltását a tagjelöltek reptereiről el tudják érni.

\section{V/6.3.3. Közúti közlekedés}

Az autóbusz közlekedés nyújtotta lehetőség fontos alternatívát kínál minden közlekedő állampolgár számára, így fejlődésének alakulása az EU-tagállamok és tagjelöltek számára sem mellékes, hiszen az az utak zsúfoltságát csökkentheti.

Az EU részéröl tapasztalható enyhe növekedés mellett a jelöltek vegyes képet mutattak: míg Magyarországon az EU-t is jobban meghaladó módon nőtt az utasszám (ami a személyautó és a vasút kiváltását jelenti), addig a többieknél (pl. Bulgáriában, Csehországban) stagnált vagy csökkent az autóbusszal utazók száma (lásd: V/6.8. sz. táblázat). Ennek egyik oka lehet az, hogy Magyarország kivételével a többi tagjelölt ország nem tudott olyan strukturális átalakítást (árpolitikát) felmutatni, ami e szállítási formának a piaci jelentőségét megtartaná. Mégis a bővüléssel együtt megnyíló piac az EU jelenlegi piacának (utasszámban kalkulálva) mintegy 19 százalékát jelentené. Az autóbusz közlekedés környezetvédelmi hatása (több gépkocsi kiváltása) és a tömegközlekedési útvonalak zsúfoltságának elkerülése 
(egységnyi térfogatra jutó magasabb utasszám) szempontjából kedvező az EU tagországainak, de mint megszerezhető piac sem elhanyagolható.

V/6.8. sz. táblázat: Autóbusszal történö utazás változása a tagjelölt országokban

\begin{tabular}{|l|c|c|c|c|}
\hline \multicolumn{1}{|c|}{ Ország } & $\begin{array}{c}\mathbf{1 9 9 4} \\
\text { (millió utas) }\end{array}$ & $\begin{array}{c}\mathbf{1 9 9 4} \\
\text { EU \%-ában }\end{array}$ & $\begin{array}{c}\mathbf{1 9 9 7} \\
\text { (millió utas) }\end{array}$ & $\begin{array}{c}\mathbf{1 9 9 7} \\
\text { EU \%-ában }\end{array}$ \\
\hline Bulgária & 7941 & 2,1 & 4379 & 1,1 \\
\hline Csehország & 11523 & 3,1 & 8804 & 2,2 \\
\hline Észtország & 2314 & 0,6 & 2238 & 0,6 \\
\hline Magyarország & 8641 & 2,3 & 10168 & 2,6 \\
\hline Lettország & 1795 & 0,5 & 1720 & 0,4 \\
\hline Litvánia & 4627 & 1,2 & 3191 & 0,8 \\
\hline Lengyelország & 34262 & 9,2 & 33128 & 8,4 \\
\hline Románia & 14058 & 3,8 & 13531 & 3,4 \\
\hline Szlovákia & 10574 & 2,8 & 9969 & 2,5 \\
\hline Szlovénia & 2595 & 0,7 & 2195 & 0,6 \\
\hline EU & $\mathbf{3 7 3 9 7 0}$ & $\mathbf{1 0 0 , 0}$ & $\mathbf{3 9 2 8 0 0}$ & $\mathbf{1 0 0 , 0}$ \\
\hline
\end{tabular}

Forrás: Eurostat, [2000], saját számítás

A statisztikák alapján látható (V/6.9. sz. táblázat), hogy a tagjelöltek felzárkózása lendületes a személygépkocsik számát illetően, hiszen Románia kivételével az 1998ban mérhető százalékos arány összevethető a görög, portugál és spanyol fejlettségi szinttel. (Érdemes kiemelni, hogy Portugáliában 1988-ban - tehát a csatlakozás után két évvel - ezer före 214 személygépkocsi jutott, Görögországban 150, Spanyolországban 279.) Különösen magas az arány Szlovéniában és Csehországban, ugyanakkor a többi gazdasági adathoz képest szerény Magyarországon. A gyors robbanás egyik oka olyan munkahelyek elterjedése volt a rendszerváltás után, amelyek elérésében a független közlekedés lényeges (1990 és 1999 között a növekedés üteme meghaladta az EU-átlagot szinte minden tagjelölt országban). Emellett a nyugati demonstrációs hatás és az áruhiány megszünése is közrejátszott a tagjelölt országok gépkocsi számának növekedésében (Ehrlich, [1999]). Ugyanakkor meg kell jegyezni, hogy a gépkocsik müszaki állapota és átlagos életkora mindegyik országban meghaladja az európai átlagot, bár a modernizáció (új, korszerű típusok vásárlása) ezen a területen is érezteti hatását. Ezzel van szoros korrelációban a környezetvédelmi adatok (lásd: V/10. fejezet) illetve a baleseti statisztikák javulása. A tagjelöltek gépkocsi közlekedésének gyors felfutása azzal az előnnyel is járhat, 
hogy rákényszeríti az ottani kormányokat az útfejlesztésekre, ami a tranzit miatt az EU-nak is elsődleges érdeke.

V/6.9. sz. táblázat : A személygépkocsik számának alakulása

(ezer före jutó gépkocsik száma)

\begin{tabular}{|l|c|c|c|c|}
\hline \multicolumn{1}{|c|}{ Ország } & $\mathbf{1 9 9 0}$ & $\mathbf{1 9 9 8}$ & $\begin{array}{c}\mathbf{1 9 9 8 / 1 9 9 0} \\
\text { (százalék) }\end{array}$ & $\begin{array}{c}\text { EU=100 } \\
\text { (1998) } \\
\text { (százalék) }\end{array}$ \\
\hline Bulgária & 174 & 219 & 126 & 48 \\
\hline Csehország & 278 & 339 & 122 & 75 \\
\hline Észtország & 202 & 311 & 154 & 69 \\
\hline Magyarország & 212 & 219 & 103 & 48 \\
\hline Lettország & 135 & 197 & 146 & 43 \\
\hline Litvánia & 160 & 265 & 166 & 58 \\
\hline Lengyelország & 168 & 230 & 137 & 51 \\
\hline Románia & 68 & 125 & 184 & 28 \\
\hline Szlovákia & 190 & 222 & 117 & 49 \\
\hline Szlovénia & 324 & 410 & 127 & 90 \\
\hline Görögország & 171 & 254 & 149 & 56 \\
\hline Portugália & 258 & 321 & 124 & 71 \\
\hline Spanyolország & 309 & 408 & 132 & 90 \\
\hline EU & 402 & 454 & 113 & 100 \\
\hline
\end{tabular}

Forrás: Eurostat, World Statistics Pocketbook, ENSZ, [2000], saját számítás

Megjegyzés: az 1990-es adat gépjárművekre vonatkozik, ezért nagyobb összehasonlítási bázist adhat a valóságnál.

\section{V/6.4. Tényleges piaci lehetőségek a bővülés után az EU számára}

Bár a társulás igen lényeges liberalizációt jelentett az EU számára, de néhány területen nem hozott teljes piacnyitást, így az ebből adódó előnyök csak a felvétel után lesznek élvezhetőek az EU vállalkozói vagy polgárai számára.

Az EU-tagországok közlekedési beruházásainak GDP-hez viszonyított aránya 1994ben 0,7 (Dánia) és 1,7 (Portugália) százalék között mozog. Az OECD felmérése szerint a 1992-96 között a közúti és vasúti közlekedés infrastrukturális beruházásai néhány fejlettebb jelölt országban (Csehország, Szlovákia, Lengyelország) 0,8-0,9 százalék körüli volt (jármüberuházások nélkül). Ugyanez a mutató Magyarországon és Romániában 0,54 százalék volt (Ehrlich, [1999]). Tekintettel a kibontakozó 
jelentős beruházásokra, melyek a gazdasági növekedéssel párhuzamosan jelennek meg, ez a GDP 1 százaléka fölé fog nőni, ami már jelentős piacot biztosít a tagállamok vállalatai számára. (Ez Magyarországon 0,5, Csehországban 0,6, de Lengyelországban is 2-3 milliárd euró évente.) Mint az előzőkben említettem, az Európai Bizottság szerint 2015-ig a térség GDP-jének 1,5 százalékát kell (91 milliárd euró) modernizációs beruházásokra költenie a közlekedési infrastruktúra területén. Az EBRD ennél jelentősebb GDP-arányos beruházást feltételez, hiszen 10 év alatt határozott meg 90 milliárd euró beruházási igényt.

V/6.10. sz. táblázat: A tagjelöltek teljes beruházási igénye a közlekedési szektorban

\begin{tabular}{|c|c|c|}
\hline Ország & $\begin{array}{c}\text { Teljes beruházási } \\
\text { igény } \\
\text { (milliárd euró) }\end{array}$ & $\begin{array}{c}\text { Éves beruházás a } \\
\text { GDP százalékában } \\
\text { (tíz évre számolva) }\end{array}$ \\
\hline Bulgária & 5,3 & 4,6 \\
\hline Csehország & 10,2 & 2,0 \\
\hline Észtország & 0,6 & 1,1 \\
\hline Magyarország & 10,2 & 2,2 \\
\hline Lettország & 2,0 & 3,4 \\
\hline Litvánia & 2,3 & 2,3 \\
\hline Lengyelország & 36,4 & 1,3 \\
\hline Románia & 11,2 & 3,5 \\
\hline Szlovákia & 6,5 & 3,5 \\
\hline Szlovénia & 5,7 & 3,1 \\
\hline Összesen & $\mathbf{9 0 , 4}$ & $\mathbf{2 , 6}$ \\
\hline
\end{tabular}

Forrás: EBRD [2000], (Transition Report)

Megjegyzés: a befektetéseket az EBRD az 1999. évi GDP alapján tíz éves periódusra számolta

$\mathrm{Az}$ EU részéről a legnagyobb várakozás a légügyi piac megnyitásához, illetve a közúti árufuvarozás liberalizálásához (pl. kabotázs műveletek, vagyis belföldi szállítás) kapcsolódik. Nagy piacról van szó, hiszen a lengyel közúti árufuvarozás 1998-ban az EU teljes piaci teljesítményének 5,5 százalékát tette ki, Magyarország esetében is meghaladta az 1,0 százalékot, Csehországban pedig több, mint 2,7 százalékot (Eurostat, [2000] alapján saját számítás). Igaz, félelem is megfogalmazódik az EU oldalán a közúti kabotázs lehetőségek megnyitásával a társult országokból érkező konkurencia miatt, elsősorban az ottani alacsony bérek és az önkizsákmányoló magatartás miatt. Ez azonban ösztönzi is az EU-t arra, hogy a közúti közlekedés terén erősítse a szociális alapnormák meghatározása irányába tett 
lépéseit. Ugyanakkor kedvező tény a belső piac integrációja szempontjából, hogy a kontinens két fele közeledik egymáshoz, a legnagyobb különbség az elöbbiekben említett bérarányokban van, ugyanakkor a költségek szempontjából a bérek csak egy részt képeznek.

V/6.11. sz. táblázat: Költségek a nemzetközi közúti áruszállításban 1998-ban (euró/km)

\begin{tabular}{|c|l|}
\hline $0,50-0,60$ & Bulgária \\
\hline $0,60-0,70$ & $\begin{array}{l}\text { Csehország, Észtország, Magyarország, Litvánia, } \\
\text { Lengyelország, Románia }\end{array}$ \\
\hline $0,70-0,80$ & Lettország \\
\hline $0,80-0,90$ & Szlovénia, Szlovákia, EU \\
\hline
\end{tabular}

Forrás: Európai Bizottság, Közlekedéspolitikai Fehér Könyv, [2001]

A fajlagos költségek alapján látható, hogy Szlovénia és Szlovákia nincs előnyben az EU-hoz képest, míg a tagjelöltek élcsoportjában számon tartott Magyarország és Csehország, valamint Lengyelország jelentős versenyelőnyt élvez. Ez is magyarázatot ad arra, hogy a közúti kabotázs piac megnyitásánál az EU átmeneti időszakot kényszerített ki.

Lényeges piacnyitást jelent a vasúti áruszállítási piac. Bár nagyrészt a kelet-európai országok piaca zsugorodik, de még így is jelentős, pl. a lengyel piac az EU-hoz képest csaknem 25 százalék(!), és Magyarország három, Csehország nyolc százaléka a belső piacnak. (Az adatok természetesen a szállított súlyra és nem annak értékére vonatkoznak, hiszen az eltérő viszonyok miatt, az utóbbi számítás az új tagállamok piacának súlyát az EU-hoz képest kisebbnek mutatná.)

A közúti fuvarozás terén az előzőekben jelzett előnyök (műszaki normák, szociális elöírások) mellett pozitívum még az uniós fuvarozók számára az a közösségi norma, mely a fuvarozók tevékenységéhez bizonyos pénzügyi biztosítási fedezetet követel meg, ami megrostálja, illetve koncentrálja a tagjelöltektől származó fuvarozók számát. Versenyszempontból az is előnyös számukra, hogy a tagjelölt országokban a piachoz képest túl sok és ezért kis tőkeerejü szállítási vállalkozó van jelen. (Magyarországon 1999-ben több mint 27 ezer fuvarozói vállalkozást tartottak nyilván, ami gazdaságossági becslések szerint háromszor több annál, mint ami a 
piacon szükséges lenne.) Emellett további előny az is, hogy a tranzittevékenység biztosítása miatt (ld. következőkben) az új csatlakozó országoknak meg kell erősíteniük a főbb közlekedési útvonalaikat és a hidakat, ami nélkülözhetetlen az EU és legfontosabb európai, valamint ázsiai partnerei kapcsolatában. Ráadásul a megerősített útvonalak használatáért a tagság után nem kérhetnek a társultak a hazai piaci szereplőkkel szemben diszkriminatív használati díjakat sem. (Ez nem érinti az autópálya használati díjakra vonatkozó fizetési kötelezettséget.)

Mindezek a tagjelölt országok fuvarozói számára egzisztenciálisan érzékeny terület, de a fokozódó belpiaci versenyhelyzet révén közülük a legerősebbek betörhetnek a hatalmas közösségi piacra is.

\section{V/6.5. A tranzittevékenységből származó előnyök}

Az újonnan csatlakozó országok az eddigi bővítésektől eltérően nem jelentenek a kontinensen végállomást (kivéve Ausztria helyzetét a legutóbbi bővüléskor), hanem fontos összekötő szerepet töltenek be az áruszállítási vagy energia-tranzit területén. Ugyancsak a jelenlegi tagállamok számára előnyös, hogy fontos kereskedelmi, gazdasági vagy turisztikai partnerek találhatók a régión túl fekvő területeken. Érdemes megjegyezni, hogy az EU ebben az évtizedben fogja a gyakorlatba átültetni a nyugat-balkáni régióval szabadkereskedelmi koncepcióját, ezért ezen a területen várható az újjáépítés, valamint a privatizáció kibontakozása, ami komoly fellendülést és így szállítási igényt vethet fel. Hasonlóan a balkáni térséghez, a következő évtizedben Oroszország és Ukrajna is gazdasági növekedésnek néz elébe, ami importigényüket és így a szállítási szükségletüket növelni fogja. Az EU egyik tagállama (Görögország) felé a szárazföldi összeköttetés részben vagy egészben a tagjelöltek érintésével valósítható meg. A társultak egy részéhez is csak a régió nyugati határszélén fekvő országokon keresztül lehet a fizikai összeköttetést biztosítani. Ilyen szerepe van a Baltikum felé Lengyelországnak, a Balkán felé Magyarországnak vagy Szlovéniának. Szerepe van a jelzett útvonalaknak abban is, hogy a legnagyobb vendégmunkaerőt adó Törökország felé a szárazföldi összeköttetés megvalósuljon. (1998-ben 2,7 millió török állampolgár élt az EU országaiban, ebből több mint 2 millió Németországban, de jelentős létszám található Ausztriában, Hollandiában és Franciaországban is, akik nyaranta tömegesen térnek 
haza szabadságra.) Tekintettel a várható demográfiai és munkaerő piaci helyzetre (ld. IV/10. és $V / 8$. fejezet), az ukrán és a FÁK többi országa felé a személyi tranzit is fontos tényező lesz 10-15 éven belül, hiszen az európai kontinensről főleg innen várható kivándorlási hajlandóság az EU felé.

V/6.12. sz. táblázat: A Fák-országok és Törökország kereskedelmi szerepe az Európai Unió szemszögéböl

\begin{tabular}{|l|c|c|c|c|}
\hline \multirow{2}{*}{ Ország } & \multicolumn{2}{|c|}{$\begin{array}{c}\text { EU-n kívüli közösségi } \\
\text { export }\end{array}$} & $\begin{array}{c}\text { EU-n kívüli közösségi } \\
\text { import }\end{array}$ \\
\cline { 2 - 5 } & $\mathbf{1 9 9 2}$ & $\mathbf{1 9 9 7}$ & $\mathbf{1 9 9 2}$ & $\mathbf{1 9 9 7}$ \\
\hline FÁK & 3,8 & 4,4 & 4,1 & 4,3 \\
\hline ebböl Oroszország & 3,2 & 3,4 & 3,5 & 3,8 \\
\hline Törökország & 2,1 & 3,1 & 1,4 & 1,9 \\
\hline
\end{tabular}

Forrás: Eurostat, [2000]

Mint az energiafejezetben (V/9) külön is kiemelésre kerül, a nyersanyagok, elsősorban az olaj és a földgáz importjának területén a FÁK-országoknak, (ezen belül is Oroszországnak) kiemelkedő jelentősége lesz az EU számára. (Kőolajból az EU importjának 18, míg földgázból 41 százaléka származik a FÁK területéről.) Ez felértékelődhet, ha az arab világgal a kapcsolatok válságba kerülnének.

Jelenleg nagy gondot okoz az EU-országoknak az osztrák és a svájci tranzit. A két alpesi országra jelentős tranzitteher hárul, ezért például az osztrákok a belépéskor 1995-ben - bevitték az Unióba az 1992-ben kötött ökopont rendszert. Ez lényegében elérte az eredeti szándékot, hiszen a tranzitból eredő szennyezőanyag-kibocsátás csökkent. (A két legnagyobb fogyasztó e tekintetben Olaszország és Németország: 1999-ben az alpesi kis országokban megtett utak 41,6 illetve 39,7 százalékát tették ki e két tagállam fuvarozói.) Ráadásul 1999-ben 1993-hoz képest 46,3 százalékkal nőtt a tagállami szállítók által megtett összutak száma, ami tekintélyes terhet rótt a két ország infrastruktúrájára. (Fontos szállítási formát jelent a vasúti kombinált szállítás is, ahol a német-olasz viszonylat jelent 41 százalékot, de a németek és a magyarok közötti szállítások is 12 százalékot érnek el.) Svájc esetében a tranzit kérdését sikerült külön szektorális szerződéssel megoldani. Eszerint 2005-től már itt is közlekedhet 40 tonnás tehergépjármü - jelenleg csak 28 tonnás felső határ engedett - 
de ez a liberalizáció a fuvarozóknak azonban anyagi ellentételezésbe kerül, emellett ez nem segít igazán a kelet-nyugati tranzittal kapcsolatos osztrák problémákon. Ezért az új tagállamok különös szerepet töltenek be az osztrák tranzit enyhítésében. Ebben főleg Szlovénia, Magyarország, Szlovákia (Csehországon keresztüli) bekapcsolódása jelentős, mivel ezen országok belépése az EU-ba és közlekedési belső útvonallá válásuk a megfelelő kerülőutak kiépítéséhez nyújt segítséget. Ezek az országok a fő infrastrukturális vonalak támogatásáért cserébe - az Ausztriától eltérő belépési alkuhelyzetük miatt - nem fognak tudni bárminemü kvótarendszert vagy plafont érvényesíteni. Ugyanakkor figyelembe kell venni azt is, hogy Szlovénia, Magyarország, majd később Románia és Bulgária EU tagfelvétele automatikusan nagyobb közúti forgalmat generál az EU és az említett új tagállamok között, ami viszont Ausztriát negatívan fogja érinteni.

A közúti tranzitforgalmat enyhítő további körülmény, hogy a tagjelölt országokban kezd kiépülni a közút-vasút és közút-víziút (RO-RO és RO-LA) rendszere, ami tovább egyszerüsíti a teherszállítást. (Ennek jelenlegi kihasználtsága még meglehetősen alacsony.) Az Európai Bizottság tanulmányai kiemelik azt is, hogy a belső piac bővítésével megszünnek a mostani tagállamok keleti határain felhalmozódó hatalmas sorok, mindez átkerül a jelenlegi tagjelöltek keleti határára (lásd: III/3. fejezet).

Mindezek következményeként nem meglepö, hogy a pán-európai szinten meghatározott ún. európai folyosók jó része is érinti a jelenlegi tagjelölt országokat. $\mathrm{Az}$ ezekre épített transzeurópai hálózatok (TEN), és az ahhoz kapcsolódó közlekedési hálózat (TINA) rendszere már most is bekapcsolja a tagjelölteket az európai folyosók építésébe (lásd: V/6.13. sz. táblázat). Mivel a folyosók közép- és kelet-európai országokra eső részének fejlesztése az EU-nak is prioritás, ezért már a csatlakozás előtt (ISPA-támogatás vagy az EIB hiteleken keresztül) jelentős forrásokat áldoz megvalósításukra. 
V/6.13. sz. táblázat: A transz-európai hálózatban kiemelt folyosók és az ehhez csatlakozó kiemelt területek

\begin{tabular}{|c|l|}
\hline $\begin{array}{c}\text { Folyosó } \\
\text { száma }\end{array}$ & \multicolumn{1}{c|}{ Folyosó által érintett főbb városok } \\
\hline 1 & Tallin - Riga - Kaunas - (Kaliningrad) - Varsó \\
\hline 2 & Berlin - Poznan - Varsó - Minsk - Moszkva \\
\hline 3 & Drezda - Katowice - Krakkó - Lvov - Kijev \\
\hline 4 & $\begin{array}{l}\text { Nürnberg - (Drezda) - Prága - Brno - Pozsony - Budapest - Arad (Budapest } \\
\text {-Constanta) - Temesvár - Craiova - Sofia - (Plovdiv - Istambul) - Szaloniki }\end{array}$ \\
\hline 5 & Trieszt - Ljubljana - Budapest - Ungvár - Lvov - Kijev \\
\hline $5 . a$ & Bécs - Pozsony - Zsolna - Kassa - Ungvár - Lvov - Kijev \\
\hline $5 . b$ & Fiume - Zágráb - Budapest - Ungvár - Lvov - Kijev \\
\hline $5 . c$ & Budapest - Sarajevo - Neum \\
\hline 6. & Gdansk - (Posnan) - Varsó - Katowice - (Zsolna) -Brno \\
\hline 7. & Duna \\
\hline 8. & Durres - Tirana - Skapje - Sofia - Várna \\
\hline 9. & Moszkva - (Gomel) - Kijev - Kisinyov - Bukarest - Plovdiv \\
\hline $9 . a$ & Kijev - Odessza \\
\hline $9 . b$ & Gdansk - (Klaipeda) - Kaunas - Vilnius - Minsk - Gomel \\
\hline 10. & Salzburg - Ljubljana - Zágráb - Belgrád - Nis - Skopkje - Szaloniki \\
\hline $10 . a$ & Klagenfurt - Ljubljana \\
\hline $10 . b$ & Budapest - Belgrád \\
\hline $10 . c$ & Nis - Szófia - Isztambul \\
\hline
\end{tabular}

Forrás: TINA-titkárság, [2001]

Megjegyzés: A csatlakozásra váró országokon áthaladó európai közlekedési folyosók (1997-ben Helsinkiben véglegesített európai lista alapján):

\section{RÉSZ; 7. FEJEZET}

\section{A TAGJELÖLTEK AGRÁRSZFÉRÁJÁNAK INTEGRÁCIÓJA}

Bár a mai modern gazdasági rendszerekben a mezőgazdasági termelésnek a nemzetgazdaságon belül elfoglalt súlya és szerepe egyre jobban csökken, a téma a hozzákapcsolódó ellátásbiztonsági és vidékfejlesztési vonatkozásai miatt már 50 éve az érdeklődés középpontjába került Nyugat-Európában. Megkülönböztetett figyelem övezi a bővítés kapcsán az EU-ban ezt a területet, mivel a szervezet a világ legjelentősebb agrártermelője és exportöre, valamint különleges szerepet tölt be a sajátos európai kulturális gyökerek és hagyományok megőrzése miatt. Nemcsak egyszerüen a lakosság ellátásának, illetve a termények exportjának feladata hárul a mezőgazdaságra, hanem multifunkcionális jellege miatt a vidéki életmóddal és 
kultúrával összefüggő, a vidékfejlesztés mellett szociálpolitikai, sőt környezetvédelmi funkciókat is ellát. Nem véletlen tehát, hogy az EU bővítési folyamatában a mezőgazdasági fejezet lesz az egyik legkeményebb tárgyalási rész, amiben nemcsak a konkurenciától való félelem és az új tagok felvételének költsége (a közösségi költségvetés legnagyobb kiadási tételét képezi), hanem az eddig elért és világszinten is vezető színvonalúnak ismert - állat- és növény-egészségügyi színvonal megtartása is a kitüzött feladatok közé tartozik.

Dolgozatom e fejezetében azokra a kérdésekre szeretném felhívni a figyelmet, amelyek az EU érdekeltségét vagy ellenérdekeltségét a bővítés iránt igazán meghatározzák:

- az új tagállamok mezőgazdasági termelésének és fogyasztásának mértéke és potenciálja

- a kibővült belső piacon az Unió számára megnyíló piacok, vagy a további túltermelés helyzete

- az új tagok felvásárlási árainak és szubvencióinak helyzete az EU-hoz képest

- a teljes integráció költségvetési hatása

\section{V/7.1. Az új tagok mezőgazdasági termelési mértéke és potenciálja}

Az Eurostat [2001] adatai szerint az EU a tíz közép- és kelet-európai ország belépésével lakosságának 27,8 százalékával, míg területének mintegy 33 százalékával bővül. Az Európai Bizottság adatai szerint ugyanakkor a mezőgazdaságilag müvelt területek nagysága az EU területeinek mintegy 44 százalékával nő. Ennek oka, hogy az új tagállamok mezőgazdasági területeinek nagysága (kb. 55 százalék) jóval nagyobb az ország területéből, mint az EU (41 százalék) ugyanilyen mutatója. Az új tagállamok közül ebböl a szempontból Magyarország rendelkezik a legkedvezőbb mutatóval, ahol a földterület kétharmada művelhető, de magas ez az arány a két nagy tagjelölt országnál, Lengyelországnál (59,1 százalék), illetve Romániánál (62 százalék) is. Ha közvetlenül a müvelhető területek arányát vesszük figyelembe, akkor a tagjelöltek az EU-mutatót 55 
százalékkal növelik, ami még jobban aláhúzza a bővítés fontosságát. (EU Bizottság, [1997])

Szintén a könnyebb összehasonlíthatóság kedvéért kell megjegyezni, hogy a GDP-n belül a mezőgazdasági termelés aránya 1997-ben az EU-ban 1,7 százalék volt, míg a társultaknál átlagosan hét százalékot tett ki. Országonkénti bontásban 1999-ben Csehországban ez csak 3,7 százalék, Szlovéniában 3,6, a kimagasló mezőgazdasági adottságokkal rendelkező Magyarországon pedig 4,9 százalék. Romániában, Bulgáriában 10 százalék feletti a mutató értéke, ami inkább a harmadik világ adatait tükrözi, mint a fejlett Európáét. (Eurostat [2001])

Másik lényeges makrogazdasági adat, hogy a foglalkoztatottak hány százaléka él a mezőgazdaságból. (Meg kell jegyeznem, hogy a képet zavarossá teszi az a metodológiai vita, hogy ki tekinthető hivatásos mezőgazdasági termelőnek, és ki az, aki csak kiegészítő tevékenységként, szükebb vagy bővebb környezete ellátására végez ilyen munkát. A tagjelölt országokban ennek statisztikai szétválasztása nem sikerült még, ezért az agrártermelők száma és aránya a valóságosnál nagyobb lehet.) A legjobb mutatókkal 1998-ban Csehország $(5,5)$, Szlovákia $(8,2)$ rendelkezik, de relatíve nem rossz Magyarország mutatója sem (7,5 százalék). Ugyanakkor kirívóan magas a román (40), lengyel $(19,1)$, litván (21) foglalkoztatási arány, amely jóval magasabb, mint a mezőgazdaság GDP-ből való részesedése, vagyis ezekben az országokban a szektor termelékenysége alacsony. A jelenlegi kohéziós tagállamokkal összehasonlítva az egyes tagjelöltek makrogazdasági mutatóit, azt látjuk, hogy a mezőgazdasági foglalkoztatottak aránya mindhárom mediterrán tagországénál alacsonyabb Csehországban, Magyarországon, ehhez közelít Szlovákiában. Az utóbbi három tagjelölt állam mezőgazdaságának GDP-hez való hozzájárulása viszont magasabb, mint a portugál vagy a spanyol mutató (lásd V/7.1 és V/7.2. sz. táblázat).

Bár 1997-ben az ún. Agenda 2000 dokumentumban, az Európai Bizottság meglehetősen negatív képet festett a tagjelöltek termelékenységéről, az 1998-ra vonatkozó termelékenységi adatok a tagjelöltekről javuló és differenciált helyzetet vázoltak fel. Ezek az adatok ugyanis megmutatják a cseh, a magyar és a szlovén mezőgazdaság hatékonyságát, hiszen reálértékben számolva az egy főre jutó termelés ezekben az országokban megközelítette az EU átlagát, és valószínüleg felülmúlják a 
portugál mutatókat is. A többi tagjelölt termelékenysége Szlovákia kivételével azonban már nagyon elmarad az EU-tól, különösen Lengyelország áll távol a közösségi mutatóktól (lásd: V/7.2. sz. táblázat). Az alacsony hatékonysággal és nagy foglalkoztatott létszámmal működő tagjelölt országoknál az is gondot okoz, hogy az esetleges mezőgazdasági modernizáció és hatékonyságnövelés olyan nagy mennyiségü munkaerőt tesz szükségtelenné a mezőgazdaságban, amelynek foglalkoztatása más szektorokban nehezen oldható meg. A tercier szektor a társultaknál is modernizálódik, vagyis növekedését nem kizárólag új munkaerő felszívásával oldja meg, így várhatóan ez a helyzet szociális feszültséghez, magas munkanélküliséghez vezethet.

V/7.1. sz. táblázat: Főbb mezögazdasági paraméterek a tagjelölt országokban illetve a három mediterrán kohéziós tagországban I.

\begin{tabular}{|l|c|c|c|c|c|c|}
\hline \multicolumn{1}{|c|}{ Ország } & $\begin{array}{c}\text { Mezőgazdasági } \\
\text { terület } \\
\text { (teljes terület } \\
\text { százalékában) }\end{array}$ & $\begin{array}{c}\text { Traktorok } \\
\text { száma (ezer } \\
\text { mezögazdasági } \\
\text { termelőre) }\end{array}$ & $\begin{array}{c}\text { Mezógazdasági } \\
\text { foglalkoztatottak } \\
\text { (teljes } \\
\text { foglalkoztatott } \\
\text { százalékban) }\end{array}$ & \multicolumn{2}{|c|}{$\begin{array}{c}\text { Élelmiszerre } \\
\text { költött teljes } \\
\text { jövedelemhányad }\end{array}$} \\
\cline { 2 - 7 } & \multicolumn{2}{|c|}{$\mathbf{1 9 9 5 - 9 7}$ átlagában } & $\mathbf{1 9 9 3}$ & $\mathbf{1 9 9 8}$ & $\mathbf{1 9 9 3}$ & $\mathbf{1 9 9 6}$ \\
\hline Lengyelország & 59,1 & 281 & 25,6 & 19,1 & 30 & 35 \\
\hline Magyarország & 66,5 & 156 & 10,1 & 7,5 & 31 & 24 \\
\hline Csehország & 54,5 & 164 & 5,6 & 5,5 & 32 & 31 \\
\hline Szlovákia & 49,9 & 92 & 8,4 & 8,2 & 38 & 35 \\
\hline Szlovénia & 38,7 & 3.082 & 10,7 & 11,4 & 28 & 23 \\
\hline Románia & 62,0 & 84 & 35,2 & 40,0 & 60 & 58 \\
\hline Bulgária & 55,5 & 63 & 21,2 & - & 48 & 54 \\
\hline Litvánia & 48,5 & 263 & 22,4 & 21,0 & 58 & 52 \\
\hline Lettország & 39,0 & 312 & 18,4 & 18,8 & 45 & 39 \\
\hline Észtország & 32,1 & 495 & 8,2 & 9,5 & 39 & 30 \\
\hline Görögország & 27,7 & - & - & 17,7 & - & $21^{*}$ \\
\hline Spanyolország & 54,6 & - & - & 7,9 & - & $19^{*}$ \\
\hline Portugália & 20,8 & - & - & 13,8 & - & $27^{*}$ \\
\hline EU & 41,8 & - & 5,7 & 4,7 & 22 & 18 \\
\hline
\end{tabular}

Forrás: EU Bizottság, [1995,1998,1999], WDI [2000]

Megjegyzés: *az adatok 1997-re vonatkoznak 
V/7.2. sz. táblázat: Föbb mezögazdasági paraméterek a tagjelölt országokban illetve a három mediterrán kohéziós tagországban II.

\begin{tabular}{|c|c|c|c|c|c|}
\hline \multirow{2}{*}{ Ország } & \multicolumn{2}{|c|}{$\begin{array}{l}\text { Mezőgazdasági termelés } \\
\text { a GDP százalékában }\end{array}$} & \multicolumn{2}{|c|}{$\begin{array}{l}\text { Egy fó agrártermelöre } \\
\text { jutó termelés 1998-ban }\end{array}$} & \multirow{2}{*}{$\begin{array}{l}\text { Élelmiszer- } \\
\text { termelési index } \\
\text { (1996-98 termelés } \\
\text { az 1989-91 évek } \\
\text { termelésének } \\
\text { százalékában) }\end{array}$} \\
\hline & 1993 & 1999 ** & euró & $\begin{array}{c}\text { EU-átlag } \\
\text { \%-ában } \\
\text { (PPS) } \\
\end{array}$ & \\
\hline Lengyelország & 6,3 & 3,8 & 1739 & 13 & 88,2 \\
\hline Magyarország & 6,4 & 4,9 & - & 77 & 76,3 \\
\hline Csehország & 3,3 & 3,7 & - & 88 & 79,4 \\
\hline Szlovákia & 5,8 & 4,5 & 4513 & 54 & 74,7 \\
\hline Szlovénia & 4,9 & 3,6 & - & 94 & 100,3 \\
\hline Románia & 20,2 & 15,5 & 1909 & 24 & 95,9 \\
\hline Bulgária & 10,0 & 17,3 & - & 37 & 67,8 \\
\hline Litvánia & 11,0 & 8,8 & 2769 & 26 & 69,2 \\
\hline Lettország & 10,6 & 4,0 & 1281 & 12 & 48,1 \\
\hline Észtország & 10,4 & 5,7 & 4892 & 46 & 47,0 \\
\hline Görögország & - & $5,8^{*}$ & 11724 & - & 99,0 \\
\hline Spanyolország & - & $3,0^{*}$ & 19093 & - & 110,1 \\
\hline Portugália & - & $1,9^{*}$ & 6359 & - & 97,0 \\
\hline EU & 2,5 & $1,7 * * *$ & - & - & - \\
\hline
\end{tabular}

Forrás: EU Bizottság, 2. Kohéziós Jelentés [2001], FAO, WDI, Eurostat

Megjegyzés: *az adatok 1998-ra vonatkoznak

**hozzáadott érték szerint

$* * * 1996$

\section{V/7.2. Termelési szerkezet összehasonlítása}

Mielőtt a főbb termékcsoportok összehasonlítását elvégeznénk, érdemes azt megvizsgálni, hogy hogyan alakult a termelés volumene a rendszerváltás után, összehasonlítva az 1990 előtti időszakkal. Ennek azért van jelentősége, mert ez az egyik kulcspontja a csatlakozási tárgyalásoknak, a társult országok a teljes termelési potenciáljukra hivatkozva a kvótákkal és közvetlen kifizetéssel érintett termékeknél a nyolcvanas évek második felét szeretnék referencia időszaknak tekinteni, míg az EU ezt az érvelést nem fogadja el. Brüsszel szerint a szocialista mezőgazdaság egy kényszerü kollektivizmuson alapuló rendszer volt, amely a hatékonyság és a minőségi igények helyett a minél nagyobb termelési eredményekben volt érdekelt, felhasználva a nagy és igénytelen szovjet piac korlátlan felvevőképességét.

A mezőgazdaság bruttó termelési adatait tekintve megállapítható, hogy 1997-re 1989-hez képest a jelölt országok termelése visszaesett, bár különböző mértékben (ld. V/7.2. sz. táblázat utolsó oszlopát). A könnyebb történelmi örökséget hozó 
Szlovéniában (ahol nem volt akkora hagyományos piacvesztés, mivel nem volt a KGST tagja) a magántulajdonosi rendszer a sajátos jugoszláv modellben lényegében megmaradt, és a volt jugoszláv szerződési rendszer már a rendszerváltás előtt is biztosította azokat az exportpiacokat, amelyek megmaradhattak a változások után is (lényegében a kilencvenes évek közepétől csaknem 20 százalékkal tudott nőni a termelés 1989-hez képest). Romániában némi visszaesés után 1996-98-ra majdnem elérték az 1989-91-es évek termelését, amiben közrejátszott az alacsony bázis, valamint a tömeges privatizáció és a gazdaság többi szektorának nehézségei nagy tömegeket fordítottak a mezőgazdaság felé. A többi társult országban a visszaesés jelentős volt. 1996-98-as évek átlagában Lengyelországban, Bulgáriában és Szlovákiában a bázisévek termelésének 80-90 százalékát, Magyarországon és Csehországban 70-80 százalékát, míg a legsúlyosabban érintett balti köztársaságokban 40-60 százalékát termelték.

A mezőgazdasági ágazatok oldaláról is eltérö volt a rendszerváltás hatása. A növénytermesztés terén a visszaesés minimális volt 1997-ben 1989-hez képest, sőt néhány országban több termékben meghaladták az 1989-es szintet (lásd V/7.3. sz. táblázat). Az állattenyésztés sokkal jelentősebb visszaesést élt át a 90-es években szinte minden országban (lásd: V/7.4. sz. táblázat). A két ágazat közötti eltérő tendenciában szerepet játszott az ármechanizmus, az agrárolló, a szubvenciós politika különbözősége, valamint az eltérő piaci lehetőségek.

A növénytermesztésen belül az egyes termékeket illetően a messze legjelentősebb gabona (a tagjelöltek gabonatermelése 1997-ben az EU-termelés 39 százaléka volt) visszaesése nem érte el a tíz tagjelöltnél a 10 százalékot sem, az olajos magvak (1997-ben ez az EU termelésének 26 százaléka) esetében a visszaesés valamivel több volt, mint 10 százalék. Nincs visszaesés a cukorrépa esetében (1997-ben az EU termelés 21 százaléka), és valamivel 10 százalék felett esett vissza a gyümölcstermelés (EU termelésének 29 százaléka), és a zöldségtermelés (24 százalék), ugyanakkor nőtt a borelőállítás (EU bortermelésének 10 százaléka).

Az állattenyésztés területén a tagjelölteknél 1997-re majdnem felére esett vissza a szarvasmarhák száma (a tehenek esetében is közel 30 százalékos volt a visszaesés), ugyancsak 30 százalékkal csökkent a sertések mennyisége, 35 százalékos zuhanás 
látható a szárnyasok darabszáma esetében, míg a juhoknál több mint a felére esett vissza a termelés darabszám szerint (EU Bizottság, Mezőgazdasági Főigazgatóság, [1998]).
V/7.3. sz. táblázat: Föbb növénytermesztési konjunktúraszámok (1997/1989) és az EU-hoz mért mennyiségi arányaik (1997)
(százalék, kerekitve)

\begin{tabular}{|c|c|c|c|c|c|c|c|c|c|c|c|c|}
\hline \multirow{2}{*}{ Ország } & \multicolumn{2}{|c|}{ Gabona } & \multicolumn{2}{|c|}{$\begin{array}{c}\text { Olajos } \\
\text { magvak }\end{array}$} & \multicolumn{2}{|c|}{ Cukorrépa } & \multicolumn{2}{|c|}{ Gyümölcs } & \multicolumn{2}{|c|}{ Zöldség } & \multicolumn{2}{|c|}{ Bor } \\
\hline & 1. & 2. & 1. & 2. & 1. & 2. & 1. & 2. & 1. & 2. & 1. & 2. \\
\hline Lengyelo. & 94 & 12 & 38 & 4 & 119 & 12 & 130 & 12 & 100 & 11 & na & na \\
\hline Magyaro. & 92 & 7 & 81 & 5 & 97 & 3 & 56 & 4 & 85 & 3 & 121 & 3 \\
\hline Csehország & 90 & 3 & 181 & 4 & 94 & 3 & 67 & 2 & 86 & 1 & 61 & 0 \\
\hline Szlovénia & 98 & 0 & na & na & 210 & 0 & 303 & 1 & 89 & 0 & 158 & 1 \\
\hline Észtország & 64 & 0 & 1000 & 0 & na & na & 68 & 0 & 36 & 0 & na & na \\
\hline Románia & 110 & 10 & 124 & 8 & 43 & 1 & 90 & 6 & 65 & 5 & 125 & 4 \\
\hline Bulgária & 58 & 3 & 97 & 3 & 13 & 0 & 76 & 2 & 57 & 2 & 71 & 1 \\
\hline Litvánia & 101 & 1 & 195 & 0 & 123 & 1 & 58 & 1 & 102 & 1 & na & na \\
\hline Szlovákia & 88 & 2 & 183 & 2 & 116 & 1 & 228 & 1 & 76 & 1 & 100 & 1 \\
\hline Lettország & 66 & 1 & 25 & 0 & 148 & 0 & 41 & 0 & 67 & 0 & na & na \\
\hline $\mathrm{EU}$ & 108 & 100 & 125 & 100 & 112 & 100 & 99 & 100 & 113 & 100 & 87 & 100 \\
\hline
\end{tabular}

Forrás: Európai Bizottság országjelentése alapján [1998], saját számítás

Megjegyzés: 1. számú oszlop: konjunktúraszámok 1997/89

2. számú oszlop: EU=100, kerekített adatok

V/7.4. sz. táblázat: Föbb állati termékek konjunktúra számai (1997/1989) és az EU-hoz mért arányaik (1997)

(százalék, kerekítve)

\begin{tabular}{|l|c|c|c|c|c|c|c|c|}
\hline \multirow{2}{*}{ Ország } & \multicolumn{2}{c|}{ Tej } & \multicolumn{2}{c|}{ Marhahús } & \multicolumn{2}{c|}{ Sertéshús } & \multicolumn{2}{c|}{ Baromfi } \\
\cline { 2 - 10 } & $\mathbf{1 9 9 7 / 8 9}$ & EU=100 & $\mathbf{1 9 9 7 / 8 9}$ & EU=100 & $\mathbf{1 9 9 7 / 8 9}$ & EU=100 & $\mathbf{1 9 9 7 / 8 9}$ & EU=100 \\
\hline Lengyelország & 73 & 10 & 68 & 6 & 93 & 11 & 136 & 6 \\
\hline Magyarország & 67 & 2 & 63 & 1 & 60 & 4 & 85 & 4 \\
\hline Csehország & 55 & 2 & 56 & 2 & 88 & 3 & 96 & 2 \\
\hline Szlovénia & 100 & 0 & 100 & 1 & 100 & 0 & 83 & 1 \\
\hline Észtország & 55 & 1 & 29 & 0 & 24 & 0 & 20 & 0 \\
\hline Románia & 154 & 4 & 104 & 3 & 87 & 4 & 86 & 3 \\
\hline Bulgária & 54 & 1 & 52 & 1 & 64 & 4 & 50 & 1 \\
\hline Szlovákia & 58 & 1 & 46 & 1 & 76 & 1 & 95 & 1 \\
\hline Litvánia & 56 & 2 & 37 & 1 & 37 & 1 & 46 & 0 \\
\hline Lettország & 50 & 1 & 21 & 0 & 25 & 0 & 19 & 0 \\
\hline EU & 95 & 100 & 94 & 100 & 106 & 100 & 132 & 100 \\
\hline
\end{tabular}

Forrás: Európai Bizottság országjelentése alapján [1998], saját számítás

Az V/7.3. és V/7.4. számú táblázatok alapján látszik, hogy országonkénti lebontásban 1997-ben Lengyelország termelése a legtöbb terméknél meghaladja az 
EU termelésének 10 százalékát, így az EU számára is érzékeny gabona területén 12, a tejtermelésben 10, marhahús termelésben a 6 százalékot. A többi ország közül csak Románia és Magyarország gabonatermelése (az EU 10 illetve 7 százaléka), valamint a két ország olajos magvakban regisztrált termelése ( 8 illetve 5 százalék) nevezhető jelentősnek. A magyar és a román bortermelés együtt az EU termelésének 7 százalékát adja.

A fenti két táblázat azt is jól mutatja, hogy országonkénti bontásban milyen mértékü 1997-ben 1989-hez képest az egyes termékek termelése. Gabonatermelésben Románia 10 százalékkal meghaladta az 1989-ben előállított mennyiséget, de az olajos magvak és a bor elöállítása terén is negyedével haladta meg a szocializmus utolsó évének produktumát. Keleti szomszédaink a tej termelésénél több mint 50 százalékos növekedést regisztráltak. 1989-hez képest szintén jó mutatói vannak Szlovéniának mind a növénytermesztés, mind az állattenyésztés terén. A visszaesés mindkét ágazatban jelentős a balti államoknál és Bulgáriában, míg az állattenyésztés terén jelentős a csökkenés Lengyelországban, Magyarországon és Csehországban.

\section{V/7.3. A kibővített belső piac termelés-fogyasztás egyenlege}

A témával az Európai Bizottság belső anyagai 1995-ben és 1998-ban is foglalkoztak. Két tényezőt érdemes megvizsgálnom:

1. hogyan alakult a két fél között az agrártermékek kereskedelme

2. melyek az EU-ban és a társult országokban várható termelési és föleg fogyasztási trendek az egyes nagy termékcsoportokban, és melyek ezek várható egyenlege.

\section{V/7.3.1. Az EU és a társult országok kereskedelme}

Míg 1990 előtt az erőteljesebben támogatott agrárexport a társultak számára általában pozitív szaldót mutatott, addig - elsősorban a nyitás, valamint a minőségi mezőgazdasági árualap csökkenése (a termelés fogyasztást meghaladó visszaesése) miatt - a jelöltek áruforgalmi egyenlege fokozatosan romlott a kilencvenes évek közepéig. Magyarország és Bulgária kivételével a többi tagjelölt országnál negatív 
szaldót mutat, bár a romló tendencia 1994-1995 körül stabilizálódott (lásd: V/7.5. sz. táblázat).

Az agrár-külkereskedelmen belül a legfontosabb partner az EU, bár részaránya elmarad az általános külkereskedelmi adatoktól, hiszen a legnagyobb exportőr Magyarország, Lengyelország és Csehország agrárexportjában csak 30-40 százalékban részesedik, míg az importban a társultak behozatalának 40-55 százaléka származik az EU-ból. Ez arra enged következtetni, hogy a volt FÁK-piac vagy a Közép-Európai Szabadkereskedelmi Egyezmény (CEFTA) országai fontos exportpartnerek maradtak a társultak számára. Együttesen a tíz ország az EU exportpiacának 10 százalékát képviselte 1997-ban, ugyanakkor az EU importjából való részesedésük 5 százalék körüli, vagyis az Unió belső piaca szempontjából nem releváns. A tíz ország EU-val 1997-ben kialakult 1,5 milliárd eurós deficitje a 3 milliárdos exportból és a 4,5 milliárdos importból tevődött össze (Európai Bizottság, Mezőgazdasági Főigazgatóság, [1998]).

Egészen eltérő jelleget mutat azonban az országonkénti mérleg, hiszen míg a magyarok több mint 500 milliós aktívum körül stabilizálták mérlegüket (ez a teljes kereskedelmi aktívumuk több mint harmada), addig a bolgárok kiegyenlített mérlege állítható szembe a többiek negatív mérlegével.

Bár az összehasonlító adatok nem minden évben álltak rendelkezésre, az azonban látható, hogy az EU számára egyre nagyobb aktívum keletkezik (1993-ben 671 millió euró, 1997-ban pedig már 1532 millió euró). (Lásd: V/7.5. sz. táblázat) Érdemes azt is megjegyezni, hogy a 10 ország közül az ún. luxemburgi országok (Magyarország, Csehország, Lengyelország, Szlovénia, Észtország) képviselik a régió EU-ba irányuló exportjának 81, míg az import 75 százalékát (1997), ami különösen Lengyelország és Magyarország súlyát jelzi, mivel ez a két ország képes egy milliárd euró körüli exportra az EU-ba. 
V/7.5. sz. táblázat: A tagjelöltek teljes és EU-val szembeni agrárkereskedelmi egyenlege (millió euró)

\begin{tabular}{|l|c|c|c|c|}
\hline \multicolumn{1}{|c|}{ Ország } & $\begin{array}{c}\text { Teljes } \\
\mathbf{1 9 9 3}\end{array}$ & $\begin{array}{c}\text { Teljes } \\
\mathbf{1 9 9 7}\end{array}$ & $\begin{array}{c}\text { EU } \\
\mathbf{1 9 9 3}\end{array}$ & $\begin{array}{c}\text { EU } \\
\mathbf{1 9 9 7}\end{array}$ \\
\hline Lengyelország & -481 & -418 & -346 & -527 \\
\hline Magyarország & 1004 & 1553 & 384 & 529 \\
\hline Csehország & 23 & -577 & -84 & -457 \\
\hline Szlovénia & -217 & -362 & -132 & -290 \\
\hline Észtország & 49 & -225 & -32 & -249 \\
\hline Románia & -524 & $-108 * * *$ & -236 & $-134 * * *$ \\
\hline Bulgária & 261 & 232 & -47 & 75 \\
\hline Szlovákia & $-189 *$ & $-337 * * *$ & $-118 *$ & -186 \\
\hline Litvánia & n.a & -10 & $-53 * *$ & -141 \\
\hline Lettország & 75 & -119 & -7 & -152 \\
\hline Összesen & $\mathbf{1}$ & $\mathbf{- 3 7 1}$ & $\mathbf{- 6 7 1}$ & $\mathbf{- 1 5 3 2}$ \\
\hline
\end{tabular}

Forrás: EU Bizottság, Mezőgazdasági Főigazgatóság [1998] országjelentések alapján Megjegyzés: *1994, **1995, ***1996

Az EU és a társult országok közötti agrárkereskedelemben nincs teljes liberalizáció, de preferenciális kereskedelmi kedvezmények élnek, amelyeknek mértéke a tagjelöltek számára magasabb, mint az EU számára. Az EU és a tagjelöltek között 2000. július 1-től (Litvánia és Lengyelország esetében 2001. január 1-től) újabb liberalizációs egyezmények születtek. Ez már nemcsak a vámmentességre vonatkozik, hanem bizonyos termékek esetében a másik fél felé az exportszubvenciót is kizárja, vagyis a tagság előtt részlegesen az EU belső piacához hasonló kereskedelmi viszonyokat valósított meg. Ez azért lényeges, mert a legtöbb termék esetében elörevetíti azokat a versenyviszonyokat, ami a belépés után a belső piacon várható. (Természetesen az EU számára legérzékenyebb gabona és marhahússzektorban a teljes liberalizáció még várat magára.) Mivel 2002 elejétől mind a halkereskedelemben, mind a feldolgozott mezőgazdasági termékeknél további liberalizáció történik, a mellékelt táblázat százalékos arányai tovább fognak növekedni. 
V/7.6. sz. táblázat: Vámmentes kereskedelem aránya 2001. január elsejétöl, (százalék)

\begin{tabular}{|c|c|c|}
\hline Ország & $\begin{array}{c}\text { Export az EU-ba } \\
\text { (1996-1998 átlaga) }\end{array}$ & $\begin{array}{c}\text { Import az EU-ból } \\
\text { (1996-1998 átlaga) }\end{array}$ \\
\hline Bulgária & 66,4 & 51,1 \\
\hline Csehország & 54,0 & 28,6 \\
\hline Észtország & 85,3 & 100,0 \\
\hline Magyarország & 83,1 & 62,3 \\
\hline Lettország & 76,1 & 24,2 \\
\hline Litvánia & 81,7 & 8,6 \\
\hline Lengyelország & na & na \\
\hline Románia & 84,9 & 17,4 \\
\hline Szlovákia & 71,6 & 39,4 \\
\hline Szlovénia & 73,2 & 16,9 \\
\hline
\end{tabular}

Forrás: EU Bizottság, [2001]

A térség tagsága esetén az EU-n belülre kerülhet a CEFTA-kereskedelem (ennek tagjai csak az EU-val szabadkereskedelmi viszonyban lévő országok lehetnek), amelyben a tagjelöltek között már most olyan fokú liberalizáció áll fenn, amely hasonló az EU és a tagjelöltek közötti viszonyhoz az agrárkereskedelem területén. A tagjelöltek agrárimportjára vonatkozó vámtarifák (Lengyelország kivételével) kisebbek a WTO-tagok felé, mint az EU vámtarifái a WTO-tagok felé, így a harmadik országok pozícióival szemben a bővülés után a jelenlegi tagállamok piaci lehetőségei javulnak az új tagállamokban.

A közép-európai országok EU-ba irányuló exportjának szerkezetét illetően, jól látszik, hogy elsősorban az élőállat, hústermékek illetve a zöldségfélék dominálnak, míg az EU zöldségeket és feldolgozott gyümölcsöket exportál jelentősebb tételben. Kezd felfutni a bor és a szeszkereskedelem mindkét fél oldaláról. 
V/7.3.2. Az EU és a társult országok termelés-fogyasztás egyenlege

Miután láttuk, a tagjelöltek összességében nettó agrár-importőrök, érdemes megvizsgálni termelési és fogyasztási oldalról főbb árucsoportonként a belső egyensúlyi helyzetet. Az elemzés megkezdése elött egy fontos tényezőt kell megvizsgálni. 1993-ban az EU adatai szerint a társultak lakossága a jövedelmek 3060 százalékát költötte élelmiszerre, ami magasnak tünik az EU 22 százalékos mutatójához képest. 1996-ban (ld. V/7.1. számú táblázat utolsó adatoszlopát) is hasonló volt a helyzet, de ekkor már a szlovén és a magyar lakosságnál ez az arány 30 százalék alá csökkent - ezzel a mediterrán tagállamok szintjéhez kerültek közelebb -, sőt már ezen a határon mozgott Csehország és Észtország fogyasztása is. Ezeknél az országoknál így megfelelő gazdasági növekedés és ennek következtében a reáljövedelmek emelkedése (lásd: V/8. fejezet) esetén reálisan kalkulálható az, hogy képesek lesznek jelentősebb fogyasztásnövelésre vagy a fogyasztói árak növelésének elviselésére, míg a többieknél ez csak a távolabbi jövőben képzelhető el.

A vártnál gyorsabban növekvő fizetöképesség, valamint az agrártermelés lassúbb növekedési kilátásai miatt a társult országok agrárfeleslegének mennyisége a Bizottság értékelései szerint egyre jobban mérséklődik, ami a kibővített belső piacon a várható értékesítési feszültségek mérsékléséhez, tágabb értelemben a jelöltek integrálásának könnyebbé tételéhez vezethet. 
V/7.7. sz. táblázat: A termelés és fogyasztás egyenlege a tíz tagjelöltnél a Bizottság értékei, illetve elözetes becslései alapján a föbb növénytermesztési területeken

\begin{tabular}{|c|c|c|c|c|c|c|c|c|c|c|c|}
\hline \multirow[t]{2}{*}{ Ország } & \multicolumn{4}{|c|}{$\begin{array}{c}\text { Gabona } \\
\text { (ezer tonna) }\end{array}$} & \multicolumn{4}{|c|}{$\begin{array}{l}\text { Olajos magvak } \\
\text { (ezer tonna) }\end{array}$} & \multicolumn{3}{|c|}{$\begin{array}{c}\text { Cukor } \\
\text { (ezer tonna) }\end{array}$} \\
\hline & 1 & 2 & 3 & 4 & 1 & 2 & 3 & 4 & 1 & 2 & 3 \\
\hline Lengyelország & -461 & -3450 & 700 & 1390 & 71 & -83 & 415 & 153 & 174 & - & 50 \\
\hline Magyarország & 484 & 620 & 1981 & 4250 & 201 & -2 & 148 & 27 & -11 & - & 32 \\
\hline Csehország & 417 & 10 & 438 & 1000 & 50 & 172 & 46 & 198 & -38 & - & 2 \\
\hline Szlovénia & -477 & -490 & -277 & -360 & 0 & 0 & 2 & 0 & -50 & - & -33 \\
\hline Észtország & -207 & -150 & -91 & -110 & 0 & 30 & 0 & 36 & -47 & - & -47 \\
\hline Románia & 1034 & -790 & 3111 & 1750 & -205 & -45 & -177 & -30 & -350 & - & -289 \\
\hline Bulgária & 17 & 370 & 2298 & 1590 & 100 & 104 & 516 & 198 & -114 & - & -364 \\
\hline Szlovákia & 64 & -680 & 533 & 700 & 1 & -16 & 71 & 72 & -118 & - & -67 \\
\hline Litvánia & 336 & -100 & 344 & 80 & - & 10 & - & 10 & -22 & - & -23 \\
\hline Lettország & -181 & -100 & -124 & 10 & - & 2 & - & 2 & -76 & - & -75 \\
\hline KKE-10 & 1026 & -4760 & 8913 & 10300 & 218 & 172 & 1021 & 666 & -652 & - & -814 \\
\hline EU-15 & 16797 & - & - & - & -17803 & - & - & - & 2685 & - & - \\
\hline Összesen & 17823 & - & - & - & -17585 & - & - & - & 2033 & - & - \\
\hline
\end{tabular}

Forrás: EU Bizottság, Mezőgazdasági Főigazgatóság, Munkaanyag a közép- és kelet-európai országokról, [1995], [2001]

\author{
Megjegyzés: 1. oszlop: 1994 (tény); \\ 2. oszlop: 2000 (tény); \\ 3. oszlop: 2000-re vonatkozó bizottsági becslés 1994-ben; \\ 4. oszlop: 2007-re vonatkozó bizottsági becslés 2000-ben
}
V/7.8. sz. táblázat: Termelés és fogyasztás egyenlege a tíz tagjelöltnél
a Bizottság értékei és elözetes becslései alapján
a legfontosabb állati eredetü élelmiszereknél I.

\begin{tabular}{|l|r|r|r|r|r|r|r|r|}
\hline \multirow{2}{*}{ Ország } & \multicolumn{4}{|c|}{$\begin{array}{c}\text { Tej } \\
\text { (ezer tonna) }\end{array}$} & \multicolumn{4}{c|}{$\begin{array}{c}\text { Marhahús } \\
\text { (ezer tonna) }\end{array}$} \\
\cline { 2 - 10 } & \multicolumn{1}{|c|}{$\mathbf{1}$} & $\mathbf{2}$ & $\mathbf{3}$ & $\mathbf{4}$ & $\mathbf{1}$ & $\mathbf{2}$ & $\mathbf{3}$ & $\mathbf{4}$ \\
\hline Lengyelország & -400 & 350 & 175 & 111 & -14 & 54 & -43 & 40 \\
\hline Magyarország & -60 & 5 & 222 & -33 & -15 & -1 & -48 & -20 \\
\hline Csehország & 608 & 420 & 250 & 333 & 19 & -3 & 39 & -14 \\
\hline Szlovákia & -248 & 161 & 110 & 208 & 9 & 3 & -2 & 4 \\
\hline Szlovénia & 76 & 123 & 178 & 87 & -7 & 4 & 10 & 2 \\
\hline Románia & -19 & 188 & -50 & 143 & -5 & -9 & 36 & 2 \\
\hline Bulgária & 0 & -108 & 45 & -118 & -9 & -9 & -9 & -5 \\
\hline Litvánia & 413 & 546 & 598 & 584 & 38 & 9 & 92 & 9 \\
\hline Lettország & -32 & 37 & 39 & -16 & 0 & 29 & 8 & 37 \\
\hline Észtország & 105 & 153 & 116 & 198 & -14 & -1 & 24 & -1 \\
\hline KKE-10 & 443 & 1875 & 1683 & 1497 & 2 & 76 & 107 & 54 \\
\hline
\end{tabular}

Forrás: EU Bizottság, Mezőgazdasági Főigazgatóság, Munkaanyag a közép- és kelet-európai országokról, [1995], [2001]

Megjegyzés: 1. oszlop: 1994 (tény); 2. oszlop: 2000 (tény); 3. oszlop: 2000-re vonatkozó bizottsági becslés 1994-ben; 4. oszlop: 2007-re vonatkozó bizottsági becslés 2000-ben 


\section{V/7.9. sz. táblázat: Termelés és fogyasztás egyenlege a tíz tagjelöltnél a Bizottság értékei és elözetes becslései alapján a legfontosabb állati eredetü élelmiszereknél II.}

\begin{tabular}{|l|r|r|r|r|r|r|r|r|}
\hline \multirow{2}{*}{ Ország } & \multicolumn{4}{|c|}{$\begin{array}{c}\text { Sertéshús } \\
\text { (ezer tonna) }\end{array}$} & \multicolumn{4}{c|}{$\begin{array}{c}\text { Baromfi } \\
\text { (ezer tonna) }\end{array}$} \\
\cline { 2 - 10 } & \multicolumn{1}{|c|}{$\mathbf{1}$} & $\mathbf{2}$ & $\mathbf{3}$ & $\mathbf{4}$ & $\mathbf{1}$ & $\mathbf{2}$ & $\mathbf{3}$ & $\mathbf{4}$ \\
\hline Lengyelország & -96 & 100 & -111 & 183 & -46 & 25 & -39 & -11 \\
\hline Magyarország & 2 & 95 & -15 & 140 & 80 & 196 & 136 & 231 \\
\hline Csehország & -15 & -4 & 10 & -8 & 5 & -3 & 25 & 2 \\
\hline Szlovákia & -4 & -11 & -5 & 79 & -2 & -3 & 7 & 38 \\
\hline Szlovénia & -25 & -19 & -11 & -29 & 13 & 6 & 11 & -1 \\
\hline Románia & 82 & 10 & 50 & 20 & -34 & -51 & 21 & -54 \\
\hline Bulgária & -3 & 2 & 0 & 2 & -6 & -15 & 10 & -8 \\
\hline Litvánia & -3 & -8 & 11 & -7 & 10 & -9 & 7 & -14 \\
\hline Lettország & -12 & -24 & 0 & -17 & 5 & -13 & 5 & -10 \\
\hline Észtország & 6 & -14 & 16 & -14 & 1 & -13 & 9 & -14 \\
\hline KKE-10 & -68 & 127 & -55 & 349 & 26 & 120 & 192 & 159 \\
\hline
\end{tabular}

Forrás: EU Bizottság, Mezőgazdasági Főigazgatóság, Munkaanyag a közép- és kelet-európai országokról, [1995], [2001]

Megjegyzés: 1. oszlop: 1994 (tény),

2. oszlop: 2000 (tény);

3. oszlop: 2000-re vonatkozó bizottsági becslés 1994-ben;

4. oszlop: 2007-re vonatkozó bizottsági becslés 2000-ben

Az V/7.7-9 sz. táblázatokban a tagjelöltek EU számára legérzékenyebb termékekre vonatkozó termelés-fogyasztás egyenlegét vizsgálom meg az 1994-es és 2000-es tényadatok, valamint bizottsági becslések alapján. A gabonafélék esetében jósolták a túltermelés legnagyobb növekedését. 1994-ben 2000-re azt extrapolálták, hogy mintegy 9 millió tonna felesleg fog keletkezni a 10 tagjelöltnél (több mint 2 millió tonna Bulgáriából, 3 millió Romániából és majdnem 2 millió tonna Magyarországról). 2000-ben 2007-re vetítve ugyanez a fölösleg már 10 millió tonna fölött lenne, az EU-ban pedig már 2003-ra 31 millió tonna (EU Bizottság, Mezőgazdasági Főigazgatóság, [1998, 2001]), vagyis mindenféleképpen jelentős túltermeléssel kell szembenézni a jövőben a jóslatok szerint. Ehhez képest 2000-ben a közép-európai országok - igaz a rossz időjárási év miatt is - majdnem 5 millió tonna importjára kényszerültek.

A másik két kényes terület - ahol mindkét fél jelentős túltermelő marad -, a marhahús és a tejszektor. Az EU magas árai miatt a tagjelöltek részéről történő 
termelésfelfutástól félnek uniós szakértők a csatlakozás után. A marhahús vonatkozásában 1994-ben 2000-re a tagjelöltek fölöslegét 107 ezer tonnára jósolták, ehelyett 2000-ben „csak” 76 ezer tonna lett a fölösleg. 2000-ben 2007-re már nem ígértek többet az elörejelzések 54 ezer tonnánál. (Az EU Bizottság 1997-ben az Agenda 2000-ben még 435 ezer tonna felesleget emlegetett 2005-re.) Marhahúsból az EU is jelentős túltermelő, hiszen már 1997-ben is 777 millió tonna feletti feleslege volt (EU Bizottság, Mezőgazdasági Főigazgatóság, [1998]), és ez nehezen lesz csökkenthető (például a BSE-válság miatti fogyasztás-visszaesés következtében).

Hasonló lesz a helyzet a tej esetében is, 1997-ben a tagjelölteknél 2,5 millió tonna felesleg keletkezett (az EU-ban ugyanebben az évben 8,8 millió tonna), ami 2000-re 1,9 millió tonnára mérséklődött. 2000-ben a 2007-es felesleget is csak mintegy 1,5 millió tonnára jósolják a tagjelölteknél.

Lényegesen kedvezőbb a helyzet az olajos magvak illetve a cukorelöállítás területén (lásd: V/7.7. sz. táblázat), hiszen míg az elsőben az EU, addig a másodikban a társultak jelennek meg importőrként. Igaz az olajos magvak esetében a magyar és lengyel felesleg nem tudja igazán pótolni az EU igényét, de ezen a területen nincs a két fél túltermeléséből eredő érdekütközés. (Ezért is javasolják sokan, hogy gabonatermesztésről térjenek át az új tagjelöltek termelői az olajos magvakra.) A cukortermelésben pedig a társultak szorulnak importra - elsősorban Románia és Bulgária, valamint Szlovénia -, Lengyelország pedig aktívummal rendelkezik. Ebben a helyzetben a felvételt nyert országoktól függ a belső piaci egyensúly.

A sertéshús vonatkozásában főleg a közép-európai országok számítanak nagy fogyasztónak, Magyarország vagy Lengyelország az egy főre jutó fogyasztásban meghaladja a közösségi átlagot. A tagjelöltek várhatóan több százezer tonnával (250 ezer tonnát jósoltak 2005-re az Agenda 2000-ben, a 2000-es felmérésben 2007-re vonatkozóan 349 tonnát) fogják megfejelni az Unió szintén nagyon jelentős feleslegét (1997-ben 775 ezer tonna).

Hasonló a helyzet a szárnyasokkal is, annak ellenére, hogy a társultak fogyasztása e területen várhatóan megnő, még mindig jelentős lesz a többlet. Ennek okai között szerepel, hogy ezen országokban - főleg Magyarországon - megnőtt a termelés. 
1997-ben a tagjelöltek túltermelése 78 ezer tonna volt, míg az EU-nál ugyanez a mutató 620 ezer tonna (EU Bizottság, Mezőgazdasági Főigazgatóság, [1998]).

A belső egyensúlyi elemzés azt mutatja, hogy a bővítés után - bár a tagjelöltek nettó agrárimportőrök - az érzékenyebb termékeknél összességében az Uniónak további feleslege keletkezik. Ugyanakkor ebből a szempontból nem mindegy, hogy mely országok kerülnek be az első körben, hiszen ez alapvetően meghatározza a belső piaci egyensúlyt. A fejlettebb jelentkezök közül Lengyelország feleslegei a marhahús, sertéshús, tej és cukorrépa területén, Magyarország a gabona, baromfi, míg Litvánia a tej túltermelésével okozhatnak zavarokat. Az azonban látszik, hogy a második évezred első néhány évére jósolt túltermelési előrejelzések túlzóak. (Ez az V/7.7-9. sz. táblázatok 2. és 3. oszlopának összevetésével igazolható.) Ennek alapvető oka abban rejlik, hogy a tagjelöltek fogyasztása a gazdasági kibontakozással párhuzamosan gyorsabban nő, mint a termelésük.

\section{V/7.4. A mezőgazdasági piaci árak}

A keleti bővítéssel kapcsolatos nyugati tartózkodás az árak vonatkozásában nemcsak az intervenciós árak, hanem a piaci árak eleve alacsony volta miatt bontakozik ki. Emellett még gondot jelenthet az alacsony szubvenciós szint a tagjelölt országokban (lásd: V/7.11. sz. táblázat).

Ami a már létező garantált felvásárlási, illetve a piaci árszínvonal különbségét illeti, bemutatom ezek egymáshoz való arányát 1994-ben és 1997-ben. Ebből látható az EU-hoz viszonyított konvergencia megvalósulása az élenjáró tagjelölt országokban. Ha ehhez hozzávesszük, hogy ezen országok lakossága a növekvő reálbérek mellett képesek lesznek nagyobb összeget élelmiszervásárlásra fordítani - ez már bizonyításra került a kilencvenes évek alapján -, valamint figyelembe vesszük, hogy minden közgazdasági dogma szerint a felzárkózó gazdaságok valutája felértékelődik, akkor megállapítható, hogy a mezőgazdasági árak felzárkózása az EU árszínvonalához meg fog valósulni, sőt néhány termék esetében már meg is valósult. Inkább az új tagok versenyképessége lesz a továbbiakban a kérdőjel, bár mint jeleztem (V/7.2. sz. táblázat 5. oszlopa), a reálértéken mért termelékenység a legfejlettebb jelölteknél már most megközelíti az EU átlagos szintjét. Ezt a 
konvergenciát segíti, hogy input oldalon (pl. mütrágyák, energia) a költségek már most is a világpiaci árakat tükrözik.

V/7.10. sz. táblázat: Mezögazdasági termékek árának alakulása az EU-árak százalékában (1994/1997)

\begin{tabular}{|l|c|c|c|c|c|c|c|c|c|c|c|c|}
\hline \multirow{3}{*}{ Ország } & \multicolumn{2}{|c|}{ Búza } & \multicolumn{2}{c|}{ Kukorica } & \multicolumn{2}{c|}{ Tej } & \multicolumn{2}{c|}{ Marha } & \multicolumn{2}{c|}{ Sertés } & \multicolumn{2}{c|}{ Baromfi } \\
\cline { 2 - 15 } & $\mathbf{1 9 9 4}$ & $\mathbf{1 9 9 7}$ & $\mathbf{1 9 9 4}$ & $\mathbf{1 9 9 7}$ & $\mathbf{1 9 9 4}$ & $\mathbf{1 9 9 7}$ & $\mathbf{1 9 9 4}$ & $\mathbf{1 9 9 7}$ & $\mathbf{1 9 9 4}$ & $\mathbf{1 9 9 7}$ & $\mathbf{1 9 9 4}$ & $\mathbf{1 9 9 7}$ \\
\hline Lengyelorsz. & 73 & 109 & na & 88 & 33 & 50 & 40 & 54 & 103 & 74 & 88 & 94 \\
\hline Magyarorsz. & 56 & 78 & 52 & 55 & 70 & 72 & 52 & 54 & 98 & 83 & 77 & 81 \\
\hline Csehország & 66 & 92 & 72 & 90 & 54 & 65 & 59 & 71 & 94 & 83 & 68 & 77 \\
\hline Szlovákia & 63 & 89 & 67 & 77 & 52 & 64 & 50 & 69 & 88 & 79 & 74 & 58 \\
\hline Szlovénia & 131 & 146 & 89 & 79 & 92 & 90 & 80 & 99 & 134 & 113 & 81 & 94 \\
\hline Románia & 60 & 104 & 54 & 77 & 57 & 93 & na & na & na & 111 & na & 90 \\
\hline Bulgária & 40 & 86 & 51 & 65 & 36 & 59 & 24 & 63 & 53 & 81 & 44 & 99 \\
\hline Litvánia & 45 & 116 & na & na & 21 & 40 & 22 & 43 & 81 & 78 & na & 57 \\
\hline Lettország & 90 & 95 & na & na & 26 & 48 & 18 & 35 & 77 & 86 & na & 124 \\
\hline Észtország & 56 & 98 & na & na & 26 & 56 & 12 & 96 & 43 & 96 & na & 121 \\
\hline EU (euró/t) & 134 & 126 & 138 & 134 & 316 & 297 & 3130 & 2662 & 1280 & 1672 & 1340 & 1290 \\
\hline
\end{tabular}

Forrás: EU Bizottság, Mezőgazdasági Főigazgatóság, országjelentések, [1995, 1998]

A felzárkózást segíti az is, hogy az egyes WTO-fordulók az EU-t mesterségesen magas árainak csökkentésére kényszerítik. Főleg a gabona területén állapítható meg az, hogy több országban (Lengyelország, Szlovénia, Litvánia és Románia) már el is érték az EU-árszintet, igaz ebben közrejátszik a szubvenciós politikák különbözősége is. A többi területen az árak nem haladják meg lényegesen az EU-árakat, ugyanakkor bizonyos termékeknél jelentős eltérések vannak. Ilyen például a marhahús vagy a cukorrépa. A tagjelölt országok közötti összehasonlítás azt mutatja, hogy a szlovénok árai általában magasak, több esetben meghaladták vagy megközelítették az EUárakat. A lengyel árak a növénytermesztés terén, akárcsak a cseh, szlovák és román árak, magasak. Valamivel alacsonyabb és versenyképesebb a magyar és bolgár árszínvonal. Ugyanakkor minden tagjelölt országnál figyelmeztető lehet az, hogy a jócskán (30-50 százalékkal) alulértékelt valuta várható erősödése miatt még komoly versenykihívásokkal néznek szembe a belső piacra lépve, és ezért növelniük kell a termelés hatékonyságát.

A versenyképesség megítélésében reális képet akkor kapunk, ha megnézzük a szubvenciós rátákat a termékek árához képest. Ezt az EU Bizottsága az OECD adatai 
alapján az ún. Termelői Támogatói Egyenérték (PSE) alapján mérte fel [lásd V/7.11. sz. táblázat). Jól látszik, hogy az EU-ban a szubvenciós érték a termékek árának 40 százaléka fölött mozgott az utóbbi évtizedben, míg a társult országoknál (Szlovénia kivételével, mely az EU-hoz hasonlóan erős támogatást nyújt) nem haladja meg a 25 százalékot. A belépéskor - azonos támogatást feltételezve - a tagság pozitív következménye az lesz, hogy az uniós gazdákat az új belépők azonos bánásmódja nagyobb versenyre készteti. Versenyképességi szempontból különösen figyelemre méltó a balti államok, a magyar és a cseh támogatási szint alacsony volta.

V/7.11. sz. táblázat: PSE százalékos ráta néhány tagjelölt országban

\begin{tabular}{|l|c|c|c|}
\hline \multicolumn{1}{|c|}{ Ország } & $\mathbf{1 9 8 9}$ & $\mathbf{1 9 9 5}$ & $\mathbf{1 9 9 7}$ \\
\hline Lengyelország & 5 & 19 & 22 \\
\hline Magyarország & 31 & 21 & 16 \\
\hline Csehország & 55 & 15 & 11 \\
\hline Észtország & 80 & 3 & 9 \\
\hline Szlovákia & 56 & 25 & 25 \\
\hline Litvánia & 78 & 5 & 18 \\
\hline Lettország & 83 & 8 & 8 \\
\hline EU & 40 & 49 & 42 \\
\hline
\end{tabular}

Forrás: OECD, átvette az EU Bizottság [1998]

A piaci árszintek, valamint a termékek támogatási mértékének vizsgálata után érdemes azt is áttekinteni, hogy milyen mezőgazdasági vámszintekkel rendelkeznek az egyes társultak. Bár termékenként változnak az egyes tagjelöltek vámvédelmének szintjei, de a legfontosabb termékek vizsgálatánál megállapítható, hogy míg a lengyelek, románok és néhány esetben a szlovénok esetében a közösségi vámszintnél magasabbak a ráták, a közösségi vámtarifák átvételével a tagság a vámvédelem csökkenését fogja eredményezni, addig a magyarok, csehek, szlovákok vagy a baltiak esetében ezek a vámtarifák alacsonyabbak, így a vámvédelem a tagság következtében nőni fog (Európai Bizottság, Mezőgazdasági Főigazgatóság, [1998]).

A harmadik országok felé biztosított kedvezmények kapcsán ki kell emelni a CEFTA szerződésrendszert, amelynek érdekessége, hogy szabályai miatt (WTO tagság, EUval szabadkereskedelmi viszonyt takaró társulás) elsősorban a tagjelölteket öleli fel. Így nem jelent sem politikai, sem kereskedelmi szempontból kezelhetetlen helyzetet, 
ha egy vagy több CEFTA-tag belép az EU-ba, hiszen két tagjelölt viszonylatában a koncessziók nem mennek túl azon, amit az EU nekik ad.

Ha összehasonlítjuk az árak és a támogatási szintek különbségeit a tagjelölteknél, észlelhetővé válik, hogy miért a versenyképesebb cseh, magyar, szlovák oldalon vállalták a CEFTA-ban a további agrárliberalizációt 2001-ben, míg lengyel és román oldalról nem tudnak ebben partnerek lenni.

\section{V/7.5. A birtokszerkezet}

Ahogy a rendszerváltás előtt, úgy a rendszerváltás után is az egyes tagjelölt országok birtokszerkezete és birtokpolitikája különböző. Lengyelországban és Szlovéniában a kommunizmus évtizedei alatt is lényegében megmaradt a magántulajdonosi rendszer, míg a bolgárok és a baltiak esetében az állami gazdaságok domináltak, más országokban (Cseh Köztársaság, Szlovákia, Magyarország) lényegében kollektív termelöszövetkezeti rendszer müködött. A rendszerváltás után a részleges földosztástól kezdve a nagy reprivatizációig változatos formát öltött a mezőgazdasági tulajdonformák kezelése.

Megvizsgáltam, hogy milyen a különböző (magántulajdon és kollektív) formák aránya a tagjelölteknél illetve, milyen ezek átlagos mérete. Mint az V/7.12. számú táblázat is mutatja, a kollektivizmus elvétől egy ideig tartózkodó, és a privatizációs folyamatot befejező országokban nőtt a magántulajdonban lévő földek aránya, (lényegében Szlovákiában maradt csak 50 százalék alatt ennek aránya a kilencvenes években), ugyanakkor átlagos nagyságuk szinte minden országban nőtt, és ennek növekedése várható a jövőben is (Európai Bizottság, Mezőgazdasági Főigazgatóság, [1998]). Egyidejűleg a szövetkezetekből való kilépések miatt a kollektív formák átlagos nagysága csökkent. Azon hosszasan lehetne vitatkozni, hogy mekkora átlagos termőföldnagyság a hasznos és föleg életképes (a hasznosítási iránytól függően), de a magánföldeknél a növekvő birtoknagyság hosszabb távon megfigyelhető lesz. A 30 hektáros alsó határt - mely megfelelő gépesítettség mellett már életképes lehet - a jelöltek magánfarmjai közül csak Csehország éri el, és Lettország, valamint Észtország közelíti meg a kilencvenes évek második felében. A többi tagjelölt 
országnál a magánfarmok átlagos méretei ettől messze elmaradnak, vagyis jelentős birtokkoncentrációra van szükség a tagság elött.

V/7.12. sz. táblázat: Birtokformák szerinti termöföld megoszlás (százalék), és ezek átlagos egységnagysága a 90-es évek közepén

\begin{tabular}{|l|c|c|c|c|c|c|c|c|}
\hline \multirow{2}{*}{ Ország } & \multicolumn{2}{|c|}{ Szövetkezet } & \multicolumn{2}{c|}{ Állami gazdaság } & \multicolumn{2}{c|}{ Magánfarm } & \multicolumn{2}{c|}{$\begin{array}{c}\text { Egyéb forma } \\
\text { (vegyes vállalat, } \\
\text { kft) }\end{array}$} \\
\cline { 2 - 10 } & \% & ha & \% & ha & \% & ha & \% & ha \\
\hline Lengyelország & 3 & 222 & 7 & 620 & 82 & 7,0 & 8 & 333 \\
\hline Magyarország & 28 & 833 & 4 & 7779 & 54 & 3,0 & 14 & 204 \\
\hline Csehország & 43 & 1447 & 2 & 521 & 23 & 34,0 & 32 & 690 \\
\hline Szlovénia & & - & 4 & 371 & 96 & 4,8 & & - \\
\hline Észtország & & - & & - & 63 & 19,8 & 37 & 449 \\
\hline Románia & 12 & 451 & 21 & 3657 & 67 & 2,7 & & - \\
\hline Bulgária & 42 & 637 & 6 & 735 & 52 & 1,4 & & - \\
\hline Szlovákia & 60 & 1509 & 15 & 3056 & 5 & 7,7 & 20 & 1191 \\
\hline Litvánia & & - & 33 & 372 & 67 & 7,6 & & - \\
\hline Lettország & & - & 1 & 340 & 95 & 23,6 & 4 & 309 \\
\hline
\end{tabular}

Forrás: EU Bizottság, országstatisztikák alapján, [1998]

\section{V/7.6. Élelmiszeripar}

A tagjelölteknél termelt nyersanyag további feldolgozásra történő külföldre vitele a legtöbb terméknél nem rentábilis és jellemző. Az élelmiszeripar terén jelentős privatizációs tevékenység folyt le, ám a külföldi tőke elsősorban a magas hozzáadott értékü termékekre (italok, sör, dohány) szakosodott. A túlzott kapacitásokkal rendelkező és korszerütlen feldolgozóipari ágazatok (tejfeldolgozás, vágóhidak, őrlés) tőkehiányosak maradtak, ami sokáig fogja éreztetni negatív hatását a mezőgazdasági termelésre. Ugyanígy a költségek oldalán is nehéz helyzetbe került az élelmiszeripar a világpiaci árszintet elérő energia és mütrágya, valamint az alkalmazott gépek beszerzési költségeinek emelkedése miatt, ezért a nyereségesség és tőkeképződés biztosítása még a tagság után is komoly feladatot ró az új tagországokra.

\section{V/7.7. Állat- és növény-egészségügyi viszonyok}

Ez a szabályozórendszer jelenti az EU fejlődésének egyik legnagyobb vívmányát, melyet a belépő országoknak is megfelelően kell adaptálniuk. A már kibontakozott 
kereskedelmi liberalizáció ebben megfelelő kényszert hozott, hiszen bizonyos követelmények betartása nélkül már most sem lehetne a közösségi piacra lépni. Már az EU Bizottság 1995-ben írott tanulmánya megjegyezte, hogy ezen a téren a tagjelölt országok ragyogó eredményeket értek el már 1990 előtt is. Főleg a növényvédelem terén tudtak kimagasló sikereket elérni (pl. magnemesítés), elörelépésre elsősorban a képzésben van szükség.

Ennél nagyobb feladatot jelent azonban az állategészségügyi helyzet kezelése a nagy hullámban végrehajtott privatizációt követően. Ebben a védőoltások elégtelen volta, a nem megfelelő adminisztratív eszközök (pl. nyilvántartások) jelentenek gondot. Az ellenőrző laboratóriumok felszereltsége szerepel fontos beruházási igényként, amihez a vágóhidak modernizációja is hozzájárulhat. Az utóbbi időben az EU-t megrázó dioxyn és BSE-válságok miatt előtérbe került az élelmiszerbiztonság ügye is, amelyhez az új tagoknak is harmonizálniuk kell.

Az elért eredményeket tükrözi, hogy az Európai Megállapodások alapján több jelölttel (Csehország, Magyarország, Lengyelország és Szlovákia) tárgyalások indultak az állat- és növény-egészségügyi ekvivalencia megállapodásokról, sőt Csehországgal ezt sikerült is befejezni, Magyarország esetében is csak másodlagos jellegü, kisebb problémák miatt nem zárultak le a tárgyalások. Nagy szórást mutat az, hogy mely országok esetében kellett a Közösségnek védőintézkedéseket (behozatali tilalmak fertőzések miatt) tenni, és melyek esetében maradt ez minimális szinten. (Ebben a határos országok, vagyis Szlovénia, Magyarország, Lengyelország és Csehország jóval kisebb problémát jelentettek, mint pl. Románia). A legnagyobb kihívás ezért nem is a bővítés megkezdésében lesz a jelenleg határos országokkal, hanem annak biztosítása, hogy ezek az országok képesek legyenek keleti határaikon a beáramló veszélyekkel felvenni a küzdelmet, lokalizálni és kivédeni a belső piacra váró veszélyeket. Az EU-val jelenleg határos jelölt országokban az eddigi eredmények és fejlesztések erre garanciát adnak. (Ebböl a szempontból sajátosan kedvező a csehek helyzete, mivel keleti oldalain olyan országok veszik körül, amelyek vagy vele együtt bekerülnek az EU-ba, vagy legalábbis állat- és növényegészségügyi vonatkozásban inkább védőjelleget adnak, mintsem veszélyforrásként jelennek meg.) A fentiek alátámasztására lehet említeni azt a tényt is, hogy az EU-t sújtó sorozatos állategészségügyi botrányok (BSE, dioxyn, hormonkezelt állatok) a 
csatlakozásra várókra általában nem jellemzőek, részben a külterjesebb és természetesebb kultúra, részben a megfelelő ellenőrzési mechanizmusok miatt. Ugyancsak elönyként jelenik meg a tagországokkal szemben az is, hogy a tagjelöltek környezetvédelmi helyzete részben jobb (pl. kisebb volt a mütrágyázással kimerített földek veszélye), részben a strukturális politika révén javítható, (természetbarát művelési rendszer, erdősítés) amivel a mezőgazdasági munkaerő-felesleg is megfelelően köthető.

\section{RÉSZ; 8. FEJEZET \\ A MUNKAERŐPIACON JELENTKEZŐ VÁLTOZÁSOK}

Az Alapszerződések által biztosított egyik legfontosabb alapjog, a személyek és munkaerő szabad áramlása a csatlakozási tárgyalások és a bővítés egyik kritikus pontja a mezőgazdaság és a költségvetési kérdések mellett. Ez a probléma már élesen felvetődött az elöző olyan bővítési körök kapcsán, amelyben az EU-átlagnál fejletlenebb országok léptek be, akiknél nemcsak alacsonyabb volt az egy före jutó jövedelem, de a fizetések reálértéke is elmaradt az uniós átlagok mögött. Ez történt az 1986-ban megvalósított ibériai bővítés esetén is, amikor eredetileg hét éves átmeneti időszakot határoztak meg a munkaerő szabad áramlására, de ezt később öt év után felülvizsgálták, és hat évre mérsékelték, mivel kiderült, hogy az intézkedések fenntartásának semmilyen közgazdasági értelme nincs. Ennek ellenére a jelenlegi csatlakozási tárgyalások folyamán is olyan rezsimet alakított ki az Unió, amely a felek számára lehetővé teszi a maximum hét éves átmeneti időszak fenntartását a munkaerő szabad áramlására.

\section{V/8.1. A társult országok jelenlegi helyzete}

A tagjelölt országok európai munkaerőpiachoz való hozzáférését jelenleg is kétoldalú szerződések szabályozzák (munkavállalói kvóta, határon átnyúló szolgáltatások, ingázás), emellett szerepet játszanak a tagjelöltek és az EK, valamint tagállamai között kötött Európai Megállapodások. Ez utóbbi elsősorban a tagállamok vállalatai 
kulcsszemélyzetének, ezen felül a magyar és a cseh egyéni vállalkozók letelepedésével függ össze.

Az EU Bizottság becslései szerint jelenleg mintegy 300.000 legálisan foglalkoztatott személy él a közép-és kelet-európai tagjelölt országokból az EU mostani tagállamaiban. Ez az EU munkaerőpiacának 0,2 százaléka, és külső (nem EUállamokból származó) munkaerejének 6 százalékát reprezentálja, ami abszolút és relatív mércével is csekély mértékü. Nem változtat ezen a magánvállalkozók letelepedésének lehetősége sem, hiszen a megszorítások miatt - nemzeti elbánás feltételei - csak néhány esetben volt regisztrálható Magyarországból vagy Csehországból egyéni vállalkozó letelepedése az EU-országokba. Az 1990-97-es években az Unióba bevándoroltak között - az ezt mérö nyolc tagállam statisztikáiban - csak 13 százalékot képviselt a 10 tagjelölt ország (Hönekopp, [1999] nyomán Európai Bizottság, [2001]). 1998-ban a tagjelöltektől származó, az EUtagállamokban élő rezidensek (kb. 853.000 fö) mintegy 77 százaléka Németországban (65) és Ausztriában (12) volt található, ami földrajzi, történelmi okokkal, valamint a helyi stabil gazdasági viszonyokkal és jövedelmekkel magyarázható. Így a munkaerő áramlásban csak két ország érintett igazán, Ausztriában a térségből származó rezidensek képviselték 1995-ben a nemzeti munkaerőpiac 1,14 százalékát, Németországban 0,49, míg ehhez képest Görögországban csak 0,22, Svédországban 0,17, a többi tagországban kevesebb, mint 0,1 százalékát (Hönekopp, [1999] nyomán Európai Bizottság, [2001]). Ezek az arányok azt támasztják alá, hogy a közösségi munkaerőpiacra gyakorolt hatás jelentéktelen, és a külső (migráns) munkaerő viszonylatában is lényegtelen hányadot foglalnak el a tagjelöltektől származó munkavállalók.

Az Unióban alkalmazott régióbeli munkaerő származási helyét vizsgálva jelentős aránytalanságok tapasztalhatók. 1998-ban a becslések szerint a térségből származó munkavállalók fele érkezett Lengyelországból (ez meghaladja a régióban a lakossági arányukat), amit Románia követett 17 százalékkal, majd Magyarország 16 százalék, a Cseh Köztársaság és Szlovákia együtt 11 százalék és Bulgária 9 százalék következett (Brücker et al, [2000], Eurostat, Európa Tanács adatok alapján). Románia és Lengyelország a domináns, ők adják a munkavállalói létszám kétharmadát. A külföldi beruházások miatt (főleg a kulcsszemélyzet révén) az 1990- 
es évek eleje óta egyre több EU-állampolgár érkezik a tagjelölt országokba. Ennek következtében is csökkent az EU és a térség közötti migráció mérlege, (azaz a középés kelet-európai országokból mennyivel többen vállaltak munkát az Unióban, mint fordítva): 1997-ben csak 13.624 fö az 1991-ben regisztrált 124.839 főhöz képest. Magyarországon a migrációs egyenleg 1996 óta azt mutatja, hogy több uniós polgár vállal Magyarországon legálisan munkát, mint fordítva. A magyar munkavállalók száma felére csökkent az Unióban az évtized eleje óta (Magyar Tárgyalási Pozíció, [1999]).

Figyelembe véve, hogy a 10 tagjelöltből származó munkavállalók nagy része a határ menti régiókban vállal munkát, külön kell kezelni a határ menti ingázás jelenségét. Hönekopp 1999-es felmérései szerint 1998-ban Burgenlandban a teljes foglalkoztatottak több mint 6 százalékát teszik ki a tagjelöltektől származó munkavállalók, de ez az arány 2 százalék fölötti Alsó-Ausztriában és magas, 1 százalék feletti Bécsben is. Németország esetében Bajorország Csehországgal határos oldalán figyelhető meg nagyarányú régióbeli munkavállalás, de ott a foglalkoztatottak 2,5 százalékát sem haladja meg a térségbeli dolgozók aránya, vagyis itt a probléma súlya kisebb, mint Ausztria keleti tartományaiban. Az ingázás sajátos jellemzője az, hogy nem a jövedelmek reálértékét hasonlítják össze az ingázók, hanem a nominális jövedelmeket, mivel keresetüket hazai körülmények között, nem a munkavállalás helyszínén költik el (ld. V/8.6. alfejezet). Ezért a nominális jövedelemkülönbségek miatt még hosszabb távon (10-15 év) lehet az ingázással számolni.

\section{V/8.2. Spanyol és portugál tapasztalat}

Mint azt már ismert kutatók több ízben kimutatták (Magyarországon ld. Hárs Ágnes munkáit) az előző bővítésekkel kapcsolatos fenntartások a munkaerő-áramlás területén alaptalannak bizonyultak. Hasonlóan az EGK létrejötte utáni olasz helyzethez, ezekben az országokban sem indult meg lényeges addicionális kivándorlás az átmeneti időszak után, sőt visszatelepedésre is volt példa. A belépéssel kapcsolatos fellendülés perspektívája évi 15.000 spanyol és portugál visszacsalogatását eredményezte. Az átmeneti időszak alatt 7.000 engedélyt kaptak a két ország munkavállalói, de az átmenet lejárta után is csak évi 30.000 munkás 
telepedett le az EU-ban. Jelenleg 900.000 portugál (az ország lakosságának 9 százaléka), és 500.000 spanyol (kb. a lakosság 1,2 százaléka) lakik országán kívül más EU tagországban. Bár a Bizottság adatai szerint a volt NDK-ból az egyesülést követő tíz évben a munkaerő 7,3 százaléka vállalt munkát a nyugat-német oldalon, a kulturális és nyelvi azonosság miatt ez nem tekinthető mérvadónak. Összesen 5 millió EU-polgár él hazáján kívül (ebböl 2,7 millió munkavállaló), a 2000. évi 376 milliós létszámnak csak mintegy 1,3 százaléka (EU Bizottság, [2001]).

\section{V/8.3. Munkaerő-piaci helyzet az Európai Unióban}

Mint a demográfiai kérdésekről szóló fejezetben is jeleztem, Európa öregedése, a lakosság számának csökkenése elé nézünk. A születési ráták 10 ezrelék alatt stabilizálódtak, Németországban, Svédországban, Olaszországban megkezdődött a természetes fogyás, de hamarosan ezzel néz szembe valamennyi tagállam az írek és talán a franciák kivételével. Az ENSZ felmérései szerint Európának csak a jelenlegi lakosság fenntartásához évi 270.000 bevándorlóra lenne szüksége, (az eltartottak arányának esetében még többre), enélkül súlyos strukturális zavarokhoz fognak kialakulni. Ugyanakkor leszögezhetjük azt is, hogy az új tagállamok is követik a nyugat-európai tendenciát, vagyis lakosságuk száma a közeli jövőben - nagyrészt már most is - csökkeni fog, ami a népesség elöregedéséhez, és így az eltartottmunkavállalói arány megbillenéséhez fog vezetni. Mindez előrevetíti azt, hogy az új tagok nem fognak nettó munkaerő-kibocsátók lenni, sőt esetükben munkaerőigényről kell beszélnünk. (Az Európai Bizottság maximum évi 300.000 fős kivándorlással számol a tagság elején, mely a későbbiekben - a spanyol-portugál mintához hasonlóan - csökkenni fog.) Ezért különböző szakértői felmérések (ld. IOM, [1998]) 10-15 éves perspektívában azzal számolnak, hogy az új tagállamok jelentős munkaerő-beáramlásra szorulnak pl. a környező országokból, elsősorban Oroszországból, Belorussziából és Ukrajnából. Egyúttal arra is fel kell hívni a figyelmet, hogy az Unió - mely Lisszabonban elindította a tudásalapú, modern információs társadalom kialakítása felé vezető utat, és a globális versenyképessége érdekében a belső piac teljes megvalósítására törekszik - jelentős, mintegy 30 milliós munkahelyteremtést tűzött ki célul maga elé a következő évtizedre, ami meghaladja a jelenlegi 15 milliós munkanélküliségi sereget. Tekintettel arra, hogy a munkaerőpiac az EU-ban nyelvi, egzisztenciális, kulturális stb. okokból meglehetősen rugalmatlan, 
még azzal sem lehet számolni, hogy a munkaerőigény kielégítését a belső munkanélküliség felszámolásával lehet megvalósítani. (Erre jellemző példa a német kormány több ezer informatikai szakember bevonására vonatkozó terve az Unión kívülről.)

\section{V/8.4. Gazdasági kilátások}

Mint a makrogazdasági felzárkózásról írott fejezetben (V.1.) is láthattuk, mind az EU, mind a társult országok részéről az elkövetkező években fellendülésre lehet számítani. Ez jelentős konvergenciával jár a gazdasági fejlődés terén, mivel az új országok növekedési üteme általában meghaladja a régiekét. Jó esély van arra, hogy néhány ország (Szlovénia, Csehország, Magyarország, esetleg Szlovákia) számára 2005-re elérhető legyen az EU fejlettségének minimum 55-60 százaléka, ami már Portugália, Írország esetleg Görögország belépéskori fejlettségét mutatja. Ugyanakkor Romániának még jelentős különbséget kell ledolgoznia, de nagy a lemaradás Bulgáriában, valamint Litvániában és Lettországban is. Másrészt azt is láttuk, hogy mind a tagállamoknál, mind a tagjelölteknél csökkeni fog a munkanélküliség, de nemcsak a lakossági arányok módosulása miatt (többen lépnek nyugdíjba, mint ahányan fiatalon a munkaerőpiacra), hanem foglalkoztatásteremtéssel is. A munkahelyteremtés és a munkanélküliség ilyen jellegü kapcsolata ki fogja zárni a keleti tagállamokból meginduló jelentős kivándorlást. Mindez igaz a most megfelelő teljesítményt nyújtó Szlovéniára, Magyarországra, Csehországra, hiszen itt nem kockáztatható meg a meglévő munkahelyek elhagyása, ha ehhez a jövőben megfelelő reálbér-növekedés perspektívája párosul. Minden tagjelölt a gazdasági fellendüléssel párhuzamosan jelentős reálbér-növekedést tüzött maga elé a közép- és hosszú távú gazdasági programban, megkezdték (ld. Magyarország) a minimálbérnek az átlagbér felé közelítését (ld. IV/5. fejezet).

\section{V/8.5. Kulturális hatások, nyelvi, történelmi elem}

A közép-és kelet-európai tagjelölt országok lakossága nagy részénél nincsenek identitási zavarok, hiszen legtöbben olyan államok részeként éltek, amelyek évszázadok óta európai típusú állami és nemzeti fejlődést mutattak. Számukra ezért az EU-tagság nem jelent történelmileg olyan új kulturális közeget, amely őket eddigi 
értékeik feladására ösztönöznék, ha megfelelö fejlődési lehetőséget látnak maguk előtt. Mint látható a vonatkozó fejezetben (IV.2), az egyetlen tényezö, amely az életszínvonal különbségeken kívül a kivándorlásra ösztönözhet, az etnikai konfliktusok veszélye. Ebből a szempontból a homogén, és stabil történelmi tudattal rendelkező Magyarország, Csehország, Szlovénia jelent megfelelő abszorpciós erőt (itt csak a roma népesség jelenthet gondot), a többi országban ennél nagyobb a kivándorlási potenciál. Ezt igazolja az 1995-ben végrehajtott felmérés eredménye is (IOM), amely szerint a társult országok lakosságának ragaszkodása a nemzeti környezetükhöz nagyon erős, ami hasonlatos az EU-országok lakosságának kötődéséhez. Mivel ez a kapcsolat bizonyítottan fordítottan arányos a migrációs hajlamhoz, jól jelzi, hogy tömeges elszakadástól nem kell tartani, bár itt is országonként árnyaltabb a kép. (Talán ez a magyarázata annak, hogy a magas - több éven keresztül 20 százalék feletti - spanyol munkanélküliségi mutató ellenére nem volt lényeges spanyol kivándorlás, köszönhetően erős nemzeti kötődésüknek.) Az V/8.4. sz. táblázatban látható, hogy a szülöföldhöz való ragaszkodásban legmagasabb értéket mutató Magyarország lakosságának saját megyéjéhez való ragaszkodása is milyen magas, ami ugyan az országon belüli mobilitás gátja, de jelzi azt, hogy a nyugati határmenti ingázók várható száma az országon belüli áttelepülés nehézkessége miatt nem fog lényegesen nőni. Viszonylag mobilabb a lengyel, szlovák, lett lakosság, de ezek mértéke sem olyan magas, mint a német, brit, holland vagy a svéd mutatók.

\section{V/8.6. Jövedelemkülönbségek}

Nyugati oldalon sok elemző és politikus a jövedelmi tényezőt látja a legfontosabb elemnek a bővítés migrációs vitájában, mivel szerintük akkora jövedelmi különbségek vannak a térség országai és főleg a határos tagállamok (Ausztria és Németország) között, ami óhatatlanul is szívó hatást fog gyakorolni az új tagállamok munkaerejére. Az elemzéshez érdemes azt is figyelembe venni, hogy a jelenleg jelentősen leértékelt valuták megszünnek, a tagság után két-három évvel az új tagoknak be kell lépniük a közös valutaunióba (lásd: V/1. fejezet). A tagjelöltek gyors gazdasági felzárkózása miatt már a tagság előtt - a megnövekedett importszükséglet, valamint az ún. Balassa-Samuelson hatás miatt - valutájuk felértékelődik, 
ami euróban mérve a fizetések gyors - a reálbéreket meghaladó - felzárkózását eredményezi. (Európai Bizottság, Enlargement argumentaire, [2001])

1989 után a rendszerváltó országokban a nagy munkanélküliség okozta bő munkaerő-kínálat, valamint a versenyképesség kényszerü fenntartása a modernizációs fordulat alatt, továbbá a müködő tőke becsalogatásának kényszere oda vezetett, hogy a reálbérek jelentősen visszaestek. 1996-ban még egyik ország sem érte el az 1989-ben regisztrált reálbérét Csehország kivételével. Különösen súlyos volt ez a helyzet a bolgároknál és a balti államoknál, ahol a 89/96-os reálbérarány 60 százalék alá esett, de Magyarországon és Lengyelországban is csak 75-78 százalékát érték el a rendszerváltás előtti értéknek (ld. EBRD, Transition Report, [1998]). A kilencvenes évek második felében a tagjelölteknél a reálbérek felzárkózása megindult (a tagjelöltek és az EU Bizottság közös értékelései, [1996-2000]).

A fenti mechanizmusok miatt a kilencvenes évek végén az euróban mért nominális bérek felzárkózása is megkezdődött (lásd: IV/8.7. sz. táblázat). Az V/8.1. számú táblázatban azt elemeztem, hogy a bérek felzárkózásában leginkább érintett Ausztria átlagfizetéséhez képest hogyan változtak egyes tagjelölt országok euróban mért bruttó bérei. Ekkor látszik, hogy az elmúlt évtizedben komoly - a lengyeleknél háromszoros, a cseheknél majdnem kétszeres - bérfelzárkózás volt megfigyelhető. A havi átlagbéreket tekintve még az EU-n belül is jelentősek a különbségek, hiszen az OECD 2000-es adatai szerint a teljes munkaidőben foglalkoztatottaknál Portugália 1117 dolláros bruttó fizetési összeggel (1999-ben) nem sokkal haladta meg a vonatkozó szlovén mutatókat (1081 USD), és lényegesen - háromszor - kisebb volt a legmagasabb tagállami mutatónál (Belgium, 3331 USD), mégsem billent fel az EU-n belül a munkaerőpiac. Természetesen a kibővített EU-ban nem a portugálok belépésekor emlegetett 1:5, hanem ennél többségében magasabb tagállamok közötti bérarányok lesznek (kb. 1:3 és 1:30 szélső értékek között volt ez 1999-ben). A bérkülönbségek valóban jelentősek lesznek, amit az elöbbiekben jelzett felértékelési és reálbér-emelési (és ehhez nélkülözhetetlen termelékenység-növekedési) tendenciákkal lehet csak kiküszöbölni. Meglepő módon a kilencvenes években leginkább Lengyelország zárkózott fel, nominális bruttó bérei meghaladták 1999-ben a vonatkozó cseh és magyar mutatókat is, ami nemcsak a reálbérek emelkedését, hanem a zloty erősödését is jelzi. Ugyanez érvényes Szlovéniára is. A többi 
országnál a GDP fejlettségéhez képest jelentős az elmaradás a bérek fejlődése területén az EU-hoz vagy föleg Ausztriához képest.

V/8.1. sz. táblázat: A közép-európai tagjelölt országok bérmutatói

\begin{tabular}{|l|c|c|c|c|c|}
\hline \multirow{2}{*}{ Ország } & \multicolumn{2}{|c|}{$\begin{array}{c}\text { Bruttó bér } \\
\text { (euró) }\end{array}$} & $\begin{array}{c}\text { Bruttó bér } \\
\text { (Ausztria átlag } \\
\text { bruttó bérének } \\
\text { százalékában) }\end{array}$ & $\begin{array}{c}\text { Bruttó } \\
\text { bér } \\
\mathbf{1 9 9 9 / 1 9 9 0}\end{array}$ \\
\cline { 2 - 5 } & $\mathbf{1 9 9 0}$ & $\mathbf{1 9 9 9}$ & $\mathbf{1 9 9 0}$ & $\mathbf{1 9 9 9}$ & \\
\hline Csehország & 183 & 366 & 9 & 16 & 2,00 \\
\hline Magyarország & 213 & 325 & 11 & 14 & 1,53 \\
\hline Lengyelország & 108 & 430 & 6 & 19 & 3,98 \\
\hline Szlovákia & 179 & 259 & 9 & 11 & 1,45 \\
\hline Szlovénia & $610^{*}$ & 953 & 31 & 41 & 1,56 \\
\hline Bulgária & $61^{*}$ & 108 & 3 & 5 & 1,77 \\
\hline Románia & 151 & 128 & 8 & 6 & 0,85 \\
\hline Ausztria & $\mathbf{1 9 5 7}$ & $\mathbf{2 3 2 0}$ & $\mathbf{1 0 0}$ & $\mathbf{1 0 0}$ & $\mathbf{1 , 1 9}$ \\
\hline
\end{tabular}

Forrás: WIIW, [2000], saját számítás

Megjegyzés: * 1991

A balti államokban (ezt a WIIW nem számolta) a bruttó fizetések 1994-98 között szintén duplájára nőttek, és jelenleg a magyar és szlovák fizetésekhez hasonlíthatók.

Természetesen a munkaerő-vándorlásnál a vásárlóerő-paritáson mért bérkülönbségek dominálnak. Erre vonatkozóan a magyar kormánynak a csatlakozási tárgyalásokon megfogalmazott egyik érve az volt, hogy már az 1996-os számítások szerint is a PPS-ben mért éves magyar kereset (6716 USD) az akkori portugál kereset 63,5 százalékát tette ki. Míg az EU-ban a legmagasabb és a legalacsonyabb fizetések közt különbség (Portugália és Dánia) 1:3 volt (10.573 illetve 28.993 USD), azonban ez már csökkent a portugál belépés időpontjához képest. Magyarországon PPS-ben számolva már kevesebb, mint ötszörös $(1: 4,3)$ volt a fizetési különbség a legmagasabb dániai jövedelmekhez képest, ami jobb mutató, mint a portugálok belépéskori szintje. (OECD, [1997]) Megfigyelhetjük, hogy Portugáliából sincs kezelhetetlen munkaerő-áramlás Dánia felé, ezért joggal feltételezhetjük, hogy néhány év múlva Magyarországról sem lesz a legmagasabb átlagfizetést biztosító tagállamok felé. 
A keleti bővítés bizonyos hatását jól tükrözi a német egyesülés tapasztalata. Míg 1991-ben a keresetek az új tartományokban a nyugati bérek 50 százalékára rúgtak, ez 1997-re már elérte a 75 százalékot (Boeri és társai, [2000]). Sajátos módon az ún. fehérgalléros alkalmazottaknál a lemaradás 1991-ben az átlagnál nagyobb volt, mint a fizikai alkalmazottaknál, de az évtized végére ez kiegyenlítődött.

A szabad munkaerő-áramlásnak a bérekre gyakorolt hatását Németországban és Ausztriában, mint az igazán érintett országokban, empirikus minták alapján végezte el a Herbert Brücker vezette kutatói csoport 1999-ben. Eredményeik alapján a külföldi eredetü munkások egy százalékos növekedése Ausztriában a bérek 0,25, míg Németországban 0,6 százalékos csökkenését eredményezik. Eltérő azonban a fizikai és a szellemi munkások bérére gyakorolt hatás: míg Ausztriában a fizikai munkásoknál 0,35 százalékos csökkenést jelent, a szellemi munkásoknál lényegtelennek mutatkozik, addig Németországban a fizikai munkásoknál 1,6, a szellemi munkásoknál 0,1 százalékos csökkenést okozna. Ugyanakkor az elbocsátás veszélye egy százalék külső munkaerő bebocsátása esetén az osztrákoknál 0,8 százalékkal, míg a németeknél 1,6 százalékkal nő. Tekintettel arra, hogy a munkaerő ilyen mértékű (1 százalékos) növekedése az előbbiekben jelzettek szerint rövid időn belül a társult országokból nem valószínü - Lengyelország és Románia lehet kivétel a tagság elején - ennek mértéke marginális, tényleges hatása minimális (Németországban a munkaerő 1 százaléka kb. 650 ezer fó, míg Ausztriában 35 ezer fö). Ezért jelentős, a bérszínvonalat és a munkanélküliséget érzékelhető módon befolyásoló hatása csak a lengyel és a román munkaerőmozgás liberalizációjának lesz.

Mint már említettem a nominális bérkülönbségeknek kiemelkedő szerepük lesz az ingázás ösztönzésében. Az Európai Bizottság véleménye szerint a határmenti munkaerő 1 és 8 százaléka közötti része fog ingázni a tagság után. Ez elsősorban Ausztriában jelent komoly gondot, mivel itt a lakosság kétharmada (beleértve a fővárost is) él olyan közel a cseh, magyar és szlovák határhoz, ahol a bővítés után az ingázó munkaerő elérheti az osztrák munkahelyeket (lásd: V/8.2. sz. táblázat). Emellett még az az osztrák aggodalom is megjelenik, hogy az ingázó munkaerő elfogadja az osztrák minimálbért, ami veszélyezteti az osztrák munkahelyeket és a kollektív szerződésekben kialkudott béreket. Az Európai Bizottság felmérései szerint 
az ingázás lehetősége az első időben mintegy 110.000 potenciális főt jelenthet a határ menti területeken, és az - a jelenlegi 50.000 fős főleg boszniai menekült befogadása mellett - már megterheli az osztrák munkaerőpiacot főleg a határ mentén.

V/8.2. sz. táblázat: Az EU és a közép- és kelet-európai országok határmenti régióinak az ingázás szempontjából lényeges paraméterei (1998)

\begin{tabular}{|c|c|c|c|c|c|}
\hline Határmenti terület & $\begin{array}{l}\text { Havi bruttó } \\
\text { fizetések } \\
\text { aránya } \\
\text { (árfolyam- } \\
\text { paritás) }\end{array}$ & $\begin{array}{c}\text { Munkanél- } \\
\text { küliségi } \\
\text { ráta } \\
\text { EU* } \\
(\%) \\
\end{array}$ & $\begin{array}{l}\text { Munkanél- } \\
\text { küliségi } \\
\text { ráta } \\
\text { KKE }^{* *} \\
(\%)\end{array}$ & $\begin{array}{c}\text { Népsürüség } \\
\mathbf{E U} \\
\left(\mathbf{f o ̈} / \mathbf{k m}^{2}\right)\end{array}$ & $\begin{array}{c}\text { Népsürüség } \\
\text { KKE } \\
\left(\mathbf{f o ̈} / \mathbf{k m}^{2}\right)\end{array}$ \\
\hline Finno./Észto. & 11 & 7,7 & 9,7 & 200 & 32 \\
\hline Németo./Lengyelo. & 20 & 21,6 & 13,0 & 81 & 82 \\
\hline K-Németo./Cseho. & 20 & 18,9 & 11,1 & 232 & 152 \\
\hline Bajoro./Cseho. & 15 & 11,7 & 7,3 & 230 & 130 \\
\hline Ausztria/Cseho. & 16 & 6,7 & 6,1 & 58 & 71 \\
\hline Ausztria/Szlovákia & 13 & 7,6 & 12,8 & 470 & 188 \\
\hline Ausztria/Magyaro. & 16 & 8,4 & 12,3 & 70 & 88 \\
\hline Ausztria/Szlovénia & 49 & 7,1 & 7,6 & 97 & 109 \\
\hline Olaszo./Szlovénia & 48 & 5,6 & 7,6 & 191 & 98 \\
\hline Görögo./Bulgária & 7 & 10,6 & 16,1 & 71 & 66 \\
\hline
\end{tabular}

Forrás: Brücker és társai, in Európai Bizottság, [2001]

Megjegyzés: A határmenti területek 50 kilométeres mélységben számolva

* EU-oldalon fekvő határmenti régióban

** közép-és kelet-európai oldalon fekvő határmenti régióban

Az osztrák kamarák és a kutatóintézetek felmérései szerint jelenleg a burgenlandi bérek az osztrák átlagbérek 80-90 százalékán mozognak, és a vásárlóerő-paritáson mért különbség a szlovák határ menti régióhoz képest 100:66, míg a magyar határ menti régióhoz képest 100:46 körül mozgott a kilencvenes évek végén (nominális értéken ennél jóval kevesebb). Modellezésük szerint az utóbbi években megfigyelt felzárkózási ütemet figyelembe véve - feltételezve a reálérték és a nominális érték előzőekben indokolt konvergenciáját - 2010-re a határ menti magyar területek el fogják érni a burgenlandi reálbérek mintegy felét. Ennél gyorsabb ütemü (kétszeres) felzárkózás esetén - amire reális esély van -, ez az arány már eléri addigra nominális értéken is a 60 százalékot, ami már közel jár ahhoz a határhoz, amikor az ingázásnak nincs értelme, hiszen ez pótlólagos költségekkel - utazási költség, kieső idő - jár (ld. V/8.3. sz. táblázat). Az nyilvánvaló, hogy az áttelepedéssel járó munkaerő-vándorlás e felzárkózási ütem mellett tömegesen értelmetlenné válik 2005 és 2010 körül. 
Természetesen bizonyos munkakörök esetében nagyobb lehet az olló a két ország között, és ekkor a munkavállalói hajlam is nőhet.

V/8.3. sz. táblázat: Fizetések konvergenciája a magyar-osztrák határon a jelenlegi felzárkózási ütem (alapszenárió) illetve ezt megduplázó felzárkózás

(gyors felzárkózási szenárió) alapján

\begin{tabular}{|c|c|c|c|c|c|c|c|c|}
\hline \multirow{3}{*}{ Év } & \multicolumn{4}{|c|}{ Alapszenárió } & \multicolumn{3}{c|}{ Gyors felzárkózási szenárió } \\
\cline { 2 - 9 } & \multicolumn{2}{|c|}{ PPS } & \multicolumn{2}{|c|}{ Árfolyamon } & \multicolumn{2}{c|}{ PPS } & \multicolumn{2}{c|}{ Árfolyamon } \\
\cline { 2 - 9 } & GyMS & Vas & GyMS & Vas & GyMS & Vas & GyMS & Vas \\
\hline $\mathbf{1 9 9 5}$ & 40,41 & 37,27 & 18,54 & 17,14 & 41,14 & 38,00 & 19,17 & 17,74 \\
\hline $\mathbf{2 0 0 0}$ & 45,84 & 42,76 & 28,54 & 26,61 & 50,07 & 47,07 & 32,60 & 30,91 \\
\hline $\mathbf{2 0 0 5}$ & 51,10 & 48,13 & 38,83 & 37,10 & 58,35 & 55,61 & 46,81 & 45,13 \\
\hline $\mathbf{2 0 1 0}$ & 56,11 & 53,29 & 49,34 & 47,65 & 65,73 & 63,32 & 59,87 & 58,38 \\
\hline
\end{tabular}

Forrás: WiiW, WiFO és a budapesti Növekedési Intézet közös kiadványa, Bécs, [1999]

Megjegyzés: GyMs: Győr-Moson Sopron megye

Az ingázásra vonatkozóan sajátos késleltetett hatást látunk, vagyis a közgazdaságilag racionális küszöb az ingázás feladására minden bizonnyal 5-6 évvel később jelenik meg, tehát a feszültség ennyivel lesz hosszabb az EU oldaláról tekintve a letelepedéses vándorláshoz képest. Ez minden bizonnyal külön rezsim megvitatását eredményezi a csatlakozási tárgyalásokat követő kétoldalú egyeztetéseken a határmenti területekre vonatkozóan.

\section{V/8.7. Migrációs hajlandóság}

Az előzőekben elemzett tényezők - gazdasági felzárkózás, bérek közeledése, valuták felértékelődése, kulturális kötődések - mellett érdemes megvizsgálni azokat a tényeket, amelyek a potenciális tagállamok migrációs hajlandóságát mutatják.

A kilencvenes évek közepén készült felmérés, mely a mobilitási hajlamot vizsgálja 0-4-ig terjedő skálán (lásd: V/8.4. sz. táblázat) a lakóhelytől számított különböző távolságra való letelepülés függvényében. A felmérés azt mutatta, hogy a társult országok munkaerejének hajlandósága az ország elhagyására az EU-tagállamok lakosainál kisebb. A lettek, csehek, magyarok és a szlovénok értékei az osztrákokhoz vagy az írekhez hasonlíthatóak, ennél nagyobb a külföld felé megnyilvánuló 
migrációs hajlam viszont Bulgáriában, Lengyelországban, Szlovákiában, (Románia kimaradt ebből a vizsgálati részből), bár ezek sem haladják meg a legmobilabb európai értékeket.

V/8.4. sz. táblázat: Migrációs hajlandóság néhány országban 0-4-ig növekvö skálán

\begin{tabular}{|l|c|c|c|c|c|}
\hline \multicolumn{1}{|c|}{ Ország } & $\begin{array}{c}\text { Közvetlen } \\
\text { szomszédság }\end{array}$ & Város & Megye & Ország & Kontinens \\
\hline Oroszország & 2,04 & 1,92 & 1,64 & 1,65 & \\
\hline Lettország & 2,11 & 1,87 & 1,67 & 1,72 & 1,53 \\
\hline Bulgária & 2,58 & 2,48 & 2,32 & 2,31 & 2,08 \\
\hline Lengyelország & 2,79 & 2,50 & 2,37 & 2,07 & 1,91 \\
\hline Csehország & 2,92 & 2,41 & 2,31 & 1,70 & 1,53 \\
\hline Szlovákia & 3,06 & 2,72 & 2,54 & 2,16 & 1,90 \\
\hline Magyarország & 2,37 & 2,10 & 1,88 & 1,53 & 1,37 \\
\hline Szlovénia & 2,68 & 2,50 & 2,23 & 1,83 & 1,65 \\
\hline Ausztria & 2,54 & 2,19 & 2,03 & 1,60 & 1,43 \\
\hline Kelet-német & 3,06 & 2,62 & 2,43 & 1,71 & 1,58 \\
\hline Nyugat-német & 3,36 & 2,96 & 2,67 & 2,15 & 1,89 \\
\hline Hollandia & 3,45 & 3,20 & 2,92 & 2,34 & 2,08 \\
\hline Svédország & 3,30 & 2,79 & 2,60 & 2,42 & 2,16 \\
\hline Norvégia & 3,41 & 3,01 & 2,51 & 2,12 & 1,88 \\
\hline Olaszország & 3,16 & 2,69 & 2,47 & 2,00 & 1,82 \\
\hline Spanyolország & 2,89 & 2,75 & 2,52 & 2,03 & 1,92 \\
\hline Nagy-Britannia & 3,37 & 3,05 & 2,75 & 2,21 & 2,07 \\
\hline Írország & 2,60 & 2,35 & 2,16 & 1,81 & 1,67 \\
\hline Kanada & 3,68 & 3,27 & 2,86 & 2,43 & 2,30 \\
\hline USA & 3,74 & 3,37 & 2,99 & 1,93 & 1,87 \\
\hline Ausztrália & 3,40 & 3,11 & 2,69 & 2,09 & 2,09 \\
\hline Új-Zéland & 3,35 & 2,94 & 2,79 & 2,28 & 2,10 \\
\hline Japán & 2,53 & 2,39 & 2,26 & 1,61 & 1,71 \\
\hline Fülöp-szigetek & 2,92 & 2,85 & 2,70 & 2,61 & 2,47 \\
\hline
\end{tabular}

Forrás: Csepeli György - Örkény Antal: Nemzetközi összehasonlító felmérés a nemzeti öntudatról, Szociológiai Szemle 1998/3., [1998]

A Nemzetközi Migrációs Szervezet (IOM) 1998-ban készített összefoglaló statisztikai felmérést a közép-európai országokban arról, hogy milyen migrációs hajlandóságot lehet kimutatni a külföldön eltöltendő idő függvényében (V/8.5.sz. táblázat), illetve, hogy ténylegesen milyen konkrét elökészületeket tettek a megkérdezettek külföldi munkavállalás érdekében (V/8.6. sz. táblázat). 
V/8.5. sz. táblázat: A közép-európai tagjelölt országok lakosságának migrációs hajlandósága (a megkérdezettek százalékában)

\begin{tabular}{|c|c|c|c|c|}
\hline Ország & $\mathbf{1 .}$ & $\mathbf{2 .}$ & $\mathbf{3 .}$ & $\mathbf{4 .}$ \\
\hline Bulgária & 13 & 17 & 19 & 7 \\
\hline Szlovénia & 29 & 26 & 18 & 7 \\
\hline Magyarország & 33 & 30 & 20 & 8 \\
\hline Lengyelország & 46 & 37 & 18 & 14 \\
\hline Románia & 48 & 47 & 36 & 21 \\
\hline Csehország & 49 & 44 & 24 & 11 \\
\hline Szlovákia & 56 & 47 & 27 & 10 \\
\hline
\end{tabular}

Forrás: Nemzetközi Migrációs Szervezet, [1998]

Megjegyzés: A válaszok a valószínü, vagy nagyon valószínü megnevezések százalékát mutatják.

1. néhány hétre szeretne külföldre menni dolgozni

2. néhány hónapra szeretne külföldre menni dolgozni

3. néhány évre szeretne külföldre menni dolgozni (tartós migráció)

4. végleg külföldön szeretne letelepedni és dolgozni

V/8.6. sz. táblázat: A közép-és kelet-európai polgárok elökészületei a migrációra a megkérdezettek százalékában (1998)

\begin{tabular}{|l|c|c|c|c|c|c|c|}
\hline \multicolumn{1}{|c|}{ Ok } & $\begin{array}{c}\text { Lengyel- } \\
\text { ország }\end{array}$ & Szlovákia & $\begin{array}{c}\text { Magyar- } \\
\text { ország }\end{array}$ & Szlovénia & Bulgária & Románia & $\begin{array}{c}\text { Cseh- } \\
\text { ország }\end{array}$ \\
\hline $\begin{array}{l}\text { Nyelvet } \\
\text { tanult }\end{array}$ & 39 & 17 & 13 & 14 & 10 & 13 & 24 \\
\hline $\begin{array}{l}\text { Képesítéseket } \\
\text { szerzett }\end{array}$ & 21 & 9 & 10 & 13 & 7 & 9 & 17 \\
\hline $\begin{array}{l}\text { Értékesítette } \\
\text { tulajdonát }\end{array}$ & 11 & 2 & 0 & 2 & 0 & 2 & 1 \\
\hline $\begin{array}{l}\text { Információkat } \\
\text { gyüjtött }\end{array}$ & 38 & 14 & 8 & 9 & 15 & 14 & 13 \\
\hline $\begin{array}{l}\text { Munkát } \\
\text { kért }\end{array}$ & 28 & 5 & 4 & 2 & 6 & 4 & 5 \\
\hline $\begin{array}{l}\text { Lakóhelyet } \\
\text { talált }\end{array}$ & 23 & 4 & 2 & 2 & 3 & 1 & 5 \\
\hline $\begin{array}{l}\text { Engedélyért } \\
\text { folyamodott }\end{array}$ & 24 & 3 & 3 & 2 & 5 & 2 & 3 \\
\hline $\begin{array}{l}\text { Kapcsolatot } \\
\text { létesített }\end{array}$ & 16 & 2 & 6 & 2 & 7 & 4 & 3 \\
\hline Egyéb & 12 & 2 & 2 & 3 & 2 & 4 & 4 \\
\hline
\end{tabular}

Forrás: Nemzetközi Migrációs Szervezet, [1998] 
A két táblázat összehasonlításából azonnal kitünik, hogy nagyon erös a migrációs szándék a lengyelek esetében, hiszen nemcsak azt vallották be sokan, hogy hosszabbrövidebb idöre szeretnének kivándorolni, és máshol dolgozni, hanem ehhez komoly előkészületeket is tettek. 11 százaléka a megkérdezetteknek már eladta tulajdonát, tekintélyes hányaduk információkat gyüjt, sőt már engedélyeket is kért és lakóhelyet is keresett. Ugyanakkor kisebb a tényleges lépések súlya a magyarok, szlovénok, valamint csehek esetében, ami azt jelenti, hogy érdeklődésük még inkább csak látens, mint valódi. A két táblázat együttes vizsgálata megerősíti, hogy a tényleges migrációs szándékok esetében szakadás található a régióban, hiszen a megfelelően felzárkózó és fejlődő élcsapatban - Magyarország, Csehország és Szlovénia alacsony a migrációs, és föleg a hosszú távú külföldi munkavállalási szándék. A többi országnál a nehézségek fokozódásával párhuzamosan nő a külföldi munkavállalási hajlam, sőt mint látjuk annak hossza is. A felmérés alapján elmondható, hogy a megfelelő társadalmi helyzet, fejlődési perspektíva és kulturális gyökerek megléte esetén nincs magas migrációs szándék, még a jelentős roma populációval rendelkező országokban sem.

Ezt támasztja alá az a felmérés (szintén az IOM részéről), amely a kitelepülni vágyóknál a távozás okait vizsgálja. Az alapvetően domináns gazdasági okok mögött (jobb életszínvonal, magasabb bérek) nagyon jelentős az etnikai konfliktusokra való hivatkozás (Szlovákiában 56 százalék, Romániában 41 százalék, de még Magyarországon is 34 százalék ezt nevezte meg), ami az etnikai vagy nemzeti kisebbség magas arányát jelzi a kivándorolni készülők között. Szintén a politikai okok között található az is, hogy Szlovákiában és Romániában a emigrálni készülők 65 , illetve 68 százaléka a nagyobb szabadságot jelölte meg vonzó faktorként, míg a többiek esetében ez 50 százalék alatt van.

Végül még érdemes megvizsgálni azt, hogy a kitelepülni vágyók hova kívánnak tartós vagy végleges munkavégzésre kiutazni. Ebből kiderül, hogy a fejlettebb tagjelöltek (Magyarország, Szlovénia, Csehország, Lengyelország) válaszadói nagyon jelentős hányadban jelölték meg az Egyesült Államokat, tehát más kontinensbeli célországot, másrészt az országok zöménél Németország (valamennyi ország) és Ausztria (csehek és magyarok valamint a szlovákok), tehát a szomszédok 
előkelő helyet foglaltak el a célországok között. A csehek jelölték meg nagyobb arányban Franciaországot, Skandináviát és Nagy-Britanniát, a többi ország az EU-n belül kisebb szerepet játszik célországként. Érdemes még megjegyezni, hogy a szlovákok 5 százaléka jelölte meg Csehországot kivándorlási célországként, egyébként a keresztvándorlás a tagjelöltek között nem jelentős. (Nem véletlen, hogy a cseh kormány részben emiatt kért és kapott hosszabb átmeneti időszakot a többi belépő térségbeli ország munkavállalóinak automatikus beengedésére.) A felmérés, amely a térségbeli államok közül vizsgálta Jugoszlávia, Horvátország és Belorusszia valamint Ukrajna lakosságának - a tagjelölteknél jóval magasabb - kivándorlási hajlamát, kimutatta azt is, hogy a tartósan EU-ban letelepedni szándékozó ukránok 16-20 százaléka jelölte meg - a fó EU-célországokkal azonos preferenciaként Lengyelországot, Csehországot, Magyarországot, Szlovákiát vagy Szlovéniát. Ez azt jelzi, hogy számukra szinte mindegy, hogy a régi vagy az új EU-tagoknál tudnak dolgozni, nekik ez egyaránt vonzó perspektíva. Így a hamarosan szintén munkerőhiányban szenvedő Közép-Európa számára Ukrajna - és valószínűleg Oroszország - kínálja magát nagy tételben munkaerő-utánpótlásként.

Összefoglalásként megállapítható, hogy az összes, e fejezetben is említett elemzések egyetértenek abban, hogy a jelenlegi mintegy 850 ezer, tíz közép- és kelet-európai országból érkező rezidens személy - ebbe bele kell érteni a teljes családot is - évi mintegy 270-370 ezer fővel fog bővülni az EU-ban a szabad piaci viszonyok között az évtized végére, amikor ez elérheti a 1,5-2 millió föt. (Ebből 53 százalék lengyel, és 19 százalék román állampolgár az Eurostat becslései szerint.) Majd ezután ez a szám meredeken csökkenni kezd, sőt 2020 és 2025 körül már stagnálni fog, ami az erőteljes visszaáramlás jegyeit mutatja. Ezek a kalkulációk azonban nagyon gyengén értelmezik az előbbiekben jelzett kulturális és történelmi tényezőket, a spanyolportugál példát, és inkább matematikai elemzéseken alapulnak. Ausztriában lehet a közép-kelet-európai bevándorlók aránya a legmagasabb, ahol az évtized végére a jelenlegi 8 millió lakoshoz a 300-350 ezer fő betelepedőt lehet jósolni, ami a lakosság mintegy 3,8-4,4 százalékát jelentené. 


\section{RÉSZ; 9. FEJEZET}

\section{ENERGIAPOLITIKA}

Tekintettel arra, hogy maga az Európai Unió is energia-ellátásában importfüggő, mind biztonsági, mind környezetvédelmi szempontból fontosságot tulajdonít annak, hogy e téren milyen adottságú országok csatlakoznak az EU-hoz. A környezetvédelem nemcsak az Alapszerződésekben lefektetett céljai közé tartozik, hanem nemzetközi kötelezettségek (így a Kyotói Konferencia) is összehangolt stratégiára készteti az EU-országokat, ami az új tagállamok felvételénél kritériummá vált. További lényeges szempont, hogy az új országok jelenleg és a jövőben mekkora piacot képviselnek, illetve, hogy az integrálódó belső piacba mennyire lesznek képesek bekapcsolódni. Sajátos szempont az is, hogy a csatlakozó országok milyen típusú nukleáris energiatermeléssel rendelkeznek, ezek milyen veszélyforrást jelentenek, milyen kontroll alá lehet helyezni, pontosabban: a jövőben megvalósítandó nukleáris energiapolitikájukat hogyan lehet befolyásolni.

\section{V/9.1. Az új tagországok energiapiacának nagysága és energiafüggősége}

Az EU 15 országában 1997-ben a teljes energiatermelés 759,2 millió tonna olajegyenérték (toe) volt, míg a 10 csatlakozni kívánó ország esetében ez 203,2 millió toe, vagyis a lélekszám várható 28 százalékos növekedésével az energiatermelés 26,8 százalékos növekedése állítható szembe. Lengyelország energiatermelésével (101 millió toe) 1997-ben az EU-ban a negyedik helyen állt volna, Csehország (31,5) vagy Románia termelése (31) Olaszország $(34,7)$ és Svédország (31,7) termeléséhez, míg Magyarország (12,7) termelése nagyságrendjében Belgiumhoz $(12,6)$ hasonlítható (lásd: V/9.1. sz. táblázat). A piaci nagyságrendek érzékelhetősége miatt, valamint az ellátás biztonságának fontossága végett érdemes mérlegelni az energiafüggőséget mindkét félnél. 
V/9.1. sz. táblázat: Föbb energiahatékonysági mutatók a tagállamokban illetve a társult országokban (1997)

\begin{tabular}{|l|r|r|r|c|}
\hline \multirow{2}{*}{ Ország } & \multirow{2}{*}{$\begin{array}{c}\text { Lakosság } \\
\text { (millió fö) }\end{array}$} & \multicolumn{2}{c|}{ Energia (millió toe) } & \multirow{2}{*}{$\begin{array}{c}\text { Energia } \\
\text { fogyasztás } \\
\text { (toe/fö) }\end{array}$} \\
\cline { 3 - 4 } & & fogyasztás & termelés & \\
\hline Belgium & 10,07 & 59,7 & 12,6 & 5,93 \\
\hline Dánia & 5,27 & 24,5 & 20,3 & 4,65 \\
\hline Németország & 82,01 & 346,3 & 138,3 & 4,22 \\
\hline Görögország & 10,48 & 29,1 & 9,9 & 2,78 \\
\hline Spanyolország & 39,29 & 111,0 & 30,8 & 2,83 \\
\hline Franciaország & 58,49 & 245,3 & 123,2 & 4,19 \\
\hline Ínország & 3,65 & 12,4 & 2,9 & 3,40 \\
\hline Olaszország & 57,46 & 168,9 & 34,7 & 2,94 \\
\hline Luxemburg & 0,41 & 3,3 & 0,0 & 8,05 \\
\hline Hollandia & 15,56 & 88,3 & 65,6 & 5,67 \\
\hline Ausztria & 8,06 & 28,0 & 9,1 & 3,47 \\
\hline Portugália & 9,93 & 22,0 & 3,6 & 2,22 \\
\hline Finnország & 5,13 & 33,1 & 14,7 & 6,45 \\
\hline Svédország & 8,84 & 51,7 & 31,7 & 5,85 \\
\hline Egyesült Királyság & 58,90 & 225,9 & 261,8 & 3,84 \\
\hline Bulgária & 8,28 & 11,0 & 10,0 & 1,33 \\
\hline Szlovénia & 1,98 & 4,6 & 2,9 & 2,32 \\
\hline Csehország & 10,29 & 25,5 & 31,5 & 2,48 \\
\hline Észtország & 1,45 & 3,0 & 3,8 & 2,07 \\
\hline Magyarország & 10,13 & 16,8 & 12,7 & 1,66 \\
\hline Lettország & 2,45 & 3,9 & 1,7 & 1,59 \\
\hline Litvánia & 3,70 & 5,0 & 4,0 & 1,35 \\
\hline Lengyelország & 38,66 & 67,4 & 100,9 & 1,74 \\
\hline Románia & 22,52 & 29,0 & 31,0 & 1,29 \\
\hline Szlovákia & 5,38 & 11,9 & 4,7 & 2,21 \\
\hline KKE 10 & $\mathbf{1 0 4 , 8 4}$ & $\mathbf{1 7 8 , 1}$ & $\mathbf{2 0 3 , 2}$ & $\mathbf{1 , 7 0}$ \\
\hline EU 15 & $\mathbf{3 7 3 , 5 5}$ & $\mathbf{1 4 4 9 , 5}$ & $\mathbf{7 5 9 , 2}$ & $\mathbf{3 , 8 8}$ \\
\hline & & & & \\
\hline
\end{tabular}

Forrás: Eurostat, [2000]

Az Eurostat adatai szerint az EU-tagállamok energiatermelése nőtt (az 1994. évi 721,6 millió toe-ról az 1997-ben 759,2 millió toe-ra, vagyis 5,2 százalékkal). Összességében hasonlóan szerény növekedést (2,7 százalék) mutatott a társultak mérlege is.

Ugyanakkor az EU-államok nettó importfüggősége igen jelentős, 1997-ben meghaladta a 47 százalékot. Ráadásul a tagállamok közül kizárólag Nagy-Britannia képes többlettermelésre (36 millió toe 1997-ben), igaz az EGT-ben tag - így a belső piacon is müködö - Norvégia ugyanebben az évben 187 millió toe többletet ért el. A társult államok közül Csehország, Lengyelország és Románia 1997-ben nettó energiaexportőr volt. Lengyelország (34 millió toe) feleslege lényeges mennyiség, 
még ha ennek radikálisabb csökkenése is várható. Ugyanakkor többlete (6 millió toe) jelentős még Csehországnak.

A társult országok integrációja kapcsán elmondható, hogy összességében 178,1 millió toe fogyasztás állítható szembe 203,2 millió toe termeléssel, ami 1997-ben 14 százalékos energia felesleget jelentett. A mélyebb elemzésből azonban kiderül, hogy az EU számára legfontosabb kőolajból csak Románia számít nettó exportőrnek (az EU függősége a jelenlegi 75 százalékról 2020-ra legalább 85 százalékra nő). Földgázból sem rendelkeznek a tagjelöltek exportárualappal, sőt importfüggőségük itt is jelentős (Csehország esetében 90 százalék feletti, Lengyelországban 70 százalék, Magyarországon 60 százalék), mely függőség az EU-hoz hasonlóan a jövőben nőni fog. A jelenlegi EU a földgáz 52 százalékát képes saját forrásból ellátni, bár a fogyasztás növekedése afelé mutat (a földgázzal üzemelő erőművek veszik át a széntüzelésű erőművek helyét), hogy e szénhidrogén fajtából 40 százalék alá süllyed önellátásának aránya (Zöld könyv az Európai Energiapolitikáról, Európai Bizottság, [2000]).

Ennél borúsabb képet kapunk akkor, ha az EU Bizottság jóslata beválik, miszerint az EU jelenlegi 50 százalék körüli energiafüggősége 2030-ra (vagyis a bővítés után) 70 százalékra növekszik. Ennek okai a következők:

- A jelenlegi tagállamoknál a következő időszakra a Bizottság enyhe (30 év alatt 11 százalékos) energiaigény növekedést jósol, míg az újonnan csatlakozók igénynövekedése eléri az évi 2 százalékot. Utóbbi országok még nem jutottak el a jelenlegi EU-színvonalú energiatakarékos szolgáltatói szektor kiépítéséig, valamint itt a legnagyobb fogyasztói ágazat, a közlekedés még robbanásszerü növekedés elött áll, részben a várható gazdasági növekedési ütem (évi 2-4 százalék), részben a személygépkocsik nagyarányú elterjedése miatt. Összességében a kibővített - Norvégiát is magába foglaló - 30 tagú EU 25 százalékos fogyasztási igénynövekedése várható 2030-ra a jelenlegi helyzethez képest. Ez még akkor is jelentős növekmény, ha közben a hatékonysági mutatók javulnak, és így a várható GDP-növekedéshez (a jelenlegi tagállamoknál 91 százalékos, a tagjelölteknél pedig jóval 100 százalék feletti) viszonyított fogyasztás növekedése kisebbre prognosztizálható. 
- Amennyiben a jelenlegi energiafelhasználási trendek folytatódnak, akkor az EU mostani és 2030-ban várható fogyasztása az egyes energiaforrások bontásában az alábbiak szerint alakul:

V/9.2. sz. táblázat: Az EU energiafelhasználási szerkezete energiaforrások szerint

\begin{tabular}{|c|c|c|c|}
\hline Energiaforrások & $\begin{array}{c}2000 \\
\text { (százalék) }\end{array}$ & $\begin{array}{r}2030 \\
\text { (százalék) }\end{array}$ & $\begin{array}{l}\text { Áram előállítás } \\
\text { költsége 2000-ben } \\
\text { (cent/kwh) }\end{array}$ \\
\hline Kőolaj & 41 & 38 & \\
\hline Földgáz & 22 & 29 & 3,18 \\
\hline Szilárd tüzelő & 19 & 16 & 3,29 (importszénnel) \\
\hline Megújítható forrás & 6 & 8 & $\begin{array}{l}\text { 4,46 (szélenergia } \\
\text { szubvencióval) }\end{array}$ \\
\hline Nukleáris energia & 15 & 6 & 4,51 \\
\hline Összesen & 100 & 100 & \\
\hline
\end{tabular}

Forrás: Európai Bizottság, Energia Főigazgatóság, [2000]

Megjegyzés: Kerekített értékek

A fenti táblázatból egyértelmü, hogy a földgáz lehet a legolcsóbb előállítású alapanyag az áramellátáshoz még akkor is, ha a megújuló források igénybevételét az EU-ban szubvencionálják (környezetvédelmi és energiafüggetlenségi okokból), illetve a szén esetében az olcsóbb importot részesítik előnyben a hazai termelés helyett.

- Az energiafelhasználás növekedését elsősorban a közlekedés és kisebb mértékben a háztartások fogják jelenteni, a többi hagyományos ágazat minden bizonnyal szinten tartást vagy csökkenést fog mutatni technikai fejlődésének megfelelően. Ezt még csak növeli a bővítés hatása. Mindez pedig nyilvánvalóan a kőolaj és földgáz dominanciáját fogja erősíteni feltéve, ha nem lép életbe új energiapolitika (pl. adóintézkedésekkel, szubvenciókkal a megújítható energiaforrások felé terelés). Mivel a jelenlegi trendek az EU-ban a nukleáris energia visszaesését jelzik (lényegében nincs új nukleáris erőmü nyitás az EUban az utóbbi másfél évtizedben), az EU nehezen tudja tartani a Kyotoban vállalt 
ígéretét - 2008-2012 között 8 százalékos szén-dioxid kibocsátás-csökkentés 1990-hez képest -, sőt valószínüleg a szennyezettség még növekedni is fog.

Az ellátásbiztonság és a belső piac importigénye kapcsán ki kell emelni azt is, hogy a közösségi jogszabályok rendelkeznek arról, hogy a kőolajkészletek terén (három kategóriában: kerozin, dízelolaj, benzin) minden tagállamnak 90 napot meghaladó tartalékokkal kell rendelkezni. Ezt a jelenlegi csatlakozási tárgyalásokon valamennyi társult országnak el kell fogadnia, ami a nagyobb piacot tekintetbe véve stabilizáló erővel hat. (2000-ben Magyarország és Csehország már rendelkezett ezzel a tartalékkal, sőt Magyarország meghaladta a 100 napi készletet is.)

Nem mellékes szempont az sem, hogy az új tagállamok az energiabiztonság és környezetvédelmi okokból prioritásként meghatározható kőolaj és földgázból milyen függőséggel rendelkeznek, honnan szerzik be a számukra lényeges kőolaj- és gázszármazékokat. (A jelenlegi és a kibővülő EU szénhidrogén importfüggőségét az előzőekben jellemeztem.) Kőolajból az EU jelenleg ismert készlete 8 évre lenne elegendő a mostani fogyasztási szint mellett, ráadásul ennek kitermelési költsége 711 USD körül mozog a közel-keleti 2-3 USD-vel szemben (Zöld Könyv az Európai Energiapolitikáról, [2000]). Tekintve, hogy az EU kőolajimportjának több mint a fele (a teljes felhasználás 51 százaléka) az OPEC-országokból érkezik, a függőség jelentős, hiszen igazi termelésnövekedési potenciállal csak Szaúd-Arábia rendelkezik; politikai fordulat esetén Irak (mely még jelentős tartalékokat tudhat magáénak) sem tudja az EU ellátási problémáját végleg megoldani. Ezért az EU figyelme a volt FÁK-térség felé fordul, bár itt magasak ugyan a kitermelési költségek, de az EU hosszú távon is olyan olajárban érdekelt, amely kiszámítható, és mindig lehetőséget ad a diverzifikációra (20 USD fölötti olajár esetén ez a volt szovjet terület mindenféleképpen gazdaságosan kiaknázható). Ezért az oroszországi és a Kaszpi-tengeri tartalékok feltárásában és Európába juttatásának megoldásában már lépéseket is tettek (ld. Prodi bizottsági elnök EU-orosz energiaegyüttmüködéséről szóló terve, [2000]). Ebből a szempontból a kőolaj és gázimportban történelmi okokból jelentős orosz függőségben lévő új tagállamok felvétele kiegyensúlyozott helyzetet teremthet, hiszen számukra a hazai termelést szinte kizárólag az orosz kőolaj egészíti ki. Ugyanez érvényes a mind jobban előtérbe 
kerülő földgáz esetében is, ahol a társult országok az import teljes vagy legalább 80 százalékát elérő hányadát szerzik be az oroszoktól. Szlovákián keresztül halad pl. az EU gázellátásának 25 százaléka. Meg kell jegyezni, hogy ebben nem lehet kivetnivalót találni, hiszen a kiépített infrastruktúra és a piaci kapcsolatok miatt ez a leggazdaságosabb forrás. A lényeg ezért abban áll, hogy az energiarendszerben megteremtsék az alternatív importra a reális feltételeket. (A kőolaj, földgáz és áram tekintetében ez a szlovén, cseh és magyar fél részéről már kiépült, ami azt jelenti, hogy az orosz beszerzés esetleges megszünésével is képesek a szükséges energiát beszerezni a kellő mennyiségben.)

V/9.3. sz. táblázat: Az EU köolajimportja eredet szerint, 1999 (\%)

\begin{tabular}{|c|c|}
\hline FÁK & 18 \\
\hline Mexikó & 2 \\
\hline Norvégia & 21 \\
\hline Opec & 51 \\
\hline Szaúd-Arábia & 13 \\
\hline Líbia & 10 \\
\hline Irán & 9 \\
\hline Irak & 7 \\
\hline Nigéria & 4 \\
\hline Algéria & 4 \\
\hline Venezuela & 2 \\
\hline Kuvait & 2 \\
\hline Egyéb & 8 \\
\hline
\end{tabular}

Forrás: Európai Bizottság, [2000]

Ebből is látható, hogy a bővítés révén - tekintettel arra, hogy az új tagok importjukat a volt Szovjetunióból, elsősorban Oroszországból szerzik be - az OPEC domináns szerepe csökkenni fog, emellett megkönnyíti az utat a FÁK felé a tranzit szempontjából.

V/9.4. sz. táblázat: Az EU földgázimportja eredet szerint, 1999 (\%)

\begin{tabular}{|c|c|}
\hline Eredet & Százalékos megoszlás \\
\hline FÁK & 41 \\
\hline Algéria & 29 \\
\hline Norvégia & 25 \\
\hline Egyéb & 5 \\
\hline
\end{tabular}

Forrás: Európai Bizottság, [2000] 
Mivel a csatlakozni kívánó országok is alapvetően a FÁK-országokból importálnak földgázt (pl. Csehország 79 százalék, Magyarország 83,5 százalék, Lengyelország és Litvánia 100 százalék, vagy Szlovákia 97 százalék), ezért a bővítés után a FÁK és ezen belül Oroszország szerepe nőni fog.

Földgáz terén az EU a világ tartalékainak 2 százalékával rendelkezik (kb. ugyanakkora hányada van Norvégiának is), ami a jelenlegi fogyasztás mellett is csak 20 évre elegendő készletet jelent. Érdemes még megjegyezni, hogy bár kőszénből az EU jelentős tartalékokkal rendelkezik, ami főleg a bővítés után növekszik meg a tagjelölt országok (elsősorban Lengyelország) készleteivel, de gazdaságossági és környezetvédelmi okokból szerepe csökkeni fog az energiatermelésben, és ezt is hamarosan teljes mértékben importból fogják megoldani. Hasonlóan a kőszénhez, a nukleáris energia visszaeső termelését alapvetően import nyersanyagból fogják megoldani, mivel a jelenlegi ismert és prognosztizálható árak mellett nem gazdaságos a saját uránium készlet (a világ készletének 2 százaléka) kiaknázása.

V/9.5. sz. táblázat: A kőolaj és földgáztartalék százalékos megoszlása a világon, 1997-ben

\begin{tabular}{|c|c|c|}
\hline Térség & Köolaj & Földgáz \\
\hline EU-15 & 1 & 2 \\
\hline FÁK & 7 & 39 \\
\hline Amerika & 16 & 10 \\
\hline Afrika & 7 & 7 \\
\hline Közel- és Közép- Kelet & 65 & 34 \\
\hline Távol-Kelet, Óceánia & 4 & 6 \\
\hline
\end{tabular}

Forrás: Eurostat, [2000]

Megjegyzés: A földgáz esetében Norvégia is rendelkezik még jelentős tartalékokkal 


\section{V/9.2. Energiaszerkezet}

Az EU országaiban 1988. és 1997. között a szén és a lignit energiatermelésen belüli aránya 31 százalékról 16,5 százalékra esett vissza. Csökkenő trend figyelhető meg a társult országok felhasználásában is bár Csehországban és főleg Lengyelországban ez még túlzottan magas. Az EU-országokban a kőolaj-felhasználás aránya számottevően nem csökkent (az 1994. évi 21,2 százalékról 1997-ben 20,3 százalékra). A társult országokban a csökkenés általában magasabb (Eurostat, [2000]). A földgázfelhasználás aránya (mely 2,5-szer kevesebb szén-dioxidot bocsát ki, mint a széntüzelésű erőmü ugyanakkora energiafelhasználása esetén) Magyarországon 1998-ban a 40 százalékos volt, amivel az EU-ban a harmadik legmagasabb szint lenne, de Szlovákia (33) és Románia (38), vagy Csehország (20) is meghaladja, vagy megközelíti az EU (22) átlagot(lásd: V/9.6. sz. táblázat). Az említett tagjelöltek részéről ez egy korszerü felhasználási arány, hiszen földgázból lehet a legolcsóbban áramot előállítani (lásd: V/9.2. sz. táblázat), ami még a környezetet is védi.

A nukleáris energia részesedése a teljes energiafelhasználásban az Európai Unió országaiban különböző, hiszen míg Dániában, Görögországban, Írországban, Olaszországban, Luxemburgban, Ausztriában és Portugáliában nincs atomerömü, addig Belgiumban 20, Franciaországban 37, és Svédországban 34 százalékot képvisel a teljes energiafelhasználásban. A társult országokat tekintve Észtországban, Lettországban és Lengyelországban nincs nukleáris termelés, ugyanakkor az energiafogyasztáson belül Litvániában 35, Bulgáriában 21, Szlovéniában 19, Szlovákiában 18, míg Magyarországon 14 százalékot képvisel. A politikai okokból érzékeny nukleáris termelés tehát a tagjelölteknél is fontos szerepet tölt be az energiaellátásban.

Érdemes kiemelni a megújítandó energiaforrások - vízi erőmű, szélenergia, biomassza, geotermikus energia - arányának növekedését (az EU-ban 1998-ra 1989hez képest 26 százalékkal nőtt az energiatermelésen belüli aránya), tekintve, hogy alternatív energiaforrásként nincs importfüggősége és káros környezeti hatása. Természetesen a felhasználás mértéke eltérő az egyes tagállamokban, például Finnországban 17, Portugáliában a teljes energiatermelés 14 százalékát teszi ki, míg Belgiumban vagy az Egyesült Királyságban minimális arányt (1 százalék) képvisel. 
A társult országokban is elkezdtek a megújítható energiaforrások felhasználásával foglalkozni, Romániában, Szlovéniában és Észtországban magas, 10 százalékot elérő az aránya, igazán csak Magyarország mutatója (1 százalék) szerényebb.

V/9.6. sz. táblázat: A teljes energiafelhasználás megoszlása 1998-ban az EU tagállamaiban és a tagjelölteknél (százalék)

\begin{tabular}{|l|c|c|c|c|c|}
\hline \multicolumn{1}{|c|}{ Ország } & $\begin{array}{c}\text { Szilárd } \\
\text { anyag }\end{array}$ & $\begin{array}{c}\text { Köolaj és } \\
\text { származékai }\end{array}$ & Földgáz & Nukleáris & Megújítható \\
\hline Ausztria & 23 & 43 & 23 & 0 & 11 \\
\hline Belgium & 15 & 42 & 22 & 20 & 1 \\
\hline Dánia & 26 & 46 & 20 & 0 & 8 \\
\hline Finnország & 22 & 34 & 10 & 17 & 17 \\
\hline Franciaország & 7 & 36 & 13 & 37 & 7 \\
\hline Németország & 25 & 41 & 21 & 11 & 2 \\
\hline Görögország & 35 & 60 & 0 & 0 & 5 \\
\hline Írország & 22 & 54 & 22 & 0 & 2 \\
\hline Olaszország & 16 & 11 & 59 & 14 & 0 \\
\hline Luxemburg & 4 & 71 & 23 & 0 & 2 \\
\hline Hollandia & 13 & 37 & 47 & 1 & 2 \\
\hline Portugália & 16 & 67 & 3 & 0 & 14 \\
\hline Spanyolország & 16 & 54 & 11 & 13 & 6 \\
\hline Svédország & 28 & 32 & 1 & 34 & 5 \\
\hline Egyes. Királyság & 24 & 45 & 15 & 15 & 1 \\
\hline Bulgária & 36 & 23 & 15 & 21 & 5 \\
\hline Csehország & 50 & 20 & 19 & 8 & 3 \\
\hline Lengyelország & 66 & 19 & 10 & 0 & 5 \\
\hline Észtország & 52 & 25 & 12 & 0 & 10 \\
\hline Magyarország & 16 & 29 & 40 & 14 & 1 \\
\hline Lettország & 33 & 39 & 24 & 0 & 4 \\
\hline Litvánia & 6 & 35 & 17 & 35 & 7 \\
\hline Románia & 18 & 29 & 38 & 3 & 12 \\
\hline Szlovákia & 26 & 19 & 33 & 18 & 4 \\
\hline Szlovénia & 18 & 42 & 11 & 19 & 10 \\
\hline
\end{tabular}

Forrás: Európai Bizottság, Zöld Könyv az Európai energiapolitikáról, [2000]

\section{V/9.3. Nukleáris biztonság}

A nukleáris energia előállításának és felhasználásának biztonságának erősítése terén a bővítés több kedvező következménnyel jár a tagországok számára:

- Az EU az új tagok felvétele esetén (sőt már a tagfelvételi tárgyalások folyamán is) konkrét hatást tud gyakorolni szomszédai nukleáris energiapolitikájára. Ez azt eredményezheti, hogy az új tagoknál megfelelő segítséggel és koncepcióval el 
tudja érni, hogy az atomlétesítmények teljesen biztonságos formát öltsenek. Ez egyrészt jelenti a meglévő atomerőművek biztonsági rendszerének átalakítását, vagy bezárásának kierőszakolását (lásd: V/9.7. sz. táblázat).

- Az EU politikai eszközökkel el tudja azt is érni, hogy a leendő új tagállamok energiakoncepciójukban ne számoljanak új nukleáris létesítmények építésével sem. (Az EU-ban az utóbbi két évtizedben már nem adtak át új nukleáris erőmüvet.)

- Komoly probléma viszont a nukleáris hulladék elhelyezésének megoldása, mivel ennek visszavételétől Oroszország nyilvánvalóan vonakodik majd, még akkor is, ha az uránt az új tagok tőlük vásárolják. Kedvező viszont, hogy a nukleáris erőművek müködtetéséhez szükséges nyersanyag beszerzésében, valamint a hulladék elhelyezésében közös európai koncepciókat lehet kidolgozni, és a későbbiekben érvényesíteni.

- Az új tagállamokra az EURATOM szerződés ki fog terjedni, ami szélesebb lehetőségeket (ellenőrzés, pénzsegély, stb.) ad az ott lévő nukleáris létesítmények biztonságosabbá tételére a jelenlegi helyzettel szemben.

- Az EU rákényszerül arra, hogy az atomerőmüvek biztonságáról konkrét jogszabályokat dolgozzon ki, illetve ezek megoldására programokat léptessen életbe. Mivel jelenleg az atomerőmüvek biztonsága az EU-ban csak politikai követelmény és a nemzetközi szervezetek ez irányú jogi garanciáinál az EU saját új tagjaitól előre biztosítékot kér, a fenti jogszabályok elfogadása elkerülhetetlen. 
Az alábbiakban ismertetem az Európai Bizottság által felkért szakértői csoport (WENRA) véleményét a tagjelöltek létesítményeinek jelenlegi helyzetéről.

V/9.7. sz. táblázat: Nukleáris erömüvek a tagjelölt országokban

\begin{tabular}{|l|l|l|c|}
\hline \multicolumn{1}{|c|}{ Ország } & \multicolumn{1}{|c|}{ Erőmü } & \multicolumn{1}{c|}{ WENRA vélemény } & Bezárás \\
\hline Bulgária & $\begin{array}{l}\text { Kozludy 1-4 } \\
\text { Kozludy 5-6 }\end{array}$ & $\begin{array}{l}\text { Nem megfelelö } \\
\text { Modernizáció szükséges, ez } \\
\text { folyik }\end{array}$ & 2003. \\
\hline Csehország & $\begin{array}{l}\text { Duhovay 1-4 } \\
\text { Temelin 1-2 }\end{array}$ & $\begin{array}{l}\text { 2004-ben megfelel } \\
\text { Keleti és nyugati technológia } \\
\text { összehangolása szükséges }\end{array}$ & - \\
\hline Magyarország & Paks 1-4 & Nyugat-európai szint & - \\
\hline Litvánia & Ignalina 1-2 & Nem megfelelö & 2005. \\
\hline Románia & Cernavoda & Biztonságosnak mondható & - \\
\hline Szlovákia & Bohunice V1 & $\begin{array}{l}\text { Javult, de nem } \\
\text { teljesen jó } \\
\text { 2002-ben megfelelö lesz }\end{array}$ & 2006. \\
& Bohunice V2 & $\begin{array}{l}\text { Megfelelö } \\
\text { Megfelelö }\end{array}$ & - \\
\hline Szlovénia & Krsko & \multicolumn{2}{|c}{} \\
\hline
\end{tabular}

Forrás: WENRA, [2000], illetve a tagjelölt országok kormányainak vállalásai a csatlakozási tárgyalásokon

\section{V/9.4. Az energiahatékonyság}

A vizsgálatot három területre érdemes fókuszálni:

1. mekkora az adott ország lakosságának fogyasztása

2. mekkora az energiafogyasztás szektorális megoszlása

3. mekkora az adott ország GDP-jének elöállításához szükséges energiaigény (azaz $1 \mathrm{~kg}$ olajegyenértékü /kgoe/ energiával mennyi USD hazai terméket lehet elöállítani). 
V/9.8. sz. táblázat: Föbb energiahatékonysági mutatók a tagállamokban illetve a társult országokban (1997)

\begin{tabular}{|c|c|c|c|c|c|}
\hline \multirow{2}{*}{ Ország } & \multicolumn{2}{|c|}{$\begin{array}{c}\text { Energiahatékonyság } \\
\text { (Ppp usd/kgoe) }\end{array}$} & \multirow{2}{*}{$\begin{array}{l}\text { Közlekedési } \\
\text { szektor } \\
\text { (százalék) }\end{array}$} & \multirow{2}{*}{$\begin{array}{l}\text { Ipari szektor } \\
\text { (százalék) }\end{array}$} & \multirow{2}{*}{$\begin{array}{c}\text { Egyéb } \\
\text { szektor } \\
\text { (százalék) }\end{array}$} \\
\hline & 1980 & 1997 & & & \\
\hline Belgium & 2,2 & 4,1 & 25,2 & 34,3 & 40,5 \\
\hline Dánia & 2,5 & 6,0 & 31,3 & 20,0 & 48,7 \\
\hline Németország & - & 5,2 & 28,5 & 26,3 & 45,2 \\
\hline Görögország & 4,0 & 5,7 & 39,0 & 25,2 & 35,8 \\
\hline Spanyolország & 3,5 & 5,9 & 41,4 & 32,3 & 26,3 \\
\hline Franciaország & 2,7 & 5,0 & 32,0 & 25,7 & 42,3 \\
\hline Írország & 2,2 & 6,0 & 33,8 & 21,5 & 44,7 \\
\hline Olaszország & 3,7 & 7,3 & 31,9 & 30,9 & 37,2 \\
\hline Luxemburg & - & - & 45,4 & 31,9 & 22,7 \\
\hline Hollandia & 2,1 & 4,6 & 27,4 & 26,8 & 45,8 \\
\hline Ausztria & 3,2 & 6,7 & 28,6 & 28,1 & 43,3 \\
\hline Portugália & 5,1 & 7,1 & 35,2 & 35,6 & 29,2 \\
\hline Finnország & 1,6 & 3,2 & 18,7 & 45,7 & 35,6 \\
\hline Svédország & 2,0 & 3,5 & 22,9 & 37,2 & 39,9 \\
\hline Egyesült Királyság & 2,4 & 5,3 & 33,5 & 24,5 & 42,0 \\
\hline Bulgária & 0,8 & 1,9 & 10,4 & 58,8 & 30,8 \\
\hline Szlovénia & - & 4,4 & 33,6 & 28,4 & 38,0 \\
\hline Csehország & - & 3,3 & 15,1 & 50,5 & 34,4 \\
\hline Észtország & - & 2,0 & 19,1 & 30,7 & 50,2 \\
\hline Magyarország & 1,9 & 4,0 & 17,0 & 29,1 & 53,9 \\
\hline Lettország & - & 3,1 & 19,4 & 27,1 & 53,5 \\
\hline Litvánia & - & 2,6 & 25,4 & 29,6 & 45,0 \\
\hline Lengyelország & 1,0 & 2,7 & 14,9 & 37,6 & 47,5 \\
\hline Románia & 1,4 & 3,2 & 14,7 & 45,5 & 39,8 \\
\hline Szlovákia & - & 3,0 & 10,7 & 51,0 & 38,3 \\
\hline
\end{tabular}

Forrás: Eurostat, [2000], Világbank, [2001]

Megjegyzés: Szektorok részesedése a teljes energiafogyasztásból

Az egy före jutó energiafogyasztásban az EU tagállamai 1,2-4-szeres mértékben meghaladják a társult országok fogyasztását (ld. V/9.1. sz. táblázat utolsó oszlopa). Az adatok összehasonlító elemzéséhez figyelembe kell venni az éghajlati tényezőket (hidegebb országban többet kell füteni), valamint a földrajzi elemeket (gyérebben lakott országban nagyobb a szállítási-utazási kötelezettség). Hasonló népsürüségi és földrajzi fekvésű tagországot figyelembe véve, az egy före jutó energiafogyasztás Ausztriában (3,47 toe) meghaladja bármelyik közép-európai tagjelölt ország mutatóját (pl. a legmagasabb egy főre jutó energiafogyasztással rendelkező 
Csehország 2,47 toe mutatóját), de a tagjelöltek közlekedési szektorának várható gyors növekedésével ez a különbség csökkenni fog.

A fajlagos energiahatékonysági mutatók vizsgálatánál (lásd: V/9.8. sz. táblázat 2. és 3. oszlopa) nemcsak az EU-tagállamokban, hanem a társultaknál is jelentős fejlődés figyelhető meg az egységnyi energiafelhasználásra eső GDP-termelés terén 1997-ben 1980-hoz képest. Szlovénia $(4,4)$ és Magyarország $(4,0)$ fajlagos teljesítménye Hollandiához $(4,6)$ és Belgiumhoz $(4,0)$ hasonlítható, de nem sokkal marad el Franciaország $(5,0)$ teljesítményétől sem, ami a gazdaság hatékonyságának fejlődését jelzi, bár a tagjelölt országokban a személygépkocsik sürüsége (ami növeli az energiafogyasztást és csökkenti a fajlagos hatékonyságot) még nem éri el az európai színvonalat (lásd: közlekedési fejezet). A többi tagjelölt ország a privatizációval és a modernizációval párhuzamosan jelentős hatékonyságnövekedést ért el (pl. Lengyelország), de teljesítményük még elmarad az európai szinttől, sőt felzárkózásuk még hosszabb időt vesz igénybe.

Összességében elmondható, hogy az Európai Unió a bővítéssel nem enyhít az energiafüggőségén, hanem ezt még növeli is, mivel az új tagok kőolajból és földgázból nagyrészt importra szorulnak. A relatív hatékonysági mutatók elmaradnak az európaitól, de a felzárkózás megindult. Nagy előnyt jelent viszont a bővítés az energiaellátás szempontjából lényeges kőolaj és földgáz importja eredetének diverzifikálása felé, valamint a volt szovjet utódállamok irányába éppen e célból kiépítendő tranzit szempontjából is. Az energia-előállítás forrásaiban a tagjelöltek követik az európai trendeket, de attól még több esetben (pl. a szilárd tüzelőanyagok nagyobb hányada miatt) elmaradnak. Ezért a tagság első időszakában az új tagállamok az energia-előállítás révén általában az EU-nál nagyobb környezetszennyezést okoznak, de ennek trendje meredeken csökkenni fog. Ebben a legjobb példát éppen Magyarország mutathatja, ahol a földgázalapú energiatermelés európai viszonylatban is magas (40 százalékos). A bővítés haszna lehet az is, hogy az európai közvéleményben nagy nyugtalanságot kiváltó, és Nyugat-Európában visszaszoruló nukleáris energiatermelés terén az új tagállamok a tagság - de már az előtt is - kellő befolyás alá helyezhetők, és így egész Európa nukleáris biztonsága növelhető. Az energiafelhasználás hatékonysága Magyarországon és Szlovéniában 
már az EU-átlagához hasonlítható, a többi országban ez még jócskán elmarad a megkívánttól.

\section{RÉSZ; 10. FEJEZET KÖRNYEZETVÉDELEM}

A sürün lakott és magasan fejlett európai földrész már évtizedekkel ezelőtt szembesült a fejlődésből eredő szennyezések káros hatásaival, ezért az utóbbi 15 évben fokozatosan beépítette politikái közé a környezetvédelem ügyét, ez látható az előző fejezetek (közlekedés, energia, mezőgazdaság) elemzésénél is. Mivel a szennyeződés nem ismer határokat, a sürün lakott európai kontinensen bármelyik országnál történő környezetszennyezés érinti a kontinens többi részét is, így az EU tagállamait is, ami akár bővítéssel, akár nélküle egyértelmüen fokozott veszélyek kezelését teszi szükségessé. Elég, ha csak a csernobili tragédia után átélt nyugateurópai félelmekre és a nukleáris felhő vándorlására gondolunk, de ezt támasztja alá a Balti-tenger mostani erős, vagy a német folyók lengyel eredetű szennyeződése. A bővítés alkalmas lesz arra is, hogy a folyóvizekben jobban kiszolgáltatott országok, így az alvízi térségnek minősíthető Magyarország is képes legyen szomszédaival a kapcsolatokat rendezni.

\section{V/10.1. A jelenlegi állapot}

A leendő tagállamok viszonylag kedvező természeti adottságokkal rendelkeznek, magas az erdők aránya és nagy a biodiverzitás, hiszen viszonylag nagy számú egyedi vagy védett (ritka) állat- és növényfaj található területükön (lásd: V/10.1. sz. táblázat). (Ebből a szempontból a Kárpád-medence a maga sajátosan összefüggő erdőségeivel, illetve a sajátos klímával együtt járó növény- és állatvilágával nemzetközileg is kimagaslóan fontos örökségnek minősül.) 
V/10.1. sz. táblázat: Az erdöterület aránya az egyes országok területéböl, illetve a védett emlösök, halak, madarak aránya az ismert fajok százalékában

\begin{tabular}{|l|c|c|c|c|c|}
\hline \multicolumn{1}{|c|}{ Ország } & $\begin{array}{c}\text { Erdőterület } \\
\text { (százalék) }\end{array}$ & $\begin{array}{c}\text { Erdővagyon } \\
\text { használata } \\
\text { (kitermelés/ } \\
\text { növedék)* }\end{array}$ & $\begin{array}{c}\text { Emlősök } \\
\text { (százalék) }\end{array}$ & $\begin{array}{c}\text { Madarak } \\
\text { előfordulása } \\
\text { (százalék) }\end{array}$ & $\begin{array}{c}\text { Halak } \\
\text { (százalék) }\end{array}$ \\
\hline Ausztria & 47,6 & 0,6 & 35,4 & 37,0 & 65,5 \\
\hline Belgium & 22,2 & 0,9 & 31,6 & 27,5 & 54,3 \\
\hline Dánia & 10,5 & 0,6 & 24,0 & 10,6 & 18,2 \\
\hline Finnország & 75,5 & 0,8 & 11,9 & 6,7 & 11,9 \\
\hline Franciaország & 31,4 & 0,7 & 20,2 & 14,3 & 6,6 \\
\hline Németország & 30,1 & 0,4 & 36,7 & 29,2 & 68,2 \\
\hline Görögország & 22,8 & 0,6 & 37,9 & 13,0 & 24,3 \\
\hline Írország & 8,8 & 0,6 & 6,5 & 21,8 & 33,3 \\
\hline Olaszország & 23,3 & 0,3 & 32,2 & 24,7 & - \\
\hline Luxemburg & 34,4 & 0,5 & 54,1 & 50,0 & 38,2 \\
\hline Hollandia & 9,2 & 0,6 & 15,6 & 27,1 & 82,1 \\
\hline Portugália & 35,3 & 0,8 & 17,3 & 13,7 & 18,6 \\
\hline Spanyolország & 32,3 & 0,5 & 21,2 & 14,1 & 29,4 \\
\hline Svédország & 73,5 & 0,7 & 18,2 & 8,6 & 12,7 \\
\hline Magyarország & $\mathbf{1 8 , 9}$ & $\mathbf{0 , 6}$ & $\mathbf{7 1 , 1}$ & $\mathbf{1 8 , 8}$ & $\mathbf{3 2 , 1}$ \\
\hline Csehország & $\mathbf{3 4 , 1}$ & $\mathbf{0 , 7}$ & $\mathbf{3 3 , 3}$ & $\mathbf{6 6 , 1}$ & $\mathbf{2 9 , 2}$ \\
\hline Lengyelország & $\mathbf{2 9 , 7}$ & $\mathbf{0 , 6}$ & $\mathbf{1 5 , 5}$ & $\mathbf{1 6 , 6}$ & $\mathbf{2 7 , 1}$ \\
\hline
\end{tabular}

Forrás: OECD Környezeti Adattár, [1999] in: Környezetpolitikai Vizsgálatok Magyarország, OECD, [2000]

Megjegyzés: * fakitermelés/fa termőképesség (évi folyónövedékkel mérve)

A kedvező természeti adottságok mellett kiemelek két olyan tényezőt, amely az emberi beavatkozás következményeként hatással van a környezet állapotára:

- Az erdővagyon kitermelése a növedékek állományához képest a három jelzett OECD-tag és EU-ban tagjelölt ország a tagállamokkal megegyező vagy jobb mutatót jelez. A három tagjelölt országnál magas az ún. jelentősebb védett területek aránya, amely az ország összterületéből magyar és lengyel oldalon meghaladja a 9 százalékot, míg a cseheknél ez az arány több, mint 16 százalék. (Az EU-ban 7 tagállam esetében ez 9 százalék alatti értéket képvisel.) (OECD Környezeti Adattár, [1999])

- A termőföld szennyezettségét érintő mutató, a mütrágya felhasználás a rendszerváltás után jelentősen visszaszorult a mezőgazdasági termelésben (lásd: V/10.2. sz. táblázat). 1999-ben Magyarország, Csehország és Lengyelország mütrágya felhasználása jóval alacsonyabb volt $\left(5-7 \mathrm{t} / \mathrm{km}^{2}\right)$, mint a legtöbb EU 
tagállamnál, mindössze Portugália és Spanyolország rendelkezik alacsonyabb fajlagos mutatóval, míg Írországban, Hollandiában 7-8-szoros érték figyelhető meg. Ez feltételezi a tagjelölt országokban a mütrágyázással kevéssé szennyezett mezőgazdasági földterület létét, ami kedvezően befolyásolja a kibővített EU földvagyonának állapotát és az ún. biotermelési kultúra lehetőségét.

V/10.2. sz. táblázat: Az $1 \mathrm{~km}^{2}$ szántóföldre jutó nitrogénmütrágya felhasználása (tonna), 1999-ben

\begin{tabular}{|c|c|}
\hline Ország & Felhasználás \\
\hline Luxemburg & - \\
\hline Portugália & 4,0 \\
\hline Magyarország & 5,4 \\
\hline Spanyolország & 5,4 \\
\hline Lengyelország & 6,1 \\
\hline Csehország & 6,8 \\
\hline Finnország & 7,1 \\
\hline Svédország & 7,3 \\
\hline Ausztria & 7,6 \\
\hline Görögország & 7,8 \\
\hline Olaszország & 8,4 \\
\hline Dánia & 12,3 \\
\hline Franciaország & 13,4 \\
\hline Németország & 14,8 \\
\hline Belgium & 18,8 \\
\hline Hollandia & 37,7 \\
\hline Írország & 43,2 \\
\hline
\end{tabular}

Forrás: OECD Adattár, [1999] in: Környezetpolitikai Vizsgálatok Magyarország, OECD, [2000]

\section{V/10.2. A környezetvédelmi politika aggregát értékelése}

A davosi székhelyű Világgazdasági Fórum elkészítette 122 ország környezeti állapotának felmérését és 22 jelzőszám (indikátor) alapján helyezte el őket egy 1100-ig terjedő listán, amely az adott országban a környezetvédelmileg fenntartható fejlődés esélyeit értékeli. 
V/10.3. sz. táblázat: 2001. évi környezetvédelmi fenntarthatósági index, (ESI) 1-100-ig

\begin{tabular}{|c|l|}
\hline Finnország & 80,5 \\
\hline Svédország & 77,1 \\
\hline Ausztria & 67,8 \\
\hline Dánia & 67,0 \\
\hline Hollandia & 66,0 \\
\hline Franciaország & 65,8 \\
\hline Németország & 64,2 \\
\hline Egyesült Királyság & 64,1 \\
\hline Írország & 64,0 \\
\hline Szlovákia & 63,2 \\
\hline Portugália & 61,4 \\
\hline Magyarország & 61,0 \\
\hline Litvánia & 60,3 \\
\hline Szlovénia & 59,9 \\
\hline Spanyolország & 59,5 \\
\hline Észtország & 57,7 \\
\hline Csehország & 57,2 \\
\hline Lettország & 56,3 \\
\hline Olaszország & 54,3 \\
\hline Görögország & 53,1 \\
\hline Lengyelország & 47,6 \\
\hline Bulgária & 47,4 \\
\hline Románia & 44,1 \\
\hline Belgium & 44,1 \\
\hline
\end{tabular}

Forrás: Világgazdasági Fórum, [2001]

Az adatokat vizsgálva látható, hogy a tagjelölt országok mutatói általában gyengébbek, mint a tagállamoké (a legjobb tagjelölt mutatójánál is 9 tagállam tudott jobb értéket elérni). Jó a környezetvédelmi jövőképe Szlovákiának, Magyarországnak, Litvániának és Szlovéniának, a többi tagjelöltnél már rosszabb a kép. Különösen meglepő és aggasztó Lengyelország helyzete, hiszen egy jelentős nagyságú országról van szó, amely a jelenlegi EU-tagok számára kimagasló fontossággal bír és olyan intenzív mezőgazdasági termeléssel vagy magas népsürüséggel sem dicsekedhet, mint Belgium. Más tényezők vizsgálatához hasonlóan Románia és Bulgária lemaradása is szembetűnő, de a kohéziós tagállamokhoz hasonlítható a balti országok teljesítménye is. E komplex mutató alapján (mely a GDP nagyságától kezdve a járműsűrüségen át az iparimezőgazdasági és környezetvédelmi terhelésen keresztül a népsürüségig sok tényezőt figyelembe vesz) Szlovákia, Magyarország, Litvánia és Szlovénia felvétele már a kezdetektől javítja vagy legalább is nem rontja a fenntartható fejlödés lehetőségeit a kibővített EU számára, sőt jelentősebb EU-források nélkül is jobb 
vagy ugyanolyan eredményt mutatnak, mint a három mediterrán kohéziós tagállam,

(Görögország, Spanyolország, Portugália) és Olaszország.

\title{
V/10.3. A levegő szennyezettségének állapota a tagjelölteknél
}

\author{
V/10.4. sz. táblázat: $\mathrm{A} \mathrm{CO}_{2}$, SO és $\mathrm{NO}$ kibocsátás mértéke \\ a tagállamokban és a tagjelölteknél
}

\begin{tabular}{|l|c|c|c|c|c|c|}
\hline \multirow{2}{*}{ Ország } & \multicolumn{2}{|c|}{ CO2 (t/fö) } & \multicolumn{2}{c|}{ SO (kg/fö) } & \multicolumn{2}{c|}{ NO (kg/fö) } \\
\cline { 2 - 7 } & $\mathbf{1 9 9 4}$ & $\mathbf{1 9 9 7}$ & $\mathbf{1 9 9 4}$ & $\mathbf{1 9 9 7}$ & $\mathbf{1 9 9 4}$ & $\mathbf{1 9 9 7}$ \\
\hline Belgium/Luxemburg & 11,0 & 11,4 & 25 & $24^{*}$ & 34 & $33^{*}$ \\
\hline Dánia & 12,1 & 12,1 & 31 & 21 & 52 & 47 \\
\hline Németország & 10,5 & 10,1 & 30 & 19 & 25 & 22 \\
\hline Görögország & 7,3 & 7,9 & 51 & $52^{*}$ & 35 & $36^{*}$ \\
\hline Spanyolország & 5,7 & 6,2 & 53 & $49^{* *}$ & 32 & - \\
\hline Franciaország & 5,8 & 6,1 & 17 & $10^{*}$ & 30 & $29^{*}$ \\
\hline Írország & 9,0 & 9,9 & 49 & $40^{*}$ & 33 & 32 \\
\hline Olaszország & 6,7 & 6,8 & - & - & - & - \\
\hline Hollandia & 10,5 & 10,9 & 10 & 8 & 33 & 32 \\
\hline Ausztria & 6,8 & 7,4 & 6 & $5 *$ & 22 & $19^{*}$ \\
\hline Portugália & 4,5 & 4,8 & 26 & - & 26 & - \\
\hline Finnország & 11,6 & 11,4 & 23 & 20 & 55 & 51 \\
\hline Svédország & 6,2 & 5,8 & 11 & 10 & 44 & 38 \\
\hline Egyesült Királyság & 9,2 & 9,0 & 46 & $35^{*}$ & 39 & $35^{*}$ \\
\hline Bulgária & 7,2 & - & 175 & 164 & 27 & 27 \\
\hline Csehország & 12,0 & 12,6 & 123 & 68 & 42 & 41 \\
\hline Észtország & 15,3 & 14,6 & 99 & 82 & 28 & 31 \\
\hline Magyarország & 6,2 & 6,4 & 72 & 65 & 18 & 20 \\
\hline Lettország & 4,7 & 5,3 & 34 & 18 & 19 & 18 \\
\hline Litvánia & 6,7 & 5,1 & 31 & 21 & 21 & 15 \\
\hline Lengyelország & 9,7 & 9,4 & 68 & 56 & 29 & 29 \\
\hline Románia & 4,2 & 4,7 & 47 & 40 & 15 & 15 \\
\hline Szlovákia & 7,9 & 8,4 & 44 & 37 & 32 & 23 \\
\hline Szlovénia & 7,2 & 8,2 & 89 & 60 & 33 & 36 \\
\hline
\end{tabular}

Forrás: Eurostat [2000], [2001]

Megjegyzés: *1996, **1995

A levegőszennyezettségi adatok különösen jó eredményeket mutatnak a tagjelölteknél elsősorban a kéndioxid-kibocsátás csökkentése révén, hiszen az 1994es elég magas értékeket három év alatt jelentősen csökkentették. Ez föleg a nehézvegyipar összeomlásával, illetve korszerüsítésével függ össze és EU viszonylatban is elfogadhatónak mondható, ha a mediterrán kohéziós országok $50 \mathrm{~kg}$ körüli fejenkénti kibocsátását vesszük alapul. A nitrogéndioxid-kibocsátás az EU- 
tagállamoknál és a tagjelölteknél is hasonló. A kibocsátás abszolút értékeit illetően a tagjelöltek - néhány kivételtől eltekintve - az európai értékeket tükrözik.

Az EU kyotói vállalásai szempontjából - a mérgező gázkibocsátás 8 százalékos csökkentése 2008-2012-re a kilencvenes éves elejéhez képest - a széndioxid kibocsátásnak van leginkább jelentősége. Ezt az általában magas mutatókkal rendelkező tagjelöltek - a tagállamok váltakozó trendjével ellentétben - képesek lesznek csökkenteni, vagy szinten tartani (pl. a széntüzelésü erőmủvek visszaszorításával) annak ellenére, hogy jelentősen nőtt és nőni fog gépjármüveik száma. A széndioxid-kibocsátás csökkenését az energiafelhasználás hatékonysága és az ipari termelés korszerüsödése segíti elő.

\section{V/10.4. A vizek szennyezettsége a tagjelölteknél}

Az új tagállamok vízkivételi és felhasználási mutatói európai szinten is jónak mondhatók, hiszen a vízkivétel mennyisége Észtország, Magyarország és Litvánia kivételével nem haladja meg a személyenkénti $500 \mathrm{~m}^{3}$-t évente, míg a tagállamok közül 7 ország $500 \mathrm{~m}^{3}$ felett fogyaszt, sőt Belgiumban és Spanyolországban a 800 $\mathrm{m}^{3}-\mathrm{t}$ is meghaladja. Az OECD felmérései szerint Magyarország az éves rendelkezésre álló vízkészlet 5 százalékát veszi ki (Csehország 15,6, Lengyelország 18,7 százalékát), míg ez a mutató 5 tagállamnál meghaladja a 20 százalékot (lásd: V/10.5. sz. táblázat). Ez azt jelenti, hogy a jelenlegi trendek alapján az új tagállamok megfelelő víztartalékkal rendelkeznek és a hiányhelyzetet vagy a túl gyors felhasználással járó ökológiai problémákat sokkal hatékonyabban tudják majd kezelni, mint legtöbb jelenlegi tagállam.

Az EU környezetvédelmi politikájának fontos része a szennyvíztisztítás kérdése. A belépés így kényszerítő hatással lesz a tagjelöltekre, hiszen a közösségi szabályok szerint - a tárgyalásokon elért átmeneti időtől függően - a kétezer lélekszám fölötti helységekben a szennyvíz gyüjtését és tisztítását meg kell oldani. Ez jelentős beruházásokat kíván meg - a tagság után a strukturális alapok révén, de már az ISPA előcsatlakozási alapok segítségével is ezt támogatja az Unió -, ami az új tagállamok részéről is nagy anyagi áldozatokat tesz szükségessé. A közüzemi szennyvíztisztításban a fejlettebb tagjelöltek egy része (Csehország, Észtország,) a 
kohéziós tagállamoknál jobb helyezést érnek el, de többségében még jelentős a tagjelöltek lemaradása. Ugyanakkor komoly fejlesztési feladatok várnak a tagság szempontjából éllovas jelölteknek számító Szlovéniában és Magyarországon a hatóságokra.

V/10.5. sz. táblázat: A tagjelöltek és a tagállamok néhány vízgazdálkodási mutatója a kilencvenes években

\begin{tabular}{|c|c|c|c|}
\hline Ország & $\begin{array}{c}\text { A lakosság } \\
\text { közüzemi } \\
\text { szennyvíz- } \\
\text { tisztításba } \\
\text { bekapcsolt } \\
\text { hányada (\%) }\end{array}$ & $\begin{array}{c}\text { Egy före jutó } \\
\text { vízkivétel } \\
\left(\mathbf{m}^{2} / \text { fó) }\right. \\
(\mathbf{1 9 9 5 )}\end{array}$ & $\begin{array}{c}\text { A víz- } \\
\text { felhasználás } \\
\text { intenzitása } \\
(\%) * * *\end{array}$ \\
\hline Portugália & 21 & $735 * *$ & 11,9 \\
\hline Magyarország & 22 & 614 & 5,0 \\
\hline Belgium & 27 & 804 & 42,5 \\
\hline Szlovénia & 30 & n.a. & n.a. \\
\hline Bulgária & 36 & 354 & n.a. \\
\hline Görögország & 45 & n.a. & 12,1 \\
\hline Spanyolország & 48 & 850 & 36,8 \\
\hline Lengyelország & 49 & 305 & 18,7 \\
\hline Románia* & 51 & 411 & n.a. \\
\hline Szlovákia* & 51 & 244 & n.a. \\
\hline Litvánia & 52 & 1291 & n.a. \\
\hline Írország & 61 & 327 & 2,6 \\
\hline Olaszország & 61 & $991 * *$ & 32,2 \\
\hline Csehország & 62 & 244 & 15,6 \\
\hline Észtország & 70 & 1200 & n.a. \\
\hline Ausztria & 75 & 280 & 2,7 \\
\hline Finnország & 77 & 477 & 2,2 \\
\hline Franciaország & 77 & 700 & 23,9 \\
\hline Dánia & 87 & 170 & 15,7 \\
\hline Luxemburg & 88 & 140 & 3,4 \\
\hline Egyesült Királyság & 88 & 207 & 14,6 \\
\hline Németország & 89 & 532 & 24,4 \\
\hline Svédország & 93 & 307 & 1,5 \\
\hline Lettország & n.a. & 215 & n.a. \\
\hline Hollandia & 97 & $524 * *$ & 4,9 \\
\hline
\end{tabular}

Forrás: OECD Környezeti Adattár, [1999] in: Környezetpolitikai Vizsgálatok Magyarország, OECD, [2000], Eurostat, [2000]

Megjegyzés:

*A teljes csatornázottságba bekapcsoltak aránya függetlenül attól, hogy a szennyvizet kezelik-e (tisztítják-e) vagy sem.

$* * 1990$

***Vízkivétel a rendelkezésre álló készlet százalékában 


\section{V/10.5. Hulladékgazdálkodás}

A tagjelölt országokban a hulladékok keletkezésének mértéke alatta marad az EUátlagnak, amiben nagyfokú hasonlóságot mutatnak a már tag mediterrán országokhoz. Mint a 2. Kohéziós Jelentés (2001-ben) megállapította, a tagjelölteknél az EU-átlag 70 százaléka körül mozog a kommunális szemét mennyisége, de 2010-re (éppen a gyors gazdasági növekedés mellékhatásaként) mintegy 50 százalékos növekedés prognosztizálható, vagyis ebben erőteljes „felzárkózás” lesz tapasztalható.

V/10.6. sz. táblázat: Egy före jutó kommunális hulladék egyes EU és tagjelölt országokban 1999-ben

$\left(\mathrm{kg} / \mathrm{fo}^{\prime \prime}\right)$

\begin{tabular}{|c|c|}
\hline Ország & Hulladék \\
\hline Belgium & 480 \\
\hline Dánia & 560 \\
\hline Németország & 460 \\
\hline Görögország & 370 \\
\hline Spanyolország & 390 \\
\hline Franciaország & 590 \\
\hline Írország & 560 \\
\hline Olaszország & 460 \\
\hline Luxemburg & 460 \\
\hline Hollandia & 560 \\
\hline Ausztria & 510 \\
\hline Portugália & 380 \\
\hline Finnország & 410 \\
\hline Svédország & 360 \\
\hline Egyesült Királyság & 480 \\
\hline Magyarország & 500 \\
\hline Csehország & 310 \\
\hline Lengyelország & 320 \\
\hline Bulgária & $438(1997)$ \\
\hline Észtország & 385 \\
\hline Lettország & $253(1997)$ \\
\hline Litvánia & $426(1998)$ \\
\hline Románia & 326 \\
\hline Szlovákia & $316(1996)$ \\
\hline Szlovénia & $514(1995)$ \\
\hline
\end{tabular}

Forrás: OECD, Eurostat, [2000] 
A hulladékok keletkezésével kapcsolatban a legnagyobb probléma az, hogy a tagjelölteknél ezeket (80 százalékban vagy ennél is nagyobb arányban) szemétlerakó helyekre viszik (gyakran illegálisan), ami újabb környezetvédelmi problémákat vet fel; kicsi a korszerü módszerekkel megsemmisített hulladékok aránya. (Az EU-ban a szemétlerakás aránya 66 százalék, igaz, hogy több tagállamban, így Görögországban, Írországban, Olaszországban is meghaladja a lerakásokkal kezelt hulladék aránya a 90 százalékot.) Szintén gondot okoz a keletkezett hulladék visszaforgatásának problémája. (Portugáliában is csak 4 százalék kerül újrahasznosításra.) Az EU-ba való belépés egyik nyilvánvaló következménye lesz a tagjelöltek számára, hogy a megfelelő direktívák végrehajtása révén teljesíteniük kell a veszélyes és olajhulladékok elhelyezését, általában a szelektív hulladékgyüjtést, valamint a csomagolóanyagok visszaforgatásáról rendelkező előírásokat. Kategóriától függően 50-65 százalékban újra kell hasznosítani a hulladékot, míg a csomagolóanyagok 2545 tömegszázalékában kell, hogy újrafelhasználásra kerüljenek. Megfigyelhető, hogy pl. az üvegekre vonatkozó relatíve magas betétdíj miatt a tagjelölt országokban nagyobb visszaváltási fegyelem alakult ki, mint a jelenlegi tagállamokban.

\section{V/10.6. A felzárkózási költségek nagysága és a környezetvédelmi normák átvételének gazdasági hatása}

Az Európai Bizottság 1997-ben elvégzett felmérései szerint a 10 tagjelölt országnak mintegy 120 milliárd eurót kellene arra fordítania, hogy teljesítse az EU környezetvédelmi elöírásait (lásd: V/10.7. táblázat). Ez a becslés például Lengyelországra 34-35 milliárd euró kiadási kötelezettséget ír, míg ugyancsak Lengyelország esetében a CEPS 2000-ben kiadott tanulmánya 40 milliárd eurót lát szükségesnek, ami 2010-ig számolva évi 3 milliárd euró beruházást feltételez. Jelenleg Lengyelország az említett összeg felét költi erre a célra, de már ez is GDPjének 1,5 százalékát jelenti. Az EU Környezetvédelmi Főigazgatósága szerint Magyarország a rendkívül ambiciózus felkészülési programja alapján évi GDP-jének több mint 2,5 százalékát fogja környezetvédelemre fordítani. Ezek a számarányok azt mutatják, hogy a ráfordítások az EU-tagállamok hasonló kiadásait jelentősen meghaladják, hiszen az első Kohéziós Jelentés szerint az EU 1992-ben GNP-jének 1,2 százalékát költötte környezetvédelmi célokra, sőt a kohéziós tagállamok (akiknek akkori gazdasági-szociális helyzete hasonlatos volt a tagjelöltek tagság utáni években 
várható helyzetéhez) közül Portugália és Görögország is csak 0,5 százalékot, Spanyolország pedig 0,8 százalékot. (A tagállamok közül csak Németország, Franciaország, Hollandia és az Egyesült Királyság költött a GNP 1 százalékánál többet.)

V/10.7. sz. táblázat: A teljes befektetési szükséglet a tagjelölteknél a környezetvédelmi területen az EU-elöirások figyelembevételével (milliárd euró)

\begin{tabular}{|c|c|c|}
\hline Ország & Becsült minimum & Becsült maximum \\
\hline Baltikum & 8,9 & 9,3 \\
\hline Bulgária & 11,7 & 15,0 \\
\hline Csehország & 10,4 & 12,4 \\
\hline Magyarország & 11,5 & 13,7 \\
\hline Lengyelország & 34,1 & 35,2 \\
\hline Románia & 20,2 & 22,0 \\
\hline Szlovákia & 4,1 & 5,4 \\
\hline Szlovénia & 1,84 & 1,84 \\
\hline Összes & $\mathbf{1 0 8 , 4}$ & $\mathbf{1 2 1 , 5}$ \\
\hline
\end{tabular}

Forrás: Európai Bizottság, [1997]

Megjegyzés: A költségeket 20 évre kalkulálták, vagyis évente 5,4-6 milliárd eurót, vagyis a tagjelöltek jelenlegi GDP-jét (1999-ben 342,4 milliárd euró) alapul véve is a térség bruttó nemzeti termékének 1,6-1,8 százalékát kell erre a felzárkózásra fordítania.

A bővülés gazdasági, versenyképességi elveit illetően a rendkívül nagy beruházási igény (évi 5,4-6 milliárd euró) komoly lehetőségeket rejt a jelenlegi tagállamok vállalatai számára, akik a belső piacon - azonos pályázati feltételekkel - helyzeti előnyt élvezhetnek a külső vetélytársakkal szemben. Sajátos lehetőséget ad a hulladékmegsemmisítés (föleg égetés) relatív alacsony költsége az új tagállamokban, ami nemcsak jó befektetés, hanem skálahozadékot növelö, és versenyképességet javító hatású lehet az erre szakosodott közösségi vállalkozók számára. Ugyanakkor a tagjelöltek számára is jelentős hasznot hoz az EU környezetvédelmi előírásainak betartása, elsősorban az egészségügyi kiadások, a turizmus, a könnyebb ivóvízelőállításra gyakorolt hatás miatt. Ennek haszna az ECOTEC Kutatóintézet 2001 novemberi felmérése szerint 12,4-68,9 milliárd euró között lehet évente a tíz ország számára, ami makrogazdasági szempontból rentábilissá teszi az ennél kisebb (az EBRD szerint évi 5,5-6 milliárd euró) beruházást. (Természetesen ennek előfeltétele, hogy a beruházások ne veszélyeztessék a versenyszféra versenyképességét.) 
Ugyanakkor versenyképességet befolyásoló tényező a belső piacon az, ha a közösségi tagsággal a jelenlegi alacsony víz és energia árak tényleges árakká alakulnak át. Mivel ennek megvalósítása az ezekbe a szektorokba befektetők jó profitkilátásai mellett ösztönzik a jelenlegi örökölt pazarlás megszüntetését, ez környezetvédelmi szempontból fontos vívmány lehet. Ennek elérését racionális (befektetés-ösztönzési és szociális) szempontok hátráltathatják, de a szabad verseny elindításával a kezdeti árnövekedési hatás későbbi árcsökkentésekkel kiegyensúlyozható. 


\section{RÉSZ}

\section{KÖVETKEZTETÉSEK}

\section{VI/1. A téma aktualitása és jelentősége a közvélemény számára}

A keleti irányú bővítés régóta napirenden lévő téma az Európai Unió szakmai és tudományos közvéleményében, de csak az Európai Bizottság által kiadott Agenda 2000. dokumentum (1997. július), illetve a luxemburgi csúcsértekezlet (1997. december) óta foglalkoznak vele mélyrehatóan. A 2001. decemberében tartott EUcsúcsértekezlet megerősítette a tagállamok eltökéltségét abban, hogy 2002. végére, az arra kész tagjelöltekkel a tárgyalásokat befejezik, így lehetővé válik az, hogy az új tagállamok 2004-ben részt vehessenek az Európai Parlament választásain. Mint a dolgozatom elején írott általános áttekintésben is leszögeztem, a most várható bővítés az EU fejlödésének legfontosabb eseményei közé sorolható, hiszen soha nem látott mértékü növekedést indukál, aminek következtében lakossága csaknem 28 százalékkal fog bővülni. Bár világpiaci jelentősége nem fog ilyen mértékben nőni, mégis a nemzetközi politikai élet egyik legfontosabb szereplője lesz, csak az Amerikai Egyesült Államokhoz, vagy később Kínához lesz mérhető, feltéve ha az ázsiai szuperhatalom fejlödési üteme az elkövetkezendő évtizedekben hasonlatos lesz az utóbbi évek teljesítményéhez.

Sajátossága ugyanakkor a bővítésnek az, hogy az Európai Unió olyan országokat vesz fel soraiba, amelyek az európai integráció létrejöttekor, a múlt század közepén és második harmadában olyan társadalmi és politikai rendszert építettek - alapvetően a szovjet megszállás kényszeréből -, amelyek ellenséges rendszernek számítottak, sőt létük az európai integráció létrejöttének egyik vezérmotívuma is volt. Másik sajátossága a bővítésnek, hogy a legnagyobb eddigi bővítési elképzelés megvalósulása során sok szempontból fejletlenebb országokat fog az Európai Unió integrálni. Az EU, illetve elődjei (EGK, EK) bővülésénél - Írország, Spanyolország, Görögország, Portugália felvételekor - erre már volt példa, de a mostani bővítés nagyságrendje szokatlan. Ráadásul az 1945 után felnőtt nyugat-európai nemzedék számára nem a klasszikus nyugati értékközösség részeként belépő országok 
csatlakozásáról van szó, hanem számukra évtizedekig ellenséges világhoz tartozók belépéséröl.

Dolgozatomban ezért legelőször azt vizsgáltam meg, hogy a bővítés ténye, illetve főbb meghatározó elemei miként jelennek meg az EU-tagországok közvéleményének tudatában, illetve milyen a legfontosabb brüsszeli döntéshozók hozzáállása ehhez a kérdéshez. Lényegesnek tartottam azt is áttekinteni, hogy a tagjelölt államok közvéleménye hogyan vélekedik a belépésröl, hiszen a bővítés - mint nagy politikai terv - megalapozottságát az állampolgárok akaratának figyelembe vételével kell megvalósítani mindkét fél számára.

A közvélemény-kutatások eredményei alapján meglepő volt, hogy maga a bővítés nem szerepel az EU polgárainak prioritásai között, csak a megkérdezettek 28 százaléka tekintette ezt kifejezetten fontosnak. Minden, az Unió előtt álló nagy feladatot a polgárok lényegesebbnek tartottak, föleg a munkanélküliség, a szociális és belbiztonsági területet emelték ki. A bővítést érintő - az új tagok irányába megfogalmazott - elvárások közül a demokrácia és az emberi jogok tiszteletben tartása, a szervezett bünözés elleni harc és a környezetvédelem elsődleges fontosságúak a tagországok polgárainak, és kevésbé emelték ki a bővítés gazdaságiköltségvetési vonatkozásait. Az EU-országokban dolgozó csúcsvezetői réteg azonban már kiemelten kezeli a bővítés ügyét, vagyis számukra ez nemcsak benyomásokon alapuló, hanem racionálisan megítélhető terület (több információval rendelkeznek a tényleges érdekeltséget tükröző faktorokról, mint az átlagpolgárok). Ugyanakkor nem szabad elfelejtkezni arról sem, hogy a prioritásokat illetően nem szakadhat el a társadalmi elit a választóitól.

A tagjelöltek állampolgárai részéről az EU-image kifejezetten pozitív, hiszen a 13 tagjelölt ország lakosságának csak 18 százaléka nyilatkozott negatívan az EU-ról, és több mint fele mondott elismerő véleményt a brüsszeli székhelyü integrációról.

Ha országonkénti bontásban vizsgáljuk az egyes tagállamok és tagjelöltek közvéleményének a bővítésről alkotott véleményét, igen heterogén képet kapunk. Míg a tagállamok részéről a skandináv és a mediterrán országok támogatják azt leginkább és a kulcsszerepet játszó Németország, Franciaország, Ausztria az átlag 
alatt van, addig a tagjelöltek közül a balti államokban, a cseheknél, lengyeleknél alacsonyabb, míg a felkészültségben elmaradó Romániában és Bulgáriában a legmagasabb a tagság támogatottsága. Ennél is érdekesebb, hogy a tagjelölt országok közül csak Magyarország, Csehország, Lengyelország (vagyis a három NATOtagállam) felvételét támogatja több EU-országbeli polgár, mint amennyi elutasítja, (az osztrákok csak Magyarországot emelik ki), míg a tagjelöltek mindegyikében a belépésnek több híve van, mint a kívülmaradásnak. Mindez arra utal, hogy a közvélemény megítélése szerint csak a három új NATO-tagállam vonatkozásában állapítható meg az, hogy mindkét fél hasznosnak érzi a bővítést, vagyis az angol kifejezéssel élve „win-win excercise” érvényesül.

A dolgozatban általam vizsgált bővítési faktorok szerint (melyet összesen 23 területen foglaltam össze) kérdőíves felmérést végeztem a legfontosabb döntéshozói és előkészítői körökben, ami alátámasztotta azt a feltételezésemet, hogy a bővítés legfontosabb tényezője az EU számára is Európa politikai és kulturális újraegyesítése. A politikai-szakmai felmérésem eredményében előkelő helyet kapott a külső és belső biztonság erősítése (elsősorban a bevándorlási, bünözési terület), valamint az EU gazdasági haszna, mely utóbbi a közvélemény részéről nem kapott prioritást.

A bővítés gazdasági vonatkozásai közül a legnagyobb ellenérzés a költségvetési hatásokat övezte. Elönyösnek látták ugyanakkor a döntéshozók a belső piac kiterjedésének kedvező hatásait és optimistának bizonyultak a tagjelöltek gazdasági felzárkózási képességeit illetően is. Pozitív volt a felmérésemben a válaszuk arra a kérdésre, hogy az Unió külkapcsolataira - beleértve a transzatlanti viszonyt és a térség országai egymás közötti kapcsolatait - jó hatással lesz az új tagok felvétele. Számomra meglepő módon aggodalommal reagáltak a bővítésnek az EU intézményi rendszerére gyakorolt hatására, valamint a mezőgazdasági túltermelés veszélyére. Kevésbé lényeges, vagy kevésbé látványos tényezőnek tartják a bővítés szempontjából a térség kisebbségi (roma) helyzetét, valamint a térség országainak kommunista közelmúltját, a tagság jelentette versenykihívást, a tranzitlehetőségeket, az eurózóna kiterjesztésének lehetőségét. 
A politikai realizmus tükröződik az általam megkeresett 14 döntéshozó és előkészítő válaszaiban akkor is, amikor megítélésük szerint a bővítésre csoportosan (nem egyedi országok felvételével) kerül sor, de némi megalapozottságot látok abban, hogy az elkövetkezendő 15 évben csak a keleti bővítésbe már most bevont országok egy csoportjával vagy annak teljes körével várható a bővítés. Ezt meghaladóan (Nyugat-Balkán, volt szovjet térség) azonban szerintük a bővítés középtávon (15 éven belül) nem reális.

Az említett 23, általam fontosnak ítélt téma köré csoportosítva megvizsgáltam a bővítést befolyásoló objektív tényezőket, aminek alapján azt a következtetést vontam le, hogy a bővítés a pozitív és negatív hatások végső eredőjeként kedvező az Európai Unió számára. Ugyanakkor az is végkövetkeztetéseim közé tartozik, hogy a közvetlen haszonmérleg romlik, ha minél inkább Kelet felé haladunk az integrációban, mivel a gazdasági-politikai nehézségek vagy különbözőségek növekedésével az integrálás humán és gazdasági költségei egyre magasabbak lesznek. Ezért a magam részéről a jelenlegi tagjelöltek két vagy három hullámban történő felvételét látom racionálisnak, amit alátámasztanak azok a vizsgálataim, amit a tagjelöltek körében országonkénti bontásban bővítési faktoronként (fejezetenként) végeztem. A legtöbb területen szinte ugyanazok a tagjelöltek emelkedtek ki a humán, történelmi és a gazdasági tényezők vizsgálata során.

Kutatásaimban az egyes EU-tagállamok szerepét, részesedését, fejlettségét is nyomon követtem az általam vizsgált területeken. Az elemzések azt az általános következtetést tették lehetővé számomra, hogy megállapítsam: a legtöbb faktornál az igazi szakadék nem mindig a tagországok és a tagjelölt országok, hanem az utóbbiak között húzódik meg. Több esetben az is megállapítható volt, hogy a fejlettebb tagjelöltek (elsősorban Szlovénia, de legtöbb kérdésben ide sorolható Magyarország, Csehország, esetenként Észtország vagy Szlovákia, néhány kérdésben Lengyelország is) közelítik vagy néhány minőségi paraméterben felül is múlják a kevésbé fejlett mediterrán, kohéziós tagállamokat (Portugália, Spanyolország, Görögország).

Az egyes tagjelöltek között megfigyelhető, esetenként jelentős különbség nemcsak a vizsgált szektorokban mutatkozott meg, hanem felzárkózási lehetőségeik és képességeik eltérő jellege miatt is. Ezért állítom, hogy a jelenlegi tagjelöltekkel való 
bővülés időben több lépcsőben, a kevésbé felkészültek számára nagyobb csatlakozás előtti felzárkózási időszakot hagyva valósítható meg. Ettől csak politikai döntéssel a nagycsoportos „big bang” koncepcióval - lehet eltérni. A bővítés jelentőségénél nem szabad figyelmen kívül hagyni azt sem, hogy a 10 térségbeli országból demográfiai súlya - mely előrevetíti az integráció politikai vetületét Lengyelországnak és Romániának van, hiszen ez a két ország adja a bővülés lakossági és területi növekedésének mintegy 60 illetve 50 százalékát. A többi tagjelölt ország lakosságának és területének nagysága elmarad az 1986-os ibériai bővítés súlyától, ám még így is meghaladja az 1995-ben megvalósított bővülés lélekszám szerinti nagyságrendjét. Ez cáfolja azokat az állításokat, hogy Lengyelország és/vagy Románia első körös tagsága nélkül nem beszélhetünk igazi bővülésröl.

\section{VI/2. A bővülés előnyei a történelmi és a humán területeken, valamint hatása az}

\section{Unió intézményrendszerére}

Az általam megkérdezett politikusokhoz és szakértőkhöz, valamint számos kutatóhoz hasonlóan nagy jelentőséget tulajdonítottam az integráció történelmi tényezője vizsgálatának. Ez azt mutatta, hogy a jaltai döntéssel egy szerves fejlődési folyamat szakadt meg Európában. A politikai megosztottság megszünése magában hordozta a gyors történelmi felzárkózás lehetőségét, hiszen még a két világháború között is a térség országainak az EK 15 tagállama akkori átlagához képest mért gazdasági fejlettsége a jelenleginél is magasabb szinten állt. Csehszlovákia, Magyarország, Lengyelország az olasz vagy a finn szintet közelítette meg 1938-ban az egy före jutó GDP-becslésekben, és messze meghaladták az ibériai államokat vagy Görögországot. Ebben az időszakban a tagjelölt államok jóval nagyobb szerepet töltöttek be az európai kereskedelemben, mint jelenleg, ennek az aránynak a már elkezdődött és a továbbiakban várható természetes visszarendeződése segíti gazdasági felzárkózásukat. Megítélésem szerint, ez a történelmi helyreállítás az Unió keleti peremén található országoknál - ide sorolom még Szlovéniát és Szlovákiát is hamarosan bekövetkezik, ami a kohéziós tagországok belépéskori, az Unióhoz viszonyított relatív gazdasági fejlettségi szintjének elérését teszi lehetővé néhány éven belül. A peremországok közül Szlovénia és Csehország már el is érte a kohéziós tagországok belépéskori gazdasági szintjét, de más paramétereket 
figyelembe véve - pl. munkaerő termelékenysége, GDP megoszlása a főbb nemzetgazdasági szektorok között, középfokú oktatás hatékonysága Magyarországgal együtt már meg is haladták azokat. Mindez azt jelenti, hogy a fejlettebb tagjelöltekkel megvalósítandó bővítés nem jelent az EU-átlagnál alacsonyabb fejlettségi szintű országok integrálásakor nagyobb nehézséget, mint a spanyol-portugál-görög bővítési hullámkor. Ez a tagjelöltek közötti különbözőség újra megerősíti a keleti bővítés több hullámban való megvalósításának ésszerüségét.

Az egyes humán és gazdasági faktorok elemzése révén az is nyilvánvalóvá vált, hogy a fentiek alapján fokozatosan végrehajtott bővítés nem fog új helyzetet teremteni a közösségi jogban vagy az Unió fejlődési filozófiájában. Mindez arra enged következtetni, hogy a bővítésnek az új uniós fejlödési pályára, résztagságokra vonatkozó elméletei nem megalapozottak, az Unió továbbra is a jelenlegi jogi és intézményi rendszerben müködik majd tovább. Kétségtelen, hogy a 20 fölötti taglétszám előtérbe helyezi a megerősített együttmüködés kibontakozását néhány területen, de ez nem érinti az egységes közösségi és uniós jogi és intézményi rendszert. Érinti a bővítés az Unió müködésének néhány (pl. a munkanyelvek megerösödése, közösségi szervek munkamódszerei) aspektusát, de müködésének alapelveit nem. Ez volt a Nizzai Szerződés világos üzenete. Az intézményi vonatkozásoknál - a döntéshozatal bonyolultabbá válása mellett - azt a következményt is elörevetítettem, hogy nőni fog a minősített többséggel meghozatalra kerülö területek száma, pozitív hatású lesz az uniós és közösségi szerződésrendszer (az elsődleges és másodlagos jogforrások) egyszerüsítése, melyek a bővítés nélkül is napirenden lévő témák. Ugyanakkor a teljes bővítés kizárja azt, hogy a tagjelöltek általános érdekei elleni döntéseket hozzanak minősített többség révén.

A különbözö történelmi tényezők vizsgálata alapján megállapítottam, hogy a régmúlt és a közelmúlt gazdasági (elsősorban kereskedelmi) kapcsolatai alapján nem véletlen a kereskedelmi és gazdasági kapcsolatoknak már a hetvenes-nyolcvanas években (tehát a formális rendszerváltás előtt) elkezdett, és a kilencvenes évek elején felgyorsult helyreállítása. Ezt követte a tagjelöltek külkapcsolataiban az EU politikai és gazdasági szerepének növekedése a kilencvenes évek folyamán. Bár még a csatlakozni kívánó országok nem érték el az európai exporton belüli két világháború 
közötti helyüket, de eredményeik biztatóak, Írország kivételével a legtöbb európai országot meghaladó (1993-98 között Szlovéniát leszámítva 1,75-4,21-szeres) felfutásuk további reményekre ad garanciát. Nem véletlen, hogy a különböző gravitációs modellek (amelyek a GDP fejlődésén túlmenően több faktort, így a földrajzi tényezőt is vizsgálják) még további fejlődési lehetőségeket prognosztizálnak a két fél kereskedelmében. A gazdasági és politikai kapcsolatok 1990 előtti időszakának elemzésekor kiderült az is, hogy a történelmi múltban szorosak voltak a kapcsolatok, amelyek a szovjet dominancia éveiben is megmaradtak, de a keleti országok szempontjából alárendelt - nyersanyagszállító, egyoldalú kedvezményekre kényszerített - szerepet termelt újjá, ami nem egyedi a történelemben. A természetes történelmi integrációt mutatja, hogy a kilencvenes évek végére olyan szintet ért el az EU szerepe a tárgyalt tagjelöltek külkapcsolataiban (kereskedelem, befektetések, tudományos, kulturális kapcsolatok), amely még a tagállamok egy részére sem volt jellemző. Nem következett be EU-tól eltérő orientáció, sem a regionális integráció előtérbe helyezésével, sem újabb keleti orientációval (Oroszország felé), sem pedig más világgazdasági erőpólusok (USA, Japán) irányába.

A humán faktorok vizsgálatánál láthattam azt, hogy a leendő tagállamok történelmi, vallási, kulturális fejlődésükben az európai modellhez hasonló pályát jártak be. Különösen kiemelkedik Lengyelország, Csehország és Magyarország szerepe, hiszen ezek az országok évezredes keresztény államiságra tekinthetnek vissza, amelyek maguk feláldozásával is védték a nyugati kultúrát a keleti veszélyek ellen. Ennek során még az európai átlagnál is erőteljesebben őrizték saját társadalmukban a kontinens közös értékeit (például az állam és a polgár közötti kapcsolatok, vagy az üzleti etika pozitív hatása, a tolerancia jelenléte). Mivel Szlovénia sorsa évszázadokon keresztül Velencéhez illetve Ausztriához, Szlovákia sorsa pedig Magyarországhoz kapcsolódott, náluk is jól megfigyelhető az európai típusú társadalomfejlődés, bár önálló történelmi államiságuk hiánya érzékelhető abban, ahogy a nemzeti kisebbségek kérdését kezelik. Nem hatott ez ösztönzően a belső belpolitikai stabilitásra sem, hiszen nincsenek történelmileg megfelelően beágyazott párt és intézményrendszeri struktúrák ebben a két kis országban. 
Nyugat-Európától eltérő és nem feltétlenül pozitív mozzanat, hogy a térségben sokszor zajlottak birodalmi hódítások, aminek következményeként önkényes, az etnikai viszonyokat nem tükröző határokat húztak. Ez táplálja az általános európai fejlődéstől eltérő nacionalizmust a térségben. Bár nem lehet Huntingtonnak a civilizációk harcára vonatkozó állításait teljes mértékben a régióra illeszteni, mert a keleti és nyugati kereszténységet jelképező határok most sok esetben országokon belül húzódnak meg (Románia, Ukrajna, Jugoszlávia), de látható, hogy az európai fejlődés néhány konkrét eleme nem érte el Romániát, Bulgáriát (vallási tolerancia, protestáns etika, parlamentarizmus). A többi tagjelöltnél ugyanakkor elismerésre méltó a tolerancia mellett az önkormányzatiság és az önszerveződés történelmi hagyománya, amelynek nagy szerepe lehet a tagság után, mivel az európai, soknemzetiségű fejlődés záloga az alulról, demokratikusan építkező társadalom léte, hiszen az EU-politikák és direktívák önálló átültetése és végrehajtása az egyes országokba az Unió müködésének alapeleme. A vallási gyökerek, valamint ezeknek a társadalmi életre gyakorolt hatása a fejlettebb tagjelölteknél hasonló az uniós tagállamokéhoz. Ugyanakkor a devianciák iránti tolerancia kisebb ezekben a társadalmakban.

A közép-és kelet-európai régió vallási és nemzetiségi összetétele is nagy hasonlóságot mutat az európai uniós országokhoz. A tagjelölt országok egy része nemzetiségileg és etnikailag sem homogén (talán Lengyelország, Szlovénia és Magyarország tekinthető annak), de az anyaországi határokon túl megtalálható, és Nyugathoz kötődő nemzeti és etnikai csoportok (németek, magyarok, zsidók) húzóerő és hídszerep révén képesek lesznek a regionális kapcsolatok stabilitását erősíteni. Komoly társadalmi problémát a térség néhány országában meglévő jelentős számú roma lakosság, valamint a balti államokban (főleg Lettországban és Észtországban) élő orosz kisebbség integrálódása jelent. A roma származású lakosság aránya a tagjelölteknél az európai átlagnál jóval magasabb (különösen Romániában, Szlovákiában, Bulgáriában és Magyarországon), így a bővítéssel az EU-ban több mint duplájára nő majd számuk. Ezek a rétegek a rendszerváltás vesztesei, mivel alacsony iskolázottságuk és ebből is eredő munkakultúrájuk miatt elsőként lettek munkanélküliek. A belépő államok az Unió már most is észlelhető segítségével a romák társadalmi integrálódását megpróbálják kezelni, ám ez több évtizedes megoldandó feladatot jelent. Ugyanakkor alaptalan az a félelem, hogy a 
romákat a bővítést követően a tagjelöltek a tagállamokra zúdítják, mivel a középeurópai romák nagy részére nem jellemző a vándorló életmód.

A leendő tagállamoknak az európai szellemi fejlődés fő vonulatához füződő viszonya tükröződik az üzleti etika vagy a korrupcióra való hajlam jelenkori mérésekor: a (protestáns) Észtország, valamint Szlovénia és Magyarország mennyire eltér a térség többi országaitól (nemcsak a két balkáni típusú államtól, hanem Szlovákia vagy Litvánia mutatóitól is). A történelmi háttér és az európai értékek, az államiság szerepének eltérő jellegét láttam megjelenni a migrációs és menekültügyi statisztikákban, ahol a románok, bolgárok jelentenek érthető problémát NyugatEurópa számára. Ezzel szemben a stabil történelmi háttérrel nem harmonizál, hogy a lengyelek is nagyobb mobilitási hajlandóságot mutatnak.

A demográfiai helyzet elemzése kapcsán megállapítottam, hogy az európai negatív demográfiai trendek a tagjelölt országokra is jellemzőek, de esetükben az alacsonyabb életkor (korábbi az elhalálozás) miatt az időskori eltartottak aránya egy ideig még kedvezőbb marad, mint az EU jelenlegi országaiban. Sajnálatos módon a termékenységi ráták a rendszerváltás után a tagjelölteknél az európai átlag alá süllyedtek, lényegében a legrosszabb tagállami (Olaszország, Spanyolország) mutatók közelébe vagy az alá, amiben az értékzavarok mellett a létbiztonság elvesztése és az általánosan csökkenő életszínvonal is szerepet játszott. Mivel a csatlakozás után, a gazdasági fellendüléssel párhuzamosan növekvő létbiztonság hatására a halálozási statisztikák a tagjelölt országokban is javulni fognak, tehát a várható életkor magasabb lesz, az időskori eltartottak aránya a tagjelölteknél is növekedni fog, és egy-két évtized alatt eléri az EU paramétereit. Ha ez a tendencia megvalósul, és a születési ráták nem javulnak jelentősen, akkor egyre kisebb lesz a munkaképes korúak aránya az új tagállamokban, akik nem jelenhetnek meg a mai tagállamok felé munkaerő-feleslegként. Sőt ezek az országok 10-15 év múlva szintén jelentős nagyságú - Lengyelország esetében 1 milliós - bevándorlót kell, hogy befogadjanak a belső eltartotti arányok megőrzése céljából.

A demográfiai viszonyokhoz hasonlóan a betegség tüneteit mutatja a tagjelölt országok egészségügyi helyzete is, hiszen Szlovénia, Szlovákia és Csehország kivételével nagyon rosszak a betegségi statisztikák, valamint a szerény gazdasági 
fejlettséghez képest is alacsony egészségügyi ráfordítási arányok jellemezik az összes többi jelöltet, beleértve a más területeken jó eredményeket elért Lengyelországot és Magyarországot is.

Kifejezetten biztatónak látom viszont a régió nagyon erős alap- és középfokú képzést nyújtó oktatási színvonalát és ennek hatását az Unió belső piaci müködésére. Felzárkózás indult meg a felsőoktatás területén is, de a felsőoktatási képzésben részesülök aránya a kilencvenes évek végén még nem érte el az EU-átlagot, bár Észtország és Bulgária megközelítette azt. A felzárkózási folyamatot segíti, hogy Románia és Bulgária kivételével a gyorsan fejlődő GDP-ből magas arányt fordítanak a tagjelöltek a közoktatásra. (Különösen magas a ráfordítás Lengyelországban és a Baltikumban.) Sőt bizonyos tagállamokhoz - így Portugáliához, Görögországhoz, Spanyolországhoz - képest már most kedvezőbb mutatókat értek el a GDP-arányos oktatási ráfordításban, a középiskolai végzettek arányában. Hasonló mondható el a kutatás-fejlesztés, a nemzetközi tudományos elismertség területén is föleg Csehországban, Magyarországon, Szlovákiában. A jelenkor igényeit tükröző informatikai iskolai képzésnél Magyarország, Szlovénia valamint Csehország felvette a versenyt, lényegében a tagállamokhoz hasonlítható a közoktatásba való beépítettsége. A többi ország (főleg Bulgária és Románia) azonban még nem tudták az oktatásba a modern információs társadalom vívmányait beépíteni.

Hasonlóan kedvező az új informatikai technológiák alkalmazási képessége (Észtország, Lengyelország, Magyarország, Csehország), ami különösen figyelemre méltó, mivel a tagállamokhoz képest megjelenő anyagi különbségekből (számítógépilletve mobiltelefon-vásárlás és fenntartás) fakadó gondok ellenére a szellemi nyitás képességét egyértelműen jelzi. Azokon a területeken, ahol nincs szükség több évtizedes infrastrukturális lemaradás felszámolására, a tagjelölt országok nagy része a tagállamok egyenrangú partnere. A kibővült közös piacon a világ egyik legnagyobb és legerősebb tudásalapú, a modern információs technológiát alkalmazó és fejlesztő térsége jöhet így létre.

Éles különbséget tár fel a tagjelöltek között a rendszerváltás előtti időkből örökölt szociális helyzet, ami migrációs potenciáljukat és társadalmi fejlődési képességüket befolyásolja. A felmérések igazolják, hogy a társadalmi egyenlőtlenség a 
rendszerváltás után minden tagjelölt országnál differenciáltan nőtt. A munkaképes korú lakosság foglalkoztatási szintje alacsony, magas az inaktív réteg aránya, bár a nőknél a foglalkoztatás európai szinten is magas maradt, meghaladva a mediterrán tagállamokat. A munkanélküliség a munkahelyteremtések kibontakozása ellenére ugyanakkor magas maradt a férfiaknál. A foglalkoztatást főleg Észtország, Szlovákia, Magyarország tudja növelni, míg a lakosság szociális helyzetére fordított magas jövedelemarány elsősorban a fejlettebb tagjelöltekre jellemző. Az abszolút és relatív szegénységi mutatókat vizsgálva látszik, hogy míg Románia lakosságának 27,5 százaléka élt a kilencvenes évek közepén 2 USD/nap alatt, (Lengyelországban és Lettországban is magas volt ez az arány), addig Csehországban, Szlovéniában és Szlovákiában csak a lakosság 2 százalék alatti hányada mondható abszolút szegénynek. Csehország, Szlovákia és Szlovénia európai szinten is megfelelő elosztási arányokat tudott felmutatni a társadalom alsó és felső rétegei között. A szociális polarizáció kizárásával a társadalom kisebb hányada lesz hajlamos a különböző devianciákra, bünözésre és migrációra, ugyanakkor viszonylag nagy számú munkaerőt lehet az egységes belső piacon a szakképzett munkaerőt kívánó gazdasági ágazatokba munkába állítani.

A reálbérek is olyan nagymértékü szóródást mutatnak a tagjelöltek között (1:8 arány euróban mérve), ami nem kezelheti közös nevezőn öket. Bár a fizetések jelentős hányada marad a dolgozóknál, mégis cáfolható a szociális dömping vádja, amely szerint a jövendő tagállamok a szociális gondoskodás visszaszorításával, kirívóan alacsony közterhekkel tennék versenyképessé munkaerejüket. A nők foglalkoztatása és a férfiakhoz mért keresete európai viszonylatban is jónak mondható a tagjelölt országokban, politikai érdekképviseletük viszont gyenge.

A humánfaktorok vizsgálatának nagy szerepe van abban, hogy a belső piaci integrálódás képességét elemezzük. A tagjelöltek eltérő korrupciós mutatói, üzleti, etikai, szociális viszonyai a differenciált megközelítést támasztják alá. A fejlettebb tagjelölt országok (elsősorban Szlovénia, Csehország, Magyarország) több területen közelebb állnak az európai normákhoz, mint a többi tagjelölt országhoz és néhány területen a mediterrán tagállamok szintjét is elérik, sőt meghaladják (korrupció, nők munkaerő-piaci helyzete, tudományos idézetek és szabadalmak relatív száma, információs technológia alkalmazása). A tagjelöltek egyéni prioritásait tükrözi, hogy 
a balti államok nagyon nagy energiákat fordítanak az oktatási helyzet javítására, ugyanakkor elhanyagolják a szociális és az egészségügyi felzárkózást, sőt a bünözés területén is komoly gondjaik vannak. A magyar és a lengyel gyenge egészségügyi színvonal akadályokat gördíthet a nemzetgazdasági fellendüléshez szükséges megfelelő egészségi állapotú munkaerő biztosításához. A régión belüli teljes polarizáltság tükröződik a menekültügyi helyzetben, hiszen Románia nagy kibocsátó, míg Csehország és Magyarország egyre jelentősebb befogadó országként jelenik meg, ami megkönnyíti ez utóbbiak számára a közös menekültügyi politikába való bekapcsolódást. A humánfaktorok összesített helyzetét jelzi az is, hogy az ENSZ humán fejlettségi jelzőit illetően (Human Development Indicator) az utóbbi tíz évben (1990-99) sokat javultak a tagjelöltek. Ebben is látható a tagjelöltek közötti nagy különbség, hiszen míg Szlovénia mutatója megegyezik a portugál jelzővel és a magyar, cseh, lengyel, szlovák mutató is közel áll ehhez, a többi tagjelölt ettől még messze elmarad.

\section{VI/3. A bővítés kedvező hatásai a közös kül-és biztonságpolitika valamint a bel- és igazságügyi együttmüködés területén}

Mind a kutatásaim, mind a kérdőíves felmérés eredményei alapján lényegesnek látom annak megvilágítását, hogy az új tagok közös kül- és biztonságpolitikába (és védelempolitikába), valamint a bel- és igazságügyi együttmüködésbe való bevonása a közvetlen gazdasági hatásokhoz hasonló hasznot fog hozni az EU-tagok számára. A keleti szomszédok tagfelvétele tovább javítja az EU-országok biztonságpolitikai helyzetét, segíti, hogy a jelenlegi tagállamok az európai kelet-nyugati konfrontációra korábban épített katonai költségeit, valamint nagy létszámú katonaságát tovább csökkentsék. Ezáltal forrásokat csoportosíthatnak át új típusú feladatok (pl. békefenntartás, etnikai konfliktusok kezelése, terrorizmus elleni fellépés) végrehajtására, a haderőreform (professzionális hadseregek kiépítése, megfelelő technikai fejlesztések és beszerzések megvalósítása) véghezvitelére. Mivel a katonai költségvetések csökkentése tagállamoktól függően a GDP 0,1-1,2 százaléka között mozgott a kilencvenes években, már ez a csökkenés meghaladja azt az összeget (a közösségi GDP 0,25 százaléka), amibe 2006-ban - a jelenlegi közösségi pénzügyi irányelvek utolsó éve, amelynek során az új tagállamok a legnagyobb pénzügyi támogatást fogják kapni - a teljes tagfelvétel maximálisan kerül a közösségi 
költségvetésnek. Emellett a tagjelöltek - ld. a három új NATO-államot - már a következő 10-15 évben 10 milliárd eurós nagyságrendü légierő, légvédelmi, híradóeszközöket felsorakoztató fejlesztéseket hajtanak végre, lehetőséget adva többek között az európai hadiiparnak. (A cseh és magyar kormány alapvetően európai eredetü korszerű repülőgépek beszerzéséről döntött 2001-ben.) Mivel a többi tagjelölt is szeretne a NATO-hoz csatlakozni, illetve megfelelő módon hozzájárulni az európai védelmi képességek fejlesztéséhez (ezt már tagjelöltként az európai erőkhöz tett felajánlásaik is igazolják), további nagy horderejü beszerzések várhatók a tagjelöltek gazdasági megerősödésével párhuzamosan. (Ebben nemcsak a szovjet eredetü technika elavultsága, hanem a védelmi költségvetések várható növekedése is szerepet játszhat.) Az EU számára továbbá fontos momentum, hogy az új tagországok szerződéses rendszerben fogják az EU-álláspontokat, szankciókat átvenni, és jelentős létszámmal járulnak hozzá az EU 2003 után várható petersbergi típusú (pl. békefenntartás, béketeremtés, humanitárius jellegü) akcióihoz.

A schengeni rendszerbe belépő országok révén Németország 1252, Ausztria 1258 km-es határszakaszán leépítheti a szigorú határellenőrzést. Az új tagok a legszigorúbb rendszer szerint lesznek kénytelenek őrizni az orosz (Kalinyingrád), belorusz, ukrán és délszláv határszakaszokat, ami a jelenlegi helyzethez képest keletre kitolt előzetes szürőnek minősíthető a jelenlegi tagállamok szempontjából. Különösen nagy terhet ró a határvédelem a balti államokra, Magyarországra és Lengyelországra.

Nem számszerüsíthető, de nagy előnyt jelent a szervezett bünözés és főleg az embercsempészet elleni védekezés kitolása az új tagok keleti határára, beleértve a tagjelöltek felelősség-átvállalását az illegális bevándorlók visszatoloncolásában. EUtagként több tízezer menekült kezelésének és esetleges letelepítésének problémáját veszik át az első belépő államok a tagállamoktól. Mint láttuk Magyarország vagy Csehország példáján, ez elindult már a kilencvenes évek végén.

Itt hangsúlyozom a történelmi elemzések fontosságát, hiszen a tagjelölt országok megfelelő európai szolidaritással - készek ellátni a modern Európa védőbástyájának szerepét, amit történelmi tapasztalataik révén szívesebben látnak el európai tagországként, mint korábban ún. pufferzónákként vagy „kompországként”. 


\section{VI/4. A bővítés gazdasági előnyei}

A fenti, évi több milliárd euróban mérhető biztonsági és biztonságpolitikai haszon mellett ki kell emelni a belső piac kiterjesztéséből eredő gazdasági előnyöket. Az új tagok gazdasága - amit a kérdőívre adott válaszok is előre jeleznek - várhatóan dinamikusan fog nőni az elkövetkezendő évtizedekben, amire garanciát ad az a magas beruházási ráta, amit a belső megtakarítások és a külföldi tőkebefektetések együttesen biztosítanak. A belső piac kiterjesztése és a gazdasági növekedés pótlólagos kereskedelmi előnyöket fog jelenteni a tagjelöltek piacára belső piaci szabályozók szerint bekerülő EU-tagállamból származó vállalatoknak. Csak a gravitációs modellekből eredő - a kereskedelem bővülésére vonatkozó - elemzések (pl. a WIFO vagy Schumacher, Mimosa elemzései) a közösségi GDP 0,1-0,4 százaléka közé sorolják a pótlólagos piaci lehetőségek okozta addicionális GDPnövekedést. Ez természetesen nem egyenletesen oszlik el a jelenlegi tagállamok között, de a közeli Ausztria és Németország fogják élvezni ennek jelentős előnyét. Ez a bővülésből adódó pótlólagos előny nem mérhető össze a kilencvenes évek elején történt nyitásból adódott előnyökkel (Ausztriának csupán a kereskedelmi nyitás is mintegy 1,5 százalékos gazdasági növekedést hozott a kilencvenes évek első felében), de mindenféleképpen jelentős nagyságrendű lehet. Kifejezetten kedvező a társult országok kereskedelmi szerkezete is, hiszen exportjukban visszaszorultak az EU számára érzékeny szektorok (textil, acél, agrár). Kedvező az is, hogy a végtermékek kereskedelme mellett az iparágakon belüli kontinentális munkamegosztás válik fontossá.

Hasonlóan nagy lehetőséget ad a megnyíló pénzügyi piac, ahol az EU már most is a legnagyobb befektető, és a tagság által garantált befektetési biztonság (a politikai és gazdaságpolitikai kockázatok gyakorlatilag megszünnek) a kockázati prémiumok csökkenése révén további extraprofitot eredményeznek a régi tagok számára. Ez főleg Ausztria és Németország, valamint a szintén jelentős befektető Franciaország és Nagy-Britannia részére hoz jelentős hasznot, mint azt Baldwin is megállapította. (Ausztria az Európába kihelyezett tőkéjének több mint harmadát, Németország és Olaszország több mint hetedét-nyolcadát a régióba vitte a kilencvenes években.) 
A tagság előnyeként aposztrofálható az EU-országok közvéleménye számára érzékeny környezetvédelmi vonatkozások, hiszen a közösségi belépés révén olyan hatalmas ipari beruházások - évi 5,5-6 milliárd eurós nagyságrendben - fognak megvalósulni, amelyek a tagállamok vállalatai számára nagy megrendelésekkel kecsegtetnek. A tagság esetén olyan országok kerülnek be az EU-ba, amelyek 1990 óta szinten tartják vagy csökkentik (pl. kéndioxid) szennyezőanyag kibocsátásukat, így javuló tendenciát mutatnak fel a vállalt nemzetközi kötelezettségek (pl. Kyotoi Egyezmény) teljesítése terén. Az új tagállamok az EU számára kedvező biodiverzitást hoznak, a termőföldek vegyi terhelése is jóval alatta maradhat az EUátlagnak, jogilag kontrollálhatóvá válik a szennyezőanyag-kibocsátás és a hulladékgazdálkodás, valamint az atomerőmüvek biztonságos müködtetése is.

Alapvetően előnyös hatása van az Unió kiterjedésének a közlekedési és az energia szektorra, hiszen számára kedvező és korszerü szerkezeteket - vasút-közút arány kedvező volta, gázfelhasználás előtérbe helyezése, nukleáris energia és hulladékgazdálkodás ellenőrzése -, valamint megfelelő tranzitlehetőségeket biztosít a bővítés (egyrészt a keleten növekvő piacok elérhetősége exportoldalon, másrészt az EU importigényének kielégítése elsősorban kőolaj és földgáz révén). A közlekedési szolgáltatások (elsősorban fuvarozás kiterjesztése az új tagállamok belső piacaira, légi és a nemzetközi vasúti közlekedés megnyitása a közösségi partnerek számára) jelentős haszonnal járnak, még ha a kérdőíves felmérésem eredményei ennek prioritását nem is igazolták vissza. A közlekedési oldalon a tranzit és szolgáltatási lehetőségeket negatívan befolyásolja a gyenge fizikai infrastruktúra és a külső határátkelök állapota, aminek fejlesztését az EU-nak kell részben megfinanszíroznia.

Az energiapolitika területén nem kedvező, hogy a tagjelölt országok is - Románia, Csehország és Lengyelország kivételével - energiahordozók vagy energia behozatalára szorulnak. Ezt főleg a volt Szovjetunió utódállamaiból szerzik be, ami a közösség energiaimportjának diverzifikálását (a túlzott mediterrán és közel-keleti függés mérséklését) segíti elő. Mivel a tagjelöltek egyre növekvő szerepet töltenek be a közösség belső kereskedelmi és gazdasági kapcsolataiban, kifejezetten előnyös az EU számára a közösségi versenypolitika kiterjesztése a tagság által, hiszen így biztosíthatóvá válik a jelenlegi közösségi államok számára az egyenlő versenyhelyzet a közösségi jogszabályok közvetlen kiterjesztése és ellenőrizhetősége révén. 


\section{VI/5. Kényes kérdések a csatlakozás menetében}

A kényes kérdések közül az agrárpiacot elemezve megállapítható, hogy a tagjelölt országokban a vártnál kisebb termelésfelfutás és nagyobb fogyasztásnövekedés miatt a kibővített belső piaci túltermelés nem ér el olyan szintet, mint ahogy ezt az évtized elején vagy közepén jósolták (pl. 1997-ben az Európai Bizottság az Agenda 2000 dokumentumban). Ugyanakkor a kibővített Európai Közösségnek növekvő exportszubvencióval vagy azt pótló más támogatási formákkal kell elhelyezni a gabona, marhahús, tejfeleslegét (ebben a jelenlegi EU és az új tagállamok összessége is túltermelö). Kiemelhetö, hogy az EK a közösségi szabályozás révén - föleg az állategészségügyi és élelmiszerbiztonsági területeken - egyenlő versenyfeltételekre tudja sarkalni az új tagállamokat. Az olcsó termőföldpiac csak a tagság után - igaz átmeneti időszakkal - lesz hozzáférhető az új tagállamok területén a jelenlegi tagországok számára, ami a bővítés egyik előnye lesz a közösségi gazdák (és más befektetők) részére. Hátrány és feszültségforrás lesz az új tagok alacsony hatékonysága az agrárszférában, ahol hatalmas különbségek vannak az e téren fejlettebb tagjelöltek (a csehek, a magyarok, szlovénok, szlovákok) és a többi jelölt között. Az agrárszférában Lengyelország és Románia (hatékonyság, túltermelés), illetve Magyarország (túltermelés) okoznak piaci szinten érzékelhető gondokat. Nem lesz viszont nagy feszültség a kibővült EU-n belüli piaci agrárárak eltéréséből, mivel a tagjelöltek árai felzárkózásának tendenciája figyelhető meg, amit segít a valuták várható felértékelődése is. Igazán a birtokok szétaprózottsága jelent kezdetben gondot (csak a cseheknél van jelentős átlagos birtokméret), de megfelelő birtokkoncentrációs programok beindításával a probléma orvosolhatóvá válik, ami által a hatékonyság is javulhat. Mivel az új tagok belső lakossági fogyasztása gyorsabban fog nőni a növekvő reálbérek miatt, mint sok esetben a termelés, valamint az EU számára a teljesen szabad piacra jutás csak a csatlakozás révén érhető el, a tagság ténye ezen a területen is pótlólagos piacot nyit a jelenlegi tagok számára. A tagsági tárgyalásokra maradó kérdés ezért a termelési kvóták nagyságának meghatározása lesz bizonyos szabályozott termékeknél - mivel az EU nem fogadja el a nyolcvanas évek magas termelési adatait -, illetve a tagjelöltek közvetlen termelői támogatása nagyságának eldöntése. 
További érzékeny területnek minősíthető a munkaerő szabad áramlásának ügye. Mivel a tagjelöltek nehéz demográfiai helyzetben vannak, nyilvánvaló, hogy esetükben is munkaerőhiány lép fel az elkövetkezendő évtizedekben, ami drágítani fogja a munkaerőt. Másrészt megfelelő gazdasági felzárkózási és termelékenységnövekedési képesség esetén a régi és az új tagok munkabérei közötti különbség nem fog belső piaci zavarokat okozni. Ami gondot jelent, az a lengyel és a román migrációs hajlam, valamint az egész térségben jelenlévő roma népesség; a régió többi népcsoportjának migrációs potenciálja elhanyagolható. Az Unión belüli keletnyugati migráció csak a bővülés utáni kezdeti éveket jellemzi problémaként, ezután Európa mindkét fele munkaerőt kell, hogy importáljon. A jelenlegi EU-ban csak két tagállamban - Németország és Ausztria -, ezen belül is a képzetlen munkaerőt igénylö munkakörökben jelentkezhet feszültség, ugyanakkor a tagjelöltek képzett munkaerejének tagállamokba történő bevonása a jelenlegi EU számára is kívánatos, annak olcsó és fegyelmezett volta miatt. Az ingázás nem fog 2010 után problémát jelenteni, egyrészt a munkabérek várható kiegyenlítődése, másrészt a jelenlegi tagállamok határmenti régióinak növekvő munkaerőigénye miatt. Nézetem szerint a munkaerő szabad áramlása meggondolt bővítés esetén a kezdeti években sem jelent olyan mértékü problémát, mint amekkora félelem az EU részéről ezt övezi, a liberalizáció általános elmaradása viszont nehezíti a tényezők árának (munkabér) kiegyenlítődését, mint azt a német egyesülés utáni kelet-német ellenpélda is igazolja. Úgy vélem, hogy 2010 után az EU számára az új tagok - melyek belső eltartotti arányai ekkor fognak hirtelen megromlani - munkaerő importjának forrása és minősége fog igazán fejtörést okozni, nem pedig az új tagállamokból a régiek felé történő mennyiségi kiáramlás. Határon túli nemzeti tartalékai csak Magyarországnak és Romániának vannak, a többi tagjelölt alapvetően távolabbi földrészekről vagy országokból tudja megoldani munkaerő-utánpótlási gondjait. Különösen jelentős lesz a lengyel munkaerőigény (mintegy 1 millió fő) az ország nagy mérete miatt.

Fókuszpontban lévő terület és differenciált bővítést kíván a regionális (strukturális) és kohéziós támogatások témaköre. Biztató, hogy már a közösségi strukturális alapok átvétele elött megindult a tagjelöltek élcsoportjának felzárkózása. Azonban az egyenlőtlen tőkebefektetések miatt az egyes országokon belüli regionális különbségek nőnek. (Ez volt jellemző a három mediterrán kohéziós tagországra is belépésük után). Ugyanakkor nincs abszolút mértékben vett leszakadás az elmaradott 
régiókban az EU átlagához képest, ami a tagság után a közösségi források révén a regionális és ezzel párhuzamosan a szociális kohéziót, az új tagországokon belüli regionális kiegyenlítődést teszi lehetővé. (Ezt támasztja alá az a tény is, hogy az előző bővítések is képesek voltak kezelni az új tagállamokon belüli leszakadó térségek problémáját, és a kérdőíves válaszaim is optimistának bizonyulnak e tekintetben.) Egyelőre reménytelennek tünik viszont a várt közösségi támogatások ellenére Románia, és csak hosszú távon reális Bulgária, Lettország és Litvánia makrogazdasági felzárkózása az EU átlagához.

A kibővítés közvetlen költségvetési hatásairól szólva kiemelhető, hogy a kilencvenes években született különféle becslések (35-40 milliárd euró közötti összegről) okafogyottá váltak azzal, hogy az egyik legjelentősebb tételként kezelt Strukturális Alapok esetében a GDP négy százalékában húzták meg a felvehető összegek plafonját, másrészt a mezőgazdasági integráció terén is történtek a felvétel költségeit csökkentő lépések a tagjelölteknél. A négy százalékos plafon ugyan a legszegényebbek felzárkóztatásának elvével csak részlegesen egyeztethető össze (minél „gazdagabb szegény” egy új tagország, annál több támogatást kaphat), de az abszorpciós kapacitás - amelyben a saját hozzájárulás elvileg minimum 25 százaléka (kivételes esetekben a kohéziós alapoknál ez lecsökkenhet 15 százalékra) lesz az egyes projekteknek - valóban gátat szab a felvehető összegek reális felhasználásának.

A közvetlen költségvetési hatások másik fontos faktora az agrárszektor közvetlen kifizetéseinek nagysága (közvetlen termelői támogatások), ami Románia és Bulgária nélkül évi 5 milliárd euróra becsülhető. (A két balkáni tagjelölt ország nélkül az Európai Bizottság által számított termelési kvóták alapján mintegy 9 milliárd euró lenne a teljes agrártámogatás.)

Ha az előbb említett közösségi közvetlen költségeket (2006-ban maximum a közösségi GNP 0,25 százalékát, azaz 25 milliárd eurót) összevetjük az EUállamokban müködő üzleti szféra által a bővítés révén élvezett haszonnal (a becslések a GDP 0,1-0,4 százaléka körül mozognak), akkor látjuk, hogy a tagság után az utóbbiaktól befolyó költségvetési bevételek (pótlólagos adók, járulékok) pénzügyileg rentábilissá teszik a bővítést, igaz, ez a bevétel nem a közösségi 
költségvetésnél, hanem a jelenlegi tagállamok nemzeti büdzséjében jelenik meg. Ehhez kell még hozzászámolni az EU-tagállamok szempontjából a biztonságpolitikai költségek csökkenését (ez is érzékelhető a GDP legalább 0,1 százalékánál), valamint a közösségi határok keleti kiterjesztése, (az EU jelenlegi határainak fizikai leépítése), továbbá a belső piac bővülése mellett az euróövezet kiterjesztésének hasznát is.

A tagjelöltek szempontjából a közösségi költségvetésböl érkező pénzügyi transzfer (mintegy 20-25 milliárd euró) mellett a tagság által gerjesztett pótlólagos gazdasági növekedés is legalább ugyanekkora hasznot hozhat 2010 körül. Ezzel szemben a tagságra való gyorsított felkészülés költségei állhatnak, de ezeket a költségeket nagyrészt a demokratikus jogállamiság megszilárdítása, a piacgazdaság fejlesztése, valamint az EU-piacokra történő bejutásra való ráutaltság egyébként is szükségessé teszi.

A két félre a bővítés által gyakorolt gazdasági hatások összevetéséből megállapítható, hogy mindkét fél nyertesként kerülhet ki („win-win excercise”), igaz a közvetlen hasznot mérve a tagjelöltek járhatnak jobban, hiszen a tagállamok szempontjából a fő hasznot már a kilencvenes évek elején a térség társadalmainak és gazdaságainak nyugat felé történő nyitása jelentette.

Magam részéről így igazolva látom a kiinduló feltételezésemet, miszerint az EU számára a közvetett és közvetlen költségek összevetése révén nyereséges vállalkozás a bővítés. Az új tagok felvételét azonban megítélésem szerint csak fokozatosan, két vagy három részletben célszerü az Uniónak megvalósítania, mivel az igazi szakadékot nem az EU és a legfejlettebb jelentkező országok, hanem az EU és a felkészületlenebb tagjelöltek között kell áthidalniuk. Egy nagy csoportos felvétel a bejutók rendkívül heterogén fejlettségi szintje miatt megnehezítené azt, hogy az első csoport felvételéhez szükséges intézményi lépéseket és a közösségi politikába történő beilleszkedésüket megvalósíthassák. (Erre az 1999-es NATO-bővítés - ahol csak három új tagállam volt - az élő példa).

A bővítés sikere azon múlik - és ez befolyásolja az Unió müködésének további menetét is -, hogy az új tagok felvétele egyenlő elvek és elbánás szerint történik-e. (Ez is a differenciált bővítés mellett szól, hiszen néhány tagjelölt még hosszabb 
átmeneti megállapodásokkal sem képes a tagsági kihívások teljesítésére.) Ha ez az egyenlő elbánás megvalósul, akkor valóban kizárható az, hogy a bővítés után jaltai vonalak jelenjenek meg az EU-n belül. E veszélyek hatástalanítása esetén az új Európai Unión belül nem lesz olyan regionális csoportosulás vagy szövetségi rendszer, ami nem reális értékeken vagy érdekeken, hanem hidegháborús törésvonalakon alapul. A dolgozatom által kimutatott hatalmas felkészültségbeli különbségek kezelése felveti az Unió geopolitikai felelősségét, hiszen Románia és Bulgária tagjelöltként való kezelése egyik oldalról, Horvátország és később Jugoszlávia vagy más balkáni országok bővítésből való kizárása másik oldalról politikailag kezelhetetlen helyzetet hozna létre, mivel ezt a különbségtételt nem lehetne fejlettségbeli vagy felkészültségbeli különbségekkel megmagyarázni.

Ezért dolgozatom továbbfejlesztéseként a bővítésnek a belső piacra, a külső kapcsolatrendszerekre gyakorolt hatásai mellett annak a kérdésnek a vizsgálata lehet fontos, amely újabb tagjelöltek (pl. a Nyugat-Balkánon) esetleges felvételét elemzi, illetve modellezi. Ezért újabb kutatások tárgya lehet annak további taglalása, hogy hol húzódik az a geopolitikai határ, ami a bővítést minden szempontból rentábilissá teszi az EU számára. Ez lehet később Európa földrajzi határa. 


\section{IRODALOMJEGYZÉK}

\section{KÖNYVEK}

Avery G. - Cameron F. [1998]: The enlargement of the European Union, Sheffield Academic Press. p. 198.

Balázs Péter [1996]: Az Európai Unió külkapcsolatai és Magyarország. KJK, p.176.

Brunner, Georg [1996]: Nationality Problems and Minority Conflicts in Eastern Europe. Bertelsmann Foundation Publishers, Gütersloh, p. 198.

Ehrlich Éva [1998]: Infrastruktúra Szolgáltatások. ISM, Budapest, p.135.

Európa Kislexikon [1999], Második kiadás, Aula Kiadó, p.404.

Grabbe, Heather - Hughes, Kirsty [1997]: Eastward enlargement of the European Union. Royal Institute of International Affairs, London, p. 67.

Grabbe, Heather [2001]: Profiting from EU enlargement, Centre for European Reform. London, p. 65.

Hönnekopp, Elmar [1999]: Central and Eastern European Citizens in the Member Countries of the European Union since 1990. In: magyar Kormány háttéranyaga az EU Bizottság számára a személyek szabad áramlásáról. Institute for Employment Research, Nuremberg

Horváth Zoltán [1999]: Kézikönyv az Európai Unióról. Második, bővített kiadás. Magyar Országgyülés, Budapest, p.323.

Izikné Hedri Gabriella [1979]: Magyarország a kelet-nyugati gazdasági kapcsolatokban. Kossuth Könyvkiadó

Izikné Hedri Gabriella [1988]: Egy Megállapodás története. Kossuth Kiadó, Budapest

Kengyel Ákos [1999]: Az Európai Unió Regionális Politikája. Aula, Budapest, p.203.

Kocsis Károly - Kocsis-Hódosi Eszter [1998]: Ethnic geography of the Hungarian minorities in the Carpathian Basin. Földrajzi Kutató Intézet MTA Kisebbségi Kutatói Programja, Budapest, p.240. 
Mayhew, Alan [1998]: Recreating Europe. Cambridge University, Cambridge, p. 400.

Monti, Mario [1996]: Single Market and Tomorrow's Europe. Publication of the European Commission, p. 161. Brussels

Szentes, Tamás [1995] : A világgazdaságtan elméleti és módszertani alapjai. Aula, Budapest, p. 891

\section{PUBLIKÁCIÓK, DOKUMENTUMOK}

Adapting the Institution to make a success of enlargement. [2000], Commission opinion, COM (2000) 34,

Agenda 2000 Volume I., Volume II. [1997], European Commission, Brussels DOC $/ 97 / 7$

Agricultural Situation and Prospects in the Central and Eastern European Countries. [1995], European Commission, Brussels

Agricultural Situation and Prospects in the Central and Eastern European Countries. Summary Report [1998], European Commission, Brussels

Az Integrációs Stratégiai Munkacsoport koordinátorainak szektor-elemzései. [1997], ISM, Budapest

Amato, G. - Batt J. [1998]: Minority Rights and EU enlargement to the East. European University Institute, RSC policy paper 98/5.

Amato, G. - Batt, J. [1999]: The Long Term Implications of EU Enlargement: The Nature of the New Border. RSC, Florence

Amato, G. - Batt, J. [1999]: The Long Term Implication of EU Enlargement: Culture and National Identity. RSC, No 99/1, Florence

Annual benefits of full compliance with EU environmental "acquis". [2001], ECOTEC et al in: Uniting Europe 168/2001

Annual Report on Equal Opportunities for Women and Men in the EU 2000. [2001], European Commission, Brussels

Az EU 2000-2006 közötti pénzügyi irányelvei. [1999], Intézményközi Megállapodás, Brüsszel,

Az Európai Unió bővítésének szociális aspektusai. [1999], Európai Parlament, Brüsszel 
Az Európai Unió és a magyar közvélemény. [2000], Szonda Ipsos, Budapest (KÜM megrendelésre)

Baldwin Richard [1992]: An eastern enlargement of EFTA: Why the East European should join and the EFTANS should want them. Brussels

Baldwin, Richard [1994]: Towards an integrated Europe. Centre for Economic Policy Research, Brussels

Bodré, Denis [1996]: Rapport d'information fait au nom de la délégation du Sénat pour l'Union Européenne sur les conséquences économiques et budgétaire de l'élargissement de l'Union Européenne au pays associés d'Europe Centrale et Orientale. Sénat, Paris

Brücker - Boeri - Herbert et al [2000]: Analysis on the impact of Eastern Enlargement on employment and wages. European Commission, Brussels

Brücker - Boeri - Herbert et al: [2001]: The Impact of Eastern Enlargement on employment and Labour Markets in the EU Member States. European Commission, Brussels

Communication from Vice President Andriessen to the European Commission [1992]: Towards a closer association with the countries of Central and Eastern Europe. Brussels

Cooperation in the area of justice and home affairs in the enlargement process. [1999], European Parliament PE 167.690/rev.1.

Costs, Benefits and Chances of Eastern Enlargement for the European Union. [1996], Bertelsman Foundation, Güterslah

Current Roma migration from the EU Candidate States. [2001], International Centre for Migration Policy Development, Vienna

Czech Republic: Towards EU Accession. [1999], World Bank, Washington

De Jesus, Avelino - Ramos Silva, Joaquim - Barros, Carlos [1998]: O impacto sobre Portugal do alargamento da UE aos PECO. Universidade Técnica de Lisboa

Demographic Report. [1997], European Commission, COM[97] 361 final, Brussels

Demographic Yearbook 1997. [1999], UN, New York.

Economic Commission for Europe. [2000], Economic Survey of Europe

Economic Forecasts for the Candidate Countries. [2000], Information Note From Commissioner Pedro Solbes Mira to the Commission, Autumn 2000. European Commission, Brussels 
Ehrlich Éva [1999]: A közlekedési infrastruktúra fejlesztésének és finanszírozásának, beruházásai alakulásának nemzetközi összehasonlító vizsgálata az 1990-97-es időszakban. Budapest

Ehrlich Éva [2000]: A magyar közlekedés: A jelen és a jövő várható tendenciák és elörejelzések 2006-ig. Budapest

Employment and labour market in Central European Countries. [2001], European Commission, Brussels

Enlargement Papers: Enlargement argumentaire. [2001], European Commission Directorate-General for Economic and Financial Affairs, Brussels

Enlargement Papers: Progress towards meeting Economic criteria for Accession: The Assessment from the 2001. [2001], Regular Report, European Commission Directorate-General for Economic and Financial Affairs, Brussels

Enlargement Strategy Paper: Report on progress towards accession by each of the candidate countries. [2000], European Commission, Brussels

Environment for Europeans. [2000], Special issue on enlargement. European Commission, Directorate-General for the Environment, Brussels

EU Enlargement Monitor Central and Eastern Europe. [2000], [2001] Deutsche Bank Research

EU Enlargement: Freedom of Movement of Persons. [2000], The Austrian Perspective, Brussels

EU - Osterweiterung: Österreichs Interessen. [1996], (vázlat), WIFO, Bécs

Eurobarométer felmérés a csatlakozó országok közvéleményéről az EU bővítés ügyében. [1997], [2000], [2001], Európai Bizottság, Brüsszel

Eurobarométer felmérések az EU bővítéséröl. [1999], [2000], [2001], 51. szám, 53. szám, 54. szám, Európai Bizottság, Brüsszel

European Report on quality of school education, sixteen quality indicators. [2000], European Commission, Directorate-General for Education and Culture, Brussels

Eurostat Yearbook. [2000] and [2001], European Commission, Luxembourg

EU support for Roma communities in Central and Eastern Europe. [1999], European Commission, Brussels

Fact sheets on Hungary. 5/2000, [2001], Ministry of Foreign Affairs, Budapest

First Cohesion Report. [1996], European Commission, Brussels 
First progress report on economic and social cohesion. [2002], European Commission, Brussels

Free movement of workers. [2000], Ministry of Foreign Affairs, Budapest

General conclusions of Wenra on nuclear safety in candidate countries to the European Union. [2000], Brussels

Glatz, Ferenc [1993]: Minorities in East-Central Europe. Europa Institut, Budapest

Grassini, Maurizio [2001]: Eastern Enlargement to the EU: Economic Costs and Benefits for the EU Present Member States? The Case of Italy. European Commission, Brussels

Green paper on European Transport Policy. [2001], European Commission, Brussels

Hovy Bela [2000]: „Statistically Correct” Asylum Data: Prospects and limitations. UNHCR, Geneva

Hungary-European Union Impact on Austria .[1999], WIIW - Gazdasági Növekedési Intézet, Vienna

Hungary's Accession to the EU: the impact on selected areas of Hungarian-Austrian relations. [1999], WIIW, WIFO, ICMPD, Gazdasági Növekedési Intézet, Vienna-Budapest

Hungary: On the Road to the European Union. [1999], World Bank, Washington

Integráció és versenyképesség. [1999], A Magyar EU Bővítési Üzleti Tanács jelentése, Budapest

Investing in the New Millennium. [1999], CEER

Joint assessments of the European Commission and the Government of Hungary, Czech Republic, Poland, Estonia, Lithuania, Latvia, Bulgaria, Slovenia on the macroeconomic perspective of the candidate countries. [1996-2000], Brussels

Keuschnigg, Christian - Kohler, Wilhelm [1999]: Eastern Enlargement to the EU: Economic Costs and Benefits for the EU Present Member States? Final Report; The Case of Austria, European Commission, Brussels

Keuschnigg, Christian - Kohler, Wilhelm [1999]: Eastern Enlargement to the EU: Economic Costs and Benefits for the EU Present Member States? Final Report; The Case of Germany, European Commission, Brussels

Környezetpolitikai Vizsgálatok. Magyarország. [2000], OECD, Párizs

Közlekedés, posta és távközlés, vízgazdálkodás adatai 1996-99. [2000], Közlekedési és Vízügyi Minisztérium, Budapest 
Kristensen, Tony - Jensen, Peter [2001]: Eastern Enlargement to the EU: Economic Costs and Benefits for the EU Present Member States? Final Report; The Case of Denmark, European Commission, Brussels

Lackó Mária [2000]: Egy rázós szektor, a rejtett gazdaság súlya és összetevői a mai Magyarországban. Táblázatok és ábrák. Budapest

Landesmann, A. Michael [2000]: Structural Change in the Transition Economies since 1989. Web site: www:/pollak/landesm/UN-ECE-SPRING00.doc

Les Fonds structurels en 1998. [1999], Commission européenne

L'Europe Centrale et Balkanique. [1995], Atlas d'Histoire Politique, Bruxelles

Long Term Prospects Grains, Milk and Milk Markets. [1997]: European Commission, Directorate-General for Agriculture, Brussels

Ludlow, Peter [1996]: Preparing for Membership: Eastward and Southern Enlargement of the EU. CEPS, Brussels

Measures taken by the State to promote the social integration of Roma living in Hungary. [2000], Igazságügyi Minisztérium, Nemzeti Etnikai és Kisebbségi Hivatal, Budapest

Migration potential in Central and Eastern Europe International Organisation for Migration. [1999], Geneva

More members for the EU? [1997], EVA, L. (Centre for Finish Business and Policy Studies), Helsinki

OECD in figures: Statistics on the Member Countries. [2000], OECD, Paris

Opinion on the Impact on the Single Market of the enlargement of the European Union. [1999], Economic and Social Committee of the European Communities, Brussels

Overseas direct investment 1999. [2001], National Statistical Office, United Kingdom

PAN-European Transport Corridors. [1999], TINA Secretariat, Vienna

Potocnik, A - Huter, C. [1997]: Position Paper of the Austrian Federal Economic Chamber for Eastern European Enlargement. Wirtchaftskammer, Vienna

Progress Report to the Ecofin Council on the Impact of ageing populations on public pension systems. [2000], European Commission, Brussels

Progress towards meeting Copenhagen economic criteria by accession countries and the need for macrofinancial stability assessments. [2000], European Commission, Directorate-General for Economic and Financial Affairs, Brussels 
Prospects for Agricultural Markets in the associated Central and Eastern European Countries. [2000], European Commission, Brussels

Protocole sur l'élargissement de 1'Union européen. [2001], Officiel Journal of the European Union OJC 2001/80

Real Convergence in Candidate Countries. [2001], European Commission, Directorate-General for Economic and Financial Affairs, Brussels

Regional Gross Domestic Product in the Central European Countries. [1999], European Commission, Directorate-General for Regional Development, Brussels

Replacement migration: Is it a solution to declining and ageing population. [2000], UN population division, New York

Web site: www.un.org./esa/population/execsum.htm

Report from the Commission to the Council on the Transit of Goods by Road through Austria. [2000], European Commission, COM 2000/862 final, Brussels

Scenarios Europe 2010. [1999], European Commission Forward Studies Unit, Working Paper, Brussels

Second European Report on S+T Indication Report + Appendix. [1997], European Commission, Brussels

Second report on economic and social cohesion (Enlarging, solidarity, uniting Europe). [2001], European Commission, Brussels, Külön: Statistical Annex

Security and Defence and Enlargement of the European Union. [1998], European Parliament, PE 167.877.

Seeler, Hans Joachim [1986]: Jelentés az EGK és a KGST, illetve azok tagállamaival való kapcsolatokról. Európai Parlament, DOC.A.2 - 187/86, Brüsszel

Special Report of the Eurobarometer. [1993], Survey No. 38.

Statistical Overview. [2000], UNHCR, Geneva

Statistical regions in the EFTA countries and the Central European Countries. (CEC) [1999], Eurostat, Luxembourg

Statistical Yearbook 1998. [1999], UNESCO, Paris

Statistical Yearbook on candidate and South-East European Countries. [2000], European Committee, Eurostat, Luxembourg

Statistical Yearbook on central European countries. [1999], Eurostat, Luxembourg 
Study on alternative strategies for the development of relations in the field of agriculture between the EU and the associated countries with a view to future accession of these countries (Agricultural Strategy Paper). [1995], European Commission, Brussels

The Agricultural situation in the European Union. [1999], European Commission, Directory of General Agriculture

The Agricultural Situation in the European Union, 1999. [2000], Report COM (2000)485 final, Brussels

The Common Foreign and Security Policy and Enlargement of the European Union. [1999], European Parliament, PE 167.822/rev.2.

The East-West win-win business experience. [1999], A report by the European Round Table of Industrialists, Brussels

The Economic impact of enlargement. [2001], European Commission, DirectorateGeneral for Economic and Financial Affairs, Brussels

The effects of the policies of the European Union of enlargement to the associated countries of Central and Eastern Europe (Impact Study). [1997], European Commission, Brussels

The Environment in European Enlargement. [2000], CEPS,

The European Countries and United Germany. [1991], The Development of Public Opinion in East and West Germany. [1992], Eurobarometer Survey No. 35, 36, 38, European Commission, Brussels

The free movement of persons for the pursuit of economic activity in the context of enlargement. [2000], European Commission, Directorate-General for Enlargement, Brussels

The new European Union: WWF Agenda for Accession. [2000]

Towards a European Research Area, Key Figures. [2000], European Commission, Brussels

Towards an European strategy for the security of energy supply. [2000], Green paper of the European Commission, Brussels

Trade and enlargement: The benefits for third countries. [1998], European Commission, Brussels

Transparency International, [1998] and [1999]: Corruption Perceptions Index. Web site: www.trasparency.org/documents/cei/index.htm

Weizsäcker R., von - Dehaene J.-L - Simon D. [1999]: The Institutional implications of enlargement Report to the European Commission. Brussels 
WHO: World Health Report. [2000], Statistical Annex, Web site: www.nt.who.int/WHOSIS/statistics

World Competitiveness World Book, Results. [2000]. International Institute for Management Development, Lausanne

Web site: www.imd.ch/Wcy/ranking/ranking.cfm

World Development Indicators. [2000], World Bank, Washington, Web site: www. worldbank.org/wdi

World Economic and Social Development Report. [2000], UN, Statistical Annex

World Economic Outlook IMF. [2000], Washington

World Statistics Pocketbook. [2000], UN, New York

\section{CIKKEK, BESZÉDEK}

Arató Krisztina [1998]: Érdekképviselet és érdekegyeztetés az Európai Unióban. Acta Humana N.33, Budapest

Baldwin, Richard - François, Joseph - Portes, Richard [1997]: The costs and benefits of eastern enlargement: the impact on the EU and Central Europe. Economic Policy 1997/24, London

Csepeli György - Örkény Antal [2000]: Nemzetközi összehasonlító felmérés a nemzeti öntudatról. Szociológiai Szemle 1998/3, In: a magyar kormány háttéranyaga a személyek szabad mozgásáról.

Kertész Imre [1999]: A bün európai útjain. Belügyi Szemle, Budapest

Mayhew, Alan [1997]: Eastern enlargement: a win-win entreprise. European Policy Centre, Brussels

NATO tükör. [1999], [2000], tavaszi számok, Brüsszel

O’ Keefe, David [2000]: Free movement of persons - Human dimension. University College London, (Előadás írásos változata), Gent

Schreyer, Michaele [2001]: Financing Enlargement of the European Union. (Beszéd írott formában), London

Sípos Katalin [1998]: „A szociális Európa” az amszterdami szerződés tükrében. Acta Humana N.33, Budapest

Suisse - Union Européen. [1999], Rapport sur l'intégration, Bern 
Treaty of Nice. [2001], 0J/C/2001/80, Brussels

Ulram, A. Peter [1999]: A new Union of hopes and fears: Public opinions on the EU Eastern Enlargement in EU-Member and Candidate Countries. (vitapapír), Paris,

Utitárs. 5/2000 [2000]: Kereszténység a Baltikumban

Valki László [1997]: A két integráció közötti kapcsolatok jogi, intézményi problémái. MKI

Várhelyi Olivér [1998]: A közbeszerzés szabályozása az Európai Unióban. Európa Tükör 


\section{A SZERZŐ E TÉMÁBAN MEGJELENT PUBLIKÁCIÓI}

1. Európai Unió előnyei a keleti bővítésből, [1999] in: Európa Kislexikon, Az Európai Unió és Magyarország BKE Vezetőképző Intézet, Budapest, p. 10

2. Európai Unió előnyei a keleti kibővítésből, [1999], in: Európa Kislexikon, Az Európai Unió és Magyarország, Aula Kiadó, Budapest, p. 10 